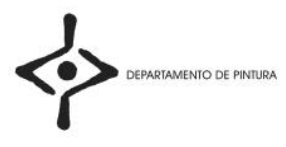

Facultad de Bellas Artes de San Carlos

Departamento de Pintura

Programa de Doctorado

Artes Visuales e Intermedia

\title{
Tesis Doctoral \\ UNA CONSTRUCCIÓN TEÓRICO-PRÁCTICA DEL PAISAJE EN EL CAMPO ESCULTÓRICO
}

\author{
Presentada por \\ Samuel José Travassos Rama
}

Dirigida por

Dra. Amparo Carbonell Tatay

Enero 2013 

Ao meu avô materno, marceneiro de profissão ... por me ter dado a conhecer, passeando, as árvores e a paisagem onde crescem

\section{Agradecimientos:}

Quiero agradecer públicamente a todos los responsables institucionales que acogieron los proyectos prácticos, así como a mis ayudantes, que pacientemente y con esfuerzo me asistieron en la realización de algunas piezas. En la orientación teórica fueron importantes las sugerencias de Emídio Ferreira, así como el lúcido apoyo de Philip Cabau, Fernando Poeiras e Isabel Baraona. Sin las lecturas y la comprensión de Catarina y la invitación de la profesora Adriana Veríssimo Serrão a colaborar con el grupo de investigación en Filosofia e Arquitetura da Paisagem, este trabajo probablemente hubiera sido distinto. No puedo dejar de mencionar tampoco a todos los compañeros de trabajo que participan en dicho grupo por sus aportaciones, esenciales para la aclaración de las múltiples cuestiones suscitadas por el paisaje.

La investigación contó con el apoyo incuestionable del Instituto Politécnico de Leiria por la creación y profundización del contacto con la Universidad Politécnica de Valencia y el equipo coordinado por Francisco Sanmartin.

Estoy en deuda con mi tutora de tesis, la profesora Amparo Carbonell Tatay, por su apertura y paciente acompañamiento durante todo el proceso, así como también a Emilio Martínez, quien estuvo presente en el periodo inicial de la investigación. Por último, agradezco a Alberto Piris Guerra la traducción cuidada de la tesis. 



\section{UNA CONSTRUCCIÓN TEÓRICO-PRÁCTICA DEL PAISAJE EN EL CAMPO ESCULTÓRICO}

Samuel José Travassos Rama 


\section{ÍNDICE DE LA TESIS}

\begin{tabular}{lr}
\hline Resumen & 08 \\
\hline Resum & 11 \\
\hline Abstract & 13 \\
\hline INTRODUCCIÓN: & 18 \\
\hline a. Motivación Personal & 19 \\
\hline b. Objetivos & 20 \\
\hline c. Metodología & 23 \\
\hline
\end{tabular}

\section{CAPITULO I: PAISAJE Y REPRESENTACIÓN}

1.0 - ¿Qué es un paisaje?

1.1 - Representación de las escenas exteriores

1.2 - El Hombre Moderno y la Aparición del Paisaje

1.3 - Institución del Paisaje

1.4 - Bosque - breve cartografía de sus re-presentaciones

\section{CAPITULO II - ¿QUÉ ES UNA ESCULTURA?}

2.0- Notas introductorias 63

2.1 - Construcciones y figuras esculpidas

2.2 - Estatuaria hierática y la sugerencia del movimiento 68

2.3 - Primera narrativa pre-cinematográfica 73

2.4 - La estatuaria y el espacio jerárquico 74

2.5 - Renacimiento, hacia la transparencia 75

2.6 - Determinaciones de la Estatuaria 79

2.7 - Determinaciones de la Escultura

2.8 - Rodin, apología de la opacidad o la inauguración del campo estricto de la escultura $\quad 81$

2.9 - Escultura como el resultado de un diálogo 85

2.10 - Descubrimiento del espacio como determinación activa de la escultura 89

2.11 - Primeras esculturas que son arquitecturas o la reversión del espacio exterior en uno $\quad 91$ interior.

2.12 - Los ready-mades y el valor de la decisión 96

2.13 - El Arte Minimalista 99

2.14 - Escultura en el campo expandido 104

2.15 - La escultura como metáfora 116

2.16 - Cómo determinar lo escultórico 119

2.17 - Dos bosques en la cartografía de las posibilidades de la escultura 120

\section{CAPITULO III: EL PAISAJE Y LO ESCULTORICO: ¿LA FORËT, DE 1950, ES UNA ESCULTURA PAISAJISTA?}

3.0 - Alberto Giacometti - breve introducción. 125

3.1- Una visión efectiva del mundo 130

3.2 - «Bastaría con que supiéramos dibujar y podríamos pintar todos los cuadros y hacer 137

todas las esculturas que quisiéramos»

3.3 - Espacio entre artista y modelo

3.4 - La forêt y la relación con la idea de paisaje

3.5 - La cabeza o el deshacer del rostro 155

$\begin{array}{ll}3.6-\text { La forêt } & 158\end{array}$

3.7 - Escultura y campo visual 162

3.8 - La mirada y el Paisaje 166

3.9 - La forêt, un paisaje erótico 174

3.10 - Teatralidad en Alberto Giacometti 179

3.11 - Alberto Giacometti, constructor de islas 188

3.12 - El Laberinto - Fusión de la Escultura con el Paisaje y la Arquitectura 195 


\section{CAPITULO IV: EL PAISAJE Y LO ESCULTORICO. ¿UMA FLORESTA PARA OS TEUS SONHOS ES UN PAISAJE?}

4.0 - Notas introductorias. 199

4.1 - Breve biografía y fases de trabajo de Alberto Carneiro 201

$\begin{array}{ll}4.2 \text { - Autobiografía y paisaje } & 207\end{array}$

4.3 - El campo de lo escultórico y Uma floresta para os teus sonhos 213

4.4 - Dibujo de proyecto de Uma floresta para os teus sonhos 218

4.5 - Idea de paisaje en Uma floresta para os teus sonhos o la idea de paisaje en el objeto - El 223 artista y el paisaje

$\begin{array}{ll}4.6 \text { - Paisaje - arte - paisaje } & 228\end{array}$

$\begin{array}{ll}4.7 \text { - Dispositivo teatral } & 231\end{array}$

4.8 - Analogía entre el paisaje real y los vectores paisajísticos en el ambiente Uma floresta 238 para os teus sonhos

4.9 - Espacio paisaje como dispersión 250

$\begin{array}{lr}4.10 \text { - El paisaje en la acción } & 255\end{array}$

$\begin{array}{ll}4.10 \text { a. - El vacío } & 255\end{array}$

4.10 b. - Construcción de la espacialidad por el desplazamiento de un cuerpo 261

\section{CAPITULO V: PROPUESTAS DE ARTICULACIÓN PRÁCTICA ENTRE EL PAISAJE Y LA ESCULTURA}

$\begin{array}{ll}5.0 \text { - La expresión y la palabra } & 280\end{array}$

5.1 - Paisaje y arte - imagen e instalación 285

5.2- El paisaje en el campo de lo escultórico a través de la fotografía 287

$\begin{array}{ll}5.2 \text { a. - Apertura del campo artístico } & 288\end{array}$

$\begin{array}{ll}5.2 \text { b. - Paisaje } & 288\end{array}$

\begin{tabular}{lr}
5.2 c. - La fotografía & 289 \\
\hline 5.2 d. - Escultura & 291
\end{tabular}

$\begin{array}{lr}5.2 \text { d. - Escultura } & 291\end{array}$

5.2 e. - Campo expandido de la Escultura 292

5.2 f. - El paisaje en el campo de lo escultórico/instalación 295

5.2 g. - Una propuesta de punto de vista sobre el lugar a través de la fotografía en su relación 301 con lo escultórico

$\begin{array}{ll}5.3 \text { - Habitar a Penumbra } & 304\end{array}$

$\begin{array}{ll}5.4 \text { - Desenhar, Esculpir, Fotografar } & 306\end{array}$

5.5 - Árvore (s) Enquanto desejo de posse do desenho 308

\begin{tabular}{ll}
5.6 - Dobrar a terra & 312 \\
\hline 5.7 - Vontade, Fadiga de Estruturas, Wander & 314
\end{tabular}

5.7 - Vontade, Fadiga de Estruturas, Wander $\quad 314$

$\begin{array}{lc}5.8 \text { - Transformación del tiempo en espacio } & 323\end{array}$

\begin{tabular}{ll}
5.9 - MEAGAPARSECS & 331 \\
\hline $5.10-M A G M A$ & 332
\end{tabular}

\begin{tabular}{ll}
5.10 - MAGMA & 332 \\
\hline $5.11-$ Mna ética y estética de la tierra & 339
\end{tabular}

$\begin{array}{ll}5.11 \text { - Una ética y estética de la tierra } & 339\end{array}$

$\begin{array}{ll}5.12 \text { - En dirección al paisaje concreto } & 344\end{array}$

\begin{tabular}{lr} 
6. CONCLUSIONES & 350 \\
\hline
\end{tabular}

$\begin{array}{ll}\text { a. Notas preliminares } & 350\end{array}$

\begin{tabular}{lr} 
b. Arte y lenguaje verbal & 350 \\
\hline
\end{tabular}

$\begin{array}{ll}\text { c. Naturaleza, Paisaje y Ambiente } & 351\end{array}$

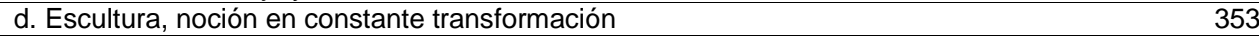

$\begin{array}{ll}\text { e. Lanzar puentes hacia adelante } & 356\end{array}$

f. La noción de espacio paisaje "como vista" ya no nos sirve $\quad 365$

\begin{tabular}{ll} 
g. MEGAPARSECS & 378 \\
\hline
\end{tabular}

7. CONCLUSIÓN PRÁCTICA - SU IMPACTO EN EL MEDIO CULTURAL 382 
a. Bibliografía Citada

b. Otra Bibliografía de referencia consultada

c. Catálogos sobre la obra de Alberto Giacometti y Alberto Carneiro 454

d. Otros Catálogos 457

e. Material audio y vídeo 458

f. Diccionarios 458

g. Recepción crítica de las exposiciones realizadas durante el curso de la investigación 459 (selección de artículos)

h. Catálogos y libros relacionados con las exposiciones realizadas durante el curso de la investigación (selección)

10. ÍNDICE DE IMÁGENES PRESENTADAS 465 



\section{Resumen}

El presente trabajo de investigación intenta dar cuerpo a una posibilidad de articulación teórico-práctica del paisaje en el campo de lo escultórico. De esta forma, se ha pretendido construir un itinerario reflexivo en torno a una serie de cuestiones -enunciadas por nuestras palabras clave-, que fueron suscitadas por un conjunto de propuestas plásticas realizadas antes del inicio de este trabajo de investigación.

Palabras clave: naturaleza, paisaje, ambiente, cuerpo, escultura, escultura en el campo expandido, fotografía, miniatura, mirada, deambulación, memoria, ausencia, vacío, proceso, proyecto, lenguaje, espacio, tiempo, teatro, estética y ética.

Son varios los desafíos planteados. En primer lugar, el de no ceder a la tentación de que el autor hacedor se erija en comentador privilegiado de su propio trabajo. En segundo lugar el de usar un método y una estrategia que permita estar alerta en cuanto a la naturaleza muda del arte. La atención a la naturaleza muda del arte implica reconocer que el funcionamiento del lenguaje verbal es diferente al funcionamiento del lenguaje de la naturaleza muda de los materiales de la escultura. En otras palabras, no hay traducibilidad fiable entre lo que constituye el territorio de la práctica artística y lo que puede fijarse en lenguaje verbal (puesto que esta sujeta a interpretación). El reto fue emprender un método que fuera lo menos redundante posible en relación a la naturaleza propia del arte, haciendo que la propia articulación verbal de este itinerario meditativo acabase por ofrecer mejores puntos de apoyo y vectores de acción tanto para la práctica artística como académica, revelándose de este modo que en arte teoría y práctica no pueden ser consideradas en el ámbito de una investigación entidades separadas, sino, antes bien, un mismo campo que integra el hacer y el pensamiento.

Los trabajos artísticos propios que motivaron la elección de las obras objeto del trabajo interpretativo fueron principalmente Vontade, 2004, (fig. 63) y Fadiga de estruturas, 2005-2006, (fig. 65). La primera fue realizada en un periodo inicial, previo a esta investigación, mientras que la segunda ya corresponde a 
este marco temporal, tal como Wander, 2007, (fig.66) y MAGMA, 2008, (figs. 69, 70, 71 y 72). Por último, podemos citar MEGAPARSECS 2012 (fig. 67), una obra que funciona como una suerte de corolario de nuestro itinerario meditativo, algo que se produjo naturalmente y sin que mediara ninguna acción programática previa. Todas estas propuestas fueron objeto de presentaciones públicas y recepciones por parte de la crítica especializada. En este sentido, todas las obras seleccionadas para figurar en el capítulo $V$ tuvieron su existencia natural en el contexto nacional e internacional del circuito profesional del arte, incluyendo la participación en algunos premios internacionales, dos de los cuales precisamente en España.

Por su parte, las dos obras objeto de nuestra interpretación fueron La forêt, 1950, (fig. 24) de Alberto Giacometti, y Uma Floresta para os teus sonhos, 1970, (fig. 41) de Alberto Carneiro, distantes entre sí veinte años, pero vinculadas entre sí, en la medida en que la obra de Giacometti es, asumidamente, una referencia del artista portugués. Ambos "bosques" encuentran su lugar en este trabajo al reflejar, cada uno a su modo, la transformación de las ideas de paisaje y escultura.

El paisaje se presenta como algo que emana de la división dilacerante del hombre en relación a la naturaleza, expresada en la idea de paisaje "como vista", informada por la convención renacentista del espacio. El tiempo revelará que la noción de paisaje "como vista" ya no nos sirve, y en este contexto proponemos una nueva noción de paisaje basada en la deambulación. Nacida del esfuerzo moderno, a fin de relativizar la convención renacentista, y germinada por la fenomenología naciente, esta noción se mostrará útil para comprender el carácter paisajístico de La forêt y Uma floresta para os teus sonhos, respectivamente a dos niveles: el nivel del objeto esculpido en miniatura por un proceso de trabajo manual del artista y el nivel ambiental surgido de una concepción del arte como idea y de la disciplina de proyecto.

De hecho, estas piezas, junto con MEGAPARSECS, funcionan como sumatorio de las ideas contenidas en La forêt y en Uma floresta para os teus sonhos, teniendo en común con ellas también el hecho de que todas han surgido 
de la auscultación de la memoria, que es la modalidad más creativa del pensamiento.

MAGMA 2008, procuró articular de forma deliberada los campos de la estética y de la ética, proponiendo la escultura como ejercicio de regeneración de la tierra y usando en este ámbito tanto las intervenciones escultóricas tridimensionales como las intervenciones escultóricas bidimensionales.

Todos estos ejemplos, tanto los que fueron objeto de nuestra interpretación como los que surgieron de una práctica artística propia, testimonian la idea de que la noción de paisaje "como vista" ya no nos sirve, precisamente porque está en el origen de nuestros problemas contemporáneos.

Arnold Berleant, autor traído a colación únicamente en la conclusión, nos ofrece una pista certera para la articulación entre los campos de la estética y de la ética, defendiendo que la idea de paisaje como vista ya no nos sirve, pero la estética positiva tampoco, pues se basa en la distancia del observador en reacción al paisaje observado. En vez de eso propone, como forma de religar el hombre y el medio ambiente, una estética del compromiso que plantea el paisaje como entorno y que problematiza la noción de lo "sublime negativo". En otras palabras, dado que a través de lo sublime el hombre reafirma su posición ética con la naturaleza, se hace urgente rehabilitar también su atención en relación a los paisajes concretos dominados por la contaminación, por el crecimiento desordenado de las ciudades, etc. Su propuesta radica en la idea de que si el hombre descubre finalmente que es responsable de las abismales transformaciones operadas en la naturaleza, se destruirá la idea de paisaje como ventana y la movilidad y el desasosiego aportados por lo sublime impelerán al hombre a actuar ante la naturaleza según un criterio estético capaz de garantizar la sostenibilidad. 


\section{Resum}

Aquest treball de recerca intenta donar cos a una possibilitat d'articulació teoricopràctica del paisatge en el camp de l'escultura. D'aquesta manera, s'ha pretès construir un itinerari meditatiu entorn d'una sèrie de qüestions, enunciades per les nostres paraules clau, que van ser suscitades per un conjunt de propostes plàstiques realitzades abans de l'inici d'aquest treball de recerca. Després, i com a forma d'aprofundir en aquestes qüestions, es va decidir usar el mètode interpretatiu per a trobar, en dos objectes exteriors a la pràctica autoral pròpia $i$ realitzats per dos artistes, els mitjans de comprensió dels conceptes esmentats a continuació:

Paraules clau: naturalesa, paisatge, ambient, cos, escultura, escultura en el camp expandit, fotografia, miniatura, mirada, deambulació, memòria, absència, buit, procés, projecte, llenguatge, espai, temps, teatre, estètica i ètica.

Els desafiaments plantejats són diversos. En primer lloc, el de no cedir a la temptació que l'autor faedor siga el comentador privilegiat del seu propi treball. En segon lloc, el d'usar un mètode i una estratègia que permeta estar alerta en relació a la naturalesa muda de l'art. L'atenció a la naturalesa muda de l'art implica reconèixer que el funcionament del llenguatge verbal és diferent del funcionament del llenguatge dels materials muts de l'escultura. En altres paraules, no hi ha traduïbilitat fiable entre el que constitueix el territori de la pràctica artística $\mathrm{i}$ el que pot fixar-se en llenguatge verbal. El repte va ser emprendre un mètode que fóra el mínim refractari possible en relació a la naturalesa pròpia de l'art, tot fent que la mateixa articulació verbal d'aquest itinerari meditatiu finalment oferira millors punts de suport i vectors d'acció tant per a la pràctica artística com acadèmica, per a d'aquesta manera revelar-se que en art teoria i pràctica no són, en l'àmbit d'una investigació, entitats separades, sinó, més aviat, un mateix camp que integra el fer i el pensament.

Els treballs artístics propis que van motivar la tria de les obres objecte del treball interpretatiu van ser principalment Vontade (2004, fig. 61) i Fadiga de estruturas (2005-2006, fig. 63). La primera va ser realitzada en un període inicial, 
previ a aquesta investigació, mentre que la segona ja correspon a aquest marc temporal, tal com Wander (2007, fig.64) iMAGMA (2008, fig. 67, 68, 69 i 70). Finalment, podem citar MEGAPARSECS (2012, fig. 65), una obra que funciona com a corol-lari del nostre itinerari meditatiu, un fet que es va produir naturalment i sense que hi intervinguera cap acció programàtica prèvia. Totes aquestes propostes van ser objecte de presentacions públiques i recepcions per part de la crítica especialitzada. Per tant, totes les obres seleccionades per a figurar en el capítol $V$ van tenir una existència natural en el context nacional i internacional del circuit professional de l'art, inclosa l'obtenció d'alguns premis internacionals, dos dels quals precisament a Espanya.

Per la seua banda, les dues obres objecte de la nostra interpretació van ser La forêt (1950, fig. 24), d'Alberto Giacometti, i Uma floresta para os teus sonhos (1970, fig. 41), d'Alberto Carneiro, distants entre si vint anys (de fet, aquest últim autor assumeix tenir com a referència l'obra del primer). Tots dos boscos troben un lloc en aquest treball perquè reflecteixen, cadascuna a la seua manera, la transformació de les idees de paisatge i escultura.

El paisatge es presenta com quelcom que emana de la divisió dilacerant de l'home en relació a la naturalesa, d'ací naix la idea de paisatge com a vista, informada per la convenció renaixentista de l'espai. El temps revelarà que la noció de paisatge com a vista ja no ens serveix, i en aquest context hem proposat una nova noció de paisatge basada en la deambulació. Nascuda de l'esforç modern, a fi de relativitzar la convenció renaixentista i nascuda de la fenomenologia naixent, aquesta noció es mostrarà útil per a comprendre el caràcter paisatgístic de Laforêti Uma floresta para os teus sonhos, respectivament a dos nivells: el nivell de l'objecte esculpit en miniatura per un procés de treball manual de l'artista i el nivell ambiental sorgit d'una concepció de l'art com a idea i de la disciplina de projecte.

De fet, aquestes peces, juntament amb MEGAPARSECS, funcionen com a sumatori de les idees contingudes en La forêt i enUma floresta para os teus sonhos, i té en comú amb aquestes també el fet que totes han sorgit de l'auscultació de la memòria, que és la modalitat més creativa del pensament. 
MAGMA (2008; fig. 67, 68, 69 i 70) va procurar articular de forma deliberada els camps de l'estètica i de l'ètica, proposant l'escultura com a exercici de regeneració de la terra i usant en aquest àmbit tant les intervencions escultòriques tridimensionals com les intervencions escultòriques bidimensionals.

Tots aquests exemples, tant els que foren objecte de la nostra interpretació, com els que van sorgir d'una pràctica artística autoral pròpia, testimonien la idea que la noció de paisatge com a vistaja no ens serveix, precisament perquè es troba en l'origen dels nostres problemes contemporanis.

Arnold Berleant, autor portat a col-lació únicament en la conclusió, ens ofereix una pista precisa per a l'articulació entre els camps de l'estètica i de l'ètica, defensant que la idea de paisatge com a vista ja no ens serveix, però l'estètica positiva tampoc, perquè es basa en la distància de l'observador en reacció al paisatge observat. En comptes d'això proposa, com a forma de relligar l'home i el medi ambient, una estètica del compromís que planteja el paisatge com a entorn i que problematitza la noció del sublim negatiu. En altres paraules, atès que a través del sublim l'home relliga la seua posició ètica amb la naturalesa, es fa urgent rehabilitar també la seua atenció en relació als paisatges concrets dominats per la contaminació, pel creixement desordenat de les ciutats, etc. La proposta d'aquest radica en la idea que si l'home descobreix finalment que és responsable de les abismals transformacions operades en la naturalesa, es destruirà la idea de paisatge com a finestra, i la mobilitat i el desassossec aportats pel sublim impel-liran l'home a actuar davant la naturalesa segons un criteri estètic capaç de garantir la sostenibilitat.

\section{Abstract}

This thesis focuses specifically on the articulation of sculptural field with landscape and it is based on a particular reading guided by an authorial practice. The aim was to build a meditating path around issues related to our key words which emerged from a set of plastic arts proposals created before the writing of this dissertation. In order to go as deeper as possible, the interpretation method 
was chosen to find outside the authorial own practice - in two works of art from two different artists - the understanding means of the concepts indicated below.

Key words: nature, landscape, environment, body, sculpture, sculpture in the expanded field, photography, miniature, look, wandering, memory, absence, emptiness, process, project, language, space, time, theatre, aesthetics, and ethics.

This dissertation intends to give shape to a possibility of theoreticalpractical articulation of landscape in sculptural field. First, it was quite a struggle for the author creator not to fall into the temptation of commenting exclusively his own work. Another challenge was to use a method and a strategy that would enable us to be alert to the mute nature of art. Watching the mute nature of art means recognizing that the functioning of verbal language is different from the functioning of the language of mute materials of sculpture, that is, artistic practice is not translatable reliably into verbal language. The challenge was to define a method that would be as less antagonistic as possible towards the characteristic nature of art. From verbal articulation of this meditating path, we obtained better bases and action vectors for artistic and academic practice, so it was shown that, in the scope of research about art, theory and practice are not separate entities but a common field which comprises thinking and making.

The authorial works of art that instigate the study of the objects of this interpretation work were mainly "Vontade" 2004 (fig. 63) and "Fadiga de estruturas" 2005-2006 (fig. 65). The first was created before the beginning of this study but the second was during, just like "Wander" 2007, (fig.66) and "MAGMA" 2008, (fig.69, 70, 71 e 72); eventually "MEGAPARSECS" (fig. 67) 2012 came naturally, without any deliberate action and became the pinnacle of our meditating path. All these proposals were submitted to public and critics. Therefore, all the pieces chosen to figure in chapter $\mathrm{V}$ had their natural existence in the professional world of art at national and international scale and some even participation as a finalist in several international prizes, two of which in Spain.

The two objects of our interpretation were "La forêt" 1950 (fig. 24) by Alberto Giacometti and "Uma floresta para os teus sonhos" (a forest for your dreams) 1970 (fig. 41) by Alberto Carneiro. Twenty years separate one from each other and yet Alberto Carneiro has taken A. Giacometti as a reference; these 
forests find their place in this dissertation in the way that leads to the understanding of the transformation of the ideas of landscape and sculpture. Landscape is presented as something that descends from the dilacerating division of man towards nature which explains the idea of landscape as "view" established by the Renaissance convention for space. Sculpture descends from statuary and preserved from it the idea of absence which still qualifies today the sculptural space. However, sculpture, in restricted sense, which was inaugurated by the work and writings of Rodin, lasts only a little more than half a century. In the middle of the twentieth century, the promise of including the body as part of the sculptural experience brings to memory the experiences of Russian constructivists like El Lissitzky and the Dadaists like Kurt Schwitters who created respectively the "Proun Space" and "Merzbau" in 1923. In those, a penetrable sculptural space was created, as a set of surfaces defined from inside.

Time will show that the notion of landscape as "view" will lose its validity, so a new notion of landscape based on wander was proposed. Its roots can be traced back from Modern period, who questioned the Renaissance convention, and from emergent phenomenology. This notion will be useful to understand the landscape character in "La forêt" and in "Uma floresta para os teus sonhos" (a forest for your dreams) at two levels respectively: the level of the sculpted object in miniature by means of the artist hand work and the environmental level which comes from a conception of art as an idea, and discipline of drawing project. A project consisting of a set of two hundred wood logs, piled up in ten different layers and displayed all over the exhibition room. These wood logs work as scene objects once they are part of a theatrical structure that causes an effect on the bodies of spectators as these are stimulated to wander, to walk through this labyrinth and at the same time they are offered an pre-cinematographic and imaginative experience, or a dream, as defends Gaston Bachelard who repeats in the context of architecture and culture the same assumptions of an experience of immersion realized in a natural landscape.

In this process of sculpture emancipation, emptiness plays an important role as it is part of a theatrical structure which is common to both objects of our study. The spectator of "Vontade", "Fadiga de Estruturas" and "Wander" walks in 
emptiness while his experience oscillates between two degrees of experience virtualization: the one given by the construction of a visual field in miniature whose structure is handmade with water and sand and the one which results from the act itself of walking once that a pre-cinematographic experience is being taught. Indeed, these pieces together with "MEGAPARSECS" work as the continuation of the ideas found in "La forêt" and "Uma floresta para os teus sonhos (a forest for your dreams)"; another thing they have in common with these is the fact that all derive from memory auscultation, which is the more creative genre of thought.

"MAGMA" 2008, sought the intentional articulation of aesthetics with ethics by proposing sculpture as an exercise of earth regeneration and by using in this context not only tri-dimensional sculptural interventions but also bidimensional ones as well. All the mentioned examples of sculpture, not only the ones that are the object of our study, but also the ones that were born from our own authorial artistic practice, testify the idea that the notion of landscape as a "view" is no longer valid for the reason that it is the cause of our contemporary problems. Our contemporary world witnesses all kind of environmental troubles. We do not fail to recognize that landscape is built by the action of man; the problem lies in the scale of that action which no longer enables earth to regenerate, jeopardizing man himself. Landscape as a "view" corresponds to the conception of the space that provoked this state of things; This notion of landscape noticed that when an individual watching a landscape is distant from the object viewed, it gives him the illusion that the landscape is an isolated window. As a result, all kinds of landscape changes are accepted precisely because the individual does not take into account that himself will be affected by nature degradation.

If for us the bi-dimensional representations of forests convey the idea of nature, in reality, they end up revealing a natural tendency for negative aesthetics. The great medieval European forest was the place of hunting, of legends, myths and monsters and that entire fictional legacy turned forest representations into the paradigms of oddness, of what is uncomfortable, uncertain and grotesque, instead of conveying the paradigm of pleasant beauty. 
This issue, which was approached in chapter $I$, is related to the practical proposals presented in the last chapter. Arnold Berleant, who is only mentioned in the conclusion of this dissertation, gives us a true clue for the articulation between aesthetics and ethics. In the opinion of this author, the idea of landscape as a "view" is no longer valid for us and neither is positive aesthetics because it is based on the detachment of the watcher from the landscape that is being watched. Instead, in order to re-attach man to his environment, Berleant suggests commitment aesthetics which considers landscape as a milieu, questioning the notion of "negative delight". That is, because delight makes man become ethically closer to nature, it is then urgent to call his attention for actual landscapes subjugated to pollution, for the chaotic growth of cities etc... His proposal is based on the idea that when man will realize that the abyssal transformations that occurred in nature are his own responsibility, then the idea of landscape as a window will fade and anxiety brought by delight will persuade man to have a different attitude towards nature, following aesthetic criteria that will assure sustainability. 


\section{INTRODUCCIÓN}

El presente estudio, titulado Una Construcción Teórico-Práctica del Paisaje en el Campo Escultórico, explora una posible forma de presentación de un proceso creativo que tiene como uno de sus índices principales de práctica artística el tema del paisaje encuadrado por la noción de campo escultórico.

Todo el trabajo de escritura e investigación estuvo relacionado, de forma más o menos alternada, con mi producción como artista plástico, e inevitablemente también con mis responsabilidades como profesor de Artes Plásticas. Por lo tanto, no nos pareció necesario acentuar una distinción entre teoría y práctica, investigación y experiencia del cuerpo, o entre un método de investigación y los datos recogidos a partir de la práctica artística. Tampoco creemos necesario establecer distinciones entre las tradicionales categorías académicas, pues ese ejercicio parece siempre crear un desvío en relación al proceso artístico, siempre complejo, intrincado e incompleto. El título Una construcción teórico-práctica del paisaje en el campo escultórico nos pareció una posible aproximación a esa realidad compleja que implica trabajar en el entorno de las artes plásticas, donde algunas de las determinaciones más importantes dependen del reconocimiento de que el lenguaje del arte es un "lenguaje mudo", "no verbal" $y$, por lo tanto, no totalmente traducible a cualquier lenguaje verbal.

El lenguaje del arte es a veces un "lenguaje mudo": es el lenguaje de los materiales, de la forma sensible cómo fueron organizados y decididos. Por eso, en arte, cabe "hacer" lo que no se puede decir con palabras, apelando así a otro tipo de entendimiento que no pasa total y únicamente por la idea de comunicación, sino por la expresión ${ }^{1}$.

\footnotetext{
1 En Filosofia em Nova Chave (São Paulo, Perspectiva, 1989), Susanne Langer establece la distinción entre lo que, en el arte, es y no es del orden verbal. En su libro El lenguaje del Arte, Psicología y Sociología del Arte, Buenos Aires, Editorial Paidós, 1965, 1a ed., pág. 25, Jacobo Kogan resume así la problemática de Langer, quien "distingue entre "símbolos discursivos", "que son los del lenguaje propiamente dicho, y "símbolos presentativos", que son las formas significativas visuales y auditivas, como los dibujos y combinación de sonidos, que en sus expresiones elementales son los instrumentos más primitivos de la inteligencia, pero que en las formas artísticas adquieren estructuras complejas, constituyen símbolos de honda significación y presentan una articulación lógica peculiar".
} 
Lo que se fija a través de la palabra puede, en algunos casos, inviabilizar futuras prospecciones de trabajo. Esto por variadas razones, de las cuales enumeraría sólo algunas: todo artista sabe que no puede hacer públicos, ya sea en forma de comunicación o de análisis, algunos de sus motores, que podemos denominar en sentido extenso creencias. No se trata de una mera fantasía. Por el contrario, no se puede desvelar lo que constituye la raíz del trabajo, porque mucho de lo que condiciona las opciones de los artistas no pertenece al campo de lo racional o de lo conocido, y nadie conoce un lenguaje verbal que funcione bien en un registro irracional o de lo desconocido. En este sentido, no es improbable que, en determinados momentos, haya llegado demasiado lejos en el comentario a mi propio trabajo; de ser así, tendrá consecuencias sobre la práctica cotidiana en el estudio o en el paisaje, que es un estudio sin techo.

\section{a) Motivación Personal}

La principal preocupación de este trabajo de investigación consiste en integrar en la producción plástica propia los contenidos teóricos relacionados con ella. Tal como defiende Jean Lancri, "una tesis de artes plásticas tiene por originalidad entrecruzar una producción plástica con una producción textual"². En el cruce entre práctica plástica y lenguaje verbal exigido para la redacción de una tesis, se deben hacer varias consideraciones. La primera es que la práctica de las artes plásticas desde siempre se ha definido por ser algo que está en constante transformación y devenir. El arte es siempre una promesa de transformarse en otra cosa; en ese sentido, la práctica del arte siempre ha integrado aportaciones de otras artes, como la poesía, la literatura, el teatro, la música o la danza, y, más recientemente, la contribución aún más acentuada de la estética, de las ciencias sociales y humanas, de la historia en general y de la historia del arte en particular, prueba de que tal movimiento de integración de otros saberes en el territorio de las artes plásticas es la gran hibridación de sus contenidos, muchas veces plasmada en texto por artistas.

\footnotetext{
${ }^{2}$ LANCRI, Jean, "Modestas proposições para as condições de uma pesquisa em artes plásticas na Universidade" in O meio como ponto zero: Metodologia de Pesquisa em Artes Plásticas - Instituto de Artes- URFGS, Porto Alegre, 2002. p.19.
} 
La segunda mitad del siglo XX conoció un gran incremento de producción teórica hecha por artistas que necesitaron reflexionar sobre su propio trabajo. Esa producción teórica se convirtió en una importante herramienta, tanto para los propios artistas, como para los investigadores del campo de las artes. Sin embargo, a pesar de ser incesantemente citados en el medio académico, sus trabajos nunca llegaron a adquirir la autoridad científica que los validaría como conocimiento de forma más amplia. Porque funcionan de forma aforística, a través de notas sueltas, o responden a las circunstancias propias de una entrevista, los escritos de los artistas no son considerados como verdaderas tesis, porque no obedecen a un método científico previamente definido, ni a una argumentación acotada por la lógica de la causa/efecto.

La solución para este embrollo parece ser mantener un pie dentro y otro fuera de las restricciones circunstanciales del método científico. A este respecto, quiero reconocer aquí la gran sensibilidad y apertura de mi tutora cuando discutimos estas problemáticas.

\section{b) Objetivos}

Como consecuencia de lo anteriormente expuesto, surgieron varias preguntas previas: ¿cómo presentar un proceso creativo sin que eso se confunda con método de la investigación científica comúnmente aceptado en el contexto institucional? ¿Cómo usar el lenguaje verbal para realizar una aproximación a la práctica artística y al lenguaje muchas veces mudo que lo caracteriza? ¿Cómo fijar de forma provisional y abierta, cuestiones pertenecientes al campo del arte, sin ceder totalmente a la idea de demostración?

La respuesta a estas preguntas previas desencadenó la estrategia y los objetos de estudio de esta tesis. Así, se empezó por intentar auscultar empíricamente cómo funciona un proceso creativo. Por deber de síntesis, llegamos a las tres condiciones capaces de desatar el proceso creativo. La primera condición es que es necesario tener convicciones y valores. La segunda implica la posesión de un bagaje y la profundización en lo que podríamos calificar de afinidades. Por último, es necesario desarrollar un mecanismo de valoración 
sensible e intelectual de la obra que se va produciendo y que más tarde podrá (o no) ser presentada y tener existencia pública.

Las convicciones y los valores personales fundan nuestra personalidad, arraigan en nuestras memorias y predestinan nuestras acciones futuras de modo no programático. Entre muchas otras, debo mencionar algunas que me interesan particularmente, como la preocupación ecológica. Mi convicción es que el arte debe tener un papel de disminución paulatina de la velocidad exterior introduciendo arcaísmo. Debe ser susceptible de provocar sobresalto, interrumpir la vorágine de los días, mezclarse con la vida, ser expresivo más que comunicativo y tener un papel amplio que va de la estética, pasando por la ética y por la política.

En la actualidad, las preocupaciones ecológicas encuentran acogida en mi trabajo, pero no como una mera ilustración o actitud política panfletaria de esa preocupación. En realidad, si ese valor puede ser el punto de partida del trabajo, no es el punto de llegada. Esto porque el propio proceso de trabajo se encarga de transformar la urgencia del aquí y el ahora del mundo empírico en una manifestación sensible e intelectual que se quiere "no datada" y "no traducible al lenguaje verbal". En este contexto, la escultura/instalación trabajada, ya sea mediante la práctica tridimensional, o a través de la bidimensionalidad de la fotografía, surge muchas veces como modo de proponer la regeneración de la tierra a través del arte, ${ }^{3}$ por medio de un proceso creativo que explora escalas de tiempo más lentas, como la geológica y la biológica.

El encuentro de afinidades y su profundización es esencial, ya que cualquier artista necesita tomar partido. Para ello tiene que encontrar aquello que los otros hicieron, hacen, dijeron o dicen. En el fondo, se trata de encontrar un grupo de autores cuyas obras parecen compartir las mismas preocupaciones que constituyen nuestras convicciones. Naturalmente que ésa es muchas veces la base de cualquier proceso creativo y tan importante es cuanto nos aproxima a un

\footnotetext{
${ }^{3}$ Estas afirmaciones mías fueron reproducidas en el artículo publicado en el Jornal de Letras una semana antes de la realización de la cumbre de Copenhague 2009, coordinada por Maria Leonor Nunes, con el título "Uma Cultura da Natureza", In Jornal de Letras, Artes e Ideas, no 1022, 2 de diciembre de 2009, pp. 12-17.
} 
proceso de trabajo, o a la obra de un autor, como lo que nos distingue. Toda aproximación tiene como finalidad última la distinción, es decir, la búsqueda de aquello que puede ser singular, separado de aquello que es igual. Esta prospección de las afinidades es un trabajo incesante. Una vez iniciado el proceso creativo, empiezan también las dudas. Por eso, para continuar pensando plásticamente, el artista tiene que forzar su propio pensamiento, testar la resistencia del trabajo realizado, ver si aguanta y si es lo suficientemente fuerte como para poder ser presentado en público.

Para el artista que busca afinidades, la historia del arte no existe, ${ }^{4}$ porque ésta se construye a partir de un punto de vista que no es el del artista. El punto de vista del historiador se centra en la recepción crítica de las obras, en la comprensión de las influencias, en el análisis de los elementos del estilo y de la transformación de estos, etc. $Y$ éstas son premisas de estudio que no interesan en absoluto a los artistas. Lo que reviste interés para el artista plástico es la historia existencial y de concepción que permite reconocer, en la producción de un conjunto de artistas, obras que para él han sido decisivas. Si la Historia del Arte fuese aquello que es para el artista, entonces no sería universal. Para el artista, lo que cuenta es la división de esta categoría en muchas historias singulares. La Historia del Arte hecha por un historiador tampoco es el trabajo de rememoración del pasado en función de los intereses de un artista; de hecho, aunque ese trabajo pueda ser hecho por un historiador, no es muy común. Esa historia sólo puede ser hecha por el artista, el único que tiene la capacidad de extraer paulatinamente todas las consecuencias de sus referencias, mezclándolas con su experiencia de vida.

Por último, un artista debe crear y alimentar un mecanismo de valoración sensible e intelectual de la obra que va produciendo. A menudo la valoración

\footnotetext{
${ }^{4}$ Georges Didi-Huberman, en su libro titulado Devant le temps. Histoire de l'art et anachronisme des images, París, Éditions de Minuit, 2000. [ed. castellana, DIDI-HUBERMAN, Georges, Ante el tiempo, Historia del arte y anacronismo de las imágenes, trad. de Oscar Antonio Oviedo Funes, Buenos Aires, Editorial Adriana Hidalgo, 2005]. Presentamos una idea de nivelación de las obras de arte a partir de ellas mismas y de su capacidad para hacernos parar en la vorágine del tiempo. En este libro, DidiHuberman critica, recordando a Marc Bloch, la noción científica de historia, mostrando el "apoderamiento impuro» que ejerce, un efecto de montaje que corrompe su pretensión «abstracta metafísica» y «absoluta». Para este autor, la concepción más profunda de historia se asienta en la acción rememorativa o mnemónica.
} 
sensible se compone del aprendizaje hecho por el cuerpo, a través de gestos, mnemónicas de proceso, memorias, así como por el sentimiento de placer o displacer, además de otros índices susceptibles o no de ser nombrados. El mecanismo de valoración sensible e intelectual se fundamenta naturalmente en las dos primeras condiciones esenciales para que exista un proceso creativo: las convicciones y la profundización de las afinidades. El mejor o peor resultado de este mecanismo se refleja en la materialización de los objetos plásticos producidos, y no tanto en cualquier verbalización que se pueda hacer de ese proceso. Eso sucede porque en la valoración no sólo participan conocimientos y saberes que se pueden nombrar por medio del lenguaje verbal, sino también y sobre todo cuestiones que pertenecen al orden de lo inefable, de aquello que no puede ser verbalizado y mucho menos ordenado en una relación de causa y efecto $\mathrm{y} / \mathrm{o}$ de narrativa lineal.

La respuesta a las tres preguntas antes mencionadas [¿Cómo presentar un proceso creativo sin que eso se confunda con método de la investigación científico comúnmente aceptado en el contexto institucional?, ¿Cómo usar el lenguaje verbal para hacer una aproximación a la práctica artística y al lenguaje mudo que lo caracteriza?, ¿Cómo fijar de modo provisional y abierto cuestiones que me interesan, sin ceder totalmente a la idea de demostración?] se basa en las tres condiciones esenciales para que se pueda constituir un proceso creativo: tener convicciones, profundizar las propias afinidades y desarrollar un mecanismo de valoración sensible e intelectual de cuanto se va produciendo.

\section{c) Metodología}

Entre las tres condiciones para la constitución de un proceso creativo, la segunda -tener y profundizar afinidades- se afirma como criterio capaz de estructurar la presente tesis, teniendo en cuenta las contingencias enumeradas y la necesidad de convertir la investigación en algo productivo y concomitante con el desarrollo del trabajo plástico individual.

Entre muchos autores posibles para anclar el inicio de la reflexión, que se caracteriza por un recorrido meditativo a partir de la idea de paisaje en el campo 
de lo escultórico, escogí, por necesidad de síntesis, las obras de Alberto Giacometti y de Alberto Carneiro. Pero ese era aún un campo demasiado amplio, y señalar la investigación a partir de estos dos autores no daba mucho margen para expresar de qué modo tales afinidades podrían formar parte importante de un nuevo proceso de trabajo, cuya complejidad y proveniencia de las afinidades es bastante más lato. Así, se decidió restringir aún más el campo de investigación a dos de sus obras más representativas, respectivamente, La forêt, (El bosque), 1950 y Uma floresta para os teus sonhos, (Un bosque para tus sueños), 1970. Ambas obras son esculturas que participan de la condición de paisaje.

Antes de profundizar más específicamente en cada una de estas obras, la tesis comienza por presentar, en el primer capítulo, titulado Paisaje $y$ representación, lo que se entiende por paisaje en su doble vertiente de relación con un territorio, pero también, y sobre todo, como representación. Mostraremos cómo el paisaje como representación es un dato cultural relativamente reciente inaugurado en la modernidad europea, para, a continuación, proceder a una breve cartografía de las representaciones bidimensionales, sobre todo pinturas, y las presentaciones tridimensionales entendibles en el plano de las prácticas escultóricas de bosques trabajados por el arte, desde el renacimiento hasta la actualidad. La preferencia por el tema del bosque surge en este contexto porque "El bosque es el exponente de lo natural", 5 quedando así definido desde luego que el interés por el paisaje implica en este caso una aproximación a la naturaleza y a su dimensión estética, ética y política.

El segundo capítulo, titulado ¿Qué es una escultura?, presenta el mapa teórico y conceptual anclado en el contexto de la evolución histórica del concepto de escultura. En este capítulo no se trata de responder de forma contundente la pregunta planteada (lo que, por otra parte, sería imposible), sino de mostrar un camino posible de problematización iniciado con una pregunta que tiene toda la utilidad para contextualizar no sólo el análisis de nuestros dos bosques como esculturas paisajistas, sino entender en cada uno de ellos su carácter procesal y

\footnotetext{
5 TAVARES, Gonçalo, M., Arquitectura Natureza e Amor, Oporto, eds. André Tavares y João Rosmaninho, Dafne editora, 2008. p.3, www.dafne.com.pt.
} 
proyectual y finalmente dar pistas para la contextualización de mi propio trabajo plástico.

En este segundo capítulo la gran amplitud de la cartografía se justifica por las conexiones lejanas que implica cada uno de los bosques. Denotando de esa forma un cierto vínculo con la condición europea de la práctica artística que al contrario de la norteamericana nunca se encuentra completamente libre del peso de la historia y del mito. En mayor o menor grado, según se trate respectivamente del trabajo de A. Giacometti o de A. Carneiro, podemos inferir en relación al análisis de nuestros objetos el grado de compromiso con la historia de la que se derivaron las nociones de espacio utilizadas en la creación de esculturas de carácter paisajista.

Los capítulos tercero y cuarto se centran en el estudio de los dos autores, de dos afinidades, a partir de dos obras emblemáticas: La forêt, de A. Giacometti, y Uma floresta para os teus sonhos, de A. Carneiro, que fueron consideradas especialmente interesantes y adecuadas para actuar como núcleos irradiadores de nuevas preguntas y amplias lecturas sobre el paisaje en el campo de la práctica de la escultórica.

En estes capítulos se exploran cuestiones esenciales del espacio escultórico, así como también se busca expresar y trabajar relaciones con el paisaje y la naturaleza. En estes capítulos, todavía centrados en los dos bosques de A. Giacometti y A. Carneiro, la naturaleza del espacio plástico de estos bosques es abordada procurando estrechar la relación entre el pensar y el hacer, explicitando la noción de espacio como proceso, como la de espacio como proyecto, recurriendo sobre todo a referencias bibliográficas procedentes de la fenomenología.

En el quinto capítulo se pretende presentar la forma como la investigación, hecha a partir del criterio de la afinidad, interfiere de modo productivo en algunos de los trabajos desarrollados en el periodo de tiempo contiguo al de la investigación teórica. En este punto del trabajo, quedarán patentes las proximidades y las distancias que se quisieron establecer inicialmente con las dos referencias y afinidades de donde partió este recorrido 
meditativo que, en toda la extensión, pretende llevar al lector a dar un paseo a veces acotado y caprichoso, con mayor o menor profundidad de campo, más 0 menos amplio, pero siempre "como forma de afrontar la realidad interna y externa, la manera de relacionar macro y microcosmos," ${ }^{\text {" }}$ utilizando la misma lógica del paisaje entendible en el entorno de la cultura.

Los dos obras que sirven de pretexto para ese proceso meditativo son, como ya fue mencionado, La forêt, 1950, y Uma floresta para os teus sonhos, 1970, de Alberto Gicometti y Alberto Carneiro respectivamente. Curiosamente, Alberto Carneiro tiene como referencia el trabajo y los escritos de Alberto Giacometti, por quien siente afinidad. Ambos bosques, cuya realización dista temporalmente dos décadas, son representativos de una posibilidad de contacto entre naturaleza y cultura y de dos modos de crear espacio o hacer paisaje en el campo escultórico.

Restringir el entorno inicial de la investigación a las dos obras anteriormente citadas facilitó la profundización de la afinidad, porque no interesaba tanto explotar su significado en el contexto de la historia del arte, de la crítica de arte o de la biografía de los artistas en cuestión, como lo que cada obra tiene de productivo para desencadenar un proceso de pensamiento y escritura, al tiempo que, paralelamente, se iban produciendo en el ámbito del taller y eran presentadas públicamente varias propuestas que cruzaban la cuestión de la naturaleza y del paisaje con el campo de la escultura.

La elección de las obras de Alberto Giacometti y Alberto Carneiro tuvo también como criterio y metodología el conocimiento directo, in situ, con las obras en diversas exposiciones realizadas dentro y fuera de Portugal. El primer contacto con la obra de Giacometti tuvo lugar en 1998, en el marco de una exposición significativa del trabajo del artista en la Fundación Arpad SzenesVieira da Silva, comisariada por Jean-Louis Prat. El entonces director de la Fundación Maeght reunió cerca de 40 trabajos, entre esculturas y dibujos, todos ellos pertenecientes a dicha fundación, que cubrían la producción del artista entre

${ }^{6}$ FULLAONDO, Juan Daniel, Oteiza y Chillida en la moderna historiografía del arte, Bilbao, Editorial La Gran Enciclopedia Vasca, 1976. 
los años 1945 y 1962. La forêt, así como muchas otras obras emblemáticas de este periodo existencialista, estaban presentes en la exposición.

En noviembre 2009, el Museu Berardo muestra la exposición titulada Silêncios. En ella estaba de nuevo la obra La forêt, pero esta vez con un enfoque particularmente interesante para el objetivo de estudio de esta tesis. En efecto, el comisario de la exposición, Marin Karmitz, siguió también como criterio para la elección de los artistas y de las obras el de la afinidad, "una forma de autorretrato que se diseña progresivamente, en la cual cada creación (...) demarca una historia, simultáneamente personal y colectiva"7. En el montaje de Karmitz, marcadamente existencialista, La forêt ocupaba el centro de toda la exposición, pareciendo situarse allí el punto de gravedad de todo el posible recorrido del espectador en una exposición organizada en forma de laberinto, diseñado por el arquitecto Patrick Bouchain, que constaba de quince obras más de otros tantos artistas contemporáneos, como Annette Messager, Juan Muñoz, Tadeusz Kantor, Mario Merz, Bruce Nauman, Chris Marker, Robert Gober, llya\& Emilia Kabakov, Christian Boltanski, etc. Todas las obras se relacionaban con La forêt, la más antigua del conjunto expuesto; sin embargo, por la forma como fue expuesta, se volvió inequívocamente contemporánea y no datada, ocupando el centro de una exposición que reúne y piensa la cuestión del cuerpo con el paisaje en el campo de la práctica artística.

En 1970, Alberto Carneiro, artista portugués nacido en 1937 en São Mamede do Coronado, S. Tirso, impulsado por una infancia y adolescencia vivida en el seno del mundo rural, presenta, en la galería Buchholz, Lisboa, Uma floresta para os teus sonhos ${ }^{8}$.Se trata de un ambiente que participa en el orden de la instalación, constituida por doscientos troncos de madera, escalonados en diez alturas diferentes, tendiendo a ocupar la totalidad de la sala. La intervención se presenta, en palabras del comisario, como una suerte de laberinto lúdico para ser experimentado por el espectador en sus recorridos apretados y caprichosos.

\footnotetext{
${ }^{7}$ KARMITZ, Marin, Silences: un propos de Marin Karmitz, Lisboa, Museo Berardo, 2009, p. 16.

${ }^{8}$ Exposición comisariada por el crítico de Arte Rui Mário Gonçalves, que según declaraciones del artista, con mucha dificultad consiguió llevar adelante el proyecto bastante osado para la época.
} 
El contacto con la obra de Alberto Carneiro en exposiciones se produjo antes; durante muchos años pude observar varias obras de este artista, como por ejemplo en el Centro de Arte Moderno José de Azeredo Perdigão de la Fundación Calouste Gulbenkian, donde su bosque estaba expuesto de forma permanente. Más tarde, volví a experimentarla en otros contextos expositivos individuales, como en la gran exposición individual en 2001 en CGAC, Centro Gallego de Arte Contemporáneo en Santiago de Compostela, comisariada por Cecilia Pereira. Más recientemente, y ya como docente de la Escuela Superior de Artes y Diseño de Caldas da Rainha (Escola Superior de Artes e Design de Caldas da Rainha), dirigí una invitación al escultor Alberto Carneiro -quien amablemente la aceptó- para realizar una conferencia en abril de 2004. De ese encuentro productivo, se generó la voluntad de querer profundizar la afinidad que ya mantenía con la obra y los escritos de este artista portugués. Reconocí en su trabajo mucha pertinencia y singularidad de las cuales aún no habían sido sacadas importantes consecuencias. También debo señalar que, durante el periodo de investigación, fue creciendo en el medio artístico y académico portugués y español el interés por el trabajo y por los escritos de Alberto Carneiro, algo que no era evidente cuando inicié este trabajo en 2006 y que confirma nuestra convicción de que nos encontramos ante un artista excepcional tanto en el panorama nacional como internacional.

Entre las singularidades más fuertes producidas por A. Carneiro, destacaría un concepto de paisaje escultórico contaminado de un entendimiento de la noción de espacio como proyecto derivado del dibujo del proyecto, que puede experimentarse en su obra Uma floresta para os teus sonhos. Se trata de una propuesta escultórica que se puede encuadrar en un campo expandido de la escultura, y se produce en un periodo de tiempo en que el artista negó el trabajo manual, transformándose, en palabras de Ernesto de Sousa, en un "operador estético", o sea, alguien que, no siendo un ejecutante de la obra a través del trabajo manual, opera y moviliza un conjunto de condiciones capaces de crear una obra en el espacio para el/los espectador/es. En este contexto, el trabajo de diseño de proyecto es esencial, pues es allí donde se vuelca toda la proyección conceptual de la obra. Más que representar, el bosque de A. Carneiro muestra 
literalmente una posibilidad de la existencia en el espacio real de la arquitectura del espacio expositivo, un bosque que tiene su existencia en el plano cultural de la práctica escultórica.

El criterio para la elección de estas dos obras, La forêt y Uma floresta para os teus sonhos, no es el de la mera analogía, sino el de la afinidad; es decir, no remite al hecho de que sean dos bosques, sino a que ambos expresan dos formas distintas, comunicantes a pesar de todo, de pensar el espacio de la multiplicidad, de la relación entre ciudad y naturaleza y del paisaje en su relación con la escultura. Más allá de la noción de paisaje entendido como "vista".

La metodología, además de privilegiar el contacto directo con las obras en contextos expositivos y de contar con declaraciones y conversaciones con Alberto Carneiro, también se deriva del análisis de los escritos producidos por los dos artistas, así como del análisis de algunos de los ensayos críticos más relevantes sobre el trabajo de Alberto Giacometti y de Alberto Carneiro que se encuentran reflejados en libros o catálogos de exposiciones realizadas en importantes instituciones.

Toda la investigación bibliográfica sirvió de base para la construcción de una reflexión propia susceptible de contribuir a la creación de aproximaciones y distanciamientos patentes en el proceso creativo propio. Para proceder a esa selección y avance productivo, fueron movilizadas para el presente estudio las obras de diversos pensadores, en su mayoría filósofos del área de la fenomenología.

La tesis tuvo una primera fase de investigación teórica y, paralelamente, una fase de trabajo práctico que se fue realizando y presentando en el marco de varios premios, exposiciones colectivas e individuales, dentro y fuera de Portugal. Los avances prácticos condicionaron la organización inicial de la estructura de la tesis y dictaron que se presentase en el formato actual. El trabajo práctico desarrollado fue objeto de selección para importantes exposiciones y premios internacionales en Portugal y España, como por ejemplo el IV International Expanded Painting Prize, patrocinado por el Ayuntamiento de Castellón, y expuesto en el Museo de Bellas Artes de esa ciudad, que tuvo como Jurado 
internacional Susanne Boecker, crítica de arte, Demetrio Paparoni, crítico de arte y comisario de la Trienal de Milán, Philippe Van Cauteren, sociólogo e historiador de arte, director del Stedelijk Museum voor Actuele Kunst de Genty de la Bienal de Ceará, Javier Panera, curador y Wences Rambla, artista plástico y profesor. Otro ejemplo es el $X$ Premio Internacional Unión Fenosa, patrocinado por esta empresa, cuya muestra se realizó en el Museo de Arte Contemporáneo Unión Fenosa, en la ciudad española de La Coruña, concedido por un jurado internacional que contaba entre sus miembros a Marta González Orbegozo, Historiadora de Arte y antigua conservadora jefe de las exposiciones temporales del MNCARS, Madrid, a Manolo Quejido Villarejo, pintor, a Rafael Doctor Roncero, Director del MUSAC, a David Barro López, crítico de arte y comisario de exposiciones, y al brasileño Paulo Reis, crítico de arte y comisario de exposiciones. Otro ejemplo más es el Premio Adquisición en la XV Bienal de Cerveira, Portugal, otorgado a una intervención individual que cruza el dibujo, la escultura y la fotografía, en el entorno del programa comisariado por Fátima Lambert para la XV Bienal de Cerveira titulada Incorporal, Simulacro ou Intangível. Este premio también fue concedido por un jurado internacional. A estos premios y a estas exposiciones, se juntan muchas otras realizadas entre 2006 y 2011. El trabajo producido y presentado en algunas de estas exposiciones será abordado en este estudio sólo en el cuarto capítulo a partir de los criterios inicialmente establecidos, para que se constituya y presente en lenguaje verbal un proceso creativo que busca, en las determinaciones del paisaje y en el campo de lo escultórico, una posibilidad, una forma de entender la práctica de la escultura más allá de sus determinaciones tradicionales. 


\section{CAPÍTULO I:}

\section{PAISAJE Y REPRESENTACIÓN}

\section{0}

\section{¿Qué es un paisaje?}

Al buscar el término "paisaje" en cualquier diccionario de portugués, encontramos las siguientes acepciones: «porción de territorio que se alcanza con la vista; cuadro que representa un lugar campestre, dibujo sobre un motivo rústico; aspecto, vista». ${ }^{9}$ Estas definiciones de paisaje inmediatamente acentúan el doble sentido que dicho término posee: tanto sirve para designar una parte del territorio tal como se percibe por los sentidos, en especial por la visión que ofrece la mirada, siendo que en este caso su "carácter resulta de la acción de factores naturales y/o humanos y de sus interrelaciones."10 (en ese sentido se habla de paisaje para designar una parcela de la naturaleza como una planicie, una montaña o un bosque) como también se puede dar la categoría de paisaje a una imagen, como por ejemplo una pintura o una fotografía, e incluso a obras como La forêt y Uma floresta para os teus sonhos, cuyo entorno de actuación se encuentra inscrito en lo escultórico.

La cuestión de decir que una cosa cualquiera se entiende como paisaje está relacionada con el hecho comunicativo del nombramiento por vía del lenguaje de un determinado tipo de realidad, o bien como representación de una realidad dada.

\footnotetext{
${ }^{9}$ En este caso el de Porto Editora, 8a edición, 1999: "porção de território que se abrange num lance de olhos; quadro que representa um sítio campestre, desenho sobre um motivo rústico; aspecto, vista".

${ }^{10}$ SERRÃO, Adriana Veríssimo, O que é uma paisagem para a filosofía. Texto amablemente cedido por la autora, que sirvió de base de apoyo para el curso de reflexión sobre el tema del paisaje. Departamento de Filosofía de la Facultad de Letras de la Universidad de Lisboa.
} 
"El siglo XVI presencia al nacimiento de la palabra: Paesel paesaggio, en la expresión pittura di paesaggio."11 Es en ese momento cuando la palabra paisaje gana un significado doble que "sigue manteniendo en el lenguaje corriente de muchas lenguas actuales: el de objeto real y el de representación o imagen representada de ese objeto. En alemán y holandés se forman Landschaft y Lanschap, en inglés Landscape todos estos términos designando territorio, región, provincia. En francés Pays que significa territorio, región, provincia y Paysage, de donde se deriva el término portugués Paisagem. Paysage se presenta como un neologismo para referirse a la pintura que representa una porción de territorio; sólo más tarde Paysage pasa a referir el modo de percibir aquello que de un territorio es perceptible por medio de la mirada"12.

Para comprender la naturaleza paisajista de obras escultóricas como $\mathrm{La}$ forêt y Uma floresta para os teus sonhos, antes deben ser establecidas algunas condiciones. En primer lugar, el paisaje no es un dato inexpugnable de la realidad existente a priori; es decir, la naturaleza no tiene paisajes, luego la noción de paisaje es un hecho cultural. Por otra parte, la noción de paisaje puede ser entendida, para mejor análisis de las obras de Alberto Giacometti y Alberto Carneiro, como una realidad mediadora entre la naturaleza como un todo, y el hombre separado de ésta porque vive en la civilización urbana, predominante desde hace algún tiempo.

\section{1}

\section{Representación de las escenas exteriores}

Para contextualizar el concepto de representación de paisaje establecido en el Renacimiento, tendremos que retroceder a la representación de escenas exteriores. En su trabajo de investigación, António J. S. Meireles elabora un

\footnotetext{
${ }^{11}$ Idem, Ibidem.

${ }^{12}$ Idem, Ibidem.
} 
resumen sobre los inicios de las primeras representaciones de paisajes. Así, según este autor, el hombre paleolítico (c. 500.000-8.000 a.C.) ejecutaba grabados rupestres representando animales. Las representaciones son cercanas a la realidad "hasta el punto de ser posible identificar las especies representadas". ${ }^{13}$ El espacio entre las figuras crea un lugar de existencia que en su conjunto parece configurar el espacio del territorio. El mismo autor señala que es muy rara, o prácticamente ausente, la existencia de elementos que muestren el contexto, como podrían ser los "elementos vegetales, la base como el suelo o el agua." ${ }^{14}$ Las formas se presentan en espacios no delimitados y sobre fondos no diferenciados. Así, este tipo de organización es extraño a la lógica del paisaje que se desarrollará posteriormente. En el mismo estudio se introduce la idea de que el sedentarismo y el cultivo de la tierra se implantaron alrededor de 8000 4000 a.C., en el Periodo Neolítico. La agricultura introdujo cambios profundos en la relación del hombre con la naturaleza envolvente, se constituyeron en ese momento los primeros asentamientos de población estables. El territorio comienza a ser trazado, diseñado, a partir de la función indicada por las prácticas agrícolas que tenían como principal objetivo el aprovechamiento de la tierra. ${ }^{15} \mathrm{De}$ plantaciones fragmentadas, se pasa progresivamente a una creciente geometrización, líneas rectas y figuras geométricas varias son inscritas en los terrenos, regularizándolos y estableciendo lindes. Tal fenómeno sucedió principalmente en Mesopotamia, en las márgenes de los ríos Tigris y Éufrates, o en torno al río Nilo, lugares donde se desarrollaron las primeras civilizaciones agrícolas. $^{16}$ Es en el arte egipcio donde encontramos las primeras y más ricas representaciones de elementos naturales conteniendo un poder simbólico ${ }^{17}$. En

\footnotetext{
${ }^{13}$ MEIRELES, António José Santos - As paisagens do desenho: características formais do desenho de paisagens. Lisboa: Universidade de Lisboa, Faculdade de Belas Artes, 2004, p. 27

${ }^{14}$ Idem, Ibidem.

${ }^{15}$ JELLICOE, Geoffrey e Susan, The Landscape of Man. Londres, Thames and Hudson, 1996.

${ }^{16}$ MEIRELES, António José Santos - As paisagens do desenho: características formais do desenho de paisagens. Lisboa: Universidade de Lisboa, Faculdade de Belas Artes, 2004, p. 28, 29.

${ }^{17}$ Ernst Cassirer en su Ensayo sobre el Hombre señala que, en el pensamiento primitivo, «un símbolo primitivo se ve como si fuese dotado de poderes mágicos o físicos. Con el avance del progreso de la cultura humana, sin embargo, la diferencia entre las cosas y los símbolos se siente con más claridad, lo que significa que la distinción entre realidad y posibilidad también queda cada vez más pronunciada». CASSIRER, Ernst, Ensaio sobre o Homem, Introdução a uma filosofia da cultura humana, trad. al portugués de Tomás Rosa Bueno, São Paulo, Martins Fontes, 2005. p. 97.
} 
el Egipto de esta época, se presentaban en bajorrelieves pintados los diversos trabajos en los campos, en función de las estaciones del año y de los "ciclos de

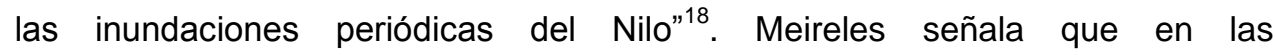
representaciones egipcios tanto tenemos acceso a las representaciones de escenas de caza como de los trabajos en el campo. En un bajorrelieve del "túmulo de Ti, podemos ver un pastor que transporta un pequeño animal recién nacido, para que no se ahogue en las aguas" ${ }^{\text {"19 }}$. Es en Mesopotamia, c. 1500 600 a.C., donde surgen en el arte asirio los primeros indicios de representación de escenas de exterior ${ }^{20}$ que explotan, de forma realista, los elementos que construyen el paisaje. En el Saqueo de la ciudad de Hamanu por Asurbanipal, c. 650 a.C., conservado en el Museo Británico de Londres, se reconoce con precisión la jerarquía espacial del paisaje, donde se sitúan los guerreros: la narrativa se desarrolla claramente en un espacio puntuado por árboles y el palacio de Asurbanipal, en Nínive, que ayudan a crear el espacio de la representación. ${ }^{21}$ En este aspecto, el arte asirio se aproxima bastante a aquel que constituirá el nacimiento del tema del paisaje.

Durante el periodo helenístico romano se encuentran también hermosos frescos cuya configuración servirá de base para los primeros escritos sobre el paisaje. Sobre el arte helenístico, E. H. Gombrich dice a propósito de un paisaje del siglo I, Pintura mural, Villa Albani, Roma, I, (Fig. 1), que:

Esos cuadros no son vistas reales de una casa de campo particular o de un bello paraje. Son más bien conglomerados de todo aquello que constituye una escena idílica: pastores y castillos, sencillos santuarios, casas de campo y montañas en la lejanía. Cada cosa estaba encantadoramente colocada en esos cuadros, y el conjunto parecía contemplado desde su aspecto mejor. Frente a estas obras experimentamos la sensación de que estamos contemplando realmente una escena apacible. Sin embargo, incluso esas pinturas son mucho menos realistas de lo que a primera vista podríamos creer. Si tuviéramos que responder a preguntas impertinentes acerca de la localidad, o tratar de

\footnotetext{
${ }^{18}$ MEIRELES, António José Santos, Op. Cit, p. 38.

${ }^{19}$ JANSON, H. W, História da Arte, trad. de J. A. Ferreira de Almeida y Maria Manuela R. Santos, Lisboa, Fundação Calouste Gulbenkian, $5^{\mathrm{a}}$ ed, 1992, p. 63.

${ }^{20}$ MEIRELES, António José Santos, Op. Cit, pp. 29-30.

${ }^{21}$ JANSON, H. W, Op. Cit, pp. 78-79.
} 
trazar un mapa de ella, nos daríamos cuenta de pronto que no nos es posible. Ignoramos cuál es la distancia que se supone existe entre la casa de campo y el santuario, ni si éste se encuentra cerca o lejos del puente. El hecho es que incluso los artistas helenísticos ignoraban lo que nosotros llamamos las leyes de la perspectiva. ${ }^{22}$

H. W. Janson se refiere a una pintura mural romana, Vista de un jardín, pintura mural de la Villa de Livia $^{23}$ (Fig. 2), cuya representación comprende espacios y formas naturales con exquisita atención al detalle, y que es un ejemplo de verdadero paisaje en la acepción que el término fue adquiriendo siglos más tarde. Otros ejemplos de frescos de esta época incluyen también personajes presentados en diversos actos e integrados con otros y variados elementos del paisaje natural.

La Edad Media codificó la realidad y, desde el final del Imperio Romano occidental hasta el Renacimiento, aproximadamente entre los siglos $\mathrm{V}$ y $\mathrm{XV}$, no hubo una relación de fidelidad entre la imagen creada y la realidad. En esta época, fuertemente dominada por la teología cristiana, que guía la "vida de los hombres, y principalmente la muerte, adquieren especial relevancia las teorías neoplatónicas, que condicionan la existencia del hombre menospreciando todo cuanto se relaciona con la vida terrena, en favor de la primacía de la vida espiritual." ${ }^{24}$ Meireles defiende que, en este contexto, el arte de representación del paisaje en la Edad Media europea no tenía sentido porque la representación, siendo fiel a un objeto, sería también simultáneamente una pálida imagen de su verdadero objeto y el mundo espiritual se constituía en otra realidad dotada de mayor profundidad y obedeciendo a la imagen verdadera de Dios. Así, cada imagen producida en esta época debería constituir un medio más eficaz de acceso a ese mundo pleno, y no debería ser nunca un retroceso a las cosas terrenas a cuya función de la copia de lo real se prestaba.

Se desarrolló entonces un lenguaje simbólico de fuerte propensión a la simplificación, muchas veces de corte geométrico, y, en algunos aspectos,

\footnotetext{
${ }^{22}$ GOMBRICH, E. H., La Historia del Arte, Madrid, Ediciones Debate, 2003, p. 114.

${ }^{23}, \mathrm{JANSON}, \mathrm{H}$. W, História da Arte, trad. de J. A. Ferreira de Almeida e Maria Manuela R. Santos, Lisboa, Fundação Calouste Gulbenkian, 5ª̂ed, 1992. p. 193.

${ }^{24}$ MEIRELES, António José Santos - As paisagens do desenho: características formais do desenho de paisagens. Lisboa: Universidade de Lisboa, faculdade de Belas Artes, 2004, pp. 31-32.
} 
abstracción de sus componentes. Así, cada planta no valía por aquello que significaba en el mundo natural, sino por la acción que desempeñaba simbólicamente en toda la estructura de la teología cristiana, de quelas sagradas escrituras eran su exponente máximo. Esa estructura definía también una jerarquía para todos los elementos naturales.

En el mundo medieval, si todas las formas de existencia natural no pasaban de "pálidas referencias de su origen divino" ${ }^{25}$, la atención concedida a la representación de los espacios donde esas formas de la naturaleza existían era aún mayor. Tal hecho dejó en un segundo plano el desarrollo de su traducción en términos de perspectiva.

Las codificaciones medievales van siendo cuestionadas a medida que se asiste al nacimiento de la modernidad basada en la revalorización del hombre, como individuo que crea, expresa sus emociones y promueve la cultura del saber.

Antes mencionamos el modo de existencia paisajístico en la Edad Media, o sea, las formas de representación de espacios exteriores que pueden ser encontradas desde el momento en que el hombre empezó a producir estructuras simbólicas. Hablar de paisaje en estas épocas sólo tiene sentido a través del análisis del estilo, ya que los términos en que aparece y se desarrolla el arte del paisaje sólo harán su aparición durante el Renacimiento Italiano.

\section{2}

\section{El Hombre Moderno y la Aparición del Paisaje}

El término paisaje, así como sus materializaciones en el campo de las artes, son una invención del hombre moderno. El episodio que se considera el primero y más importante testigo de la aparición de una consciencia paisajista es

\footnotetext{
${ }^{25}$ Idem, Ibidem.
} 
la descripción de la Subida al Monte Ventoso ${ }^{26}$, de Francesco Petrarca. Realizada en el inicio del Renacimiento, plantea la cuestión de la aparición de la noción de paisaje todavía en un momento de punto de inflexión entre la época medieval, portadora de toda una estructura teológica basada en lo absoluto divino de la figura de Dios, y la época renacentista, inicio de una modernidad que se encargó de relativizar la presencia totalizadora de la imagen de Dios. Para Kenneth Clark, Petrarca es el hombre clave de la transición del mundo medieval al mundo moderno. "Petrarca aparece en todos los libros de historia como el primer hombre moderno; y con acierto, pues por su curiosidad, escepticismo, desasosiego, ambición y autoconsciencia, es ciertamente uno de nosotros" ${ }^{27}$ aunque dominado por una modernidad ambigua pues "estas características están aún dominadas por la filosofía monástica." ${ }^{28}$ Según ésta, la vida terrena del hombre no es más que un "breve interludio, el ambiente en que se la vive no debe absorber nuestra atención. Si las ideas son la imagen de Dios, y las sensaciones viciosas, nuestra interpretación de las apariencias debe ser todo lo posible, simbólica, y la naturaleza, de la cual nos enteramos por nuestros sentidos, se vuelve positivamente pecaminosa. San Anselmo, que escribió a principios del siglo XII, sostenía que las cosas son peligrosas en proporción a las sensaciones agradables que despiertan en nosotros, y por consiguiente consideraba peligroso estar sentado en un jardín donde había rosas que daban placer por su aroma y color, así como escuchar canciones e historias que agradaban a los oídos." ${ }^{29}$ Frente a esta situación, Petrarca humanista se sitúa en una zona de punto de inflexión entre el mundo medieval y el mundo moderno. En Voir la terre, ${ }^{30}$ Jean-Marc Besse analiza la carta de Petrarca que relata La Subida al Monte Ventoso como siendo el momento fundador que instaura la idea de paisaje a partir de la idea de separación. Este poeta Italiano quiere hacer que el

\footnotetext{
${ }^{26}$ PETRARCA, Francesco, La ascensión al Mont Ventoux, 26 de abril de 1336, Asociación de Amigos del Museo de Bellas Artes y Artium de Álava, 2002.

${ }^{27}$ CLARK, Kenneth, Paisagem Na Arte,Trad.de Lúcia H. O. Gerardi y Silvana M. Pintaudi, Lisboa, Editorial Ulisseia, 1969, p. 25.

${ }^{28}$ Idem, ibidem.

${ }^{29}$ Ibidem, p. 20.

${ }^{30}$ BESSE, Jean-Marc, Ver a Terra. Seis ensaios sobre a paisagem e a geografía,Trad. de Vladimir Bartalini, São Paulo, Editorial Perspectiva, 2006.
} 
lector penetre alegóricamente en otro espacio, el de una experiencia espiritual que implica transgresión, a través de la descripción de su ascenso a la montaña, para poder disfrutar, contemplando desinteresadamente desde su cima el mundo natural abierto a la mirada. Allí residiría la fórmula de su experiencia paisajista y por eso moderna del poeta y moralista italiano. Pero su formación teológica lo lleva a postergar su subida; el texto muestra que, mientras su hermano toma el camino más corto para la subida, Petrarca zigzaguea, volviendo el recorrido más lento, melancólico y contemplativo, pero también intentando atrasar su resolución final, la llegada a la cumbre de la montaña. Su proyecto es la descripción de las fuerzas contradictorias que le llevan a ser osado y transgresor, y esas teológicamente lo constituyen, instaurando una división irresoluble.

El paisaje se eleva a categoría de espacio; se instaura el yo y el otro, se inician los papeles de observador y observado, de activo y pasivo, de la mirada y de la devolución de la mirada. Son estos los pares dialécticos que hacen posible la categoría del paisaje.

Un paisaje sólo existe como tal, como especie de pedazo o retazo de territorio, o incluso como objeto de representación en una descripción textual, en una pintura o escultura, a partir del momento en que el hombre moderno, en el comienzo del Renacimiento, se ve en una situación nueva: la de estar separado de una totalidad que constituiría el absoluto teológico medieval. Se inaugura la fragmentación de la experiencia humana y la desvinculación generalizada del hombre en relación al anterior periodo medieval. Es esta situación de separación la que instaura el individuo como observador de un observado. Es en este momento cuando aparece el dispositivo artista/modelo y también la posibilidad de que un fragmento de lo real pueda ser denominado paisaje.

Yves Bonnefoy observó que "un artista de la Edad Media no hubiera soñado con hacer estudios de paisajes, no se representa lo particular cuando se tiene la felicidad de lo universal, no hay porqué detenerse en los hechos del azar cuando lo posible, y también lo obligatorio, es celebrar aquello que los transciende. El paisaje comienza en el arte con las primeras angustias de la consciencia metafísica, que se inquieta de repente con la sombra que se mueve 
bajo las cosas." ${ }^{31}$ A partir del Renacimiento, surge la posibilidad de representar lo particular, el paisaje, porque toda la estructura teológica medieval comienza allí a dar sus señales de debilidad. El sincretismo medieval implicó un mundo absolutamente pleno, sin vacíos, todo lleno por una presencia absoluta de la imagen de Dios. Es el plano de imagen medieval el que justifica todas las conexiones existentes y, de cierta forma, las cristaliza y estabiliza. De esta forma, no hay espacio para la invención de nuevas conexiones o ni siquiera perspectivas inesperadas. Esto quiere decir que la conexión con la naturaleza como paisaje nunca podría haber existido en el mundo medieval, porque se trata de un tipo de relación y conexión individual inesperada e inventiva, lo que estaría fuera de lo ya instituido por la estructura teológica medieval cristiana.

La Edad Media poseía un centro ideal de valores que importan, poseía un valor supremo, al cual todos los demás valores estaban sujetos: la creencia en el dios cristiano (...) era un sistema total del mundo basado en la fe, un sistema del mundo enteramente fundado en el ser y no en el porvenir, y su estructura social, su arte, sus lazos sociales, en una palabra, toda la estructura de valores estaba sometida al valor vital de la fe, que a todos abarcaba. ${ }^{32}$

Toda la estructura teológica medieval cristiana se fundaba en una "idea" ${ }^{33}$ fuerte 0 , lo que viene a dar a lo mismo, en una imagen fuerte y movilizadora de lo real, dotándolo de un orden bien definido. Pero ese orden empieza a mostrar señales de fragilidad ya durante la Edad Media, permitiendo violencias en cadena y sin conseguir dar respuesta a la tortura y al sufrimiento impuesto por las varias guerras y privaciones sucesivas. La estructura teológica medieval cristiana sólo funcionó mientras logró suspender la violencia; a partir del momento en que la violencia y la muerte empezaron a ser la regla y no la

\footnotetext{
${ }^{31}$ BONNEFOY, Yves, Le peintre dont l'ombre est le voyageur, RueTraversière et autres récits en rêve. París, Gallimard, 1992, p. 162. Op.cit. Besse, Jean-Marc, Ver a terra seis ensaios sobre a paisagem e a geografia, trad. de Vladimir Bartalini, São Paulo, Editorial Perspectiva, 2006.

${ }^{32} \mathrm{BROCH}$, Hermann, Os Sonâmbulos, vol. III Huguenau ou o realismo, Lisboa, Edições 70, 1989, p. 112.

${ }^{33}$ Idea viene del griego ideia, que significa imagen fuerte. En Europa Occidental la imagen de Dios tuvo éxito por lograr interrelacionar de forma intensa una serie de elementos dispersos de forma eficaz. La imagen de Dios como ideal garantizaba la inmortalidad, la belleza de los cuerpos y la ausencia de la enfermedad, volviendo a la mortalidad, la fealdad de los cuerpos y la enfermedad como algo provisorio y transitorio.
} 
excepción; se hizo difícil creer en la transitoriedad del sufrimiento propuesto por la teología cristiana ${ }^{34}$, dándose el inicio de su colapso, justificando en cierto modo el Renacimiento y con él la situación moderna.

\section{3}

\section{Institución del Paisaje}

En el análisis del tema del paisaje en el Arte deben ser considerados dos autores y sus abordajes específicos: Kennet Clark y E. H. Gombrich. El primero, en Paisagem na Arte $^{35}$, cuya primera edición data de 1949, hace un abordaje de la evolución del estilo. Gombrich, en su texto Teoria da Arte no Renascimento e a Elevação da Paisagem ${ }^{36}$ reflexiona sobre el aspecto institucional, más precisamente cómo la teoría del arte renacentista creó el marco necesario para la aparición y el éxito del arte del paisaje.

No nos vamos a concentrar en la obra de Kennet Clark, ya que su perspectiva de análisis de la evolución de los estilos nos será más útil en el momento de la cartografía de las representaciones de bosques en la historia de la pintura occidental. Sin embargo, es importante mencionar que este autor sugiere que la aparición del paisaje en la pintura se debe a un proceso que pasó a primer plano las escenas de naturaleza que antes ocupaban el fondo, los planos intermedios o el margen. En este contexto, la historia de la pintura de paisaje comienza en Grecia y en Roma pasando por la Edad Media, y por lo que llamó "paisaje de símbolos", y de ahí en adelante, hasta comienzos del siglo XX. Según este planteamiento, el paisaje toma su lugar en los planos de frente a

\footnotetext{
${ }^{34}$ MIRANDA, Bragança, Seminario de "Cibercultura» insertada en el curso de maestría en comunicación y cultura contemporánea, marzo-junio 2006, FCSH-Universidade Nova de Lisboa. Notas de la charla. Mimeografiado.

${ }^{35}$ CLARK, Kenneth, Paisagem na Arte, trad.de Lúcia H. O. Gerardi y Silvana M. Pintaudi, Lisboa, Editorial Ulisseia, 1969.

${ }^{36}$ GOMBRICH, Ernst Hans, "A Teoria da Arte no Renascimento e a elevação da Paisagem", trad. de Alexandra Lopes y Helena Buescu, in Concerto das Artes, Lisboa, Campo das Letras, 2007. pp. 261291.
} 
partir del Renacimiento, siendo Alberto Durero uno de los grandes pintores de paisaje. Pero E. H. Gombrich, en su texto arriba mencionado, nunca integró la institución de la pintura de paisaje, pues "probablemente consideraba sus famosas acuarelas topográficas meros estudios que sería incapaz de vender a cambio de dinero honesto" ${ }^{37}$. La razón principal para la no inclusión de A. Durero dentro del contexto de la pintura de paisaje es que él, siendo un pintor del Norte, a pesar de tener contacto con Italia, no gozó del marco teórico que en el Renacimiento Italiano creó un mercado próspero de pintura de paisaje.

Para contestar la pregunta “¿Qué es un paisaje?”, y después de haberlo hecho desde el punto de vista filosófico, falta ahora describir el proceso institucional abordado por E. H. Gombrich. Éste, en el texto anteriormente mencionado, centra toda la cuestión del paisaje en el conjunto de las teorías que en el Renacimiento Italiano crearon un marco cultural y una predisposición mental para la aparición y florecimiento de este género. Para llevar a cabo esta reflexión, Gombrich empieza por definir lo que para él es paisaje o pintura de paisaje, "cuando hablo de pintura de paisaje no me refiero a la reproducción de escenas exteriores, sino a un género artístico aceptado y reconocido". ${ }^{38}$ Para definir este punto Gombrich cita a un pintor del XVII, Edward Norgate, y su Miniatura or the Art of Limning, 1650, como un verdadero descubrimiento.

Para Gombrich, en la segunda mitad del siglo XVI el paisaje pasó a ser un tema aceptado, tanto en cuadros como en grabados: se convirtió en una institución. Lautensack e Hirschvogel ya consideraban que su oficio era producir paisajes que eran demandados en el mercado en expansión formado por grandes coleccionistas famosos y otros anónimos. Esa circunstancia configuraba un mercado de obras de arte originales no sometidas a la lógica del encargo, propiciada por la emancipación del artista y, de resultas de esa libertad, la creación de variados géneros artísticos.

Es la creación del mercado de arte permite el desarrollo del par institucional consumidor en la figura del coleccionista/artista. El primero regula la

\footnotetext{
${ }^{37}$ Ibidem, p. 264.

${ }^{38}$ Ibidem, p. 261.
} 
oferta y el segundo se especializa progresivamente, en particular en pintura de paisaje, hecho que aquí interesa resaltar. Pero “¿cómo se explica que alguien buscase cuadros de paisajes a no ser que el concepto y la palabra ya existieran?" ${ }^{39}$ Esta es la pregunta que Gombrich va a contestar. La palabra paisaje utilizada en el arte de la pintura aparece por primera vez en Venecia y no en Amberes, que en la época era la ciudad que tenía el mercado de arte más avanzado, competitivo y abierto. En su trayecto para contestar la pregunta planteada, Gombrich argumenta que es en el sur de Europa, y más en concreto en Italia, donde se origina el arte del paisaje. Aunque en el norte los pintores estuviesen más avanzados en la creación de fondos paisajísticos, no hay relatos en los que conste algún paisaje en las colecciones más importantes en esa región geográfica, como si ocurre en Italia, en las colecciones del cardenal Grimaldi y la de Frederico Gonzaga, se encuentran ya manifestaciones de este género artístico. En el primero, se encuentran pintores como Alberto de Holanda (también identificado como Albert Outwater), Domenico Campagnola, pero principalmente, Giorgione que para Marc Antonio pertenecía también a la categoría de paisaje. Es curioso también el hecho de que la colección de Frederico Gonzaga de Mantua posea paisajes flamencos. Éstas son "indicaciones que nos llevan a creer que ésta pudo haber sido el regalo que el sur Renacentista ofreció al norte Gótico" ${ }^{\prime 0}$. La primera condición para este obsequio es, para Gombrich, una actitud estética que valora la obra y el genio, y por lo tanto la autonomía creativa del artista. Estas transformaciones no se produjeron "del día a la noche", sino que fueron el resultado del Renacimiento Italiano, y más precisamente de las teorías producidas en ese momento de la historia por Alberti o Leonardo da Vinci, o revalorizadas, como Plinio y Vitruvio, que produjeron esta actitud estética altamente intelectualizada y que pusieron el término paisaje en el entorno de la producción crítica del Renacimiento. Las preguntas formuladas por estos autores sirven para demostrar cómo la pintura del paisaje sólo podría surgir como tal, si ya hubiera condiciones para su recepción crítica. En caso contrario, no existiría mercado ni artistas

\footnotetext{
${ }^{39}$ Ibidem, p. 265.

${ }^{40}$ Ibidem, p. 266.
} 
especializados en practicar este género en tan gran escala desde el Renacimiento.

En Diez Libros de Arquitectura, Alberti dedica un capítulo a la decoración de edificios y sus interiores, donde no se encuentra una idea pura de paisaje: el paisaje aún se considera como el lugar de actividad humana y, sin embargo, se evidencia ya la valorización de estas pinturas como arte equivalente a la poesía y no ya como mero ornamento o ilustración.

Pero quien fija en texto las condiciones de emancipación del artista renacentista como un individuo que piensa y por eso crea es Leonardo da Vinci. Es el propio proceso creativo el que inventa paisajes, como los que podemos encontrar descritos en su Tratado de Pintura. El pintor inventa la pintura tal como el poeta inventa una poesía: ésta era una cuestión aceptada en el Renacimiento y tiene como antecedente Horacio. Fue dentro de este marco que Giorgione pudo desarrollar los primeros ejemplos totalmente nuevos de un arte del paisaje e incluso ver a ese trabajo aceptado y reconocido en su tiempo.

Era en Plinio, en su Historia Naturalis, $X X X V$, donde cualquier italiano culto buscaba el vocabulario y los patrones de la crítica para entender el arte de su tiempo. Su escritura se prestaba a innumerables posibilidades interpretativas y en ese sentido, sus teorías sobre el paisaje configuraban el nacimiento de un importante filtro teórico que incluía ya la idea de pintura de paisaje y de artista especializado.

Finalmente, Vitruvio, en vez del Grotesco, que calificaba de "moda inicua", propone formas decorativas constituidas por paisajes realistas para ser usados en los edificios. Esta opción estaba de acuerdo con los principios de simetría, semejanza y buen gusto. Estas concepciones de valor ornamental tuvieron, según E. H. Gombrich, impacto en los panoramas ilusionistas de Perugino y en los frescos de Veronés e de Caracci. Sus concepciones, de carácter fuertemente ornamental, están quizás en la raíz del idealismo y de lo pintoresco en el paisaje.

Queda así demostrado por Gombrich que la aparición del arte del paisaje como evento moderno se deriva más de toda la estructura teórica antes 
mencionada y de todo el mercado creado en torno a ella, que de un mero avance de los fondos paisajísticos de la Edad Media a los primeros planos de representación de la naturaleza.

\section{4}

\section{Bosque - breve cartografía de sus re- presentaciones}

En Europa, hasta el final de la Edad Media, existía un gran bosque denso y continuo que ocupaba toda Europa central y del Norte. Denso y oscuro, era ese el territorio donde se depositaban memorias, mitos, leyendas, fábulas, creencias, visiones aterradoras y de seres sobrenaturales que constituían un bestiario grotesco a quien muchas veces el pueblo supersticiosamente apelaba a la benevolencia, por ejemplo, cuando tenían necesidad de llevar allí a pastar su ganado, cazar o realizar otra actividad cualquiera. El bosque era lugar de alimento para el ganado, como está representado en una de las miniaturas que acompañan Les Très Riches Heures del Duque de Berry, ejecutadas por los Hermanos Limbourg para el hermano del rey de Francia. Todas las miniaturas, en un total de doce, acompañaban un calendario compuesto por brillantes y minuciosas representaciones de la vida del hombre en la naturaleza. En la miniatura correspondiente al mes de noviembre, podemos ver a un pastor de cerdos que tira un palo contra los árboles del bosque para provocar la caída de bellotas, alimento para su piara. Al mes de diciembre corresponde, en el mismo grupo de miniaturas, una escena de caza que será abordada más adelante.

El gran bosque europeo se fue destruyendo por ser una fuente importante de materias primas. Al final de la Edad Media, inicios del Renacimiento, el bosque acusaba ya algún retroceso en relación a la extensión que antes había ocupado. En proporción a su destrucción, las ciudades europeas fueron creciendo bastante en área, población y campos de cultivo. Estas ciudades, $y$ todos los otros grupos de población, encontraban en el bosque una 
importante fuente de madera, que servía para las más variadas funciones constructivas, y abastecía de leña para calentar, cocinar en los hogares, calentar los hornos de panaderías, fábricas de cerámica y cristal, fundiciones, etc. Estos usos del bosque se encuentran también representados en la segunda miniatura, correspondiente al mes de febrero. En ésta, que representa el Invierno, se observa en un plano intermedio a un hombre empuñando un hacha y cortando vigorosamente árboles de un bosque en el auge de la nieve de Invierno. Además de ser "el paisaje más antiguo de nieve de la historia del arte occidental, nos da una imagen lírica y encantadora de la vida de aldea en el auge del Invierno, con las ovejas en el redil, las aves hambrientas picoteando en la era y una criada calentándose las manos con el vapor, mientras va corriendo hacia sus compañeras que están en la caldera". ${ }^{41}$

El rápido crecimiento de las ciudades desde el Imperio Romano, durante la Edad Media y hasta el Renacimiento no podría explicarse sin el recurso constante al bosque europeo. El historiador Fernand Braudel, en su texto Venecia, da una imagen magnífica y literal de este soporte, observando que esta ciudad tuvo que ser recreada a partir de la tierra fangosa rodeada de agua, a partir de la consolidación de su lugar "con piedras y sobre todo con miles o millones de troncos de árboles, robles, sumergidos en la vertical. Venecia se equilibra sobre un bosque sumergido" ${ }^{42}$.

La descripción más antigua de un artista que representó bosques, y que según E. H. Gombrich protagonizó una de las más importantes aportaciones para la aceptación del género de paisaje en Europa, la hizo Plinio, quien en su Historia Naturalis, $X X X V$ describe el trabajo de un artista latino llamado Studius (o Ludius) "que trabajó bajo el Emperador Augusto" y que se granjeó fama pintando "villas, pórticos, parques, bosques, matorrales, colinas y lagos de peces (...) y allí pintó toda la especie de gente caminando o navegando, andando por tierra rumbo a aldeas, montada en burros o en carros e incluso pescadores, halconeros,

\footnotetext{
${ }^{41}$ JANSON, H. W., História da Arte, trad. al portugués de J. A. Ferreira de Almeida y Maㅡ Manuela Rocheta Santos, Lisboa, Fundação Calouste Gulbenkian, 5ª ed., 1992, p. 357.

${ }^{42}$ BRAUDEL, Fernand, "Veneza" in Braudel/ Duby, O Mediterrâneo, os homens e a herança, traducida al portugués por Manuela Torres, Teorema, 1987, p.114.
} 
cazadores y vendimiadores". Estas descripciones, como vimos anteriormente, influenciaron y crearon la base teórica necesaria para el mercado de coleccionismo, ya que el Renacimiento Italiano adquiría innumerables pinturas de paisaje, entre las cuales se encontraban las de bosques.

Aunque tal descripción de Plinio, célebre naturalista romano, sea anterior a la época medieval, y habiendo sido importante para la aparición de la teoría del paisaje en el Renacimiento, su contribución no podría haber sido tenida en cuenta para la creación de una idea de paisaje en una época medieval fuertemente dominada por la estructura teológica cristiana. Kenneth Clark, en su Paisagem na Arte, comienza el tema del paisaje con aquello que denomina paisaje de símbolos, siendo que, en este contexto, la palabra paisaje debe ser entendida como una forma de expresión usada por comodidad de lenguaje, ya que no se tratan de efectivos paisajes, pero constituyen aún así importantes documentos para la comprensión de la representación de espacios exteriores, entre los cuales el jardín, que fuera su forma más aceptada por ser la prueba de la belleza y creación divina. Los bosques oscuros de la Edad Media comenzaron por encontrar su lugar, en el entorno de estas representaciones, en los espacios reservados a los fondos de las composiciones, situados del más allá del muro del jardín, o más al fondo, y en las tapicerías de Aviñón (siglo XV) donde el bosque, ocupando el centro de la representación, aparecía como forma de relleno decorativo aprovechado como referente para la ejecución de un trabajo ornamental de vigorosa vegetación, la fabricación en imagen de hojas y troncos.

En la Divina Comedia de Dante, aunque en menor cantidad que la belleza divina, hay innumerables referencias a la belleza de la naturaleza, surgiendo el bosque en este contexto como el opuesto de esa belleza. A lo largo del poema, "podemos sentir el cambio del mundo amenazador de la Edad Media primitiva hacia un mundo más suave del microtheos, cuando Dios se debe manifestar en la naturaleza. Dante inicia su viaje en un bosque escuro, aproximándose desde el fin cuando el bosque es menos denso y se ve más allá de un arroyo una señora cantando y juntando flores que orlan la vereda por 
donde pasa.“43. De hecho, es al inicio de la Edad Media cuando se inician las visiones terríficas del bosque y este aspecto se mantuvo hasta el final de ese periodo; allí ella representa un tipo de paisaje que aún es atemorizante y perturbador por su vastedad, siendo por lo tanto, el espacio que se abre a pensamientos pecaminosos. Hieronimus Bosch, El Bosco, uno de los pintores con más autoridad en el norte de Europa, expresaba bien el escepticismo reinante en aquella época, hasta el punto de que éste venciera el idealismo pictórico que la representación del jardín normalmente manifestaba. Su Jardín de las Delicias es una versión grotesca de ese espacio tratado a través de su estilo gótico. El jardín está lleno de voluptuosidad y pecado, siendo una de las más intensas formas de aversión por la condición humana.

El terror producido por el bosque va a abrir un linaje de representaciones en muchos aspectos relacionables con lo grotesco y más tarde todos los géneros de expresionismo de que, en parte, La forêt de Giacometti es tributaria.

En el siglo la razón principal que llevó a los hombres a hacer incursiones dentro del territorio del bosque es la caza. Esta actividad despertó un tipo de representación muy particular. La miniatura referente al mes de diciembre, siglo $\mathrm{XV}$, (Fig.3) de la misma serie de miniaturas anteriormente citadas, representa una escena de caza oriunda de Europa Septentrional. En esta imagen, la cacería se desarrolla en el primer plano, en un claro abierto en el bosque que se sitúa en el plano intermedio. El plano de fondo representa el castillo de Vincennes, lugar de nacimiento del Duque de Berry. En esta cacería, los cazadores se representan mirando a los perros que devoran a su presa al final de una montería de jabalí. Esta forma de exploración del bosque a través de las cacerías va a relacionar, de forma duradera, el bosque al instinto de matar. Otro buen ejemplo de cacería en el bosque, sacado esta vez del arte de Europa Meridional, es La Caza, de Paolo Uccello, (Fig. 4) de la década de 1460 y en pleno Quattrocento italiano. En esta pintura, se puede ver representado un bosque que sirve de escenario para una cacería, los troncos verticales de los árboles, conjugados con

\footnotetext{
${ }^{43}$ CLARK, Kenneth, Paisagem na Arte, traducción de Lúcia H. O. Gerardi y Silvana M. Pintaudi, Lisboa, Editorial Ulisseia, 1969, p. 23.
} 
otros inclinados en la horizontal crean simultáneamente profundidad y orientación del punto de fuga que en la composición se sitúa al centro. La cacería dispone así de espacio para realizarse en el interior del bosque. Recordemos que, en el caso de la cacería representada por los Hermanos Limbourg, como en otras de la misma época o más antiguas, la escena sólo podría ser representada fuera del bosque. Eso se debe a la falta de conocimientos sobre perspectiva lineal que, en última instancia, es la que permite en el plano de la representación la entrada de la cacería en el interior del espacio forestal. Aquí, el tema de la cacería en el bosque nos es dado por Uccello en acto; podemos ver el desarrollo de la cacería con sus cazadores de vestimentas ricamente ornamentadas y coloridas montados en sus caballos. El alargamiento de los perros se curva en la dirección del punto de fuga y de la caza. Es el propio hecho de que Uccello haya desarrollado un sistema perspectivo lineal, que ya anteriormente había sido explorado por el arquitecto florentino Brunelleschi, el que nos da, a nosotros como expectadores, la posibilidad de ver la cacería desarrollarse dentro del bosque con su profundidad y luz propia, a partir de una ventana que es el cuadro.

La comprensión del desarrollo de la perspectiva monofocal del Renacimiento Italiano es determinante para que entendamos algunas de las cuestiones ya planteadas en este estudio, como la aparición del género de Paisaje, así como otras que más adelante serán abordadas, específicamente cómo este proceso también trabaja y caracteriza ciertas estrategias modernas y postmodernas de pensar la escultura en su intercepción con el paisaje.

Perspectiva significa "'ver a través de'. Así intentó Durero explicar el concepto de perspectiva" ${ }^{44}$ Entre las muchas perspectivas, la Renacentista italiana surgió concomitantemente con el surgimiento de la idea de individuo que observa la realidad exterior, incitado y condicionado por su deseo, intención y voluntad. Desde la Antigüedad Clásica se intentó comprender el proceso óptico de la visión. Se sabía que la imagen visual procede de líneas rectas que unen el ojo con los objetos del mundo exterior, creándose la pirámide o cono visual que configuraba lo visible, a partir de la idea simple de que los objetos situados más

\footnotetext{
${ }^{44}$ PANOFSKY, E., A perspectiva como forma simbólica. Lisboa: Edições 70, 1999, p. 17.
} 
cerca del ojo son mayores que los más alejados, más pequeños. Pero fue necesario llegar al Renacimiento Italiano para que tal saber tuviera sentido en el momento de la aparición del sujeto moderno.

Giotto creaba perspectiva a través de sus composiciones circulares y de la sucesión de figuras del plano de frente que ocultaban los planos de atrás. Piero della Francesca sistematizó las reglas de la perspectiva en su tratado titulado De Prospectiva Pingendi concediendo en ese estudio importantes aportes para el tratamiento del paisaje. Brunelleschi demostró que la imagen se genera por alguien, una especie de espectador activo que en el espacio real pasa al espacio imaginario; para que tal adhesión del espectador se produzca, es necesario comprender la noción de que una pintura renacentista italiana funciona, como demostró Alberti, como ventana para un espacio virtual, donde todo lo que se encuentra representado camina hacia un punto de fuga. La mejor demostración del carácter virtual de la perspectiva Italiana habría sido hecha por Brunelleschi al intentar proyectar en su lugar actual el Baptisterio de San Giovanni en Florencia. Para eso, realizó una experiencia bastante sencilla, orientado del lado opuesto donde quería prever y localizar el edificio, acercó a su rostro una chapa grabada con el dibujo del Baptisterio, a partir de un orificio localizado en el centro de esa chapa dibujada "parecía verse la iglesia verdadera y real” ${ }^{45}$ en su localización futura y enmarcado por el paisaje gracias a un espejo que sostenía con el brazo extendido, de modo a encuadrar el dibujo (grabado) del edificio con el cielo.

A partir del momento en que teóricos y artistas renacentistas sedimentaron las herramientas técnicas de la perspectiva central Renacentista, puede inaugurarse el dominio sobre el espacio, pues éste podía subdividirse en unidades iguales en una métrica regular.

Se inaugura la posibilidad de instaurar un observador en relación a otra cosa que es observada. Este observador es el sujeto que posee una doble connotación: activa porque es un "yo" o cogito cartesiano "yo pienso", pero también pasiva "si sujeto a". Queda así demostrado que existe, desde la

\footnotetext{
${ }^{45}$ DAMISCH, H., L'origine de la perspective. París: Flammarion. 1987, p. 276.
} 
invención de la perspectiva Renacentista Italiana, una ambivalencia en la condición del sujeto, pues el vértice donde está situado no es el origen sino el destino de los rayos de luz.

Es cierto que ese punto de fuga, principio indiscutible de la visión monofocal, marca solamente el punto ideal de observación del espectador pero trae consigo, (...) el "punto del sujeto": el punto en el que hace su aparición el "yo". La proyección en perspectiva conlleva por tanto una decisión fundamental a propósito de una relación consigo mismo específicamente moderna del sujeto. O formulándolo más sucintamente: el individuo de comienzos del Renacimiento no inventa la perspectiva sino que la perspectiva inventa al individuo. ${ }^{46}$

Es en este momento de la concepción renacentista ordenadora del espacio que la misma noción de paisaje emerge. Como ya vimos, el nacimiento del paisaje es relativamente reciente en la historia humana, pues sólo aparece con el Renacimiento Italiano. El nacimiento del paisaje va a ocupar el previo y ancestral concepto de naturaleza vigente en Occidente. Para Joachim Ritter ${ }^{47}$, el paisaje es por eso una noción moderna que ni los medievales, ni los antiguos necesitaban. En la modernidad, se plantean entonces dos preguntas: ¿Por qué ya no nos alcanza la naturaleza que antes satisfacía a los antiguos, a las culturas arcaicas ya los orientales? y ¿ Por qué razón sucedió esta escisión entre hombre y naturaleza justamente en el nacimiento de la época moderna? Estas preguntas tienen como respuesta el surgimiento de la subjetividad, el descubrimiento del yo o el individualismo de los seres que, al emanciparse de la teología dominante en la Edad Media, comenzaron a trazar una distancia en relación a la naturaleza.

El ser moderno, al tener la capacidad de experimentar una percepción estética, da pruebas de conformarse como un sujeto soberano y por lo tanto consciente de su singularidad en el mundo; lo que equivale a decir un sujeto separado de la naturaleza. Para Joachim Ritter, el sentimiento estético compensa

\footnotetext{
${ }^{46}$ MAYER, Michael, "Un Cambio de Perspectiva» in Máquinas de Mirar. O cómo se originan las imágenes. El Arte Contemporáneo mira la colección Werner Nekes, Sevilla, Centro Andaluz de Arte Contemporáneo, Consejería de Cultura, 2010. p. 78.

${ }^{47}$ RITTER, Joachim. Paysage, fonction de l'esthétique dans la societé moderne. Besançon, Les Éditions de l'Imprimeur, 1997.
} 
esa unidad perdida con la naturaleza, haciendo que ésta entre decididamente en el campo cultural.

Así, y con la modernidad, el hombre se desprende de la naturaleza y ésta da lugar a una forma cultural nueva, el paisaje. Concomitante con este proceso de emancipación del ser en relación a la naturaleza es el desarrollo de una métrica para el espacio. La perspectiva renacentista reveló al hombre como alguien que tiene poder sobre el espacio, y eso tuvo consecuencias tanto en el espacio real, como en el espacio de la representación, haciendo, como ya vimos, que en la misma proporción de la destrucción de la naturaleza natural, se intensificasen en la cultura estrategias para expresar la naturaleza en el campo artístico en la que el bosque es su mayor exponente.

Prosiguiendo en nuestra cartografía de las representaciones de bosques, en 1482-1483, aún con el mecanismo perspectivo Renacentista Italiano no totalmente establecido, el bosque es escenario de una cacería poco común pintada por Botticelli: las cuatro tablas de la historia de Nastagio degli Onesti, (fig. 5). La escena se desarrolla preferentemente en el interior de un frondoso pinar. Las cuatro tablas, encargadas a Botticelli por el mercader florentino Antonio Pucci para el casamiento de su hijo Giannozzo, tienen como tema una historia de amor cortés sacada del Decamerón de Bocaccio. En ella, Nastagio degli Onesti, caballero de Rávena, infeliz, busca la soledad en un bosque, después de que la mujer amada se negara a casarse con él. Es lo que se puede ver en el lado izquierdo de la composición frontal perteneciente a la primera tabla. De inmediato se ve una mujer perseguida por un caballero y atacada por un perro suyo, lo que se puede ver en la escena central de la primera tabla. La segunda tabla prosigue con la escena dramática rememorando al fondo la persecución del caballero a la mujer desnuda que en el plano frontal es asesinada por el caballero, que le arranca el corazón y las entrañas, para dárselas como alimento a sus perros que surgen a la derecha, en primer plano. Nastagio degli Onesti huye al fondo y la mujer se encuentra viva y sin cualquier rastro de violencia, aunque siendo perseguida. Es esta escena del fondo que hace la conexión con la tercera tabla. Y el drama recomienza: Nastagio le pide al caballero que le explique las escenas misteriosas y crueles que había presenciado, y aquél le cuenta que se trata de un 
castigo eterno, una premonición a la que él y su compañera estarían destinados, al sufrimiento conjunto manifestado en el suicidio del caballero por un amor no correspondido, en el amor y, en el asesinato de la mujer, por motivo pasional. Aturdido, Nastagio invita a su amada a un banquete realizado en el bosque de pinos; durante la comida, aparece de nuevo la joven perseguida por los perros y por el caballero como preanuncio de un final terrorífico. En esta tabla se ven los árboles de adelante inclinados, para que la escena principal del banquete y de la persecución puedan ser vistas claramente. Durante este pasaje descrito en la tercera tabla, la amada de Nastagio toma conciencia del pesado y severo presagio y acepta casarse con él. Ahora, en la cuarta tabla, está representado el banquete donde sucede la boda ordenada. El pinar se transforma en un bosque de columnas organizadas, en una arquitectura basada en los principios de la simetría y el buen gusto que culminan, al fondo, en un arco del triunfo, símbolo de la victoria del amor.

En este conjunto de pinturas, el bosque surge como espacio de una escena macabra donde el erotismo se mezcla con lo siniestro, la muerte y lo informe. Botticelli (Florencia) pertenece a un grupo de artistas nacidos en grandes ciudades, para quien los bosques, entretanto reducidos, ya no valen por su amenaza real, sino por su capacidad de evocar el mito y lo desconocido. De esta forma, podía usarlos de forma consciente para excitar el sentimiento de horror. Será también este aspecto el que, en cierta forma, será explotado por el Surrealismo del que La forêt es heredera.

Pero el lenguaje expresionista se encuentra fundamentalmente en el Norte de Europa, que, siendo "anti-clásica prolonga tanto en la iconografía como en sus ritmos complejos el arte inquieto y orgánico del periodo migratorio. Tiene su origen en el bosque e incluso cuando no representa abetos y maleza -como sucede invariablemente en la pintura alemana- sus formas hostiles y densas dominan la composición"48. Grünewald y Altdorfer son dos artistas que, para K. Clark, son los exponentes máximos de lo que podría denominarse "paisaje fantástico", en la medida en que ambos pintores expresaron una actitud de

\footnotetext{
${ }^{48}$ CLARK, Kenneth, Paisagem na Arte, traducción al portugués de Lúcia H. O. Gerardi y Silvana M. Pintaudi, Lisboa, Editorial Ulisseia, 1969, p. 59.
} 
construcción de paisajes fantásticos partiendo de la naturaleza "en su forma más pura, provenían de los bosques de las márgenes del Riny del Danubio". A Grünewald, en lo que interesa a nuestro tema, se debe referir el carácter expresionista en el tratamiento de los árboles que "descubrió en los pedazos viscosos de musgo que caen de las ramas sin hojas, un perfecto símbolo de la decadencia. Sus verticales repetidas imponen una quietud horrible, sólo quebrada por la caída de una rama partida" ${ }^{49}$. Altdorfer es, para K. Clark, el pintor más "representativo del espíritu germánico, de hecho es el más alemán de todos los pintores, una vez que su mirada penetra profundamente en el bosque del norte con sus arbustos y trepaderas retorcidas, sus charcos y musgo brillando como esmalte, los observa con una cierta gemütlichkeit (serenidad), una comodidad como si la escena fuese observada por la ventana de una casa de campo" ${ }^{\circ 0}$. Su San Jorge, pintado en 1511, (fig. 6) se opone a la tradición pictórica italiana de la misma época. En él, San Jorge es casi tragado por el frondoso bosque que llena todo el cuadro. En esta imagen de Altdorfer, la vegetación se presenta como amenazadora, pesada y orgánica. Gombrich, en su Historia del Arte $^{51}$, refiriéndose al Paisaje (1526-28) (fig.7) del mismo pintor, nota la ausencia de figuras humanas: "se trata de una gran importancia, ya que incluso los griegos y romanos, con todo su amor a la naturaleza, sólo pintaron paisajes para situar en ella sus escenas pastorales. ${ }^{\text {"52 }}$ Al sur, el florentino Piero di Cosimo (1461-62 /1521) pintaba también, en la década de1520, los primeros paisajes que en el arte italiano no atribuyeron importancia a la figura humana, más precisamente en El incendio del bosque (Ashmolean Museum, Oxford). Este cuadro trata de la historia relatada en el quinto libro de Lucrecio sobre el descubrimiento accidental del fuego a través de la fricción accidental entre dos ramas.

También en el sur de Europa, en Italia, los venecianos Giorgione y Ticiano, dice Sannazzaro, pintaron "bosques y colinas de la más deliciosa

\footnotetext{
${ }^{49}$ Ibidem, p. 60. Kenneth Clark se refiere a la tabla La visita de san Antonio a san Pablo, 1512-16.

${ }^{50}$ Idem, Ibidem.

${ }^{51}$ GOMBRICH, E. H., La Historia del Arte, Trad. al castellano de Rafael Santos Torroella, Madrid, Debate, 2003.

${ }^{52}$ Ibidem, p. 356.
} 
belleza, llenos de árboles frondosos y de una centena de especies de flores". ${ }^{53}$ En el eje Francia-Italia, en Roma, se debe destacar a Poussin (1594-1665) en cuya obra el bosque ya surge como fondo, ya se acentúa como formando parte del tema principal, pero siempre cumpliendo la función de subrayar el contenido moral e intelectual de su pintura.

En la Francia del siglo XIX vivió aquel pintor cuya afinidad es bien conocida con el elemento agua: Corot (1796-1875). Es considerado al mismo tiempo el último paisajista clásico y el primer impresionista; la atmósfera y los árboles están cargados de agua y, por lo tanto, de luz que va a ser el tema más importante para los impresionistas.

Los impresionistas construyeron un efecto de luz en la retina del observador, a través de la yuxtaposición de colores puros colocados lado a lado en comas registradoras. Fue la primera vez que, en la historia del arte occidental, el motivo entre los cuales se encuentran algunos bosques vale sólo por la creación de un fenómeno abstracto de luz y no por su aspecto simbólico.

Para nuestro estudio de representación de bosques, no podemos dejar de citar al mayor pintor romántico alemán, Caspar David Friedrich, que, en el siglo XIX, presenta pictóricamente bosques de una intensa atmósfera melancólica y de lo sagrado. En La cruz en la montaña, de 1812 (fig. 9), desde el plano frontal de la pintura hacia el fondo, se puede ver la crucifixión de Cristo, abetos verticales formando un pequeño bosque y una catedral gótica. El romanticismo de Friedrich parece haber interpretado el arte gótico en una relación con el bosque y "se vio allí revivir el genio de los bosques, un naturalismo confuso mezclado con los ardores de la fe." ${ }^{.54}$ Aunque el pintor represente el paisaje con un fuerte sentido de lo sagrado, C. D. Friedrich fue uno de los principales responsables de la independencia ganada por este género, en la medida en que la pintura de paisaje pasó a ser un tipo de representación cada vez mas desconectada de discursos mitológicos o históricos y hasta religiosos. A

\footnotetext{
${ }^{53}$ CLARK, Kenneth, Paisagem na Arte, traducción de Lúcia H. O. Gerardi y Silvana M. Pintaudi, Lisboa, Editorial Ulisseia, 1969, p. 74.

${ }^{54}$ FOCILLON, Henri, A Vida das Formas. Seguido de Elogio da Mão, Trad. de Ruy Oliveira, Lisboa, Edições 70, 2001, p. 91.
} 
pesar de que La cruz en la montaña representa lo sagrado, no puede ser confundido con religiosidad, pues lo sagrado es ya un valor que une al paisaje con el espíritu individual.

Aunque sea más conocido como escritor, Víctor Hugo (1802-1885) produjo también innumerables dibujos y pinturas ${ }^{55}$ usando aguadas de tinta sepia y negra. Su bosque, de 1857, refleja uno de los rasgos fundamentales del siglo XIX, la tensión polarizada entre naturaleza y ciudad y la ruina de ambas. Su aspecto fragmentado se corroe como el de su ciudad Palimpsesto en Los Miserables. El siglo XIX se define por el concepto de ruina que une la ciudad y los bosques desaparecidos. Tanto en Baudelaire ${ }^{56}$ como en Víctor Hugo, la luz de la ciudad es la luz de los dos crepúsculos que ilumina las masas y los rostros melancólicos de los habitantes de la ciudad. Una de las primeras voces que alertaron una emergencia ética de cariz ecológico surge precisamente con Víctor Hugo que, en un diario de viaje después de haber pasado por los bosques de los Alpes y Pirineos, escribió:

En la relación de los seres humanos con los animales, con las flores, con los objetos de la creación existe un gran vacío ético, pero que eventualmente romperá, surgiendo como un complemento de la ética humana [...] Sin duda fue primero necesario civilizar a los hombres en sus relaciones con los otros hombres. Se debe empezar por aquí y los varios legisladores del espíritu humano tuvieron razón en sacrificar a esta todas las otras preocupaciones [...] Pero es igualmente necesario civilizar las relaciones de los seres humanos con la Naturaleza. En este dominio está todo por hacerse. ${ }^{57}$

Del otro lado del Atlántico Henry David Thoreau escogió vivir en el bosque. En Walden ou a vida nos bosques ${ }^{58}$, considerada un clásico de la ética ambiental, reflexiona sobre las consecuencias nefastas de la revolución industrial

\footnotetext{
${ }^{55}$ Estos dibujos fueron presentados en el Museo Thyssen-Bornemisza, Madrid, de 2 de junio el 10 de septiembre de 2000.

56 BAUDELAIRE, Charles, A Invenção da Modernidade (Sobre Arte, Literatura e Musica), Trad. y Notas de Pedro Tamen, Relógio D’ Água, 2006.

${ }^{57}$ HUGO, Victor, En Voyage, -Alpes et Pyrénées, París, J. Hetzel, 1890, pp. 180-181 (entrada de 11 de agosto de 1843).

${ }^{58}$ THOREAU, H. D., Waldenou a vida nos bosques, Trad. de Astrid Cabral, Lisboa, Antígona, 2009
} 
y apela a la liberación interior de cada individuo, preconizando ya en el siglo XIX, una actitud de sostenibilidad de la vida frente a los recursos naturales existentes.

Es durante el siglo XIX que los practicantes de fotografía de paisaje intentaron establecerla como arte, pero no lograron ir muy lejos en esa tarea. En Estados Unidos, y ya en el siglo XX, Ansel Adams se distingue como fotógrafo de paisajes, en especial bosques (fig.10), motivado por la grandilocuencia de los paisajes de Norteamérica, pero sobretodo siguiendo el legado de los pintores románticos como Albert Bierstadt, F. E. Church y Thomas Cole. Estos son algunos de los pintores que en el siglo XIX reinventaban los paisajes de los Estados Unidos a partir del ideal de tierra prometida.

En la Europa de la primera mitad del siglo $X X$, surge en París un movimiento de vaga inspiración freudiana y marxista tutelado por André Breton: el Surrealismo, del cual Alberto Giacometti formó parte entre 1930 y 1940 . Este movimiento trató de destruir muchas servidumbres y convencionalismos, expresando las relaciones del inconsciente mediante procesos que van de un realismo casi fotográfico a los extremos de la abstracción.

Siguiendo la tradición de los románticos alemanes, que consideraban el sueño como la manifestación más sincera de las aspiraciones del alma, los Surrealistas, apoyados en el Psicoanálisis, representan sus sueños con una persistente esperanza en la síntesis del sueño y de la acción. En Paul Delvaux (1897-1994), la dimensión del sueño se encuentra anclada en esquemas de representación realista. En ellos se encuentran algunos ejemplos que ponen en relación mujer y bosque en una especie de secuencia de sueños. En El despertar del bosque (1939), la desnudez de las mujeres se relaciona con la atmósfera soturna y atemorizante del bosque donde los hombres las observan. Erotismo y muerte se confunden en la macro escala de helechos, volviendo los gigantes; componen y compiten con el bosque, haciendo de éste un escenario ambiguo. En El Crepúsculo (1937) (fig.11), también del mismo autor, árbol y mujer se funden debajo de la misma atmósfera soturna. También Max Ernst se destacó por sus pinturas y dibujos de bosques. En El bosque (1927) (fig. 12), éste se representa como un espacio sofocante y petrificado resultante de su técnica de frottage. El bosque aparece representado verticalmente, paralelo a los bordes 
laterales de la tela; abajo y al centro, aparece un pájaro rojo pintado por M. Ernst como exorcismo del terror de la muerte.

El bosque es, dentro de la historia de la representación del paisaje, un tema por excelencia de la pintura, incluso cuando se representa en bajorrelieve de piedra 0 madera desde la Edad Media. El tema bosque, en las representaciones tridimensionales, también se encuentra contemplado en las teorías de la representación pictórica. Hasta Rodin, la estatuaria estaba sometida a las teorías de la pintura, siendo por eso frecuente encontrar, en tratados o escritos sobre la representación pictórica, consideraciones sobre la estatuaria. Con Rodin (1840-1917) y sus incursiones en el campo de la tridimensionalidad, la estatuaria da lugar a la escultura. Es en este ámbito que La forêt (1950) de Alberto Giacometti puede ser comprendida como escultura paisajista. Será preciso esperar a la segunda mitad del siglo XX para que el campo expandido de la escultura, descrito por Rosalind Krauss $^{59}$, trajera claramente a la práctica escultórica el paisaje, y con él también el bosque, como es el caso específicamente de Uma floresta para os teus sonhos (1970), de Alberto Carneiro, que destacamos como objeto de nuestro estudio.

Si atendemos al título de esta exposición, Bosque - breve cartografía de sus re-presentaciones, veremos que tiene dos objetivos: primero, el de hacer un breve pasaje dentro del contexto de la producción pictórica de paisaje que aparece representado una y otra vez en todo el espacio de la cultura occidental, segundo -y sobre el cual vamos a reflexionar de aquí en adelante- el de mostrar, a través de ejemplos concretos, cómo el tema del bosque puede pasar a ser presentado con un carácter puramente escultórico, donde las lógicas de la estética y de las teorías fenomenológicas de las prácticas bidimensionales dan lugar a nuevas categorías teóricas, integradas en prácticas que son poéticas, éticas e incluso políticas. En este contexto,se deben destacar los bosques de Yves Klein, Giuseppe Penone, Joseph Beuys y Agnes Denes, casos útiles para establecer inferencias en relación a Uma floresta para os teus sonhos (1970).

\footnotetext{
${ }^{59}$ KRAUSS, Rosalind E., La originalidad de la Vanguardia y otros mitos modernos, Trad. al español de Adolfo Gómez Cedillo, Madrid, Alianza Editorial, 2002.
} 
El color principal, materia de la pintura, siempre se definió por su capacidad de sugerir transparencia. A pesar de opaco, el color organizado por el pintor consigue representar el espacio forestal, porque ilusoriamente usa las convenciones que hacen sugerir en el cuadro perspectiva lineal y atmosférica, color local, claroscuro, etc. Pero esta capacidad ilusionista comenzó a ser discutida desde el siglo XIX con el impresionismo y pos impresionismo. Ya a mediados del siglo $X X$, esta concepción de la pintura comienza a ser discutida cada vez más por Yves Klein. Este artista fue uno de los principales responsables de retirar el color de su condición falsamente transparente, trayéndola de nuevo hacia su verdad opaca, al mismo tiempo que transformó la pintura en un acontecimiento monocromático preferentemente azul en el espacio real.

En 1959, Yves Klein presentó en la galería Iris Clert en París, la exposición titulada La forêt d'éponges et les bas-reliefs monochromes (Bosque de esponjas y bajorrelieves monocromos). A través de la problematización del monocromatismo en la pintura, Klein proponía, a través de este bosque que se sitúa deliberadamente entre la pintura y la escultura, una inmersión en el color a través del bosque de esponjas naturales, cubiertas de pigmento azul, unidas cada una a su base a través de una hasta de alambre fino. Estas formas recuerdan un conjunto de árboles colocados más o menos aleatoriamente en plintos a diferentes alturas en la sala de exposición. "las colocó a diferentes alturas, y en una combinación que simulaba un bosque fantástico"60.

Este bosque asociado a los bajorrelieves presentaba, de forma evidente, la idea del vacío poblado de la lisura del color azul que se nos ofrece en un ambiente para ser penetrado. "La masa azul de la esponja que, más que la copa de un árbol, semejaba un organismo que crecía con independencia del tallo, es decir, alimentado desde el aire, no desde la tierra." ${ }^{61}$ La esponja presenta la imagen de un organismo vivo que capta, en todos sus intersticios, la materia azul

\footnotetext{
${ }^{60}$ ARNALDO, Javier, Yves Klein, Madrid, Editorial Nerea, 2000, p. 41.

${ }^{61}$ Idem, Ibidem.
} 
venida del aire. Así, más que opaca o visual, la esponja posee una carga sensible de lo inefable.

Las esponjas o árboles del bosque sirven de puntos para situar el vacío, el arte y la vida. El vacío es para Klein el centro de toda su poética. El "vacío" es una zona libre de cualquier narrativa o influencia del mundo empírico. Es neutro, por eso mismo crea el espacio necesario a la proyección de cada uno. El bosque de esponjas, a pesar de ser materialmente constatable en el espacio real de la exposición, pretende en la realidad transportar a cada observador a la inmaterialidad que son sus propias ideas, emociones y percepciones.

En 1979, el artista italiano Giuseppe Penone presenta una obra titulada repetir el bosque (fig.13): una instalación de carácter escultórico, constituida por un conjunto de vigas de madera que se revelan árboles a través del trabajo del artista. Estos tienden a ser dispuestos de diversas formas según el espacio expositivo que los acoge. Penone es un artista procedente del arte povero que, en la Italia de los años 60, se distinguió por el uso de materiales considerados pobres; uno de los materiales más importantes para Penone es la madera, no por su calidad abstracta sino precisamente por aquello que contiene de concreto: la vida de un árbol. El proceso poético de Penone reconoce en el funcionamiento de la naturaleza los procesos del pensamiento en arte, que configuran la escultura como cultura. Cada viga de madera abstracta y cortada geométricamente antes de ser bosque es excavada capa por capa, siguiendo los anillos de crecimiento del árbol inscritos en la madera. En ese proceso de recuperación, diríamos de corte arqueológico, Giuseppe Penone trabaja el tiempo y la memoria. Retrocediendo en el tiempo biológico del crecimiento del árbol, encuentra en la materia muerta de la viga de madera algo concreto y vivo como escultura, árbol. En este sentido, la madera no es entendida como material disponible para la creación de una forma cualquiera, como hacía Brancusi, por ejemplo, sino antes bien al contrario: cada viga de madera es ya una escultura en potencia, cabiéndole al artista el trabajo de retirar el exceso, de modo a transformar la madera en árbol. Durante dicho proceso, el artista inserta su propio cuerpo y su pensamiento en un proceso de pensamiento natural, útil para su arte. De este modo, hombre, tiempo y naturaleza se encuentran para producir 
arte. En sus bosques, cada árbol se eleva "verticalmente y busca de manera incesante su equilibrio" ${ }^{2}$. Alrededor de cada uno de estos árboles se crea un campo de gravedad en torno al cual se mueve el espectador, teniendo por lo tanto la oportunidad de confrontar su condición urbana con el reconocimiento de la naturaleza y sus ciclos temporales propios.

En 1982, el artista Joseph Beuys construyó un bosque al que bautizó con el nombre de 7000 Robles (fig.14). Esta escultura obedece a un pensamiento conceptual y ecológico de base antropológica, ética y política. Ya no se trata de un bosque meramente estético, sino de una transformación de la política en arte o viceversa, configurando una intervención efectiva en el mundo vivo y en la ciudad del día a día de las personas. El bosque surge, en esta obra, como un concepto que es preciso representar mentalmente. Son necesarios miles de árboles para que se pueda construir un bosque. Beuys superpone a una ciudad (Kassel) un bosque; a este proceso, Beuys llamó Die Verwaldung von Kasse ${ }^{63}$. A cada uno de los árboles que fueron plantados por toda la ciudad, Beuys hizo corresponder 7000 bloques de basalto que fueron previamente marcados y después enterrados a media altura juntamente con cada árbol. Estos bloques, antes de iniciar el trabajo de plantación, se fueron amontonados en una de las principales plazas de la ciudad (Friedrichsplatz). Así, a medida que los árboles se iban plantando, el caos de bloques de piedra amontonados como escombros iba desapareciendo a los ojos de los habitantes de la ciudad. El Dia Center for the Arts de Nueva York, institución que financió el proyecto, se asoció a este evento plantando diversos tipos de árboles en esa ciudad. La obra de Joseph Beuys integra el concepto de escultura social pensada para despertar las consciencias humanas, asumiéndose este bosque como una especie de revolución en el intelecto de cada uno. Se trata de un bosque, nacido del artificio de un arte relacional, que sitúa a la ecología como punto central a tener en cuenta en la vida de las personas y en su sociedad urbana que es, desde hace algún tiempo, la única que poseemos.

\footnotetext{
62 Santiago de Compostela, Guiseppe Penone 1968-1998, catálogo de la exposición, Comisario Miguel Fernández - Cid, 22 de enero a 4 de abril de 1999, p. 11.

${ }^{63}$ Arborización de Kassel.
} 
Por último, Agnes Denes, artista húngara nacida en 1938, realizó innumerables trabajos en Nueva York, entre los que destaca Wheatfield - A confrontation, realizado en el verano de 1982 en un terreno baldío situado muy cerca del centro financiero de Nueva York. Allí plantó trigo que después fue recolectado por una cosechadora. El resultado fueron mil libras de trigo de excelente calidad. Este trabajo establecía deliberadamente un contraste entre una de las ciudades más populosas del mundo y el ritmo biológico del crecimiento del trigo. Más allá de todas las inferencias poéticas que puedan derivarse, debe ser considerado el hecho de haber creado un espacio dentro de otro. En Tree mountain - A living time capsule, 10000 Trees, 10000 People, 400 Years (1982) (fig. 15), una intervención de inspiración ecológica implicó, como el título mismo indica, a 10.000 personas de todo el mundo que plantaron respectivamente 10.000 árboles, en los terrenos anteriormente ocupados por las minas de grava de Pinziö, cerca de Ylöjarvi, en Finlandia, configurando un proyecto de arte relacional y paisajista que comprendió una amplia intervención de regeneración de terrenos patrocinada tanto por el gobierno finlandés como por el programa ambiental de la ONU. A. Denes proyecta y construye su bosque a partir de dos arquetipos: la montaña y el bosque. Esta heterotopía, que también superpone dos lugares en un sólo espacio de la antigua mina desactivada, funciona como forma de recreación ética, política y estética de la vida, resultando todo esto en obra de arte, concretada en un imaginario paisajístico organizado a partir de la sección áurea, disponible para que todos la puedan disfrutar.

Estos tres ejemplos, protagonizados por tres artistas influyentes en el contexto cultural de la segunda mitad del siglo XX, encuentran, más allá de cuestiones éticas, políticas y estéticas coincidentes, una fuerte afinidad entre el concepto de tiempo y de bosque. 


\section{CAPÍTULO II:}

\section{¿QUÉ ES UNA ESCULTURA?}

\section{0}

\section{Notas introductorias}

Después de haber presentado lo que significa el paisaje en el arte, es útil para nuestro estudio establecer también algunos puntos nodales importantes para comprender lo que se entiende por escultura. A lo largo de este panorama se usarán palabras como: estructuras edificadas, figuras esculpidas de la prehistoria, estatuas, esculturas, y otras como esculturas en el campo expandido o campo de lo escultórico. El uso de cada una de estas expresiones pretende determinar mejor cada zona de la producción tridimensional, al mismo tiempo que vamos a aclarar el término escultura dentro de su contexto cultural, mostrando hasta qué punto se encuentra integrado en una cadena de relaciones culturales.

La elección de los dos bosques obliga a una cartografía amplia, ya que las referencias implicadas presentan un conjunto de aspectos que se define mejor a partir de la evolución del concepto.

No se puede contestar de forma precisa la pregunta: “¿Qué es una escultura?". Intentar responder esta pregunta, sin circunscribirla a un periodo histórico, a un marco geográfico o a un contexto cultural específicos, parece una tarea hercúlea. Además, la pregunta nos lleva a un territorio bastante complejo, en la medida en que es una de las formas de expresión humana que más se ha transformado a lo largo de la historia del arte.

La escultura deriva de un arte bastante más antiguo, la estatuaria, que posee una dimensión celebrativa o evocativa inseparable de la lógica del monumento. La estatuaria dio origen a la escultura a partir del momento en que se sistematizaron las especificidades técnicas, críticas y expresivas de su 
práctica. Pero, como veremos, esta existencia tuvo una duración muy corta. Tiene inicio a finales del siglo XIX y permanece como linaje principal de la práctica del género hasta mediados del siglo XX. A partir de ese momento la escultura empieza a existir en lo que Rosalind Krauss denominó, siguiendo un esquema de análisis estructuralista, como "Sculpture in the expanded field". Esta expansión del territorio de la escultura ha seguido su curso, de forma que actualmente ciertos artistas ya no se definen como escultores, sino como artistas que, para expresarse, se sirven de determinados procedimientos procedentes de la escultura.

Sin embargo, esta apertura del campo de la escultura no debe servir para convertir en inoperante el término escultura, hasta el punto de dejar de ser útil para nombrar o situar los procedimientos escultóricos dentro del arte contemporáneo. No se pretende con este enfoque delimitar o defender un punto de vista de retorno a las características fundamentales de los tradicionales medios de expresión, como la escultura o la pintura, tal como defendieran Michael Fried o Clement Greenberg, sino más bien intentar reconocer lo que es específico de la escultura actuando aún hoy dentro de propuestas de artistas contemporáneos cuyo trabajo supera la práctica del género, y que han ayudado a crear un territorio de libertad importante para cuestionar en conjunto el espacio, el objeto y el espectador.

Intentaremos hacer un ensayo de respuesta a esta pregunta para, a continuación, presentar la especificidad escultórica de las obras de A. Giacometti y A. Carneiro, escogidas para nuestro estudio, en su entrecruzamiento con la cuestión del paisaje.

\section{1}

\section{Construcciones y figuras esculpidas}

Desde tiempos remotos, los seres humanos se preguntaban sobre su origen. Al observar el cielo, el hombre primitivo reconocía en el sol caliente una 
fuente de vida. Por la noche, contemplaba la luna y las estrellas, sin ninguna respuesta para la sucesión entre el día y la noche o la secuencia de las estaciones del año. El universo se presentaba a los primeros hombres como algo rígido, hostil y agresivo.

Los pueblos primitivos necesitaban entender su mundo, tener algún control sobre la naturaleza para reducir la imprevisibilidad. Desde muy pronto, el hombre asoció la naturaleza con los dioses para establecer una relación con ellos. Construcciones tridimensionales relativamente sencillas, como las de Stonehenge o el Círculo de Goseck, ayudaban a entender el cielo. Dichas construcciones eran el resultado de años y años de observación atenta, estableciendo sobre todo las cadencias que se repetían a lo largo de un año o de una secuencia de años. Cada construcción es, en este sentido, la materialización en la tierra de un determinado orden cósmico celeste.

Tanto Stonehenge como las pirámides de Chichen Itzá eran estructuras de observación simple que ayudaban a los pueblos primitivos a entender las mutaciones del universo. En Alemania, el Círculo de Goseck es uno de los monumentos más antiguos para entender el sol, la luna y las estrellas. Esta construcción tridimensional integrada en el paisaje fue levantada cerca de 4900 a.C. y habría sido utilizada por los primeros agricultores para calcular la época de las Iluvias. Construido dos mil años antes que Stonehenge, se trata del calendario más antiguo de Europa. Durante los solsticios de invierno y de verano, que corresponden al día más corto y al más largo del año, el sol se alineaba perfectamente con las puertas de la construcción circular del observatorio. El conocimiento de estas fechas ayudó a las poblaciones a entender que el sol generaba la vida. Por la noche, el cielo nocturno funcionaba como un reloj gigantesco que les permitía calcular el mejor momento para plantar y cosechar y por lo tanto, su sustento dependía de la comprensión de los cambios cíclicos del sol y del cielo.

El obelisco egipcio representa la petrificación del primer rayo solar sobre la tierra. Era de granito, un material que permite esculpir una forma monumental duradera. Gran parte de estas construcciones tenían una masa considerable. Poseían también una afirmativa verticalidad, denunciando una evidente relación 
entre el cielo y la tierra, al mismo tiempo que se destacaban del caos horizontal de la tierra. La inscripción de estas construcciones en el espacio del paisaje instituía un orden en medio del caos. Donde antes no había nada para leer, empieza a existir un orden que puede ser traducido y usado. Estas características, como la escala monumental, la verticalidad, la gravedad, la masa y el orden, asumirían una extrema importancia para el territorio de la escultura. Sin embargo, estas construcciones no pueden ser consideras esculturas, como veremos más adelante.

También las estatuas de la Isla de Pascua, denominadas moais, pudieron no haber sido creadas como escultura. Erguidas en agradecimiento a los dioses, después de un periodo fértil en la isla de Pascua, estas estatuas podrían haber comenzado como representaciones de los jefes tribales, líderes o antepasados importantes. No obstante, la forma como están representadas, su escala monumental y la masa imponente les confieren la capacidad de transformarse en un objeto que se venera. Cada moai es una figura de divinidad y de esa forma las representaciones de los líderes se habrían vuelto dioses.

De hecho, el arte prehistórico y, en consecuencia, todas las figuras esculpidas durante ese periodo histórico, poseen una función mágica y ritual. Algunos historiadores, como H. W. Janson, defienden que estos objetos debieron "obedecer a un propósito mucho más serio que el simple gusto por decorar. De hecho, parece no haber dudas en que fueron ejecutadas para servir un rito mágico." ${ }^{64}$ También Herbert Read defiende la idea de que el hombre primitivo "representando simbólicamente un acontecimiento (...) piensa provocar ese acontecimiento en la realidad. El deseo de descendencia, de la muerte de un enemigo, de supervivencia después de la muerte, o el exorcismo o propiciación de un espíritu maligno, son motivos para la creación de determinados símbolos. De aquí se infiere que cuando estudiamos el arte primitivo estamos ante el arte en el sentido más pleno de la palabra: con arreglos formales que expresan actitudes emocionales (...) el estudio del arte primitivo nos conduce a una comprensión del mismo en sus formas más elementales, y lo más elemental es

${ }^{64}$ Traducción libre. In JANSON, H. W., História da arte, Lisboa, Fundação Calouste Gulbenkian, pp. 29-30. 
siempre lo más vital." ${ }^{65}$ Las primeras formas tridimensionales de cuerpos referidos a figuras humanas datan del Paleolítico Superior. "Algunas de esas esculturas parecen haber nacido del reconocimiento y la elaboración de semejanzas accidentales. En una fase anterior, los hombres de la Edad de Piedra se conformaban coleccionando guijarros $u$ otros objetos en cuya configuración natural descubriesen cualquier poder "mágico". Aún se encuentran ecos de esta forma de ver en piezas más trabajadas de tiempos posteriores. Así, la llamada Venus de Willendorf, en Austria, una de las muchas estatuillas femeninas de la fertilidad, tiene las formas redondeadas y bulbosas de una "piedra sagrada". Su ombligo, que marca el centro del diseño, es una cavidad natural del canto" ${ }^{\prime 66}$. Todas estas características cumplían la función de una pieza que daba significado al valor de la fertilidad humana encerrada en la figura de la mujer capaz de generar nuevos seres humanos. En la descripción del antropólogo André Leroi-Gourhan, los "senos enormes que penden del cuerpo macizo, la cabeza no posee ningún detalle, los brazos son un mero esbozo, y las piernas, cortas y esquemáticas, afinándose rápidamente, constituyen la prolongación de los muslos" sirven para corroborar la idea de que en el arte primitivo la representación de seres vivos no está sujeta a una transposición precisa de las proporciones, ni a una versión puramente afectiva de los caracteres anatómicos." ${ }^{67}$ Y Gourhan agrega: "entre la figuración y la realidad pura, existe sólo el desenfoque necesario para que el sabor de las figuras se vuelva sensible." 68

Aunque el análisis de historiadores de arte y antropólogos se detenga bastante en el análisis de los caracteres formales, estudios más recientes revelan que nos debemos centrar más en la idea de que las figuras esculpidas de la prehistoria valen más allá de la forma que presentan. No valen por lo que son en

\footnotetext{
${ }^{65}$ Traducción libre. In READ, Herbert, O Significado da Arte, trad. de A. Neves Pedro, Lisboa, Editora Ulisseia, 1968, p. 51.

${ }^{66}$ Traducción libre. In JANSON, H. W, História da Arte, Lisboa, Fundação Calouste Gulbenkian, 5 edición, 1992, p. 29.

${ }^{67}$ Traducción libre. In GOURHAN, André Leroi, O Gesto E A Palavra, Memória e Ritmos, Trad. de Emanuel Godinho, Lisboa, Edições 70, 2002, p. 194.

${ }^{68}$ Traducción libre. Idem, p. 196.
} 
sí mismas, sino por lo que significan más allá de ellas mismas. En esa evasión de lo que es la pura consideración formal reside el valor simbólico de la escultura que está íntimamente relacionado con los impulsos más vitales del hombre. Esta característica interesó mucho, como veremos, a Alberto Giacometti, principalmente en la fase de su obra posterior a 1935.

En el arte cicládico se deben destacar los ídolos, que "tienen formas y dimensiones muy variables, desde figurillas de algunos centímetros hasta obras de tamaño natural" ${ }^{69}$, y presentan un nivel de sofisticación y buen gusto que los sitúa "por encima del nivel del arte paleolítico o primitivo". En relación al Ídolo de Amorgos, 2500-1100 a.C, fig. 18, H. W. Janson destaca su "elegancia y sofisticación" e identifica también "un extraordinario sentido de la estructura orgánica del cuerpo en las delicadas curvas del contorno y en las convexidades, levemente sugeridas, marcando las rodillas y el vientre" ${ }^{\prime 70}$. Esta obra es tan extraordinaria que muchos de los artistas del siglo XX vieron en ella una señal de modernidad, como fue el caso del suizo Alberto Giacometti o del escultor inglés A. Gormley, entre otros.

\section{2}

\section{Estatuaria hierática y la sugerencia del movimiento}

También el valor de la estatuaria egipcia debe ser apreciado no sólo a partir de lo que representa, sino también de lo que cada estatua es en sí misma. Aparte de que puedan tener un valor político y/o sagrado, cada estatua exhibe caracteres formales que demuestran una sofisticación propia de civilizaciones culturalmente evolucionadas, como era el caso de la egipcia. Tal vez los rasgos más distintivos de este tipo de estatuaria sean la simetría, la verticalidad y la quietud afirmativa, expresando sin duda la eternidad, comprensible en una

\footnotetext{
${ }^{69}$ Traducción libre. In JANSON, H. W, História da Arte, Lisboa, Fundação Calouste Gulbenkian, 5ª edición, 1992, p. 87

${ }^{70}$ Idem, Ibidem.
} 
civilización donde el arte sirve para actuar después de la vida, hasta el punto de que las estatuas divinas eran perfumadas, alimentadas, levantadas y vestidas diariamente, en un ritual que las aleja claramente de otras estatuas y esculturas producidas por las civilizaciones que les sucedieron.

Existen dos tipos de estatuaria egipcia: la hierática y la popular. La primera dependía de una clase sacerdotal, muy exclusiva y que fue protegida por los túmulos, la segunda, la popular, se desarrolló paralelamente al arte hierático pero era completamente independiente de él y, por eso, era un arte más lírico. No obstante, la mayor parte de la estatuaria que ha llegado hasta nuestros días pertenece a la primera categoría. Hay que destacar que dicha tradición interesó sobremanera a Alberto Giacometti, especialmente porque se configura a partir de los valores bidimensionales del diseño, es decir, a partir de las líneas de contorno. Por eso la estatuaria egipcia parece mantener también la rigidez del bloque que le dio origen. Como nos dice Hildebrand, la estatuaria "surgió indudablemente del dibujo, condujo al relieve mediante la profundidad. Hemos de comprenderla como una vivificación del plano (...) Los antiguos egipcios esculpían figuras agachadas en sencillos dados de piedra, en los que los lados de piedra, se mantienen completos pero se han convertido en miembros de una figura agachada. Del mismo modo que, a cierta distancia, un cubo de piedra puede parecernos un hombre agachado, el cubo de piedra se transformará realmente en una figura. La piedra pierde, así, su objetividad en la representación, pero continúa existiendo en el reposo como forma total de la figura. El ojo experimenta esa unidad espacial, al igual que en el dibujo de la imagen uniforme o del plano visual." ${ }^{71}$ En la estatuaria egipcia, parece existir una interdependencia del bloque con la figura esculpida y viceversa, lo que le confiere su postura hierática y estática que también encontramos, de alguna manera, en todas las esculturas que Gaicometti produjo después de 1935.

La gran evolución de la estatuaria egipcia a la asiria se produce porque la segunda da inicio a la representación del movimiento. El conocido bajorrelieve mostrando a Asurbanipal cazando leones, fechado en 669-631? a.C, es el

\footnotetext{
${ }^{71}$ HILDEBRAND, A. Von, El problema de la forma en la obra de arte, traducción al español de María Isabel Peña Aguado, Madrid, Visor, 1988, pp. 97-98.
} 
ejemplo de una imagen esculpida con el objetivo de glorificar los hechos guerreros del Rey Asurbanipal. Se trata de una síntesis figurativa de gran realismo que representa los momentos de la caza, en especial en el que el león ataca el Rey y éste le propina un golpe fatal. Este bajorrelieve está entre las primeras representaciones bien logradas de cristalización del clímax de una acción. Las escenas son tan realistas que podemos adivinar la tensión misma de aquella evocación mítica de una caza.

En la estatuaria griega, la representación del cuerpo tuvo esencialmente dos fases: la de la época arcaica y la de la clásica. La primera se caracteriza esencialmente por una extraordinaria proximidad con el arte egipcio. En las estatuas de varones y mujeres, las semejanzas con la escultura egipcia se nota en el "carácter macizo y cúbico [...] En la silueta delgada de hombros anchos, en los puños cerrados, la pierna izquierda adelantada, rótula acentuada". Janson ejemplifica esta fase del arte griego con dos figuras: una femenina (Kore) y otra masculina (Kourós). "El tratamiento formalista del pelo, como si fuese una cabellera postiza, el vestido ajustado al cuerpo y el brazo erguido de la estatua femenina son otros tantos puntos de semejanza." ${ }^{72}$ Pero las estatuas griegas de esta época también poseen cualidades propias, "son las estatuas más antiguas humanas de bulto redondo, en tamaño natural y de piedra, que fueron realizadas de pie y sin ningún apoyo. El escultor egipcio nunca osaría separarlas completamente del bloque en el cual permanecían más o menos incorporadas"73.

Sin embargo, para los griegos, el estilo egipcio dejó de ser suficiente y por eso los escultores empezaron a usar sus ojos, a usar el sentido de la vista como forma de analizar y de medir la realidad, principalmente el cuerpo humano, cosa que nunca antes había sucedido, ya que el centro de todas las otras formas de cultura anteriores no residía en el hombre, sino en algo que estaba más allá de él, en la divinidad. Aunque la mitología griega fuera protagonizada por divinidades, los mitos guardaban una gran proximidad con la vida de los hombres. Los acontecimientos y los lugares de los dioses se localizaban en la

\footnotetext{
72 Traducción libre. GOURHAN, O Gesto e a Palavra, Memória e Ritmos, Trad. de Emanuel Godinho, Lisboa, Edições 70, 2002, p. 112.

${ }^{73}$ Idem, Ibidem.
} 
geografía de la Grecia antigua, en el Mediterráneo; por eso, aunque tuviesen un papel soberano en relación a los hombres, eran hechos a su semejanza, protagonizaban y reflejaban los problemas concretos de la vida del hombre, dando sentido, a través de la mitología, a sus miedos, ansias, pasiones, etc. Esta estructura de sentido creó condiciones para que el arte de la estatuaria buscase un realismo irreprensible teniendo como base la representación del cuerpo humano. Policleto creó el canon basado en la observación atenta de las características proporcionales del cuerpo humano. En él, la cabeza es la séptima parte del cuerpo, el arco torácico y el pliegue inguinal construyen un círculo y el rostro está dividido en tres partes, correspondientes a la frente, la nariz y de ésta hasta el extremo del mentón. De esta forma, Policleto establecía las primeras reglas y principios de verosimilitud y buen gusto que posteriormente serían recuperados durante el Renacimiento Italiano. Del desarrollo de estas convenciones dependió otra fase de la estatuaria griega: la voluntad de esculpir un hombre que reemplazara al humano. De esta forma, los practicantes de la estatuaria empezaron a montar todo el potencial de una representación humana perfecta, lo que muchas veces suponía una actualización de las proporciones en nuevos cánones con acentuaciones en relación a la verdad anatómica.

El periodo mayor de la estatuaria griega es el clásico, durante el siglo V. En esa época, la figura del cuerpo humano adquirió más realismo, belleza, perfección y, posteriormente, también la idea de movimiento, como se puede constatar en la estatua de Poseidón (Zeus?), (c. 460-450 a.C.). El trabajo para sugerir el movimiento "se enfrentaba a la vieja tradición"74 que siempre había privilegiado el estatismo o la quietud, con excepción de los bajorrelieves asirios. Esta nueva concepción de la estatuaria introducía la noción de movimiento, mediante la elección de una posición del cuerpo representado de forma que sugiere en la imaginación del espectador no sólo el movimiento anterior, sino también el siguiente.

Una de las formas más poderosas de sugerir movimiento del cuerpo en escultura es el grupo de Laocoonte, representado en la figura 1. Es una posible

\footnotetext{
${ }^{74}$ Traducción libre. JANSON, H. W, História da Arte, Lisboa, Fundação Calouste Gulbenkian, 5a edição, 1992, p. 132.
} 
copia romana de una escultura helenística tardía ejecutada posiblemente por Agesandro, Athenodoro y Polydoro, todos ellos de Rodas. Esta estatua representa a Laocoonte y a sus dos hijos, Antiphantes y Thymbraeus, siendo atacados por dos serpientes marinas. Las figuras se entrelazan en una lucha entre hombres y animales, cuerpo a cuerpo y sin la mediación de cualquier otro artefacto de lucha, como por ejemplo una espada. A propósito de esta estatua que trata del dramático episodio de la Guerra de Troya ${ }^{75}$, J. W. Goethe, en Escritos sobre arte ${ }^{76}$, trabaja el concepto de momento decisivo a partir del grupo de Laocoonte (fig. 19), para señalar la idea de que la estatua se representa en su momento de mayor tensión donde aún nada ha sucedido, y donde todo está por suceder; todo esto congelado en mármol.

Tal estrategia les permitía a los griegos tener acceso en diferido a todo el drama de sus historias y mitos épicos, pues la estatua, al ser el resultado de la elección de un momento inmediatamente antecedente al clímax, logra transmitir de forma más intensa las emociones de los personajes que, por ser tratados de forma más realista y reveladora, llevan al observador a identificarse con sus mitos y con el carácter emocional de los personajes implicados.

De la estatuaria egipcia a la griega, se produjeron importantes cambios en la realización escultórica, relacionados con los modelos de concebir el espacio. La cuestión del espacio como entidad que se opone a la masa de la escultura sólo se plantea cuando los griegos, al entender la medida como forma de conocimiento (Aristóteles), empiezan a calificar la noción de extensión física. La medida determina, localiza y ordena. Para los egipcios, esa forma abstracta de entender el espacio de su estatuaria no existía, pues cada estatua no dependía directamente de él, ya que, no siendo leída exclusivamente desde la forma, su realización pretendía un espacio y una dimensión sagrada. $\mathrm{O}$, más bien, las estatuas no se ubicaban en nuestro espacio empírico porque estaban destinadas al espacio de lo sagrado que mejor convenía a la vida más allá de la

\footnotetext{
${ }^{75}$ Relatada en la llíada de Homero y en la Eneida de Virgilio.

${ }^{76}$ GOETHE, J. W, Escritos de arte, Madrid, Editorial Síntesis, 1999, pp. 107-120.
} 
muerte, ya que toda la producción artística estaba orientada por la religión que también justificaba la organización social y política.

\section{3}

\section{Primera narrativa pre-cinematográfica}

El arte romano, fuertemente influenciado por el arte etrusco y por la expresión del arte griego-helenístico, se va a caracterizar por un trabajo de idealización del cuerpo, principalmente el de los emperadores, en un proceso muchas veces de carácter político, elevándolos al estatuto de divinidad.

De todas las realizaciones romanas, la Columna de Trajano, 100 a.C, es la forma narrativa más alta existente. Con 35 metros de altura, la columna en mármol dominaba todos los edificios de la Roma antigua. Esta columna posee un tipo de narrativa tan elaborada que condensa todos los saberes sobre narración visual desde la antigüedad. A lo largo de un friso continuo en espiral, con 200 metros, que rodea la columna vertical 23 veces, el monumento cuenta la historia detallada de la campaña de Trajano contra los Dacios, donde hoy se sitúa la moderna Rumanía, y que funciona como una película épica congelada en piedra. En las representaciones presentes en la columna, Trajano es un líder incuestionable, poderoso y digno. Al contrario, el líder del pueblo Dacio se representa como un villano, calculador, astuto y malo. En la columna, las emociones de cada una de las 2500 figuras son representadas individualmente y podemos decir, como muchos estudios más recientes, que esta narrativa que la columna parece anticipar algunas de las técnicas cinematográficas que se han convertido en familiares en nuestros días. Árboles esculpidos en la vertical sirven como divisiones para la representación de escenas diferentes de la misma narrativa. En ciertos momentos, los escultores decidieron mostrar escenas de combate vistas desde arriba en simultáneo con representaciones de escenas vistas desde abajo. De esta forma, los escultores demuestran entender las ventajas que los múltiples puntos de vista tienen en la descripción dramática de 
una batalla. Por último, el observador, al ver la columna a partir del Noroeste, tiene varios puntos alineados en la vertical que funcionan como una versión resumida de la narrativa o lo que hoy podríamos designar como trailer. La narrativa cinematográfica en el contexto escultórico sólo volverá a aparecer al principio y a mediados del siglo $\mathrm{XX}$, ya no con carácter evocativo, sino participativo en el entorno de propuestas radicalmente nuevas, derivadas de la fabricación de protocolos por parte de los artistas, de cara a la participación del espectador que en el espacio representa una lógica pre-cinematográfica en función del objeto u objetos instalados.

\section{4}

\section{La estatuaria y el espacio jerárquico}

En la Edad Media, el cuerpo era la sede de los pecados de la carne; la única imagen del cuerpo permitida y fuertemente difundida era la del cuerpo de Cristo, es decir, una idea de un cuerpo que se sacrificó por los demás. En esta época fuertemente determinada por las concepciones teológicas, el canon es superado por las determinaciones de la jerarquía que determinaban, con respecto a la figura de Dios, el lugar y la escala de todos los otros personajes en bajorrelieve 0 estatuas, casi siempre soportadas por arquitecturas, específicamente iglesias y catedrales.

En parte, durante la Edad Media, volvemos a tener la misma dificultad en articular la práctica de la estatuaria con la noción de espacio; como había sucedido en la estatuaria egipcia, la noción de espacio sólo se puede determinar a partir de la jerarquía. "Durante la Edad Media, bajo los rescoldos del pensamiento aristotélico, se aprecia todavía la imposibilidad de comprender el espacio como abstracción apriorística, la idea de espacio estaba reducida a 
localizaciones, a posiciones jerarquizadas en las que el espacio celeste se opone al terrenal, el sagrado al profano" ${ }^{, 77}$.

\section{5}

\section{Renacimiento, hacia la transparencia}

En el Renacimiento se establecen las bases de nuestra era moderna, en ese contexto, nace, como vimos, el arte del retrato y del paisaje. En relación a la Edad Media, el artesano da lugar al individuo que es artista dotado de pensamiento, cultura e invención propios, porque deja de estar sometido a los presupuestos de la teología que abarcaba toda la existencia. El artista puede ahora adoptar una posición de observador en relación a otra cosa, a un paisaje o a un modelo que se observa, lo que, como analizamos anteriormente, crea las condiciones para el surgimiento del género del paisaje y del retrato y autorretrato, respectivamente.

Artista renacentista absolutamente insoslayable, Miguel Ángel nos presenta en sus estatuas una situación paradójica: son objetivamente en piedra, pero sólo funcionan como negación de la piedra. Esta situación también es válida para la estatuaria griega clásica, la renacentista y la neoclásica, que sólo funcionan cuando suspendemos su materialidad, de la misma forma que una pintura renacentista sólo comienza cuando suspendemos el cuadro y nos involucramos en su espacio virtual, en profundidad, producido a través de la convención de la perspectiva lineal del Renacimiento Italiano. La estatuaria renacentista sólo ejerce su verdadero poder cuando creemos en la piel pegada a una musculatura activa de la estatua de mármol, con el título de David, 15011504, de Miguel Ángel, y que por dentro le corre sangre en las venas y cuando creemos que un velo representado en una piedra opaca es verdaderamente transparente, y que, si le retirásemos el velo, como dijo Nietzsche, toda la estatua

\footnotetext{
${ }_{77}$ MADERUELO, Javier, La Idea de Espacio en la arquitectura y el arte contemporáneos 1960-1989, Madrid, Akal, 2008, p. 22.
} 
se desmoronaría. Esta suspensión de la materialidad y del proceso es un acuerdo tácito establecido entre el espectador y la obra, y es esencial para la existencia de la estatua provista de todo su valor evocativo. Es decir, la estatua es siempre transparente, o más bien, convencionalmente transparente.

Entre las reflexiones teóricas más revalorizadas en el Renacimiento Italiano están las de Plinio el Viejo. En dos momentos de la Historia Natural, Plinio se refiere al origen de la pintura y de la estatuaria, que asocia al origen del dibujo del contorno de un retrato. El mito describe la invención del modelado en arcilla: "Al utilizar también la tierra, el ceramista Butades de Sición fue el primero en descubrir el arte de modelar los retratos en arcilla; esto pasaba en Corinto, y él debió su invención a su hija que se había enamorado de un joven. Como éste iba a marcharse al extranjero, ella dibujó con una línea el contorno de la sombra de su rostro proyectada en la pared por la luz de una linterna; su padre aplicó la arcilla sobre el esbozo, e hizo un relieve que puso a endurecer al fuego con el resto de sus cerámicas, después de haber secado." ${ }^{78}$ En otro fragmento posterior, Plinio describe y refuerza también la invención mítica de la escultura. "La primera persona que modeló en yeso a semejanza de un ser humano partiendo de la técnica de retirar el molde de una cara viva, y estableció el método de volcar cera líquida dentro de ese molde en yeso, haciendo después pequeñas correcciones finales en la matriz fue Lisístrato, también de Sición. Fue él quien introdujo la práctica de dar similitud al objeto con su intencionalidad en un proceso de elaboración muy cuidadoso dentro de lo posible. El mismo artista también inventó el proceso de sacar moldes a partir de estatuas, este método avanzó hasta el punto de que ninguna figura o estatua eran elaboradas sin un modelo de barro. Esto muestra que el conocimiento del modelado en barro era más antiguo que las figuras congeladas en bronce"79. En estos fragmentos de Plinio, quedan desde luego establecidas las que serían las determinaciones más importantes de la estatuaria que se define esencialmente por su estado de congelación de formas tridimensionales en una materia perenne. O sea, se pretende que alguien o algún acontecimiento sean guardados y/o exaltados para

\footnotetext{
${ }^{78}$ Traducción libre. PLíNIO, o Velho. História Natural. XXXV. 151.

${ }^{79}$ Idem, Ibidem.
} 
la posteridad. Esa persona o acontecimiento pueden ya no estar presentes pero son reemplazados por la estatua. La estatua es, por lo tanto, la evocación de una ausencia como presencia. Pero además de ese aspecto, la estatuaria desciende claramente del dibujo, del dibujo del contorno; el relieve se construye a partir de la superficie bidimensional, por lo tanto del plano. Después puede ser reproducido con la ayuda de moldes.

El plano es el principal vehículo que garantiza la transparencia de la estatuaria moderna, clásica griega y neoclásica. Por transparencia se entiende la capacidad que tiene la estatuaria de hacernos olvidar su condición material y procesal, en dirección a su narrativa, sea ella de origen histórico o mítico. Esto es, la conexión con la estatua sólo sucede cuando reconocemos en ella un sentido significante interno y completamente indisociable de la narrativa que le dio origen y no un sentido autorreferencial. Pero para que esa narrativa pueda cristalizarse en tres dimensiones en una única estatua, el artista tiene que escoger un momento de acción entre los más fecundos, es decir, el que es más sugerente y que puede dar pistas en relación a lo que sucedió anteriormente y a lo que deberá suceder posteriormente. Esta exigencia en la representación obliga a premisas muy específicas en la elaboración de una estatua, ya que no se pretende que el observador se pierda en sus características procesales y autorreferenciales, sino que se conecte lo más rápido posible con su narrativa. Para que eso suceda la estatua se piensa como imagen, de ahí el rigor exigido en la definición de sus contornos a partir de un dibujo que debe ser revelado paulatinamente en tres dimensiones. "La imagen es en cada fase uniforme, es decir, uniforme en el sentido de que posee una comunidad de planos y comporta la unidad de una visión común desde un punto de vista, en tanto que no ha adquirido una realidad real como forma material para los diferentes puntos de vista." ${ }^{" 80}$ Este proceso constructivo, descrito por Hildebrand, es típico desde la escultura clásica: hace depender la estatuaria del rigor del dibujo de contorno, puesto que la configuración de las formas de la escultura se realiza a partir de la yuxtaposición o pre-visualización virtual de numerosos planos dibujados sobre el

\footnotetext{
${ }^{80}$ HILDEBRAND, A. Von, El problema de la forma en la obra de Arte, traducción al español de María Isabel Peña Aguado, Madrid, Visor, 1988, pp. 100-101.
} 
bloque. "Sólo cuando está tallado el primer nivel de la representación, puedo avanzar hasta el próximo, puesto que la naturaleza de las condiciones técnicas imponen la necesidad de liberar la imagen de la piedra desde adelante, antes de pasar a la profundidad. (...) Miguel Ángel describe gráficamente este proceso del trabajo que avanza en el mármol cuando afirma que sería preciso imaginar la imagen, inmersa en el agua, que surge progresivamente, de tal modo que la figura emerge cada vez más a la superficie hasta que está totalmente libre." ${ }^{\prime 1}$ Queda claro, en este fragmento de Hildebrand, que cada estatua de Miguel Ángel ya está dentro del bloque de piedra, cabiéndole al artista sólo desbastar toda la masa del bloque que envuelve la estatua para que sea revelada. En el esclavo El Atlas, 1519, encontramos bien expresada esta formulación de configuración que cobra forma sobre la piedra. La estatuaria deriva entonces del diseño que configura una imagen que se proyecta o se anticipa instintivamente por el artista en el plano del bloque a desbastar.

El Rapto de las Sabinas de Giambologna (Juan de Bolonia, 1583), nos parece suficientemente rico, tanto en la concepción como en la ejecución, para llamarle escultura. No obstante, el tema de la escultura provino "de las leyendas de la Roma Antigua, parece una extraña elección para la estatuaria: los fundadores de la ciudad, una banda de aventureros venidos del otro lado del mar, así cuenta la historia, intentaron en vano encontrar mujeres entre los vecinos, los Sabinos; por último, recurrieron a una estratagema: invitaron a toda la tribu de los Sabinos a un pacífico festival en Roma y se abalanzaron sobre ellos, arrancándoles las mujeres a la fuerza y asegurando el futuro de su raza. En realidad el artista dibujó al grupo sin ningún tema específico en mente, sólo para acallar a los críticos que dudaban de su capacidad como escultor monumental en mármol. Escogió lo que parecía ser la tarea más difícil, tres figuras de carácter contrastante, unidas en una misma acción. La identidad de estas figuras fue discutida entre los más cultos conocedores del tiempo, que finalmente se decidieron por El Rapto de las Sabinas como el título más adecuado." ${ }^{82}$

\footnotetext{
${ }^{81}$ Idem, p. 101.

${ }^{82}$ Traducción libre. JANSON, H.W, História da Arte, Lisboa, Fundação Calouste Gulbenkian, 1992. p. 473.
} 
La leyenda del Rapto de las Sabinas de Juan de Bolonia ha servido de pretexto para esculpir. "Durante los últimos cuatrocientos años los artistas, a la pregunta: ¿qué es lo que va a esculpir el escultor? respondieron: «vamos a tallar un bloque de piedra o de mármol con la verdadera imagen del concejal Jones, o de Miss Simpkins en pose de Venus, o de un león moribundo o de un pato volando»; y los hombres se maravillaron con el ingenio de que el artista ofrece pruebas ejecutando esta tarea difícil." ${ }^{" 33}$ Esta afirmación de H. Read es evidentemente crítica en relación con la lógica evocativa de la estatuaria porque, según él, llevaría sólo a la demostración del virtuosismo de los artistas en su trabajo de esculpir.

\section{6}

\section{Determinaciones de la Estatuaria}

La estatua guarda el punto de vista y el dibujo a partir del cual fue elaborada, posee por lo tanto ese punto de vista como el más favorable para observarla. Así, la estatuaria presupone un punto de vista ideal "que contendrá la totalidad de la información necesaria para una aprehensión conceptual del objeto" $^{\prime 4}$, o sea, la estatuaria está sujeta al principio integrador que R. Krauss enumera citando a Hildebrand, donde "todos los detalles de la forma más abarcadora (...) todos los juicios particulares de profundidad deben integrarse en un juicio unitario, comprensivo, de profundidad. De forma que, en último análisis, toda la riqueza de la forma de una figura se nos presenta como una condición anterior al único y simple plano $(. .$.$) donde eso no sucede se pierde el efecto$ pictórico unitario de la figura" ${ }^{85}$. La estatuaria está así sometida a las lógicas de la representación bidimensional e ilusionista por lo menos desde la época clásica

\footnotetext{
${ }^{83}$ Traducción libre. READ, Herbert, O Significado da Arte, trad. de A. Neves Pedro, Lisboa, Editorial Ulisseia, 1968, p. 165.

${ }^{84}$ Traducción libre. KRAUSS, Rosalind E., Caminhos da Escultura Moderna, traducción de Julio Fischer, São Paulo, Martins Fontes, 2001. p. 22.

${ }^{85}$ Idem, p. 16.
} 
griega hasta finales del siglo XIX. Fueron estas condiciones las que garantizaron la transparencia de la estatuaria. Por la competencia manual, el escultor logró que el observador se sintiese cómodo a través de la observación de las capacidades virtuosas de los escultores por ser transportado directamente al significado interno de cada estatua, sin detenerse en sus aspectos procesales y materiales, al contrario de lo que se puede testimoniar en la obra de Rodin.

\section{7}

\section{Determinaciones de la Escultura}

Rosalind Krauss, en su texto titulado Sculpture in the expanded field, 1979, presenta la escultura como una categoría no universal, por lo tanto, no válida para todos los pueblos y culturas. Es una categoría históricamente determinada y, en ese sentido, la escultura es una convención que tiene su lógica o conjunto de reglas internas, "aunque pueda aplicarse a distintas situaciones, no puede modificarse demasiado." ${ }^{86}$ La lógica de la escultura es inseparable del monumento $y$, siendo la estatuaria una representación conmemorativa o evocativa, tiene una relación específica con un lugar determinado, "se asienta en un lugar específico y habla en una lengua simbólica sobre el significado o el uso de dicho lugar." ${ }^{87}$ Las estatuas funcionan por lo tanto en relación con la lógica de su representación y de su papel como hito, por eso son "figurativas y verticales, y sus pedestales son parte importante de la estructura dado que sirven de intermediarios entre la ubicación real y el signo representacional." ${ }^{88}$ Sin embargo, la autora recuerda que la convención no es inmutable y sitúa el momento en que la convención de la estatuaria empieza a destruirse. Ese momento es el final del siglo XIX, con el trabajo de Rodin, más

\footnotetext{
${ }^{86}$ KRAUSS, Rosalind E., La originalidad de la Vanguardia y otros mitos modernos, versión española de Adolfo Gómez Cedillo, Madrid, Alianza Editorial, 2002, p. 292.

${ }^{87}$ Idem, Ibidem.

${ }^{88}$ Ibidem.
} 
precisamente con sus estatuas de Balzac, 1893-97, y sobre todo con las Puertas del Infierno, 1880-1917. Ambas desvalorizan la lógica narrativa del monumento, y de esa condición negativa del monumento o de la estatuaria, nace la escultura.

\section{8}

\section{Rodin, apología de la opacidad o la inauguración del campo estricto de la escultura}

En Passages in Modern Sculpture, Rosalind Krauss se sirve del ejemplo de las Puertas del Infierno para establecer una relación entre la estatuaria y la inauguración del campo de la escultura propiamente dicho. Claramente el argumento de Krauss ubica a la escultura de Rodin del lado de la opacidad, mientras que la estrategia clásica y neoclásica de la estatuaria se encuentra del lado de la transparencia. "Los ingeniosos arreglos de Canova y Carpeaux habían hecho que las vistas externas de sus figuras pareciesen transparentes a un sentido de significado interno." ${ }^{89}$ Por el contrario, la obra de Rodin, y muy especialmente las Puertas del Infierno, reflejan características nuevas que se acercan a la opacidad; valdría decir a una relación de autorreferencialidad propia de la escultura.

Las Puertas del Infierno es una obra encargada para formar parte de la arquitectura del futuro Museo de Artes Decorativas de París, no obstante, nunca pudo funcionar en el lugar para donde fue concebida, se volvió demasiado pesada e inoperante, por eso no tuvieron en cuenta su función. Entre 1880 y 1917, año de la muerte de Rodin en Meudon, el escultor transformó la puerta en una especie de laboratorio o en un vivero de esculturas que después fueron tratadas individualmente.

\footnotetext{
${ }^{89}$ Traducción libre. KRAUSS, Rosalind E., Caminhos da Escultura Moderna, trad. al portugués de Julio Fischer, São Paulo, Martins Fontes, 2001, p. 25.
} 
Como encargo, la obra Las Puertas del Infierno tenía todas las condiciones para que Rodin siguiera las convenciones clásicas y neoclásicas de creación de relieves narrativos basados en la representación del flujo temporal secuencial. Además de estar sometida a una arquitectura, y por lo tanto de ser un encargo, las Puertas deberían funcionar como ilustración de la Divina Comedia de Dante. De hecho, sus primeros esbozos indicarían que el artista podría haber tratado la narrativa a partir de premisas aceptadas como correctas por los practicantes de la estatuaria del siglo XIX. Sin embargo, en su "versión final, Las Puertas del Infierno resiste a todos los intentos de ser comprendida como una narrativa coherente.." ${ }^{90}$ Esto sucede porque Rodin demuestra tener, en muchos aspectos de su práctica, un retroceso y una conciencia crítica en relación con lo que otros escultores hacían e hicieron, como se puede testimoniar en sus escritos. ${ }^{91}$ En ellos, el artista demuestra capacidad de teorización de la escultura, al pensar, por ejemplo, acerca del trabajo de Fidias y Miguel Ángel.

En las Puertas, la narrativa secuencial se ve frustrada porque Rodin utiliza la repetición de figuras, hecho que rompe con el principio de la "singularidad espacio-temporal que es un prerrequisito de la narrativa lógica, puesto que la duplicación tiende a destruir la posibilidad misma de una secuencia narrativa lógica." ${ }^{92}$ En la parte superior de las Puertas, las tres figuras representadas son idénticas, de esta forma que el observador se ve obligado a ver la misma figura en rotación, lo que demuestra una actitud de "parodia de la tradición de agrupar figuras tríplices, típica de la escultura neoclásica." ${ }^{93}$ Esta estrategia le permite al espectador ver el mismo objeto "a partir de todos los puntos al mismo tiempo," ${ }^{94}$ lo que cuestiona las nociones tradicionales de composición de la estatuaria, basadas en la composición unificada y equilibrada en la disposición de las formas. "Por la simple repetición de la misma figura tres

\footnotetext{
90 Idem, p. 19.

${ }^{91}$ RODIN, AUGUST, L'art, París, Bernard Grasset, 1911.

92 Traducción libre. KRAUSS, Rosalind E., Caminhos da Escultura Moderna, trad. de Julio Fischer, São Paulo, Martins Fontes, 2001, p. 21.

93 Idem, p. 22.

${ }^{94}$ Ibidem, p. 23.
} 
veces, Rodin le quita al grupo la idea de composición." ${ }^{95}$ Al mismo tiempo, su trabajo se vuelve opaco, ya que las tres figuras repetidas, que Rosalind Krauss denomina sombras, no crean entre sí "una relación que parezca susceptible de significación, de crear un signo transparente a su significado. Por el contrario, la repetición de las sombras cae en la creación de un signo totalmente autorreferente." 96

A partir de esta autorreferencialidad, la escultura se inaugura como proceso autónomo que reflexiona y se recrea a partir de sus condiciones específicas. Otra prueba de esa autorreferencialidad, que se puede observar también en las Puertas, procede de la forma como se proyecta la sombra de la escultura como consecuencia de la luz incidente. Mientras que, en los bajorrelieves neoclásicos, el fondo funciona como «el plano de un cuadro», que más allá de él la sombra proyectada de las figuras recrea virtualmente la totalidad de su profundidad, en las Puertas de Rodin, la sombra proyectada parece enfatizar el aislamiento y la indiferencia de las figuras con pleno volumen en relación al fondo del relieve y reforzar en esa impresión de ese fondo como objeto sólido aparte, una especie de objeto que no permite la ilusión de que alguien pueda ver, a través de él, un espacio proyectado." ${ }^{97}$ En las Puertas del Infierno, el fondo asume el papel de segmentador de las figuras, hecho $\sin$ parangón en la historia de la estatuaria, al "presentarlas como literalmente truncadas negándoles la ficción de un espacio virtual en donde pueden dar la apariencia de expandirse. Por eso la puerta se ve despojada simultáneamente del espacio y del tiempo que le sirvieron de soporte para el desarrollo de una narrativa. El espacio en la obra se congela e inmoviliza: las relaciones temporales son conducidas a una densa ausencia de claridad." 98

Por otro lado, la opacidad característica de la escultura, se encuentra también expresada en el tratamiento de las mismas figuras. Tanto en las Puertas, como en otras obras de Rodin, los cuerpos representados parecen no obedecer

\footnotetext{
95 Ibidem, p. 24.

96 Ibidem, p. 25.

97 Ibidem, p. 29.

98 Ibidem.
} 
a la sub-estructura del esqueleto. Este tratamiento hace que la claridad del contorno deje de verse. "Los cuerpos se funden, así, en un único contorno que vuelve la reciprocidad de su gesto altamente ambigua." ${ }^{99}$ La verdad anatómica que les garantizó a los clásicos proporción, realismo y contorno puro es ahora sometida a la fuerza del gesto del escultor que asume las marcas del proceso de trabajo como forma de hacer sucumbir el orden esquelético y muscular de los cuerpos. La escultura así concebida se convierte en una sugerencia de "bola de carne" que proyecta simultáneamente en el observador sensaciones paradójicas de peso y levedad.

La escultura de Rodin ya no es exclusivamente gobernada por el mito o por la historia que exigían reglas de ejecución premeditadamente rígidas para su ejecución. La escultura se libera del peso del mito y de la historia y se convierte en el resultado de una "creencia en la manifiesta inteligibilidad de las superficies esculpidas." ${ }^{100}$ Quiere decir que la escultura sólo sucede para el escultor en acto, sin ninguna estructura rígida previa de apoyo universalmente aceptada. La superficie se convierte en el lugar donde el observador de la escultura se detiene, y tanto expresa el resultado de las fuerzas internas como de las externas. Internas son las fuerzas anatómicas y musculares, mientras que las externas son las "que provienen del artista: el acto de manipulación, el artificio, su proceso de elaboración." 101

Esta atención a la superficie que coloca en plano de igualdad representación, gesto y materialidad de la escultura se acentúa por referencias deliberadas y bien pronunciadas de Rodin a su proceso de trabajo. Lo que "obliga al observador, en repetidas ocasiones, a entender la obra como el resultado de un proceso, un acto que dio forma a la figura a lo largo del tiempo." ${ }^{102}$ Marcas del bisel y de la mano modelando las materias transitorias de la escultura como el barro o el yeso, hacen que el significado de la escultura no

\footnotetext{
99 Ibidem, p. 31.

100 Ibidem, p. 33.

101 Ibidem, p. 36.

102 Ibidem, p. 37.
} 
se produzca previamente al acto de observar y esculpir, "sino que suceda en el proceso mismo de la experiencia.." ${ }^{103}$

A partir de Rodin, Alberto Giacometti ya podrá entender la superficie de la escultura como lugar de combate y testigo de un proceso externo de formación. Su ejecución, a partir de 1935, se realiza de tal forma que sentimos que estamos observando algo modelado por la erosión. El avance protagonizado por la obra de Rodin fue de gran importancia ya que, al mostrar distanciamiento crítico en relación a la práctica de la estatuaria, inaugura el campo de la escultura como territorio libre del peso del mito, de la historia y de la tradición clásica y académica. Con Rodin se inaugura el campo estricto de la escultura, pero también el movimiento de la escultura hacia afuera de sí misma. Comprendemos muy bien este movimiento de emancipación de la escultura, cuando comparamos el acto de Rodin con lo que serían las prácticas escultóricas de mediados del siglo XX, especialmente las norteamericanas.

\section{9}

\section{Escultura como el resultado de un diálogo}

Obviamente, la lógica de la producción de la estatuaria no se detuvo con los avances de Rodin, subsistió paralelamente en muchos escultores. No obstante, el trabajo de Rodin se afirma aquí como un punto nodal fundamental para la práctica modernista del arte en general y de la escultura en particular. A partir de aquí, el proceso de una escultura moderna deja de caracterizarse esencialmente por ser una lucha del escultor con la dureza del material, pasando a funcionar más bien como un diálogo donde la escultura expresa, según Herbert Read, un "principio orgánico"; este concepto vitalista reconoce la forma como algo que es determinado en primera instancia por las características físicas naturales del material. "Las intenciones de un escultor como Henry Moore no

${ }^{103}$ Traducción libre. KRAUSS, Rosalind E., Caminhos da Escultura Moderna, traducción de Julio Fischer, São Paulo, Martins Fontes, 2001, p. 37. 
tienen nada que ver con la capacidad virtuosa de dominio de un material. Si es piedra, considerará su estructura, su grado de dureza, la forma de reaccionar a su cincelado. Considerará cómo la calidad de la piedra ha reaccionado a la acción de las fuerzas naturales, como el viento y la lluvia, ya que éstas con el transcurso del tiempo, fueron revelando las cualidades inherentes de la piedra. Por último, se preguntará cuál es la forma que podrá realizar mejor, dado el particular bloque de piedra que tiene delante; y si esa forma es, digamos, la figura de una mujer tumbada, imaginará (y es este aspecto que revela su peculiar sensibilidad y percepción para imaginar), qué apariencia tendría una mujer tumbada si la carne y la sangre se volviesen la piedra que tiene delante (...) El cuerpo de la mujer puede entonces (...) adquirir la apariencia de una

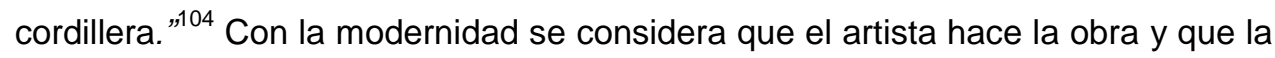
obra hace al artista. Muchos aspectos de la confección de una escultura sólo se deciden durante el hacer: "La forma, aunque pueda ser analizada en términos intelectuales, como medida, equilibrio, ritmo y armonía, es, en realidad, de origen intuitiva; no es, en la práctica real de los artistas, un producto del intelecto. Se trata más bien de una emoción dirigida y definida, y cuando describimos arte como «deseo de dar forma» no estamos imaginando una actividad exclusivamente intelectual, sino una actividad exclusivamente instintiva"105. Esta noción de la escultura parte de la base de que el artista exterioriza, dialogando con el material, su espacio interior. La escultura se correspondería así con las percepciones, emociones y concepciones del artista, siendo de esta forma una traducción material de todos estos elementos. Ese espacio interior es de "donde proviene la energía de la materia viva, a partir de la cual su organización se desarrolla como los anillos concéntricos que anualmente se forman en dirección al exterior a partir de un núcleo constituido por el tronco del árbol." ${ }^{106}$ Esta concepción, muy importante para la práctica de la escultura moderna, coincide perfectamente con los intentos realistas de Alberto Giacometti.

\footnotetext{
${ }^{104}$ Traducción libre. READ, Herbert, O Significado da Arte, trad. de A. Neves Pedro, Lisboa, Editorial Ulisseia, 1968, pp. 165-166.

${ }^{105}$ Idem, p. 17.

${ }^{106}$ Traducción libre. KRAUSS, Rosalind E., Caminhos da Escultura Moderna, trad. de Julio Fischer, São Paulo, Martins Fontes, 2001, p. 301.
} 
Otra distinción entre la estatuaria clásica y la modernista tiene que ver con el hecho de que el escultor modernista ya no es obligado a producir una similitud evocativa, sino más bien una similitud expresiva, o incluso a no producir ninguna $y$, por lo tanto, a proponer la elaboración de una escultura deliberadamente abstracta y autorreferencial. La escultura moderna se basa en condiciones específicas como la materialidad, la fetichización del pedestal, valores compositivos subjetivos, etc.

Para un escultor como Henry Moore, la escultura es el resultado del diálogo entre dos fuerzas: una que viene de adentro, dada por las condiciones mismas de la materialidad y otra que viene de afuera, dada por las decisiones subjetivas del escultor al esculpir un determinado material. La superficie de la escultura se teje constantemente por estas dos fuerzas; el lugar de encuentro de estas dos fuerzas es el contorno de la escultura, por lo tanto es el lugar del dibujo. Para la mayoría de los escultores modernos, pero particularmente para $\mathrm{H}$. Moore, "la forma es entonces una intuición de la superficie hecha por el escultor, imaginariamente sentida en el centro de gravedad del bloque que está ante él. Bajo la dirección de esa intuición, la piedra es lentamente llevada de un estado de existencia arbitrario a un estado ideal". ${ }^{107}$ Moore, pero también Jean Arp, querían trabajar la idea de que "[en el] centro de la materia inerte de la escultura, existía una fuente de energía que daba forma y vida a ella. Pretendían establecer una analogía entre la formación lenta de los estratos de roca, o de las fisuras de la madera, y el crecimiento de la vida orgánica a partir de la minúscula semilla que es su punto de partida. Al usar la escultura para crear esa metáfora, estaban estableciendo el significado abstracto de su trabajo; estaban afirmando que el proceso de creación de la forma es, para el escultor, una mediación visual sobre la lógica del desarrollo orgánico mismo" ${ }^{108}$. Para Moore, "las vetas del mármol, las estrías de caliza o los nódulos de la madera tal como se forman en la naturaleza, se convierten en los mapas que los instrumentos de entalladura seguirán en el trabajo del artista directamente sobre el bloque sólido,

\footnotetext{
${ }^{107}$ Traducción libre. READ, Herbert, O Significado da Arte, trad. de A. Neves Pedro, Lisboa, Editora Ulisseia, 1968, pág. 166.

${ }^{108}$ Traducción libre. KRAUSS, Rosalind E., Caminhos da Escultura Moderna, trad. de Julio Fischer, São Paulo, Martins Fontes, 2001, pp. 301 y 303.
} 
penetrándolo en dirección al centro." Esta premisa configuradora de la materia fue trabajada posteriormente por el artista Italiano Giuseppe Penone, ya no como metáfora, sino de forma literal. Por ejemplo, en cada elemento de su obra Ripetere il bosco, 1997, que anteriormente presentamos como un ejemplo de bosque en el campo de la escultura, la forma ya se encuentra previamente en cada viga de madera, se trata por eso de una escultura literalmente transparente que aparece después de que el escultor rescata la forma natural, retirando el exceso de material hasta descubrir los contornos puros de un árbol que, como vimos, es el testigo de un tiempo anterior. "Giuseppe Penone realiza una labor opuesta a la que se lleva a cabo en una serrería, donde el árbol es transformado en vigas uniformes $\mathrm{o}$ en tablas que después serán trabajadas y pulidas por el ebanista. El artista parte del volumen de la viga, que excava hasta alcanzar un anillo de crecimiento, a partir del que hace surgir el tronco, con los nudos de la madera indicando el punto en el que nacieron las ramas. Penone deja de lado la representación y lo que presenta a partir de los materiales de construcción es la forma matricial del árbol, que él revela, reencontrando su memoria, «reconstruyéndola a partir de vigas. En este caso, no añade nada, sino que, por el contrario, retira lo que sobra, retomando así la concepción de Miguel Ángel de la escultura, «que se hace, a fuerza de ir quitando». Penone descubre la memoria, el vestigio de la forma natural del árbol captada en un momento particular de su crecimiento, cuando fue cortado. Ex huma las capas olvidadas, rehaciendo muchos de los gestos del corte tradicional de los leñadores: podando, pelando, desbastando, descortezando, amolando, incidiendo, excavando... hasta volver a hacer surgir la forma del árbol tal como era con sus ramas. Vemos la tabla volver a ser árbol, el árbol renacer, tras haber estado embutido en su ganga como en un ataúd." 109

Los árboles de Penone, cuando se consideran individualmente, prueban que la mediación visual usada por Moore para comprender la vida orgánica no llegó tan lejos como sería de esperar, diríamos hoy, al observar las esculturas de Penone. Pero, en el caso de Moore, tenemos que mencionar que, a pesar de que

\footnotetext{
${ }^{109}$ Traducción libre. DUMAS, Robert, Tratado da Árvore, Ensaio de uma Filosofia Ocidental, trad. de Maria Jorge Vilar de Figueiredo, Assírio \& Alvim, 2007, pp. 242-243.
} 
su escultura parta de ese protagonismo de las condiciones mismas del material, ellas no son el punto de llegada de la escultura. Precisamente porque la tesitura entre las dos fuerzas, una interior y otra exterior, demuestran la calidad fundamental del espacio en la escultura. A pesar de todo, la misma no es inmune a la tradición clásica de composición basada en el equilibrio de masas que retoma la idea de tactilidad ideal defendida por Hildebrand, sólo posible porque la composición de sus obras obedece a la idea clásica de valoración unitaria que permite al observador aprehenderla en su totalidad.

\subsection{0}

\section{Descubrimiento del espacio como determinación activa de la escultura}

La estatuaria y gran parte de la escultura fueron concebidas para ser vistas siempre desde fuera, "como un cierto número de superficies que definen una masa". ${ }^{110}$ La masa de la escultura es el espacio sólido de la escultura, entonces el espacio es lo inverso a la masa. De aquí podemos concluir que el acento siempre estuvo en la masa, en la figura o en la forma esculpida, siendo ésta pensada como lo positivo de un espacio envolvente negativo y pasivo, contra el que la forma se recorta contra un fondo. Eduardo Chillida fue uno de los más importantes artistas que transformó esta idea del espacio. Al considerar primero el espacio y sólo después la masa, o más bien, al considerar la masa siempre en función del espacio, deja de ver el espacio como instancia negativa, pasiva y vacía, para verlo como profundamente activo, positivo y lleno. En la raíz de esta transformación está, según Kosme Barañano ${ }^{111}$, el cuestionamiento de la idea dominante de espacio que remonta a la Grecia antigua, es decir, la idea de

\footnotetext{
${ }^{110}$ Traducción libre. READ, Herbert, O Significado da Arte, traducción de A. Neves Pedro, Lisboa, Editorial Ulisseia, 1968, p. 32.

111 BARAÑANO, Kosme, "Chillida: desarrollo de la obra". In Maria M. Argila (Coord.) ¿Qué es la escultura moderna? Del objeto a la arquitectura. (pp. 241-262). Madrid, Fundacion Cultural MAPRE VIDA, 2003.
} 
que existe un Pleon y un Kenon, respectivamente, uno lleno que corresponde a la masa o a la materia de un cuerpo y uno vacío que envuelve ese cuerpo. Ese vacío es el primero a ser cuestionado por Parménides y después por Demócrito, llegándose a la noción de que no hay vacío porque éste equivaldría al espacio, es decir, una nada donde se mueven las cosas.

Chillida, fuertemente influenciado por los estudios sobre el espacio, se aproxima a la lectura de Heidegger, quien invierte el problema del espacio postulado por Aristóteles. Mientras que Aristóteles concebía el espacio como un lugar que puede ser medido, determinado, localizado y ordenado, para Heidegger sólo tiene sentido proceder a un análisis de las cosas del espacio, no a partir de sus relaciones, sino a partir de la espacialidad del ser humano. Así, para Heidegger, el espacio deviene siempre del uso que de él hace cada ser humano, efectuando intercambios por su dinamismo, así el cuerpo es el que justifica el espacio y le da sentido. $\mathrm{Y}$ donde hay espacio, en el sentido heideggeriano, hay también tiempo. "El tiempo se presenta siempre donde está el espacio. Sobre todo cuando hay un espectador que se mueve y que está vivo, se mueve y hay un espacio, pero ese espacio llama al tiempo porque tú te mueves y ya es tiempo lo que está ocurriendo entre tú y la obra que estás mirando; es el tiempo el que está jugando (...) En todas las esculturas el tiempo siempre está presente si hay un ser vivo que las mira. En una escultura el tiempo es un valor añadido." ${ }^{112}$ En esta entrevista, Chillida señala claramente la idea de que el espacio y el tiempo no están desconectados y que el sentido pleno de ambos sólo se activa por la presencia de un ser humano, porque el espacio se define en función del ser humano en el mundo. De esta forma, la escultura aparece como lugar de "formación y cuestionamiento del espacio, donde pensamiento e invención se corporeizan." ${ }^{113}$ Esta forma de pensar la escultura, colocando el acento en el espacio que es activado por el cuerpo del hombre, se encuentra bien representado en su serie de esculturas tituladas "Lo profundo es el aire”, que el artista realizó entre los años 1980 y 1990, en las cuales Chillida

\footnotetext{
${ }^{112}$ CHILLIDA, Eduardo, in Entrevista de Sanjuana Martínez a Eduardo Chillida (www. Babab.com)

${ }^{113}$ BARAÑANO, Kosme, "Chillida: desarrollo de la obra". In Maria M. Argila (Coord.) ¿Qué es la escultura moderna? Del objeto a la arquitectura. (pp. 241-262). Madrid, Fundacion Cultural MAPRE VIDA, 2003, p. 251.
} 
concretó su utopía de hacer una "serie de penetraciones" en bloques de basalto y granito, dejando su exterior original y en bruto.

Más tarde estas piedras darían lugar a la posibilidad de esculpir el interior de una montaña en Tindaya, Fuerteventura. Ese proyecto utópico, que tendrá un área excavada en el interior de la montaña equivalente a la del Panteón de Roma, será un ejemplo de escultura monumental que al mismo tiempo nos retrotrae a los observatorios primitivos, colocando al hombre literalmente dentro de la escultura.

\subsection{1}

\section{Primeras esculturas que son arquitecturas o la reversión del espacio exterior en uno interior.}

Colocar al hombre dentro de la escultura implica una gran transformación del entendimiento de esta práctica, ya que la escultura, al dejar de ser entendida como un cierto número de superficies que delimitan una masa, se convierte, como en la arquitectura, en un cierto número de paredes que delimitan espacios.

En 1923, deben ser citados dos proyectos originales para entender la apertura del campo temático estricto de la escultura a la arquitectura. Se trata de la Merzbau de Kurt Schwitters y el Proun de El Lissitzky, ambos construidos en Alemania e influidos por el arte abstracto. Iniciado en 1923, la Merzbau, fue un proyecto que tuvo continuidad a lo largo de la vida de Schwitters. Elisabeth Burns ${ }^{114}$ describe que al principio la construcción de este espacio había empezado por ser una columna construida en el taller, luego fue creciendo a través de la adición de varios elementos y, de esa forma, la escultura pasó a ocupar las paredes, el piso y el techo del taller. El resultado de ese proceso acumulativo es la Merzbau que al principio llevaba por nombre "The cathedral of

\footnotetext{
${ }^{114}$ GAMARD, Elisabeth Burns, Kurt Schwitters Merzbau The cathedral of erotic misery, Nueva York, Princeton Architectural Press, 2000.
} 
erotic misery", resultante de su connotación sexual, puesto que la construcción funciona a partir de la idea de gruta o pasaje interior representado que parece tener origen en Wagner o en las ideas grotescas contenidas en algunos ejemplos de la literatura gótica del siglo XIX. En esta literatura suceden frecuentemente descripciones donde espacios exteriores se vuelven interiores escenificados, como se puede testimoniar en Edgar Allan Poe, en particular en la descripción que hace en La caída de la casa Husher, donde la vivienda, familiar vista desde el exterior, termina por revelarse extraña en su interior. La Merzbau es un espacio de gruta, heteróclito, construido con materiales variados que delimitan las superficies interiores, todas recubiertas y unificadas por la blancura del yeso que le da a la escultura una piel común que uniforma el conjunto de la intervención y obliga a que sea vista más como conjunto que como detalle, dándole a la obra la idea de reverso de una escultura. La Merzbau no es una arquitectura, al entender de Schwitters, es una escultura que sólo tiene existencia a partir del movimiento del espectador en su interior. "En palabras del artista, se trataba de "una escultura cubista a la cual se puede ir y volver, es decir, una escultura penetrable y habitada por el espectador," ${ }^{115}$ que al moverse construye una cinemática del espacio derivada de la virtualización del mismo, realizada por la mirada.

El Proun de El Lissitzky fue presentado en 1923, en Berlín. Éste consistía en una muestra de todo el léxico visual de Malevich dentro de una arquitectura que es simultáneamente el reverso de una escultura, en el sentido en que estamos ante una inversión de una escultura que se da vuelta, es por lo menos eso lo que se puede ver en los dibujos de proyecto, ya que una escultura ha sido siempre algo que se ve desde fuera. El Proun funciona como un espacio donde el observador entra; es por lo tanto un espacio híbrido que abarca diferentes aspectos de la arquitectura y de la escultura y que se afirma como uno de los primeros ejemplos de abertura del campo de la escultura y que se produjo de forma deliberada a mediados del siglo XX. De esta obra forman parte los dibujos preparatorios y los dibujos de proyecto titulados Proyecto Proun que el artista

\footnotetext{
${ }^{115}$ Traducción libre. SARDO, Delfim, Instalação in http://www.arte-coa.pt, activo el 16 de agosto de 2011.
} 
calificaba también como obras de arte autónomas de la concreción final del Proun. Aunque la construcción final del Proun consista en una sala cerrada, podemos observar en el dibujo de proyecto (Fig. 22), que ese espacio se describe como si se tratara de un espacio abierto, porque, para El Lissitzky, su proyecto no obedece a la concepción renacentista y euclidiana puesto que lo que importa es su temporalidad construida por el espectador que, al recorrer el espacio, va construyendo para sí mismo una determinada temporalidad.

Tanto el Merzbau de Kurt Schwitters como el Proun de El Lissitzky son ejemplos de prácticas artísticas híbridas y heterodoxas y, por lo tanto, amplias. Por eso, contribuyeron a la desvalorización de los medios tradicionales, como la escultura, que ahora ya no obedece a un proceso en el que el artista, dialogando con el material, exterioriza su espacio interior dotando así a su obra de originalidad, sino en el que la escultura usa los procedimientos disciplinarios proyectuales de la arquitectura y del diseño que hasta aquí le estaban vedados. Podemos decir entonces que esta abertura a estas nuevas obras, sólo existe si las mismas son usadas por el observador que les da sentido en la medida de su experiencia al recorrer estos espacios concebidos a partir de una práctica que El Lissitzky denomina laboratorial, con el objetivo de que el arte sea destinado al espacio real de la vida de las personas.

La mayor abertura del Merzbau, como el Proun, crea también un nuevo entendimiento para la obra de arte que se convierte en el resultado de varias cuestiones creadas a partir del tema de la exposición inaugurada por el constructivismo ruso. Schwitters y El Lissitzky ya no se concentran en los procedimientos propios de las categorías académicas tradicionales para darle mayor atención al contexto expositivo que resulta de su concepción de espacio como proyecto concebido para proporcionar a cada uno una experiencia temporal, una cinemática del espacio en el que cada uno es su propio editor, como si se tratase de un momento pre-cinematográfico. Pues el espectador, al caminar, por ejemplo en el Abstract cabinet, 1927-28 de El Lissitzky, tiene la libertad de trazar para sí mismo una determinada experiencia del espacio; puede avanzar y retroceder, puesto que, en el entorno de esta obra, esas decisiones personales implican, de acuerdo con la estructura construida del espacio, una 
modificación concreta de su percepción, ya que las paredes del Abstract cabinet, de acuerdo con el ángulo en que son observadas, adquieren formas y colores diferentes debido a las barras verticales que cubren las mismas. Por lo tanto, la configuración del espacio es tan dinámica como el grado de movimiento del espectador, y ese recurso plástico ya se encontraba previsto en el proyecto.

Como vimos, Schwitters y El Lissitzky transformaron considerablemente el campo de la escultura, al proponer espacios que podían ser penetradas por el hombre. A partir de aquí y, por vía del uso de las disciplinas de proyecto, la escultura se transforma también en una construcción autorreferencial y simultáneamente social que tenía como territorio de intervención privilegiado el espacio público. Cuando no hay lugar a la intervención en el espacio público, la escultura se muestra entonces a partir de su proyecto, maqueta o modelo, puesto que estos funcionan como laboratorio de posibilidades constructivas, como es el caso del Monumento a la Tercera Internacional, de Vladimir Tatlin, construido en los años 1919-20 y que, debido a su escala monumental, sólo existió como maqueta. Esta propuesta de Tatlin era simultáneamente una escultura y el edificio sede de la III Internacional. El artista concibió el monumento como un edificio torre, "que debería tener un tercio más de altura que la Torre Eiffel, con un revestimiento externo de vigas de acero envolviendo tres grandes volúmenes de vidrio superpuestos que funcionaban como salas de reunión y oficinas (...) Tatlin proyectó el volumen inferior como un gigantesco tambor de vidrio que giraría lentamente a la velocidad de una rotación completa por año; el volumen siguiente, de forma piramidal, describía una rotación completa una vez por mes, mientras que el volumen superior -un salón cilíndrico coronado por un hemisferio- haría una rotación completa por día."116 Esta escultura, que funcionaba como homenaje a la revolución soviética, expresaba una actitud holística, de reunión de varias artes en la escultura, como la arquitectura y la pintura. Su concepción no era intuitiva y estaba completamente comprometida con la idea de construcción o de realidad espacial.

\footnotetext{
116 Traducción libre. KRAUSS, Rosalind E., Caminhos da Escultura Moderna, trad. al portugués de Julio Fischer, São Paulo, Martins Fontes, 2001, pp. 75-76.
} 
Estos proyectos del inicio del siglo XX son ejemplos de procesos de creación artística que corresponden a una emancipación del arte en relación con los medios tradicionales o creativos, de cara a la realización de un objeto, contribuyendo así a la creación de espacios de experiencia colectivos basados en el tema de exposición y con el objetivo de actuar en el espacio real de la vida de las personas, negando de esa forma una cierta noción de virtualidad exigida por otras obras modernistas de la primera mitad del siglo XX. El Merzbau y el Proun son obras de arte concebidas para que el espectador sea un actor en la configuración del espacio y de la realidad a partir del proyecto de exposición que será su principal herramienta de trabajo. De esta forma, la obra de arte se libera de la idea secular de ser considerada el producto de un individuo para transformarse en un lugar de participación y adhesión a una experiencia propuesta por un artista. Estamos ante un desplazamiento del arte, de su territorio contemplativo estético al arte, con una tónica en la realidad de la escultura que construye un espacio a escala 1/1 para ser usado por el cuerpo humano. No obstante, estas propuestas de Schwitters, El Lissitzky y Tatlin, a pesar de surgir en torno a 1920, permanecieron como excepción durante la primera mitad del siglo XX y sólo se volvieron regla en el campo de lo escultórico a partir de la segunda mitad del siglo XX, en el momento de la aparición del minimalismo americano que, desvalorizando el trabajo manual, se centró en la valorización del arte como idea, o en la idea de que el momento de decisión era el que presidía al trabajo artístico, en detrimento de la lógica tradicional de la escultura y de la estatuaria que daba un envase central a la idea de que cualquier obra sólo existía después de un trabajo manual idóneo y competente en la elaboración y transformación de las materias. Como veremos, es en este punto que se va a ubicar la obra y los comportamientos de Alberto Carneiro en el periodo comprendido entre los años 1968-80, periodo durante el cual fue proyectada y presentada Una floresta para os teus sonhos, 1970.

La escultura abre entonces su campo de actuación a favor de una idea holística de obra de arte en general. En el sentido de la topografía de una arqueología del arte entendido en general y no sometido a sus tradicionales categorías, se debe mencionar la idea de Obra de arte total, Gesamtkunstwert, 
propuesta por Wagner en su texto La obra de arte del futuro, 1849, donde se defiende la unión de varias prácticas artísticas como el teatro, la danza, la música, la escenografía, el canto, a favor de un arte mayor que sería la ópera que, según Wagner, sería la forma más eficaz e intensa de implicar al espectador. Habrá sido esta idea de Obra de arte total la que le dio el tema necesario para concretar los intentos revolucionarios de las vanguardias rusas, específicamente en las obras que vimos de Tatlin, El Lissitzky o Schwitters. Sin embargo, las propuestas de estos artistas, a pesar de mostrar casi simultáneamente, en el entorno de lo escultórico, un nuevo entendimiento del cuerpo, es decir, un cuerpo que deja de verse como el motivo para una tarea representativa de sus similitudes antropomórficas (como había sucedido en la estatuaria y en muchas esculturas de la primera mitad del siglo $X X)$ se convierte en la creación de lugar destinado a una experiencia del hombre. A pesar de esta constatación, estas propuestas permanecieron como excepción durante la primera mitad del siglo $X X$ y sólo se volvieron regla en el campo de lo escultórico desde la segunda mitad del siglo XX hasta nuestros días.

\subsection{2}

\section{Los ready-mades y el valor de la decisión}

El recorrido de transformación del arte, como arte en general, no estaría completo sin mencionar una parte de la obra de Marcel Duchamp, específicamente sus ready-mades auténticos, como la Rueda de bicicleta, 1913, pero sobre todo los ready-mades no auténticos, como Fuente, de 1917, y Portabotellas, de 1924. Estos consistían respectivamente en ensamblajes simples de objetos o simplemente la retirada de un objeto cualquiera de su ciclo funcional, como un urinario, presentándolo firmado y como arte en el espacio institucional del museo o galería de arte. "El portabotellas firmado, su primer ready-made, fue transportado del mundo de los objetos comunes al dominio del arte por el simple hecho de haber sido firmado por el artista. Este caso (así como 
en el caso de los ready-mades siguientes (...), el artista claramente no fabricó o construyó la escultura, en lugar de eso, escogió un objeto entre un número casi infinito de productos industriales que llenaban pasivamente el espacio de su experiencia cotidiana. Un objeto sobre cuya fabricación él no tuvo el menor control. Por consiguiente, no podría ser considerado como portador de la marca de un acto creativo, es decir, el objeto no surgía como algo proveniente del manantial de ideas y emociones personales del artista"117. Al retirarle la funcionalidad y al operar procesos simples de exposición, un objeto banal y cotidiano podía ahora ser elevado a la condición de escultura o de arte en general, resultando este acto sólo de un trabajo de decisión previo y no de una acción de modelado realizado por el trabajo manual. A través de esta estrategia, Duchamp buscaba obsesivamente la respuesta a su pregunta: “¿Qué hace una obra de arte?" ${ }^{118}$. La respuesta a esta pregunta hará que el arte pueda ser considerado como idea, es decir, "el objeto de arte puede no ser un objeto físico, sino una pregunta." ${ }^{119}$ La obra de arte, que hasta aquí se definía como una transformación del material por acción de la mano y del cuerpo, pasando por varios estadios hasta la decisión por parte del artista de que la obra está terminada, pasa ahora, con los ready-mades de Duchamp, a definirse sólo por su último estado. La obra es sólo el resultado de la decisión; podemos decir que en los ready-mades sólo tenemos acceso al momento de decisión, pasando el arte a disfrutar de una especie de desmaterialización, hecho que, como veremos, será de suma importancia para el minimalismo y para la concepción de Uma floresta para os teus sonhos, de Alberto Carneiro. De hecho, siendo el resultado de una anamnesis, la obra es el resultado de una decisión de querer mostrar solamente una imagen que pasa en la cabeza del artista.

Rosalind Krauss, en su libro Voyage in the North Sea: Art in the age of the post-mediun condition, estudia la obra del artista belga Marcel Broodthaers y defiende que, en arte, existe un antes y un después de Duchamp, caracterizando

\footnotetext{
117 Traducción libre. KRAUSS, Rosalind E., Caminhos da Escultura Moderna, trad. de Julio Fischer, São Paulo, Martins Fontes, 2001, pp. 88-91.

${ }^{118}$ Idem, p. 88.

${ }^{119}$ Ibidem, p.91.
} 
al primero como el resultado de un trabajo efectivo del cuerpo y de la mano en la transformación del objeto artístico que crea la expresividad y la singularidad de la obra y, el otro, post-duchampiano, en el que la idea de que el arte deriva del esfuerzo físico y del empeño psíquico del artista es cuestionado a favor, como vimos, de la centralidad que ahora tiene el momento de decisión.

Con la erradicación de cualquier motricidad transformadora, se hace difícil garantizar la singularidad de la obra, el aura, su estatuto especial en el contexto cultural, así como su carácter excepcional. Para entender la obra de arte como idea, los criterios pre-duchampianos dejan de ser válidos, creándose otros que confieren a la idea y a la capacidad conceptual del artista el centro de toda la actividad creadora. En este contexto post-duchampiano, la idea es el centro y la forma del material es secundaria, efímera, desprovista de valor e incluso desmaterializada. ${ }^{120}$ Esta nueva condición para la creación fue designada por Rosalind Krauss «The post-medium condition» ${ }^{121}$; es decir, el arte que se practica, poniendo la centralidad en el componente conceptual, haciendo que un artista pueda darse el lujo de practicar un género sin dominar los fundamentos de esa práctica. En muchos casos, esa nueva práctica es omisa o extraña a los procedimientos tradicionalmente establecidos, como siendo los naturales para la práctica de ese género. En esta condición, cada artista utiliza los saberes y los procedimientos de la disciplina que mejor le convenga, pretendiendo un determinado objetivo libre de cualquier condicionamiento.

\footnotetext{
${ }^{120}$ El término desmaterialización aplicado a la obra de arte fue trabajado por Lucy Lippard en su libro The dematerialization of the art object, editado en 1973. LIPPARD, Lucy. Six Years: The dematerialization of the art object from 1966 to 1972. Berkeley/Los Angeles: University of California Press, 2001.

${ }^{121}$ KRAUSS, Rosalind, "Voyage in the North Sea: art in the age of the post-mediun condition", Thames and Hudson, 1999. En este libro Rosalind Krauss estudia la obra del artista belga Marcel Broodthaers, para profundizar en la situación del paisaje del objeto moderno vinculado a una condición medium específica, para el objeto post-moderno. En Voyage on the North Sea: art in the post-medium condition, se es artista, éste ya no se guía exclusivamente por la práctica informada del género, sino por la capacidad de adecuar las cuestiones que quiere trabajar a los medios más eficaces para expresarlas, comunicarlas o exponerlas.
} 


\section{13}

\section{El Arte Minimalista}

A partir de este contexto, se vuelve cada vez más difícil definir lo que es escultura. Richard Wollheim, en su texto Minimal art, 1966, identifica el carácter minimalista, no en los artistas que hoy designamos minimalistas, sino en la obra de Ad Reinhard, Robert Rauschenberg y Marcel Duchamp. En relación a este último, Wollheim defiende que mediante sus ready-mades existe una inversión del componente trabajo del artista a favor del proceso de decisión. Así, en la obra, el trabajo da lugar al pensamiento conceptual y a la función proyectual.

If we survey the art situation of recent times, as it has come to take shape over, let us say, the last fifty years, we find that increasingly acceptance has been afforded to a class of objects that, though disparate in many ways-in looks, in intention, in moral impact have also an identifiable feature or aspect in common. And this might be expressed by saying that they have a minimal art-content: in that either they are to an extreme degree undifferentiated in themselves and therefore possess very low content of any kind, or else the differentiation that they do exhibit, which may in some cases be very considerable, comes not from the artist but from a non artistic source, like nature or the factory. Examples of the kind of thing I have in mind would be canvases of Reinhardt or (from the other end of the scale) certain combines of Rauschenberg or, perhaps better, the: non"assisted" ready-mades of Marcel Duchamp. The existence of such objects, or rather their acceptance as works of art, is bound to give rise to certain doubts or anxieties, which a robust respect for fashion may fairly permanently suppress but cannot effectively resolve. 122

Esta identificación de un contenido artístico mínimo, que es común a la obra de los artistas abordados por Wollheim, también se puede identificar en otros artistas y obras de los años 60, como Robert Morris que, en 1965, en su exposición Primary structures, presenta tres grandes formas en $\mathrm{L}$ hechas de aglomerado de madera pintada. "Morris presenta tres formas idénticas en diferentes posiciones en relación al suelo. La primera $L$ es vertical, la segunda se apoya en la lateral y la tercera se apoya en sus dos extremos. Tal disposición

\footnotetext{
${ }^{122}$ WOLLHEIM, Richard, Minimal Art. In Gregory Battcock (coord.) Minimal Art A Critical Anthology, Califórnia, University of Callfornia Press,1995, p. 389.
} 
altera cada una de las formas, volviendo más denso el elemento inferior de la primera unidad o curvando los lados de la tercera (es imposible verlos todos de la misma forma." ${ }^{123}$ Por lo tanto, esta instalación está formada por tres elementos iguales que pretenden ser leídos como tres obras diferentes. La obra causó polémica porque ponía en tela de juicio la idea de la originalidad de la obra de arte; por un lado, podía ser reproducible, y por el otro, planteaba el problema de la teatralidad porque, puesto que las obras eran realizadas en un material banal como el aglomerado de madera y dispuestas en el mismo suelo donde el espectador circulaba, eran vistas por Morris y la mayor parte de los minimalistas de los años 60 como elementos de un escenario. Existe un pensamiento de la obra en función del espectador y del espacio. En lugar de tratar la noción de escultura como resultado de la exteriorización del mundo interior del artista que sólo conduciría a la expresión de "contenidos de un espacio psicológicamente particular" ${ }^{\prime 24}$, buscan más bien explorar el espacio externo, real, de convivencia pública, lo que recrea una cierta teatralidad para el espectador que se transforma en participante de la obra de arte.

El minimalismo americano sólo puede tomar estas actitudes de rechazo del idealismo del arte europeo porque el arte americano no se comprometía con el peso de la historia y del mito como lo hacía el arte europeo. De esa forma, el desarrollo del campo de lo escultórico conoció una extraordinaria emancipación; cuando uno de los artistas del arte minimalista, Carl André, crea suelos, está reportándose a una escala que es la del mundo real y, por lo tanto, está también haciendo una escultura $1 / 1$, rechazando cualquier especie de ilusionismo. Simultáneamente, coloca la escultura directamente en el suelo, de modo que pueda ser pisada y usada por el espectador, negando las reglas convencionales de la escultura y de la estatuaria e incluso de las construcciones megalíticas. "En todas las culturas el gesto ha sido el mismo, colocar en posición vertical una o varias piedras que sirven de hito en un lugar dotándole de un carácter y una significación determinadas y diferenciadoras cuyo objeto puede ser sacralizar el

\footnotetext{
${ }^{123}$ Traducción libre. KRAUSS, Rosalind E., Caminhos da Escultura Moderna, trad. de Julio Fischer, São Paulo, Martins Fontes, 2001, pp. 318-319.

${ }^{124}$ Idem, p.317.
} 
lugar, como sucede en el caso de Stonehenge". ${ }^{25}$ Esta posición erecta permaneció siempre en toda la estatuaria, ya que garantizaba que las formas y figuras evocativas cumpliesen su función conmemorativa que definió el monumento.

Con el desvanecimiento de la lógica del monumento, la escultura cayó en una "condición negativa", "en una especie de deslocalización, de ausencia de hábitat, una absoluta pérdida de lugar"126 y ésta, como expone Maderurelo, es "una situación nueva para la escultura moderna que, no teniendo que conmemorar algo concreto en un lugar determinado, se realiza sin tener que atender a las particularidades de ceñirse a un asentamiento específico, pudiendo ser instalada en cualquier lugar, lo que la convierte en un arte nómada. La escultura se convierte de esta manera en un arte sin raíces y, por lo tanto, sin necesidad de pedestal que la ate al suelo"127 La escultura experimenta esa condición negativa convirtiéndose, en palabras de Barnett Newman, en lo que se toca cuando se retrocede para ver una pintura. En estas condiciones, la presencia de la base en el arte vanguardista, o funciona como un órgano que permaneció del componente conmemorativo de la escultura, o es objeto de citación del mismo dispositivo, es decir, los artistas la usan porque se convirtió en marca de una convención, cualquier cosa que se coloque sobre un pedestal "es una obra de arte y requiere a su alrededor un espacio sacralizado que el espectador no debe transgredir". La base de la escultura de la primera mitad del siglo XX es, en palabras de R. Krauss, objeto de un fetiche. "Mediante la fetichización de la base, la escultura se extiende hacia abajo hasta absorber el pedestal y separarlo de su ubicación; y a través de la representación de sus propios materiales o del proceso de su construcción, la escultura representa su propia autonomía. El arte de Brancusi es un extraordinario ejemplo de la forma como esto ocurre. En una obra de arte como Gallo, la base se convierte en generador morfológico de la parte figurativa del objeto; en las Cariátides y la

\footnotetext{
${ }^{125}$ MADERUELO, Javier, La pérdida del pedestal, Madrid, Círculo de Bellas Artes, 1994, p. 18.

${ }^{126}$ KRAUSS, Rosalind E., La originalidad de la Vanguardia y otros mitos modernos, versión española de Adolfo Gómez Cedillo, Madrid, Alianza Editorial, 2002, p. 293.

${ }^{127}$ MADERUELO, Javier, La idea de espacio en la arquitectura y el arte contemporáneos 1960-1989, Madrid, Akal, 2008, p. 117.
} 
Columna sin fin, la escultura es toda ella un basamento." ${ }^{128}$ Con el cuestionamiento de las reglas del clasicismo en el campo de lo escultórico, se rechaza por primera vez la posición erecta de la escultura a favor del "plano del suelo y su extensión en él, como sucede con las esculturas de Carl André" ${ }^{129}$ que muy pronto mostró interés por el tema de la valorización del soporte en la escultura de Brancusi, "comprendió que la mejor manera de acabar con el problema del pedestal, que afianzaba la verticalidad de la obra, era renunciar a que la obra escultórica siguiera siendo un elemento erecto sobre el suelo sin, por ello, perder una buena cualidad de presencia. El problema, tal como lo planteó Carl André, consistía en realizar una obra que fuera el equivalente de la columna sin fin de Brancusi, pero que se extendiera por el suelo." ${ }^{130}$ Esta idea de Carl André se encuentra en sus trabajos, pero sobre todo en Lever (Palanca), de 1966. Construida con una sucesión de ladrillos refractarios alineados en el suelo, la elección de los ladrillos tiene que ver con que no representan ningún contenido previo; es esa neutralidad que les va a interesar a los minimalistas, quienes de esta forma lograban "tratar el ready-made como una unidad abstracta y concentrar la atención en las cuestiones más genéricas, relativas a cómo se podría disponer del mismo." ${ }^{131}$ El sentido de la obra minimalista sólo se logra a través de un proceso basado en la decisión y fundamentado en la dimisión del trabajo, privilegiando el uso de materiales y procesos industriales. De este modo, se incorporan a la práctica de lo escultórico prácticas extrañas a la tradición de la escultura y que no dependen de la idea de configuración o modelado de una materia, sino de un proyecto y de la apropiación que lleva a la práctica de la escultura al territorio de la práctica del arte en sentido general.

El avance de la escultura vía negación de sus condiciones tradicionales en relación al espacio real también pudo deberse en gran parte al trabajo y a los

\footnotetext{
${ }^{128}$ KRAUSS, Rosalind E., La originalidad de la Vanguardia y otros mitos modernos, versión española de Adolfo Gómez Cedillo, Madrid, Alianza Editorial, 2002, p. 293.

${ }^{129}$ MADERUELO, Javier, La pérdida del pedestal, Madrid, Círculo de Bellas Artes, 1994, p. 18.

${ }^{130}$ MADERUELO, Javier, La idea de espacio en la arquitectura e el arte contemporáneos 1960-1989, Madrid, Akal, 2008, p. 117.

${ }^{131}$ Traducción libre. KRAUSS, Rosalind E., Caminhos da Escultura Moderna, trad. de Julio Fischer, São Paulo, Martins Fontes, 2001, p.298.
} 
escritos de Donald Judd, quien, en el texto Specific objects (1965), denomina a su campo de acción artístico como el de las tres dimensiones, en oposición a la limitación restrictiva de las dos dimensiones de la pintura, específicamente de la pintura moderna apoyada críticamente por Clement Greenberg.

Judd dice que no trabaja la pintura o la escultura, sino una categoría de objetos nuevos a los que llamó "específicos", que tienen tres dimensiones y que, no siendo utilitarios, se asumen como construcciones que pretenden ser indiferentes y provistas de forma, superficie, color e imagen unitarias, usando materiales y pinturas industriales. Las obras pretenden representar nada más que lo que son en su literalidad, por lo tanto no existe otro significado además de las condiciones materiales de los objetos expuestos. En el trabajo de Judd y de gran parte de los minimalistas, las obras tienen que asegurarse a ellas mismas $^{132}$; para eso, el dispositivo de exposición e instalación de los mencionados objetos en el espacio de la arquitectura asume un papel central, pues los objetos específicos, al no poseer una relación de jerarquía entre las partes, necesitan ser seriados en el espacio. Su escala es amplia, lo que crea un ambiente que el espectador debe activar mediante su experiencia. En las propuestas de Donald Judd no hay ningún significado oculto, porque no se produce una separación entre las cuestiones de la forma y del sentido.

Pero las propuestas de Judd estaban encuadradas en un cierto formalismo que exigía también la relación entre figura y fondo, o una figura que se recortaba contra un fondo. Fue Robert Morris quien trabajó desde el punto de vista teórico y práctico la liberación del dispositivo escultórico de la dependencia gestáltica. En el último de los ensayos publicados en un conjunto de textos aparecidos en la revista ArtForum, titulados Notes on sculpture ${ }^{133}$, de 1969 , Morris se desliga del cuestionamiento de la escultura como algo que se recorta contra un fondo, y plantea la idea de la escultura como algo que ya no es necesario recortar contra un fondo, puesto que ella misma se configura como un

\footnotetext{
${ }^{132}$ Traducción libre. JUDD, Donald, Specific Objects,in Thomas Kellein, Donald Judd: Early Work, 1955-1968, Nueva York: D.A.P., 2002. Editado originariamente en Arts Yearbook 8, 1965.

133 Traducción libre. MORRIS, Robert, Continuous Project Altered Daily, The Writings of Robert Morris, Massachusetts, MIT Press, 1995.
} 
campo sin jerarquía para la mirada. Así como sucede en la obra Untitled (Threadwaste), 1968, presentada en el MoMA de Nueva York y que consistía en el llenado total de una sala con restos de residuos de tejido, asfalto, fieltro, espejos y restos de tubos. Funciona como un espacio paisajístico sin jerarquía, por lo tanto desdiferenciado ${ }^{134}$ para la mirada del espectador; "este nuevo tipo de arte introduce una distinta forma de ver, una visión que ya no es figurativa sino paisajística, periférica, una visión de campo más que de figura. Siguiendo al psicoanalista Anton Ehrenzweig (1973), Morris habla de una visión desdiferenciada que se vincula con el caos más que con el orden. Una visión que se aleja de la figura pura de la Gestalt. Ahora la totalidad no es una imagen concebible y aprehensible, sino una sensación que moviliza al sujeto" ${ }^{135}$.

Desde que presentamos el trabajo escultórico de Tatlin, El Lissitsky, Schwitters, Carl André, Robert Morris y la noción del objeto específico de Donald Judd, oscilamos y dudamos en designar estas propuestas como escultura, denominándolas objetos escultóricos o el resultado de la práctica del arte en general.

\subsection{4}

\section{Escultura en el campo expandido}

Si buscamos en un diccionario el término escultura, podemos leer: "arte de esculpir; obra esculpida; estatuaria; una de las artes plásticas cuyo medio de expresión es el volumen y la forma." ${ }^{136}$ En otro diccionario, más especializado en

\footnotetext{
${ }^{134}$ Anton Ehrenzweig en su libro The Hidden Order Of Art - A Study in the Psychology of Artistic Imagination, que fue una de las referencias para que R. Morris escribiera "Notes on Sculpture, Part 4: Beyond Objects". Anton Ehrenzweig establece dos momentos distintos pero sucesivos en la construcción de la espacialidad en la obra de arte. El momento de la desdiferenciación y el de la diferenciación, el primero se caracteriza por no tener centro, composición, jerarquía, y por lo tanto un momento de búsqueda que está cerca del caos, el segundo es el momento en que la obra de arte adquiere orden y composición para ser leída.

${ }^{135}$ NAVARRO, Hernández, Miguel A. Robert Morris, San Sebastián, Editorial Nerea, 2010, p. 50.

${ }^{136}$ Dicionário de Língua Portuguesa, Oporto, Porto Editora, 8. edição, 1999.
} 
términos de arte, para la palabra escultura se lee: "1- cualquier obra de arte ejecutada en tres dimensiones. 2- con el advenimiento del arte conceptual en los años 70, el término también empezó a ser aplicado a una gran variedad de obras de arte de Vanguardia, algunas consistían solamente en una serie de estatutos escritos [...] y otros usando la dimensión del tiempo así como la del espacio. Cuando el artista inglés Richard Long realizó uno de sus programados paseos [...] y registró en un mapa lo que había hecho. Su "action" fue etiquetada «escultura». ${ }^{137}$ Por último, en otra publicación del mismo género, pero ahora sobre mitología griega, encuentro la afirmación de que "Dédalo es considerado el primer escultor."138

Si en la primera definición el esfuerzo de síntesis se generaliza en lo que todos pueden reconocer como escultura, en la segunda, la duda y la fragmentación del término obliga a una respuesta no concluyente. Por último, en la tercera, encontramos extraordinarias afinidades con artistas como Robert Smithson y Robert Morris y, en consecuencia, con el arte contemporáneo, el Barroco y sus puntos de vista múltiples y con lo que empezó por ser el campo expandido de la escultura.

Pero, ¿serán necesarias definiciones exactas para la especificidad del campo de actuación artístico contemporáneo? Hoy, como en los años 60-70, con Robert Smithson, Robert Morris y Dan Graham, ésta no es una cuestión urgente. Es grande el mestizaje y fragmentación de las dos principales categorías académicas, Pintura y Escultura, cuyos lindes ya en los años 60 empezaban a sufrir una prolongación o diversificación en muchas otras categorías cuyos contornos se fueron aproximando cada vez más a la realidad de las personas y a las preocupaciones de orden social, antropológico, etc.

\footnotetext{
${ }^{137}$ Traducción libre. EDWARD-LUCIE, Smith; Dicionário de Termos de Arte, D. Quixote. p. 80

${ }^{138}$ Dédalo, un reputado arquitecto, escultor y constructor, fue condenado al destierro por el tribunal Ateniense por haber matado por celos a su sobrino Talos, también inventor y constructor muy hábil, refugiándose en Creta, donde se puso al servicio del rey Minos. Diseñó para la mujer de este último, Parcifal, que quería tener relaciones con un toro, una construcción que le permitía esa posibilidad; también construyó el laberinto donde fue encerrado el Minotauro. UITTERHOEVE, Wilfried y MOORMANN, Eric M. "Dédalo \& Ícaro» in Temas sobre la mitología griega en la literatura, música, teatro y artes plásticas, Traducción de Jesús Martínez Sánchez, Madrid, Akal Ediciones, 1997, p. 95.
} 
A la pregunta: ¿ahora ya es un artista?, Dan Graham contesta que su trabajo se define por el medium que escoge para mejor servir a una determinada intencionalidad, y este medium se define por el espectador/ usuario. Así, si éste dice que una determinada obra es escultura, entonces la obra será escultura, verificándose el mismo proceso en relación a la arquitectura. Dan Graham no se define como artista: es la sociedad quien lo define, o no, como artista. ${ }^{139}$

En 1966, la revista Art Forum publica el relato de un viaje de Tony Smith conduciendo un automóvil en una carretera en construcción por los alrededores de Nueva Jersey. Smith experimentó una especie de éxtasis de lo inefable, que define como el "fin del arte". El arte no estaba siguiendo al nuevo paisaje. "El asfalto ocupa gran parte de nuestro paisaje artificial, sin embargo, no se lo puede considerar como obra de arte" ${ }^{140}$. Se plantea entonces la misma cuestión que Thierry de Duve planteó en relación a los ready-mades de Duchamp: "o es arte o no es nada" ${ }^{141}$.

En junio de 1967, el crítico Michael Fried se molesta por el relato de Tony Smith y publica en la misma revista un artículo titulado Art and Objecthood en el cual la experiencia de T. Smith era considerada como un claro ejemplo de la guerra que, según él, el teatro y la literatura le habían declarado al arte. La preocupación de Fried era que todas las artes volviesen a los límites de las materias académicas tradicionales, pues la pintura y la escultura habrían sido invadidas por otras artes.

La historia del arte nos muestra que la escultura, más que haber o no salido del campo disciplinar, se confrontó primero con sus propios límites mediante una experiencia en las márgenes para lograr ampliar el campo mismo de acción. Más que ser invadida por el espacio "escénico", la escultura invadía de una forma deliberada el espacio vivido y, en consecuencia, se encontraba con el teatro, la danza, la arquitectura y el paisaje. La experiencia de Tony Smith

\footnotetext{
139 GRAHAM, Dan, «Dan Graham in relation to architecture», Dan Graham, Works 1965 -2000, Oporto, Fundação de Serralves, 2001, pp. 317-327.

140 Talking With Tony Smith, Art Forum, diciembre de 1966 in Walkscapes, Editorial Gustavo Gili, Barcelona, 2002.

${ }^{141}$ DE DUVE, Thierry, “Kant After Duchamp”, 2ª ed, MIT Press, Massachusetts, 1997.
} 
encontró eco en los objetos de Carl André concebidos para ser caminados o más radicalmente con Richard Long donde el mismo acto de caminar es concebido como arte.

Sculpture in the expanded field, 1979, el ensayo de Rosalind Krauss, será una primera constatación de que el término escultura existe como un punto en la periferia de un campo delimitado por las coordenadas paisaje/ no paisaje y arquitectura/ no arquitectura. Más tarde, a partir del estudio de la obra del artista belga Marcel Broodthaers, Krauss profundiza, como ya citamos, la situación del paso del objeto modernista vinculado a una condición medium specific, al objeto post-modernista. En Voyage on the North Sea, art in the post-medium condition se es artista $^{142}$ : éste ya no se define por la limitación unívoca de un único medium. Se trata de una postura rizomática que reemplaza a la tradicional postura en forma de raíz única erguida ${ }^{143}$ vigente en la modernidad. Esta postura sirvió para los intentos vanguardistas del progreso humano en la historia, dentro de una narrativa lineal positivista, al mismo tiempo que direccionaba todo en búsqueda de la nueva materia, en una expresión de moda. La linealidad era algo en cierta medida extraño para la mayor parte de los artistas del Land Art, como Robert Smithson. Éste se aproxima a una forma rizomática de hacer arte que tiene su campo de actuación en una área más vasta y, por lo tanto, múltiple. Esa multiplicidad crea el principio de la horizontalidad (donde todo está al mismo nivel). De este modo, un trabajo de ámbito rizomático se caracteriza por un mayor dinamismo actuante; es un proceso de construcción y no de fijación, como sucedía en la escultura modernista y en la estatuaria moderna.

R. Smithson, como otros artistas del Land Art, nos presenta una forma rizomática de hacer arte: usa varios medios y disciplinas artísticas y denota tener una mayor conciencia del cuerpo del espectador y de lo que en él hace operar

\footnotetext{
${ }^{142}$ KRAUSS, Rosalind, Voyage In The North Sea, Art In The Age of The Post-Mediun Condition, Thames and Hudson, 1999.

${ }^{143}$ DELEUZE, Gilles y GUATTARI, Félix Mille Plateaux Capitalisme et schizophrénie, 2. Rizoma se define por oposición a raíz recta hacia donde todo confluye para crear una línea (narrativa). El rizoma establece relaciones espaciales sin que exista cualquier escala jerárquica de valores, funcionando según un principio de horizontalidad dotado de movilidad. DELEUZE, Gilles, e Guattari, Félix, Mil Platôs Capitalismo e Esquizofrenia, Trad. de Ana Lúcia de Oliveira, 5 vols., São Paulo, Editora 34, 1997 y DELEUZE, Gilles y GUATTARI, Félix, Trad. Rafael Godinho, Lisboa, Assírio \& Alvim, 2004.
} 
mutaciones en la conciencia. Así, la escultura se trabaja como lugar de reconocimiento de la naturaleza transitoria de la materia. Smithson, tal como Heráclito, está de acuerdo en que todo en la vida es mutable, por lo tanto, desarrolla estrategias creativas que permiten el trabajo y la experiencia en el espacio real por parte del espectador que se vuelve participativo al ser él el centro de la obra, dándose cuenta de las transformaciones sucedidas a lo largo de una determinada duración obtenida por su caminar o visualización de una película.

Esa idea de pasaje, de hecho, es una observación de la escultura moderna. La encontramos en el Pasillo de Nauman, en el Laberinto de Morris, en el Desvío de tierras y en el Muelle o malecón en espiral de Smithson. $Y$, con esas imágenes de pasaje, la transformación de la escultura, de un vehículo estático e idealizado en un vehículo temporal y material que empezó con Rodin, alcanza su plenitud. En cada uno de los casos, la imagen del pasaje sirve para poner tanto al observador como al artista ante el trabajo, y el mundo, en una actitud de humildad fundamental con la finalidad de que encuentre la profunda reciprocidad entre cada uno de ellos y la obra. ${ }^{144}$

La Spiral Jetty, como otras obras de Smithson, está siempre en construcción, de acuerdo con la actuación de los agentes erosivos. Crean una abertura al azar. En este entorno de trabajo, el accidente abre lo posible; más importante que el objetivo final, es el camino para llegar. Ésta es una zona del azar que tiene conexiones obvias con el trabajo de Duchamp que, además, fue bastante incrementado en los años 60 .

A partir de la constatación de que las categorías académicas pintura y escultura tienen un grado elevado de elasticidad, Krauss ya no puede definir la escultura como un punto fijo entre no paisaje y no arquitectura, como sucedía, tanto con la escultura monumentalista, como con la modernista, que, siendo diferentes en todos los otros aspectos, mantenían el mismo telón de fondo: la arquitectura y el paisaje.

Los espejos de Robert Smithson o las cajas espejadas de R. Morris disparan la topología de Krauss. Las dos condiciones, paisaje y arquitectura, que

\footnotetext{
${ }^{144}$ Traducción libre. KRAUSS, Rosalind E., Caminhos da Escultura Moderna, trad. de Julio Fischer, São Paulo, Martins Fontes, 2001. pp. 341, 342.
} 
antes servían como telón de fondo, ahora son absorbidas y forman parte de la obra. El espejo absorbe el lugar y el no lugar que es él; puede volverse de nuevo un lugar espejado a través del reflejo, ${ }^{145}$ absorbiendo el contexto del espectador, pero no le deja entrar. De este modo, el espejo es superficie y por otro lado profundidad. Por lo tanto, el espejo es ilusoriamente inclusivo, pero, en verdad, opera una serie de exclusiones; "el espejo es un símbolo de la ilusión, tan inmaterial como una película proyectada" ${ }^{146}$. Un espejo es lo que Foucault denomina heterotopía $^{147}$. Estas obras no son ni arquitectura, ni paisaje, aunque pueden simultáneamente ser ambos; los espejos en la arquitectura pueden reflejar el paisaje.

La naturaleza de estas obras, que desde el minimalismo ejecutan modificaciones espacio-temporales de la percepción, exige la ampliación del campo más allá de las coordenadas no paisaje/no arquitectura. Se añaden paisaje y arquitectura, reclamados por los nuevos trabajos como parte integrante de la posibilidad de la escultura.

El historicismo buscó sostener esta ampliación del campo de la escultura relacionándola con ejemplos históricos anteriores, traídos a colación para justificar la idea de que las propuestas del Land Art tenían al final un vínculo obvio con la historia, con Stonehenge, las líneas de Nazca o los itinerarios ritualistas marcados en el paisaje legitimaban estas formas de arte insertándolas en una cadena narrativa continua histórica. "Podía recurrirse a cualquier cosa

\footnotetext{
${ }^{145}$ Smithson en su dialéctica lugar/ no lugar esquematiza varias situaciones donde el espejo aparece como no lugar y el reflejo como lugar. SMITHSON, Robert, Robert Smithson: The Collected Writings, California, Editado por Jack Flam, University of California Press, 1996, p. 153.
}

146 "Ultramoderne", Arts Magazine, Sep/ Oct de 1967, Robert Smithson, in Smithson, Robert Smithson: The Collected Writings, California, Editado por Jack Flam, University of California Press, 1996 op cit, p. 64.

${ }^{147}$ Michel Foucault describe la imagen en un espejo como estando a su vez, entre la utopía y entre lo que él llama heterotopía: "en contraste con las utopías [hay] lugares que son absolutamente otros con respecto a todos los arreglos de disposición que ellos reflejan y de los cuales ellos hablan. [tales] lugares pueden ser llamados heterotopías. Entre esos dos, yo podría establecer una especie de experiencia de la mezcla que participa de las cualidades de ambos tipos de localización: el espejo. Es, a pesar de todo, una utopía [...] yo me veo a mí mismo donde no estoy. Al mismo tiempo [...] En la heterotopía, el espejo existe verdaderamente y tiene una especie de efecto de retorno en el lugar que ocupo. Vuelvo hacia atrás en mí mismo, empezando a volver los ojos hacia mí mismo y reconstituyéndome donde no estoy en realidad". La idea de Foucault de este espacio de duplicidad hace un registro inicial más allá del terreno. FOUCAULT, Michel «Espaços Outros» in Revista de Comunicação e Linguagens. Espaços, Lisboa, Centro de Estudos de Comunicação e linguagens, 2005, pp. 243-252. 
para justificar la conexión de la obra con la historia, y de esa forma legitimar su entidad escultórica. Era evidente que tanto Stonehenge como los campos en que los toltecas jugaban a la pelota no eran exactamente esculturas, y su papel como precedentes historicistas, por lo tanto, empezaba a resultar sospechoso."148 Aunque exista una extraordinaria afinidad de ciertas estructuras megalíticas con algunas propuestas hechas por artistas contemporáneos, como Richard Long, Robert Morris, Robert Smithson o James Turrel, la recurrente presencia en algunos trabajos de estos artistas de formas circulares, de observatorios o de líneas/dibujos trazados sobre el paisaje, y también su afinidad con algunas de esas estructuras y lugares podría llevarnos a releer, a la luz del campo de lo escultórico, las líneas marcadas en el paisaje de la Pampa de Nazca, las construcciones de Chichen Itzá en México, así como Stonehenge en Inglaterra, o el Círculo de Goseck en Alemania. No obstante, los trabajos del Land Art son realmente distintos de las construcciones megalíticas, tanto en el contexto cultural, como en su función. Los artistas de la segunda mitad del siglo XX, aunque conociesen y adoptasen muchas de estas formas primitivas como laberintos, círculos, o líneas dibujadas en la tierra, estaban usándolas porque ya formaban parte de "un universo o un espacio cultural en el que la escultura era simplemente una parte más: no eran equivalentes, como lo son en cierto modo para nuestra mentalidad historicista. Su propósito y su satisfacción residen precisamente en que son opuestos y diferentes." ${ }^{149}$ La afinidad de los artistas con estas construcciones servía para incrementar un cierto arcaísmo en el arte y, como veremos, para crear zonas de relación entre espacio institucional del arte y la tierra o el paisaje real.

Estos trabajos de Land Art en realidad son nuevos en arte. Y lo nuevo es extraño, causa impacto. El Historicismo es una forma de retirarles la extrañeza volviéndolos familiares. Lo que estos artistas buscaban en esas formas primitivas, en su arcaísmo, era la rehabilitación del cuerpo en su experiencia de

\footnotetext{
${ }^{148}$ KRAUSS, Rosalind E., La originalidad de la Vanguardia y otros mitos modernos, versión española de Adolfo Gómez Cedillo, Madrid, Alianza Editorial, 2002, pág. 292.

${ }^{149}$ Idem, p. 297.
} 
la intemporalidad y no de cualquier grado de superioridad que tiene siempre una visión progresista.

Morris defiende que, si no tenemos en cuenta el cuerpo del espectador, el objeto no es crítico, ni dialogante con el espacio. "El Barroco suponía la emergencia de una representación transformativa (inclusión del espectador en la obra, puntos de vista múltiples, uso de las distancias y continuidad espacial, exploración de nuevas relaciones con la naturaleza, asunción de los aspectos subjetivos de la percepción) que se prolonga en la contemporaneida ${ }^{150}$. Estas afirmaciones expresan la voluntad e importancia que el espectador tiene en el contexto de la obra. En los espejos de Smithson y Morris, en la Spiral Jetty del primero o en los laberintos del segundo, no se puede estar del lado de afuera, como sucedía con la mayor parte de la escultura moderna encuadrada por el pedestal; tenemos que estar adentro, interactuando rizómaticamente con la obra. Así, en el límite, cuerpo, objeto y espacio deben converger. Esta inclusión del espectador en la obra y su adecuación con referencias, tanto paisajísticas, como arquitectónicas es la evidencia de que la escultura se habrá convertido en una especie de ausencia ontológica. Hablar del campo expandido es para Krauss una estrategia que deriva de una mutación histórica determinante, a la cual denominamos postmodernidad, "obliga a emplear enfoques diferentes para pensar en la historia de la forma o desarrollar las estrategias de la crítica" ${ }^{\text {"151 }}$. La expansión de lo campo a la que se refiere la autora permite analizar las oposiciones paisaje/ no paisaje y arquitectura/ no arquitectura; por un lado se obtiene un campo cuaternario que refleja la oposición original y, por el otro y al mismo tiempo, el campo es abierto ${ }^{152}$.

Además de las cuatro coordenadas mencionadas anteriormente y que delimitan el campo, Krauss agrega tres términos más que complementan el lugar donde antes se encontraba la escultura entre no paisaje y no arquitectura. Esos

\footnotetext{
${ }^{150}$ FLÓREZ, Fernando Castro, "Robert Smithson. El dibujo en el campo expandido", in Estrategias del Dibujo en el Arte Contemporáneo, Capítulo XV, Madrid, Cátedra, 2002, p. 554.

${ }^{151}$ FLÓREZ, Fernando Castro, "Robert Smithson. El dibujo en el campo expandido", in Estrategias del Dibujo en el Arte Contemporáneo, Capítulo XV, Madrid, Cátedra, 2002, p. 556.

${ }^{152}$ Idem, Ibidem.
} 
términos son: site construction, o una especie de lugar de retorno al monumento dotado de fijación y relacionándose con el site, marked sites, como por ejemplo la Spiral Jetty o las instalaciones con espejos, y las Axiomatic structures, o trabajos más cercanos a las esculturas de tipo tradicional como algunas propuestas de Richard Serra.

Estamos ante una rejilla de análisis puesta en objetos que ya existen y, como cualquier malla o conocimiento de tipo científico, sólo es verdadero y operante hasta encontrarse con un contraejemplo. ${ }^{153}$ Krauss, para que todo pueda corroborar su argumento, analiza estas obras de Land Art como pura fisicalidad en el espacio: ahora bien, cualquiera de estas nuevas obras sobrepasa ese perímetro físico.

Un laberinto, la Spiral Jetty o el concepto de entropía enuncian una condición humana fundamental y fundadora: la experiencia de perdernos en el laberinto y la capacidad de, más que encontrar la salida, crear una relación corporal que se establece con el territorio donde nos perdemos en la búsqueda del yo en una realidad que adquiere sentido admitiendo sus propias reglas. En el límite, la Spiral Jetty, el laberinto y el concepto de entropía, son lo mismo. La Spiral Jetty, que puede ser vista como arquitectura en el paisaje, es "un laberinto en forma de planetario, una arquitectura del vértigo." ${ }^{154}$ Castro Flores escribe que durante el desplazamiento, el espectador implicado fenomenológicamente pierde la noción de las medidas y la escala se invierte, el pensamiento se enreda en una escala de centros, los puntos centrales están ordenados, a pesar de su incompatibilidad. Siguiendo los pasos en espiral regresamos a nuestros orígenes $^{155}$. Se trata de un lugar y de un no-lugar simultáneamente ${ }^{156}$. Es un intento de controlar el caos sin anularlo nunca.

\footnotetext{
${ }^{153}$ El contraejemplo en Matemáticas es la excepción a la regla que obliga a la reformulación o incluso a la eliminación de una preposición hasta entonces considerada verdadera.

${ }^{154}$ FLÓREZ, Fernando Castro, "Robert Smithson. El dibujo en el campo expandido", in Estrategias del Dibujo en el Arte Contemporáneo, Capítulo XV, Madrid, Cátedra, 2002, Op cit. p. 566.

${ }^{155}$ Idem, Op cit. pp. 565 y 569.

${ }^{156}$ Es una Heterotopia: «las Heterotopias no ofrecen consuelo, al contrario producen distorsión, inquietan a quien las recibe: lugares sin localización, como espejos capaces de producir en el tiempo de la mirada del sujeto una mezcla de realidad y fantasmagoría.» FOUCAULT, Michel «Espaços
} 
El concepto de entropía es fundamental para la comprensión del trabajo de Robert Smithson. Implica el reconocimiento de que todo se desmorona más tarde o más temprano: "Vivimos de estructuras y estamos rodeados de marcas de referencias, pero la naturaleza las va desmantelando hasta llegar a un estado que ya no tiene integridad [...] el artista actual está empezando a entender el proceso de desintegración de estructuras como un estado muy desarrollado (...) Claude Lévi-Strauss habría sugerido el perfeccionamiento de una disciplina nueva Ilamada 'Entropología'. El artista y el crítico deberían desarrollar algo similar. ${ }^{157}$

En un texto de James Lingwood y Maggie Gilchrist, titulado «El Entropólogo", los autores relacionan y profundizan la relación entre la afirmación citada de Smithson y la Antropología de Lévi-Strauss, quien "elaboró las reglas básicas de la disciplina. Cuanto más compleja es la organización cultural de una sociedad, más entropía produce. Cuanto más desarrollada es la estructura, mayor es su desintegración. Así, las sociedades «primitivas» o «frías», (cuyo mecanismo comparó L. Stauss compara al del reloj) producían poca entropía, o ninguna, Las sociedades "calientes" (asimiladas a los motores de combustión), producían cantidades enormes" ${ }^{\prime 158}$. Aunque la Antropología de Lévi-Stauss no escape a una cierta patología evolucionista, empieza a poner en evidencia uno de los factores fundamentales de las sociedades contemporáneas y que Smithson tan bien entendió, la movilidad.

En su Antropologia do Espaço, Filomena Silvano presenta la movilidad como uno de los conceptos fundamentales para entender la cultura y el modo de vida postmoderno o super-moderno (Augé). La movilidad se encuentra en muchos autores que empezaron pensarla a partir de las imágenes que la ciudad les ofrecía. Walter Benjamin, fuertemente influido por Simmel, entiende la movilidad como un factor de la organización de la cultura y del espacio de la

Outros" in Revista de Comunicação e Linguagens, Espaços, Lisboa, Centro de Estudos de Comunicação e linguagens, 2005, pp. 243-252.

${ }^{157}$ Traducción libre. SMITHSON, Robert, « Art through the Camera's eye», in, The Collected Writings, California, Ed. por Jack Flam, University Of California Press, 1996, pp.. 374 -375,

${ }^{158}$ GILCHIST M. y LINGWOOD J., «El entropólogo», in Robert Smithson. El paisaje entrópico, Valencia, Instituto Valenciano de Arte Moderno, 1993. p. 22. 
ciudad. La figura del extranjero de Simmel, el flâneur para Benjamin, conceptualiza el espacio y la cultura juntos, vive entre el espacio nómade y el espacio fijo, espacialmente es la persona que llega hoy y que se quedará mañana, no tiene raíces, por eso, a él se le define por su movilidad, sintetizando la proximidad y la distancia, revelándose como una importante metáfora para entender el modo de vida que se desarrolla en las ciudades, siempre en un frenesí y constante flujo de personas, bienes, servicios, economía, cultura, etc. ${ }^{159}$

En el texto de Paul Virilio, La ciudad sobreexpuesta ${ }^{160}$, el concepto de sobreexposición aparece asociado a un fenómeno de invasión que empezó en la sociedad preindustrial y que se prolongó durante la sociedad industrial. En esta invasión se produjo la indiferenciación entre lo que es la ciudad y el medio rural o natural. Donde ayer era campo, hoy es ciudad o suburbios; hay por lo tanto una contaminación entre lo que es campo y ciudad, y ese hecho nos afecta social y emocionalmente.

En The monuments of passaic, Smithson a que volveremos en el último capítulo para pensar la relación de la escultura con la fotografía. Smithson aborda el tema de la movilidad y retoma el acto de recorrer el espacio de los alrededores suburbanos e industriales de la ciudad, como ya lo había hecho Tony Smith. De este trabajo forma parte una presentación de un mapa negativo mostrando la región de los "monumentos" a lo largo del Passaic River y más de 24 fotografías en blanco y negro de dichos "monumentos", como puentes, estructuras abandonadas, conductos de aguas residuales... Smithson invita a cada uno que visita la galería, a enfrentarse él mismo con este espacio abandonado y entrópico, donde la Tierra se olvidó del tiempo. Parece un lugar suspendido entre la ficción científica y los orígenes caóticos de la humanidad.

The Monuments of Passaic es una obra constituida simultáneamente por el territorio suburbano de Passaic River. Al recorrerlo, Smithson lanza una invitación para que todos lo hagan, a través del mapa, las fotografías y los escritos del artista. Este es un buen ejemplo de un tipo de trabajo en arte en el

\footnotetext{
${ }^{159}$ SILVANO, Filomena, Antropologia do Espaço, Oeiras, Edições Celta, 2001. pp. 21-26.

${ }^{160}$ VIRILIO, Paul, O Espaço Crítico, Trad. de Paulo Roberto Pires, São Paulo, Editora 34, 2005, pp. 721.
} 
cual la expansión del campo se realiza por la estética entrópica, por la voluntad política de intervención en el espacio vivido por personas y, en consecuencia, de reacción a los tradicionales espacios del arte ${ }^{161}$. Smithson se convierte en una especie de artista-antropólogo al identificar estos espacios de disolución, los nonsites.

El concepto de no-lugar de Smithson es gemelo del propuesto por Marc Augé. Para este antropólogo los lugares antropológicos tienen, en oposición con los no-lugares, un carácter fijo, pero la novedad en relación con los "lugares" utilizados anteriormente para pensar cuestiones antropológicas es que éstos se encuentran en relación directa o mediatizada con el exterior ${ }^{162}$.

Si nuestra cultura ya no puede ser localizada con exactitud por el tiempo, donde la historia fue transformada en espectáculo, queda el espacio. Los nolugares son espacios de flujo por excelencia: carreteras, aeropuertos. Quien los atraviesa es el "viajero -y no el flâneur de Benjamin o Baudelaire, que Augé clasifica como moderno."163 Filomena Silvano sistematiza y recuerda que el viajero es super-moderno, articula el espacio antiguo y el espacio moderno en un todo productor de sentido ${ }^{164}$. Este viajero atraviesa espacios que ni siquiera son de él, ni de los demás que se encuentran en tránsito; no hay relación con los otros, ni identificación con el grupo, por eso no son espacios de identificación.

La vivencia contemporánea está dominada pela presencia de los nolugares, donde "El pasajero de los no lugares hace la experiencia simultánea del presente perpetuo y del encuentro de si. (...)El espacio del no-lugar no crea ni identidad ni relación, sino soledad y similitud, (...) mientras que el lugar es triplemente simbólico al dar cuenta de la relación de cada uno de sus ocupantes consigo mismo, con los demás ocupantes y con la historia común. La multiplicación de los no-lugares reduce al sujeto a la condición de pasajero o

\footnotetext{
${ }^{161}$ Robert Smithson propone el museo del vacío contra la cristalización que el museo siempre opera en los objetos que alberga, a través de la armadura metafísica de los conceptos. Smithson propone el museo del vacío con el objetivo de frustrar expectativas. Un museo es siempre un lugar que alberga obras de arte, y vaciarlo de las mismas es construir una instalación en que el mismo museo es el principal médium. Este acto es comparable al de Duchamp al concebir los ready-mades.

${ }^{162}$ SILVANO, Filomena, Antropologia do Espaço, Oeiras, Edições Celta, 2001, p. 80.

${ }^{163}$ Traducción libre, SILVANO, Filomena, Antropologia do Espaço, Oeiras, Edições Celta, 2001, p. 81. ${ }^{164}$ Idem, Ibidem.
} 
consumidor"165. En suma, el "no-lugar" en Smithson, remite a los límites cerrados, el "lugar" a los límites abiertos. En el fondo, se trata de mostrar nuestra relación con el paisaje, al mismo tiempo que este dualismo determina nuestra imaginación que, a su vez, influye en nuestra vivencia del espacio. Es decir, a través de la experiencia del espacio, yo tengo la noción del tiempo.

Ciertamente que Rosalind Krauss, al ampliar el campo a la arquitectura y al paisaje, no estaba pensando en la posibilidad de que estos pudieran interactuar según una plataforma de realidad social, como lo demuestran claramente la obra, los comportamientos y los escritos de Robert Smithson. Y por aquí se desprende el rotundo fracaso de su análisis puramente físico o formal de estas nuevas formas de arte que empezaron a surgir a mediados del siglo XX.

No obstante, Rosalind Krauss conocía de cerca a la mayor parte de las obras que fue relacionando en su ensayo Sculpture in the expanded field. Y este ensayo marca un momento inaugural según el cual el paso de la escultura de la modernidad a la posmodernidad muestra nuevas características que obligan a recolocar este medio como categoría o, más aún, como posibilidad para la contemporaneidad.

\subsection{5}

\section{La escultura como metáfora}

La escultura se transformó tanto que, en muchos autores, se usa como metáfora para su métier. Andrei Tarkovsky asocia el acto de esculpir al desbaste del tiempo producido en el cine. En su libro titulado Esculpir o tempo ${ }^{166}$, define la tarea del director esencialmente como un trabajo asiduo en el tiempo en que "es libre de seleccionar y combinar eventos sacados de un «bloque de tiempo» de

\footnotetext{
${ }^{165}$ FLÓREZ, Fernando Castro, "Robert Smithson. El dibujo en el campo expandido", in Estrategias del Dibujo en el Arte Contemporáneo, Capítulo XV, Madrid, Cátedra, 2002, p. 555.

${ }^{166}$ TARKOVSKY, Andrei - Esculpir o tempo, (Die Versiegelte zeit) trad. al portugués de Jefferson Luiz Camargo, São Paulo, Martins Fontes, 2002.
} 
cualquier ancho o largo". Para este director, "esculpir el tiempo" es una labor equivalente al trabajo del escultor, así como el escultor toma un bloque de mármol y, guiado por la visión interior de su futura obra, elimina todo lo que no forma parte de ella; del mismo modo, el cineasta, a partir de un «bloque de tiempo" construido por una enorme cantidad de hechos vivos, corta y rechaza todo lo que no necesita, dejando sólo lo que deberá ser un elemento de la futura película, lo que será un componente esencial de la imagen cinematográfica". Equivalente a las escorias lanzadas al suelo por el escultor, para Tarkovski, es el rodaje de "millones de metros de película, en los cuales, sistemáticamente segundo tras segundo, día tras día y año tras año, la vida de un hombres es seguida y registrada, por ejemplo, desde el nacimiento hasta la muerte, de todo eso se provechan sólo dos mil quinientos metros, o una hora y media de proyección". El tiempo adquiere densidad por su relación con el componente moral y la experiencia de vida.

En Le Temps, ce grand sculpteur, de Marguerite Yourcenar, podemos reconocer el término escultura fuera de cualquier restricción cultural, material o conceptual que la lectura estructuralista hecha por Rosalind Krauss contiene. En Yourcenar, la ampliación del término "escultura" aparece asociado a la literatura y al mismo tiempo como agente modelador de la vida y, en consecuencia, inductor de la narrativa. Tarkovsky, cuando propone el título de Esculpir o tempo, centra su preocupación de esculpir y de la escultura fuera de cualquier restricción histórica de estas palabras, buscando más bien los movimientos fundamentales que el cine permite, como agente modelador poético. Por otro lado, el término escultura aparece dentro del aparato dispositivo del cine, instalando un nivel de lectura de la creación cinematográfica en particular y de las artes plásticas en general, fuera de cualquier convención, mostrando las ideas que hacen posible cualquier abordaje escultórico, independientemente del medio en que se manifieste.

Pero la escultura entendida como metáfora se expresa también en los mismos artistas plásticos que, al considerar la abertura del espacio de acción del arte, pusieron en marcha estrategias creativas, poniendo el acento en los lugares y espacios de la convivencia convocando al campo del arte, además de la 
estética, las dimensiones éticas, políticas y sociales que adquieren una importancia creciente en las propuestas de los artistas más recientes.

En este contexto de entendimiento de la escultura como metáfora o apertura de la escultura más allá de la estética en dirección a la ética y a la política, se debe mencionar el concepto de escultura social de Joseph Beuys. Para este artista, la escultura social es algo que escapa a la pura configuración de un objeto encerrado en sí mismo o en el campo del arte, mezclándose con la vida. Derivada de la concepción holística germánica y wagneriana de que la obra de arte debe ser total, Beuys propone que la escultura debe ser esencialmente pensamiento y acción sobre la vida: la obra debe ser abierta para que permita la identificación y creación por parte de cada hombre. Para que eso suceda, Beuys parte de la premisa antropológica de que todo hombre es un artista y, si para el artista la escultura no es sino formación del pensamiento, ${ }^{167}$ la escultura es entendida como actividad modeladora en el sentido más amplio, es decir, debe ser la creación de las condiciones para que cada uno ejerza el libre pensamiento que es transformador de la realidad.

La escultura social comprende la política, la educación, pero también la cultura y la organización social. Así, según Beuys, los objetos, las instalaciones, las conferencias, las clases y las performances, deben estar vinculados a la vida y servir de estímulo para la transformación de la escultura o del arte en general, «deben provocar reflexiones sobre lo que la escultura puede ser y sobre cómo el concepto de escultura puede ser expandido a materiales invisibles usados por todos. Cómo podemos modelar nuestros pensamientos o cómo podemos formar nuestros pensamientos en palabras, o cómo modelamos o damos forma a las palabras en las cuales vivimos: la escultura como un proceso evolutivo; todos como artistas. Esto porque la naturaleza de mi noción de escultura no es fija y acabada. El proceso continúa en la mayor parte de ellas. Con las reacciones químicas, fermentaciones, cambios cromáticos, degradación, y secado. Todo en estado de cambio». ${ }^{168}$ La importancia del pensamiento y del poder que éste tiene

\footnotetext{
${ }^{167}$ Traducción libre. BEUYS, Joseph, Joseph Beuys in America Writings By And Interviews With The Artist, Compilado por Carin Kuoni, New York, Four Walls Eight Windows, 1990, p. 91.

${ }^{168}$ Idem, p. 19.
} 
al ser expresado mediante la palabra, es la herramienta de trabajo fundamental para que Joseph Beuys pueda modelar el mundo a partir de la educación y de la cultura. La escultura social es entonces una escultura inmaterial que se niega a morir en el museo. Tampoco se sirve del museo como forma de cuestionar el arte en su contexto institucional, como hace Duchamp. La mira de la escultura social está puesta en valores éticos y políticos como el de la ecología: estos valores una vez expresados por la palabra y corroborados por las materias fluidas de sus objetos y acciones serían entonces agentes modeladores del mundo.

Queda así patente que el campo de lo escultórico ha estado y sigue estando en constante transformación de sí mismo a través de la prueba de sus límites. Hemos visto que la escultura no es definible, en la medida en que sólo se sitúa en un proceso continuo de transformaciones, hasta el punto de que podemos denominar «escultura» a una fotografía, como veremos más adelante. No obstante, tres características sobrevivieron desde la prehistoria hasta la estatuaria, pasando por la escultura y la escultura en el campo expandido: el dibujo, el espacio y la idea de ausencia.

\subsection{6}

\section{Cómo determinar lo escultórico}

Es el dibujo hecho por las construcciones megalíticas insertadas en la tierra y orientadas hacia el cielo, el dibujo que anticipa el contorno lineal de la estatuaria, el dibujo como lugar de encuentro dialogado entre las fuerzas de la materia y las que vienen en su dirección, en gran parte de la escultura moderna, el dibujo de proyecto como exaltación del pensamiento, designio y decisión. Pero es también el dibujo representado nuevamente en la tierra por los artistas del Land art, un dibujo que se borra in situ por el transcurso del tiempo, pero que puede ser cristalizado, registrado a través de la fotografía o del vídeo.

Pero también el espacio es tema central en la escultura, desde la noción de espacio como marcación de un lugar, o forma de negar el caos en las 
estructuras megalíticas, pasando por la noción de espacio sugerido por la jerarquía de la estatuaria, por ejemplo egipcia y medieval: el espacio del monumento y su vinculación a la obligación evocativa, el espacio pasivo de alguna de la estatuaria y el espacio activo de algunas esculturas modernistas como de H. Moore o Eduardo Chillida. La escultura también se caracteriza por un espacio penetrable, como sucede con la Merzbau de Kurt Schwitters y el espacio Proun de El Lissitzky, o como podrá suceder con el proyecto de Eduardo Chillida para perforar y agregar espacio a la montaña de Tindaya, en Fuerteventura. Sin embargo, en la escultura, tendremos que considerar también el espacio como lugar de encuentro, de convivencia, holístico, con dimensiones estéticas, éticas, políticas y sociales, que adquiere especial importancia en las propuestas de los artistas más recientes.

Por último, la escultura, ya se llame estatuaria, escultura en sentido estricto o escultura en el campo expandido, se define por la idea de ausencia. La ausencia no es el vacío, pero supone que algo "estuvo alli", pero ya no lo está, se ha desplazado. Así, escultura es siempre representación, presentación, expresión o constatación de una pérdida, es siempre la evocación de una ausencia como presencia.

\subsection{7}

\section{Dos bosques en la cartografía de las posibilidades de la escultura}

La gran amplitud de esta cartografía del campo de lo escultórico se justifica por las conexiones lejanas que tienen con cada uno de los bosques: $\mathrm{La}$ forêt de Alberto Giacometti y Uma floresta para os teus sonhos, de Alberto Carneiro. Dado que ambas obras escogidas se sitúan en un campo de relación entre escultura y paisaje, se hizo necesario comprender cómo entró el paisaje en el campo de la escultura. Pero este panorama también denuncia la situación en la que cada uno de los artistas y su obra se encuentran. Henri Focillon, en su 
libro Vie des formes, recuerda que "la obra de arte es una aproximación a lo único, se afirma como un todo, como absoluto, y, al mismo tiempo, forma parte de un sistema de relaciones complejas. Es el resultado de una actividad independiente, traduce una imaginación superior y libre, pero en ella vemos igualmente converger las energías de las civilizaciones." ${ }^{169}$ Aunque antiguo, pues este modelo de análisis de la obra no sirve para valorar muchas propuestas contemporáneas, es, no obstante, útil para situar y entender lo que definió al artista europeo hasta hace poco tiempo; es decir, alguien profundamente comprometido con la historia. Esto se verifica totalmente en la obra de Alberto Giacometti, pero también, aunque con un grado de compromiso menor, en la obra y en los escritos de Alberto Carneiro.

Pero la afirmación de Focillon encaja perfectamente en la definición de obra moderna y en el modelo idealista del que Giacometti, a pesar de las muchas singularidades, era un continuador. Profundamente comprometido con la historia, enseguida comprendió el valor de la copia, dibujando directamente en los libros de historia del arte: lo hacía como forma de acceder a la información o como método de rememoración de lo anteriormente visto en diversos museos europeos. Así, desde muy pronto se fue modelando la afinidad por el arte prehistórico, cicládico y egipcio. De alguna forma, sus opciones estaban siempre ancladas en la comprensión existencialista de la historia del arte, la noción de sugerencia de movimiento, la verticalidad y el cuestionamiento de la base son planteados y transformados a partir de referencias más o menos lejanas. En relación con la noción de espacio de la escultura a partir de 1935, podemos aproximarla a Miguel Ángel, en la medida en que busca retirar la materia hasta llegar a la escultura. Pero lo que Giacometti pretende obtener es radicalmente distinto a lo que Miguel Ángel y gran parte de la escultura clásica buscaban: un contorno límpido que confiriera a la escultura transparencia convencional. Por el contrario, Giacometti busca una sucesión de contornos, así como en su dibujo: esa búsqueda es el proceso manual, de tal modo que el artista sólo sabe lo que está haciendo cuando trabaja. De este proceso se obtiene una escultura de

\footnotetext{
${ }^{169}$ Traducción libre. FOCILLON, Henri, A Vida das Formas. Seguido de Elogio da Mão, trad. de Ruy Oliveira, Lisboa, Edições 70, 2001, p. 11.
} 
aspecto inacabado, lo que condiciona el disfrute del espacio, por ejemplo en La forêt, como un espacio activo donde lo que importa, más que las figuras, es el espacio entre ellas.

Alberto Carneiro parece conservar, en determinados momentos de su carrera, una cierta influencia de la tradición europea de la práctica de la escultura. Para comenzar debemos mencionar que su práctica está influida por un carácter "religioso, en el sentido en que se puede entender la religión a partir de su étimo (religare) que significa buscar la totalidad, el encuentro del mundo consigo mismo, en la ancestral unidad de sus fundamentales principios. Alberto Carneiro es por esta vía, legítimo heredero de esa tradición que se inauguró con la Venus de Willendorf y que llevó a Nietzsche a interrogarse sobre las razones que llevan al hombre a querer buscar en los dioses su justificación, cuando deberían más bien ver la tierra y su ínfimo misterio." ${ }^{170}$ Pero su influencia europea prosigue, específicamente en los años más recientes en que el trabajo sobre la madera busca el ritmo orgánico de la madera situando al trabajo muy cercano al concepto de vitalismo orgánico que sirvió a Herbert Read para analizar la escultura de Henry Moore. No obstante, en Uma floresta para os teus sonhos, obra representativa de un periodo en el que Alberto Carneiro renegó del virtuosismo del trabajo manual, tenemos una clara opción por la valorización del arte como idea que coincidió con el florecimiento del conceptualismo y con la revalorización de los dadaísmos. Derivada de una anamnesis, Uma floresta para os teus sonhos es una instalación formada por 200 troncos de madera apoyados en el suelo y orientados en vertical, situados en el interior de una arquitectura. Pero la Floresta es sobre todo un proyecto diseñado, o una idea de espacio laberíntico lúdico a la disposición de la experiencia de cualquiera. La escultura hecha de troncos de madera tratada industrialmente puede ser penetrada por el espectador; allí, podrá tener la experiencia del sueño, no de la fantasía, pero del sueño despierto, o, lo que es lo mismo, tener la experiencia de la transformación literal del tiempo en espacio a través de un mecanismo pre-cinematográfico proporcionado por el paseo. Por último, la Floresta debe ser también

\footnotetext{
${ }^{170}$ Traducción libre. ALMEIDA, Bernardo Pinto, Idade De Homem, in Alberto Carneiro, Exposición Antológica, Lisboa, Oporto, Fundação Calouste Gulbenkian, Fundação de Serralves, 1991, p. 15.
} 
comprendida desde un punto de vista ético y político, sobre todo cuando juntamos a la intervención escultórica tangible y al proyecto los textos de Alberto Carneiro preconizando un arte conceptual y ecologista. 


\section{CAPÍTULO III:}

\section{EL PAISAJE Y LO ESCULTÓRICO: ¿LA FORÊT, DE 1950, ES UNA ESCULTURA PAISAJISTA?}

\section{0}

\section{Alberto Giacometti - breve introducción.}

Alberto Giacometti nace en 1901 en Stampa, en el Cantón de los Grisones. Hijo de un pintor post-impresionista, Giovanni Giacometti, hereda de él los primeros gestos pictóricos y el hábito de dibujar del natural, a partir de modelo. En 1919 asiste a clases de escultura en la Escuela de Artes y Oficios de Ginebra. En 1920 visita la Bienal de Venecia con su padre, comisario en representación de Suiza. Visita Florencia y Roma, donde toma contacto con una multitud de formas de arte de las más diversas épocas y procedencias. En 1922 se instala en París, donde años más tarde realizará La forêt. En 1925 abandona el trabajo a partir de modelo, para dedicarse a un arte inspirado en el cubismo. En los años treinta forma parte del grupo surrealista de París, del que sin embargo será excluido alrededor de 1935. A partir de mediados de esa década, A. Giacometti vuelve a trabajar a partir de modelo. Es en este periodo en el que se centra nuestro estudio, a fin de mejor comprender el contexto general que explica la emergencia de La forêt.

Stampa era muy importante para Giacometti, probablemente por todos sus recuerdos de infancia: la nieve que colocaba los troncos de árbol negros en un frágil equilibrio, la diferencia de escala entre la montaña y su casa y, en ésta, el lugar de encuentro con su madre y su hermano, Diego Giacometti. 
Giacometti tomó contacto con el arte muy pronto, a través de su padre, un conocido pintor impresionista. Cabe imaginar que no habrá permanecido ajeno al espacio del taller y al tipo de tarea creativa que en él se realizaba.

El dibujo de Alberto Giacometti no es tan sólo una certeza del artista maduro; por el contrario, se trata de una constante que desde el principio alimenta su impulso creador, jugando un papel central en su trabajo.

En un primer momento, A. Giacometti trabajó sobre todo siguiendo un proceso académico, creando a partir de modelos, ya se tratara de paisajes, de su madre o de su propio autorretrato. Muy joven, en 1914, modela en escayola una pequeña cabeza naturalista de su hermano Diego.

Sigue un periodo de diez años durante los que A. Giacometti desarrolla una práctica escultórica abstracta, de raigambre surrealista, con marcada influencia del arte de los llamados pueblos primitivos. Esta fase, muy creativa, ha sido exaltada por algunos de los más importantes teóricos de la escultura, como Herbert Read y Rosalind Krauss $^{171}$, ya estaba puntuada por algunas cabezas y rostros, cuya presencia rivalizaba con su práctica abstracta. Pero, a pesar del éxito, eso le paralizaba. ${ }^{172}$

En los mismos años en que Giacometti se planteaba abandonar la práctica de la escultura abstracta, Brancusi propuso una enorme revolución de la práctica escultórica. En La columna sin fin (1937/38), de Brancusi, que aparece como una síntesis del trabajo que había realizado hasta entonces, la escultura desciende hasta el nivel del suelo, absorbiendo el plinto. Este último se asume

\footnotetext{
${ }^{171}$ Rosalind Krauss declara que la escultura formada por figuras verticales y aisladas, que en nuestro estudio denominamos como esculturas del periodo existencialista, son menos interesantes por ser menos radicalmente innovadoras. "Si contemplamos su obra desde una perspectiva individual, las principales esculturas de Giacometti son sus monumentos: la figura vertical, aislada, que se yergue conmemorativamente en el espacio, hierática, inmóvil, enhiesta. Podemos seguir este motivo desde la Mujer-cuchara, pasando por el Objeto invisible, hasta cualquiera de las figuras en pie de los años cincuenta, y proporcionar de este modo una unidad conceptual a toda su obra. Sin embargo, desde el punto de vista de la historia de la escultura -en un planteamiento impersonal y mucho menos comprensivo-, sus monumentos verticales son menos interesantes, es decir, menos radicalmente innovadores, que las obras realizadas entre 1930 y 33, caracterizadas por su horizontalidad". Ver KRAUSS, Rosalind E., La originalidad de la Vanguardia y otros mitos modernos, Versión española de: Adolfo Gómez Cedillo, Madrid, Alianza Editorial, 2002, p. 88.

172 GIACOMETTI, Alberto. Je ne sais ce que je vois qu’en travaillant. París: L`Échoppe, 1988, p. 9, “ Mais ce succès, précisément, ça me paralysait».
} 
como escultura dando origen a un megalito ritmado, en un primer momento proyectado en dibujo sobre una fotografía y posteriormente realizado en el espacio real de la ciudad de Targu Jiu, en Rumanía. A pesar de esta idea poética, de que éste y otros trabajos de la misma época se caractericen por una forma de autorreferencia, circunscribiendo y recreando lo que es propio de la escultura en sentido estricto, restringían su entendimiento a la propia práctica del arte, a una ontología que aprisionaba cualquier posibilidad de que la escultura se refiriera a algo exterior a ella, a la vida. En vez de eso, se encerraba en una especie de armadura conceptual, delimitando un territorio que para Giacometti no podría ser ni de libertad, ni de acción constantes.

A mediados de la década de 1930, Giacometti sintió, a pesar del éxito, la necesidad de poner en cuestión toda su práctica abstracta de la escultura, pues notó en ella una calidad inherente al objeto y no a la escultura. Lo comprendió durante el periodo de diez años en los que, trabajando a partir de modelos, no expuso. Para sobrevivir, trabajó con su hermano Diego y en colaboración con el decorador Jean Michel Frank. En ese periodo de tiempo, produjo una serie de objetos utilitarios, como cuencos y lámparas, entre otros objetos decorativos. ${ }^{173}$

Los manifiestos, que en la Modernidad dominaban y orientaban las Vanguardias, se traducían en la creación de movimientos bien acotados en el tiempo, articulando todo el pensamiento inherente a la acción artística para un determinado grupo, de forma que cada artista considerado individualmente no podría responder directamente en su práctica artística al flujo del pensamiento. De otro modo, este es atravesado, interrumpido constantemente con datos de orden circunstancial, fijándose así mucho más en procesos como el de la cognición, y dando origen a esculturas cuyo carácter objectual y material en el espacio, toman en sí un peso desmesurado, llegando incluso a ser estos los únicos índices de esas esculturas.

Giacometti, al optar por perseguir lo que considera como escultura, y no meros objetos, inaugura una bifurcación en la Historia da Arte, simplemente

\footnotetext{
${ }^{173}$ Ibidem, p. 15. "Ça m'a servi de faire des objets utilitaires (lampes, vases, lustres, appliques, tables, etc.). Je croyais que ça me perdait du temps. Mais, en réalité, ça m'a servi; ça m'a appris à voir les choses à leur place, dans leur domaine».
} 
recuperando un determinado tipo de visión inmediata y efectiva de las cosas, en la continuidad del arte de las sociedades llamadas primitivas. Giacometti necesitaba tener libertad para trabajar, ya no le interesaba la escultura abstracta, de la que había comprendido el funcionamiento. Seguir produciéndola desembocaría en meras repeticiones de cosas que ya había hecho antes. Giacometti, al necesitar libertad para trabajar, escoge correr riesgos: "si pensara en el objeto antes de empezarlo, lo veía ya acabado y hacerlo se tornaría una mera ejecución, o sea la copia de la imaginación es una mera reproducción". ${ }^{174}$ Por el contrario, una cabeza es un estímulo que implica un reto de extrema dificultad en la tarea de percibirla porque, cuanto más la observa, más difícil se torna su realización. Se trata de una tarea sin fin, que Giacometti nunca dio por concluida. Su curiosidad se aguza mucho más delante de un rostro que ante todas las demás esculturas posibles. Dicha constatación trae al campo de su investigación una renovación, ansiedad y movimiento siempre constantes, en la búsqueda de algo que se encuentra de nuevo, en un paradigma académico de continuidad del trabajo con el modelo en presencia, y de forma simultánea de ruptura con ese paradigma, como vimos, en la medida en que ya no le interesa usar en su proceso de trabajo códigos, convenciones e incluso clichés fijados por el clasicismo.

En una época dominada por la Abstracción, trabajar a partir de un modelo equivale a uno de los presupuestos creativos más abominables para la corriente Moderna, siendo visto como un signo de debilidad y conservadurismo insoportable. De hecho, trabajar a partir de un modelo es considerado en este medio creador como un acto de provocación, semejando que "el artista habita en una región del tiempo que no se integra forzosamente en la historia de su tiempo" ${ }^{\text {"175 }}$. Pero Giacometti parece haber adoptado una actitud tan provocadora como silenciosa, que nada tiene que ver con la estridencia Dadaísta o de otras vanguardias. Su revolución de la escultura y del dibujo es de alguna manera solitaria en el panorama de las últimas décadas de la primera mitad del siglo XX.

\footnotetext{
174 IL Sogno di una testa - Testimonianze per Alberto Giacometti (1901-1966), un documental realizado por Giorgio Soavi y Grytzko Mascioni, RAI, 1977.

${ }^{175}$ FOCILLON, Henri, A Vida das Formas. Seguido de Elogio da Mão, Trad. de Ruy Oliveira, Lisboa, Edições 70, 2001, p. 98.
} 
Otros artistas del siglo $\mathrm{XX}$ también trabajaron a partir de modelos, como Bonnard, Balthus (amigo de Alberto Giacometti), y más tardíamente Avigdor Arikha. Pero ninguno de ellos se sirvió, como Giacometti, de los grandes dispositivos de las tradicionales Academias de Bellas Artes, donde el modelo, generalmente femenino, se sitúa en el centro de un enorme anfiteatro, obedeciendo al profesor en cuanto a la orientación de las poses, acciones y posturas musculares, así como al tiempo de exposición de las mismas. En el contexto académico tradicional, el modelo debe plegarse a posturas autoritarias, viendo limitada su capacidad de relación erótica. En esta circunstancia, lo que se exige al dibujante es el dominio de las reglas de ejecución, preceptos de canon, triangulaciones o cálculo de las distancias; "ver bien» en este contexto se confunde con «reproducir bien». Giacometti no busca reproducir bien, labora centrado en la producción, su dispositivo ante el modelo es de gran simplicidad. Se coloca ante el modelo en el mismo plano del suelo. Ahí, donde Eros es más fuerte $^{176}$, la permuta reflexiva entre observador y observado es constante, se trata de un espacio «entre», lleno de movimiento y ansiedad, momento generador de esculturas y dibujos.

El problema fundamental para Giacometti en la realización de sus figuras escultóricas es, como afirma el propio escultor, la ejecución de la cabeza. Una cabeza puede tomar varios puntos de vista para ser observada, al menos esto es válido para casi todas las esculturas, incluyendo las de Aristide Maillol, por ejemplo. Pero a partir de 1945, la exigencia de conservar la gran dimensión desencadenó un proceso en el que, contra su voluntad, sus figuras iban encogiendo: "La razón es sencilla: cuanto más nos aproximamos de alguna cosa, más la vemos reducida. En este caso, lo que yo veía reducido era la anchura". ${ }^{177}$ Ver reducida la anchura es una característica de sus dibujos y esculturas, principalmente de los rostros filiformes y frágiles, sus esculturas deben ser vistas

\footnotetext{
${ }^{176}$ En el libro de James Lord, titulado Retrato de Giacometti, podemos leer a propósito de la relación erótica entre artista y modelo "Jean Genet ha escrito que Giacometti tiende a desarrollar relaciones emocionales con sus modelos e incluso sentimientos románticos en relación a ellos." LORD, James, Retrato de Giacometti, traducción de Amaya Bozal, Madrid, La Balsa de la Medusa, 2005, p. 57.

${ }_{177}$ GIACOMETTI, Alberto, Je ne sais ce que je vois qu'en travaillant. París: L' Échoppe, 1988, p. 10. «La raison en est simple: plus on est près d'une chose, plus on la voit en raccourci. Dans ce cas, c'était la largeur que je voyais en raccourci.»
} 
de frente, así como su principal obsesión: la cabeza. La visión frontal parece contener el punto donde el rostro se apoya o la zona hacia la que caminan todas las intensidades. Queda de este modo claro que el principal problema para Giacometti es el de construir la cabeza.

\section{1}

\section{Una visión efectiva del mundo}

Ver las causas en su lugar implicó la identificación de dos niveles de relación con el mundo: uno que construía objetos (esculturas abstractas) y otro que construía la escultura tal como el artista pasó a entenderla desde mediados de la década de 1930. Giacometti identifica la abstracción como el punto del pensamiento plástico a partir del cual esas esculturas se convierten en objetos, pues, una vez aparecidas en el pensamiento, sólo había que fabricarlas, lo que para él valía como movimiento auto-referencial dentro de una práctica artística en general y de la escultura en particular $y$, por tanto, fuera de la vida y de una visión inmediata y efectiva de las cosas. "Las esculturas modernas (abstractas o que tienden a la abstracción) no descienden de la primera escultura que representa a una mujer, sino de las hachas prehistóricas". ${ }^{178}$

En cuestión parece estar la voluntad del artista de querer realizar una obra durable. Por eso valora el arte prehistórico, buscando comprender lo que ha hecho persistir a través del tiempo la primera escultura que representa una mujer, ${ }^{179}$ que para Giacometti es radicalmente diferente de la escultura abstracta y de los útiles, como el hacha.

\footnotetext{
${ }^{178}$ Idem, p. 15 «Les sculptures abstraites- ou qui tendent à l'abstrait ne «descendent» pas de la première sculpture qui représente une femme, mais des haches Préhistoriques.».

${ }^{179}$ Como vimos en el capítulo anterior, la llamada Venus de Willendorf, en Austria, una de las muchas estatuillas femeninas de la fertilidad, tiene las formas redondeadas y bulbosas de una "piedra sagrada. Todas estas características cumplían la función de una pieza que daba significado al valor de la fertilidad humana comprendida en la figura de la mujer capaz de generar nuevos seres humanos. Entonces esas esculturas primitivas poseían un poder que excedía cualquier concepción
} 
La cuestión parece tener que ver con la forma de ver del artista y, por lo tanto, de pensar el mundo. La manera como el artista ve, piensa y expresa en arte el mundo es, en el entender de Maria Filomena Molder, un caso de «inactualidad», que supone no tanto "una crítica del presente, distanciándose de él a partir de una concepción perspectivística, sino un reatar de relaciones con una forma de ver que ha sido fragmentada, operando con ella como condición de la crítica de su propio presente" ${ }^{180}$ Es decir, el arte del periodo existencialista de Giacometti se manifiesta por el retorno al arte hecho a partir del modelo, hecho que en plena modernidad era visto como un signo de debilidad del artista, en la medida en que estaba optando por trabajar a partir de un esquema de subjetividad que ya había sido usado por la tradición académica. No obstante, si Giacometti recurre a ese método académico, lo hace relativizando las convenciones renacentistas: "No me parece que la visión clásica sea una visión inmediata y afectiva de las cosas, más bien pienso que se trata de una reconstitución racionalizada. Los clásicos buscaban comprender lo que veían. Actuaban más como sabios que como pintores". ${ }^{181}$ Giacometti continúa citando la investigación de las Leyes de la Perspectiva por artistas protorrenacentistas, como Ucello, o por las disecciones e investigaciones anatómicas de Leonardo, que dan prueba de que su voluntad era más actuar como sabios que como pintores.

Actuar como sabio, tener una visión que es reconstitución racionalizada, fue la manera que Giacometti encontró para hablar de un arte occidental que en su origen trató generalizadamente con códigos y convenciones axiomáticas, llevando a una generalizada lectura de las obras del Renacimiento como obras de arte del arte: "Poco a poco, las obras de los clásicos, que representaban un conjunto de conocimientos, el conjunto de conocimientos que tenían de la realidad y no su visión, esas obras acababan incluso por sustituir la propia visión

del arte por el arte: decoraban y tenían un efecto real en la vida de los hombres, y era eso lo que buscaba A. Giacometti a partir de 1935.

\footnotetext{
${ }^{180}$ MOLDER, Maria Filomena, O Absoluto que Pertence à Terra, Lisboa, Vendaval, 2005, p. 131.

${ }^{181}$ GIACOMETTI, Alberto. Je ne sais ce que je vois qu en travaillant. París: L` Échoppe, 1988, p. 12. «La vision classique ne me semble pas une vision immédiate et affective des choses, mais une reconstitution raisonnée. Les classiques voulaient comprendre cequ'ils voyaient. Ils agissaient moins comme des Peintres que comme des savants.».
} 
de la realidad. Es por eso por lo que las obras de arte del Renacimiento son consideradas por casi toda la gente como las obras de arte del arte; lo que equivale a decir las representaciones más válidas de la realidad." 182 En las obras de los clásicos, las reglas transformadas en convención, contribuyeron, como vimos en el capítulo anterior, a la creación de la noción de transparencia en la escultura. Este trayecto es, según Giacometti, engañadoramente más próximo de la realidad, ya que en el lugar de la construcción de la mirada sobre la realidad, pone solamente reglas, sin que se pueda así generar una mirada efectiva e individual sobre las cosas del mundo.

Para plantear una mirada efectiva sobre las cosas del mundo, A. Giacometti parece hacer la apología de un cierto «empirismo o experiencia sutil» que hace mucho había sido fijada en una máxima de Goethe. En la máxima 509, este autor esclarece que "existe una empiria delicada que trata de identificarse interiormente con el objeto y que de ese modo se transforma el hecho en teoría. Pero ese proceso de elevación de las facultades espirituales sólo es posible en una época de gran elevación cultural." ${ }^{183}$ Este empirismo sutil de Goethe está relacionado con la dinámica entre mundo interior y exterior, que constituye la subjetividad del sujeto. En esta máxima, el autor expresa la posibilidad de pensar la coincidencia entre aquel que conoce y aquello que es conocido, o sea, entre sujeto y objeto, entre mundo interior y mundo exterior, o entre el sujeto y el paisaje. Esta es una experiencia sutil porque provoca, según una lectura de Goethe de Maria Filomena Molder ${ }^{184}$, una metamorfosis radical en quien conoce; o sea, deja de haber separación entre quien conoce y lo que es conocido. Se trata de una intensificación de nuestra facultad espiritual, pues la polaridad entre interior e exterior es supuestamente insuperable, pero existiría en una época de

\footnotetext{
${ }^{182}$ Idem, p. 13. «Ça n'empêche pas que, peu à peu, les œuvres des classiques, lesquelles représentaient une somme de connaissances, la somme des connaissances qu'ils avaient. de la réalité, et non pas leur vision, ces œuvres se sont substituées li la vision même de la réalité. Et c'est pour cela que les chefs-d'œuvre de la Renaissance, sont encore considérés par presque tout le monde comme les chefs-d'œuvre de l'art, c'est-a-dire les représentations les plus valables de la réalité.».

${ }^{183}$ GOETHE, J.W. Máximas e Reflexões, trad. de Miranda Justo, Lisboa, Relógio d’Água, 2000, p. 130.

${ }^{184}$ MOLDER, Maria Filomena, Seminario Internacional titulado: "Goethe. A Botânica das Cores", Anfiteatro de la Fundación de la FCUL, 20 Noviembre de 2009. Notas de seminario. Mimeografiado.
} 
gran elevación cultural, lo que equivale a decir, según Maria F. Molder, que se trata de una manera irónica de mantener viva la distancia entre quien conoce y lo que es conocido, entre quien lanza la mirada y quien devuelve la mirada actualizada.

El conocimiento más elevado es entonces imposible de verificarse, pues implicaría la transformación de quien conoce en la cosa conocida. Ahora bien, Giacometti afirma que "desde siempre la escultura, la pintura o el dibujo han sido para mí medios para comprender mi propia visión del mundo exterior” ${ }^{185}$ [por más que] "la realidad nunca ha sido para mí un pretexto para crear obras de arte, sino el arte un medio necesario para darme un poco más cuenta de lo que veo. Por tanto, mi concepción del arte es totalmente tradicional." ${ }^{186}$ Pero este trabajo de copiar lo que ve se convirtió para el artista lo más difícil de realizar. "Dicho esto, sé que me es completamente imposible modelar, pintar o dibujar una cabeza, por ejemplo, tal y como la veo." No obstante, siguió siendo la única tarea que siempre intentó realizar. Pero de toda esa insistencia tan sólo obtuvo una pálida imagen de lo que ve. "Todo lo que yo pueda hacer no será sino una pálida imagen de lo que veo y mi éxito estará siempre por debajo de mi fracaso, o tal vez el éxito siempre igualará al fracaso. No sé si trabajo para hacer algo o para saber algo, porque no puedo hacer lo que quisiera." ${ }^{187}$

Lo que Giacometti busca, cuando ve el modelo humano o paisaje, es fijar inmediatamente en arte el resultado de una especie de éxtasis que, como demostró Goethe, está condenada al fracaso, pues la anulación de la distancia entre artista y modelo es imposible de producirse, ya que tal cosa implicaría una transformación radical del artista que así perdería todas sus características acabando por disiparse.

Es como si la realidad siempre se hallara detrás de la cortina que arrancamos (...) pues aún hay otra (...) una y otra vez nos queda otra. No obstante, tengo la impresión, o quizá la ilusión, de que voy haciendo progresos día a día. Eso me impulsa, como si realmente fuera a ser posible comprender la esencia del mundo. Así continuamos

\footnotetext{
${ }^{185}$ GIACOMETTI, Alberto. Escritos. Trad. José Luis Sánchez Silva. Madrid: Síntesis, 2001, p. 128.

${ }^{186}$ Idem, Ibidem.

${ }^{187}$ Ibidem, p. 128.
} 
nuestro camino, a sabiendas de que cuanto más nos aproximamos a la 'cosa', más se aleja ésta de nosotros. La distancia que hay entre mí y el modelo aumenta continuamente; cuanto más nos aproximamos, tanto más se aleja la 'cosa' de nosotros. Es una búsqueda $\sin$ fin. $^{188}$

Los trabajos del periodo existencialista de Giacometti no son más que testimonios de un proyecto fallido. Sin embargo, se trata de un esfuerzo destacable y significativo en el contexto del pensamiento y la producción artística moderna europea, porque a través de este proceso fue capaz de mostrar en obra dibujada y esculpida el modo como la vida sucede o el modo como reconocemos el proceso de la vida. Giacometti dio al arte la posibilidad de tener objetos que son el resultado de la negación de muchas de las características ordinarias, de los aspectos más comunes y de perspectivas reduccionistas sobre el hombre. Lo que le importó a Giacometti fue la posibilidad de cavar hondo, de mostrar y expresar con profundidad lo que muchos conocían y/o expresaron más o menos bien. El proyecto de expresar esa «visión efectiva del mundo», a pesar de ser un proyecto fallido en la medida en que no se llegó a concluir, desde el punto de vista del proceso, podemos afirmar haber sido exitoso, pues nos dio obras que obedecen, en palabras de Paul Éluard, al «duro deseo de durar». Así, no es de extrañar que se trate de un artista constantemente revisitado por muchos artistas contemporáneos y presentado en el contexto de exposiciones de arte contemporáneo, como la que tuvo lugar recientemente en el Museu Berardo de Lisboa, titulada Silencios, cuyo comisario fue Marin Karmitz.

Esta búsqueda de las apariencias en el sentido más profundo presenta otros matices que es necesario explicitar, el rechazo de la tradición Renacentista tiene para Giacometti una figura tutelar que de aquí en adelante nos servirá de puente interpretativo: Cézanne. Así, "La importancia de Cézanne reside en el hecho de que haber sido el único en romper profundamente con esta visión. Gracias a él hoy puede cuestionarse toda la visión de la realidad. En realidad, abrió un abismo ante el que cada uno intenta huir como puede." ${ }^{189}$ Para Maria F.

\footnotetext{
${ }^{188}$ BOCOLA, S. El Arte de la Modernidad. Barcelona: Ediciones del Serbal, 1999, p. 375.

${ }^{189}$ GIACOMETTI, Alberto. Je ne sais ce que je vois qu`en travaillant. París: L’ Échoppe, 1988, p. 14. «L'importance de Cézanne vient du fait qu'il est le seul ayant rompu profondément avec cette vision.
} 
Molder, el "modo de protegerse propio de Giacometti consiste en intentar restituir lo que ven los ojos, y en descubrir que sólo sabe lo que sus ojos ven en el momento en que está pintando y dibujando o esculpiendo" ${ }^{\text {190 }}$. Sólo sabe en cada momento de la acción de crear y no antes ni después, lo mismo que pasa en Cézanne. John Berger cita a este pintor y defiende que "Las apariencias, en cualquier momento dado, son una construcción que surge de los desechos de todo lo que ha aparecido con anterioridad. Algo así es lo que entiendo en aquellas palabras de Paul Cézanne que tan a menudo me vuelven a la mente: «Está pasando un minuto en la vida del mundo. Píntalo como es»." ${ }^{191}$ Maria Filomena Molder prosigue y especifica que lo que los ojos de Giacometti ven,

no depende de una condición irremediablemente restringida a un punto de vista, sino de una acción, de los efectos que sobre los ojos ejercen esas cosas que el artista está viendo en el momento en el que se decide a imitarlas. Ahí ellas aparecen en su soberanía intacta, y sus ojos sólo tienen que someterse, coadyuvados por los movimientos de las manos. Obediencia a la irradiación de la cosa en vez de dominación de la cosa por las reglas de la óptica o de la mecánica o de la electrónica. De aquí, de la subversión de las armonías científicamente construidas, procede el inacabamiento sin remisión, las deformaciones y la reducción inherentes a las obras de Giacometti, lo que conduce a la distinción entre obra de arte y objeto. ${ }^{192}$

Pues como vimos, para Giacometti, una escultura se distingue por el hecho de que su objetivo estético y axiológico se encuentra fuera de ella, «la escultura tiene que ser la representación de una cosa diferente de ella». La escultura nace del movimiento constante de la mano del artista, pero este trabajo es siempre provisional porque no se prevé alcanzar ninguna materialización estable, precisamente porque para Giacometti la tarea "más difícil es copiar lo que se ve».

Et c'est à cause de lui qu'aujourd'hui toute la vision de la réalité est remise en question. En fait, il a ouvert un gouffre devant lequel chacun cherche à se sauver comme il peut.».

${ }^{190}$ MOLDER, Maria Filomena, O Absoluto Que Pertence À Terra, Lisboa, Vendaval, 2005, pp. 131132.

${ }^{191}$ BERGER, John, Sobre el Dibujo, Trad.: Pilar Vázquez, Barcelona, Editorial Gustavo Gili, 2011, p. 52.

${ }^{192}$ MOLDER, Maria Filomena, O Absoluto Que Pertence À Terra, Lisboa, Vendaval, 2005, p. 132. 
Giacometti repudia el resultado y el procedimiento sistemático del arte clásico y se aproxima a la obra de Cézanne, la única capaz de romper profundamente con el pensamiento y la visión hegemónica renacentista que tiende a crear "reconstituciones racionalizadas", proponiendo todo un otro espacio de abertura a la visión y el pensamiento en constante invención y no sistematizado o acabado. Una vez abierto por Cézanne, el abismo inmediatamente se convirtió en un territorio inestable y una exigencia extraña a quienes le sucedieron. Así, según Giacometti los cubistas buscaron en Cézanne no los "medios", sino sus "fines": "Cézanne se servía de cubos, colores y esferas para transmitir su visión de una manzana. Sin embargo, para los cubistas la manzana dejó de ser un fin. Por el contrario se convirtió en un medio o un pretexto para hacer cubos, conos y esferas". ${ }^{193}$ De esta forma, los cubistas regresaban a la «visión clásica», es decir, se encontraron de nuevo ante un pensamiento permanentemente atravesado por códigos fijos en la elaboración de su arte. Este parece haber sido el origen de la obstrucción que dominó las Vanguardias de comienzos del siglo XX y del cual Giacometti procuró distanciarse, trabajando a partir del modelo, no con el objetivo de mimetizar el modelo, sino para comprenderlo fijando provisionalmente la forma como lo veía.

Giacometti no optó solamente por una mera práctica escultórica figurativa determinada por la labor en presencia del modelo, en detrimento de la escultura abstracta y autorreferencial vigente en el Movimiento Moderno de la época. Su decisión es bastante más distinta y radical: consiste en transformar poéticamente el mundo a través del pensamiento generado por los ojos y por la mano en acto. Más que copiar lo que ve, Giacometti quiere copiar cómo ve.

\footnotetext{
${ }^{193}$ GIACOMETTI, Alberto. Je ne sais ce que je vois qu 'en travaillant. París: L’ Échoppe, 1988, p. 14: "Cézanne se servait des cubes, des cônes et des sphères pour rendre sa vision d'une pomme, mais pour les cubistes, la pomme cessa d'être une fin. Elle devint, au contraire, un moyen, ou un prétexte qui leur servait à faire des cubes, des cônes et des sphères.».
} 


\section{2}

\section{«Bastaría con que supiéramos dibujar y podríamos pintar todos los cuadros $y$ hacer todas las esculturas que quisiéramos»}

En el mismo momento en que Giacometti intentaba copiar las apariencias del mundo, inaugura una verdadera teoría del dibujo, en la medida en que es la comprensión de este medio de expresión que abre la puerta a la comprensión de la totalidad de su obra, independientemente de que sea pintada, esculpida o propiamente dibujada. "Bastaría con que supiéramos dibujar y podríamos pintar todos los cuadros y hacer todas las esculturas que quisiéramos," ${ }^{194}$ defiende Giacometti, porque tanto la pintura como la escultura obedecen a las premisas del dibujo. Para este artista buena parte de la comprensión de su obra se encuentra ya inscrita en la comprensión del dibujo.

Philip Rawson, en su libro titulado "Drawing", define el dibujo como siendo "ese elemento en una obra de arte que es independiente del color o del espacio propiamente tridimensional." ${ }^{195}$ A continuación, el mismo autor concibe el dibujo como una actividad previa a las categorías de la pintura o de la escultura. También John Berger, en su libro titulado Berger on Drawing, distingue el dibujo de la pintura, refiriendo un cierto carácter transparente del dibujo en el sentido de que este no tiende a borrar las marcas de su génesis por debajo de artificios. "Los dibujos revelan más claramente el proceso de su ejecución, de su propia mirada. La facilidad imitativa de una pintura a menudo funciona como ser más importante que las razones para referirse a ello. Las grandes pinturas no están disfrazadas de esta forma. Pero incluso un dibujo de tercera categoría revela el proceso de su creación." ${ }^{196}$ Revelar el proceso de su creación implica devolver la

\footnotetext{
${ }^{194}$ Traducción libre. In GIACOMETTI, Alberto. Je ne sais ce que je vois qu en travaillant. París: L’Échoppe, 1988 p. 8, «ll suffirait de savoir dessiner et l'on pourrait faire toutes les peintures et toutes les sculptures que l'on voudrait ».

${ }^{195}$ RAWSON, Philip, Drawing, Philadelphia, University of Pennsylvania Press, $2^{\text {a }}$ ed., 1987. p.1.

${ }^{196}$ BERGER, John, Sobre el Dibujo, Trad.: Pilar Vázquez, Barcelona, Editorial Gustavo Gili, 2011, p.
} 56 . 
presencia como ausencia de quien realizó el dibujo, implica el reconocimiento del aura, es decir, el reconocimiento de que aquella imagen fue hecha por ser un humano concreto que realizó gestos específicos y nunca más volvió a repetirlos, marcando así su subjetividad.

Rawson subraya este carácter subjetivo y espiritual que el dibujo exhibe con especial agudeza. Cuando se está ante un dibujo, se está ante una experiencia de un individuo en un determinado momento que nunca más se repitió; sólo el dibujo ofrece la posibilidad de fijar cada minuto de la vida del mundo. Es esta claridad de los presupuestos de acción del dibujo que interesa a Giacometti, pues lo que le importa a este artista es la aprehensión de los contornos del mundo en cada momento en que es percibido y no la confirmación de los códigos y convenciones que se atraviesan en lo percibido y en la propia subjetividad del artista.

El dibujo muestra un menor artificio, cabría hablar de una ausencia de disfraz que tanto puede ser reconocida en un dibujo auténtico, como incluso en una reproducción. Lo que contrasta con la teoría defendida por Walter Benjamin, ${ }^{197}$ quien en sus textos sobre la fotografía y el cine relaciona la noción de aura con el carácter auténtico de la obra de arte, es decir, en el vínculo que una obra de arte tiene con un ser humano concreto que realizó determinadas marcas y gestos sobre un soporte en momentos determinados y nunca más los repitió. La inferencia que se hace, a partir de la lectura de estos textos de Walter Benjamin, es que, ante una reproducción, no podemos restituir una relación con el otro artista que estaba vivo mientras creó; pero, por el contrario, cuando estamos ante una obra original, tenemos acceso a esa experiencia del aura. El dibujo, como muy bien comprendió Giacometti, tiene una relación diferente con la cadena histórica en que es producida; por ser absolutamente transparente e inmediato, revela, como vimos, el proceso de su creación, incluso cuando estamos ante una reproducción.

\footnotetext{
${ }^{197}$ BENJAMIN, Walter, A Modernidade. Obras escolhidas de Walter Benjamin. Edición y traducción de João Barrento, Assírio \& Alvim, 2006, pp. 207-327.
} 
En El diálogo con la historia del arte. Alberto Giacometti, exposición realizada en el IVAM en 2001, podemos reconocer que Giacometti estableció desde muy pronto una relación productiva incluso con las imágenes impresas de la historia del arte. "Siempre hice copias, desde la infancia, copiaba todo lo que caía al alcance de mi mano, cuadros y esculturas de todas las épocas, y poco a poco, me fui sintiendo interesado o atraído por casi todo lo que se había hecho antes. Había cosas que me gustaban de otras épocas y hacia las que mis sentimientos no han variado. Otras que, en el momento en que se presentaron, hicieron nacer en mí un sentimiento apasionado que luego ha desaparecido casi por completo. Hay desde luego cosas que han ido quedándose conmigo, que han adquirido cierta permanencia." ${ }^{198}$ En la copia de un dibujo de Katsushika Hokusai, Fig. 25, podemos observar que Giacometti comprende la obra a través del valor de la copia, en que la acción de la copia no sólo busca la información, sino la restitución de una determinada experiencia en diferido a partir de la experiencia primera de quien dibujó el dibujo original. Así, si la reproducción no restituye totalmente el aura, por lo menos su grado de empobrecimiento no se produce como ocurriría ante una reproducción de una pintura o escultura convencionales, pues estas se derivan de una formulación procesal que tiende a ocultar la presencia y la sucesión de las marcas que le dieron origen. En el trabajo de Alberto Giacometti, esa ocultación de la presencia no existe en el dibujo, en la pintura, ni tampoco en la escultura; por eso se puede hablar del dibujo como modelo de comprensión de toda su obra: un modelo apoyado en el trabajo directo de la mano sobre los soportes y materias, haciendo que todo el espacio generado a partir de ahí deba que ser entendido como proceso derivado de la actividad de la mano.

Henri Focillon hace el "elogio de la mano» y la presenta como una colaboradora atrevida del pensamiento y de la creación. Para este autor, el trabajo manual del artista es mucho más que una actividad motriz; por el contrario, incita al espíritu, revelándolo. Así, las manos "son casi seres animados (...) dotados de un género enérgico y libre, de una fisionomía -caras sin ojos y

\footnotetext{
${ }^{198}$ GIACOMETTI, Alberto, Escritos de Alberto Giacometti, Trad. al castellano de Miguel Etayo y José Luis Sánchez Silva, Madrid, Editorial Síntesis, 2001, p. 287.
} 
sin voz, pero que ven y hablan." ${ }^{199}$ El sentido del tacto captura la percepción de las apariencias, y por la acción la mano expresa esa captura, "aprende, crea, y a veces se diría incluso que piensa (...) el hábito, el instinto y la voluntad de acción meditan en ella" ${ }^{200}$. Para Focillon, la mano se convirtió en una colaboradora del pensamiento porque durante su evolución el hombre la rescató del "mundo animal, la liberó de una esclavitud antigua y natural, pero la mano hizo al hombre. Le permitió establecer ciertos contactos con el universo que sus otros órganos y partes del cuerpo no conseguían." 201 En este contexto, el artista hace la obra y la obra hace al artista. Éste, en particular el escultor, necesita profundizar «una especie de instinto táctil»: su vista es auxiliada en lo que ve porque la mano fue la primera en conocer el mundo en profundidad. La visualidad permanece pegada a una memoria táctil previamente constituida en el ser por la mano. A lo largo de la vida, este primer conocimiento propio del cuerpo hace que los nuevos gestos de prospección del mundo y de las materias multipliquen "el conocimiento con una variedad de toques y de contornos de que un hábito milenario nos esconde la capacidad inventiva." ${ }^{202}$ Es mediante el trabajo de la mano que un artista como Giacometti, a partir de 1935, busca comprender lo que ve, capta sus apariencias. Pero también es a partir del trabajo que la mano le devuelve que el artista se convierte en uno de los más proficuos pensadores de su labor.

Jacques Dupin identifica una afinidad entre la línea dibujada por Giacometti y aquella que escribe, transforma y traduce su pensamiento plástico en lenguaje verbal. "Como sus dibujos, sus pinturas y sus esculturas, la escritura de Alberto Giacometti nunca es estática, firme, nunca es lineal ni perentoria. Toma impulso, duda, se bifurca, se borra, vuelve. Busca un apoyo, un trampolín, para recusarlos después y liberarse de ellos. Progresa a saltos, rupturas, retoques, avances y retrocesos, agudezas y derrumbamientos. ${ }^{203}$ Dupin

\footnotetext{
${ }^{199}$ FOCILLON, Henri, A Vida das Formas, Seguido de Elogio da Mão, Trad. de Ruy Oliveira, Lisboa, Edições 70, 2001, p. 107.

${ }^{200}$ Idem, p. 108.

201 Ibidem, p. 110.

202 Ibidem, p. 111.

${ }^{203}$ DUPIN, Jacques, «Una Escritura Sin Fin», In Escritos de Alberto Giacometti, Trad. de José Luis Sánchez Silva. Madrid: Síntesis, 2001, p. 16.
} 
identifica la discontinuidad como medio de "acercamiento y aprehensión de lo real." ${ }^{204}$ Mediante el trabajo de la mano la escultura de Giacometti busca comprender lo que ve, devolviendo al mundo una singularidad de extraño parecido con ciertas formas de la escultura antigua. Eso sólo sucede porque el trabajo de la mano consigue transformar el arcaísmo en forma contemporánea. "El artista (...) toca, palpa, calcula el peso, mide el espacio, modela la fluidez del aire para ahí prefigurar la forma, acaricia la superficie de todas las cosas, y es con el lenguaje del tacto que compone el lenguaje de la vista." ${ }^{205}$ La búsqueda de una visión efectiva del mundo en Giacometti tiene tanto de visual como de táctil, por más que la visualidad tome la delantera, como veremos más adelante con la demostración de que la escultura procede de un dispositivo pictórico derivado de una cierta idea de campo visual fuertemente análogo al propuesto por MerleauPonty. La componente táctil se encuentra completamente encostrada en la visual pero también porque cada particularidad de lo visual sólo es realmente vista cuando la mano entra en acción. En el dibujo, por ejemplo,

existe una gran diferencia entre ver una cosa sin el lápiz en la mano y verla dibujándola. O mejor, son dos cosas muy diferentes las que vemos. Hasta el objeto más familiar a nuestros ojos se torna completamente diferente si intentamos dibujarlo: reparamos en que lo ignorábamos, en que nunca lo habíamos visto realmente. El ojo hasta entonces había servido únicamente de intermediario. Nos hacía hablar, pensar; guiaba nuestros pasos, nuestros movimientos comunes; despertaba algunos de nuestros sentimientos. Hasta nos arrebataba, pero siempre por efectos, consecuencias o resonancias de su visión, sustituyéndola, y por tanto aboliéndola en el propio hecho de disfrutar de ella. Pero el dibujo de observación de un objeto tiene el dibujo como fin y como medio simultáneamente. No puedo hacer precisa mi percepción de una cosa sin dibujarla virtualmente, y no puedo dibujar esa cosa sin una atención voluntaria que transforme de forma notable lo que antes creía percibir bien. Descubro que no conocía lo que no conocía: la nariz de mi mejor amiga... ${ }^{206}$

\footnotetext{
${ }^{204}$ Idem, p. 16.

${ }^{205}$ FOCILLON, Henri, A Vida das Formas, Seguido de Elogio da Mão, Trad. de Ruy Oliveira, Lisboa, Edições 70, 2001, p. 115.

${ }^{206}$ VALÉRY, Paul, Degas Dança Desenho, Trad. Christina Murachco y Célia Euvaldo, São Paulo, Cosac \& Naify, 2003, p. 69.
} 
En estas condiciones, podemos afirmar que el dibujo incita a la disciplina de la mirada, a aclarar la mirada sobre el mundo, a comprender su complejidad y a hacer de ella presencia plástica. También para Focillon "los dibujos, que nos ofrecen la alegría de la plenitud con el mínimo de medios" nos muestran "todo el generoso peso del ser humano (...) y toda la vivacidad de su impulso, con el mágico poder de la mano que nada, en adelante, traba o retarda., 207

El dibujo es generalmente un tipo de representación que implica una cierta producción de semejanza; es decir, una cierta relación con lo real, que es la misma que nos hace reconocer en la representación el equivalente representado que se encuentra en el mundo real. No obstante, esta equivalencia del dibujo en relación al mundo, que le sirve de modelo, porque es representación, no es "semejanza directa»; presupone entonces que el dibujo mantenga una relación simbólica que Manuel Castro Caldas relaciona con el hecho de que el dibujo sea un trabajo altamente subjetivo de construcción "que trasparece en su forma final como su base cinética" ${ }^{208}$. Esto es como la fuerza que hace surgir el dibujo. Es la razón por la que un dibujo realizado a partir de un modelo nunca se confunde con el modelo, en el sentido de que nunca es igual al que vimos, implica siempre un proceso mental, afectivo e intelectual que está asociado, o crea, el proceso simbólico y/o señaléctico que hace al dibujo portador de significado, comunicabilidad o expresividad humana.

El dibujo fija lo que es propio del dibujante, su cadena de sensaciones y esos índices -en comparación a los códigos, convenciones y clichés instituidos que Castro Caldas denomina «cifrado del dibujo»-, son vistos desde el punto de vista académico como errores, "desviaciones, discontinuidades, conexiones, rupturas, quiebras de la línea, de la marca, o del trazo. Lo que queda registrado es algo como una falta de coincidencia fundamental entre las conexiones sensibles y las conexiones cifradas de lo visible", o sea, sistematizadas, reducidas, codificadas "porque ya se trate de la página en blanco o del motivo

\footnotetext{
${ }^{207}$ FOCILLON, Henri, A Vida Das Formas, Seguido de Elogio da Mão, Trad. de Ruy Oliveira, Lisboa, Edições 70, 2001, p. 121.

${ }^{208}$ CALDAS, Manuel Castro, "Topos Outopos", in Catálogo O Génio do Olhar: Desenho como disciplina 1991-1999, Instituto de Arte Contemporânea, Lisboa, 2000, p. 14.
} 
exterior percibido, es siempre por encima de los trazos y de las líneas de un lenguaje que ya está siempre allí -cristalizado, eternizado, comunicacional-, en torno de ellas, en su sustitución, por encima del cliché y oponiéndose a él, que la inscripción del dibujo se hace". ${ }^{209}$ Los clichés son las imágenes hechas, y estas anulan la presencia o manifestación del dibujo porque la inscripción del dibujo se hace por oposición al cliché, a lo cristalizado. Los códigos y convenciones tan sólo informan y no expresan. Son únicamente «una contingencia o herramienta que es necesario superar». Si el dibujo fuera la confirmación de los clichés, entonces no sería espiritual, subjetivo e inventivo; no contenía cualquier aura, se confundiría con las reglas de los muchos códigos y convenciones que son usados para representar la realidad. Si así fuera, el reino de las imágenes no obtendría cualquier renovación: el dibujo estaría hecho antes de empezarlo, no valdría la pena hacer una cosa cuyo resultado final ya se sabría. Y por aquí se comprende la necesidad de Giacometti en restituir una visión inmediata y efectiva de las cosas, combatiendo la visión renacentista del mundo. Recrear las condiciones para una visión efectiva del mundo implica negar toda la visión estereotipada o convenida y la construcción para sí mismo de un "reglamento provisional de la visión" ${ }^{210}$ que, para este artista, también se traduce en la naturaleza de su relación con el modelo, y que más adelante abordaremos.

El dibujo es la forma más inmediata de expresión humana, su diligencia adecuada y expedita tiene que ver con la economía de medios; la práctica del dibujo no requiere de ningún aparato significativo. Basta tener un medio para rayar o marcar y un soporte plano para que podamos inmediatamente poner en acción una de las formas de expresión más inmediatas que sólo encuentra equivalencia con la música o la poesía, pues también estas se derivan de una práctica que privilegia la disminución de la fricción o resistencia entre quien se quiere expresar y el medio que usa para ese fin.

Por ser inmediato, el dibujo puede poseer tanto un fondo animal o impulsivo del hombre, como intelectual y por lo tanto sensible e inteligible,

\footnotetext{
${ }^{209}$ Idem, pp.14-15.

${ }^{210}$ CALDAS, Manuel Castro, "Topos Outopos", in Catálogo O Génio do Olhar: Desenho como disciplina 1991-1999, Instituto de Arte Contemporânea, Lisboa, 2000, p. 15.
} 
implicando la percepción, la concepción o la actividad conceptual más elaborada. Teniendo en cuenta estas determinaciones, no es de admirar que el dibujo interese tanto a Giacometti; este es de hecho el medio más inmediato entre el cerebro y la mano, la expresión se produce con el mínimo de resistencia, de modo que el acto puede ser instantáneo. En el dibujo tiene lugar un proceso idéntico al que Hannah Arendt identificó como siendo propio de la poesía y de la música en su libro titulado La Condición Humana. Esta autora defiende que "en la música y en la poesía, que son las menos «materialistas» de las artes porque su «material» consiste en sonidos y palabras, la reificación y la artesanía necesarios son mínimos." 211 Para esta autora, "el joven poeta y el niño que es un genio musical pueden alcanzar la perfección sin mucho entrenamiento y experiencia, fenómeno que difícilmente ocurre en la pintura, en la escultura o en la arquitectura". ${ }^{212}$ La explicación es sencilla: la pintura y la escultura convencionales imponen un mayor grado de resistencia, sus soportes exigen gradaciones sucesivas de trabajo técnico y, por consiguiente, muestran también grados de cristalización cada vez mayores. Por el contrario, el dibujo, que sería aquí el equivalente de las artes plásticas, equiparable a la poesía y a la música, es la forma de expresión "cuyo producto final permanece más próximo del pensamiento que lo inspiró." ${ }^{213}$ Es lo que podemos testimoniar en cada dibujo de Giacometti.

En el dibujo, en la pintura o en la escultura de Giacometti, se reconoce un cierto movimiento de inscripción y tachadura que es inherente a la propia creación de la imagen como una «escritura sin fin». ${ }^{214}$ cada dibujo exhibe una imagen que es indisociable del acontecimiento que le dio origen, parece estar incompleta, ser provisional. El artista no muestra las apariencias del mundo

\footnotetext{
${ }^{211}$ ARENDT, Hannah, A Condição Humana, trad. de Roberto Raposo, Lisboa, Relógio D’Água, 2001. p. 210.

${ }^{212}$ Idem, Ibidem.

${ }^{213}$ Ibidem.

${ }^{214}$ Jacques Dupin, en la introducción a las ediciones francesa y castellana de los escritos de Giacometti, presenta un texto titulado originalmente Une écriture sans fin, que se detiene en la profundización de la afinidad entre dibujo y actividad reflexiva materializada en los escritos de artista de Giacometti. DUPIN, Jacques, "Una Escritura Sin Fin", In Escritos de Alberto Giacometti, Trad. de José Luis Sánchez Silva. Madrid: Síntesis, 2001, pp. 15-27.
} 
hechas, sino siendo hechas. Dibujo, pintura o escultura se equivalen porque están en permanente construcción y desgaste, promesa de presencia y de desaparición. El momento de la acción que inscribe la línea, la pincelada o la acumulación de greda fresca, así como el momento de rectificación o tachadura de la línea inscrita, de la pincelada que deshace y oculta o del gesto erosivo en la escultura permaneciesen pegados al acontecimiento, a la rapidez del gesto que busca crear una actividad "tan incesante y repetitiva como la propia vida." ${ }^{215}$

Mientras que Jean Genet encuentra paralelo entre la música y la actividad modeladora de la escultura, Jaques Dupin y Michel Leiris encuentran una estrecha relación entre la caligrafía y el dibujo. Jean Genet cita un diálogo entre Federico II y Mozart poniendo en consonancia el acierto musical del músico con los dedos de A. Giacometti que buscan apoyo en el yeso o barro húmedos. “¡Qué notas! ¡Qué notas! Mozart - Señor no hay una sola de más. Mis dedos repiten el recorrido de los de Giacometti, pero mientras los de él buscaban apoyo en el yeso húmedo o en el barro, los míos le retoman los pasos con seguridad. Y -ial final!- la mano vive, la mano ve." ${ }^{216}$ Para Giacometti, "la mayor invención siempre viene de la mano de la mayor similitud." 217

Michel Leiris defiende que "Alberto Giacometti procede siempre con los medios que tiene al alcance de su mano (...) sus obras plásticas (la mayoría simples pero regularmente juzgadas intentos fallidos, tan grande era la exigencia de dar cuenta de algo automáticamente) tienden a la caligrafía." ${ }^{218}$ El antropólogo Tim Ingold presenta algunas determinaciones de la inscripción lineal del dibujo, en lo que tiene de proximidad con la caligrafía. Esas cualidades que tanto nos sirven para comprender la naturaleza del dibujo de Klee basado en el concepto de "forma en formación" (gestaltung), como el dibujo de Giacometti. Según este antropólogo, el dibujo aún no se ha desvinculado de la observación en la medida

\footnotetext{
${ }^{215}$ Idem, p. 211.

${ }^{216}$ GENET, Jean, O Estúdio De Alberto Giacometti, Trad. de Paulo da Costa Domingos, Lisboa, Assírio \& Alvim, 1999, pp. 35-36.

${ }^{217}$ GIACOMETTI, Alberto, Escritos de Alberto Giacometti, Trad. al castellana de Miguel Etayo y José Luis Sánchez Silva, Madrid, Editorial Síntesis, 2001, p. 319.

${ }^{218}$ LEIRIS, Michel, "Giacometti Oral y Escrito», In Escritos de Alberto Giacometti, Trad. de José Luis Sánchez Silva. Madrid: Síntesis, 2001, p. 12.
} 
en que, al mismo tiempo que la mano dibuja, el ojo es levado a encontrarse con los «acontecimientos que constituyen la propia vida en el mundo.

El dibujo subvierte los prejuicios que contaminan la polaridad entre texto e imagen. Sus líneas ni se solidifican como imágenes, ni se organizan ellas mismas en formas estáticas como sucede con el texto. Ellas no capturan el mundo en su totalidad, devolviéndolo enteramente al observador o al lector. Es decir, las líneas del dibujo son llevadas hacia adelante en tiempo real, en consonancia con los movimientos del mundo en formación. O sea, las manos que se mueven y el registro de trazos sobre la superficie de la imagen están siempre absolutamente coincidentes uno sobre el otro (...) todo dibujo es también el retorno a la caligrafía, sustituyendo la oposición rígida entre imagen y texto en un continuo de prácticas y procesos en los que la frontera entre caligrafía, dibujo, esbozo y línea acabada no tienen sentido... ${ }^{219}$

Basta observar con atención cualquier dibujo de Giacometti para estar de acuerdo con este vínculo fuerte entre caligrafía y dibujo. Para Jacques Dupin, las cualidades de la línea pasan por ser "fluida, ligera, arrebatada, pero también abandonada, retomada, borrada, multiplicada, aventurada, una línea reveladora del espacio abierto que fomenta una digresión esencial... Una palabra, una línea, que se buscan, se interrogan, cuestionando lo próximo y lo lejano, conjugando el tiro de precisión y la ciega penetración de la niebla." ${ }^{220}$ Además de las determinaciones de la inscripción lineal, Dupin nos introduce otra dimensión de la inscripción que es común no sólo al dibujo sino también a la pintura y la escultura. Se trata de la tachadura.

Alberto Giacometti se relaciona con la escultura y con el dibujo como cualquier cosa que está permanentemente en construcción, a partir de la cual el

\footnotetext{
${ }^{219}$ INGOLD, Tim, University of Aberdeen, Creativity - Abduction or Improvisation? (Conference at Keble College, Oxford, UK, 2011.20.06, frag.). Recogida realizada y cedida por Philip Cabau.

«But drawing subverts the assumptions that underpin the polarity of text and image. Its lines neither solidify into images, nor compose themselves into the static forms of the printed text. They don't capture the world in its totality and render it back to the viewer or reader, but they are rather carried forward, in real time, in concert with the movements of the worlding world, in an ever unfolding relation between observant eyes, gesturing hands and their descriptive trace (...) So a return to drawing is also a return to handwriting, replacing the rigid opposition between image and text with a continuum of scribal practices or processes of line-making ranging from handwriting through calligraphy to drawing and sketching with no clear points of demarcation between them.»

${ }^{220}$ DUPIN, Jacques, «Una Escritura Sin Fin», In Escritos de Alberto Giacometti, Trad. de José Luis
} Sánchez Silva. Madrid: Síntesis, 2001, p. 16. 
artista encuentra paulatinamente la relación con el otro, sobre todo el modelo humano o el paisaje. A partir de esa relación con el otro el artista desarrolla la obra al tiempo que se desarrolla a sí mismo, en una producción donde inscripción y tachadura tienen lugar de forma simultánea. Cada dibujo, así como cada pintura o escultura, incorpora tanto la promesa de desarrollo, como el error: la promesa de desarrollo realizada por la inscripción del trazo del dibujo, de la colocación de la tinta en la pintura o de la greda fresca en la escultura, y el error, o la tachadura, que tiene un carácter de reacción a lo que antes había sido rayado, pintado o esculpido. En Giacometti, muchas veces, es el propio acto de inscripción como promesa de edificación de la imagen que contiene en germen su equivalente opuesto, el desgaste o la excavación de la imagen.

Tomemos como ejemplo las obras ilustradas con las figuras 26,27 y 28 , que muestran dos obras con el mismo título: Femme debout. El dibujo de 1946 presenta una figura femenina de pie, realizada a lápiz y posteriormente borrada. En esta imagen reconocemos los repetidos gestos de incisión y erosión de la línea. Esta insistencia del gesto que inscribe la línea sobre el soporte se opone a la creación de una imagen dotada de un contorno límpido y naturalista, como sucedía con mucha de la producción clasicista. El artista no buscaba describir el modelo a partir de un único contorno porque para él eso equivaldría a transformarlo en una cosa. En vez de eso, la imagen se desarrolla a través de múltiples contornos, en cuya acción sucesiva de rayar o tachar implicó también gestos sucesivos de saturación y ocultación de la imagen. Reconocemos en este gesto la insumisión frente a los códigos y convenciones renacentistas, pues la multiplicidad de trazos crean una vibración de contornos impuros que no dejan margen a un entendimiento de la imagen basada en la simplificación y la geometrización. En consecuencia, es más presentación que representación, si por representación entendemos una cosa que es secundaria en relación al modelo. Las líneas se desarrollan unas por encima de las otras en un acto que tacha por superposición, recreando, a la manera de Cézanne, la profundidad propia de lo que se ofrece a la mirada como realidad altamente compleja e inagotable que es preciso aprehender en el acto propio del dibujo. 
Paradójicamente, en Giacometti el acto de inscribir incita el rechazo de esas mismas inscripciones, por el borrado. El acto de tachar, en este contexto, no es propiamente o totalmente la negación de la inscripción hecha, sino una etapa más de esa búsqueda inagotable. La eliminación de las inscripciones y marcas ya realizadas conduce a la construcción de una rarefacción y precariedad de la imagen, hasta el punto de que corre el riesgo de dejar de existir como tal. Pero eso no sucede totalmente; la tachadura, que funciona por sustracción, no devuelve a la superficie inicialmente inmaculada y blanca del papel. En vez de eso, permanece la mácula, el dibujo como palimpsesto, o, como en "Femme debout" en nuestro ejemplo, el acto de tachar va más lejos y llega incluso a excavar y macerar la propia superficie del papel, mostrando un nuevo nivel de edificación de la imagen basada en el desgaste y la erosión. Así, no hay ninguna posibilidad de que la imagen pertenezca a la misma categoría de la idea tradicional de representación; por el contrario, es sobre todo, y una vez más, acontecimiento y testimonio de la dificultad o resistencia que el artista siente en crear imágenes nuevas a partir de las mismas motivaciones de siempre.

La escultura procede del mismo modo que el dibujo, pues, como defiende Oscar González,"Giacometti ha inventado las esculturas-dibujo, porque ellas poseen líneas y trazos"221. No por casualidad Giacometti dice no considerarse escultor, pues sólo realiza sus esculturas en greda o yeso cuando están frescos. Sólo las trabaja mientras el material le permite el mismo grado de manipulación inmediata y por eso equivalente al dibujo. Escultor era su hermano Diego ${ }^{222}$ que muchas veces, en su ausencia, o en los intervalos de trabajo de su hermano Alberto, hacía los moldes de las piezas y las cristalizaba en bronce.

Fechada un año después que el dibujo, la escultura también titulada Femme debout, (fig. 28) no se deriva directamente de aquel, en el sentido de que el dibujo no funciona como paso preparativo para la realización de la escultura. En realidad, la escultura funciona como un nuevo dibujo, en la medida en que su

\footnotetext{
${ }^{221}$ GONZÁLEZ, Oscar, «Alberto Giacometti: un Escultor». Revista de Cultura (Fortaleza, São Paulo). N. $=24$, mayo de 2002. http://www.revista.agulha.nom.br/ag24giacometti.htm

222 «El escultor no soy yo, sino Diego», Henri Cartier-Bresson cita a Alberto Giacometti en su libro $O$ imaginário segundo a natureza, Barcelona, Ediciones Gustavo Gili, 1996, p. 67.
} 
proceso de ejecución obedece a los mismos gestos de acumulación y desgaste. Femme debout, como todas las esculturas realizadas a partir de 1935, fue construida a partir de la agregación y el desgaste de pequeñas partículas de greda fresca. La superficie de la escultura presenta una diferencia fundamental en relación al dibujo propiamente dicho: es que el acontecimiento del modelado tiene lugar en el espacio de las tres dimensiones, mientras que, en el caso de la escultura, la tachadura derivada de los sucesivos gestos erosivos espacializa la imagen, a través de una activación del vacío espacial que rodea la forma. Esto sucede tanto en la escultura como en el dibujo,

toda escultura es una escritura, por eso mismo A. Giacometti, lo que hace en sus esculturas es escribirse y escribirnos. La forma no es lo esencial, sino el teatro escritural de la forma, la que llama e invoca el vacío, el vacío como el principio de la forma. La técnica de la escultura de Giacometti es la forma y el vacío, como lo es para los orientales. Vacío de todo y vaciado de la forma en la escultura, en su escritura. El escultor intenta escribir con la escultura, para inmovilizarse en el vacío de la forma. La forma es el vacío para él. La escultura de Giacometti habla del vacío y escribe la forma, pero una forma vaciada de sí misma, podríamos decir una forma sin forma, como de una escritura sin leyes escriturales. Él las inventa y las crea. ${ }^{223}$

Veremos más adelante, y en varios momentos, como esta activación del vacío espacial alrededor es el responsable de la creación de un campo de visión y de una cierta noción de espacio/paisaje para la escultura en todo semejante a las formulaciones de la fenomenología de Erwin Sraus y, a partir de éste, de Merleau-Ponty.

La práctica de la pintura vuelve a desarrollarse en las dos dimensiones y también repite e integra la mayor parte de los presupuestos inmediatos del dibujo. Esto sucede porque Giacometti sigue el mismo principio inaugurado con Cézanne, según el cual en la práctica de la pintura no existe una distinción entre el dibujo y el color.

La enseñanza clásica distingue el dibujo y el color: se dibuja el esquema espacial del objeto, a continuación se rellena de color. Por el contrario, Cézanne dice: «a medida

\footnotetext{
${ }^{223}$ GONZÁLEZ, Oscar, «Alberto Giacometti: um Escultor». Revista de Cultura (Fortaleza, São Paulo). N. -24 , mayo de 2002. http://www.revista.agulha.nom.br/ag24giacometti.htm
} 
que se pinta se dibuja» - queriendo con esto decir que, ni en el mundo percibido ni sobre el cuadro que lo expresa, el contorno y la forma del objeto son estrictamente distintos del cese o la alteración de los colores, de la modulación coloreada que todo debe contener: forma, color propio, fisionomía del objeto con los objetos vecinos. Cézanne quiere generar el contorno y la forma de los objetos como la naturaleza los genera bajo nuestros ojos: por el arreglo de los colores. De ahí que la manzana que él pinta, estudiada con una paciencia infinita en su textura colorida, acabe por hincharse, por reventar hacia fuera de los límites que el sabio dibujo le impondría. ${ }^{224}$

La pintura de Giacometti nunca es el resultado de la aplicación de grandes áreas de color por encima de un dibujo que las guía. Por el contrario, dibujo y pintura acontecen simultáneamente hasta el punto de que el criterio más congelado de la típica pintura clásica sea completamente sumergido por la fuerza del dibujo. La aplicación del color se produce en una secuencia continua de pinceladas relativamente finas con objeto de valorar la tesitura del color a partir de la yuxtaposición y ocultación sucesivas; no hay diferencias entre la pincelada que dibuja y la que aplica el color, ambas permanecen pegadas una a la otra. Las diversas pinceladas de muchos colores, una vez mezcladas, redundan siempre en un gris difuminado de elevada densidad y duración.

En el retrato de James Lord, Fig. 30, lo retratado en el libro ${ }^{225}$ que escribió sobre el desarrollo de la pintura de su retrato, identifica más de dieciocho estadios relativos al desarrollo de su retrato; evidentemente esos estadios sólo existieron en las fotografías que fue haciendo de las varias etapas de ejecución de la pintura, porque, desde el punto de vista del trabajo de Giacometti, tales pasajes nunca existieron precisamente porque la imagen es generada y animada por un movimiento sinóptico continuo en el que las observaciones y pinceladas anteriores actúan y prometen, lanzando puentes hacia adelante. James Lord escribe que Giacometti lo "miraba constantemente mientras trabajaba, a mí y al espacio circundante (...) nunca daba más de cuatro o cinco pinceladas sin mirarme y se alejaba del lienzo una y otra vez, contemplando y estudiándolo a

\footnotetext{
${ }^{224}$ MERLEAU-PONTY, Maurice, Palestras, Lisboa, Edições 70, 2003, p. 29.

${ }^{225}$ LORD, James, Retrato de Giacometti, trad. Amaya Bosal, Madrid, Machado Libros, 2005.
} 
través de sus gafas, con los ojos entornados" ${ }^{\text {"26 }}$. La indecisión, la movilidad y ansiedad son todo lo que J. Lord observa en la ejecución de la pintura. Nota en varios momentos la insatisfacción e incluso la cólera del artista por no conseguir copiar las apariencias de lo que ve, lo que indica la producción de un tipo de imagen que no pretende sedimentarse en un estadio definitivo, como sucede con la pintura clásica. La pintura es antes la promesa de querer ser otra imagen, por eso sigue el espíritu del dibujo que revela y oculta continuamente.

El trabajo de Giacometti enfatiza la importancia del sumatorio de todos los instantes en que el modelo es percibido, de esa forma se da cuenta de cualquier cosa desconocida para él. La densidad espacial de su pintura es el resultado de la acumulación de instantes temporales, de ahí que los mejores ejemplos de su arte sean aquellos en los que los modelos aguantaron más horas posando ante el artista. Yanaïhara, por ejemplo, sirvió de modelo durante 36 para Giacometti. Una vez que sólo percibe lo que está haciendo cuando está trabajando, podemos considerar que su técnica de modelado y realización de una semejanza se confunden, instalando el arte como lucha del artista para aproximarse del lado sensorial promovido por el contacto con el modelo. Giacometti crea una especie de saber en acto, donde no existe separación o relación de causa/efecto entre la teoría y la práctica, pues ambos funcionan como momentos de un mismo trabajo reflexivo entre artista y creación, entre sujeto y objeto "que se convierte, ni más ni menos, en existencia."227

\section{3}

\section{Espacio entre artista y modelo}

La relación de A. Giacometti con el modelo no implica la sumisión de éste, como sucede en las tradicionales academias de Bellas Artes, e incluso con

\footnotetext{
${ }^{226}$ Idem, p. 20.

227 BARRERO, Manuela, "Giacometti-Sartre. Transformaciones absolutas", Anales de Historia del Arte, Madrid, Universidad Complutense de Madrid, 12, 227-238, 2002, p. 232.
} 
algunas prácticas artísticas clásicas. Es sobre todo una relación de producción, tal vez la única posible si queremos pensar en la idea de "relación" con toda propiedad. Entre un polo y otro, entre el artista y el modelo, se juegan sinergias importantes, tal como entre la concentración del artista y la tentativa de que el modelo siempre tiene que influir en su acción. En algunos casos, A. Giacometti intentaba ejercer su poder procurando contener dentro de determinados parámetros las situaciones en que el modelo se movía o cambiaba de estado de espíritu, a uno diferente del que ambos habían acordado. Esto porque en el espacio de trabajo de un taller "están presentes por todos lados las tentativas, las experiencias, y las intuiciones de la mano," ${ }^{228}$ así, cualquier cambio en relación a esa mnemónica procesal supone un bloqueo para el artista que, de esa forma, no conseguiría concertarse. Hay transformaciones de la relación entre artista y modelo a lo largo de la duración del trabajo, que son dictadas por la conducta que el artista demanda al modelo. Después de este acuerdo tácito, esas transformaciones implican importantísimas repercusiones en el campo de la percepción y el pensamiento y se manifestarán en la realización tangible de la escultura y el dibujo.

Las transformaciones se producen pero tienen una velocidad; en otras palabras, cuando la sesión comienza, A. Giacometti y el modelo vienen dotados de un ritmo propio al que corresponden dinámicas y movimientos propios. Una vez frente a frente, se exige el máximo de concentración. Giacometti toma su lugar de siempre en la geografía del taller y, frente a él, el modelo toma también el lugar de todos los otros modelos que hasta entonces han sido objeto de su labor. Las miradas y las posiciones se ajustan, adecuándose mutuamente a partir de entonces. Alberto marca el compás, diapasón a partir del cual el modelo debe regirse. O sea, no hay espacio para saltos bruscos de registro por parte del modelo. Las transformaciones, los cambios de nivel deben ser graduales hasta que el ritmo del pensamiento y la percepción del artista encuentre coincidencia en la construcción de la escultura o del dibujo. Tal vez por eso A. Giacometti

\footnotetext{
${ }^{228}$ FOCILLON, Henri, A Vida das Formas. Seguido de Elogio da Mão, Trad. de Ruy Oliveira, Lisboa,
} Edições 70, 2001, p. 117. 
haya trabajado tanto con su hermano Diego, pues éste se habrá dado cuenta precozmente de sus necesidades rítmicas.

A partir del entendimiento de ese espacio, que media entre el artista y el modelo, el artista puede extraer todo aquello que puede ayudarle en la construcción de la obra. El lugar del dibujo o de la escultura es el espacio donde la percepción y el pensamiento cae y se materializa. Por tanto, el artista transforma el tiempo en espacio; es decir, transforma el tiempo que es determinado por la sucesión en espacio que es determinado por la simultaneidad. De esa forma, al ser observada con atención por un espectador, la obra es traducida de nuevo en duración. Cada obra hecha condensa fenomenológicamente en espacio varias categorías de tiempo personal y colectivo. Giacometti cree que la esencia de lo humano sólo se comprende en plena acción/pensamiento, de ahí que sólo sepa lo que ve en el exacto momento en que trabaja en su taller, cuando tangibles sus percepciones, emociones y concepciones.

De ese y en ese espacio entre, existen siempre faltas de coincidencia; hay siempre algo que quedó por hacer o que falló, residuos de caos. Por eso, el artista sabe siempre que va a fallar su objetivo de copiar como ve una cabeza, pero ese fracaso anunciado es también lo que le hace intentarlo una y otra vez. Cada obra no es sino el testimonio de meras tentativas.

\section{4}

\section{La forêt y la relación con la idea de paisaje}

La forêt (1950) es tal vez uno de los pocos ejemplos de escultura moderna que trabaja la idea de paisaje. Ya el propio título nos indica que esta obra se coloca en el ámbito de la relación de la escultura con el paisaje. En efecto, a partir de esa dimensión literaria que el título constituye, A. Giacometti opera una vinculación inmediata con la historia de la representación del paisaje, más específicamente con las representaciones de bosques realizadas por otros 
artistas a lo largo de la Historia del Arte. Así, el título configura un marco poético y conceptual a partir del cual el espectador puede acceder a la obra. Debe subrayarse que desde mediados de la década de 1930, A. Giacometti pasa a remitir sus títulos siempre a lo que le hace descubrir "un poco del mundo exterior", o sea, la semejanza.

Pero consideremos insuficiente esa prueba paisajista que sugiere el título y continuemos más en profundidad la investigación de saber si La forêt es una escultura paisajista. Sabemos que Alberto Giacometti entendió bien el valor de la copia al mismo tiempo que construía su noción de historia ${ }^{229}$ a través de dibujos muchas veces hechos en las páginas de libros de Historia de Arte. Giacometti hacía copias del arte de todas las épocas, garabateando en libros y hojas sueltas, mostrando que su comprensión de la historia no es tanto la de la Historia del Arte hecha por los historiadores, sino antes bien la búsqueda de un phatos formal. Su historia es un esfuerzo de continuidad con la obra de los artistas anteriores, un movimiento de rememoración en relación a los objetos, obras o artistas que fueron decisivos para desencadenar su trabajo. Entre esas obras, se encuentran algunos paisajes, como la copia del Fresco del túmulo de Dupi en Tebas (1942) y del Camino con cipreses (s/ fecha) de Van Gogh.

En sus escritos también podemos encontrar referencias a concepciones paisajistas como en Charbon d'herbe o Hiere Sables Mouvants, ambos datados de 1933, donde habla de la sensación de estar lejos de sí: "la llanura estaba limitada en uno de sus lados, bastante lejos de mí, por un bosque de abetos, un bosque monótono y oscuro. Miraba aquella llanura y aquel bosque por la pequeña ventana de la isba (...) donde me hallaba y en la que hacía mucho calor. Era todo. Pero muy a menudo viajaba mentalmente a aquel lugar" ${ }^{\prime 230}$. En sus textos À propôs de Jacques Callot (1945) y Paysage! Paysage! (1952) encontramos un trazo fundamental, muestran paisajes dominados por la idea de

\footnotetext{
229 IVAM, Centre Julio González, El diálogo con la historia del arte, Alberto Giacometti, coord. Barañano, Kosme, Catálogo de la exposición, 11 de diciembre de 2000 a 25 de febrero de 2001, Valencia.

${ }^{230}$ GIACOMETTI, Alberto, Escritos de Alberto Giacometti, Trad. al castellano de Miguel Etayo y José Luis Sánchez Silva, Madrid, Editorial Síntesis, 2001, p. 43.
} 
abandono, sus paisajes de infancia, pero también los lugares de sus miedos y violencias latentes, a los que no es ajeno el ambiente de posguerra.

También su padre ejercitó bastante en su pintura el género del paisaje. Fue de él que Giacometti recibió sus primeras influencias. En el cuadro Paesaggio (1919), un óleo sobre lienzo de Alberto Giacometti, puede verse dicha influencia, no sólo en la temática, como en su tratamiento de manchas anchas de colores puros.

\section{5}

\section{La cabeza o el deshacer del rostro}

Además de la cuestión paisajista, La forêt incorpora el problema de la construcción de la cabeza, que reviste una posición central para Alberto Giacometti, quien durante sus últimos años de creación repetía incesantemente que "sólo quería crear una cabeza".

El rostro se hace por sustracción de la materia. La greda fresca se agrega en pequeñas dedadas a un núcleo informe previo pero frágil, que es un alambre recubierto de barro, del que inicialmente parten todas sus esculturas.

De esta forma, Giacometti consigue expresar rostros de materialidad precaria. Parece que la única cosa que los sostiene son las zonas de unión de las varias partículas de greda. En la construcción de la escultura cada actuación sobre la cabeza va recubriéndola de una organización espacial que no alcanza a ser plenamente estructurada. ¿Será un rostro? Las partículas de greda fresca, la lectura de su acumulación dejan marcas, agujeros, líneas interrumpidas, elevaciones, depresiones y, tal como en un paisaje, podemos adivinar con los dedos y los ojos su hacer.

Pero si en la escultura la construcción del rostro obedece a la partícula y en el dibujo al rayar permanente, eso no significa que Giacometti realice la construcción del rostro como una unión de varias partes separadas, ojo, nariz y 
boca, sino teniendo una noción de la totalidad y de su infinito a través de la comunicación de varias partes. Para A. Giacometti, una cabeza no tiene más objetivo que sostener la mirada, por tanto, toda su labor se centra en entenderla y determinarla en el espacio de todo el rostro. "No pienso directamente en la mirada, sino en la misma forma del ojo... en la apariencia de la forma. Si consiguiese captar la forma del ojo, probablemente eso daría algo parecido a la mirada. Sí, tal vez todo el arte consiste en conseguir situar la pupila... Lo que hace la mirada es el entorno del ojo". ${ }^{231}$ En otra conversación con Jacques Dupin, Giacometti es aún más claro en lo que se refiere a la cuestión de la mirada: ahí, no procede tan sólo de los ojos, sino también de la boca, muchas veces central, de las fosas nasales, de las orejas y finalmente de todos los poros y de todas las pinceladas del cuadro. "Si tengo la curva del ojo, también consigo tener la órbita; se tengo la órbita, consigo tener la raíz de la nariz, la punta de la nariz, los agujeros de la nariz y la boca. Así, el todo puede al final dar una verdadera mirada, sin que nos fijemos en el propio ojo". ${ }^{232}$ El ojo adquiere aquí, tal como en todo el arte del retrato, un papel de metonimia del rostro que a su vez es metonimia del cuerpo.

La cabeza surge frecuentemente con pequeñísimas dimensiones en relación al cuerpo que la sostiene. "El cuerpo que brota de ahí sostiene en lo alto la cabeza minúscula. Esa enorme masa de yeso o bronce en proporción a la cabeza podría llevarnos a imaginar pies cargados de toda la materialidad liberada por la cabeza... pero no; hay un ininterrumpido intercambio entre estos pies macizos y la cabeza." ${ }^{233}$ La pequeña cabeza permanece como si de la acción de hacer el rostro pudiera quedar apenas un vestigio de rostro o una constatación de que el rostro sólo funciona más eficazmente cuando dotado de coberturas continuas, abiertas e incompletas que van alojando pero no congelando consciencias, pasiones, redundancias y zonas de probabilidad, tal

\footnotetext{
${ }^{231}$ Idem, p. 317.

232 “Si j'ai la courbe de l'œil, j'aurai aussi l'orbite; si j'ai l'orbite, j'ai la racine du nez, j'ai la pointe du nez, j'ai les trous du nez, j'ai la bouche. Donc le tout pourrait à la fin donner quand même un regard, sans qu'on se fixe sur l'œil même." Conversación con Jacques Dupin en la película Alberto Giacometti de Ernst Scheidegger y Peter Münger, 1965, en Face to Face to cyberspace, op.cit.
}

${ }^{233}$ GENET, Jean. O estúdio de Alberto Giacometti. Lisboa : Assírio \& Alvim, 1999, p. 38. 
como en un diálogo en que el eventual oyente guía sus decisiones por el rostro de quien habla. ${ }^{234}$

"El ojo siempre parece frío y distante. Pero la dificultad para expresar realmente ese «detalle» es la misma que para traducir, para comprender el conjunto. Si yo le miro de frente, olvido el perfil. Si miro su perfil, olvido la cara. Todo se vuelve discontinuo. Ese el hecho. Ya nunca consigo captar el conjunto."235 Hacer un rostro como una lámina de un cuchillo coloca en el mismo plano cara y perfil, mirada frontal y mirada lateral. Cuando estamos ante un dibujo o una escultura de Alberto, la mirada circula por una línea media del rostro, su plano de simetría donde se encuentran la nariz, la boca y el mentón. De ahí se pasa a las orejas que, en el extremo opuesto a la línea media, casi se tocan.

"Pienso que el rostro ofrece toda la fuerza de su significado cuando está de frente, $y$ todo debe nacer de ese centro y servir para alimentar, fortificar lo que

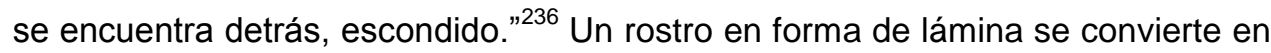
un plano, guarda el punto de vista, el único lugar desde donde Giacometti puede contemplar su situación en el espacio. Los rostros de sus esculturas funcionan como brújulas que apuntan a su centro magnético, la relación escultor/modelo imprime una memoria espacial y relacional. Frente al modelo, Alberto Giacometti trabaja una presencia como ausencia. El rostro se afila y adquiere intensidad, se concentra en un limbo laminar, una especie de plano de simetría que dialoga intensamente con el escultor y, más tarde, con el espectador. El busto concentra el problema fundamental de la «factura de la cabeza» que es el punto a partir del cual la escultura debe ser vista y la única capaz de devolver la mirada.

\footnotetext{
${ }^{234}$ DELEUZE, Gilles y Guattari Félix, Capitalisme et Schizophrénie, Mille Plateaux. París: Les Editions de Minuit, 1980. p. 206.

${ }^{235}$ GIACOMETTI, Alberto, Escritos de Alberto Giacometti, Trad. al castellano de Miguel Etayo y José Luis Sánchez Silva, Madrid, Editorial Síntesis, 2001, p. 317.

${ }^{236}$ GENET, Jean. O estúdio de Alberto Giacometti. Lisboa, 1999, Assírio \& Alvim, p. 54.
} 


\section{6}

\section{La forêt}

La escultura La forêt, realizada por A. Giacometti en 1950, surge de manera directa del aprovechamiento de una tirada de dados del azar, pues desciende directamente de la caída al suelo de La place Auxtrois figures, un grupo de esculturas del que derivan directamente La Chairière y La forêt, ambas de 1950. La forêt se compone de un busto y siete figuras femeninas/árboles fuertemente determinadas por la calidad hierática de la estatuaria egipcia; son afirmativas pero de frágil verticalidad, representando, como su propio título indica, un bosque. Esta escultura miniaturizada se refiere -como sabemos a través de los escritos de Giacometti- a una memoria de infancia. Su escala reducida remite, como nos explica el artista, directamente al hecho de derivarse de la prospección de una memoria. "Queriendo hacer de memoria lo que había visto, para mi terror, las esculturas se hacían cada vez más pequeñas, sólo quedaban parecidas cuando pequeñas, y sin embargo rechazaba esas dimensiones, e incansablemente recomenzaba para llegar, después de algunos meses, al mismo punto." ${ }^{237}$ Esta constatación está relacionada con el hecho de que cada escultura de este periodo resulta de una cierta idea de campo visual que encierra un espacio y una figura o conjunto de figuras, como tendremos ocasión de profundizar más adelante.

Antes de iniciar la prospección de ese texto escrito que da cuenta de la aparición de La forêt como cualquier cosa que tuvo un vínculo fuerte a una memoria de infancia, conviene recordar que "en el hombre no podemos describir la memoria como un simple retorno de un evento, como una vaga imagen o copia de impresiones anteriores. No es simplemente una repetición, sino, antes bien, un renacimiento del pasado; implica un proceso creativo y constructivo. No basta con recoger datos aislados de nuestra experiencia pasada; debemos realmente re-coger-las, organizar-las y sintetizar-las y reunir-las en un foco de pensamiento. Es este tipo de recuerdo que nos proporciona la forma humana característica de

${ }^{237}$ GIACOMETTI, Alberto, "Alberto Giacometti. Carta a Pierre Matisse", in Teorias da Arte Moderna, São Paulo, Martins Fontes, 1999. p. 612. 
la memoria." ${ }^{238}$ Por lo tanto, la memoria ya es ella misma una de las modalidades del pensamiento más creativas, siendo de ahí que parte La forêt. Pero esa memoria posee una cualidad específica: la soledad. El espacio del que deriva $\mathrm{La}$ forêt a partir de una memoria de infancia es un espacio de soledad constructivo. "Los espacios en los que sufrimos la soledad, disfrutamos la soledad, deseamos la soledad, comprometemos la soledad, son indelebles en nosotros. Y es precisamente el ser que no desea apagarlos. Sabe por instinto que esos espacios de soledad son constructivos." ${ }^{239}$ Es la memoria del espacio como soledad la que convoca las intensidades del lugar y el deseo de poseerlo una vez más, ahora en estado adulto, y que encontrará eco en la expresión de la escultura, tal vez traduciendo la soledad en abandono.

En una carta dirigida a Pierre Matisse, escrita el 28 de septiembre de 1950, Alberto Giacometti describe "un área de bosque vista en los numerosos años en que los árboles ( $\sin$ ramas hasta la copa) y de troncos desnudos y esbeltos se parecían a personajes inmovilizados en su andar y se hablaban (...) en ese lugar reconozco también un punto concreto donde la cabeza ocupa el lugar de una piedra. Hay bloques de granito aislados entre los árboles pero yo había soñado en hacer esas cabezas acabadas hace casi 20 años." ${ }^{240}$ A partir de esta declaración, somos llevados a pensar que La forêt supuso un mecanismo de sustitución de una cabeza en el lugar donde en el paisaje recordado se situaba una piedra. En relación a esta escultura, Max Reithman nota que "parece no haber perspectiva común entre los personajes de la primera línea y los del fondo (...) todos los criterios sincrónicos, que garanticen un continuo espacial común, coordinador y perspéctico quedan abolidos". ${ }^{241}$ Oscilando entre proximidad y distancia y "pasando de lo continuo a lo discontinuo", las figuras de La forêt se

\footnotetext{
${ }^{238}$ CASSIRER, Ernst, Ensaio sobre o Homem. Introdução a uma filosofia da cultura humana, Trad. al portugués de Tomás Rosa Bueno, São Paulo, Martins Fontes, 2005, p. 88.

${ }^{239}$ BACHELARD, Gaston, A Poética do Espaço, Traducción de António Danesi, São Paulo, Martins Fontes, 2000, p. 29.

${ }^{240}$ REITHMAN, Max, Regards sur Giacometti, in catálogo da exposición Giacometti, La Collection du Centre Georges Pompidou, Musée National d'Art Moderne, programación del Musée d'Art Moderne de Saint-Etienne 1999. p. 21.

${ }^{241}$ Idem, p. 16.
} 
presentan en suspenso; el espacio que las media adquiere mucha importancia debido a su tratamiento informe dado por el inacabamiento asumido.

Entre las varias figuras, parece extenderse un espacio vacío donde, en palabras de Jean Paul Sartre, el vacío surge de la plenitud "amasando el yeso, de la plenitud él crea la vacuidad." ${ }^{242}$ Este acontecimiento en la escultura ya había sido observado por Hildebrand, en 1907, en relación a todo el trabajo de configuración inacabado y realizado en arcilla. Para este autor ya citado, el modelado realizado a partir de la arcilla es muy diferente del modelado hecho en piedra. "Aquí falta en el espacio lo que no está modelado, no existe ningún espacio -arcilla común fuera del modelado. Al contrario, lo modelado penetra el aire y el espacio real y efectivo de tal manera que la imagen de arcilla inacabada obtiene así todavía más positividad, es decir, aparece como una imagen acabada, anteponiéndole a la fantasía lo inacabado como acabado." ${ }^{243}$ También Javier Maderuelo identifica que Giacometti "intenta desarrollar un tipo de escultura del espacio. Para conseguirlo pretende liberar a la escultura de su aspecto de masa pesada recurriendo a los modelos del primitivo arte etrusco y situándola en estructuras y plataformas que destacan el entorno de la figura, pero desde el punto de vista de lo espacial, sus obras no consiguen pasar de ser hermosas estatuas antropomórficas muy estilizadas." ${ }^{244}$ Tales constataciones hacen que, en La forêt, lo importante sea el espacio entre las figuras situadas sobre la base o escenario de la escultura y no tanto las figuras en sí. Esta importancia concedida al espacio será de la mayor utilidad cuando, más adelante, establezcamos un puente entre la idea de paisaje como imagen para ser vista, hacia la idea de paisaje para ser habitada por un cuerpo. Aún en La forêt, reconocemos como rasgo distintivo de la naturaleza de su espacio la expresión del abandono que, como vimos, es desde el siglo XIX la determinación que une la naturaleza en decadencia y la ciudad.

\footnotetext{
${ }^{242}$ SARTRE, Jean-Paul, «Les peintures de Giacometti », Derrière le miroir, №. 65, Mayo de 1954.

${ }^{243}$ HILDEBRAND, A. Von, El problema de la forma en la obra de Arte, Trad. al castellano de María Isabel Peña Aguado, Madrid, Visor, 1988, p. 103.

${ }^{244}$ MADERUELO, Javier, La Idea de Espacio en la Arquitectura y el Arte Contemporáneos 1960 1989, Madrid, Akal, 2008, p. 50.
} 
En La forêt, el busto contenido en ella es escultura, lo que implica que no es "un objeto hermoso, sino un medio para intentar comprender un poco mejor lo que veo, para intentar comprender un poco mejor lo que me atrae y me maravilla de cualquier cabeza". En este sentido, para Giacometti, una buena escultura "no sería más que un medio para decir a los demás, para comunicar a los otros lo que veo." ${ }^{245}$ A la pregunta de André Parinaud: “- ¿esculpe usted para los ojos?”, A. Giacometti responde: "-Para los ojos. Únicamente para los ojos." ${ }^{246}$ Esta insistencia en la cuestión de la mirada nos lleva directamente al problema clásico de concepción de la escultura y también del paisaje. La concepción tradicional y clásica de la escultura, como vimos, está ligada al dibujo de contorno que, una vez colocado en el plano y del material a esculpir, obliga la forma a ceñirse a un punto de vista frontal y a la capacidad del ojo para imaginar y prever cada plano del material a ser esculpido a partir de una cierta idea de plano pictórico. Así, el proceso escultórico de Giacometti, incluso cuando realizado en greda fresca, parece derivar del que fue llevado a cabo por Miguel Ángel en la medida en que "El espacio mismo, en el sentido de forma real, se transforma en forma activa para el ojo". ${ }^{247}$ Recordamos de nuevo a Hildebrand, para quien el modo de construcción de un punto de vista para la escultura la aproxima a una cierta idea de campo de visión característico de la pintura, hay una diferencia entre esculpir en piedra y esculpir en arcilla; en ésta, el cuerpo de la escultura se crea paulatinamente alrededor de la estructura que soporta la masa de barro, no hay la imposición de un punto de vista determinado. No obstante, A. Giacometti impone un punto de vista que se sitúa frente a la escultura, vale decir en relación a la cabeza que modela. Eso lo aproxima del mismo modelo de modelado en piedra, en que la presencia del dibujo y de una imagen que se va proyectando en el material es decisiva. "En este sentido, la representación objetiva de la imagen se refiere siempre, la representación visual que puede tener de la imagen desde

245 GIACOMETTI, Alberto, "Diderot y Falconet Estaban de Acuerdo", in Escritos de Alberto Giacometti, Trad. José Luis Sánchez Silva, Madrid, Editorial Síntesis, 2001, p. 83.

${ }^{246}$ PARINAUD, André, “¿Por qué soy escultor?, Entrevista a Giacometti”, in Alberto Giacometti, Obras, Escritos, Entrevistas, Dir. Ángel González, Barcelona, Polígrafa, 2006, p. 147.

${ }^{247}$ HILDEBRAND, A. Von, El problema de la forma en la obra de Arte, Trad. al castellano de María Isabel Peña Aguado, Madrid, Visor, 1988, p. 93. 
mi punto de vista"248. A pesar de que la concepción del dibujo en Giacometti sea, como vimos, esencialmente errante e incompleta, «esculpir para los ojos» remite también a la idea de que el acto de esculpir está sujeto a la creación de un plano virtual derivado del dibujo, un plano virtual o pictórico que persiste; aunque no haga distinguir figura y fondo, por lo menos se comporta "como el fondo ilusionista de una pintura, ese plano abre el espacio virtual" ${ }^{249}$; así, el fondo virtual construido sobre todo por el vacío y la noción de campo miniaturizado en perspectiva, aunque no haga emerger una jerarquización de las figuras típica de la convención renacentista, por lo menos crea un lugar espacial donde estas oscilan o se presentan errantes a nuestra mirada.

\section{7}

\section{Escultura y campo visual}

Según Manfred Schneckenburger, el gran descubrimiento de Giacometti, "que tardó diez años en alcanzar (...) fue ésta: nosotros nos observamos unos a otros meramente como una «aparición» rodeada por el espacio, dentro de un cierto campo de visión en perspectiva reducida. Giacometti estaba determinado a transponer este modo de percepción, desde hace mucho aceptada como componente de la pintura, al campo de la escultura. En 1945, el filósofo Maurice Merleau-Ponty publicó su famoso estudio «Fenomenología de la Percepción» donde examinó cuan específicamente la realidad concreta es modificada por la situación en la que se inscribe y le presta sentido"250. El mismo autor profundiza esta identificada proximidad de la obra existencialista de Giacometti con las teorías de Merleau-Ponty y, citando a Reinhold Hold, aclara: "Reinhold Hold, en

\footnotetext{
${ }^{248}$ Idem, p. 104.

${ }^{249}$ KRAUSS, Rosalind E., Caminhos da Escultura Moderna, Trad. al portugués de Julio Fischer, São Paulo, Martins Fontes, 2001, p. 15.

250 SCHNECKENBURGER, Manfred, «Posições no Pós-Guerra: O existencial e o Abstracto» in Arte do Século XX, Vol. II, Trad. Ilda Boavista. (pp. 487-498), Colonia, Taschen, 2005, p. 487.
} 
su estudio monográfico de Giacometti ${ }^{251}$, afirmó que «el tamaño natural no existe», y redujo sus figuras a dimensiones de cerilla, haciéndolas casi desaparecer, hasta un punto en que ellas, de hecho, en 1943, se deshacían entre los dedos" 252 . También Rosalind Krauss interpreta las decisiones formales tomadas por Giacometti de acuerdo con la teoría del «campo visual» de Maurice Merleau-Ponty.

El texto en cuestión es la Fenomenología de la percepción de Merleau-Ponty, un texto que se utiliza comúnmente como fundamento interpretativo de las decisiones formales tomadas por Giacometti en su obra de posguerra. Esas figuras alargadas, afiladas, cuya elaboración plástica las hace vibrar y les confiere una permanente vaguedad visual, se interpretan a menudo como la contrapartida escultórica de la redefinición fenomenológica de la percepción como una función de la intencionalidad, como la causa y a la vez el resultado de la «prise sur le monde» del espectador. La distancia y el punto de vista no se añaden al objeto, sino que forman parte inherente de su significado (...). Merleau-Ponty pregunta a su lector: « ¿No es más pequeño un hombre situado a doscientas yardas que un hombre situado a cincuenta yardas? Así es si le aíslo del contexto percibido y mido su tamaño aparente. De lo contrario, ni es más pequeño ni tiene realmente el mismo tamaño: es anterior a la igualdad o la desigualdad; es el mismo hombre vista desde más allá». Los «datos» perceptivos se redefinen de este modo como los significados que las cosas presentan en un determinado punto de vista. «La convergencia y el tamaño aparente no son signos ni causas de la profundidad; están presentes en la experiencia de profundidad de igual modo que un motivo, aunque no se articule ni se plantee por separado, está presente en una decisión». Y más adelante: «La convergencia y el tamaño aparente» no actúan milagrosamente como 'causas' que producen la apariencia de organización en profundidad; motivan tácitamente dicha apariencia en la medida en que ya forma parte de su significado, y en la medida en que ya implican un determinado modo de mirar a distancia» ${ }^{253}$.

Es la comprensión de esta idea de «campo visual que encierra en sí una figura rodeada de espacio» que nos ofrece las pistas necesarias para comprender dos cuestiones fundamentales e incluso antagónicas del trabajo de

\footnotetext{
${ }^{251} \mathrm{HOHL}$, Reinhold, Alberto Giacometti. Nueva York: Abrams, 1971.

${ }^{252}$ SCHNECKENBURGER, Manfred, Op. Cit., pp. 487-488.

${ }^{253}$ KRAUSS, Rosalind E. La originalidad de la Vanguardia y otros mitos modernos. Trad.: Adolfo Gómez Cedillo. Madrid: Alianza, 1996. Richard Serra: una traducción, pp. 275-288.
} 
Giacometti: el vínculo de la escultura de Giacometti, en particular La forêt, con un cierto dispositivo pictórico capaz de expresar la idea de distancia, que se podría confundir con una cierta idea de distancia contemplativa y, por otro lado, la inauguración de un cierto potencial de apertura de la escultura al espacio concreto que, como veremos, caracterizará Uma floresta para os teus sonhos, de Alberto Carneiro.

Pero concentrémonos en la idea de la creación de una distancia contemplativa derivada de una cierta noción de «campo de visión» y que ha sido el soporte de la pintura. Cuando estamos ante las esculturas de Giacometti, tenemos la impresión de que sus figuras en miniatura, aisladas en medio de su base $o$ inseridas en una placa o escenario horizontal, se presentan en otro lugar, ajenas a nuestra presencia, precisamente porque presentan una distancia. "Esta noción de «un determinado modo de mirar a distancia» influyó en los entusiastas espectadores de la obra de Giacometti, para quienes: «Él invento un nuevo campo de creación. Él introdujo la representación de la distancia en la trimilenaria historia de la escultura». Y esta representación de la distancia en las figuras de Giacometti se asociaba con la fenomenología porque se veía como la relación mutua existente entre el objeto y el espectador, el contemplador y lo contemplado" 254 . Por más que nos aproximemos, la distancia continúa allí. Se trata de "una representación de la «visión a distancia» que ningún examen cercano de la obra disiparía ni ninguna ampliación dispersaría. En el significado del objeto estaba implícita la marca de la separación del espectador respecto a dicho objeto; la escultura representaba un cuerpo humano atrapado para siempre en la aureola de la mirada del observador, llevando para siempre la huella de lo que estaba destinado a ser visto por otro desde el lugar desde el cual mira"255.

En "Fenomenología de la Percepción", Maurice Merleau-Ponty defiende que "la cosa es grande si mi mirada no puede abarcarla; es pequeña, al contrario, si la abarca ampliamente, y las grandezas medias se distinguen unas de otras conforme, en distancia igual, dilatan más o menos mi mirada o la dilatan

\footnotetext{
${ }^{254}$ Idem, p. 278.

${ }^{255}$ Ibidem.
} 
igualmente en diferentes distancias." ${ }^{256}$ A través de su dispositivo de subjetivación constituido por la relación artista/modelo, Giacometti traduce a lenguaje plástico todas las determinaciones fijadas por Maurice Merleau-Ponty. En varios momentos, Giacometti nos da cuenta de ese exceso que constituye la mirada lanzada sobre la realidad, que no es una cantidad, sino una cualidad. Y en que ningún objeto nos es ofrecido de modo neutral, y que por eso mismo, cualquier búsqueda de las apariencias depende siempre de la distancia y del ángulo de visión.

Así, en el trabajo de búsqueda y determinación de las apariencias, el tamaño de la escultura es importante, pues, cada una debe obedecer a la cualidad o fuerza que la hizo nacer, ya sea por medio de la observación directa o de la memoria. Cada obra, repetimos, es siempre el resultado de adecuación de una figura rodeada por un espacio y, dentro de un determinado campo de visión, la figura, el espacio y el campo de visión deben recrear una determinada expresión de distancia que es subjetiva y propia de la visión del artista; ese es el desafío de Giacometti, para quien algunos centímetros a menos o a más comprometerían todo el acierto visual y pictórico de la escultura "porque no sé lo que voy a hacer. La cosa que veo, la veo, la siento, pero ignoro completamente por qué medios puedo realizarla. Por tanto, hay muchas probabilidades de que empiece por equivocarme de tamaño. Para reflejar lo que uno ve, el tamaño desempeña un papel primordial. Basta con quedarse cinco centímetros por encima o cinco por debajo para que la obra fracase." ${ }^{257}$ Paulatinamente, Giacometti comprendió que:

la realidad de cierto fenómeno que llamamos escultura. Cuando miro el vaso, de su color, de su forma, de su luz, sólo me llega, en cada mirada una cosa diminuta muy difícil de determinar que puede traducirse en un guión diminuto, una manchita. Cada vez que miro el vaso, parece que vuelve a recomponerse, es decir, que su realidad se vuelve dudosa, porque su proyección dentro de mi cerebro es dudosa, parcial. Lo veo como si desapareciese... resurgiese... desapareciese... resurgiese... es decir, que se encuentra

\footnotetext{
${ }^{256}$ MERLEAU-PONTY, Maurice, Fenomenologia da Percepção, Trad. Carlos A. Ribeiro de Moura, São Paulo, Martins Fontes, 1999. p. 407.

${ }^{257}$ GIACOMETTI, Alberto, Escritos de Alberto Giacometti, Trad. al castellano de Miguel Etayo y José Luis Sánchez Silva, Madrid, Editorial Síntesis, 2001, p. 286.
} 
siempre entre el ser y el no-ser. Y eso es lo que hay que copiar... todo el esfuerzo de los artistas modernos participa de esa voluntad de aprehender, de poseer algo que huye constantemente. Quieren poseer la sensación que tienen de la realidad más que la misma realidad. De todas maneras, no se puede poseer todo... Lo único que podríamos poseer es la apariencia. Lo que queda de la realidad es la apariencia. Si un personaje está a 2 metros de distancia - o a diez- ya no puedo traerle a la verdad de la realidad positiva. Se estoy en la terraza de un café y veo gente que camina por la otra acera, la veo minúscula. Su tamaño natural no existe. ${ }^{258}$

La dificultad de aprehender la apariencia de las cosas es el testimonio del trabajo de Giacometti. Esa aprehensión representa un ejercicio hercúleo porque el artista tiene la consciencia de la dificultad que constituye la tentativa de exprimir la transitoriedad de las cosas y del hombre. Así, se puede decir que Giacometti no representa lo que ve, sino cómo ve, tal como sucede con Cézanne. D. H. Lawrence, citado por Deleuze, dice también estar "convencido de que lo que el propio Cézanne deseaba era la representación. Querrá una representación fiel. Sencillamente quería que fuera más fiel". ${ }^{259}$

\section{8}

\section{La mirada y el Paisaje}

Para Maurice Merleau-Ponty la mirada y el paisaje son indisociables. Así, "La mirada y el paisaje permanecen como que pegados uno al otro, ningún estremecimiento los disocia, la mirada, en su desplazamiento ilusorio, lleva consigo el paisaje, y el deslizamiento del paisaje en el fondo es apenas su fijidez en el fin de una mirada que se cree en movimiento."260 Esta noción de paisaje íntimamente relacionada con la mirada presenta dos grandes ideas: la de la

\footnotetext{
${ }^{258}$ Idem, p. 320.

259 D. H. Lawrence, Eros et les chiens, Éd. Bourgois, p. 238 -261. In: DELEUZE, Gilles, Francis Bacon. Lógica de la sensación, Traducción de Isidoro Herrera, Madrid, Arena Libros, 2005, pp. 90-91.

${ }^{260}$ Consultada la edición portuguesa: MERLEAU-PONTY, Maurice, Fenomenologia da Percepção, Traducción de Carlos Alberto Ribeiro de Moura, São Paulo, Martins Fontes, 1999. p. 79. M. MerleauPonty fue influido en esta concepción por Erwin Straus.
} 
reflexividad y la del vagabundeo. La primera puede comprenderse a partir de su teoría de la reflexividad que mucho influyó en el pensamiento y la práctica artística de los años en que fue creada La forêt. En varios libros, pero sobre todo en sus notas de trabajo, Lo Visible y lo Invisible, ${ }^{261} \mathrm{M}$. Merleau-Ponty explica lo que entiende por reflexividad, que aparece en este autor tratado como un medio a través del cual se tiene acceso a la devolución de la mirada, es decir, lanzando la mirada sobre las cosas o personas, estas devuelven esa mirada actualizada. Este mecanismo de reflejo aparece así como un importante proceso de autoconocimiento, quiere decir, es a través de este mecanismo que se tiene consciencia del propio cuerpo, de la mirada sobre las cosas, del espacio, porque la mirada que se lanza es rebotada, reenviada.

También en El Ojo y el Espíritu, ${ }^{262}$ de M. Merleau-Ponty, existe una magnífica imagen de ese rebote de la mirada que hizo invertir los papeles entre el pintor y lo visible: "en un bosque, sentí varias veces que no era yo quien miraba el bosque, sentí, en ciertos días, que eran los árboles que me miraban y me hablaban.... ${ }^{263}$ Podemos decir que, en A. Giacometti, su arte, la escultura, sirven para comprender un poco mejor lo que lo atrae y lo que lo deja maravillado, es decir, la escultura sirve para comprender el punto a partir del cual la mirada es devuelta. En el caso de La forêt, el punto del paisaje en que la mirada es devuelta bajo la forma de paisaje es el busto.

La segunda gran idea contenida en la afirmación de M. Merleau-Ponty es que la mirada y el paisaje permanecen pegados uno a otro, la de deslizamiento 0 desplazamiento de la mirada. En el proceso de trabajo de A. Giacometti, a partir de mediados de la década de 1930, pocas cosas son delimitadas desde un principio. Podemos llegar a decir que son apenas dos: el artista y el modelo. En Retrato de Giacometti ${ }^{264}$, de James Lord, ya mencionado, tenemos una breve descripción de las etapas de trabajo emprendidas por el artista a partir de la

\footnotetext{
261 Idem.

${ }^{262}$ Consultada la edición portuguesa: Merleau-Ponty, Maurice, O olho e o espírito, Trad. de Luís M. Bernardo, Lisboa, Vega, 1997.

263 Idem, p.29.

${ }^{264}$ LORD, James, Retrato de Giacometti, trad. Amaya Bosal, Madrid, Machado Libros, 2005.
} 
perspectiva del modelo. A través de este retrato, nos apercibimos de la dificultad y del tiempo empleado para elaborar un retrato pictórico en sus ritmos errantes de la línea y de la mancha, la figura y el fondo. El resultado es un retrato donde caben todos los retratos posibles: el fondo invade la figura, la línea es fragmentada, interrumpida y errante, destruyendo cualquier gestalt. Aunque sea una escultura, La forêt fue modelada, agrietada, desgastada, antes de ser cristalizada en bronce. Sus figuras son informes como la tierra y son sobre todo el resultado de un proceso errante que incorpora el $\operatorname{azar}^{265}$ de una caída al suelo de un grupo escultórico realizado anteriormente.

El vagabundeo es uno de los conceptos fundamentales para la concepción de paisaje en Erwin Straus ${ }^{266}$, cuyas teorías influyeron en las de Maurice Merleau-Ponty: el paisaje del mundo real "se da al ser"; se trata de una concepción ontológica que hace del paisaje no una categoría, ni una experiencia antropológica, sino pre-cultural y pre-antropológica. En una lectura de E. Straus, para Jean Marc-Besse el paisaje es "el espacio del sentir, o sea el foco original de todo el encuentro con el mundo, en el paisaje estamos en el cuadro de una experiencia muda, «salvaje» en un primitivismo que precede toda la institución y toda la significación." ${ }^{267}$ En este sentido, se constituye por oposición al espacio geográfico que es cultural y sistemáticamente definido. Así, la concepción de paisaje en E. Straus entra en ruptura con la concepción clásica que entiende el paisaje como una "extensión de territorio que se puede abarcar en una ojeada". Para este autor, el ser afectado por el paisaje se proyecta en el horizonte que configura el limbo entre el aquí visible y el allende oculto invisible. A estas condiciones, y para que el paisaje escape a la noción de objeto y a la consciencia racional, debe juntarse el vagabundeo o el acto de perderse que crea modos de «habitar el espacio, o el tiempo», vagar como modo de llegar al paisaje invisible.

\footnotetext{
${ }^{265}$ El azar es una estrategia surrealista usada sobre todo para traer a la superficie las imágenes o manifestaciones del inconsciente.

${ }^{266}$ STRAUS, Erwin, Du Sens Des Sens, Grenoble, JéromeMillon, 1989. sobre el contenido de este libro ver también ; Maldiney, Henri, Regard Parole Espaçe, Lausane, Éditions L'Age D' Homme, 1973.

${ }^{267}$ BESSE, Jean-Marc, Ver a terra. Seis Ensaios sobre a Paisagem e a Geografia, Trad. de Vladimir Bartalini, São Paulo, Editora Perspectiva, 2006, p. 80.
} 
Para Erwin Straus, la creación de un espacio paisaje no depende de los medios usados en arte, ni del contexto. Depende siempre de una disponibilidad del sujeto que es siempre participante en la medida en que se deja afectar. Así, para E. Straus, todos los espacios pueden ser espacios paisaje; una pintura, una escultura o un dato de la vida cotidiana pueden acceder a esa dimensión porque el espacio paisaje no depende del medio o del contexto en que se encuentra el individuo, pero de la forma como los medios de la pintura o de la escultura o una experiencia cotidiana son percibidos. La cuestión está del lado de la empatía. Si el objeto proporciona un "momento pático" ${ }^{268}$, es decir, si el sujeto se deja afectar no respondiendo con un "momento gnóstico", ${ }^{269}$ entonces están reunidas todas las condiciones para crear un espacio paisaje. E. Strauss defiende que sólo dos pintores consiguieron expresar el espacio paisaje: Guardi y Vermeer. Del segundo, considera la Vista de Delft la pintura que mejor presenta el paisaje, ya que su estructura compleja excede la representación: se presenta como paisaje disponible a la mirada que en ella puede vagar sin que se fije en puntos que dominan el cuadro ${ }^{270}$. Cuanto más compleja es la pintura de paisaje, más se activa la sensación de pérdida de orientación llevando el cuerpo y la mirada a un

\footnotetext{
${ }^{268}$ Para Erwin Straus, el momento pático es el momento en que el individuo se funde o se pierde con el ambiente del paisaje, construye así el espacio paisaje que es el espacio de la pura percepción de la forma y no de la descodificación de esa forma.
}

${ }^{269}$ Para Erwin Straus, la mayor parte de los ejemplos del arte del paisaje, por ejemplo la mayoría de las pinturas de paisaje, no presentan espacios paisaje, sino que apuntan a las características de un determinado lugar o la vista morfológica de ese lugar. Por lo tanto, no nos producen empatía ni nos hacen perder durante el tiempo de observación. Cuando así sucede, se desarrolla lo que el autor designa como momento gnóstico, que corresponde a una incapacidad de la obra en afectar profundamente el cuerpo y las sensaciones, esto porque el arte se dedicó más a las causas del espíritu y del conocimiento abstracto.

${ }^{270}$ En Sobre El Dibujo, John Berger nos ayuda a entender el carácter errante de esta pintura de Johannes Vermeer. La explicación de la persistencia errante y paisajística de la mirada ante esta pintura reside no en el hecho de representar un paisaje, sino de ser una pintura acometida microscópicamente; es porque la pintura exhibe una gran densidad por milímetro cuadrado, que nosotros la observamos lentamente no como imagen acabada, sino como imagen que está siendo hecha continuamente por cada uno de nosotros. «La vista de Delf de Johannes Vermeer a través del canal muestra esto como no podrá hacerlo nunca una explicación teórica. El momento pintado ha permanecido (casi) inalterable durante tres siglos. Los reflejos en el agua no se han movido. Y, sin embargo, este momento pintado, cuando lo miramos, ofrece una plenitud y una realidad que solo experimentamos en raras ocasiones durante la vida. Experimentamos como absolutamente momentáneo todo lo que vemos en la pintura. Al mismo tiempo, la experiencia puede repetirse al día siguiente o diez años después. Sería ingenuo pensar que esto tiene algo que ver con la precisión: Delft no se pareció en ningún momento a esta pintura. Tiene que ver con la densidad por milímetro cuadrado de la mirada de Vermeer, con la densidad por milímetro cuadrado de momentos reunidos.» BERGER, John, Sobre el Dibujo, Trad. de Pilar Vázquez, Barcelona, Editorial Gustavo Gili, 2011, p. 57. 
movimiento constante próximo de la sensación de estar perdidos. "El paisaje es invisible porque cuanto más entramos en ella, más nos perdemos. Para permanecer inmersos en el paisaje tenemos que sacrificar, lo más posible, todas las definiciones temporales espaciales y objetivas. (...) En el paisaje dejamos de ser seres históricos, seres que no se pueden reconocer a sí mismos como objeto de una experiencia. Soñamos despiertos de ojos bien abiertos, estamos más allá del mundo objetivo y de nosotros mismos" ${ }^{271}$. Según Henry Maldiney, E. Straus tiene la virtud de desplazar al individuo de la rigidez de la cultura hacia el espacio universal del sentir, su roce; es esta apología de la fenomenología del sentir lo que hace el sujeto participante porque adhiere a la virtualidad de la obra, a la sensación y, por lo tanto, construye una fenomenología del espacio y del tiempo.

Straus expresó su preferencia por la pintura de Vermeer y Guardi, pero nos deja una pista importante para que usemos su argumento a propósito de la obra La forêt de Giacometti, ya que, según Straus, "influenciados por la pintura, estamos habituados a pensar en un paisaje como cualquier cosa que está delineado." ${ }^{272}$ Straus está hablando de todas las pinturas de paisaje sistematizadas a partir de la perspectiva renacentista o que insisten en mostrar contornos bien definidos. H. Maldiney ${ }^{273}$, partiendo de los estudios de Straus, añade otros artistas importantes y que realizaron el espacio paisaje: Paul Klee y Cézanne. El primero por realizar obras que obedecen a su noción de «forma en formación», Gestaltung, que se caracteriza por una autonomía de la forma que se genera continuamente a partir del conocimiento de los ritmos generatrices de las formas en su relación sinóptica con las ya inscritas en el soporte, y Cézanne por el espacio errante que crea en su pintura; un espacio que, no siendo dominado por el contorno, no se torna descriptivo de un paisaje, es la pintura ella

\footnotetext{
271 "Landscape is invisible, because the more we absorb it, the more we lose ourselves in it. To be fully in the landscape we must sacrifice, as far as possible, all temporal, spatial and objective precision. (...) In the landscape we cease to be historical beings, i,e., beings objectifiable to themselves. We are dreaming in broad daylight with our eyes open. We are beyond the reach of both the objective world and ourselves". STRAUS, Erwin, The Primary Word of Senses, Londres, The Free Press of Glencoe. 1963, p. 332.

${ }^{272}$ Idem, p. 317. "Influenced by the art of painting we are inclined to think of landscape as something already delineated."

${ }^{273}$ MALDINEY, Henri, "Le Dévoilement de la Dimension Estetique dans la Phenomenologie d'Erwin Straus". Regard, Parole, Espace. París, L'Age d'Homme, 1994.
} 
misma un paisaje, ya que las pinceladas y los contornos forman discontinuidades, no hay color local, ni perspectiva jerarquizada de líneas, colores o atmósfera. De esta forma, la lógica de la sensación es desencadenada por el vagabundeo y la pintura, ya se trate de un paisaje o de una naturaleza muerta, es dotada del espacio paisaje.

Claramente influenciado por E. Strauss, Merleau-Ponty explicita en La duda de Cézanne la cuestión del contorno tal como se planteó a los artistas modernos, y cuya concepción puede ser aplicada en toda su extensión al trabajo de A. Giacometti.

El Contorno de los objetos, concebido como una línea que los delimita, no pertenece al mundo visible, sino a la geometría. Si marcamos con un trazo el contorno de una manzana, hacemos de ella una cosa, cuando es el límite ideal en cuya dirección los lados de la manzana huyen en profundidad. No marcar ningún contorno sería retirar de sus objetos su identidad. Marcar uno sólo sería sacrificar la profundidad, esto es, la dimensión que nos ofrece la cosa, no como expuesta adelante de nosotros, sino como llena de reservas y como una realidad inagotable. ${ }^{274}$

Para Merleau-Ponty, el contorno simple es responsable de conferir identidad a las cosas, aprisionándolas en formas rígidas, o, en el lenguaje de Straus, el responsable de retirar de los paisajes pintados el espacio paisaje. Sin embargo, cuando estamos ante una profusión de contornos o contornos interrumpidos, como en el caso de la obra de Cézanne y también de Giacometti, la obra de arte se adensa y adquiere el sentido de la profundidad pues, a través de este recurso, la figura, la cabeza o el paisaje que es dibujado o esculpido acaba por expresar una figuración realizada por entrelazamientos constantes de todas las posibilidades de fusión entre figura y espacio. Toda figura o paisaje adquiere así definiciones reales e imaginarias, la escultura se tornará superficie maleable por la mirada que la recorre.

Ya vimos cómo el busto marca la posición de La forêt, confiriendo a este paisaje escultórico la perspectiva a partir de la cual debe ser observada. Eso nos

\footnotetext{
${ }^{274}$ MERLEAU-PONTY, Maurice, O espírito e o olho: seguido de $A$ linguagem indirecta e as Vozes do Silêncio e A Dúvida de Cézanne. Trad. de Paulo Neves y Maria Ermantina Galvão Gomes, São Paulo, Cosac Naify, 2004, p. 130.
} 
llevaría a pensar que ese punto funcionaba en la escultura como punto de mayor intensidad al ser considerada la escultura en su todo. Pero no nos olvidemos que Max Reithman nota que parece no haber una perspectiva común entre las figuras de la primera línea y las del fondo -y en esa medida todos los criterios sincrónicos, que según él garantizan un continuo espacial, quedan abolidos. Podemos por tanto afirmar que la noción de espacio paisaje tal como fue formulado por E. Straus es válida para La forêt.

Para J. Marc Besse, siguiendo la lectura de E. Straus, la buena pintura de paisaje no se limita a lo que vemos, haciendo visible lo invisible como algo sustraído y distanciado. "La pintura de paisaje auténtica es la que expresa este exceso: el paisaje no es saber" ${ }^{275}$ Para $\mathrm{H}$. Maldiney, ese tornar visible lo invisible se encuentra en Cézanne, en sus facetas de color no miméticas sino errantes, tal como A. Giacometti afirmaba: "sólo sé lo que estoy haciendo cuando estoy trabajando". O sea, este artista ya contiene en su propio proceso de trabajo el sentido de la desorientación. Para que el paisaje acontezca, tenemos que soñar despiertos. "Somos sustraídos del mundo y también de nosotros mismos, es el sentir. ${ }^{276}$ Esta sustracción del mundo y de nosotros mismos es, en cierto sentido, lo que hace a Giacometti abstraerse por completo de la presencia empírica y social del modelo James Lord $^{277}$ y le hace entrar en una dimensión psicológica más profunda. Durante ese proceso, que es sobre todo mental, queda un registro en pintura altamente dinámico porque ésta no se encuentra diferenciada entre figura/fondo, sino no diferenciada; o sea, fondo y figura comunican y se mezclan, de la misma forma que la erosión de las figuras de La forêt abre un espacio entre ellas como si de un desierto se tratase. De aquí en adelante veremos como $\mathrm{La}$ forêt es más deudora de un pensamiento pictórico que escultórico.

En La forêt, el busto marca el punto a partir del cual la escultura debe ser vista. A partir de esta constatación, puede pensarse en la idea de que una vista

\footnotetext{
${ }^{275}$ BESSE, Jean-Marc, Ver a terra. Seis Ensaios sobre a Paisagem e a Geografia, Trad. de Vladimir Bartalini, São Paulo, Editora Perspectiva, 2006, p. 80.

${ }^{276}$ STRAUS, Erwin, Du Sens Des Sens, Grenoble, Jérome Millon, 1989, p. 519.

277 Sacado del libro: LORD, James, Retrato de Giacometti, trad. Amaya Bosal, Madrid, Machado Libros, 2005.
} 
lateral o trasera, en relación a la frontalidad del rostro, sin ser incorrecta, es cuando menos desventajosa. El busto presenta la misma situación espacial que A. Durero, en Underwyssung der Messung (1525), invocó en su esquema explicativo del funcionamiento del portillo o la cuadrícula frente al modelo. Es decir, La forêt tiene un punto definido a partir del cual debe ser observada. Ese punto se sitúa exactamente enfrente de la cabeza del busto, será ahí donde, para el artista, el bosque se constituye como imagen de extensión ilimitada; la proximidad de la mirada anula la escala real de la miniatura y le confiere una dimensión mayor muy próxima de la estrategia usada en la representación pictórica. Al colocar el busto afilado y orientado hacia adelante detrás de las figuras de la primera línea y del fondo, Giacometti sitúa el punto privilegiado del paisaje en una situación que rompe con la continuidad metafísica del espacio pero sin anular su profundidad.

Uno de los factores determinantes para la construcción de un espacio pictórico desde el Renacimiento es la localización y orientación del punto de vista a partir del cual el pintor y después el observador se deben localizar frente al espacio representado, sintetizando las posiciones y orientaciones posibles del observador frente al espacio. En La forêt, ese esquema perspectivo del Renacimiento italiano es meramente indicativo, no pudiendo su funcionamiento ser aplicado en la pieza objeto de análisis, porque en esta no se encuentra continuidad espacial entre las figuras del plano de delante y las de detrás.

Así, el busto no es punto de fuga, sino marco. El busto en La forêt parece estar fuera del paisaje del bosque, pero no tanto como el espectador que la observa. En ese sentido, el busto supone antes un marco que un punto de fuga. Si el punto de fuga no es necesario para crear paisajes, el marco es obligatorio para hacerlo. Malcom Andrews defiende que "el encuadre define literalmente el paisaje"278 en la medida en que le confiere los límites inherentes a la idea de paisaje. Así, sin marco o encuadre, no hay paisaje entendido «como vista», y el busto garantiza el encuadre junto con el límite de la base.

${ }^{278}$ ANDREWS, Malcolm, Lansdscape and Western Art, Oxford, Oxford University Press, 1999, p. 5. 
La forêt expresa una cierta condición de abandono o de ruina, la distancia entre las figuras, a pesar de objetiva, y empíricamente determinable como pequeña. Desde el punto de vista poético, hay un desierto que las separa. Fernando Castro Flórez califica el desierto como el espacio de la soledad, del despojamiento, del abismo, de la melancolía y de la inmensidad crepuscular, pero sobre todo aproxima el desierto del sentimiento de lo sublime relacionable con lo siniestro."Tal vez el sentimiento sublime trasladado desde la naturaleza al cuerpo humano obligue a considerar en un plano no catastrófico y «natural» a las tempestades o galernas y tormentas del desierto junto al dolor del parto o los últimos estertores del sujeto en el hecho de muerte."279 De hecho, las figuras femeninas o árboles de La forêt parecen ser "esos objetos duros trabajados para imitar formas de vida orgánica que han sufrido a su manera, el equivalente del cansancio, del envejecimiento, de la desgracia." ${ }^{280}$ Este envejecimiento y esta desgracia son la marca de la ruina es el único puente de contacto entre la ciudad y la naturaleza.

\section{9}

\section{La forêt, un paisaje erótico}

La forêt expresa también el vínculo erótico entre hombre y mujer que, en el contexto del trabajo de A. Giacometti, encuentra innumerables representaciones $y$ en todas ellas, excepto en la representación de la madre, la mujer es víctima de un ataque, una siniestra intromisión sexual que encuentra paralelo teórico en Bataille. Esta obra heredó sin duda del periodo surrealista la idea de sustitución de la "serena imagen del placer como principio motor del deseo de dibujar (...) por el espíritu de destrucción. Las marcas que el niño hace en las paredes, sus garabatos sobre el papel, responden a un deseo de destruir

\footnotetext{
${ }^{279}$ FLÓREZ, Fernando Castro, "Apuntes y Visiones del Desierto" in El Paisaje, Javier Maderuelo (dir.), Huesca, Arte y Naturaleza, 1996, p. 61.

${ }^{280}$ YOURCENAR, Marguerite, O Tempo Esse Grande Escultor, trad. de Helena Vaz da Silva, Lisboa, Difel, 1983, p. 49.
} 
o mutilar el soporte. (...) Bataille ve la reafirmación de un nuevo deseo de alterar e deformar lo que antecede al sujeto: (y escribe Bataille), "El arte, cuando es verdaderamente arte, procede así mediante sucesivas destrucciones. De suponer una liberación de los instintos, dichos instintos son sádicos.»"281 A partir de 1930, según R. Krauss, Giacometti pasa a entender el primitivismo como una manifestación sofisticada de los sentimientos humanos, especialmente el sadismo y el erotismo. "Hacia 1930, año de la publicación de "La Amerique disparue», [Giacometti] había girado hacia la órbita de Bataille."282

En El Crepúsculo de Paul Delvaux, cuadro pintado en 1937 (Fig. 11), se representan figuras femeninas que son mitad árbol, mitad mujer. ¿Será este el proceso por el cual las figuras de La forêt se pueden considerar, ya sea como árboles de un bosque, ya sea como transeúntes femeninos de rostros abúlicos, paralizados o petrificados de una ciudad? La escultura no está formada por mujeres árboles, sino alternadamente por árboles y por mujeres. La respuesta teórica para este tipo de representación de ideas que faz alternar a imagen da escultura entre árboles e mujeres parece estar en Jean-Paul Sartre y en sus teorías sobre lo imaginario. En L'Imagination ${ }^{283}$ (1936) y L'Imaginaire ${ }^{284}$, la imaginación es una capacidad irrealizadora, siendo por eso capaz de tornar ausente lo que está presente o de hacer lo inverso, tornando presente lo ausente. La fuerza irrealista de la imaginación es creadora y prospectiva. Por eso, para distanciar su concepción de imaginación de la de otros autores, Sartre decide llamar a su concepto de imaginación "imaginario", y es esta dimensión la que proporciona una lectura alternada de las figuras verticales de La forêt entre árbol y mujer y viceversa. Es decir, esas formas verticales crean un potencial de transformación comparable a la que se puede observar cuando, por ejemplo, un niño convierte un zapato en un coche. Cuando se hace esta operación de la imaginación, no está presente el objeto empírico zapato dotado de funcionalidad

\footnotetext{
${ }^{281}$ KRAUSS, Rosalind E., La originalidad de la Vanguardia y otros mitos modernos. Versión española de Adolfo Gómez Cedillo, Madrid, Alianza Editorial, 2002, p. 69.

282 Idem, p. 71.

${ }^{283}$ SARTRE, Jean-Paul, A Imaginação, Trad. de Manuel João Gomes, Lisboa, Difel, 2002.

${ }^{284}$ SARTRE, Jean-Paul, L'Imaginaire. Psychologie Phénoménologique de I'Imagination. París, Galimard, 1948.
} 
propia, sino la ausencia de ese objeto (zapato) a través de un sentido libertador de su función ${ }^{285}$. En esta idea de imaginario reside la explicación para que encontremos en La forêt alternadamente árboles y mujeres, construyendo la evocación de un espacio de paisaje natural de un bosque o el espacio urbano de una ciudad de atmósfera soturna, petrificante, inmóvil y desierta. La ciudad sigue allí, tiene personas, pero está desierta desde finales del siglo XIX y después durante las dos guerras mundiales y el periodo de entreguerras, cuando la ciudad dejó de ser plenamente habitada por los hombres para ser lugar de paso, vaciado; por tanto ciudad moderna y desierto se equivalen.

En el desierto cada detalle acaba siendo emblema del mundo, más allá de los espejismos, de la promesa que sostienen, aparecen las propias huellas. Escampado de la desesperación, el sujeto interioriza la arena. El que traga la piedra acaso piense que el desierto, está perdido, caminando por la ciudad esa imagen adquiere la mayor intensidad: Ciudad y Desierto (en ocasiones, ciudad desertificada, ciudad-fantasma) se suceden y simultanean en una constante que asemeja un rizoma. La ciudad, que del desierto (vale decir: de la nada), cualquiera que haya sido su fantasía de origen, deviene también, Desierto. Este será desde entonces, para aquélla, grado cero (pero simultáneamente: destino); origen (y también: final, catástrofe); génesis (y apocalipsis correspondiente). ${ }^{286}$

La aparición de las figuras femeninas como árboles que componen un paisaje, que podríamos calificar de erótico, tiene razones más profundas más allá de la noción de imaginario de Jean Paul Sartre. En varios momentos, tanto en la obra plástica, como en sus escritos, Alberto Giacometti se muestra fascinado por la belleza siniestra y simultáneamente débil de la imagen de la mujer. En muchas de sus esculturas, como en La forêt, la imagen de la mujer aparece dotando al paisaje de un erotismo femenino. Alain Roger, en su Court traité du paysage, escribe un pequeño capítulo al paisaje erótico, titulado "¿Puede ser erótico un paisaje?", donde va respondiendo a la pregunta, situando la cuestión de lo erótico en el paisaje, no en el paisaje real, in situ, sino en el paisaje que sólo se hace delante de nuestros ojos por la mediación del arte. In visu, o sea el paisaje

\footnotetext{
${ }^{285}$ Idea trabajada por Reinério Simões. SIMÕES, Reinério luiz Moreira, A Imaginação Material Segundo Gaston Bachelard, tesis de fin de máster presentada en la Universidad de Rio de Janeiro, orientación de la Prof. Marly Bulcão L. Brito. Rio de Janeiro, 1999.

${ }^{286}$ FLÓREZ, Fernando Castro, "Apuntes y Visiones del Desierto" in El Paisaje, Javier Maderuelo (dir.), Huesca, Arte y Naturaleza, 1996, p. 71.
} 
en el arte entendido "como vista». "Nuestra percepción estética de la naturaleza siempre está mediatizada por una operación artística, una 'artealización', tanto si ésta se efectúa directa como indirectamente, in situ o in visu. Ahora bien, la erotización es una variedad particularmente espectacular de la artealización paisajística. Aunque inmediatamente se presiente que, salvo excepciones (o provocación...), no podría operar in situ y que la transformación de un país (asexuado) en paisaje (erotizado) se efectúa sobre todo in visu, por mediación de la pintura, de la fotografía, de la literatura" ${ }^{287}$ y -podemos añadir nosotros- por la mediación de la escultura.

Alain Roger nota que la mirada dirigida al paisaje engendra muy fácilmente metáforas entre la configuración de la geografía del paisaje y la anatomía de la mujer. Entre los muchos artistas que se apercibieron de esta metáfora, Roger cita a Cézanne: "unir las curvas de las mujeres a las cimas de las colinas" 288 para dar cuenta de la mayor propensión para hacer equivaler relieves femeninos a los de la geografía, pero advierte que "esta reversibilidad metafórica puede producir lo peor y lo mejor. Lo peor, la vulgaridad, un paisaje de pacotilla, sexualizado a toda prisa, incluso 'sin miramientos', pero también lo mejor, una estetización sutil en la que la desnudez y el país, realidades naturales, se erotizan mutuamente para crear las figuras del arte que son el desnudo y el paisaje."289 Roger apunta a Freud como el principal responsable de una erótica generalizada, ocurrida en el arte moderno y de la cual el paisaje no quedó libre. “¿Hay que imputarle a Freud la responsabilidad de esta sexualización, a la vez ingenua y escolástica, del paisaje? Sin duda, si lo juzgamos por algunas de las indicaciones que nos da en La Interpretación de los sueños: «No es difícil reconocer que en el sueño muchos paisajes, en particular los que representan puentes o montañas con bosques, son descripciones de órganos genitales». Freud nos confirma nuestra sospecha inicial: «El órgano genital masculino

\footnotetext{
${ }^{287}$ ROGER, Alain, Breve tratado del paisaje, Traducción de Maysi Veuthey, Ed. Javier Maderuelo, Madrid, Editorial Biblioteca Nueva, 2007. p. 177.

${ }^{288}$ Idem, p. 178-179.

${ }^{289}$ Ibidem, p. 180.
} 
representado por una persona, el órgano genital femenino por un paisaje»."290 Alberto Giacometti parece haber mantenido en su trabajo de la fase que denominamos existencialista, fuertes influencias traídas del periodo surrealista, especialmente las vinculadas al psicoanálisis de Freud. En La forêt, tenemos acceso a un paisaje sexuado en lo femenino y un busto que equivale a la persona descrita por Freud. Por lo tanto, La forêt expresa perfectamente la relación propuesta por Freud entre el busto masculino y el bosque compuesto por elementos verticales femeninos. "El paisaje es, para el inconsciente, congénitamente femenino, incluso aunque, por imprudencia, algún signo fálico se aventure en él." ${ }^{291}$

A la pulsión erótica contenida en La forêt, debe juntarse la propensión humana al reposo y la inercia que también se encuentran expresos en las figuras y en el busto. En Más allá del principio del placer, obra de 1920, Freud presenta

uno de los más extraordinarios documentos de la historia de la imaginación trágica occidental. En él se formula (...) un mito del sentido de la vida que es tan amplio y metafóricamente vigoroso como los que nos llegaron de fuentes antiguas y colectivas. Según Freud, dos divinidades, dos dioses, dos poderes irresistibles gobiernan y dividen nuestro ser: el amor y la muerte, Eros y Thanatos. Su conflicto determina los ritmos de la existencia, de la procreación, de la evolución somática y psíquica. Pero al final contrariamente a todas las previsiones intuitivas e instintivas, a todas nuestras esperanzas- no es Eros, el amor, sino Thanatos quien prevalece, quien se muestra más próximo a las raíces de lo humano. Lo que nuestra especie busca, en última instancia, no es su supervivencia y perpetuación, sino el reposo, la perfecta inercia. En el programa visionario de Freud, la explosión de la vida orgánica, que condujo a la evolución humana, fue una especie de anomalía trágica, casi una exuberancia fatal. Acarreó sufrimientos incalculables y catástrofes ecológicas. Pero esta desviación entre la vida y la consciencia acabará más tarde o más temprano. Un proceso de entropía interna está en movimiento. Una gran quietud volverá a la creación a medida que la vida regrese a la condición natural de lo inorgánico. La consumación de la libido se encuentra en la muerte ${ }^{292}$.

\footnotetext{
${ }^{290}$ ROGER, Alain, Op. Cit., p. 181.

${ }^{291}$ Idem, p. 182.

${ }^{292}$ STEINER, George, Nostalgia do Absoluto, Trad. de José Gabriel Flores, Lisboa, Relógio D’ Água, 2003. pp. 32-33.
} 
Esta construcción, que Freud llamaba "metapsicología", nada tenía de científico pero puede revelarse como auténtica teoría de la imaginación, también útil para que comprendamos La forêt, así como todo el arte que se interesaba en explorar las tensiones humanas en un periodo "ensombrecido por la recurrencia de la guerra en el mundo"293.

Haciendo inventario de los paisajes eróticos y frágiles que nos interesan en el ámbito de nuestro estudio, Alain Roger cita La Nausea, de Jean-Paul Sartre (1931), y relaciona ahí lo grotesco con la idea de belleza frágil simultáneamente trágica y escatológica.

Sartre, La Nausea, la obscenidad en femenino... «Las cosas se han desembarazado de sus nombres. Están ahí, grotescas, obstinadas, gigantes y resulta imbécil llamarlas banquetas o decir cualquier cosa de ellas: estoy en medio de las cosas, las innombrables.» Sabemos que esta experiencia de la 'existencia' se repite y culmina, dos páginas después en la famosa descripción del jardín público de Bouville; pero, en mi opinión, los comentaristas no han destacado lo suficiente que esta descripción está animada desde el interior y como inseminada por una feminización universal y obscena de las Cosas: "Ese barniz se había fundido, quedaban masas monstruosas y blandas, en desorden -desnudas, con una desnudez horrible y obscena. [...] Todas las cosas se dejaban llevar por la existencia. ${ }^{294}$

\subsection{0}

\section{Teatralidad en Alberto Giacometti}

Recientemente, entre los meses de octubre de 2009 y enero de 2010, el comisario Marin Karmitz presentó en el Museu Berardo una exposición titulada "Silêncios», de la que formaban parte obras de Juan Muñoz, Alberto Giacometti, Annette Messager, Joseph Kosuth, Tadeusz Kantor, Chris Marker, Mario Merz, Bruce Nauman, Christian Boltanski, llya y Emilia Kabakov, entre otros. De

\footnotetext{
${ }^{293}$ Idem, p. 33.

${ }^{294}$ ROGER, Alain, Breve tratado del paisaje, Trad. de Maysi Veuthey, Ed. Javier Maderuelo, Madrid, Editorial Biblioteca Nueva, 2007. p. 185.
} 
Giacometti estaba expuesta precisamente la escultura objeto de nuestro estudio, La forêt. En esa exposición, estaban bien patentes la idea de espacio y paisaje en su relación con el cuerpo. Dicha pieza era además la más antigua del grupo y ocupaba el centro de la exposición, significando así que era el punto a partir del cual irradiaba esa idea del pensamiento sobre la condición del cuerpo humano en el espacio a veces de cariz paisajístico. Marin Karmitz trabajó con el arquitecto Patrick Bouchain el dibujo de la exposición, con objeto de respetar lo más posible cada una de las obras expuestas, "el resultado fue que las obras nunca aparecen unas delante de las otras, cada una de ellas dispone de su espacio personal, de «su casa». Así, cada obra está rodeada por su propio silencio"295. Las repetidas visitas a esta exposición sirvieron de inspiración para nuestro estudio, porque demostraban la pertinencia contemporánea de la obra de Alberto Giacometti, y más precisamente de una de sus esculturas más emblemáticas La forêt, pues allí esa obra encontraba el contexto que nosotros queremos darle en nuestro estudio, o sea el contexto de la producción del arte contemporáneo.

De aquí en adelante, intentaremos ejercitar nuestro espíritu interpretativo de La forêt, como de otras obras del mismo periodo, buscando comprender una de sus principales cualidades: el espacio. Como vimos, la práctica artística de Alberto Giacometti, principalmente a partir de 1935, deriva del dibujo; los múltiples contornos del dibujo así como la práctica erosiva de la rasura buscan crear una noción de espacio que haga justicia a la profundidad de los objetos y de los modelos usados. Esa búsqueda de profundidad fue más intensa a partir de 1945. A partir de esa fecha Giacometti "empezó a tener conciencia de ver los objetos y las personas como realmente los percibía, no como, por convención, creía verlos. Así fue adelgazando conscientemente las figuras" ${ }^{296}$. El espacio propiamente tridimensional de la escultura es heredero de esa búsqueda de profundidad. Por la acción de la mano y de la disciplina de la mirada, la escultura, a imagen del dibujo, exhibe su superficie inacabada; los cuerpos por ella

\footnotetext{
295 Lisboa, Colecção Berardo, Silêncios, Marin Karmitz, Éditions des Musées de la Ville de Strasbourg, 2009, p. 27.

${ }^{296}$ GARCÍA YELO, María. «El Sublime Espacio de Alberto Giacometti». Anales de Historia del Arte. Madrid: Servicio de Publicaciones de la Universidad Complutense, Facultad de Geografía e Historia. n. $-14,2004$, pp. 229-250. ttp://www.ucm.es/BUCM/revistasBUC/portal/revistas/revista.php?id=ANHA
} 
representados se encuentran sustraídos mucho más allá de lo que los soportaría como imágenes acabadas de cuerpos o rostros humanos. Como vimos, ese deliberado inacabamiento es el resultado de la búsqueda de una visión efectiva de las cosas, de sus apariencias, que pretendió transponer de la pintura a la escultura, una cierta idea de campo de visión, virtual, aunque no jerárquico sino errante, donde se sitúa la figura o conjunto de figuras rodeadas de espacio que se muestran a nosotros en tanto que "aparición de lo lejano» en perspectiva reducida.

Cada figura o conjunto de figuras, por ser constantemente sustraídas de su masa, por la acción del trabajo de la mano, crean el lugar del espacio y del vacío, como defendió Jean-Paul Sartre. Giacometti, «amasando el yeso de la plenitud, él crea la vacuidad». Como diría Rainer Maria Rilke, lo importante en el bosque o en La forêt "no son los árboles sino el espacio sublime y patético entre ellos». Un espacio que, en el caso de nuestro objeto de estudio, deriva de la transformación de una memoria de infancia en escultura, un pequeño rincón de bosque en Suiza, donde el artista conoció una fuerte experiencia de soledad.

A la soledad del niño se sucedió, muchos años después -ya artista maduro-, la expresión escultórica del abandono que tanto caracteriza a las sociedades occidentales por lo menos desde el siglo XIX, en su relación polarizada entre naturaleza y ciudad. Pero también el abandono derivado del dolor. Sería fácil esbozar un abordaje de la escultura de Giacometti a partir de los horrores de la primera y la segunda guerra mundial; dicha aproximación no es aquí objeto de nuestro estudio, que no tiene una ambición histórica, sino de afinidad con procesos de creación. En realidad, dicho abordaje comportaría varios peligros ilustrativos y finalistas que reducirían toda la complejidad del trabajo de Giacometti. Hay en las esculturas de Giacometti también una especie de «espacio para el dolor tornado melancolía». En El Dolor, Marguerite Duras escribe: "El dolor es tan grande, se asfixia, no tiene aire: el dolor necesita espacio." ${ }^{297}$ Y, más adelante, la escritora insiste en esta idea de la necesidad de

${ }^{297}$ Consultada la siguiente edición portuguesa: DURAS, Marguerite, A Dor, Trad.Tereza Coelho, Lisboa, Difel, $2^{\mathrm{a}}$ ed., 1986, p. 13. 
espacio vacío para el suplicio: "aún preciso de espacio vacío para el suplicio."298 Conviene recordar que este libro fue escrito cuando su marido volvió de un campo de concentración. La escritora revela que, después de haber escrito el libro, pasaron varios años sin que volviera a acordarse de él; cuando más tarde recuperó el manuscrito acabó por leerlo como si fuera obra de otra persona: las palabras parecían no pertenecerle precisamente porque la situación del cuerpo de su marido se situaba fuera de lo que es representable. Evidentemente, aquí existe una referencia muy densa sobre el límite de lo humano y del terror que representa un cuerpo en disolución.

Siguiendo en la determinación de las cualidades espaciales de la escultura de Giacometti, Oscar González nos dice que "hay extinción de la forma y extensión de lo escriturable por la escultura. $Y$ en él, la escultura como es escritura es también, con la misma intensión teatro. Es la escultura de Giacometti una escultura teatral." ${ }^{299}$ Veremos cómo el trabajo resultante de la creación de una cierta distancia entre la presencia de las figuras de la escultura y el observador va a implicar una atención al espacio virtual derivado de un campo visual expreso en miniatura. Una vez llegado a este punto, el gesto de Alberto Giacometti se reveló, como defiende R. Krauss, fundamental para inserir en la práctica escultórica la idea de espacio, en una transición y continuidad lógica en dirección al espacio real disponible para el uso público y de convivialidad que naturalmente se manifestará en intervenciones de carácter escultórico, como ambientes o instalaciones realizadas en una escala $1 / 1$.

Como vimos, al trabajar a partir de la memoria, Alberto Giacometti veía cómo, contra su voluntad, sus esculturas se reducían, hasta convertirse en miniaturas. "(...) que una de las primeras estatuas que hizo, una estatua que al principio tenía un tamaño bastante grande, se fue reduciendo a medida que la iba trabajando hasta llegar a una dimensión que era la suya." ${ }^{300}$ Esta disminución

\footnotetext{
298 Idem, pp. 15-16.

${ }^{299}$ GONZÁLEZ, Oscar, “Alberto Giacometti: un Escultor». Revista de Cultura (Fortaleza, São Paulo). n. ${ }^{\circ}$ 24, mayo de 2002. http:www.revista.agulha.nom.br/aq24giacometti.htm.p

${ }^{300}$ GIACOMETTI, Alberto, Escritos de Alberto Giacometti, Trad. Castellana de Miguel Etayo y José Luis Sánchez Silva, Madrid, Editorial Síntesis, 2001, p. 287.
} 
buscaba un ajuste a un cierto modelo de «aparición» de las imágenes que aparecían siempre de forma reducida. "Me encontraba ante la necesidad de reducirla a una dimensión minúscula, que de hecho me sorprendía, me aterraba y hubiese querido evitar..." ${ }^{301}$ Detrás de esta operación subyace, además del ajuste subjetivo de la escala, una apetencia por ciertas esculturas minúsculas del pasado. "Me daba cuenta de que todas las esculturas del pasado que me emocionaban eran, como por causalidad, ¡je esa misma dimensión!...en fin, más bien minúsculas..." ${ }^{302}$ Entre las esculturas del pasado que más impresionaron a A. Giacometti se cuentan las esculturas más económicas, que se encontraban en las tumbas del pueblo llano en el Antiguo Egipto.

Existe un pasaje del arte egipcio que es fundamental para comprender la aparición de pequeñas esculturas funerarias cuyo dispositivo es en todo idéntico al realizado por A. Giacometti. Lo que se veía en los túmulos de los funcionarios antes del Imperio Antiguo estaba representado en bajorrelieve, pero este tipo de representación empezó a plantear un problema de lectura: había detalles del espacio y de las acciones que se desarrollaban en él que acababan por ser ocultados o no podrían ser descritos en toda su integridad, debido a las limitaciones que la perspectiva frontal usada no resolvía. Entonces empezaron a hacerse estatuillas en madera, que hacían la representación más legible, en detrimento de las representaciones en bajorrelieve. Las figuras 37 y 38 documentan ambas el trabajo en el campo y demuestran claramente el paso de las representaciones bidimensionales a las tridimensionales.

En este tipo de recurso representativo tridimensional (Fig. 39), se entiende mejor lo que los hombres y las mujeres están haciendo en el interior de la casa, mucho mejor que cualquier representación bidimensional podría hacerlo. La escena representada muestra una panadería donde hombres y mujeres de cuerpos estilizados preparan el pan. Esta forma tridimensional y miniaturizada de repetir el paraíso terrestre en la vida eterna del más allá encuentra muchos otros recursos interesantes; por ejemplo, una escena de trabajo en el campo era

\footnotetext{
${ }^{301}$ Idem, p. 287.

302 Ibidem, p. 287.
} 
representada recurriendo a un esquema simple que consistía en asentar sobre una tabla de madera, generalmente cortada en un formato rectangular que servía de plano paisajístico donde después eran colocados los trabajadores ejecutando los trabajos de la siega con todos los artefactos necesarios para ello.

Este recurso descriptivo miniaturizado y tridimensional era conocido por Alberto Giacometti, quien fue calificado por muchos el más egipcio de todos los escultores del siglo XX. De hecho, a partir de la década de 1940, es frecuente que encontremos esculturas formadas por una composición de figuras apoyadas encima de finas bases rectangulares o cuadradas, como es el caso muy específico de su producción del año 1950 con sus esculturas tituladas Figurine Dans Une Boîte Entre Deux Maisons (Figura en una caja entre dos casas), (Fig. 40), Place (neuf figures) o La clairière (Lugar [Nueve Figuras] El Calvero), Composition avec trois figures et une tête, y La forêt (Fig. 24). En la primera pieza citada (Figura en una caja entre dos casas), una figura femenina cristalizada en su caminar se encuentra encerrada en una caja de formato paralelepipédico, opaca en los extremos y transparente en el medio, en formato de ventana, a partir de la cual puede ser contemplada. Esta obra se eleva sobre cuatro pies, que elevan la figura destacándola de la base o plinto donde está colocada, funcionando como una especie de relicario o palco, donde se denota una cierta presencia de lo "sagrado, cuyo significado, como sugiere Reinhold Hohl, podría ser «un símbolo del paso de la vida a la muerte, como lo representaron los egipcios" ${ }^{303}$. Esta escultura fue motivada por una fotografía de prensa publicada en los periódicos de 1945, que mostraba una mujer desnuda pasando de una casa a otra en un campo de concentración. El efecto teatral de la pieza se apoya en una concepción y ejecución atenta al binomio. "Tamaño real y escala potencial se combinan en la memoria, y en el recuerdo de la visión, se definen, delimitan como un universo propio de formas e ideas." ${ }^{304}$ La caja donde se mueve la figura utiliza el mismo tipo de recurso que las pequeñas esculturas funerarias egipcias pertenecientes al periodo del imperio antiguo. Las figuras

\footnotetext{
${ }^{303}$ Barcelona, Fundació Caixa Catalunya, Giacometti, Jean-Louis Prat, catálogo de la exposición celebrada de 7 de marzo a 28 de mayo de 2000, p. 106.

${ }^{304}$ Madrid, Museo Nacional Centro de Arte Reina Sofía, Alberto Giacometti, Kosme María de Barañano, Marianne Adelmann, Lunwerg Editores, 1990. p. 472.
} 
condensan la escala, sitúan un determinado tipo de espacio y le dan un límite y una dimensión de intimidad que facilita la adhesión, pues torna más fácil la virtualización del espacio.

En las restantes esculturas, Place (neuf figures) o La clairière (1950), Composition avec trois figures et une tête (1950) y La forêt (1950), la sugerencia de movimiento de las figuras ya no existe; la base de la escultura se convierte entonces en escenario para lo mirada parada, quieta, del tiempo de la espera tan característico del teatro de Samuel Beckett, ${ }^{305}$ amigo de Giacometti.

Las esculturas de Giacometti, por el uso de la jaula o de la base que se configura como palco, aumentan la calidad ilusoria de la obra, y ese hecho, según James Lord, aproxima la obra del efecto de vida ${ }^{306}$. A veces, ese límite rectangular o cuadrado de la base aparece como marco, "frame", paisaje. Otras veces, se presenta deliberadamente como escenario para las figuras que adquieren acción en un plano virtual da escultura, como es el caso de trois hommes qui marchent (1948). En otros casos además vemos transformarse en escenario fragmentos significativos del abandono que caracteriza la ciudad moderna, como la calle. En Homme qui marche sous la pluie (1948), vemos transformarse en arte el día a día de la vida de las personas en una ciudad donde los habitantes viven sin establecer cualquier tipo de relación, la ciudad es vivida como cualquier cosa vacía, impersonal.

La estrategia de confinamiento teatral del espacio encontrado en la obra escultórica de Alberto Giacometti no se manifiesta sólo en el periodo de trabajo que va desde 1935 hasta 1966, el año de su muerte. Ya en el periodo surrealista encontramos esa dimensión, expresada, por ejemplo, en La boule suspendue, (1930-31), constituida por tres elementos envueltos por una jaula abierta

con una plataforma en su interior, sobre la que reposa una cuña en forma de media luna y una bola con una hendidura en forma de cuña en su parte inferior, este

\footnotetext{
${ }^{305}$ La obra de teatro de Samuel Beckett titulada Esperando a Godot fue escrita en 1948 y publicada en 1952. Un año más tarde fue estrenada en el Théâtre de Babylone, dirigida por Roger Blin. Se trata de una de las obras de este autor que mejor expresa las modulaciones características del tiempo de espera. BECKETT, Samuel, $\grave{A}$ espera de Godot, trad. de José Maria Vieira Mendes, Lisboa, Cotovia, 2001.

${ }^{306}$ MOULIN, Joëlle. L'autoportrait au XXe Siècle. París: Adam Biro, 1999. p. 48.
} 
último elemento pendiendo de una barra en lo alto de la jaula. El movimiento pendular de la bola y la relación de la hendidura con la media luna sugiere el posible roce de una forma por la otra -una posibilidad frustrada por el hecho de que el hilo que sostiene la forma esférica es demasiado corto para que los dos elementos de la obra efectivamente se toquen. ${ }^{307}$

Este objeto escultórico tiene evidentemente una carga erótica explícita. El movimiento pendular de la bola es real y concreto, por tanto no ilusorio. "Como el movimiento en la bola suspendida es real, el vehículo temporal en que se produce es, de forma correspondiente, literal” ${ }^{308}$ y también teatral, pues el movimiento de oscilación activa una oposición "binaria, con los dos sexos, masculino y femenino, yuxtapuestos y contrastados (...) cada elemento puede interpretar-se alternativamente como símbolo del sexo femenino y masculino (...) en una lectura de la obra, la identificación de cada forma solo es posible en oposición a su compañera; y las lecturas circulan a través de un teatro siempre cambiante de relaciones en el que se suceden cíclicamente las afirmaciones metafóricas de carácter heterosexual y las que remiten a la sexualidad transgresiva: masturbatoria, homosexual, sádica."309

Las piezas del periodo surrealista como La boule suspendue (Bola en suspensión, 1930-31), On Ne Joue Plus (Fin de juego, 1932), Homme, femme et enfant (Hombre, mujer y niño, 1931) y Le Circuit (El circuito, 1931) tratan de espacios escultóricos que articulan el tiempo de la experiencia a través de la sugerencia o participación en el movimiento literal de la(s) parte(s) móvil(es) de cada una de esas esculturas. "Tal recurso al movimiento real y al tiempo literal es una función del significado de la surrealidad, que tiene lugar a lo largo y dentro del mundo en sentido amplio, compartiendo las condiciones temporales de ese

\footnotetext{
${ }^{307}$ KRAUSS, Rosalind E., Caminhos da Escultura Moderna, Traducción Julio Fischer, São Paulo, Martins Fontes, 2001, p. 137.

${ }^{308}$ Idem, p. 137.

${ }^{309}$ KRAUSS, Rosalind E., La originalidad de la Vanguardia y otros mitos modernos, Versión española de: Adolfo Gómez Cedillo, Madrid, Alianza Editorial, 2002, p. 77.
} 
mundo, pero siendo moldeada por una necesidad interior." ${ }^{310}$ Estas esculturas son espacios reales que permiten la experiencia del tiempo literal.

En el caso de La boule suspendue, el volumen cúbico de la jaula coloca el objeto en una situación ambivalente "del espacio del mundo, en el sentido de que, al mismo tiempo que su movimiento es obviamente literal, su lugar en el mundo está confinado al escenario especial de una jaula: está aislado de las cosas que están a su alrededor. La jaula funciona, por tanto, para proclamar el carácter especial de su situación, para transformarla en una especie de burbuja de cristal impenetrable flotando en el reservatorio espacial del mundo real. Al formar parte del espacio real y, no obstante, ser de alguna forma ajenos a éste, la bola suspendida y la media luna buscan abrir una fisura en la superficie continua de la realidad" ${ }^{311}$. Las obras Bola en suspensión, Fin de juego, Hombre, mujer y niño y El circuito son esculturas que ensayan "una experiencia que a veces tenemos en la vida despierta, una experiencia de discontinuidad entre diferentes fragmentos del mundo." ${ }^{312}$ Esta fisura en la superficie de la realidad es, al final, la tentativa de materializar en escultura el sueño despierto, "un fragmento de espacio real alterado, pues es creado por el deseo de quien sueña pero se presenta simultáneamente a este como independiente de su voluntad, algo con lo que él tan sólo se da cuenta por casualidad. Esa es la razón por la que Giacometti se refería a sus trabajos como «proyecciones» que anhelaba ver materializadas -en el mundo objetivo- pero que no pretendía fabricar personalmente. Así, los confina a un pequeño palco separado y que les es propio, incluso cuando busca garantizar que parecerán continuos al espacio de lo real. ${ }^{313}$ El tablero presente en las esculturas citadas evoca, tal como vimos ya en relación a "La forêt", "un extraño paisaje separado de la realidad continua, en que las relaciones de causa efecto están implícitamente suspendidas" 314 .

\footnotetext{
${ }^{310}$ KRAUSS, Rosalind E., Caminhos da Escultura Moderna, Trad. de Julio Fischer, São Paulo, Martins Fontes, 2001, p. 138.

${ }^{311}$ Idem, p. 138.

312 Ibidem.

${ }^{313}$ Ibidem, p. 142.

${ }^{314}$ Ibidem, p. 144.
} 
Giacometti quería aumentar la escala de sus esculturas para que el espectador pudiera circular dentro de ellas como en un escenario de teatro. "Lo que dio durante aquellos años (aproximadamente 32-34), objetos que iban en direcciones bastante diferentes entre sí, una especie de paisaje -una cabeza caída en el suelo, una mujer estrangulada, con la vena yugular cortada; construcción de un palacio con un esqueleto de pájaro y una columna espinal en una jaula y una mujer en el otro extremo ${ }^{315}$. Un modelo para una gran escultura de jardín, yo quería que las personas pudieran caminar sobre la escultura, sentarse en ella, inclinarse sobre ella." ${ }^{316}$

\subsection{1}

\section{Alberto Giacometti, constructor de islas}

En las piezas de Alberto Giacometti posteriores a 1935, encontramos siempre un resto de plinto o base agarrada a sus esculturas y que aparece bajo varias formas, como masa geometrizada que soporta un busto, una pequeña estatuilla, una cabeza, un hombre que camina, un conjunto de figuras o un bosque. Tendremos que indagar sobre la necesidad de estas bases, algunas de ellas vestigiales, porque en ellas parece estar la clave para una aproximación al espacio y al carácter paisajista de este.

La base vestigial en la época de trabajo considerada varía mucho su espesor y escala, ya se trate de una escultura miniaturizada o de una escultura que represente un cuerpo en una escala un poco mayor que la humana, o incluso cuando sirve de placa o palco para situar un conjunto de figuras miniaturizadas dispuestas sobre un plano. En el caso de los pequeños bustos, la masa de la base agregada a la escultura es ella misma también escultura. En Petite buste de

\footnotetext{
${ }^{315}$ En este pasaje Giacometti se refiere respectivamente a las esculturas Femme égorgée (Mujer degollada, 1932), y Le Palais à 4 heures du matin (El palacio a las cuatro de la mañana), ambas pertenecientes al Museo de Arte Moderno de Nueva York.

${ }^{316}$ Giacometti Alberto, "Alberto Giacometti, Carta a Pierre Matisse" in, Teorias da Arte Moderna, São Paulo, Martins Fontes, 1999, p. 610.
} 
Silvio sur double socle (Pequeño busto de Silvio sobre doble pedestal, 1942-43), la base semeja duplicada, acentuando el carácter precioso y sagrado del busto, al mismo tiempo que lo aísla del mundo y expresa la distancia. En Femme au chariot (Mujer en un carro, 1942-43), Giacometti coloca la estatuilla de una mujer elevada por una masa en forma de plinto paralelepipédico, y soportando el conjunto un pequeño carro de madera que recrea la posibilidad de que la escultura pueda ser transportable, pero paradójicamente estática. En la serie de esculturas tituladas Homme qui marche, encontramos figuras humanas solas en una escala muy próxima a la humana, en las cuales la masa cargada de los pies se une a la masa cada vez más restringida de la base. En la versión de Homme qui marche, de 1947, reconocemos una espesura de la base que en la versión de 1960, fotografiada por Ernst Scheidegger, ya no existe con tanta presencia. En Trois hommes qui marchent (1948), como en Composition avec trois figures et une tête (1950), la base asume la forma de un plano con connotación deliberadamente paisajista.

Rosalind Krauss identifica el trabajo de Giacometti como uno de los responsables de la problematización de la base, haciendo que progresivamente desaparezca de las opciones estéticas de los principales escultores de la primera mitad del siglo XX. Pero si este artista cuestionó el papel de la base o plinto en la escultura, la verdad es que no dejó de usarla. La base está presente de una forma vestigial o residual, lo que nos lleva a pensar que no desapareció por un mero constreñimiento disciplinar o de estilo. Quien como él ya había ido tan lejos en la reducción del papel de la base, podría ir aún más lejos y retirarla completamente. Eso no sucedió porque en el seno de la obra escultórica de Alberto Giacometti -y sobre todo a partir de 1935-, la base cumple una función expresiva importante.

Al observar una escultura completada por su base, podemos hacer una analogía col la condición moderna del artista como alguien que se encuentra aislado y tiene constantemente que hacer prueba de su resistencia y creencia. Pero no es esa metáfora lo que nos interesa. La base es un recurso expresivo 
que transforma cada escultura en una isla ${ }^{317}$; es decir, en la expresión de la insularidad. La base torna el espacio del espectador en un espacio liso. ${ }^{318}$ También acentúa el espacio generado por el cuerpo de la escultura propiamente dicha. En suma, instaura una dinámica espacio-temporal propia distinta de la ordinaria del día a día.

El «espacio insular», instaurado por el cuerpo escultórico asentado sobre la base, potencia dos movimientos antagónicos aunque inseparables, y que deben ser siempre considerados a partir de los límites de la escultura. Por un lado, el movimiento de fuera del cuerpo escultórico hacia dentro y, por otro, el movimiento de dentro del cuerpo escultórico hacia fuera. Estos dos movimientos construyen la dinámica espacial y expresiva de la escultura.

La noción de isla en las esculturas de Giacometti es más fuerte en las esculturas más pequeñas; esas miniaturas adensan las intensidades en la inversa proporción de la reducción de escala. Gaston Bachelard, en la «poética do espacio» piensa las miniaturas como "objetos falsos» porque no respetan su escala real, pero aún así las miniaturas son objetos "provistos de una objetividad verdadera." ${ }^{319}$ Es también el lugar de evasión, de quien quiere salir del espaciotiempo ordinario a través de la imaginación. "¡Cuántas veces el poeta pintor, en su cárcel, no excavó las paredes con un túnel! ¡Cuántas veces, pintando su sueño, no se evadió por una grieta de la pared! Para salir de la cárcel, todos los medios son buenos." ${ }^{320}$ El espacio-tiempo ordinario es una cárcel, y Alberto Giacometti lo sabía bien, por eso como artista, al crear pequeñas esculturas archipiélagos, está dando a cada escultura la dimensión del mundo. "Con esos

\footnotetext{
${ }^{317}$ En la carta enviada a Pierre Matisse, Giacometti declara que: «el pedestal de la figurilla (...) independiente es para mí una barca", portando análogamente y tal como en una isla, la escultura es algo aislado sobre el océano. GIACOMETTI, Alberto, Escritos de Alberto Giacometti, Trad. al castellano de Miguel Etayo y José Luis Sánchez Silva, Madrid, Editorial Síntesis, 2001, p. 94.

${ }^{318}$ Espacio liso en este contexto debe ser entendido por analogía con la imagen del mar. Si la base es una isla, entonces el espacio de relación del espectador con la obra es el espacio del plano liso del mar, esto es, un espacio sin forma y uniforme. Para Deleuze y Guattari el espacio liso es un espacio nómada, del andar, tiene el potencial de ser infinito y de no poseer referencias, así tanto el mar como el desierto son ejemplos en el paisaje de espacios lisos. DELEUZE, Gilles y Guattari, Félix, Mil Platôs Capitalismo e Esquizofrenia, trad. de Ana Lúcia de Oliveira, vol 5., São Paulo, Editora 34, 1997.

${ }^{319}$ BACHELARD, Gaston, A Poética do Espaço, Trad. António Pádua Danesi, São Paulo, Martins Fontes, 2000, p. 157.

${ }^{320}$ Idem, p. 159.
} 
formatos pequeños Giacometti consigue una especial intensificación de la relación humana con el espacio, hace así conscientes las distancias espaciales, y reafirma los elementos plásticos -a pesar de su reducida grandeza- como tales; es decir, a partir de la reducción fenomenológica (lo que predicó E. Husserl y tradujo al Francés Merleau Ponty) la experiencia vivida, la maximalización exprimida en lo mínimo. Esas pequeñas figuritas sólo necesitan, como la aguja de un pickup que un ojo las amplifique en su conciencia." ${ }^{321}$ El espacio de cada escultura de Giacometti se asume como una ilusión tangible de la universalidad y encierra en sí un potencial de evasión. El mismo límite que aísla las esculturas también es el que ofrece la ampliación de horizontes, los paisajes se hacen virtualmente interiores a cada sujeto. Por lo tanto, el límite implica y estimula el poder de imaginar del observador.

Cada escultura parece tener una dimensión espacio-temporal específica, vinculada a la permanencia, y una carga psicológica melancólica que se traduce también en un llamamiento a la reflexión. "La miniatura se extiende hasta las dimensiones de un universo. Lo grande, una vez más, está contenido en lo pequeño.“322 Por aquí, Giacometti también aproxima su trabajo escultórico a un cierto carácter de lo sublime; hay la expresión de una elevación espiritual que corresponde a un estado de excitación interior que transforma el espacio de la escultura en una temporalidad cargada de imágenes cristalizadas y de soledad. Por un lado, las esculturas parecen expresar melancolía, tristeza y retiro, por otro, miran hacia adelante, en una postura vertical. No son la imagen de la derrota, sino la expresión de dos estados de ánimo antagónicos: el recogimiento y la melancolía y, por otro, una mirada vacía que casi hace desencadenar un sentimiento que se aproxima del sublime Romántico.

Alberto Giacometti "en su juventud se sintió atraído por los escritores del Romanticismo alemán (Goethe, Hölderlin), uno de los primeros movimientos en

\footnotetext{
${ }^{321}$ Alberto Giacometti. Dibujo, escultura y pintura, K. Mª de Barañano (comisario), MNCARS, Ministerio de Cultura, Madrid, 1990, p. 444.

${ }^{322}$ BACHELARD, Gaston, Op. Cit., p. 165.
} 
interesarse por la figura del Marqués de Sade. ${ }^{323}$ Muchas son las referencias al sadismo y a una cierta preferencia por el terror que podemos encontrar en los escritos y también en la escultura de Giacometti. A la influencia de Sade debe unirse, según María García Yelo, el interés del artista por las teorías de lo sublime de Burke. "Burke vislumbró la posibilidad de obtener deleite a través del dolor real y en su texto hizo cierta concesión al sufrimiento físico" ${ }^{324}$, la misma autora defiende que "de acuerdo con la teoría burkiana de lo sublime, lo propio de la representación artística es suscitar placer y ésta es la base de la experiencia estética. Lo terrible será motivo estético si no produce efectos reales, no afecta directamente al sujeto, que es espectador y no protagonista de la situación sublime; la distancia es la condición esencial: convierte la contemplación en experiencia estética, intelectual, y anula la posibilidad de implicación." ${ }^{325}$ Si lo sublime en Kant exige una distancia segura en relación a las experiencias de desmesura o aterrorizadoras, la teoría de lo sublime de Burke exige distancia, pero la seguridad contemplativa no es tan acentuada como en Kant, o sea a partir de la teoría de lo sublime de Burke el terror afecta realmente al sujeto, aunque no haya contacto con lo terrible, es difícil que el observador sienta, por ejemplo, un paisaje terrorrífico como algo absolutamente exterior a sí mismo; o sea, es difícil ver el "paisaje como vista», como sucede en la noción de sublime kantiana. Si a este hecho sumamos la afinidad de Giacometti con las teorías del Marqués de Sade, basadas en la experiencia del terror a partir del contacto, entendemos que Giacometti es un artista que presenta una obra bisagra; es decir, el mundo como imagen deja paulatinamente de tener sentido para sí y pasa a interesarse por el mundo él mismo. A la pregunta de André Parinaud "¿A qué se llama bello?" Giacometti responde:

¿por qué una cosa nos parece bella? ¿por qué encontramos muy hermoso cierto árbol, o el cielo, o un rostro, y no banal? Hay gente que encuentra la realidad banal y vulgar, gente que piensa que las obras de arte son más bellas. Para mí la cuestión ya no

\footnotetext{
${ }^{323}$ GARCÍA YELO, María, "El Sublime Espacio de Alberto Giacometti", Anales de Historia del Arte. Madrid: Servicio de Publicaciones de la Universidad Complutense, Facultad de Geografía e Historia. N. ${ }^{14}$, 2004, pp. 229-250. http://www.ucm.es/BUCM/revistasBUC/portal/revistas/revista.php?id=ANHA 
se plantea en esos términos. Antes iba al Louvre y los cuadros o las esculturas me daban una impresión sublime... Me gustaban en la misma medida en que daban más de lo que veía de la realidad. Los encontraba bellos y mucho más bellos que la misma realidad. Hoy, cuando voy al Louvre, no puedo resistirme a mirar a las personas que contemplan las obras de arte. Lo sublime hoy, para mí, está en los rostros más que en las obras... Hasta tal punto que las últimas veces que he ido al Louvre he acabado huyendo, literalmente. Todas aquellas obras parecian tan miserables... -un enfoque bastante miserable, precario, un acercamiento balbuceante a través de los siglos, en todas las direcciones posibles, pero extremamente sumarias, primarias, ingenuas- para acotar una inmensidad formidable miraba con desesperación a las personas vivas. Comprendía que nunca nadie podría captar completamente esta vida... Esa tentativa era trágica e irrisoria. $^{326}$

Por tanto, en el museo, en vez de las obras, Giacometti prefiere los rostros vivos. Podemos decir que en su arte, y particularmente en "La forêt" como en otras obras de cariz paisajístico del mismo periodo, en vez del paisaje «como vista», el artista hace el camino de aproximación a una cierta noción de paisaje que se quiere relacionar cada vez más con el espacio concreto del espectador que observa sus esculturas.

Los rostros escultóricos parecen apuntar a nuestro espacio, nos inducen a observar un paisaje, su propio paisaje o espacio que es tendencialmente también el nuestro. En La fôret, la cabeza del busto mira el paisaje, podemos llegar a decir que, en Giacometti y durante el periodo que consideramos, todos los pequeños bustos o cabezas piden una relación de extensión con el exterior, con lo que está fuera y por lo tanto con el paisaje posible. Esa relación es en cierta forma teatral tal como sucede en el trabajo escultórico de Juan Muñoz, en la medida en que las esculturas parecen interpelarnos en nuestro espacio real. No obstante, nosotros como observadores sentimos siempre una distancia persistente e insanable que nunca es abolida conservándose de esa forma la virtualidad del espacio de las esculturas.

En La fôret, el conjunto de figuras se presenta dispuesto como en un marco o una isla. Esta miniaturización nos conduce a un mundo plástico. "La

\footnotetext{
${ }^{326}$ GIACOMETTI, Alberto, Escritos de Alberto Giacometti, Trad. al castellano de Miguel Etayo y José
} Luis Sánchez Silva, Madrid, Editorial Síntesis, 2001, p. 321. 
miniatura es un ejercicio de frescor metafísico; permite mundificar sin arriesgar mucho. ${ }_{-}$¡Y qué reposo en tal ejercicio de mundo dominado! La miniatura es cómoda, sin jamás hacer adormecer. La imaginación permanece vigilante y feliz $^{\text {"227 }}$, incluso cuando expresa la melancolía. La forêt de Giacometti se encuentra con una importante base de entendimiento y sensibilidad común. Todos nosotros ya hemos sentido alguna vez que un "prado es un bosque, y que un matorral de hierba es un pequeño bosque. En una novela de Thomas Hardy, un puñado de musgo es un bosque de abetos. ${ }^{\text {"22 }}$ Pero si nos hemos servido de las consideraciones de Gaston Bachelard sobre la miniatura, porque nos parecieron adecuadas por proceder de una reflexión surrealista también común a Giacometti, tenemos también que hacer una salvaguarda en relación al tipo de imaginación sartreana o existencialista que en el plano teórico ejerció influencia en este artista. Si para Bachelard "la imaginación no necesita confrontarse con la realidad objetiva" ${ }^{329}$, para los artistas existencialistas, y para Giacometti en particular, esa es condición fundamental. Acordémonos que para Jean-Paul Sartre lo imaginario se derivaba siempre de la transformación de un objeto o situación real u observada en la realidad; o sea, no existe imaginario sin tener como base la realidad objetiva que después era aligerada, por ejemplo por el cambio de contexto. Este aspecto de marcado vínculo de la imaginación con la realidad objetiva está expresado, como vimos, en las esculturas de Giacometti y se encuentra en formas y gradaciones diferentes tanto en el periodo surrealista como en el existencialista.

\footnotetext{
${ }^{327}$ BACHELARD, Gaston, A Poética do Espaço, Trad. de António Pádua Danesi, São Paulo, Martins Fontes, 2000, p. 168.

${ }^{328}$ Idem, p. 169.

${ }^{329}$ Ibidem, p. 160.
} 


\subsection{2}

\section{El Laberinto - Fusión de la Escultura con el Paisaje y la Arquitectura}

Aunque represente un bosque, La forêt remite a la noción de laberinto, o a la condición de espacio laberíntico. Esta obra queda razonablemente disminuida en esa propensión al ser comparada con algunas de sus piezas del periodo surrealista, que R. Krauss denominó esculturas horizontales. Esta limitación sucede porque, al presentar semejanzas obvias con el proceso de construcción de un paisaje pictórico, La forêt fija un punto de vista frontal a partir del cual la obra debe ser observada.

Según R. Krauss, las esculturas horizontales del periodo surrealista de Giacometti dan la consigna para la escultura contemporánea que estructura la noción de paisaje en torno a la idea de Laberinto, que va a conducirnos al análisis interpretativo de Una floresta para os teus sonhos, de Alberto Carneiro.

Las esculturas horizontales a las que se refiere Rosalind Krauss, en su texto titulado Se acabó el juego, fueron realizadas entre 1930 y 1933, tal como Proyecto para un paso o el Laberinto (1930-31), Circuito (1931) y Cabeza/Paisaje (1930-31). Según la autora, estas piezas inician una relación entre la escultura y el propio espacio donde se insiere. Al contrario del trabajo del periodo existencialista, que a partir de 1935 vuelve en cierto sentido a instaurar un espacio vertical que privilegia la noción de distancia contemplativa de la escultura en relación al espectador y al espacio empírico donde se encuentra.

Pero cuando la pintura sólo es su marco, esta diferenciación no resulta tan sencilla, y la representación comienza a fundirse con su entorno. Esta fue la transformación escultórica que Giacometti llevó a cabo entre 1930 y 1933. La rotación del eje sobre el plano horizontal se reafirmo ulteriormente mediante la identificación de la obra como el "rebajamiento" del objeto, mediante su unión simultanea con la tierra y con la realidad, con la veracidad del espacio y el carácter literal del movimiento en tiempo real. Desde el punto de vista de la historia de la escultura moderna, esta es la primera 
aportación artística de Giacometti, una aportación trascendental en el replanteamiento de la escultura que se produjo después de la Segunda Guerra Mundial. ${ }^{330}$

Evidentemente, Krauss está viendo en las esculturas surrealistas antes mencionadas el acontecimiento seminal que llevará a la escultura a entrar en lo que designó como campo expandido de la escultura, ya que (por ejemplo en Proyecto para un paso o el Laberinto, de 1930-31) Giacometti coloca la cuestión de la escultura en el exacto momento de intercepción de ésta con el paisaje y la arquitectura, que es precisamente la situación en la que cualquier laberinto se encuentra. "El titulo alternativo que Giacometti dio a esta obra -El laberintorefuerza la relación existente entre su idea y el universo de lo primitivo. En el pensamiento de los primeros años treinta, con su obsesión por el Minotauro, el laberinto se oponía a las connotaciones de lucidez y control espacial propias de la arquitectura clásica. En el seno del laberinto, el hombre se siente dominado, desorientado, perdido." ${ }^{331}$ Krauss denota así que la escultura de Giacometti producida entre 1930-33 da buena cuenta de la obsesión que la escultura tendrá por la noción de paso, de desorientación o borrado de las marcas que orientan al espectador en el espacio, creando así las condiciones para que el espectador participante en la obra la complete, y esto precisamente por su deambular constante. R. Krauss, en su libro titulado Caminhos da Escultura Moderna y después en sus textos Se acabó el juego y La escultura en el campo expandido, configura una teoría para el arte americano de los años 60 , que parte de la idea de que la escultura, desde $\operatorname{Rodin}^{332}$ pasando por Giacometti, siempre tuvo voluntad de fundirse con la idea de paisaje.

A continuación, daremos cuenta de cómo esta mutación en la escultura influyó en el trabajo de Alberto Carneiro, en particular en el carácter paisajista de Uma floresta para os teus sonhos que, como veremos, es contemporánea de algunos de los artistas más importantes del Land Art americano de los años $60 \mathrm{y}$ 70 , pero que en lo esencial mantiene una cierta distancia en relación a muchos

\footnotetext{
${ }^{330}$ KRAUSS, Rosalind E., La originalidad de la Vanguardia y otros mitos modernos, trad. de Adolfo Gómez Cedillo, Madrid, Alianza Editorial, 2002, p. 89.

${ }^{331}$ Idem, p. 89.

${ }^{332}$ A este respecto, ver el análisis anteriormente hecho al caso paradigmático de las puertas del infierno, de A. Rodin.
} 
de sus procesos, lo que se tradujo en propuestas bastante singulares en el contexto del arte portugués e internacional. 


\section{CAPÍTULO IV:}

\section{EL PAISAJE Y LO ESCULTÓRICO. ¿“UMA FLORESTA PARA OS TEUS SONHOS" ES UN PAISAJE?}

Creo que soñamos para no dejar nunca de ver

Goethe, Las afinidades electivas (1809)

\section{0}

\section{Notas introductorias.}

En 1970, el escultor portugués Alberto Carneiro presentaba en la galería Buchholz, en Lisboa, una escultura penetrable o un ambiente de carácter escultórico formado por doscientos troncos de madera, cortados a diferentes alturas y colocados en posición vertical, titulado Uma floresta para os teus sonhos. A partir del método interpretativo, en este capítulo intentaremos indagar sobre algunas cuestiones suscitadas por esta obra, que empieza a ser considerada una obra maestra del arte contemporáneo portugués.

Para responder a la pregunta "¿Uma floresta para os teus sonhos es un paisaje?", tendremos que movilizar de nuevo para el estudio de nuestro objeto un conjunto de cuestiones que han ido transformando la concepción de la escultura haciendo que, en este contexto, haya dejado de ser definida como un cierto número de superficies vistas desde fuera definiendo una masa, para pasar a ser algo que es vivido desde dentro, de forma que el espectador entra literalmente dentro de la propuesta escultórica, que envuelve su cuerpo y todos sus sentidos, tanto con el espacio como con los objetos que allí se encuentran. Veremos cómo esta experiencia del cuerpo que fue proyectada por Alberto Carneiro implica, en 
el contexto de Uma floresta para os teus sonhos, un cuerpo necesariamente en movimiento, construyendo así una cierta noción de espacio/paisaje que tiene consecuencias en el plano estético, pero también a nivel ético y político.

El método de la interpretación permite la creación de un campo de sentido útil tanto para el espectador, como para el artista que busca profundizar afinidades. Ningún conocimiento es directo, sino que implica necesariamente mediaciones. Se pretende que el conocimiento de un campo teórico posibilite, por ejemplo, a los creadores participar en la construcción de algo que, partiendo de la obra, tenga consecuencias que se extiendan mucho más allá de ella. El itinerario meditativo que ahora emprendemos tiene por objeto convertir la producción de sentido en lo que Ernst Gombrich denominó la "parte del espectador".

Para interpretar Uma floresta para os teus sonhos, necesitamos convocar las problemáticas planteadas por Alberto Carneiro en el plano práctico y teórico, pero también todas las otras que, aunque puedan estar ausentes de su discurso como artista, informaron por su actualidad toda la producción y el pensamiento artístico desarrollado en torno a mediados de la primera mitad del siglo XX.

Para esta etapa de nuestro itinerario meditativo que busca en cierto modo ser un ejercicio teórico orientado a profundizar una afinidad y así intentar ampliar el radio de acción y el potencial de Uma floresta para os teus sonhos, es esencial algún esclarecimiento sobre el artista y a la obra objeto de nuestra atención. En ese sentido, empezaremos por apuntar algunas notas de carácter biográfico y presentar las fases de trabajo del artista, para después avanzar hacia la idea de que en A. Carneiro se puede hablar de una autobiografía altamente vinculada a los lugares del paisaje. Una vez en el plano de la comprensión de la obra, objeto de nuestra reflexión, intentaremos hacer varias aproximaciones a la forma como se inserta en el contexto de la producción de la escultura, entendida en sentido amplio, que implicó la creación de espacios abiertos a la participación del público y que tenía en el dibujo de proyecto una importante herramienta de trabajo. Por último, nos detendremos en dos grandes núcleos de prospección teórica: uno que va a buscar entender la idea de paisaje en el objeto y otro que intenta entender cómo la dimensión paisajística de Uma 
floresta para os teus sonhos se produce por la acción de un cuerpo en desplazamiento. Ninguno de los núcleos es estanco, ni podrían serlo, pues el objeto Uma floresta para os teus sonhos sólo existe y cobra sentido en su relación con el espectador (es siempre la relación entre estos dos núcleos la que es cuestionada); simplemente, en una primera fase, pondremos la tónica en el objeto, para después hacerlo en la acción del cuerpo sobre ese objeto. Veremos, a este respecto, cómo una cierta naturaleza de espacio altamente determinado por el cuerpo en movimiento proporciona las condiciones para que la actividad motriz del andar se transforme en un acto creativo con implicaciones psicofísicas e intelectuales susceptibles de ampliar el campo de la obra de arte más allá de lo estético y en dirección a un campo de devenir ético y político.

\section{1}

\section{Breve biografía y fases de trabajo de Alberto Carneiro}

Alberto Carneiro nació el 20 de septiembre de 1937, en la parroquia de São Mamede do Coronado, municipio de Santo Tirso. Durante su adolescencia trabajó en un taller de imagineros, donde se inició en las tecnologías de la madera, la piedra y el marfil.

Se licenció en Escultura en la Escuela Superior de Bellas Artes de Oporto. Representó a Portugal en la Bienal de Venecia, en 1976, y en la Bienal de São Paulo, en 1977. Su obra ha sido objeto de numerosas exposiciones, entre ellas la gran exposición que tuvo lugar en 2001, en el CGAC (Centro Galego de Arte Contemporánea). Personalidad polifacética, fue responsable durante el periodo de 1972-85 de la orientación artística y pedagógica del Círculo de Artes Plásticas de Coimbra. Participó en numerosos congresos e impartió conferencias sobre el arte y su enseñanza. Promovió, y continúa organizando, los Simposios de Escultura en Santo Tirso, que reúnen a artistas, arquitectos y otros agentes en la implantación de esculturas en el espacio público. Paralelamente a su trabajo 
como artista, fue profesor de la asignatura de dibujo en la Facultad de Arquitectura de la Universidad de Oporto.

En la trayectoria creativa de A. Carneiro podemos identificar, a efectos de facilidad y conveniencia de lectura, tres fases de trabajo. En la primera fase, aún como alumno de la Escuela Superior de Bellas Artes de Oporto, la escultura era determinada por el trabajo de talla directo sobre la madera. Se trataba de introducir un "descubrimiento más intuitivo" o "un contacto primordial con la madera y la piedra". En esta fase, el escultor repetía un proceso configurador designado por Herbert Read como "vitalismo orgánico"; es decir, un trabajo en el que cada escultura es el resultado del diálogo entre la idea y las condiciones o características propias del material, que inducen en esa idea un camino más favorable de forma que idea y material tengan la misma importancia y donde, de algún modo, el artista se deja seducir por las condiciones propias del material, como vimos en el capítulo II a propósito del trabajo de Henry Moore.

En Macho-fêmea ("Macho-hembra”, 1965-66) (fig. 42), Alberto Carneiro intenta expresar la disolución de dualidades conceptuales, Anima y Animus de Carl Gustav Jung. No obstante, el modo como se realiza la talla denota una atención aguda a las condiciones propias de la madera: sus vetas, nudos, zonas de mayor densidad, etc., de manera que las formas son configuradas a partir de la "lógica del propio desarrollo orgánico" ${ }^{333}$ de la madera. En 1967, todavía alumno de la facultad, Alberto Carneiro fue invitado por el arquitecto Carlos Ramos para hacer una exposición de estas piezas en el salón de exposiciones de la Escuela Superior de Bellas Artes de Oporto. En la exposición no figuraba ningún trabajo sobre la figura humana, lo que motivó comentarios peyorativos por parte de algunos de sus profesores, que impartían una enseñanza academicista y poco informada sobre la realidad de la producción moderna. Según el artista,

333 KRAUSS, Rosalind E., Caminhos da Escultura Moderna, Trad. de Júlio Fischer, São Paulo, Martins Fontes, 2001, p. 303. 
se pronunciaron comentarios del estilo de: «Alberto Carneiro tiene ahí una exposición, json todo vulvas y falos! ${ }^{334}$.

A pesar de innovador, al final de la exposición, Alberto Carneiro llegó a la conclusión de que no era aquel el camino que quería seguir. De hecho, estas piezas, aunque nuevas en el ámbito de la producción escultórica en Portugal, en el contexto internacional presentaban ya un cierto desfase en cuanto a su oportunidad y actualidad, pues las primeras esculturas de Henry Moore producidas a partir de la idea de «vitalismo orgánico» databan de finales de la década de mil novecientos veinte. Tampoco debe ser ignorado el hecho de que las piezas de este primer periodo aún obedecen a la idea clásica de «juicio unitario" que posibilita al observador aprehenderla en su totalidad; o sea, se trata de piezas que se cierran sobre sí mismas, en su condición de objeto moderno, lo que, como veremos, dejará de interesar a nuestro autor durante la segunda fase de su trabajo.

Alberto Carneiro se sentía "un alumno bastante contestatario en relación al proceso académico vigente en la escuela. $Y$ después de hacer la tesis de fin de carrera, la [Fundación] Gulbenkian me concedió una beca para ir a estudiar a Saint Martin's School of Art de Londres. Allí tuve la oportunidad de depararme con una dinámica completamente diferente, que hoy es difícil de comprender teniendo en cuenta las restricciones culturales que existían en aquella época." 335 Así, en 1968, el becario Alberto Carneiro se inscribe en Saint Martins School of Art, para hacer el curso de posgrado en escultura. Entre sus profesores se cuentan Anthony Caro y Philip King, siendo contemporáneo de alumnos como Gilbert \& George y Richard Long. Allí, Alberto Carneiro pudo disfrutar de un contexto favorable para transformar radicalmente su práctica dando seguimiento a su desconfianza en relación a los éxitos que había alcanzado hasta entonces. Es evidente que, a partir de su estancia en Londres, su práctica artística se vincula a las experiencias más avanzadas que se hacían tanto en Inglaterra

\footnotetext{
${ }^{334}$ CARNEIRO, Alberto, testimonio oral transcrito de la conferencia pronunciada por el artista Alberto Carneiro, en abril de 2004 en el Auditorio de EP 1 de la ESAD. CR/ Instituto Politécnico de Leiria, invitado por los docentes Samuel Rama y Pedro Cabral Santo. (vide Anexo).

${ }^{335}$ Idem.
} 
como en Estados Unidos. Paradójicamente, su trayectoria no implica la confirmación de esas prácticas, sino su reelaboración a partir de sus propios intereses, referencias y reminiscencias, lo que hace de la obra y de los comportamientos de este artista un caso singular de actualidad e intemporalidad en el contexto del arte portugués.

De esta segunda fase de trabajo de A. Carneiro forman parte sus performances no asistidas y posteriormente convertidas en objeto artístico, pero también una serie de ambientes como O canavial: memória metamorfose de um corpo ausente, 1968 (El Cañaveral: memoria metamorfosis de un cuerpo ausente) (fig. 43), Uma floresta para os teus sonhos, 1970 (Un bosque para tus sueños) (fig. 41) y Um campo depois da colheita para deleite estético do nosso cuerpo, 1973-76 (Un campo después de la cosecha para deleite estético de nuestro cuerpo) (fig. 44). El primer ambiente está formado por cañas que tienden a ocupar todo el espacio de la sala en una orientación vertical. El segundo, Uma floresta para os teus sonhos, consta de 200 troncos de madera dispuestos en posición vertical, igualmente ocupando todo el espacio de la sala de exposiciones, el tercero, titulado Um campo depois da colheita para deleite estético do nosso cuerpo, compuesto por haces de mies de heno y centeno. Todos obedecen a un dibujo de proyecto previo y funcionan como laberintos lúdicos que invitan al espectador a participar en una experiencia corporal multisensorial.

Delfim Sardo, en su libro Obras-primas da Arte Portuguesa, defiende que los tres ambientes "componen situaciones telúricas en las cuales la presencia del campo, recreado en el espacio expositivo por la rigurosa y cuidadosa organización de elementos del ciclo de la naturaleza, producen para el espectador máquinas de viajar en el tiempo y en el espacio (...) ante estas esculturas, somos, así, eficazmente transportados a un tiempo anterior y a un lugar originario. Claro que la distribución de las piezas, de los troncos de los haces de mies o (...) de las cañas, obedece a criterios estéticos y organizativos estrictos y rigurosos, pero la sensación que tiene el espectador es la de sumergirse, por medio de un mecanismo de transporte emocional y afectivo, en una anterioridad de lo artístico, en un tiempo perdido en el cual la emoción 
estética se vinculaba a sensaciones primeras." ${ }^{336}$ Estos ambientes -0, como nos dice Deldim Sardo, estas “máquinas de viajar en el tiempo y en el espacio"- van a ser exploradas en este capítulo, usando como ejemplo Uma floresta para os teus sonhos. Pretendemos llevar a cabo una aproximación verbal y conceptual a un objeto que tiene una naturaleza plástica no totalmente traducible a un lenguaje verbal.

Para comprender mejor la naturaleza espacial y escultórica de Uma floresta para os teus sonhos, articularemos contenidos procedentes de la Historia del Arte, así como de la práctica escultórica, con objeto de comprender cómo la construcción de ambientes es heredera de las nociones espaciales más avanzadas de Giacometti, así como también de la concepción de espacio presente en la Merzbau de Kurt Schwitters, y en los Proun de El Lissitzky, que fueron revalorizados a partir de la instauración de lo que Rosalind Krauss vino a denominar La escultura en el campo expandido, donde la práctica escultórica pasó a poder trabajar, más allá del no-paisaje y la no-arquitectura, también el paisaje y la arquitectura.

Ya en el plano de la práctica individual de Alberto Carneiro, profundizaremos en cómo la negación del trabajo manual en la realización del trabajo escultórico se volvió determinante para la invención de un campo de creación que tiene tanto de actualidad internacional como local, debido al vínculo de cada obra con su biografía. A través de la auscultación de anamnesis, A. Carneiro actúa como operador estético, es decir, como un mediador entre su experiencia individual y la experiencia individual en comunidad de todos los otros que experimentan ese ambiente, como si de un teatro sin teatro ${ }^{337}$ se tratara, que obedece a la noción de extensión de McLuhan y a un dibujo de proyecto que instaura la obra de arte en un plano conceptual. Veremos también cómo la fenomenología, la crítica y la práctica y teoría de algunos artistas contemporáneos como Robert Morris nos ayudan a formular una idea de

\footnotetext{
${ }^{336}$ SARDO, Delfim, Obras-primas da Arte Portuguesa. Século XX, Artes Visuais, Lisboa, 2011. pp. 66-67.

337 "Um teatro sem teatro" fue el título de una exposición coproducida por el MACBA de Barcelona y el Museu Colecção Berardo de Lisboa, realizada en este último museo en enero de 2008.
} 
espacio/paisaje basada en la idea de un cuerpo que se encuentra en desplazamiento, insinuando el andar como práctica estética que sólo es posible, porque el cuerpo que segrega espacio puede disfrutar del vacío que rellena el espacio entre los troncos de madera. Ese vacío no es pasivo sino profundamente activo: crea las condiciones para que el espectador, a través de su andar, sueñe -en el sentido definido por Bachelard-e imagine, esto es, piense por imágenes o construya para sí mismo un mecanismo pre-cinematográfico.

La tercera y última fase del trabajo de Alberto Carneiro se inicia en los años ochenta y se prolonga hasta hoy. Desde entonces, el artista parece haber recuperado el expresionismo del trabajo en madera, o el "vitalismo orgánico" de los primeros años, pero ahora asociado a la consciencia de espacio.

Así, A. Carneiro vuelve a la tecnología de la madera, pero de una forma diferente: "la aproximación de los aspectos formales es aparente", estos son transcendidos por la "idea" después de un periodo de trece años en que rechazó las tecnologías aprehendidas por la mano. Obra emblemática de esta fase es su pieza titulada Sobre o meu jardim (Sobre mi jardín), 1998-99 (Fig. 45). "Esta obra, Sobre o meu jardim, se compone de 163 elementos que forman un círculo y fue hecha a lo largo de dos años (...) Sobre o meu jardim remite a mi propio jardín, porque tengo muchas rosas, dalias, zinnias y muchos árboles con flor y fruto. Me gusta mucho, de mañana, dar mi vuelta por la huerta, tratar o estacar lo que debe ser estacado. $Y$ mientras plantaba una plantita, venía para dentro con el sentimiento, con el sentir, con la impresión. Y traducía esa impresión, no en el sentido figurativo, ni en el sentido de reproducir la planta, sino en el sentido de producir una equivalencia de sentidos que fuera equivalente a aquel que tuve, al plantar la planta." Se trata por lo tanto de una pieza que, tal como otras de esta fase, sugiere una concepción de escultura en la continuidad del lenguaje moderno, en la medida en que el escultor aún "busca un espacio ideal que existe anteriormente a la experiencia, esperando para ser colmatado, y a un modelo psicológico según el cual el yo existe repleto de sus significados, anteriormente al contacto con su mundo." ${ }^{\text {"38 }}$ Sobre o meu jardín es entonces una escultura de

\footnotetext{
${ }^{338}$ KRAUSS, Rosalind E., Caminhos da Escultura Moderna, Traducción de Júlio Fischer, São Paulo, Martins Fontes, 2001, p. 309.
} 
base idealista, en la medida en que pretende expresar en la forma escultórica determinados sentimientos. Mientras que, en la segunda fase, esos sentimientos estaban ausentes en la materialización de los ambientes, ahora regresan; las piezas tienden a ser cerradas, expresan contenidos de un espacio psicológico particular encuadrados por la experiencia del artista. No obstante, se presentan directamente sobre el suelo y en la pared, estableciendo diálogos deliberados con el espacio del espectador cosa, que no era tan frecuente durante el trabajo de la primera fase.

\section{2}

\section{Autobiografía y paisaje}

Muchos son los análisis que tienden a correlacionar directamente el arte y la vida de un determinado artista. La biografía del artista, es decir, la descripción de los aspectos de su vida, sólo ofrece pistas útiles para una comprensión de las obras de un determinado autor cuando se realiza en el sentido más lato. En un sentido más estricto, biografía y producción artística no se confunden, llegando incluso a constituir uno de los grandes equívocos de una cierta crítica que, elaborando relaciones fáciles entre biografía y producción de un artista, llegan a formulaciones susceptibles ya sea de destruir la obra, ya de fundar una exaltación de la historia de vida, en detrimento de la consideración de la obra del artista.

En su sentido estricto, la biografía se encuentra totalmente separada de la obra. Así, en una entrevista, a la pregunta de Christiane Mennicke: “¿Cuál es la importancia de la biografía para usted?", Louise Bourgeois responde: "Están totalmente separadas" ${ }^{\prime 39}$. A lo largo de la entrevista, la artista explicita por qué la

\footnotetext{
${ }^{339}$ CHRISTIANE Mennicke: "You Have to Be Pigheaded. A Conversation with Louise Bourgeois", Feb. 1994, in: Beatrice E. Stammer et al. (Ed.): Louis Bourgeois. Intime Abstraktionen, Berlín, Akademie der Künste 2003, S.187-193, hier: 190 (Katalog).
} 
producción artística y la biografía están separadas, demostrando cómo la biografía sólo es útil al ser entendida en el sentido más profundo y amplio. Louise Bourgeois se refiere a la forma como experimenta la relación entre arte y vida, que corresponde íntegramente a la forma como se relaciona con las obras. Al preferir explicitar cómo desde punto de vista del artista se produce esa relación, el artista encara la biografía desde un punto de vista creativo y productivo. Es decir, sólo el artista nos puede dar cuenta del modo como ve y experimenta la relación entre su arte y la vida. "La verdad es que cada obra nunca es la última, esto es, la historia de la vida de un artista es su resumen" ${ }^{340}$ La vida de un artista es, en su entraña más profunda, la descripción de la sucesión de las obras de ese artista, porque la producción tiene consecuencias en el desarrollo del artista como persona. La biografía está separada de la obra porque cada obra tiene que sobrevivir más allá de la presencia del artista, más allá de su muerte o simplemente porque, si la vida del artista es la realización de una serie de obras en una sucesión continua, entonces su presencia de vida en su articulación con una determinada obra cesa en el exacto momento en que inicia otra obra.

Con frecuencia, Alberto Carneiro, tanto en sus textos como en sus comunicaciones, e incluso en documentales ${ }^{341}$, emprende la tarea de hablar o escribir sobre su obra en función de su experiencia de vida. Se trata de una acción rememorativa, creativa, que pretende buscar el contacto entre los episodios de la vida y los lugares o paisajes.

Cualquier obra de Alberto Carneiro es indisociable de los lugares que jalonan su biografía, no porque la biografía justifique la obra, sino porque "difícilmente lo que habita cerca del origen abandona el lugar.."342 Nacido y criado en el seno del

"C.M: - We have been talking about personal tradition. My next question refers to that: What do you think of the relation between artist and artwork? Are the artworks that the artist produces separable from his life? How important is biography?

LB: - Totally separated. For instance the latest work, which I did, Was this [she shows me a series of prints]. But when it's finished, and it is finished, I go to a different subject. Subjects are temporary. The artist remains, but the subjects are temporary and you go from one subject to another."

${ }^{340}$ Idem.

${ }^{341}$ Dificilmente o que habita perto da origem abandona o lugar (50', Portugal 2008), de Olga Ramos y Catarina Rosendo.

${ }^{342}$ Esta frase, sacada de la "IVā Parte da Migração" de Hölderlin, sirve de título para el documental sobre Alberto Carneiro "Dificilmente o que habita perto da origem abandona o lugar". Dirección de 
mundo rural, nada más finalizar su licenciatura en escultura, Alberto Carneiro se dio cuenta de que las materias de su trabajo residían en aquel entorno que conocía bien: el lugar donde nació y donde vivió su infancia y su adolescencia, São Mamede do Coronado, en Santo Tirso. En la conferencia pronunciada en la ESAD de Caldas de Rainha, el artista no empezó a presentar su trabajo sino después de apuntar algunos datos biográficos:

Nací en el medio rural, en una familia sin medios económicos muy sustanciales. Mis padres trabajaban, y yo, a causa de la muerte de mis dos hermanos, quedé como hijo único. Esta situación es muy importante. En el sitio donde vivía, había dos casas: la mía y la de mi amigo Zacarias, que tiene mi edad, y por eso jugábamos juntos (...) Pero también jugaba mucho solo en el patio de la casa, que era pequeñito. Debía tener unos $18 \mathrm{~m}^{2}$ y tenía una pequeña huerta. Había un gran pinar al lado de casa( que hoy no existe) y que era mi territorio (...) naturalmente no había dinero para comprar juguetes. Por aquel entonces nadie compraba juguetes. Estábamos en 1938, 39, 40 del siglo pasado, en la época de la II Guerra Mundial. No había dinero por ninguna parte, lo único que había era hambre. Así que hube de inventar todos mis juguetes con la tierra, con trozos de tallos de coles gallegas, con las cáscaras de los pinos, con las bellotas que cogía de los robles, con varias cosas que servían para inventar los juguetes, para jugar como todos los niños juegan. ¡Y en el medio rural los niños juegan inventando sus juguetes, naturalmente! ¡Y esto es importante! ¡Muy importante! ${ }^{\beta 43}$

Alberto Carneiro sitúa aquí la aparición de su esquema corporal. $^{344}$ “Jugaba, como todos los niños juegan. Era una necesidad lúdica y una necesidad natural de la construcción de mi esquema corporal. Como saben, el esquema corporal nace y es creado dentro de nosotros y se proyecta constantemente

Olga Ramos e Investigación de Catarina Rosendo. Producción: Laranja Azul, Año: 2008, Duración: 50 min.

${ }^{343}$ CARNEIRO, Alberto, testimonio oral transcrito de la conferencia pronunciada por el artista Alberto Carneiro, en abril de 2004 en el Auditorio de EP 1 de la ESAD. CR/ Instituto Politécnico de Leiria, a invitación de los docentes Samuel Rama y Pedro Cabral Santo. (En Anexo).

344 «La noción de "esquema corporal" es desarrollada en 1923 por el neurólogo austro-americano Paul Schilder y designa, en términos latos, la formación de la estructura cognitiva de un individuo a partir de un cuerpo que se mueve y que interactúa psíquica y socialmente con el medio. Como soporte de la identidad y constituyéndose progresivamente durante la infancia, el esquema corporal se forma como una imagen, o representación, que permite situar, de modo integrado, nuestro cuerpo en el tiempo y en el espacio, es decir, nos permite formar una conciencia de nosotros mismos.» ROSENDO, Catarina - Alberto Carneiro. Os primeiros anos (1963-1975). Lisboa, Edições ColibriIHA/EAC, 2007, p. 74. 
hacia fuera, siempre que tenemos que confrontarnos con el mundo exterior. ¡Naturalmente mi imagen tiene esos índices muy fuertes, muy marcados!”. ${ }^{345}$

Esta narrativa autobiográfica está al servicio de la ilustración de su proceso creativo, al mismo tiempo que relata la relación del cuerpo con el paisaje rural, con las cosas de la naturaleza, de su cuerpo, simultáneamente como creador y gozador del mundo y de sus propias creaciones. "Considero que todo mi trabajo, toda mi obra, esto es, desde el principio hasta ahora, es portador de significado y experiencia mirando ahora hacia un itinerario y hacia sus transformaciones sucesivas." ${ }^{346}$ Naturaleza y cultura son trabajadas por la escultura por Alberto Carneiro con una profunda noción de la relación del ser humano en la historia en general y con su historia existencial en particular. "La naturaleza sueña en mis ojos desde la infancia. ¿Cuántas veces no me quedé dormido entre las hierbas? Mi primera casa fue encima de un cerezo que hoy es una escultura. Entre mi cuerpo y la tierra hubo siempre una identidad profunda. El bosque o la montaña que trabajo en un tronco de árbol o en un bloque de

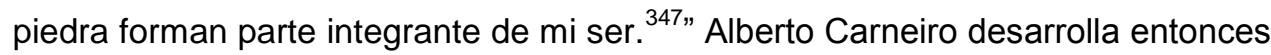
una narrativa personal de fuerte interdependencia entre naturaleza y arte, o entre la vida y el arte, o «Vidarte», una unción entre la vida y el arte a la que no es ajena la concepción de arte de Joseph Beuys, ya anteriormente presentada.

De esta forma, Alberto Carneiro realiza constantemente una cierta idea de paisaje como autobiografía ${ }^{348}$, que reviste la mayor importancia para que

\footnotetext{
${ }^{345}$ CARNEIRO, Alberto, testimonio oral transcrito de la conferencia pronunciada por el artista Alberto Carneiro, en abril de 2004 en el Auditorio de EP 1 de la ESAD. CR/ Instituto Politécnico de Leiria, a invitación de los docentes Samuel Rama y Pedro Cabral Santo. (En Anexo).

${ }^{346}$ Idem.

${ }^{347}$ CARNEIRO, Alberto, Das Notas Para Um Diário, (5 de Maio de 1965).

${ }^{348}$ En Goethe: El paisaje como imagen, Javier Arnaldo expone un tipo de relación autobiográfica de Goethe con el paisaje que puede ser útil para comprender mejor la relación que Alberto Carneiro también establece con los lugares y los paisajes, en la medida en que, tanto para Goethe como para A. Carneiro, cada paisaje es un pretexto para construir una determinada idea de auto-representación. "Las primeras composiciones de Goethe afines al modelo del paisaje ideal se produjeron, de hecho, durante su estancia en Italia, como, pongamos por caso, el estupendo apunte Paisaje costero con edificios y Bahía iluminada por la luna llena, ambos de 1987. (...) El paisajismo de Goethe se mueve y se crece entre los polos de la tipicidad y el afecto por la vida particular de la naturaleza (...) Un testimonio sobradamente elocuente de esa circunstancia nos lo ofrece la obra tardía del Goethe paisajista, que tiene una fuerte motivación autobiográfica, se presenta en series e busca, en consecuencia, un orden estructural para sus dibujos." Arnaldo, Javier, "Goethe: El paisaje como imagen" in GOETHE, Johann Wolfgang Von.- Catálogo de la exposición Johann Wolfgang Von
} 
comprendamos cómo determinados lugares o paisajes de su infancia se tradujeron en arte ${ }^{349}$, en edad adulta, como es el caso de Uma Floresta para os teus Sonhos, que tiene su origen en una anamnesis de infancia, un lugar, un paisaje de pinar al lado de su casa, donde jugaba de niño. La anamnesis, como defiende Catarina Rosendo "trae consigo, también, la adquisición consciente de una autobiografía, que es el elemento que sitúa el escultor en un espacio/ tiempo concreto y sensible" 350 .

En un texto del artista titulado Diários do Coronado: relato de uma Viagem, podemos leer, fijada en texto, la relación productiva y creativa de Alberto Carneiro con el lugar donde nació. Se trata de la descripción "del paisaje y de la vida cotidiana del valle del Coronado, simultáneamente contexto y protagonista." ${ }^{351}$ Todo el texto es el "resultado de varios desplazamientos a la región en diferentes épocas del año, pero será presentada bajo la forma de un único viaje, por lo que el elemento de escenificación o de «no verdad» presente se debe apenas a una cuestión de economía narrativa" ${ }^{352}$. $Y$ diríamos nosotros que también es una forma de "reforzar el carácter constructivo y creativo de una cierta idea de paisaje como autobiografía que represente el deseo de reforzar la idea de descubrimiento del "carácter" del lugar «a partir del fundamento de su realidad física (la tierra) y de su historia común»." 353 En este texto, se presenta el carácter laberíntico y errante de la geografía de São Mamede do Coronado. En él podemos leer: «la carretera se estrecha aún más cuando atravieso una pequeña

Goethe Paisajes, celebrada en el Círculo de Bellas Artes de Madrid entre el 31 de enero y el 6 de abril de 2008. Comisarios Javier Arnaldo y Hermann Midenberger, Madrid, Círculo de Bellas Artes, 2008, pp. 15-32.

${ }^{349}$ Para Maria Filomena Molder, la idea de traducción es fundamental en la articulación posible entre arte y vida. Fuertemente consciente de la tarea del traductor, tal como la concibió Walter Benjamin, para esta autora la comprensión de qué es la traducción implica darse cuenta de que no hay contagio entre arte y vida, en el sentido de un efecto terapéutico o de cualquier tipo de fusión que trasparezca bastante evidente y directa. Para Maria Filomena Molder, el arte es una traducción de la vida, lo que implica el reconocimiento de que ninguna traducción se puede confundir con el original. MOLDER, Maria Filomena, O Químico e o Alquimista - Benjamin Leitor de Baudelaire, Lisboa, Relógio d’Água, 2011.

${ }^{350}$ ROSENDO, Catarina, Alberto Carneiro. Os primeiros anos (1963-1975). Lisboa, Edições ColibriIHA/EAC, 2007, p. 115.

${ }^{351}$ Idem, p. 67.

${ }^{352}$ Ibidem, p. 68.

${ }^{353}$ Ibidem, p. 68. 
aldea. Finalmente llego a la pequeñísima rotonda que lleva a una de las entradas de São Mamede, con una escultura de Nuestra Señora y una fuente de agua donde los habitantes locales se abastecen. Llegué. Aparco el coche e inicio un paseo a pie que me permite, a guisa de deambulación, entender un poco de esta geografía rural y laberíntica que es tan diferente al ambiente urbano y ortogonal en el que vivo» ${ }^{354}$. Alberto Carneiro escribió este texto en un momento en que vivía en la ciudad y fuera de São Mamede. Su descripción muestra un tipo de espacio que es aprehendido por el cuerpo en movimiento ${ }^{355}$; un cuerpo en desplazamiento tiende, como veremos más adelante, a hacer periférico el espacio. Esta característica es importante, pues si aceptamos que, desde la perspectiva del artista, el paisaje es visto como autobiografía, y si todo su trabajo a partir de 1968 parte de anamnesis o reminiscencias de la experiencia de su cuerpo en los lugares reales del paisaje, entonces la experiencia del cuerpo en el paisaje habrá ofrecido, o por lo menos inducido, en los principales ambientes construidos por el artista, una disposición laberíntica que es estructurante de la experiencia que propone a cada uno de nosotros en tanto que espectadores participantes.

\footnotetext{
${ }^{354}$ Ibidem, p. 70.

${ }^{355}$ La narración hecha por Alberto Carneiro en "Diários do Coronado: relato de uma viagem" ejercita una visión periférica propiciada por un cuerpo en movimiento en el espacio del paisaje. Por eso podemos afirmar que existe una semejanza entre la narración de Alberto Carneiro y la de Jack Kerouac, por ejemplo en "On The Road" (1956). Esa semejanza no reside evidentemente en el nivel de la descripción de los referentes, sino de la posición del narrador, quien, en constante movimiento, tiende a crear una noción de espacio periférico en la que existe una proyección perfecta entre movilidad del cuerpo y paisaje. Esta coincidencia refleja un cambio de paradigma espacial, a partir del cual el paisaje deja de ser una vista para la contemplación pasiva y pasa a ser una realidad construida en el curso de un desplazamiento, como testimonia el desarrollo de la fenomenología.
} 


\section{3}

\section{El campo de lo escultórico y "Uma floresta para os teus sonhos".}

Para que podamos entender de qué modo Uma floresta para os teus sonhos participa del concepto de paisaje en el ámbito de lo escultórico, es útil que recordemos algunas conclusiones ya explicitadas anteriormente. Uma floresta para os teus sonhos se compone de 200 troncos de madera dispuestos en sentido vertical, ocupando todo el espacio de la sala de exposiciones. No es un objeto que pueda ser calificado "como un cierto número de superficies que definen una masa" ${ }^{356}$ vista a partir del exterior; si así fuera, la masa de la escultura sería la masa sólida de la escultura, y el espacio lo inverso de la masa. Uma floresta... no es un objeto resultante del modelado directo hecho por el trabajo del artista sobre un material. Por el contrario, es el resultado de una multiplicación de objetos a escala $1 / 1$, no modelados manualmente y que rodean el cuerpo. En esta circunstancia expositiva, los objetos, troncos de madera tratada, no son figuras que se recortan perfectamente contra un fondo, ni tampoco requieren distancia contemplativa y, por eso mismo, no delimitan un espacio virtual tan necesario para la mayor parte de las esculturas objeto. En vez de eso, el límite para esos objetos es el límite de la propia arquitectura; y esto nos sitúa ante un hecho nuevo en la práctica escultórica, que es la posibilidad de acceder a lo escultórico casi de la misma manera como accedemos a la arquitectura, en la medida en que lo escultórico se da a la experiencia de cada uno como hecho inmersivo. Uma floresta para os teus sonhos se da a la experiencia solamente cuando el cuerpo del espectador participante, o usuario, interactúa con los objetos dentro del espacio de la arquitectura.

En nuestro trabajo de interpretación de La forêt, recordamos todo el potencial que tenían ciertas piezas del periodo surrealista de A. Giacometti para inaugurar el camino de apertura de la práctica escultórica al espacio concreto de nuestro cuerpo. Según Rosalind Krauss, algunas esculturas de Giacometti, por

\footnotetext{
${ }^{356}$ READ, Herbert, O Significado da Arte, Trad. de A. Neves Pedro, Lisboa, Editora Ulisseia, 1968, p. 32.
} 
ejemplo las tituladas Project pour un passage (Proyecto para un paso, 19301931), Circuit (Circuito, 1931) y Paysage-tête Couchée (Cabeza/Paisaje, 1932) son piezas que inician una relación con el espacio real donde se insertan. Todas exhiben una lógica horizontal que las religa a la tierra y a la realidad. Por otro lado, implican movilidad; en Circuit existe una esfera que circula literal o potencialmente por una pista surcada en la base de madera y Paysage-tête Couchée tiene la particularidad de poder ser expuesta en la pared, y así asumir la noción de cabeza, o ser expuesta sobre la horizontal, y asumir la noción de paisaje. Estos hechos convocan nuestro espacio empírico. La escultura así concebida no funciona sólo a partir de un espacio virtual que exige distancia contemplativa, sino también como espacio que está en estrecha relación con el espacio real.

Pero la genealogía de esta tipología escultórica, bastante característica de la segunda mitad del siglo XX, que Alberto Carneiro denominó ambiente y que se suele llamar instalación, no estaría completa si no recordásemos los ejemplos ya mencionados de la Merzbau de Kurt Schwitters y del Espacio Proun de El Lissitzky, ambos de 1923, que, como vimos, son ejemplos de prácticas heterodoxas de carácter holístico derivadas de un proceso y de un proyecto que sólo está completo cuando el cuerpo del espectador usa y experimenta su espacio a lo largo de un tiempo, casi como si de una arquitectura se tratara.

Uma floresta para os teus sonhos se inscribe perfectamente en lo que Rosalind Krauss denominó «la escultura en el campo expandido», o sea, la constatación de que la escultura es tal vez la categoría más difícil de definir, pues en el núcleo de su ontología está la fuga de sí misma; en este ensayo, si la escultura en el sentido tradicional estaba situada entre no-paisaje y noarquitectura, a partir de mediados del siglo XX, pasa a convocar la arquitectura y el paisaje y, con este cambio, también sus formas de actuación propias como una cierta manera de concebir y ejecutar el dibujo de proyecto.

El contacto con esta dimensión "expandida de la escultura» generó la segunda fase del trabajo de A. Carneiro, entre 1968 y 1980, aproximadamente. Esta fase está marcada por la cerrazón que el artista encuentra en el medio académico y cultural de Oporto, y en general portugués. Dice Alberto Carneiro: 
«Yo, en relación a la universidad, tenía una posición muy crítica respecto a la situación de la Escuela Superior de Bellas Artes de Oporto. Por una razón muy simple, predominaba en la escuela la ausencia de discurso teórico. Las clases prácticas eran dadas de una manera muy fácil: «¡Haga esto! ¡Haga aquello! ¡Está bien! ¡Está mal! ¡Está mejor de lo que estaba!», No pasaban de un comentario superficial. Naturalmente yo estaba a la espera de un nivel de exigencia superior (...) Las grandes referencias dominantes, paradigmas para los profesores, podrían ir cuando mucho hasta Rodin, cuando poco hasta Bourdelle. ¡Pero no pasaba de ahí! Brancusi, los modernos todos, incluyendo los constructivistas, etc., ¡ni eran considerados ni dejaban de serlo! ¡Estaban pura y simplemente ausentes! ${ }^{357}$ A. Carneiro se sentía "un alumno bastante contestatario en relación al proceso académico vigente en la escuela. $Y$ después de redactar la tesina de fin de carrera, la [Fundación] Gulbenkian me concedió una beca para ir a estudiar a Saint Martin's School of Art de Londres. Allí tuve la oportunidad de depararme con una dinámica completamente diferente, que hoy es difícil de comprender teniendo en cuenta las restricciones culturales que existían en aquella época." ${ }^{358}$ A este respecto, Raquel Henriques da Silva nota que:

durante sus años de estudio en Londres, entre 1968 y 1970. Allí se vivía un periodo de intensa creatividad en el dominio de la escultura, que Rosalind Krauss definió como "campo expandido", que llevaba a "denominar escultura a las cosas más diversas". Sintetizando y siguiendo la poderosa reflexión de esta autora, se pueden enumerar como áreas de innovación: la influencia de la «teatralidad", proveniente de los happenings de comienzos de la década, sometida ahora a una ordenación formal en la que el «escenario» de la presentación escultórica aparece como un espacio abierto a la circulación y participación de los visitantes; la apropiación de lugares fuera de los espacios tradicionales de exposición, relacionados con la afirmación de las diversas prácticas de Land Art; la desmultiplicación y la desmaterialización del objeto escultórico, según los criterios del conceptualismo de repetición expresiva, reforzada, en muchos casos, con la

\footnotetext{
${ }^{357}$ CARNEIRO, Alberto, testimonio oral transcrito de la conferencia pronunciada por el artista Alberto Carneiro, en abril de 2004 en el Auditorio de EP 1 de la ESAD. CR/ Instituto Politécnico de Leiria, a invitación de los docentes Samuel Rama y Pedro Cabral Santo. (En Anexo).

${ }^{358}$ Idem.
} 
utilización de la escritura como concepto plástico y el uso interrogante, aparentemente documental, de la fotografía. ${ }^{359}$

Por tanto, a partir de la experiencia londinense, A. Carneiro opera una ruptura con su práctica artística. En este contexto de apertura de la práctica escultórica, Alberto Carneiro actúa como performer o mediador de sentidos. Durante esta época, fue designado por Ernesto de Sousa como «operador estético", o sea, alguien que articula ideas y espacios a partir de la auscultación de sus reminiscencias o anamnesis transformadas en arte. La designación de "operador estético", propuesta por Ernesto de Sousa, procede del reconocimiento de que la práctica artística de A. Carneiro, a partir de 1968, niega la manualidad a favor de un arte basado en el momento de decisión, muchas veces apoyada por dibujos de proyecto, especialmente los contenidos en $O$ caderno preto ["El cuaderno negro"]. ${ }^{360}$ Esos proyectos anticipaban los trabajos y circunscribían conceptualmente en sus múltiples aperturas. Bernardo Pinto de Almeida nota que los proyectos contenidos en $O$ caderno preto, como en gran medida su trabajo de la segunda fase, muestran "un programa de acción que enseguida se concentra en la potencialidad de su dispositivo de enunciación conceptual; proyectos, naturalmente realizables, pero que no necesitan realizarse en el espacio de las tres dimensiones, tanto más que en el límite, por su rigor de proyecto, cualquiera los podría ejecutar a partir de los esquemas minuciosamente elaborados." ${ }^{361}$ Estos proyectos funcionan también como reacción al mercado del arte porque, de esta forma, el artista frustra su funcionamiento siempre basado en la transacción de un objeto. Escribe $A$. Carneiro en O caderno preto: «¿Qué vemos hoy en las galerías? EL OBJETO. EI abastardamiento de la producción (...) continuamos maniatados por el servilismo cultural (...) «somos cultos», pero la erudición estrangula nuestras posibilidades de creación. Somos fértiles en subproductos. Memorizamos demasiado y

\footnotetext{
${ }^{359}$ SILVA, Raquel Henriques, Alberto Carneiro: los cuerpos de la escultura, in Alberto Carneiro, Santiago de Compostela, Centro Galego de Arte Contemporánea, Xunta de Galiza, pp. 16-17.

${ }^{360}$ CARNEIRO, Alberto, O caderno preto (ideias e projectos 1968/1971), Oporto, Galeria Alvarez, 1971.

${ }^{361}$ ALMEIDA, Bernardo Pinto de, «Idade de Homem». In Alberto Carneiro Exposição Antológica, Centro de Arte Moderno de la Fundação Calouste Gulbenkian, Fundação de Serralves, Lisboa, 1991; p. 18.
} 
pensamos «por» menos (...) El mensaje varía con la alteración de la señal, pero este es determinado en función del espectador. Lo que le ofrezco es un programa de acción. La significación y cosificación de los contenidos está en él.» ${ }^{362}$ La obra de arte como programa de acción presupone que la construcción del espacio derive de una acción proyectual basada en el valor de la decisión a la que no serán ajenos dos hechos, coincidentes en los años 60: por un lado la revalorización del dadaísmo, en particular de los ready-made de Marcel Duchamp y, por otro, la aparición del arte conceptual. El primero hacía que cualquier objeto, después de debidamente contextualizado, pudiera ser considerado arte. Por su parte, la aparición del arte conceptual coincidió con el desarrollo de las disciplinas semiológicas, haciendo más consciente el uso del lenguaje como comunicación y expresión tanto en la elaboración de los proyectos, como en su uso en las propias obras de arte.

Como vimos en el segundo capítulo, Marcel Duchamp, con sus readymades, demuestra la posibilidad de que la obra de arte no sea definida por la acción motriz de la mano que trabaja la materia de la escultura, sino por el valor de decisión. Es precisamente por eso por lo que Ernesto do Sousa prefiere calificar al artista de "operador estético», como alguien que se siente libre para convocar sus anamnesis, operando, a partir de ellas, una extensión de su propio cuerpo dirigida a los usuarios de sus obras, que simultáneamente pueden disfrutar de experiencias tanto suyas como del artista; es eso lo que podemos encontrar en sus «envolvimientos», o sea, ambientes.

Todos sus ambientes, como Uma floresta para os teus sonhos, tienen su origen en dibujos previos. Una vez construidos y escenificados, el espectador los completa como arte, penetrándolos, activando así la pieza y poniendo en práctica las comunicaciones del artista contenidas en los dibujos y en los escritos que fueron siendo publicados o en las propias obras. "Los elementos escritos, ya sean de carácter teórico, especulativo, artístico o informativo, son una constante

${ }^{362}$ CARNEIRO, Alberto, O caderno preto (ideias e projectos 1968/1971), Oporto, Galeria Alvarez, 1971, sin página. 
que acompaña la actividad de Alberto Carneiro." ${ }^{363}$ Catarina Rosendo demuestra cómo el ejercicio de la escritura por parte del artista es una forma de crear un «principio de autoría» que se comprende en la misma medida de la desaparición del trabajo directo del artista sobre la materia.

\section{4}

\section{Dibujo de proyecto de Uma floresta para os teus sonhos}

Uma floresta para os teus sonhos es una pieza cuya componente creativa es en buena parte soportada por el dibujo de proyecto que la acompaña. A. Carneiro adopta el papel de Dédalo, diseñador de laberintos y por tanto de paisajes que remontan al siglo XVI, cuando los italianos llevaron los laberintos al dibujo de jardines. El dibujo de proyecto de Uma floresta para os teus sonhos podría ser apenas un dibujo edificante de un proyecto escultórico. Sin embargo, difiere de otros dibujos preparatorios realizados por otros escultores porque su acción no se agota en la fijación y demostración de la tectónica constructiva del ambiente; además, se presenta como programa de acción más vasto que coloca la escultura en el mismo plano de pensamiento, el que pone el dibujo al servicio del protocolo de creación de la autoría como un entendimiento de la escultura como ejercicio de libre pensamiento. De esta forma, el dibujo de proyecto de Uma floresta para os teus sonhos es una obra autónoma de la escultura a la cual remite, a semejanza de los dibujos de El Lissitzky para el espacio Proun. Lo prueba también el hecho de que la escultura y el dibujo de proyecto pertenezcan a dos instituciones diferentes.

Las figuras 47 y 49 muestran más objetivamente la tectónica constructiva de Uma floresta para os teus sonhos. La primera figura presenta una posible

\footnotetext{
${ }^{363}$ ROSENDO, Catarina, Alberto Carneiro. Os primeiros anos (1963-1975). Lisboa, Edições ColibriIHA/EAC, 2007, p. 99.
} 
lógica para la distribución de los troncos de madera. La segunda evidencia el escalonamiento y la cantidad de troncos de madera necesarios para ocupar una sala con cerca de $200 \mathrm{~m}^{2}$. Las figuras 48 y 50 documentan partes del dibujo de proyecto que apuntan a la construcción de un principio autoral, ya sea por vía subjetiva o intersubjetiva: subjetiva por la convocación de una memoria de infancia e intersubjetiva por la propuesta de obra de arte abierta a todos, como prueban las frases documentadas por la fig. 50 .

El dibujo es una representación operada por medio de la reducción a los conceptos esenciales de espacio, tiempo y memoria. Es minucioso y lo bastante claro para poder ser entendido por todos $y$, de forma simultánea, posee enunciados subjetivos susceptibles de ser interpretados diferentemente. De este modo, el dibujo de proyecto se aproxima no sólo a los dibujos de jardines en su vocación para construir un paisaje, sino también de los dibujos de arquitectura. Este aspecto de la utilización del dibujo para proyectar paisajes tiene su momento de mayor incremento durante los años 60 y 70, y principalmente con los artistas de la Land Art cuyos proyectos, muchas veces por ser efímeros o exigir un extraordinario conjunto de medios, tenían que ser fijados en dibujo como forma de garantizar la existencia de la obra, independientemente de que sea o no realizada.

La palabra escrita en el dibujo introduce la presencia del artista por su carácter sonoro. Al leer sus aforismos inscritos en el dibujo, estamos convirtiéndolos en comunicación sonora del artista dirigida a nosotros, espectadores. De hecho, para el espectador conocedor, es imposible no asociar las palabras escritas al timbre de la voz del artista, una vez que aparece en algunas obras previas y contemporáneas de Uma floresta para os teus sonhos, como O laranjal - Natureza envolvente ("El naranjal - Naturaleza envolvente"). En esta última, el artista "coloca de forma algo lúdica los cinco sentidos en acción. La tierra en el centro del cubo, brillante es la silueta de un árbol que funciona como espejo como imagen diluida donde los detalles se desdibujan. En el centro del cubo y en la tierra hay un emisor de sonido, donde la tierra cuenta la historia del naranjo. La historia es contada en cuatro fases, que corresponden a las cuatro estaciones del año: la Primavera, el Verano, el Otoño y el Invierno. 
Cuenta la historia del naranjo describiendo cómo vive, en ella, la tierra. Cómo se alimenta, cómo se va transformando a lo largo de las estaciones, qué visitantes tiene (las abejas, los pájaros), etc.. ${ }^{364}$ En éste, como en otros trabajos ${ }^{365}$, además del timbre de la voz del artista, tenemos acceso al tono coloquial con que expresa la palabra. De esta forma, la palabra insufla al dibujo, deja de ser una representación o un plano de construcción, para ser ella misma factor de movilización fenomenológica del pensamiento.

En $A$ Voz e o Fenómeno, ${ }^{366}$ de Jacques Derrida, el autor aclara dos modos de hacer presente la palabra y establece la diferencia entre "la presencia real y la presencia en la representación como Vorstellung (Representación), es todo un sistema de diferencias que, a través del lenguaje, se encuentra implicado en la misma deconstrucción: entre el representado y el representante en general, el significado y el significante, la presencia simple y su reproducción, la representación como Vorstellung y la representación como Vergegenwärtigung (presentación); porque la representación tiene por representado una presentación (Präsentation) como Vorstellung". ${ }^{367}$ Esto es, en el contexto del dibujo de proyecto de Uma floresta para os teus sonhos, la palabra escrita es factor incitador de movilidad en la consciencia del espectador, el dibujo deja de ser estático y gana movimiento ante nuestros ojos y nuestra comprensión. Por lo tanto, no estamos ante un dibujo entendido como representación tectónica de

\footnotetext{
${ }^{364}$ CARNEIRO, Alberto, testimonio oral transcrito de la conferencia pronunciada por el artista Alberto Carneiro, en abril de 2004 en el Auditorio de EP 1 de la ESAD. CR/ Instituto Politécnico de Leiria, a invitación de los docentes Samuel Rama y Pedro Cabral Santo. (En Anexo).

${ }^{365}$ También en una pieza más tardía titulada Meditação e posse do espaço/paisagem como obra de arte (Meditación y posesión del espacio/paisaje como obra de arte), de 1977, constituida por una reproducción audio de la voz del artista, que va describiendo las sensaciones y pensamientos que surgen de la situación de su cuerpo en el paisaje. Las mismas descripciones se encuentran escritas en ocho dibujos enmarcados y colocados en la pared, flanqueados por dos columnas por donde sale el sonido de la voz del artista.

${ }^{366}$ En relación a la voz, Marshall McLuhan habla de ella asociada a la radio identificándola con la primera edad del tribalismo, pues la radio incorpora una componente arcaica bastante importante, en el sentido de que es la voz que, intrínsecamente humana, remite al alma, y la radio transmite justamente eso. Cuando escuchamos la radio estamos oyendo a una persona cerca y podemos entrar en una relación comunicativa casi mística. Estamos oyendo al otro de una forma muy próxima, justamente porque la voz es aquello que sirve de trabazón entre el oyente y el locutor. Así, desde el punto de vista de McLuhan, la radio tiene esa componente tribal y ocupa una posición tal vez única entre los medios de comunicación.
}

${ }^{367}$ DERRIDA, Jacques, A voz e o fenómeno, Trad. de Maria José Semião, Lisboa, Edições 70, 1996, p. 65. 
una construcción a hacer, sino de un dibujo que procura tornar presente de nuevo las intenciones del artista y la mirada que busca en el dibujo las pistas para ese plano de interpretación lo encuentra en las flechas diseñadas por entre los troncos. Así, podemos imaginarnos dentro de "un bosque para tus sueños": el espacio del bosque deja de ser apenas significativo para el artista y pasa a serlo también para cualquiera de nosotros. El bosque es tanto del artista como de cualquier espectador que quiera disfrutarlo. Puede así existir tanto en nuestra cabeza, al instalarse en un espacio específico; el bosque tanto puede constar de 200 troncos de madera como puede "tener millones de elementos. Por tanto son obras que se adaptan siempre al espacio donde están siendo expuestas” ${ }^{368}$. El dibujo de proyecto funciona como inscripción de arte como idea, Alberto Carneiro llega a decir incluso que "esta é tal vez su obra más conceptual”369.

Sobre el papel milimétrico, son diseñadas organizadamente geometrías la planta de la galería Buchholz de Lisboa, algunas proyecciones de vistas laterales, un rectángulo de oro, la representación de los diferentes troncos verticales de perfil- y aquellos que se encuentran representados encima de la planta se presentan conceptualizados en una perspectiva caballera. En oposición a esas geometrías, encontramos los vectores orgánicos que indican posibles procesos de penetración en el espacio forestal a ser tomados por el espectador participante, abajo, se encuentran las ya mencionadas frases aforísticas que, como señalamos, animan y rescatan el dibujo de la pura representación. El dibujo así concebido tiene tanto de definitivo como de abierto, en la medida en que, además de describir tectónicamente la posibilidad de construcción de Uma floresta para os teus sonhos, también presenta o hace presente la presencia del artista a través de sus propuestas aforísticas. Los aforismos escritos convocan en todos una cierta destrucción del estatismo geométrico o del espacio cartesiano representado por el papel milimétrico a favor de una organicidad propia del sentido de la errancia. En esas frases puede leerse:

\footnotetext{
${ }^{368}$ CARNEIRO, Alberto, testimonio oral transcrito de la conferencia pronunciada por el artista Alberto Carneiro, en abril de 2004 en el Auditorio de EP 1 de la ESAD. CR/ Instituto Politécnico de Leiria, a invitación de los docentes Samuel Rama y Pedro Cabral Santo. (En Anexo).

${ }^{369}$ Idem.
} 
El arte que buscas se significa en el arraigo de tu cotidiano.

Los compromisos de tu disfrute se refieren a todas tus vinculaciones.

Di no a las fórmulas de empaquetamiento de la cultura; sírvete de ella para descubrir tu pureza.

El arte es un "MEDIUM" para; su función se define en la prolongación de su propia transformación, en la renovación permanente de su campo de acción.

Los mensajes del arte que te propongo serán significantes en la autenticidad de los significados que les encuentras.

Acuéstate en el silencio de tu día y piensa que la vida es más importante que todo el arte aburguesado y tendrás entonces tu propio arte. Un arte para tu acción.

Oporto, Noviembre-Diciembre 1970

Alberto Carneiro

Estos aforismos, además de constatar el dibujo de proyecto, fueron también «transcritos en el catálogo de la exposición de esta obra en la Galería Buchholz en 1971", lo que muestra el carácter comunicativo de la obra que se pretende abierta al espectador usuario. 


\section{5}

\section{Idea de paisaje en Uma floresta para os teus sonhos}

\section{o la idea de paisaje en el objeto - El artista y el paisaje}

Como vimos anteriormente, la idea de paisaje está íntimamente relacionada con la percepción de la realidad, en la medida en que el paisaje sólo existe a partir de una mirada y de la percepción del sujeto que la porta. Esta aprehensión por los sentidos puede ser investida de placer o desplacer, pero cuando su marca es indeleble puede permanecer en nuestra memoria. Un artista como Alberto Carneiro usó en diferido una memoria, reminiscencia o anamnesis de un paisaje que le había dejado una huella en su infancia: el pinar donde jugaba cerca de su casa. Pero para que ese pinar llegara a la condición, primero de paisaje, y después de obra de arte, fue preciso que la mirada del artista materializara a lo largo del tiempo de su madurez la idea de bosque, es decir, «un todo parcial de la naturaleza» ${ }^{370}$, operando una fragmentación de la unidad del mundo natural; separó el tema bosque y se asumió como observador de un espacio exterior que le era familiar para después proponer una obra que debe ser vista desde dentro como algo relacional.

Para llegar a la condición de obra de arte, este pinar primero tuvo que tener la mirada del artista que lo aprehendió como paisaje real, prestándole significado, para después, a lo largo del tiempo, llegar por la anamnesis a la condición de subjetivación del paisaje a través de la representación o presentación idealizada en el campo de lo escultórico. Alcanzado este punto, la lógica laberíntica de Uma floresta para os teus sonhos tanto es imagen de la naturaleza primordial, como de la gran ciudad que domina la vida contemporánea. A esta relación paradójica, no es extraña la difícil y contrastante relación entre paisaje natural y ciudad, donde al avance de la segunda

\footnotetext{
${ }^{370}$ Recordemos que, para Georg Simmel, en A Filosofia da Paisagem, anteriormente ya citada, el paisaje es un todo parcial que se sustrae a la naturaleza. Mientras que para los antiguos la naturaleza era una e indivisible, en la época moderna, y con la invención del paisaje, puede fragmentarse en innumerables paisajes que corresponden a los respectivos sujetos que lo observan y le prestan sentido.
} 
corresponde al encogimiento de la primera hasta tornarse en nuestros días en una realidad residual y confinada. Esta constatación, como veremos, sustenta el aspecto estético, ético y político de Uma floresta para os teus sonhos, en la medida en que la conciencia de la pérdida del paisaje natural por parte del artista, investido por un cultura urbana, le hace proponer, proyectar e idealizar un ambiente marcado por la nostalgia y por el sueño.

En un texto titulado Mi Cuerpo y el Paisaje, ${ }^{371}$ A. Carneiro nos presenta un tipo de pensamiento sobre el paisaje en que éste no es encarado como objeto contemplado o analizado desde fuera, sino como algo relacional que es visto desde dentro, como algo de concreto activo y vivo para su cuerpo y para su experiencia, algo que ya anteriormente habíamos explorado al consagrar una parte de nuestro estudio a la relación del paisaje con la autobiografía. No obstante, el texto citado es tal vez más claro en cuanto a la definición de paisaje. Para este artista "Los paisajes están y son mis ojos y, por medio de ellos, todo mi cuerpo. Al reflexionar sobre el paisaje me descubro en él, me encuentro en su centro como ser que se mueve y así aprehende los significados culturales a través de los cuales llego a sentir y a saber que es paisaje.. ${ }^{372}$ Por tanto, para A. Carneiro, el paisaje es aprehendido a partir de su ser en movimiento; no es una definición restringida sino una definición amplia que nunca está acabada, en constante construcción a partir de su cuerpo que, en el máximo de su energía física, psíquica y mental, va articulando los datos culturales con los derivados de su experiencia corpórea directa. Así, "el paisaje (...) nunca puede ser completamente visto desde fuera ya que comporta mi estar en los correspondientes espacios en tiempos sucesivos de percepción de los elementos que lo constituyen, los cuales, yuxtapuestos y agrupados por mi mirada inteligente, me proporcionan imágenes que interiorizo junto a lo que ya viví y pensé como paisaje ${ }^{\text {"373 }}$. La definición de paisaje de A. Carneiro puede ser tanto

\footnotetext{
${ }^{371}$ CARNEIRO, Alberto, "Mi Cuerpo y el Paisaje", in VVAA, Paisaje y arte, Dir. Javier Maderuelo, Madrid, Abada Editores, 2007. pp. 243 -247.

${ }^{372}$ Idem, p. 243.

${ }^{373}$ Ibidem, p. 245.
} 
suya, como la de quien experimenta sus obras, o sea una definición en abierto y dependiente de las capacidades físicas y mentales de cada uno.

En por lo menos dos momentos ${ }^{374}$, Catarina Rosendo considera el pensamiento de Augustin Berque útil para entender la noción de paisaje en A. Carneiro. Berque también defiende un concepto de paisaje entendido como una relación viva y concreta, y no una mera extensión vista desde fuera. Este autor propone un punto de vista relacional capaz de articular ecología y fenomenología. En la génesis de esta propuesta está la constatación de que desde el mundo antiguo el hombre perdió un cierto sentido de relación armoniosa con los paisajes. Con la llegada de la modernidad, estos habrán empezado a perder un "tipo de correspondencias que hacen del cuerpo humano el patrón del mundo ambiente y, a su vez, moldean el ambiente a la medida del Hombre." ${ }^{375}$ EI pensamiento científico del siglo XVII disecó la realidad, dividiendo el mundo físico y el mundo fenoménico, "o sea, como lo real en sí, irreductible a la ilusión de los sentidos." ${ }^{376}$ Por lo tanto, se asistió al consumar de la división del mundo del objeto y del mundo del sujeto; las consecuencias todos las conocemos, y a la cabeza se encuentra el hecho de que el paisaje se haya convertido en un territorio inmensamente disponible para todas las acciones del hombre no sensible a los datos y ecos propios del paisaje. Berque identifica el origen de la crisis del paradigma moderno clásico en la reconfiguración tanto del mundo del objeto, como del sujeto. Para la primera reconfiguración, mucho contribuyó el desarrollo de las geometrías no euclidianas, así como el desarrollo de las teorías de la relatividad, iniciándose de esa forma el pensamiento relacional. A su vez, la reconfiguración del sujeto se debió sobre todo al inicio del desarrollo de la sociología, la antropología y el psicoanálisis, que "mostraron que el sujeto

\footnotetext{
${ }^{374}$ Los dos momentos se refieren a su tesis, ya citada (ROSENDO, Catarina - Alberto Carneiro. Os primeiros anos (1963-1975). Lisboa, Edições Colibri-IHA/EAC, 2007, pp. 60 y 61), así como su texto incluido en un libro que comprende otros ensayos bajo el título de Arte \& Paisagem; ROSENDO, Catarina, "Uma ideia da paisagem através da obra de Alberto Caeiro". In Margarida Acciaiuoli, Joana Cunha Leal y Maria Helena Maia (Coord) Arte \& Paisagem. (pp. 275-288) Lisboa, Instituto de História da Arte Estudos de Arte Contemporânea, 2006.

375 BERQUE, Augustin, A ecúmena: medida terrestre do Homem, medida humana da terra. In Filosofia da Paisagem. Uma Antologia, Trad. de Andreia Saavedra Cardoso (coord: Adriana Veríssimo Serrão), Lisboa, Centro de Filosofia da Universidade de Lisboa, 2011. p. 188.

${ }^{376}$ Idem, p. 189.
} 
individual no puede abstraerse, sino de forma muy imperfecta, de su ambiente social y físico. Permanece ampliamente condicionado por este ambiente, ya sea en términos simbólicos, ya por encadenamientos de causas y de efectos derivados de diversas escalas espacio-temporales"377 Pero, además de las ciencias sociales, también la fenomenología naciente contestó esta división entre sujeto y objeto, de larga tradición cartesiana. "Más radicalmente, la fenomenología cuestionó la propia noción de objeto, contestando la pretensión del sujeto individual moderno de separarse del mundo de las cosas." ${ }^{378}$

A pesar de que el paradigma ecológico y la fenomenología hayan cuestionado las acciones fracturantes existentes en la modernidad clásica entre sujeto y objeto, la verdad es que ambas, ecología y fenomenología, siguieron cada una su propia dirección. Ante esta constatación, Berque propone en $1993^{379}$ un tipo de relación al paisaje que A. Carneiro, como otros artistas de la segunda mitad del siglo XX, ya practicaban como forma de acceder al paisaje y construir obras de arte a partir de ella. La tesis de Berque, en el plano filosófico, consiste en una solución capaz de unificar y relacionar fenomenología y ecología; "precisamos hoy de un paradigma que, reconduciendo a una medida común el ambiente y el paisaje, la tierra y el Hombre, restablezca la unidad del mundo ambiente. ${ }^{380}$ Para llevar a cabo su tesis, el autor propone una acción y un proceso: la acción es la «mediancia» (mediance), el proceso es la «trayección» (trajectif). Mediancia es concebida "como un sentido al mismo tiempo subjetivo y objetivo (una significación, una sensación, una tendencia), de la relación de una sociedad con la extensión terrestre (relación que es un medio). Este sentido conjuga tres niveles: el del en-sí de las cosas y de la naturaleza (la extensión del mundo físico u objetivo); o de las relaciones ecológicas que unen la especie humana a su ambiente, y el del paisaje, donde actúan las relaciones de orden simbólico, por las cuales una cultura naturaliza la subjetividad colectiva." ${ }^{381}$ A

\footnotetext{
377 Ibidem, p. 191.

${ }^{378}$ Ibidem, p. 191.

${ }^{379}$ BERQUE, Augustin, "L'écoumène, mesure terrestre de l'Homme, mesure humaine de la Terre: pour une problématique du monde ambiant", L'Espace géographique 4, 1993, pp. 299-305.

${ }^{380}$ Idem, p. 192.

381 Ibidem, p. 193.
} 
partir de este concepto de Berque, podemos confirmar, tal como hizo Catarina Rosendo, que la mediancia se "refiere a la reciprocidad elaborada a nivel físico, fenomenal, ecológico, simbólico, factual o sensible, del que el paisaje es una de las manifestaciones. Como "sentido del medio», el paisaje posee una ambigüedad simultáneamente física/factual y simbólica/sensible, pues la misma palabra se refiere tanto a un determinado territorio como a un género pictórico. Es decir, está compuesta tanto de sus elementos concretos como de las representaciones que el hombre hace en ella y a partir de ella, siendo la cosa y, al mismo tiempo la representación de la cosa en su ausencia." ${ }^{382}$ En este sentido, Alberto Carneiro, por su profunda vinculación a los lugares y a los paisajes, se asume no tanto como un mero sujeto que se distingue del paisaje, sino como un ser que opera intercambios con el paisaje; en esta condición, es tanto agente modelador del paisaje como el paisaje es modelador de sí mismo, de su obra y de sus comportamientos. Por tanto, el artista consciente de la necesidad de inaugurar otra relación con el paisaje realiza "un movimiento en el cual el mundo subjetivo y el mundo objetivo no cesan de interactuar" ${ }^{\text {"383 }}$. Este proceso es denominado por A. Berque «trayección» (trajectif), que Catarina Rosendo interpreta, encuadrando la noción con el trabajo de A. Carneiro, como refiriéndose "al modo como el paisaje se define por un proceso que, en el tiempo histórico y en el tiempo geográfico, acompaña y participa de la interacción entre la sociedad y su medio. Esta interacción es definida por un complejo de experiencias y memorias que es desarrollado por un sujeto que aprehende el paisaje al mismo tiempo que se recogiera en ella." ${ }^{384} \mathrm{Y}$ escribe A. Carneiro:

«(...) frente al mar, en medio del campo o en la cima de un monte miro a mi alrededor y establezco relaciones entre los elementos que forman el paisaje: la línea del horizonte $y$, a partir de ella, los montes, los campos, los árboles, los arbustos, las matas, las piedras, las grandes y las pequeñas, los caminos, la sucesión de planos, las

\footnotetext{
${ }^{382}$ ROSENDO, Catarina, "Uma ideia da paisagem através da obra de Alberto Caeiro". In Margarida Acciaiuoli, Joana Cunha Leal y Maria Helena Maia (Coord) Arte \& Paisagem. (pp. 275-288) Lisboa, Instituto de História da Arte Estudos de Arte Contemporânea, 2006, p. 288.

${ }^{383}$ BERQUE, Augustin. Para um paradigma ecumenal. In Filosofia da Paisagem Uma Antologia, Trad. Andreia Saavedra Cardoso (coord: Adriana Veríssimo Serrão), Lisboa, Centro de Filosofia da Universidade de Lisboa, 2011, p. 193.

${ }^{384}$ ROSENDO, Catarina, Op. cit., p. 288.
} 
variaciones de la luz, los olores de la tierra, el perfume de las flores, las rugosidades y las tersuras de los diferentes elementos y la memoria de todos los paisajes antes vividos» ${ }^{385}$.

Este reconocimiento del artista para con el paisaje tiene lugar en un proceso fenomenológico en que el cuerpo se encuentra en movimiento y en el que está presente una lógica relacional con el mundo ambiente que "combina metáfora e identidad." ${ }^{386}$ Esta combinación es una constante en casi todo el trabajo de Alberto Carneiro y se encuentra también inscrita en la génesis de Uma floresta para os teus sonhos.

\section{6}

\section{Paisaje - arte - paisaje}

Para profundizar en la forma como Uma floresta para os teus sonhos participa del concepto de paisaje, tendremos que concentrarnos en las prácticas conceptuales y ecologistas realizadas por Alberto Carneiro entre finales de los años 60 y 70 . Durante estos años, deben ser considerados dos movimientos o estrategias creativas; uno primero que va del interior del espacio del arte, galería o museo, hacia fuera del espacio del arte, el espacio natural o ruralizado, e, inversamente, el segundo movimiento realiza el paso del exterior natural o ruralizado hacia el interior de los espacios institucionales del arte: la galería y el museo.

El primer movimiento, que opera el paso del arte del interior institucionalizado del arte hacia el espacio real natural o rural humanizado, encuentra sus mejores ejemplos en Operação estética em Vilar do Paraíso (1973), Operação estética no Alto de S. João (1974-75) y Os sete rituais estéticos sobre um feixe de vimes na paisaje (1975). En todos ellos, A. Carneiro

\footnotetext{
${ }^{385}$ CARNEIRO, Alberto, "Mi Cuerpo y el Paisaje". in A.A.V.V, Paisaje y arte, Dir. Javier Maderuelo, Madrid, Abada Editores, 2007, p. 244.

${ }^{386}$ BERQUE, Augustin, Para um paradigma ecumenal. In Filosofia da Paisagem. Uma Antologia, Trad. Andreia Saavedra Cardoso (coord: Adriana Veríssimo Serrão), Lisboa, Centro de Filosofia da Universidade de Lisboa, 2011, p. 195.
} 
convoca una serie de estrategias poéticas que cuentan con relaciones entre su propio cuerpo y las materias naturales o prácticas agrícolas, en un proceso que comprende tres fases: la prospección, la marcación y, por último, la transformación y posesión estética/poética de esos lugares donde transcurre la acción, que va siendo fotografiada y posteriormente mostrada en espacio galerístico o museológico.

El segundo movimiento llevó a A. Carneiro a crear ambientes, instalaciones de carácter escultórico que, de alguna forma, fueron transportadas hacia dentro del espacio galerístico o museológico, espacios que se pueden encontrar en el exterior, así como $O$ canavial: memória metamorfose de um corpo ausente (1968), Um campo depois da colheita para deleite estético do nosso cuerpo (1973-76) y Uma floresta para os teus sonhos (1970). Estos se encuentran entre los primeros ambientes que fueron producidos en el arte internacional, incluso antes de que Rosalind Krauss teorizara, en 1979, la cuestión del paisaje en la escultura en su ensayo Sculpture in The Expanded Field. Isabel Carlos señala la singularidad del proceso de trabajo de A. Carneiro, que fue capaz de sintonizarse consigo mismo y con sus raíces, al mismo tiempo que lo hacía en sintonía con los grandes movimientos internacionales de la práctica artística.

A partir del final de la década de 1960, el artista radicaliza la relación con el paisaje y los elementos naturales a partir de dos aproximaciones formal y físicamente distintas: una, que denominaremos transposición y presentificación; otra, invención y acción documento. Ambas son, no obstante, diálogos y profundización de un modo personal y autoral de dos movimientos artísticos internacionales que marcaron la década, el land art y el body art. Carneiro estaba así no sólo sintonizado con su naturaleza, consigo mismo y sus raíces, sino también con el tiempo y el mundo, que en su caso -al contrario de lo que generalmente sucedía en el arte portugués- no significa una derivación o ilustración de conceptos importados, sino una verdadera reinvención y creación de un lenguaje propio. ${ }^{387}$

En Trajecto de um corpo (1976-77), que en el último capítulo será descrito con más detalle, encontramos una suerte de síntesis de estos

${ }^{387}$ CARLOS, Isabel, Alberto Carneiro: a escultura é um pensamento, Lisboa, Caminho, 2007, p. 11. 
movimientos interior/exterior y viceversa, asumiéndose el artista como operador estético. Materializada en fotografía, la obra pretende trabajar una idea de movilidad, primero efectiva en el paisaje, y después metafórica en las imágenes fotográficas que constituyeron la presentación de la pieza. Se trata de una transformación ritualizada de un canto rodado en arte; el trayecto de ese cuerpo/arte, de esa escultura, recorre juntamente con el artista los lugares del paisaje más significativos de su infancia. Durante el trayecto, el canto sale de la naturaleza, entra en el espacio galerístico o institucional del arte y regresa nuevamente al espacio natural, pero ahora designado arte. Por este proceso de designación de un canto rodado como arte, vemos que A. Carneiro comprendió bien el legado de Duchamp, el primero en tener consciencia de la importancia que el plano institucional del museo o la galería de arte tienen en la determinación de lo que es o no arte a partir del contexto.

En lo que se refiere a la temática del bosque, también podemos encontrar materializaciones poéticas en estos dos movimientos creativos: desde fuera de la institución del arte hacia dentro y viceversa. En cuanto al primer movimiento, deben ser considerados Escultura dentro da floresta (1968-69) y Uma floresta para os teus sonhos (1970). La primera es una de las instalaciones que integran "as três extensões da natureza» ${ }^{388}$ constituida por una sucesión de ramas dispuestos de perfil, asentados y ligados a chapas metálicas que ocupan el espacio arquitectónico desde el suelo horizontal hasta la verticalidad de la pared inmediatamente frontal de la galería o museo. En esta última situación espacial, un conjunto de fotografías en blanco y negro a nivel de la mirada son incluidas en el conjunto de ramas, como si se tratara de una apertura en ventana. De esta forma, A. Carneiro recrea el bosque a través de la sugerencia de un camino que puede ser recorrido mentalmente, y que va desde el plano tridimensional, constituido por todas las ramas de árbol, al puramente óptico, formado por la representación del bosque en fotografías. En esta pieza coexisten así dos niveles de lectura del paisaje. El primero viene dado por la presencia

\footnotetext{
388 "las tres extensiones de la naturaleza» es la designación usada por A. Carneiro para agrupar tres importantes trabajos; además de "Escultura dentro da floresta", "Árvore dentro da escultura" y "O mar" se prolonga dentro de cada uno de nosotros, todos los proyectos fueron trabajados y presentados en dibujo e integran el Livro preto de A. Carneiro, ejecutado durante sus prácticas en Londres, que comprendía genéricamente una serie de proyectos escultóricos y paisajísticos).
} 
bruta de los materiales que componen el bosque, troncos de árbol que implican, para su percepción, el sentido de la visión, del tacto y del olfato. El segundo viene dado por la virtualidad de la imagen fotográfica ya codificada en la historia de las representaciones bidimensionales de bosques, "se trata de la recreación de un pedazo de paisaje que, convocando inicialmente la presencia del cuerpo por la sugerencia de un camino que puede ser recorrido, efectúa una alteración de plano que indica también que, gradualmente, el cuerpo se desposea de protagonismo sensitivo a favor del campo de visión abierto por la imagen bidimensional del bosque colocada en la pared, a nivel de la mirada." ${ }^{389}$

\section{7}

\section{Dispositivo teatral}

En Uma floresta para os teus sonhos se produce la integración en el plano real y virtual de la formación de la imagen que tiene lugar en cada espectador que, con su caminar, tiene un papel aún más participante en la construcción del bosque, tal como sucede en el cañaveral y en la cosecha. Durante el trayecto, el espectador construye el paisaje, deambulando como una dimensión psicofísica e intelectual del bosque.

O canavial: memória metamorfose de um corpo ausente (El Cañaveral: memoria metamorfosis de un cuerpo ausente, 1968), Um campo depois da colheita para deleite estético do nosso cuerpo (Un campo después de la cosecha para deleite estético de nuestro cuerpo, 1973-76) y Uma Floresta para os teus sonhos (Un bosque para tus sueños, 1970) son ambientes de carácter escultórico que se instalan en el "suelo para ahí desarrollarse formalmente, alargándose y dejando dentro de sí los vacíos formales (...) necesarios para que ese desarrollo se procese de forma equilibrada. Estas obras incorporan una forma nueva en el trabajo de Alberto Carneiro, basada en dos factores: el

\footnotetext{
${ }^{389}$ ROSENDO, Catarina, Alberto Carneiro. Os primeiros anos (1963-1975). Lisboa, Edições Colibri-
} IHA/EAC, 2007, p. 12. 
espectador y el horizonte; o sea, el espacio entendido en su cualidad relacional y en su totalidad de envolvimiento. Este hecho viene corroborado por el modo como los títulos se refieren a condiciones atmosféricas, materias naturales y estaciones del año. No se refieren a los aspectos vitalistas y dinámicos de la materia como entidad exterior al sujeto pero, por el contrario, implican un sentido relacional de este con aquella, lo que aporta al interior de la obra de arte una idea de paisaje." ${ }^{390}$ Esta noción de paisaje no es ajena a la configuración de un espacio eminentemente teatral; de hecho, los troncos de madera verticales de Uma floresta para os teus sonhos funcionan como «objetos de escena», no para un teatro en el sentido tradicional, sino para una cierta teatralidad surgida en la práctica de las artes plásticas. Como vimos en el segundo capítulo, la discusión de la apertura de lo escultórico suscitó varias conexiones, una de ellas fue la convocación de una cierta teatralidad exigida por los nuevos objetos escultóricos. En $L$ Beams, de Robert Morris (1965), tenemos una escultura compuesta por tres elementos realizados en MDF pintado que, en el fondo, son el mismo elemento pero en tres posiciones diferentes. Esta pieza, por su formulación radicalmente distinta de la escultura en sentido tradicional, planteó una enorme polémica, en la medida en que las piezas no son realizadas en ningún material tradicional de la escultura, ni tampoco presentaban un verdadero trabajo manual en su ejecución. Pero el aspecto más destacado era sin duda el hecho de que esta pieza pone el acento en la presencia del observador participante, sin quien la obra no existe.

En el contexto de las artes plásticas, la teatralidad fue siendo construida por lo menos desde el constructivismo ruso, a partir de la consciencia aguda tanto del contexto como de la presencia del observador o espectador. Desde los primeros ejemplos de implicación de la teatralidad en las artes plásticas quedó patente la idea de que la expresión es ampliamente condicionada por la presencia del público en un lugar específico que sirve de soporte para una acción que se presenta. Durante mucho tiempo, las prácticas teatrales del constructivismo ruso, del surrealismo y de otras vanguardias permanecieron como práctica subterránea, desde el punto de vista de la recepción, porque contenían una dimensión ideológica y política de reacción al objeto artístico. En

\footnotetext{
${ }^{390}$ Idem, p. 60.
} 
este contexto, fue más fácil la adhesión del público más amplio a la práctica objetual auto-referencial, caracterizada por un juego preferencial y directo entre autor y obra. Sería esta práctica la que, desde el punto de vista de la recepción de las obras, caracterizaría una buena parte de la producción escultórica de la primera mitad del siglo XX. Sin embargo, la teatralidad tiene orígenes mucho más lejanos; podemos afirmar que existía ya una cierta idea de teatralidad en el Renacimiento Italiano derivada del desarrollo del mecanismo de ilusión dado por la perspectiva renacentista que, una vez aplicada a la pintura por ejemplo de paisaje, por un lado naturaliza y, por otro, idealiza la pintura. Con el Manierismo, y después de forma más intensa con el Barroco, la teatralidad es también retórica, especialmente la del arte religioso, que intenta hacer su prosa religiosa a través de las imágenes. En ambos ejemplos, traer la realidad de la naturaleza o de la retórica para el arte de la pintura presupone la idea de meter en escena cualquier cosa que se presenta en el sentido más fuerte del término. Así, el camino seguido por la modernidad en algunos de sus modernismos es el camino de esa «desintensificación» de esa idea de lo teatral.

El tipo de relación teatral que se puede encontrar más frecuentemente en la segunda mitad del siglo XX no procede de la relación con las imágenes, sino de una derivación de la historia del arte a partir de los años 60 con el minimalismo. Los artistas minimalistas pretendieron crear objetos artísticos que, además de tener una cohesión interna, de no ser posible verlos parte por parte, suponían una relación con el espacio. La obra ocupaba un determinado espacio y una determinada escala de acuerdo con el contexto arquitectónico de la sala donde era expuesta y esas formulaciones acababan por implicar una relación con el espectador. En este contexto, obra, espacio y espectador establecían una trilogía inseparable para pensar la existencia de la obra de arte. Raramente los minimalistas como Donald Judd, Robert Morris, etc. dejaban de considerar la condición de que la obra era para ser vista y experimentada por personas que tenían una determinada dimensión. Por tanto, para estos artistas, hay una formulación muy clara de que las personas, los espectadores, no ven únicamente con los ojos, sino que acceden a la obra con el cuerpo globalmente implicado. Por otro lado, los minimalistas demostraron tener una aguda conciencia de las 
consecuencias en términos del fenómeno de la atención y de las expectativas que un espacio expositivo puede desencadenar en sí. Tal consciencia, de raíz Duchampiana, hace que comprendan que la obra no es la misma si está en dos situaciones distintas. El objeto no es el mismo si se encuentra en dos contextos distintos; el de la galería de arte influye en la percepción y la performatividad del espectador. Dicha constatación implica admitir que el objeto no se lee por sí mismo, no tiene autonomía, al contrario de la escultura moderna.

En la pintura de paisaje, incluso en la mayor parte de las propuestas modernas que representan o expresan la idea de paisaje, no sólo el espectador suspende la objetualidad del cuadro para poder acceder a la pintura, sino que también acepta un pacto para que pueda ver, más allá del objeto, el paisaje pintado en el objeto lienzo. En sus ambientes, A. Carneiro quiebra ese pacto y las formas son aquellas que el objeto exhibe literalmente, lo que provoca la convocación del espacio alrededor del objeto para que éste pueda ser experimentado ${ }^{391}$. A partir de aquí, el objeto está en escena, pasa a depender de la situación. El trabajo de A. Carneiro, en su segunda fase, prueba que esa teatralidad no implica necesariamente una disminución de las sensaciones, pues sus propuestas no se configuraban mayoritariamente concebidas, ejecutadas y presentadas como formas de espectáculo, que obviamente redundarían en una reducción de las condiciones de la atención que disminuyeron el potencial propio

\footnotetext{
${ }^{391}$ El crítico norteamericano Michael Fried publicó en 1967 un texto en la revista Artforum, titulado "Art and Objecthood". Este texto supone, como vimos en el segundo capítulo, la crítica más severa a la entrada de la teatralidad en el campo de las artes plásticas. En este texto, M. Fried apunta las diferencias entre la obra de arte moderna y el objeto literal del minimalismo. La cuestión fundamental a la que se refería Fried era el hecho de que el arte minimalista, al colocarse en una posición de miscegenación entre los géneros de la pintura y la escultura, obligaba al espectador a redefinir constantemente su percepción y situación ante la obra de arte; este movimiento y esta performatividad del espectador era nueva, en el contexto del arte. La teatralidad de la obra de arte minimalista se presenta para Fried como una propiedad escénica donde el espectador es incluido como si estuviese en un escenario. Esta forma de concebir y experimentar el arte es radicalmente diferente de los presupuestos del arte moderno, que, por lo menos en sus formas más convencionales, siempre se estructuró en torno a valores y estrategias que hacían al espectador salir del espacio real empírico y entrar virtualmente en el espacio virtual de la obra pictórica o escultórica.

Por el contrario, el minimalismo sitúa el espacio real empírico de la experiencia humana en el centro de su estrategia. Con el tiempo, se comprobará que esa estrategia amplió el frame donde la virtualidad puede ser experimentada, inaugurándose con eso nuevas formas de concebir y experimentar el imaginario que no desmerecen de los protagonizados por los procesos modernos.
}

FRIED, Michael, "Art and Objecthood". In: BATTCOCK, Gregory (org). Minimal Art, A critical Anthology. E. P. Dutton, Nueva York, 1968, pp. 116-147. 
de las artes plásticas. Lo que es alterado es el punto de vista de las cosas: no se experimenta un ambiente de A. Carneiro de la misma forma que se observa una pintura. De alguna manera, el artista debe eso a los dispositivos teatrales inaugurados por el minimalismo.

Ante la pérdida de la virtualidad exigida por la modernidad y que contenía en sí una cierta idea de teatralidad en la puesta en escena de los espacios casi siempre idealizados, Alberto Carneiro propone una teatralidad real y literal. Nosotros ya no nos proyectamos en lo que estamos percibiendo, sino que participamos globalmente con nuestro cuerpo en un acontecimiento que también tiene la facultad de suspender la vorágine de los días dotados de expectativas y actividades más o menos repetitivas, por más que nos demande el ejercicio de una cierta performatividad de lo banal, como es el acto de caminar. Ante la pérdida de ese pacto con el observador, en quien veía no la superficie sino la profundidad, convirtiéndose en una suerte de pantalla potencial sobre la que la percepción y la imaginación eran activadas, A. Carneiro tiene que poner el objeto en escena para que la potencialidad, en parte perdida por la casi ausencia del plano virtual, pueda ahora ser compensada por otro tipo de virtualidad basada muchas veces en la deambulación del espectador por el espacio donde se presenta la pieza. Aunque en Uma floresta para os teus sonhos, como en otros ambientes, aún subsista una estructura pictórica situada principalmente en las fronteras con las paredes de la arquitectura de la sala de exposiciones y que es responsable por la creación de una cierta apertura de cariz virtual, que la noción de paisaje requiere para ser creada. En todo caso, se trata de suspender la relación ordinaria que el espectador está habituado a establecer en su día a día. En el fondo, tanto el proceso pictórico, como el de la teatralidad real y literal buscan agilizar y transportar al espectador hacia una "realidad otra" que no la de la experiencia de la vida corriente. Se trata de proporcionar la posibilidad de tener acceso a una experiencia que se suspende en relación a los datos empíricos de la vida cotidiana.

Lo que sucedió en algunas prácticas escultóricas a mediados del siglo XX parece ser apenas una aproximación diferente en la forma como algunos artistas consideran el campo en que la obra de arte se da a experimentar al 
espectador. En ese sentido, la experiencia paisajística o ambiental, conforme se considere el pensamiento europeo o americano, no es cuestionada, no desaparece precisamente porque se produce siempre un corte con el espacio/ tiempo de la realidad y se instaura otro que puede contener espacios y tiempos diferidos.

Un ambiente de A. Carneiro obliga a una relación con el contexto; en ese sentido, cada ambiente es para leer en escena, en una situación escenográfica la pieza existe fuera de sí por correlación con un determinado espacio y con un determinado espectador potencial. Estas experiencias enfatizan y buscan al espectador y se colocan en gran medida en dependencia en relación a éste, quebrando ese nicho seguro en que, por lo menos desde el romanticismo, el autor se relaciona con su obra. Esta circunstancia une al contexto obra y observador, estableciéndose así un triángulo donde el arte pasa a ser cualquier cosa que se presenta.

La segunda fase de trabajo de A. Carneiro coincide con la emergencia del happening y de la performance, que se impone a nivel internacional durante los años 60 y 70, y que trajo consigo el efecto de perturbación cognitiva y perceptiva del espectador. En gran parte debido a una voluntad cada vez mayor de intervención no sólo estética sino también ética y política del arte, una buena parte de estas prácticas artísticas pasaron a explorar esta apertura inaugurada con el minimalismo que explota el arte en situación. El land art, la performance, los happenings acentúan esa dimensión teatral, por más que la primera se distinga de alguna manera del teatro por su relación menos jerarquizada con el espectador y con la ruptura o ignorancia de ciertos protocolos que están presentes en un espectáculo de teatro. Esta posibilidad de quebrar la línea divisoria entre el objeto y el espectador se convierte en un factor eminentemente político e ideológico. La performance, o cualquier acto que exija una participación activa del espectador, acaba por activar su conciencia o crea una especie de perturbación en el espectador, llevándole a activar su conciencia o, por el contrario, crea una situación hipnótica, o de desorientación, que coloca al 
espectador en una suerte de lugar-otro ${ }^{392}$ perceptivo. Esta última situación parece ser el caso en Uma floresta para os teus sonhos. De esa forma, entendemos que hay por lo menos dos modos o gradaciones de adhesión del espectador, esto porque la construcción de la obra considera no sólo el objeto sino también el contexto. Así, una ancla la percepción del espectador a hechos externos, ya sean culturales, políticos, éticos, etc., y otra vincula al espectador a una experiencia de inmersión completa que muchas veces apela o condiciona sus emociones, tal como sucedía en el espacio religioso barroco en que su teatralidad de característica operática coloca al espectador en un envolvimiento o espectáculo de transcendencia, sólo comparable al que, mucho más tarde, sucediera con la experiencia del cine caracterizado por una inmersión del espectador en un dispositivo dejándolo sin posibilidad de fuga.

\footnotetext{
${ }^{392}$ En un texto de Michael Foucault, titulado Espaços outros, el autor califica las heterotopías. Su calificación es bastante útil, para entender la naturaleza de los espacios ambientales o instalativos; las heterotopías son utopías realizables, son lugares reales, efectivos, "son una especie de contracolocaciones", son lugares que están fuera de todos los lugares, pero a pesar de ello localizables. Las heterotopías son una respuesta de M. Foucault a la normalización de los espacios. En A. Carneiro, cada ambiente es una heterotopía que funciona como forma de recreación de la vida a través de la materia. La construcción de la obra de arte funciona a través de una implicación física con los materiales y los espacios con los que se construye el escenario. Tal como identificó Foucault, la centralidad está en el espacio y no en el tiempo, siendo los individuos quienes recrearon a través de las heterotopías su espacialidad a lo largo del tiempo. FOUCAULT, Michel, "Espaços outros", Revista de Comunicação e Linguagens, ${ }^{\text {os }} 34 / 35$ (2005) pp. 234-252.
} 


\section{8}

\section{Analogía entre el paisaje real y los vectores paisajísticos en el ambiente Uma floresta para os teus sonhos.}

«El mundo se convierte en sueño, el sueño en mundo »

Novalis.

Rosario Assunto, en su libro titulado II paesaggio e l'estetica ${ }^{393}$, presenta la noción de paisaje que nos puede arrojar luz sobre la idea de paisaje presente en Uma floresta para os teus sonhos. Esta idea de paisaje, pensada por R. Assunto, se deriva de la "articulación con las dimensiones del espacio y del tiempo, y es descrita en el marco de estas categorías informadoras de lo real, de donde se derivan inmediatamente las cuestiones de su definición y de su identidad: identificar qué modalidades específicas del espacio configuran un paisaje y de qué modo éste asume en sí múltiples dimensiones del tiempo. Para comprender su verdadera esencia, hay que renunciar a la mera yuxtaposición del paisaje al espacio, según la cual estos dos conceptos serían co-extensivos; así como a una visión del paisaje exclusivamente realizada en el presente, ignorando su inscripción en el horizonte temporal del pasado, presente y futuro." ${ }^{394}$ Rosario Assunto empieza por distinguir el paisaje como espacio real existencial y el paisaje como representación, así "paisaje es espacio, la representación de un paisaje es representación de espacio". Aunque el libro se centre en las condiciones que cualifican la noción de paisaje real, la verdad es que muchas de sus conclusiones podrán servir, si bien que aplicadas con alguna cautela, para interpretar mejor la dinámica paisajista de Uma floresta para os teus sonhos de

\footnotetext{
${ }^{393}$ ASSUNTO, Rosario, Il paesaggio e l'estetica, 2 vols., Napoli: Giannini, 1973. La traducción portuguesa utilizada fue realizada por Pedro Sargento a partir de la $2^{\mathrm{a}}$ edición, Palermo: Edizioni Novecento, 2005. In AA.VV, Filosofia da Paisagem Uma Antologia (coord: Adriana Veríssimo Serrão), Lisboa, Centro de Filosofia de la Universidad de Lisboa, 2011.

${ }^{394}$ SARGENTO, Pedro, Rosario Assunto. In Filosofia da Paisagem: Uma Antologia, (coord: Adriana Veríssimo Serrão), Lisboa, Centro de Filosofia de la Universidad de Lisboa, 2011, p. 340.
} 
A. Carneiro, en la medida en que, al ser un penetrable o un ambiente, simula las condiciones de un paisaje real. Además, el tipo de articulación que hace R. Assunto nos interesa, pues hace coincidir el punto de vista estético con el ético y político, y por eso nos puede ofrecer respuestas para la doble adhesión del espectador: una adhesión suscitada por la simple relación de su cuerpo con el objeto y otra suscitada por hechos externos de ámbito cultural, ético y político.

Uma floresta para os teus sonhos está contenida en una arquitectura y eso hace de ella, a partir de los presupuestos de Assunto, un caso específico de no paisaje. Para Rosario Assunto, paisaje es la naturaleza entendida a partir de ciertas condiciones espaciales y temporales. "A la pregunta: ¿qué es un paisaje?, una primera respuesta, no desprovista de carácter persuasivo, es aquella que reconduce el concepto de paisaje al concepto de espacio. Es una respuesta sin duda verídica, en la medida en que el paisaje, cada paisaje -real o imaginario, espontáneo o artificial- es siempre un espacio. Es un espacio, (o representa algo que está en el espacio) (...) Cuando decimos que el paisaje es espacio (o representación de espacio) y no objeto en el espacio (o representación de objetos en el espacio), queremos con esto decir que el paisaje es el propio espacio que se constituye como objeto de experiencia y tema de un juicio -en nuestro caso, a partir del momento en que la cuestión del paisaje quiere ser, y es, una cuestión estética, paisaje es el espacio que se constituye en objeto de experiencia estética, y tema de un juicio estético.. ${ }^{395}$ La autora prosigue y nos da cuenta de la naturaleza específica de este espacio, ya que, de la misma forma que no todas las pinturas, vale decir aquí representaciones virtuales de espacio, son paisajes, tampoco todos los espacios reales son paisajes. Por ejemplo, "un salón, u otro interior cualquiera, ni siquiera metafóricamente se pueden decir paisajes: y sin embargo nadie negará que son espacios, y espacios estéticamente apreciables, juzgables en un juicio estético precisamente por su espacialidad" ${ }^{396}$. Uma floresta para os teus sonhos, por ser instalada siempre en el interior de una arquitectura de una galería o museo, se encuentra en esta

\footnotetext{
${ }^{395}$ ASSUNTO, Rosario, A paisagem e a estética. In Filosofia da Paisagem. Uma Antologia, Trad. Pedro Sargento (coord: Adriana Veríssimo Serrão), Lisboa, Centro de Filosofia da Universidade de Lisboa, 2011,p. 341.

${ }^{396}$ Ibidem, pp. 343 y 344.
} 
clase de espacio que, desde el punto de vista de R. Assunto, no es paisaje. Y el autor prosigue determinando mejor en términos espaciales la noción de paisaje entendida no como representación sino como paisaje real,

debemos ahora ver cuáles son estas notas del concepto de paisaje (...) para entender qué notas en el concepto de paisaje corresponden al ser el paisaje espacio, mientras que no todo el espacio es paisaje, podemos partir de algunas exclusiones (...) la exclusión del espacio cerrado -que un interior es espacio, incluso estéticamente, pero no es paisaje y la exclusión del espacio ilimitado, como es a nuestros ojos el cielo a cualquier hora del día o de la noche y en cualquier estación o coyuntura meteorológica. El cielo no es paisaje, pero con su presencia define el paisaje como espacio abierto -por así decir, abre el paisaje- no menos en cuanto al suelo, cualquiera que sea la configuración topográfica y esté o no poblado de construcciones humanas, ocupado por vegetación, habitado por animales determina el paisaje. ${ }^{397}$

El espacio paisaje es para R. Assunto un espacio finito pero con una promesa de apertura contenida en la propia finitud; es decir, sólo estamos ante un paisaje si ese espacio es exterior y puede ser limitado de alguna forma por nuestra percepción y entendimiento. Es del balance entre tierra y cielo entendidos como finitud y promesa de apertura que el paisaje se hace existir como espacio para el ser que lo habita y contempla. La figura 51 presenta de modo esquemático la noción de espacio/paisaje de R. Assunto. El esquema es algo rígido y demasiado estructuralista para hacer justicia a la profundidad del razonamiento del autor, pero sirve para mostrar cómo la tierra, el suelo y el cielo son agentes de apertura del paisaje que, para existir, tiene que ser un espacio paradójicamente limitado y abierto al infinito. Por el contrario, otros espacios arquitectónicos citados por el autor, como la Basílica de Santa Sofía en Constantinopla o los salones barrocos, son espacios limitados también como el espacio/paisaje, pero son finitos por ser espacios cerrados. No obstante, pueden representar el infinito y los espacios barrocos lo hacen "simbólicamente en su forma precisamente espacial”398. Empero el infinito es aquí solamente simbólico; sólo momentáneamente se olvida que un cuerpo que se encuentra dentro de una

\footnotetext{
${ }^{397}$ Ibidem, pp. 344 y 345.

398 Ibidem, p. 345.
} 
arquitectura barroca está bajo una arquitectura cerrada; estos espacios tienen que ser entendidos "como representación ilusionista del infinito en un espacio cerrado." ${ }^{399}$ Por su parte, el paisaje, por ser un espacio limitado "pero abierto, porque, a diferencia de los espacios cerrados, tiene sobre sí el cielo, esto es el espacio ilimitado; y no representa el infinito (de forma simbólica o ilusionista), pero se abre al infinito, incluso en la finitud de su ser limitado: constituyéndose como presencia, y no representación, del infinito no finito (...) esta, mientras recibe en sí el infinito, es finitud abierta, así como el infinito, pasando a la finitud es infinitud limitada" 400 .

En Uma floresta para os teus sonhos, los troncos de madera tienden a extenderse por la sala ortogonal; esa distribución, algo asistemática por las diferentes alturas de los troncos y densidades de concentración, crea la ilusión de espacio ilimitado, sobre todo porque cuando el espectador camina por entre los troncos de madera olvida o suspende la existencia física y ortogonal de las paredes de la sala de exposición. Parece haber cualquier cosa de barroco en esta estrategia, sobre todo en un cierto ilusionismo pictórico deliberadamente construido en los márgenes de la intervención escultórica, o sea, el escultor tiende a alejar al espectador de los márgenes de la arquitectura. En Uma floresta para os teus sonhos son muchos los momentos, en la disposición de los troncos de madera, en que no podemos tocar en la pared porque existen troncos de madera que quieren apuntar de modo concreto e ilusionista la idea de distancia. $Y$ en los momentos en que podemos aproximarnos de la pared, tenemos siempre un camino que se abre delante de nosotros. Esa estrategia aparece documentada de forma más obvia en las fotografías de Um campo depois da colheita para deleite estético do nosso cuerpo (Un campo después de la cosecha para deleite estético de nuestro cuerpo, 1973-76). Si observamos las figuras 52 y 53 que proceden de la instalación realizada en el Centro Galego de Arte Contemporánea, en Santiago de Compostela, el año 2001, nos damos cuenta de que el escultor ha concentrado cuidadosamente los haces de paja, tendiendo a cubrir la casi totalidad de pared visible a partir de la entrada en la sala. Además,

\footnotetext{
399 Ibidem.

${ }^{400}$ Ibidem.
} 
los haces de paja son, en ese lugar, mucho más pequeños que los que se sitúan en el centro de la sala, lo que ayuda a reforzar el carácter pictórico de la composición escultórica, pues esos haces son siempre vistos a partir de su sujeción al plano vertical de la pared y por lo tanto su dispositivo de actuación escénico es en ese lugar pictórico. Es obvio que, para A. Carneiro, la cuestión del límite era importante; ciertamente quiso mimetizar las condiciones de finitud y apertura que cualquier paisaje presenta. El problema es que, si desde el punto de vista de la realización pictórica esa es una cuestión que se resuelve en la unidad derivada del uso correcto de los recursos perspectiva lineal, cromática y atmosférica, cuando se pasa a la manipulación de objetos en el espacio, sólo la distancia del cuerpo del observador y el carácter escenográfico consiguen escenificar la idea de infinito.

A pesar de que, durante su segundo periodo de trabajo, A. Carneiro niegue las tecnologías de la mano responsables de un modelado orgánico y barroco de la superficie de la madera, material del que era hecho el objeto escultórico durante la primera fase, la verdad es que podemos decir que ese sentido del Barroco pasa del modelado del objeto a la concepción de espacios ambientales escultóricos. En este contexto el Barroco supone la transformación de la superficie de la arquitectura, proveyendo al sujeto de hitos para una vivencia del espacio a partir de puntos de vista múltiples; un espacio de esta naturaleza es incapaz de ser estático. "El Barroco supondría la emergencia de una representación transformativa (inclusión del espectador en la obra, puntos de vista múltiples, uso de las distancias y continuidad espacial, exploración de nuevas relaciones con la naturaleza, asunción de los aspectos subjetivos de la percepción) que se prolonga a la contemporaneidad. ${ }^{401}$ Para comprender de qué modo el espacio barroco induce, en palabras de R. Assunto, un tipo de «representación ilusionista del infinito en un espacio cerrado», podemos profundizar algunas de sus determinaciones a partir de la teoría sobre el Barroco de Wölfflin ${ }^{402}$, en el sentido de poder establecer relaciones entre el modo de

\footnotetext{
${ }^{401}$ FLÓREZ, Fernando Castro, "Robert Smithson. El dibujo en el campo expandido". in Juan José Gómez Molina (Coord.) Estrategias del Dibujo en el Arte Contemporáneo. (pp. 553-592). Madrid, Cátedra, 2002, p. 554.

${ }^{402}$ WÖLFFLIN, Heinrich, Renacimiento y Barroco, Barcelona, Ediciones Paidós, 1986.
} 
construir espacialidad barroca y la estrategia espacial paisajista proyectada y construida en Uma floresta para os teus sonhos.

Los ambientes de Alberto Carneiro repiten en muchos aspectos las condiciones del espacio real del paisaje, en la medida en que, siendo algo barrocos, no buscan la estabilidad -como hiciera el arte renacentista-, sino el movimiento, la inestabilidad, la empatía y la deambulación constantes.

El Barroco tal como lo definió Wölfflin tiene como principales determinaciones el hecho de no temer las proporciones impuras, ni la disonancia. Por tanto, el cuerpo que hace la experiencia de la arquitectura barroca experimenta una serie de relaciones de distancia con el espacio; su efecto de masa es responsable de la creación de un espacio de inmersión construido en la arquitectura, sobre todo por la supresión de los pilares. Así, las iglesias y los palacios barrocos privilegian una cierta noción de campo horizontal, en detrimento de las verticales que en la arquitectura son las grandes responsables de la noción de cierre propia de la arquitectura. En vez de trabajar un espacio en función del sentido de la elevación, la arquitectura barroca parece bajarse, tornándose campo, en vez de objeto. "El elemento fundamental de la impresión experimentada es la fuga horizontal de la línea basal." ${ }^{403}$ A esta noción de espacio como distancia, se juntan tipos de transición muchas veces de carácter artificial que tienden a abolir la presencia de la forma; ésta no se distingue claramente contra un fondo como sucedía con el espacio renacentista. El espacio de la arquitectura barroca hace contrastar espacios interiores con exteriores. Lo que cuenta son las apariencias y no la verdad estructural de los edificios que en el Renacimiento eran concebidos como unión de partes aisladas y que en el Barroco se convierten en espacios amplios unificados, exhibiendo escalas grandiosas y un efecto de masa que avanza, dobla y redobla el espacio en dirección al vacío $0^{404}$ no ocupado por la masa de la arquitectura.

\footnotetext{
${ }^{403}$ Idem, p. 47.

${ }^{404}$ Deleuze presenta el espacio barroco a partir de la noción de exceso que se orienta en la dirección del interior del negativo. En esta concepción, el pliegue, responsable de la ampliación del espacio, posee un interior que se abre en volutas y circulan en ese sin fin dentro del espacio que se va tornando vacío por la acción del pliegue que se despliega. Esta acción produce un tipo de espacio que se puede calificar de negativo, en el sentido de que la forma sólo adquiere sentido a partir del
} 
El Barroco, en la lectura de Wölfflin, posee esencialmente cuatro características que, una vez enumeradas, nos parecen útiles para determinar mejor la naturaleza del espacio de Uma floresta para os teus sonhos. Las características son: el estilo pictórico, lo grandioso, la masividad o efecto de masa y el movimiento. De forma sintética, el estilo pictórico se deriva del hecho de que la arquitectura quiere adoptar las características de otra arte: la pintura. Ya al comienzo de las consideraciones sobre lo que es el estilo pictórico, el autor concreta: «¿Qué significa pintoresco? Basta con decir en un principio: es pintoresco lo que constituye un cuadro, lo que, sin necesidad de añadir nada, ofrece al pintor un modelo. ${ }^{405}$ De la misma forma que un paisaje real se puede presentar como modelo para una pintura, también la arquitectura barroca o el arreglo espacial de Uma floresta para os teus sonhos se puede constituir como modelo para la pintura. Esto porque el espacio barroco $-\mathrm{y}$, en cierto sentido, como vimos, el de los ambientes de A. Carneiro- trabajan las apariencias. El estilo pictórico, por su parte, posee cinco cualidades: es irregular, accidental, impreciso, informal y elusivo. Quien experimenta Uma floresta para os teus sonhos, incluso sin querer calificar aquel espacio de Barroco, debe reconocerse que allí existe la irregularidad y el carácter accidental de los elementos -troncos de madera- que imperan. También el carácter impreciso se revela. "El desorden pintoresco requiere que la representación de los distintos objetos en sí mismos no sea totalmente clara, sino que quede en parte velada. El motivo del cubrimiento es uno de los más importantes de este estilo (...) los objetos se sobreponen, no se muestran más que en parte, estimulando la imaginación al más alto grado para adivinar lo que está oculto." ${ }^{406}$ El estilo pictórico saca partido de los grandes contrastes de luminosidad de claroscuro que ayudan a disolver los contornos de la arquitectura y su carga ornamental. Todo esto induce en el sujeto observador la impresión y expresión de movimiento, que es algo que se encuentra también en Uma floresta para os teus sonhos de A. Carneiro, donde

\footnotetext{
hueco o de lo abierto espacial. DELEUZE, Gilles, A dobra. Leibniz y el Barroco, Trad. Luís B. L. Orlandi, São Paulo, Papirus Editora, 1992.

${ }^{405}$ WÖLFFLIN, Heinrich, Renacimiento y Barroco, Barcelona, Ediciones Paidós, 1986, p. 29.

${ }^{406}$ Idem, p. 34.
} 
"mirada y pensamiento se pierden en los espacios inconmensurables." ${ }^{407}$ Esta dinámica de la imprecisión ayuda a entender porque es la responsable del carácter ilimitado que el artista quiso crear en cada uno de los ambientes, en particular en el de nuestra atención que trabaja la idea de bosque, tornando presente de forma literal para el cuerpo la casi totalidad de las características que se podrían encontrar en un bosque real, pero sin nunca abandonar la evidencia propia de un dispositivo de actuación que es simultáneamente escénico real y en parte concreto pictórico.

El estilo grandioso y el efecto de masa, además de determinar mejor la especificidad del Barroco, presentan ciertas características también comunes al rococó francés, capaces de crear un efecto inmersivo en el sujeto. El efecto de masa se deriva directamente de la aplicación del estilo pictórico que, como vimos a la luz de la reflexión de Wölfflin, potencia la imprecisión: "este estilo no busca formas, figuras, motivos tomados en sí mismos, sino un efecto de masa, no un espacio delimitado, ¡sino un espacio infinito!" ${ }^{408}$ Por último, otra característica del espacio barroco es el movimiento. La noción de movimiento remite obviamente a la vida, caracterizada por ser animada y no inerte. En el fondo, lo que el espacio barroco propone es que un cuerpo vivo viva. Mientras en la arquitectura renacentista se asiste a la evocación de la tranquilidad y de la satisfacción, el Barroco, por el contrario, "quiere cautivar con el poder del afecto, directo y arrollador. Lo que aporta no es animación regular, sino sobresalto, éxtasis, embriaguez" ${ }^{409}$ con objeto de imprimir en el sujeto una sensación fuerte que después acaba por abandonar rápidamente. "La arquitectura se vuelve dramática, la obra de arte no está constituida por una serie de bellezas cerradas, que reposan en sí mismas, sino que únicamente dentro del conjunto lo particular adquiere valor y significación, sólo en el conjunto existe una conclusión tranquilizadora y una limitación. ${ }^{\text {"10 }}$ El movimiento está asociado al accidente, al error, lo que es decir la aceptación de la vida no sujeta a la rigidez de reglas. De

\footnotetext{
407 Ibidem, p. 70.

${ }^{408}$ Ibidem, p. 35.

409 Ibidem, p. 39.

${ }^{410}$ Ibidem, pp. 74 y 75.
} 
este modo, puede crearse un campo de experiencia sensible y un espacio de empatía que, en su esencia, es paisajístico.

Se atribuye a la arquitectura barroca la sugestión de movimiento y de percepción táctil ${ }^{411}$. Intrincado con esta cuestión está el concepto de empatía trabajado por Willem Worringer ${ }^{412}$. Para este autor, la empatía (Einfühlung) es una proyección sentimental. "Esta «proyección sentimental» se puede encontrar de una manera más clara en el origen de los movimientos expresionistas que se apoyan en la sustancia y la materia, cuando hacen evidentes las cualidades sólidas de la masa y el volumen, al perfilar contornos y siluetas y mostrar opacidades y texturas" ${ }^{\prime 413}$. La cuestión central ha sido determinar cómo el espacio barroco, en el ejemplo de la arquitectura, hace desarrollar la emoción en el

\begin{abstract}
411 Para Alois Riegl, en su libro titulado Late Roman Art Industry, la principal evolución del arte tardorromano en relación a la del Antiguo Egipto es su noción de espacio. Objetivando el espacio, concluye que éste, considerado entre los objetos, pasa a ser visto como un espacio vacío; así, el arte tardorromano indicaría un uso del espacio como elemento a tener en cuenta en la arquitectura y en la escultura. A esta noción de espacio, Riegl añade la idea de que la arquitectura tardorromana inicia también la creación de una impresión de movimiento derivada directamente de la creación de espacio. Esta sugestión de movimiento se produce no porque el espacio se mueva efectivamente ante el espectador, sino porque el sentido del tacto es el que mejor aprehende la profundidad. Más precisamente, la percepción óptica es siempre coadyuvada por la reminiscencia de la percepción háptica. Son estos factores los que recrean la noción de movimiento. RIEGL, Alois, Late Roman Art Industry, Roma, Giorgio Bretschneider Editore, 1985.
\end{abstract}

Uno de los últimos libros de Alois Riegl se titula El origen del arte barroco en Roma (Die Entstehung der Barockkunst in Rom, 1908). En este libro, el autor establece el puente entre sus teorías sobre el movimiento y la tactilidad con las teorías ya antes elaboradas por $\mathrm{H}$. Wölfflin, especialmente en «Renascença e Barroco". Innumerables veces, a lo largo de rodo el siglo XX, el Barroco fue explotado de tal forma que invita a considerarlo no sólo como un momento de la historia del arte, sino sobre todo como una categoría independiente de la cronología de su aparición. A este respecto ver " $A$ Idade Neobarroca" de Omar Calabrese, (CALABRESE, Omar, A Idade Neobarroca, Lisboa, Edições 70, 1999.) y también los estudios de Christine Buci Glucksmann, en particular BUCI- GLUCKSMANN, Christine "La folie de voir. De l'esthètique baroque", París: Galilée, 1986.

${ }^{412}$ A pesar de que fue el fenomenólogo Edmund Husserl el primero en trabajar en torno al término "Einfühlung", vulgarmente traducido por "Empatía», su desarrollo en el campo de la estética se produce con el trabajo de Wilhelm Worringer, especialmente con su libro «Abstraktion und Einfühlung, Berlín, 1908». En ese libro, Worringer presenta la idea de que las creaciones artísticas de los diferentes pueblos desde la edad preclásica derivan de la manifestación de dos importantes impulsos psíquicos: la abstracción o la empatía, que son sus índices más completos a tener en cuenta en la caracterización de la voluntad y la creación de un pueblo. Así, la mayor o menor prevalencia de la abstracción o empatía va a encontrarse con certeza en la materialización de las obras de arte. En este sentido del inventario de las apetencias expresivas de los pueblos, Worringer, en la obra citada, hace notar que hay una relación directa entre la empatía y la mayor tendencia hacia el vigor orgánico manifestado en el arte, que también se puede identificar por una mayor apetencia por la representación naturalista. El título original es Abstraktion und Einfühlung, Berlín, 1908, pero aquí hemos utilizado la versión española: WORRINGER, Wilhelm, Abstracción y Naturaleza, Trad. española de Mariana Frenk. 2. ${ }^{a}$ ed., México-Buenos Aires, Fondo de Cultura Económica, 1966.

${ }^{413}$ MADERUELO, Javier, La idea de espacio en la arquitectura y el arte contemporáneos, 1960-1989, Madrid, Akal, 2008, p. 26. 
individuo que la experimenta para que, a partir de ahí, podamos crear puentes con la emoción sentida por un sujeto en el paisaje real y, por consecuencia, también en Uma floresta para os teus sonhos.

Para Wölfflin, la arquitectura tiene una capacidad expresiva, tal como una pintura o una escultura. Ante la arquitectura, el individuo puede desarrollar una determinada empatía hacia la forma de los objetos inanimados, para que ésta exista, el individuo tiene que olvidarse de sí mismo y quedar absorbido, inmerso, por esa realidad inanimada que le es exterior. También se debe considerar que, para que haya empatía, la atención debe dirigirse no solamente a cuestiones formales, sino sobre todo a otro tipo de asociaciones, como las históricas, funcionales $u$ otras características como las cualidades materiales, el color, etc. Para ser más explícito, la adhesión a objetos inanimados como la arquitectura implica para Wölfflin un tipo de vinculación o de recepción fuertes: "la compasión" ${ }^{\prime 14}$. Así, para que haya empatía o capacidad expresiva de la arquitectura, ésta no debe contener en sí un puro juego de formas y de espacios, sino estar cargada de intensidades otras, como por ejemplo morales o intelectuales. O sea, la empatía es una suma entre el pathos y el logos. De las cualidades físicas de un espacio se accede a las morales y después a las intelectuales, en una prolongación que hace desplazar al individuo del sentimiento de sí mismo hacia el exterior, hacia fuera de sí, provocando de este modo movimientos en la consciencia.

Uma floresta para os teus sonhos introduce, ya en el título, un llamamiento a la empatía. Los objetos inanimados que la constituyen -troncos de madera organizados a partir de la lógica espacial barroca- impelen al individuo a caminar, a crear una experiencia estética que se constituye como ejercicio psicofísico, afectivo e intelectual. Por tanto, será llevado a olvidarse de sí y a vagar en el espacio sin ningún propósito finalista. Ese espacio, aunque sea limitado porque Uma floresta para os teus sonhos está contenida por la arquitectura, se presenta ilimitado por su lógica laberíntica. Por otro lado, para el

\footnotetext{
${ }^{414}$ WÖLFFLIN. H., Prolegomena to a Psychology of Architecture, Empathy, forms and Space. K.W. F. Julia Bloomfield, Thomas F. Reese. Santa Monica, The Getty Center for the History of Art and the Humanities, 1994, 149-190; p.149.
} 
disfrute de la obra, tiene sentido que el espectador participante convoque varios otros niveles de información e historia como el dibujo de proyecto y la narración de la autobiografía del autor que constantemente vincula sus episodios de vida a los lugares del paisaje real, así como a sus reflexiones teóricas hechas públicas en textos ya editados. De esta forma, parecen estar plenamente reunidas todas las condiciones para que cada persona que experimenta Uma floresta para os teus sonhos lo haga encuadrada en una experiencia empática que reúne simultáneamente el pathos y el logos, seducido por el artista a través de la creación de un vínculo con la naturaleza. Podemos decir que la representación de Uma floresta para os teus sonhos es aquí pretexto para explorar los bosques que se pueden encontrar en nuestras reminiscencias 0 en el paisaje natural. Alberto Carneiro parece querer invitarnos a caminar por el paisaje real, por los lugares que nos hacen crear raíces con el exterior, porque el paisaje sólo se descubre verdaderamente por el caminar, que es lo que propone Uma floresta para os teus sonhos.

R. Assunto usa muchas veces la pintura para traducir reflexivamente el tipo de espacio virtual que recrea a su equivalente correlato en términos de espacio del paisaje real. No obstante, tenía conciencia de un cierto sentido de paisaje que no pasaba por la pintura, que, en los años en que escribió II paesaggio e l'estetica, se manifestaba en los primeros ambientes o instalaciones donde lo que era naturaleza virtual de la pintura "representación del paisaje fue sustituida por la presentación del espacio." ${ }^{415}$ A mediados del siglo XX, no se habrá producido exactamente una sustitución del espacio paisaje como representación hacia un espacio paisaje como presentación, especialmente en las prácticas escultóricas de esos años, sino una transformación y mayor heterogeneidad de los medios de expresión que pasaron a trabajar el espacio paisaje.

Si Rosario Assunto usó las representaciones bidimensionales de paisajes para inferir sobre la naturaleza espacio-temporal de los paisajes reales, podemos

\footnotetext{
${ }^{415}$ ASSUNTO, Rosario, A paisagem e a estética. In Filosofia da Paisagem. Uma Antologia, Trad. Pedro Sargento (coord: Adriana Veríssimo Serrão), Lisboa, Centro de Filosofia da Universidade de Lisboa, 2011, p. 342.
} 
sin subestimar el riesgo, usar el mismo método, aunque invertido y con los debidos cuidados. En otras palabras, podemos servirnos de las características de los paisajes reales para intentar profundizar la naturaleza espacial de Uma floresta para os teus sonhos y así sacar consecuencias que nos sean útiles, sin nunca olvidar que, de ser un paisaje, esta obra lo es en el sentido de la representación -si por representación entendemos «hacer presente de nuevo», en alemán «darstellen», y no «estar en vez de» como es el sentido normalmente asociado a la presencia virtual de la pintura.

Darstellen ${ }^{416}$ tiene un sentido más apropiado para Uma floresta para os teus sonhos, pues es un tipo de representación que pretende devolver «presencia de nuevo»; por tanto sería aquello que designamos como presentación, que se opone a la noción convencional de representación ${ }^{417}$ que remite siempre a una imagen en diferido realizada a partir de un objeto, y cuyo principal objetivo tiende casi siempre a ser la captación de la apariencia de ese mismo objeto. Ahora, lo que está en causa en Uma floresta para os teus sonhos no es la representación en diferido y a partir de la memoria de un paisaje vivido, no es la construcción de una imagen bidimensional y virtual de ese mismo bosque, sino antes una tentativa de restitución, en el contexto de lo escultórico, de una experiencia espacial que se ofrece al cuerpo casi del mismo modo que se ofrecería al cuerpo una experiencia en un paisaje real. Tendremos que indagar sobre esta condición espaciotemporal de Uma floresta para os teus sonhos, porque sólo parece encontrar equivalente en el ámbito artístico o ritual de las experiencias que los hombres prehistóricos habrán tenido ante sus espacios sagrados o megalíticos; esto es, una experiencia primordial donde todos los sentidos parecen estar implicados. Pero existen las debidas diferencias, como

\footnotetext{
${ }^{416}$ Darstellen significa: «representar; demostrar, (teat.), Interpretar; (beschreiben), describir; (bilden) construir; (quimi.) preparar; (mit worten) exponer; (téc.) elaborar; (zeigen) mostrar; bildlich, figurar, representar; sinnbildich, simbolizar». La acción de hacer presente en alemán es darstellung, y significa presentación, demostración, exhibición, etc. Dicionário de Alemão Português, $1^{\mathfrak{a}}$ ed., Oporto, Porto editora,1985, p. 210.

${ }^{417}$ En portugués, el término "representación" tiene las siguientes acepciones: 1. Acto o efecto de representar; 2; Imagen, dibujo o pintura que representa una escena, una persona o un objeto; figura; reproducción; 3. Copia; 4. Escultura, 5. Exposición; 6. (Teatro) exhibición en escena; 7. Espectáculo teatral; 8. (Cine, Teatro, Televisión) Desempeño de actores; interpretación; actuación 9. Imagen mental de percepción interior, etc. Dicionário da Língua Portuguesa, $1^{\text {a }}$ ed., Porto, Oporto editora, 2010, p. 1378.
} 
vimos en el segundo capítulo, alertados por Rosalind Krauss, pues grande es la tentación de querer colocar creaciones artísticas contemporáneas en una línea legitimadora historicista que siempre encuentra para un objeto nuevo su correspondiente antiguo. Uma floresta para os teus sonhos nos propone una experiencia nueva, perteneciente a nuestros días y está encuadrada por el arte y por la práctica de la escultura en el campo expandido; la comparación con otras formas de relación del cuerpo con el espacio y el paisaje que habrán existido en la prehistoria sólo tienen sentido a partir de un punto de vista existencialista y no historicista.

Es innegable que, a partir de mediados del siglo XX, y hasta los días de hoy, el hombre demanda del arte la oportunidad de experimentar estéticamente las condiciones de una experiencia primordial, capaz de activar el máximo de sentidos, en el fondo, una mímesis de la experiencia que sólo puede dar la presencia efectiva del cuerpo en el paisaje natural. Hoy, como a mediados del siglo pasado, esa naturaleza y esa experiencia escasean. Asistimos a la muerte del paisaje natural y, con ella, asistimos también al colapso de una experiencia humana fundamental: la de la inmersión del cuerpo que encuentra un vínculo con las cualidades espacio-temporales del paisaje. $\mathrm{Y}$ por aquí se desprende la importancia de propuestas escultóricas como Uma floresta para os teus sonhos, y la necesidad de profundizarlas tanto desde el punto de vista teórico como práctico.

\section{9}

\section{Espacio paisaje como dispersión}

Encontramos en Robert Morris que otro punto de apoyo para mejor comprender el sentido paisajístico de Uma floresta para os teus sonhos. En su ensayo de 1969, Notes on Sculpture, un conjunto de textos que el artista publicó en años consecutivos en la revista Art Forum, Robert Morris centra la cuestión de la práctica escultórica no en una definición de la Gestalt de la escultura, es decir, 
como algo que se define perfectamente recortado en el campo visual contra un fondo, sino en una acepción de la escultura que parte del campo de la visión y de un ejercicio de la mirada en relación a un fondo que no comporta figura. Para Morris, el problema es lo que le sucede al campo visual en sentido amplio, en dispositivos escultóricos como las dispersiones de materias de Barry Le Va, de Richard Serra, o de sus propias propuestas en el interior de la arquitectura de la sala de exposición, pero también de los dispositivos de espejos de Robert Smithson tanto en el interior, como en el exterior de la arquitectura.

La cuarta parte del texto de R. Morris, Beyond Objects, es tal vez el primer ejemplo de fundamentación teórica de un nuevo entendimiento de la relación entre escultura y paisaje, pues el paisaje, hasta mediados del siglo XX, había constituido, a lo largo de la historia de la pintura, la más amplia teoría de organización del campo visual a partir de la idea de jerarquización del espacio. Robert Morris y Robert Smithson son los primeros artistas en trabajar en el campo expandido de la escultura nuevas relaciones con el paisaje, y que darán los vectores principales para las prácticas que caracterizarían el postminimalismo que se centran en la idea de sustitución del paisaje en tanto que representación jerarquizada, o simplemente ordenada, del campo visual, hacia una idea de paisaje como presentación y presencia efectiva en el espacio de exposición, que se asume también como lugar de convivialidad, como operación sobre la idea de mundo, muy influida por el concepto de deriva ${ }^{418}$ de Guy Debord.

Este reencuentro con la categoría del paisaje, llevado a cabo por Robert Morris, se caracteriza primero por una reacción a la iconografía idealizada

\footnotetext{
${ }^{418}$ La Teoría de la Deriva surgió a mediados de los años 50 por la Internacional Situacionista, con antecedentes Letristas. Esta se fundamenta en la práctica de la deambulación urbana.

101- La palabra Deriva (Dérive) aparece en primer lugar en el texto de Ivan Chtcheglov, Formulário para um novo urbanismo de 1953, que describe, bajo fuerte influencia del naciente psicoanálisis, una idea de ciudad que se modifica constantemente por acción de sus habitantes.

Más tarde, en 1955, Guy Debord, escribe Introduction à une critique de la géographie urbaine, que proponía procesos de observación de la ciudad basados en el azar. En la Teoría de la Deriva, el azar, al contrario de lo que sucedía con los paseos surrealistas, no es tan determinante, pues la tónica se coloca en la llamada Psicogeografía de la ciudad, una cartografía psicológica y geográfica de la ciudad experimentada por grupos de dos o tres personas durante la deambulación por la ciudad laberíntica con sus puntos fijos y ordenados y zonas confusas o sin salida. DEBORD, Guy E., "Théorie de la derive", in Les Lèvres Nues, 8/9, Brussels, November 1956.
} 
romántica, por otro lado procuraba desafiar el carácter cristalizado de la escultura moderna dando nuevos desarrollos en relación a su propia producción anterior minimalista basada en Gestalts. A partir de aquí, este artista propone un modo paisajístico basado en la idea de un campo visual sin punto de vista determinado, y escribe R. Morris: "Campos de cosas, que no tienen ningún foco central y se extienden más allá de nuestra visión periférica, pueden entonces ofrecer un tipo de «paisaje» como un modo paisajístico oponiéndose a un tipo de auto-contenido de organización ofrecida por el objeto específico." ${ }^{419}$ En esta afirmación se reconoce el distanciamiento operado por $\mathrm{R}$. Morris en el campo teórico-práctico de la cuestión de la gestalt de la escultura, que había sido definida por Donald Judd en su idea de objeto específico (specific object). De este modo, Morris coloca la escultura en un campo ampliado donde la visión se pierde por su expansión, dejando de tener un punto de concentración estático que se ofrezca a la contemplación, como sucedía en la producción de paisajes pictóricos.

Este nuevo modo paisajístico se presenta como una mayor pluralidad perceptiva y también como alternativa en relación a lo que había caracterizado el Minimalismo. Uma floresta para os teus sonhos se integra bien en este tipo de concepción espacial que, a partir de finales de los años 60; encontraba en Alberto Carneiro uno de los más notables practicantes de esta nueva organización espacial basada en la idea de pulverización o de dispersión en el campo visual que permite superar la dicotomía entre la llamada escala objetual y monumental a través de una nueva escala, la paisajista.

El texto Beyond Objects, de R. Morris, remite a una referencia teórica importante: el crítico Anton Ehrenzweig, quien en 1967 publicó The Hidden Order Of Art - A Study in The Psychology of Artistic Imagination ${ }^{420}$, que fue importante a finales de los años 60 , no sólo para Robert Morris, sino también para muchos

\footnotetext{
${ }^{419}$ MORRIS, Robert, Continuous Project Altered Daily, The Writings of Robert Morris, Massachusetts, MIT Press, 1995, p.57. «Fields of stuff that have no central contained focus and extended into or beyond the peripheral vision offer a kind of "landscape" mode as opposed to a self contained type of organization offered by the specific object.».

${ }^{420}$ EHRENZWEIG, Anton, The Hidden Order Of Art - A Study in the Psychology of Artistic Imagination - 1aㅡ Edición Publicada en 1967 por Weidenfeld \& Nicolson, Londres. Traducción portuguesa: $A$ Ordem Oculta da Arte - A Psicologia da Imaginação Artística, Río de Janeiro, Zahar Editores, 1977.
} 
artistas portugueses, que a finales de los años 60 tuvieron acceso a esta publicación vía traducciones francesas.

Para la elaboración teórico-práctica de esta idea de paisaje como dispersión, mucho contribuyeron las ideas de Anton Ehrenzweig, para quien existen dos tipos de visión (la analítica y la sincrética o no-diferenciada) sirviendo el reconocimiento de la hegemonía de la primera para justificar su opción de profundización por la segunda. La visión no-diferenciada o sincrética se presenta más favorable y exigente en relación a un barrido (scanning) de formas más complejas, pues tanto figura como fondo en el contexto del pensamiento de este autor, como en Morris; asumen la misma importancia, siendo por eso hipersensible a las más pequeñas señales, al mismo tiempo que es bastante más eficaz ante lo indefinido o difuso. "La visión sincrética (...) surge mucho más flexible que la visión analítica. Así considerado, podemos invertir los valores normales y considerar la visión analítica como más cruda y menos sensible que los modos no-diferenciados (sincréticamente) de visión, que son conseguidos en los niveles primitivos (infantiles) de percepción. ${ }^{421}$ Este modo de visión sincrético o no-diferenciado se produce cuando el individuo tiene una "atención difusa y esparcida en contradicción con nuestros hábitos normales y lógicos de pensar." ${ }^{\text {222 }}$ El pensamiento consciente que normalmente es exigido ante un campo de visión con foco definido, "es nítidamente focalizado y altamente diferenciado en sus elementos; cuanto más penetramos en la imaginación (...) tanto más esa orientación única del pensamiento se divide y se ramifica en direcciones ilimitadas, haciendo que, al final, la estructura parezca caótica." ${ }^{423}$ Para A. Ehrenzweig, la comprensión del campo artístico no puede ser reducida a la racionalidad, pues es asimilable a un campo comunicacional y a un nivel psíquico más profundo que se deriva de una selección inconsciente y de una integración que escapa a cualquier examen intelectual, de forma que sólo esa

\footnotetext{
${ }^{421}$ EHRENZWEIG, Anton, A Ordem Oculta da Arte - A Psicologia da Imaginação Artística, Trad. de Luís Coração, Río de Janeiro, Zahar Editores, 1977, p. 24.

${ }^{422}$ Idem, p. 14.

${ }^{423}$ Ibidem, pp. 14 y 15.
} 
selección es capaz de prestar valor al caos, a lo asistemático y, en consecuencia, al movimiento.

En Uma floresta para os teus sonhos, proporcionalmente al vacío existente entre los objetos -troncos de madera- a favor de su pulverización en el espacio, se asiste a la posibilidad de que el espectador; por su performatividad, desarrolle una visión sincrética o no-diferenciada. Esta es suscitada por el andar del espectador que así experimenta un mecanismo pre-cinematográfico que corresponde, en última análisis, a una intensificación de la imaginación, derivada del hecho del caminar en un espacio laberíntico que exige constantemente nuevas tomas de dirección y de consciencia. Esta actividad psicofísica e imaginativa inducida por la instalación en estudio encuentra en Uma Línea para os teus sentimentos estéticos (1970 -71) su corolario más claro. Esta obra, que A. Carneiro considera la «más conceptual de todas» ${ }^{424}$ las suyas, consta de "una línea que recorre todo el espacio expositivo de la pared y cuando hay un intervalo, zona ocupada por una puerta, etc., se extiende por el suelo, como siempre sucede cuando nosotros tenemos un vacío, nuestros sentidos se orientan hacia el suelo." ${ }^{425}$ La línea es colocada en la pared a nivel de la cabeza del artista, acompañando sus límites superior e inferior que contienen en esos extremos, respectivamente, la siguiente frase que se repite: «aquí tus sentimientos estéticos son prolongaciones de todos tus sentidos». Y en la línea inferior se encuentra la siguiente frase: "Tras esto mis comunicaciones serán herramientas para ti mismo». Podemos imaginar esta línea con muchos kilómetros y, sobre todo, podemos imaginar la posibilidad de un deambular en Uma floresta para os teus sonhos sin fin, caminando en nuestros pensamientos, ideas y emociones, favorecidos por la dispersión y por la relación refleja del exterior constituido por troncos de árbol.

\footnotetext{
${ }^{424}$ Alberto Carneiro produjo un arte conceptual eco-logístico en el que el síntoma conceptual estaba perfectamente en sintonía con lo que se estaba haciendo a nivel internacional. Según Catarina Rosendo, A. Carneiro llegó a visitar una de las exposiciones más importantes de la tendencia conceptual del arte. En Londres, A. Carneiro visitó la exposición titulada "When attitudes becomes form: works-concepts-processes-situations-information - live in your head" (organizada en 1969 por Harald Szeeman en la Kunsthalle de Berna).

${ }^{425}$ CARNEIRO, Alberto, testimonio oral transcrito de la conferencia pronunciada por el artista Alberto Carneiro, en abril de 2004 en el Auditorio de EP 1 de la ESAD. CR/ Instituto Politécnico de Leiria, a invitación de los docentes Samuel Rama y Pedro Cabral Santo. (En Anexo).
} 


\subsection{0}

\section{El paisaje en la acción}

\subsection{0 a. El vacío}

Regresando a la materialización de Uma floresta para os teus sonhos, tendremos que mencionar que su carácter paisajístico se debió mucho a la importancia concedida al vacío y al espacio entre objetos, una apología del medio que pone al espectador en el centro de su elaboración y que traduce o escenifica, también de alguna manera, las condiciones existentes en el espacio real del paisaje.

En la raíz de esta importancia concedida al vacío por parte de $A$. Carneiro, están las teorías sobre el espacio de Giacometti, pero sobre todo la aproximación de este artista a las religiones y filosofías orientales ${ }^{426}$. En la conferencia realizada por Alberto Carneiro en la ESAD CR, el artista confirma esta influencia como siendo estructurante del segundo periodo de trabajo:

esa vía me lleva a descubrir a continuación el Zen, el Tao, el Tantra, que son sobre todo nociones con fuerte relación espiritual de transcendencia de la realidad creadas por los orientales (...) - Y por entonces hay una cosa fundamental que es el descubrimiento del Tao, en una lectura fulgurante de Libro del Camino y de la Virtud ${ }^{427}$, de Lao Tse, filósofo y poeta chino del siglo VI antes de Cristo. El Taoísmo dice: "Lo que está encima es igual a lo que está debajo, lo que está a la derecha es igual a lo que está a la izquierda, lo que está delante es igual a lo que está detrás. ¡Lo que es importante no es lo que está encima ni lo que está debajo, sino lo que está «entre»! jLo importante no es lo que está a la izquierda ni a la derecha, sino lo que está "entre»! ;Lo importante no es lo que está delante ni lo que está detrás, sino lo que está “entre»!» Esta noción lleva a considerar una cuestión que me preocupaba: si hasta 1968 realizaba escultura en el sentido tradicional -por más que ya hubiera rechazado el pedestal, porque mis piezas de esa altura ya no tenían pedestal- todavía circulaba en torno a ellas y era en esa dirección

\footnotetext{
${ }^{426}$ Recuérdese que una de las grandes influencias del constructivismo ruso que permitió a la escultura un entendimiento conectivo y participativo del espectador dentro del espacio escultórico tuvo también como referencia las filosofías orientales.

${ }^{427}$ TSE, Lao, Tao Te King, O Livro da Via e da Virtude, Traducción de António Melo, Lisboa, Editorial Estampa, 2000.
} 
hacia donde se concentraba toda la atención. Era un universo, a pesar de todo, cerrado. $^{428}$

El ambiente titulado $O$ canavial: memória metamorfose de um corpo ausente materializa ya estas influencias venidas de las filosofías y religiones orientales. "(...) con el Canavial, empiezo a considerar que lo fundamental es la apertura que se hace... Esto es, nunca podemos disfrutar de una obra o de lo que quiera que sea, si no estamos dentro (...) Entre tanto, es esta relación entre el dentro y el fuera lo que voy a trabajar en algunas obras a las que llamé envolventes y penetrables, esto es, el espectador no puede ver la obra desde fuera, tiene que penetrar en su interior y en el momento en que penetra ${ }^{429}$ él mismo pasa a ser la obra, porque el espectador que ve a otro dentro de la obra también está dentro de la obra, y así sucesivamente. - $Y$ ésta es la cuestión esencial que desarrollaré a partir de ahí en mi trabajo, hasta hoy. Por un lado están las relaciones espaciales, y a partir de esa consciencia, pasó a interesarme no tanto la forma, como el espacio, o sea, lo que la forma genera y dónde es generado. - Pasó a interesarme no tanto el lleno, sino el vacío. Por tanto pasó a interesarme mucho más la ausencia que la presencia. - Es evidente que esto es muy oriental, muy Zen o Tantra." ${ }^{430}$

El vacío no es «un nada», sino un espacio privilegiado que no está contaminado u ocupado previamente con objetos o ideas; sólo un espacio con estas características permite que cada uno se proyecte, construya, active y reflexione en él y a partir de él. Es una especie de espacio del "no-pensamiento" que, en palabras de Allan W. Watts, funciona como una vía de superación de todas las predeterminaciones que cuenta toda actividad mental. Este autor defiende que el vacío es "una función del conocimiento negativo que no deja de

\footnotetext{
${ }^{428}$ CARNEIRO, Alberto, testimonio oral transcrito de la conferencia pronunciada por el artista Alberto Carneiro, en abril de 2004 en el Auditorio de EP 1 de la ESAD. CR/ Instituto Politécnico de Leiria, a invitación de los docentes Samuel Rama y Pedro Cabral Santo. (En Anexo).

${ }^{429}$ Alberto Carneiro insiste en el acto de penetrar que, aparte de significar una relación de la obra de tipo erótica, revela también los penetrables como una dimensión del interior en el exterior dentro de la arquitectura del espacio de exposición. Sobre esta cuestión, deben evocarse los Merzbau de Kurt Schwitters.

${ }^{430}$ CARNEIRO, Alberto, testimonio oral transcrito de la conferencia pronunciada por el artista Alberto Carneiro, en abril de 2004 en el Auditorio de EP 1 de la ESAD. CR/ Instituto Politécnico de Leiria, a invitación de los docentes Samuel Rama y Pedro Cabral Santo. (En Anexo).
} 
tener parecidos con las utilizaciones del espacio - la página vacía sobre la que se pueden escribir palabras, el recipiente vacío donde se puede verter líquido, la ventana vacía a través de la cual puede entrar luz, y el tubo vacío a través del cual el agua puede correr. Obviamente, el valor del vacío reposa en los movimientos que permite o en la sustancia que delimita y contiene. Pero el vacío debe existir primero." ${ }^{311}$ También José Gil, en un libro sobre el cuerpo y la danza, dedica algunas palabras al vacío, “(...) el vacío en los pintores chinos de formación taoísta, es lo que da a ver la forma. Hay un Vacío Mediano, que cuenta el espacio entre las formas, los colores, y las superficies: se sitúa en el plano del «entre», como escribe Henry Maldiney (Art et Existence, Klincksieck, París, 1986, pág. 173). Son los blancos intersticiales de los cuadros o el hueco visible de una cerámica Sung. Pero hay otro vacío, el «gran vacío» o el vacío primordial, vacío invisible que queda fuera del plano de las formas dadas y que fascina porque no representa nada, ni nada lo representa, manifestándose apenas en la energía irradiante que irrumpe de él." ${ }^{432}$

Para entender mejor cómo el vacío de Uma floresta para os teus sonhos no funciona como entidad pasiva sino profundamente activa, precisamos de determinar mejor sus virtualidades socorriéndonos de las afirmaciones de François Cheng. En el contexto de la cultura oriental, el concepto de vacío es el centro de un pensamiento que gobierna toda la existencia y que permite entender cómo los orientales concibieron el universo; así "el vacio se presenta como un eje en el funcionamiento del sistema del pensamiento chino. Es en cierto modo insoslayable, en cuanto uno se propone en alguna medida observar la manera en que los chinos han concebido el universo. Además del contenido filosóficoreligioso que implica, rige el mecanismo de todo un conjunto de prácticas significantes: pintura, poesía, música, teatro, y de prácticas relativas al campo fisiológico: la representación del cuerpo humano, la gimnasia Taijiquan, la acupuntura, etc. Hasta en el arte militar y en el arte culinario tiene un papel

\footnotetext{
${ }^{431}$ WATTS, Allan W., O Budismo Zen, Trad. Carlos Grifo Babo, Lisboa, Editorial Presença, 2000, p. 107.

${ }^{432}$ GIL, José, Movimento Total. O Corpo e a Dança, Lisboa, Relógio D’ Água, 2001, p. 17.
} 
fundamental. ${ }^{433}$ Un artista oriental acepta el vacío como principio básico para su creación con objeto de "crear una relación abierta de reciprocidad entre el sujeto y el mundo objetivo, de transformar también el tiempo vivido en espacio viviente" $^{\mathrm{n} 34}$.

En las representaciones orientales, según François Cheng, el vacío es el responsable de la vinculación y relación entre los diversos elementos representados "De ese modo, montaña y agua ya no son percibidas como elementos parciales, opuestos e inmóviles; encarnan la ley dinámica de lo real." Por tanto, a través del vacío, el artista oriental orienta la representación hacia una idea de relación que se encuentra lejos de la estabilidad buscada por ejemplo en la cultura representacional europea, especialmente de la tradición pictórica de paisaje inaugurada con el renacimiento italiano. "Gracias al vacío que trastoca la perspectiva lineal, también se puede comprobar esta relación de devenir recíproco, por una parte, entre el hombre y la naturaleza dentro de un cuadro, y entre el espectador y el cuadro en su conjunto, por otra." ${ }^{435}$ Así, arte y vida se funden y son aprehendidas como indisociables.

La función activa del vacío, en los ejemplos que nos dan la música, la poesía y, sobre todo, la pintura es, por ende, digna de atención. Es todo lo contrario de una «tierra de nadie" que implique neutralización o compromiso, puesto que el vacío es efectivamente el que permite el proceso de interiorización y de transformación mediante el cual cada cosa realiza su identidad y su alteridad, y con ello alcanza la totalidad. En este sentido, la pintura en China es, en sentido estricto, una filosofía en acción; es vista como una práctica sagrada, porque su objetivo es nada menos que la realización total del hombre, incluyendo su parte más inconsciente. ${ }^{436}$

Los filósofos orientales, como los de la escuela Taoísta, hicieron del vacío un elemento central. "El vacio es el fundamento mismo de la ontología taoísta. Antes de cielo-tierra, es el no haber, la nada, el vacio". ${ }^{437} \mathrm{La}$

\footnotetext{
${ }^{433}$ CHENG, François, Vacío y Plenitud, traducción castellana de Amelia Herández y Juan Luis Delmont, Madrid, Siruela, 2010, p. 67.

${ }^{434}$ Idem, p. 69.

${ }^{435}$ Ibidem, p. 71.

${ }^{436}$ Ibidem.

${ }^{437}$ Ibidem, p. 78.
} 
caracterización del vacío, para las culturas y filosofías orientales, contempla una relación productiva con su opuesto, lo pleno. "El vacío mira hacia la plenitud. Permite, en efecto, que todas las cosas "plenas» alcancen su verdadera plenitud." Para las filosofías orientales, el vacío tiene una representación concreta en el paisaje, en el valle. "En el orden de lo real, el vacío tiene una representación concreta: el valle. Es hueco y aparentemente vacío, pero hace crecer y nutre todas las cosas; lleva todas las cosas en su seno, y las contiene sin dejarse nunca desbordar ni extinguir." ${ }^{438}$ Por lo tanto, se trata de una imagen paisajística que soporta las determinaciones del vacío. "La imagen del valle está ligada a la del agua. El agua, al igual que los alientos, aparentemente inconsistente, penetra por doquier y todo lo anima. Por doquier, lo lleno constituye lo visible de la estructura, pero el vacío estructura el uso." ${ }^{439}$ Esto es, el vacío impele y crea las condiciones para la realización del movimiento. "Pues el vacío intermedio, que habita el par yin-yang, habita también todas las cosas; al insuflarles aliento y vida, las mantiene en relación con el vacío supremo, permitiendo que accedan a la transformación interna y a la unidad armonizadora." 440

En el ensayo citado, François Cheng prosigue con las determinaciones del vacío, explicando que "no aparece como un espacio neutral que sirva tan sólo para amortiguar el choque sin modificar la naturaleza de la oposición. Es el punto nodal tejido con lo virtual y el devenir, donde se encuentran la falta y la plenitud, lo mismo y lo otro. Esta concepción se aplica tanto a las cosas de la naturaleza (por ejemplo, a lo que dijimos a propósito de la montaña- agua en la pintura) como al propio cuerpo del hombre (en especial, a la idea según la cual el cuerpo humano, dominado por el shen, «espíritu», y el jing, «esencia», o por el corazón y el vientre, obtiene su armonía por el vado intermedio, regulador de los alientos que animan el cuerpo.. ${ }^{441}$ Como ya fue mencionado, también para Erwin Strauss y $\mathrm{H}$. Maldiney, el vacío es condición esencial para la existencia de paisaje, pues

\footnotetext{
438 Ibidem, p. 82.

${ }^{439}$ Ibidem, p. 83.

440 Ibidem, p. 87.

${ }^{441}$ Ibidem, p. 89.
} 
sólo el vacío comporta una idea de fondo que desencadena movimientos en la consciencia.

Jean-Marc Besse, en un texto titulado Más allá del objeto y del sujeto, presenta el mecanismo por el cual se entra y se integra a un paisaje. Para Erwin Straus y después Henri Maldiney, sólo puede accederse al horizonte en el paisaje al precio de perder las referencias, de la negación del mapa, y de la aceptación de esta perdida y de esta negación: «El espacio del paisaje es, para empezar, el lugar sin lugares del ser perdido. En el paisaje (...) el espacio me envuelve a partir del horizonte de mi Aquí, y yo solo estoy Aquí a la altura del espacio bajo el horizonte del que estoy fuera». Ninguna coordenada. Ninguna referencia. «Desde el paisaje no hay progresión que lleve a la geografía; nos hemos salido del camino; como hombres nos sentimos perdidos (...)Sin duda, podemos salir del paisaje para entrar en la geografía. Pero allí perdemos nuestro Aquí. Ya no tenemos ningún lugar. Ya no tenemos lugar»." 442 El horizonte aparece así como cualificador del paisaje real. También Gilles A. Tiberghien comprende el horizonte y el punto de vista como determinaciones importantes para entender el paisaje en el contexto del arte; "El marco, el punto de vista y el horizonte son constitutivos del paisaje." ${ }^{343}$ En Uma floresta para os teus sonhos, el cuerpo que la experimenta está en movimiento, lo que implica que los puntos de vista son sucesivos y ayudan a construir una noción periférica del espacio que, por ser desarrollado en el interior de una arquitectura, parece repetir las mismas condiciones de errancia que el horizonte es capaz de generar en el paisaje real.

\footnotetext{
442 BESSE, Jean-Marc, "Las Cinco Puertas del Paisaje, Ensayo de una Cartografía de las Problemáticas Paisajeras Contemporáneas". In Paisaje y Pensamiento, Javier Maderuelo (dir.) Madrid ABADA Editores, 2006, p. 163. Op Cit, H. Maldiney, Regard, parole, espace, L' Âge d' Homme, Lausanne, 1973, p. 143. El texto de Erwin Starus que cita Maldiney procede de Du Sens des Sens. Contribution à l'étude des fondements de la psychologie, trad. francesa de Jérôme Millon, 1989, p. 515.

${ }^{443}$ TIBERGHIEN, Gilles A., "Horizontes”. In « Arte público: naturaleza y ciudad», Javier Maderuelo (ed.), Lanzarote, Fundación César Manrique, 2001, p. 126.
} 


\subsection{0 b. Construcción de la espacialidad por el desplazamiento de un cuerpo}

Para que el artista tenga la posibilidad de hacer la representación como forma de "hacer presente de nuevo" el mundo, es necesario engendrar una forma de espacio. Como vimos, el espacio estático, geométrico euclidiano y el renacentista tienen un carácter estático que implica un cuerpo, un observador pasivo y contemplativo cuya visualidad radica en la existencia de un foco determinado.

La exigencia de crear un espacio de representación activa, o de presentación en que el cuerpo define su espacio en desplazamiento, exige nuevos entendimientos sobre el espacio y sobre la noción de paisaje que se define más allá de la noción de vista. Como vimos, Uma floresta para os teus sonhos es heredera de un dispositivo teatral iniciado con el minimalismo norteamericano, especialmente por su relación privilegiada entre espectador y espacio que hace abolir completamente la noción de espacio estático procedente de la tradición renacentista. A partir de esta destrucción, surge la posibilidad de la creación de espacio a partir de puntos de vista múltiples y de un cuerpo en desplazamiento.

Marshall McLuhan propuso la noción de extensión que serviría a A. Carneiro para apoyar su plan de acción escultórico basado en la idea de prolongación del artista hacia fuera de sí, en dirección al espacio y a los otros. Esta noción de extensión propuesta por el artista es una intuición desencadenada por los escritos de McLuhan con el objetivo de buscar apenas la idea de que el hombre, a través del arte, prolonga y amplía su acción a través de los objetos que toca y usa. Por lo tanto, no es una noción de extensión que confirme totalmente la contextualización y tesis explorada por McLuhan ${ }^{444}$, en la

\footnotetext{
${ }^{444}$ Marshall McLuhan, a través del fenómeno de la generalización de la televisión que tuvo lugar desde la década de 1960, intuyó la idea de que nuestra sociedad emergería como una sociedad electrónicamente interconectada como en una aldea global. Por estos años, este autor comprendió que la sociedad occidental se configuraría en torno a las tecnologías de la comunicación que, como hoy podemos testimoniar, tienen un papel importantísimo. En Understanding Media: The Extensions Of Man (1964) y sobre todo en The Gutenberg Galaxy the making of typographic man (1962) la escritura obedece a un razonamiento no lineal y poco científico, que es sobre todo metafórico, analógico y literario. Por este hecho, McLuhan se convirtió no sólo en un visionario para todos los interesados en la teoría de la comunicación, sino también en fuente de inspira ción para algunos
} 
medida en que éste formuló la noción de extensión con vistas a la comprensión de la relación entre los nuevos medios de comunicación de masas y el ser humano. Los troncos de madera de Uma floresta para os teus sonhos son objetos que funcionan como extensión del cuerpo del artista y después como extensión del cuerpo del usuario del ambiente.

Detengámonos ahora en algunas nociones de cuerpo concebido no como cierre, sino aquel que interesa a la fenomenología que se constituye como potencia de apertura al exterior, al espacio y a los otros. En seus Cinquenta $e$ oito indícios sobre o corpo, Jean-Luc Nancy escribe algunos aforismos que se ajustan a la idea de que un cuerpo es algo complejo que se abre al exterior y en esa apertura construye alteridad y segrega espacio. Así, según el $12^{\circ}$ Indicio, "el cuerpo puede tornarse hablante, pensante, soñador, e imaginativo. Está siempre sintiendo cualquier cosa. Siente todo cuanto es corpóreo. Siente la piel, las piedras, los metales, las hierbas, las aguas y las llamas. No para de sentir." ${ }^{445}$ Más adelante, Nancy relaciona el cuerpo con el espacio presentando la propensión de éste para constituirse por la evasión de sí mismo en la dirección del espacio. "El cuerpo expresa el espíritu, es decir, lo hace brotar hacia fuera (...) y lanza todo hacia el espacio." ${ }^{\text {446 }}$ En esa fuga de sí mismo, queda claro que un cuerpo sólo existe porque otros cuerpos en el espacio lo hacen existir. Cada cuerpo confiere existencia al espacio, porque es el cuerpo el que le da sus ejes de orientación. "Un cuerpo, cuerpos: no puede haber un sólo cuerpo y el cuerpo aporta la diferencia. Son fuerzas colocadas y tendidas las unas contra las otras. El «contra» (de encuentro, al encuentro, «totalmente contra») es la categoría principal del cuerpo; es decir, el juego de las diferencias, de los contrastes, de las resistencias, de los arrebatamientos, de las penetraciones, de las repulsas, de las densidades, de los pesos y medidas. Mi cuerpo existe contra el tejido de sus vestes, los vapores del aire que respira, el brillo de las luces o las fricciones de

\footnotetext{
artistas, como es el caso de A. Carneiro. MCLUHAN, Marshall, os meios de comunicação como extenções do homem, São Paulo, Cultrix, 2002. Y MCLUHAN, Marshall, $A$ galáxia de Gutenberg: a Formação do homem tipográfico, Trad. Leonidas G. de Carvalho y A. Teixeira, São Paulo, Ed. de la Univ. De São Paulo, 1969.

${ }^{445}$ NANCY, Jean-Luc, "Cinquenta e oito indícios sobre o corpo», Revista de Comunicação e Linguagens, n 33, «Corpo, Corpo, Técnica e Subjectividade», Junio de 2004, pp. 15-23, p. 16.

${ }^{446}$ Idem, p. 20.
} 
las sombras." ${ }^{447}$ Por su parte, Maria Augusta Babo prefiere ampliar la noción de cuerpo que puede ir más allá del cuerpo humano. "Un cuerpo es cualquier objeto material caracterizado por sus propiedades físicas. Un cuerpo es intransponible. Un cuerpo ocupa espacio; es opaco; está sujeto a la ley de la gravedad. EI cuerpo es también un organismo, esto es, una totalidad organizada.. ${ }^{448}$ Además de esta definición, podemos también convocar una definición más integradora de la noción de cuerpo, para mejor entender de qué modo los cuerpos del arte afectan a nuestro propio cuerpo. Deleuze nos ayudará a hacer más conscientes las afirmaciones aforísticas e incluso poéticas de Jean-Luc Nancy; a partir de un texto sobre Spinoza ${ }^{449}$ define cuerpo, no por aquello que es internamente, sino por la intensidad y velocidad de los intercambios que un determinado cuerpo consigue realizar con el exterior. De esta forma, no cabe definir un cuerpo por su estatismo, sino por la movilidad, velocidad e intensidad de los intercambios que definen en cada momento lo que es un cuerpo.

Por lo tanto, el cuerpo humano en el mundo empírico se relaciona tanto con otros cuerpos humanos, como con otros cuerpos no humanos. En Uma floresta para os teus sonhos, el cuerpo humano se relaciona con los cuerpos de la escultura. Entonces, los troncos de madera que componen esta obra dejan de ser para el espectador madera o cosa abstracta, y se convierten en metáfora de árboles. Tal transformación sólo ocurre en movimiento. Es el cuerpo que, deambulando, opera intercambios con el exterior, activando él mismo una serie de reminiscencias y relaciones que recrean por la sensación una cierta idea de paisaje. Ningún paisaje es hecho de cosas abstractas como madera, sino de cosas concretas como árboles. Esta operación, desencadenada por la sensación, no es ninguna fantasía o delirio, podrá hasta ser sueño, pues un bosque es para

\footnotetext{
447 Ibidem, pp. 17 y 18.

448 BABO, Maria Augusta, «Do Corpo Protésico ao Corpo Híbrido», Revista de Comunicação e Linguagens, n 33, «Corpo, Técnica e Subjectividade», Junho de 2004, pp. 25-34, p. 25.

${ }^{449}$ DELEUZE, Gilles. Espinosa, Filosofia Prática. São Paulo: Editora Escuta, 2002. Deleuze nos da una definición de cuerpo tan amplia que cuerpo puede ser un cuerpo social, un cuerpo de ideas que son entidades inmateriales, como también puede ser un sujeto o individuo. La tónica no está centrada en la caracterización del objeto como cosa material, ni en la constitución interna de un individuo, sino en su capacidad de crear intercambios con el exterior.
} 
tus sueños, sino tan sólo si entendemos "sueño" a partir de las determinaciones de Bachelard, que presentaremos más adelante.

Maurice Merleau-Ponty defiende, en varios momentos de su exploración fenomenológica, que nuestro cuerpo es lo que nos da acceso al espacio, en la medida en que es ese avance del cuerpo en el espacio el que cualifica el propio espacio y, por consecuencia, a nuestra expresión como extensión. La acción del cuerpo se ejerce hacia el exterior. "Los lugares del espacio no se definen como posiciones objetivas en relación a la posición objetiva de nuestro cuerpo, sino que se inscriben alrededor de nosotros al alcance variable de nuestras miras o de nuestros gestos". ${ }^{450}$ En otra obra, M. Ponty es más concreto en su explanación sobre la reciprocidad entre cuerpo y espacio. "El espacio se sabe a través de mi cuerpo" ${ }^{451}$, en suma "corporeizamos el espacio -a través del gesto, del sexo, de la mirada, de la extensión del brazo, de nuestra altura, de la situación de nuestra mirada- o lo materializamos con la interrelación de los objetos, de los «campos» de interés y de vivencia que creamos." ${ }^{452} \mathrm{La}$ fenomenología, en especial la de Merleau-Ponty, desarrolló la noción de que un cuerpo se corporeiza y crea espacio por la movilidad del propio cuerpo. Este autor fue determinante para el desarrollo de las prácticas artísticas que quisieron incluir la participación del cuerpo de los usuarios de la obra.

En 1962, la «fenomenología de la percepción» fue traducida al inglés influyendo en la práctica y los escritos de artistas como Robert Morris y Robert Smihson y seguramente también, de forma más o menos consciente, en $A$. Carneiro ya durante su estancia en Londres.

Al hilo del pensamiento y de la noción de cuerpo propuestos por Gilles Deleuze, así como también por Merleau-Ponty, o actualización del pensamiento de estos, José Gil va a señalar que los cuerpos segregan espacio, en la medida en que son los cuerpos que le dan los ejes de orientación, definen para el

\footnotetext{
${ }^{450}$ MERLEAU-PONTY, Maurice, Fenomenologia da Percepção, Trad. Carlos Alberto Ribeiro de Moura, São Paulo, Martins Fontes, 1999, p. 199.

451 Idem, p. 257.

${ }^{452}$ BARAÑANO, Kosme de, "Chillida: desarrollo de la obra”. In María M. Argila (Cood.), ¿Qué es la escultura moderna? Del objeto a la arquitectura. Madrid: Fundación Cultural MAPFRE Vida, 2003, p. 251.
} 
espacio sentido o sentidos derivados de las direcciones y ritmos del cuerpo. Este pensador portugués encontró en la relación del cuerpo del bailarín con la danza la imagen más adecuada para pensar la «secreción de espacio» realizada por el cuerpo. Sin embargo, no es exclusiva del bailarín, puede ser aplicada a muchas otras realidades estéticas como la que protagoniza el cuerpo del espectador que deambula entre los troncos de Uma floresta para os teus sonhos. "El bailarín nunca evoluciona en el espacio como un planeador o ni siquiera como un pájaro: no sólo no se mantiene inmueble, como el espacio no es aquí dato, en un «medio», como el aire al pájaro y el agua al pez. Su espacio debe ser creado, realmente construido alrededor de su cuerpo, sin que se confunda con el espacio objetivo: es el espacio del cuerpo, «medio» donde, precisamente, su cuerpo se extravasa a cada instante, «ahí perdiendo su peso. En efecto no se danza ni en el espacio exterior ni en un espacio subjetivo interior. (...) El espacio del cuerpo es el cuerpo tornado espacio." ${ }^{453} \mathrm{Si}$ exceptuamos el hecho de que el bailarín trabaja con su cuerpo un conjunto de sensaciones que no son equivalentes a las del espectador participante, quedamos con la confirmación de que el espacio se teje por el movimiento del cuerpo. "Se sabe que el bailarín evoluciona en un espacio propio, diferente del espacio objetivo. No se desplaza en el espacio, segrega, crea el espacio con su movimiento." ${ }^{\text {454 }}$ Más adelante, en el mismo libro, J. Gil completa esta idea: el espacio se deriva y existe por correlación con la acción o movilidad de un cuerpo, "el espacio del cuerpo es la piel que se prolonga en el espacio, la piel hecha espacio." 455

Si un cuerpo se define continuamente por la velocidad e intensidad de los intercambios que realiza con el exterior, entonces un cuerpo no se define como entidad estática, sino dinámica. En el contexto del arte en general, y de nuestro objeto de estudio en particular, el cuerpo asume un papel de gran relieve, pues es en él y por él que se desencadenan las sensaciones que son la principal materia del arte. Maurice Merleau-Ponty define sensación como "la relación viva

\footnotetext{
${ }^{453}$ Gil, José, Movimento Total. O Corpo e a Dança, Lisboa, Relógio D’Água, 2001, p. 19.

${ }^{454}$ Idem, p. 57.

${ }^{455}$ Ibidem, p. 58.
} 
de quien percibe con su cuerpo y con su mundo." ${ }^{456}$ En relación a Uma floresta para os teus sonhos, podemos decir que se trata de un lugar que es sensación en la misma medida que ofrece y es capaz de recrear sensaciones en el cuerpo de quien la experimenta. Uma floresta para os teus sonhos es el lugar de la constitución de la sensación pura en acontecimiento, o sea, el lugar de la construcción de un phatos y de un ethos que se produce con el cuerpo andando por entre los troncos de madera.

${ }^{456}$ MERLEAU-PONTY, Maurice, Fenomenologia da Percepção, Trad. Carlos Alberto Ribeiro de Moura, São Paulo, Martins Fontes, 1999, p. 281.

Maurice Merleau-Ponty estructura su «Fenomenología de la Percepción» en torno a las cuestiones de la sensación, memoria, atención y juicio. Isabel Matos Dias nos ilustra sobre la noción de sensación en Maurice Merleau-Ponty: "La Fenomenología de la Percepción describe la significación natural del sentir, el lazo vivido entre el cuerpo y el mundo, irreductible a una cualidad o a un concepto (...) así, la relación vivida con el mundo -percepción o sentir- es una y no descomponible, siendo por eso artificial establecer una escisión entre la percepción y la sensación (...) en efecto, el retorno a la sensación devuelve la relación viva de quien percibe con su cuerpo y con su mundo. La sensación es una modalidad de la existencia o de nuestro ser en el mundo y no una cualidad, una impresión pura o un estado de conciencia. La sensación es intencional y manifiesta nuestra constitutiva apertura al mundo. De este modo, sensación y percepción no se distinguen: la sensación es la más simple de las percepciones, como dice Merleau-Ponty. No hay percepción de un sensible puro o aislado: todo lo sensible se integra en un horizonte perceptivo, en un campo fenomenal.» DIAS, Isabel Matos, Uma Ontologia do Sensível - A aventura filosófica de Merleau-Ponty, Lisboa, Edições Centro de Filosofia da Universidade de Lisboa, 1999, pp. 68-69.

Por su parte, Gilles Deleuze y Félix Guattari, en su libro titulado ¿Qué es la Filosofía?, implican la noción de sensación a partir de la articulación de los afectos, perceptos y conceptos. Miranda Justo, en la presentación de la traducción portuguesa de «Lógica Da Sensação», de Francis Bacon, cita a Deleuze y clarifica cada uno de los tres conceptos usados por Guattari y Deleuze y que funcionan como aglomerados de sensaciones: "Deleuze (...) dice "Creo que el concepto comporta otras dos dimensiones, el afecto y el percepto. Esto, y no las imágenes, es lo que me interesa. Los perceptos no son percepciones, son paquetes de sensaciones y relaciones que sobreviven a quienes los experimentan. Los afectos no son sentimientos, son devenires que desbordan a quien los atraviesa (que deviene otro). [...] El afecto, el percepto y el concepto son tres potencias inseparables que van del arte a la filosofía y viceversa»." Más adelante, Miranda Justo específica lo que esta formulación de Guattari y Deleuze tiene de nuevo, especialmente en relación a la noción de sensación propuesta por M. Merleau-Ponty: "Los perceptos son, en el orden del ver y del oír, aquello que escapa a la repetición preceptiva del mismo. De igual modo, los afectos no son afecciones o sentimientos, (...) son, en el orden del experimentar o del sentir, aquello que escapa a la reiteración del sujeto en tanto que vida sentimental constituida, en tanto que sentimentalidad adquirida, orgánica. Se hace así claro que la lógica del percepto y del afecto - o sea, la lógica de la sensación- se constituye en el ámbito de la lógica del devenir otro y, por consiguiente, en el ámbito de una crítica del sujeto que incluso se extiende más allá del dominio de las artes". Resumiendo: "Los afectos son precisamente estos devenires no humanos del hombre como los perceptos son los paisajes no humanos de la naturaleza." Para Deleuze y Guattari, "La propia sensación vibra porque contrae vibraciones. Resuena porque hace resonar sus armónicos. La sensación es la vibración contraída, que se ha vuelto calidad, variedad." Y "la contracción no es una acción, sino una pasión pura, una contemplación que conserva lo que precede en lo que sigue". Queda claro que, para estos autores, sólo interesa un determinado tipo de sensación, la que es generada fuera de lo previsible y de las ideas hechas en dirección a un absoluto. Véase a este respecto el subcapítulo titulado "Percepción, afecto, concepto" contenido en el libro ¿Qué es la Filosofía?. GUATTARI, Félix y DELEUZE, Gilles, O Que é a Filosofia? Trad. Margarida Barahona y António Guerreiro, Lisboa, Editorial Presença, 1992, pp. 144-175. 
En Uma Floresta Para Os Teus Sonhos, el vacío, además de ser una cualidad del espacio capaz de suscitar la proyección de la mirada, es también el espacio por donde el espectador participante camina; por el caminar imagina, o sea, piensa por imágenes, editando para sí mismo una experiencia paisajista derivada de la movilidad del cuerpo en un espacio dominado por la verticalidad de los troncos de árbol. Así, caminar en el bosque equivale a "una vida aérea nítidamente dinámica." ${ }^{457}$ En El aire y los sueños, de Bachelard, reconocemos una fuerte contribución para entender el valor de la movilidad del cuerpo que ofrece el vacío en la relación de la verticalidad del hombre con la de los árboles "El hombre, como el árbol, es un ser en quien fuerzas confusas se alzan. La imaginación dinámica no exige más para empezar sus sueños aéreos. Todo se ordena a continuación en esa verticalidad segura (...) es antes de nada una imagen de movimiento, un consejo de movimiento vegetante.." ${ }^{458}$ El espectador de un bosque tiene un tipo de "devaneo dinámico que, pasando de lo real a lo imaginario, nos permitirá seguir la transición de la imaginación de los picos a la imaginación del movimiento balanceado." Este movimiento será explorado a continuación, a partir de la idea de sueño y de mecanismo pre-cinematográfico en que la edición pertenece al espectador participante en este tipo de obra, que es una «obra abierta» ${ }^{459}$.

Además de la influencia de Bachelard en la obra y en los comportamientos de Alberto Carneiro, a la que volveremos, conviene profundizar algunos aspectos sobre el tipo de espacialidad escultórica característicos de la segunda mitad del siglo XX. En este periodo, como vimos, la implicación del cuerpo del espectador en la obra tiene consecuencias; el espacio como

\footnotetext{
${ }^{457}$ BACHELARD, Gaston, O Ar e os Sonhos, São Paulo, Martins Fontes, 1991, p. 217.

${ }^{458}$ Idem, p. 213.

459 Umberto Eco, en su libro "Obra Aberta», trabaja la idea de una obra de arte abierta por ser de algún modo indeterminada en su forma, invitando al intérprete o al espectador a participar en la construcción final del objeto artístico; para que eso suceda, la cuestión del vacío que anteriormente mencionamos es fundamental, pues el vacío recrea un espacio susceptible de generar todo tipo de proyección por parte del usuario de "Uma floresta para os teus sonhos". En el capítulo titulado «O Zen e o Ocidente», Eco nos presenta la apertura como " una exigencia de no concluir el hecho plástico en una estructura definida, de no determinar al espectador a aceptar la comunicación de una configuración dada, y de dejarlo disponible para una serie de goces libres en los que él escoja los resultados formales que le parezcan oportunos.». ECO, Umberto, Obra Aberta, Traducción de João Rodrigo N. Furtado, Lisboa, Difel, 1989, p. 232.
} 
secreción del cuerpo implica una nueva visión del espacio así como una gran cantidad de nuevos términos para calificarla, como intersticialidad, movilidad, inmaterialidad, membrana, etc. Esto significa que la visión que los artistas, en general, y los practicantes de la escultura, en particular, tenían del espacio ya no era coincidente con la noción euclidiana. En vez de eso, es obvia la proximidad con las nociones espaciales emanadas tanto del dadaísmo, como del constructivismo ruso, de que las dos piezas anteriormente mencionadas, la Merzbau y el Espacio Proun, ambas de 1923, respectivamente de Schwitters y de El Lissitzky, son tal vez el mejor ejemplo, pues implican, aparte de otras cuestiones, la noción de que la espacialidad se construye a partir de un cuerpo en desplazamiento.

Uno de los nombres fundamentales en este proceso de profundización de esta noción de espacio es, como ya vimos, Robert Morris. "De la anti-form al process art, Morris va reuniendo elementos de crítica a los objetos minimales que, a pesar de la introducción del espacio real en la obra de arte, quedaron rehenes de su carácter representativo, o sea de su vinculación a formas. Para el escultor, la forma como el process art introduce la importancia que tiene la percepción como sensación. Al mismo tiempo la atención dada a la materia es inseparable de sus procesos de mutación, y revela como la propia arte es una actividad de cambio, de desorientación y de discontinuidad que busca descubrir nuevos modos perceptivos. ${ }^{460}$ El objetivo de Morris era circunscribir una nueva noción de espacio para la práctica escultórica, denominado "paisajístico", un espacio capaz de promover un cierto sentido de desorientación, que es la determinación principal de la noción de paisaje en Erwin Straus, y también en Merleau-Ponty. Ahora bien, un espacio que promueve la desorientación promueve la movilidad del cuerpo del desorientado; de esa forma, la obra de arte

\footnotetext{
${ }^{460}$ ROSENDO, Catarina, Alberto Carneiro. Os primeiros anos (1963-1975). Lisboa, Edições ColibriIHA/EAC, 2007, p. 33.

Sobre la crítica al minimalismo hecha por Robert Morris, en "Notes on Sculpture" (Parte 4) puede leerse la siguiente afirmación: "So - called Minimal art fulfilled the Project of reconstituting art as objects while at the same time sharing the same perceptual conditions as figurative sculpture. Both objects and figures in real space maintain a figure-ground relation. This is not a depicted relation as in representational painting, but an actual one of differentiated subject within a neutral field». MORRIS, Robert, «Notes on Sculpture, Parte 4» Continuous Project Altered Daily, Chapter 5, Massachusetts, MIT Press, 1995, p. 54.
} 
recrea las condiciones del ser en el paisaje. Podemos decir que "la integración del hombre en el mundo" es reubicada en el contexto del arte, y "se hace por el establecimiento de un campo visual perceptivo que facilita el horizonte expresivo e indeterminado a las cualidades visibles y sensibles de esa integración, o sea, el sentir es la coincidencia con el sentido." Un ambiente, o penetrable, como "el mundo exterior no es recopiado en la mente, es construido, o entendido en la propia «viscosidad» del contexto, y el hombre se adhiere a él como única forma de conocerlo." ${ }^{461}$ Así, implica deambular a partir del espacio que, a ejemplo de parte del trabajo escultórico de Richard Serra, implica una concepción y "una percepción peripatética, basada en un sujeto móvil, que incorpora así una dimensión temporal al espacio escultórico. Una percepción que, además, es más física que óptica. Serra emplea el término espacios experienciales o espacios de comportamiento (behavioral space) para referirse a estas intenciones."

Al desplazarse en el espacio de Uma floresta para os teus sonhos, un cuerpo construye espacialidad, convoca y segrega espacio paisaje, ya no como representación, sino como presentación. El paisaje como representación necesita en su forma más tradicional del establecimiento de un punto de vista fijo. El paisaje en el campo de lo escultórico se hace de una sucesión de puntos de vista; pero esa sucesión no puede ser descrita como agrupación de varios puntos de vista individualizados separados, porque la sensación está implicada, como imagética sinóptica, es capaz de articular en la caminata lo que viene de atrás, prometiendo movimiento para a frente. En este contexto, el caminar es devenir y edición, o reedición constante de la noción de centro y periferia ${ }^{462}$.

\footnotetext{
${ }^{461}$ ROSENDO, Catarina, Alberto Carneiro. Os primeiros anos (1963-1975). Lisboa, Edições ColibriIHA/EAC, 2007, p. 33.

${ }^{462}$ En el arte moderno y posmoderno, este tipo de espacialidad está documentada en algunos ejemplos. En 1942, Marcel Duchamp realiza su obra titulada Mile of String" presentada en la exposición The First Papers of Surrealism (1942), Nueva York, constituida por un cordel de una longitud de una milla, que envuelve toda la exposición construyendo una telaraña alrededor de todas las obras presentadas y ocupando la totalidad del espacio de la arquitectura de la sala de exposición; este aparato, además de contaminar toda la exposición, obligaba a cada espectador a ser participante en la medida en que, para ver las restantes obras, tenía que desplazarse con dificultad entre los hilos, pero sobre todo mantenía una noción de espacio constantemente periférica, ya que la movilidad constante exigida por la intervención no deja margen para que se contente con una visión estática del espacio y de la exposición que contiene.
}

Ya a mediados del siglo XX, podemos referir el trabajo de Ed Ruscha, titulado Every Building on the Sunset Strip, de 1966, que consiste en una secuencia continua de fotografías organizadas en libro en 
Dentro de Uma floresta para os teus sonhos, el espectador es un elemento central; sin él no hay bosque, tal como testimonia la segunda parte del título: «para tus sueños»; es decir, el bosque se da al espectador participante como un campo, un laberinto lúdico como posibilidad de múltiples recorridos. Durante el trayecto, el espectador construye el paisaje, deambulando, convocando con el andar las dimensiones psicofísica, estética, poética e incluso, como veremos, ética y política del bosque, entendido ya no como imagen de una naturaleza intocada, sino antes como modo de trabajar afinidades entre el espacio natural y el espacio urbanizado de la ciudad.

La palabra "sueño" contenida en el título Uma floresta para os teus sonhos se debe muy probablemente al encuentro que Alberto Carneiro tuvo con la obra de Gaston Bachelard a partir de los años 1964-65, más específicamente con los libros que se dedican a la imaginación material. En esas obras, el concepto de sueño, primeramente de intuición surrealista, va a ser progresivamente profundizado por Bachelard hasta el punto de que se presenta con las siguientes determinaciones: está antes de la contemplación, anticipa la

formato desplegable, y que muestran las dos aceras de la calle Sunset, de Los Angeles, a medida que el artista fue fotografiándolas en una secuencia continua.

También podemos encontrar indicios de esta nueva forma de entender el espacio en la narrativa de Jack Kerouac, especialmente en On The Road, de 1956. En este libro, la escritura no denuncia la línea del recorrido, sino sus aspectos laterales y por lo tanto periféricos. KEROUAC, Jack, Pela Estrada Fora, Lisboa, Relógio d' Água, 2011.

Esta apetencia por la noción de espacio definido a partir de la valoración del cuerpo en movimiento debe ser entendida e insertada en un contexto más vasto de reapreciación, cuestionamiento y relativización de los criterios del espacio renacentista, cuyo inicio se encuentra, según Yves-Alain Bois, ya en el siglo XVII, sobre todo en «los principios enunciados por los teóricos del jardín pintoresco, que diferencian entre una visión óptica estática y una visión en movimiento, donde prima la complejidad y la variedad como categorías de lo pintoresco derivadas de esa multiplicidad de visuales» (ROSAS, Maria Ángeles Layuno, Richard Serra, Hondarribia, Editorial Nerea, 2001, op cit., pp. 62-65). También la noción de "sublime dinámico", teorizada por Kant, pone la tónica en la idea de que lo sublime implica incomodidad, adivinándose la constitución de un tipo de visión que es disruptiva para quien se entrega a la contemplación de la grandiosidad de la naturaleza. El espacio de lo sublime es disruptivo e incómodo porque el sujeto es incapaz ante la enorme complejidad del espacio. Así, para Yves-Alain Bois, «la línea kantiana del Análisis de lo sublime, que comprende un mecanismo de percepción distinto del propuesto para el juicio sobre lo bello, "introduciendo la temporalidad de la experiencia estética" (Op cit., p. 63). La relativización de los criterios renacentistas del espacio se produjo después de forma generalizada en las prácticas artísticas europeas a partir de finales del siglo XIX.

También Alberto Carneiro interioriza muy rápidamente esta noción de espacio hecho periférico, tanto en sus descripciones de los espacios de paisaje, como en sus obras, principalmente en las de la segunda fase, que demuestran o piden que experimentemos esa noción de espacio durante una determinada experiencia que es temporal. 
experiencia y el contacto con el material sin resistencia. El sueño no es una identidad descontrolada que vehicule lo fantasioso sin límites, sino que se desarrolla a través de una relación de anticipación de imagen a partir de la materia. En Uma floresta para os teus sonhos, el soñador es un observador participante que imagina ${ }^{463}$ o piensa por imágenes, a medida que se desplaza por el espacio del ambiente.

El sueño tiene la capacidad de transportar el sujeto "a otro mundo, hace del soñador alguien diferente de sí mismo (...) por más que ese otro sea aún él mismo, su doble" ${ }^{464}$.El Sueño apela también a la memoria, que es probablemente la forma más creativa de todas las modalidades de pensar el tiempo. Esta forma de imaginar, o crear imágenes, no es meramente evocativa; antes bien, se trata de una actitud productiva, que articula sensibilidad y datos constantemente actualizados de los sentidos, configurándose un mecanismo precinematográfico.

Este mecanismo merece un poco de nuestra atención. El «modo paisajístico», propuesto por Robert Morris, y del cual, en cierta medida, Uma floresta para os teus sonhos es sucedánea, implica una relación de los programas escultóricos con la arquitectura, en la medida en que sus elementos troncos de madera- implican una cierta reconstrucción del espacio previo de la galería en función de un cuerpo del espectador que se pasea; se crea entonces una cinemática del espacio, puesto que es el espectador/usuario del ambiente que está constantemente editando su experiencia, que es también experiencia propuesta por la obra. En esta situación, mirar, sentir y percibir, en términos amplios, significan siempre captar y perder, pues el espectador participante, una vez inmerso en una sala llena con 200 troncos de madera, nunca puede verlos

\footnotetext{
${ }^{463}$ Bachelard se ocupa en varios momentos de la imaginación, especialmente en la Poética do espacio: "(...) Nosotros proponemos, al contrario, considerar la imaginación como una potencia mayor de la naturaleza humana. Claro que no adelantamos nada diciendo que la imaginación es la facultad de producir imágenes. Pero esta tautología tiene por lo menos el interés de detener las asimilaciones de las imágenes en los recuerdos. La imaginación, en sus acciones vivas, nos desprende a la vez del pasado y de la realidad. Se abre en el porvenir, A la función de lo real, instruida por el pasado, tal como la desprende la psicología clásica, hay que unir una función de lo irreal igualmente positiva (...)", BACHELAD, Gaston, A poética do espaço (1957). Traducción de António de Pádua Danesi, São Paulo, Martis Fontes, 2000, p. 18.

${ }^{464}$ BACHELARD, Gaston, A Poética do Devaneio, Trad. de António Danesi, São Paulo, Martins Fontes, 2001, pp. 75-76.
} 
todos de una sola vez. Así, ver o editar su experiencia implica también el «no ver»: no ver los troncos que están fuera de su campo de visión a partir en un determinado momento, no ver los troncos total o parcialmente ocultos. Maurice Merleau-Ponty nos ayuda a entender esta lógica cinemática creada por el vacío. Para este autor, una película no es más que un "arquetipo de la visibilidad, en el sentido de que exige la comprensión y el compromiso de quien ve." ${ }^{465}$ Para ilustrar la relación entre cinemática y percepción, Merleau-Ponty nos da el ejemplo del cubo que, siendo un "sólido formado por seis caras y doce aristas iguales, en la percepción no es sino «una figura perspectiva en la cual las caras laterales son deformadas y la cara dorsal completamente escondida»". Así, lo que permite ver el cubo será el hecho de que "la permanencia de las caras escondidas del cubo «no es construida por la inteligencia, sino aprehendida por la mirada mientras desposa y adopta la organización del campo visual. ${ }^{466}$ En Lo visible y lo invisible, Merleau-Ponty escribe: «el cubo reúne en sí visibilidades incomposibles, como mi cuerpo es, concomitantemente, cuerpo fenomenal y cuerpo objetivo, y si, en fin, existe, existe como él, por un golpe de fuerza". Y más adelante escribe: «(...) la cara escondida del cubo irradia en algún lugar tan bien como la que tengo ante los ojos, y coexiste con ella.» ${ }^{467}$ Umbelino aclara esta imagen de Merleau-Ponty: "la mirada alberga como que una experiencia vinculada a la mismidad pre-objetiva de cada cosa en el mundo, que así se desvela como unidad transitiva en que una perspectiva se «desliza» a otra dentro de las estructuras de horizonte que forman sus «alrededores». El cubo -en el ejemplo de Merleau-Ponty- gana por tanto forma al tiempo que manifiesta, como cosa en el mundo, una tela de visibilidad en la que aparece incrustado y que la mirada parece saber acoger como hilo de esa misma tela. Por eso, al percibir, no vemos cosas separadas las unas de las otras y un espacio independiente de ellas, sino que comprobamos el envolvimiento de las cosas, entre sí y a través de mí, a desarrollar el espacio. Dicho de otro modo, lo que una percepción efectiva

\footnotetext{
${ }^{465}$ UMBELINO, Luís António, «Percepção e Imagem: o exemplo do cinema no contexto da meditação Fenomenológica de Merleau-Ponty sobre a Experiência Perceptiva», Phainomenon, Revista de Fenomenologia, n. 10, Primavera de 2005. pp. 47-61, p. 48.

${ }^{466}$ Idem, p. 49.

${ }^{467}$ MERLEAU-PONTY, Maurice, O Visível e o Invisível, Trad. J. Artur Gianotti y Armando M. d' Oliveira, São Paulo, Editora Perspectiva, 2000, pp. 133 y 136.
} 
del espacio nos revela no es un conjunto de objetos situados en el espacio a una distancia determinada entre ellos, sino cosas que no están localizadas sino que crean localizaciones por un envolvimiento mutuo que me rodea y traspasa, que me «espacializa» o compone mi situación, traduciéndola primero en términos de desposesión o anonimato (...) Percibir será, en este sentido, un saber previo que permite ver en la acogida de una cierta orientación de las cosas." ${ }^{468}$ Este «saber previo» puede constituirse para el usuario de Uma floresta para os teus sonhos a partir de la convocación de sus memorias de otros espacios laberínticos, ciudades o bosques que haya conocido; sólo de ese modo el espacio rellenado, no por «cubos», sino por troncos de madera, cumple su función inductora de una imagética sinóptica o una cinemática en que espacio y tiempo son inseparables del movimiento, él mismo constructor de paisaje.

El caminar implica, en el ámbito de esta obra, pensar ${ }^{469}$. Ambas acciones tienen una relación recíproca fuerte: el caminar religa la actividad motriz del cuerpo a la actividad mental, introduce un vínculo primordial con el espacio a lo largo del tiempo sin las aceleraciones derivadas de la técnica que aumentan la velocidad del tiempo exterior. Caminar no es una forma de estar fuera, por el contrario, es una forma de estar dentro del mundo o en este caso dentro del arquetipo bosque, construido por Alberto Carneiro. Mientras se anda, la sensibilidad y un sentido particular de orientación «no-diferenciada» son activados, implicando todas las estructuras perceptivas. Caminar se asume también, en esta como en muchas otras obras del Land Art de finales de los años 60 y a lo largo de la década de 1970, como una forma de meditación basada en la actualización que consta en la interrogación donde pueden participar también las estructuras intelectuales de cada individuo.

\footnotetext{
${ }^{468}$ UMBELINO, Luís António, «Percepção e Imagem: o exemplo do cinema no contexto da meditação Fenomenológica de Merleau-Ponty sobre a Experiência Perceptiva», Phainomenon, Revista de Fenomenologia, no 10, Primavera de 2005. pp. 47-61, pp. 49 y 50.

${ }^{469}$ Son muchos los pensadores que tienen necesidad de hacer caminatas diarias. Para Heidegger, era fundamental caminar todos los días cerca de 6 kilómetros, lo que le ocupaba casi dos horas. Su caminata desde su cabaña situada en Todtnauberg, en la Selva Negra, comprendía multitud de recorridos dentro y fuera del bosque, en las colinas y a campo abierto. Heiddeger escogía los itinerarios mejor adaptados a un andar tranquilo y que ofrecieran vistas amplias así como otras más limitadas del paisaje, de forma que dieran pie, durante el paseo, a una cierta variedad y calidad de pensamientos.
} 
A través del acto de caminar la transformación del tiempo en espacio se hace. Caminar, además de lo que representa para el cuerpo en términos físicos, es también un acto mental que existe en un plano de inmanencia. Para la artista brasileña Lygia Clark, caminar ${ }^{470}$ es descubrir un itinerario interior fuera de sí. "Por la primera vez descubrí una realidad nueva no en mí, si no en el mundo. Reencontré un "caminando», un itinerario interior fuera de mi" ${ }^{471}$. L. Clark, al recortar una cinta de Moebius, que dentro de la topología es considerada un caso específico de superficie unidimensional, expresa de forma muy clara lo que el acto de caminar implica en su relación exterior/interior, físico/mental, y de éstas con la dualidad tiempo/espacio. El acto de caminar "hace y rehace continuamente ${ }^{4472}$. Para L. Clark, "nosotros somos una totalidad espaciotemporal. En el acto inmanente nosotros no percibimos el límite temporal. Pasado, presente y futuro se mezclan. Existimos antes del después, pero el después anticipa el acto. El después está implícito en el acto que se realiza. Si el tiempo vive en el momento del acto, lo que deriva del acto es incorporado en la percepción del tiempo absoluto. No existe distancia entre pasado y presente. Cuando miramos hacia atrás, el pasado anterior y el pasado reciente se funden (...) Cada caminando es una realidad inmanente que se revela en su totalidad durante el tiempo de expresión del espectador-autor" ${ }^{\text {,73 }}$. Esa realidad inmanente es la que se puede experimentar en Uma floresta para os teus sonhos: una realidad donde no hay presente, porque dos fuerzas en simultáneo actúan y prometen, actúan venidas de atrás y prometen lanzando puentes hacia adelante. En este contexto, el paisaje no es un mero acontecimiento del cual nos podemos destacar o enmarcar haciendo de él un objeto estético, sino antes un modo de

\footnotetext{
${ }^{470}$ Caminando es el título de una obra de Lygia Clark datada de 1964, que consiste en una performance en que la artista recorta sucesivamente una cinta de Moebius. Aunque esta obra consista en un objeto y la caminata sea una acción, la verdad es que este objeto sólo vive ante una acción performativa de la artista que recorta la cinta de Moebius sucesivamente. La convocación de esta obra debe ser vista en el ámbito de nuestro estudio como una metáfora de una determinada idea de espacio.

${ }^{471}$ Clark, Lygia, in Lygia Clark. Série Arte Brasileira Contemporânea, Rio de Janeiro, Edição Funarte, 1980, p. 23.

472 Idem, p. 24.

${ }^{473}$ Idem, p. 23.
} 
sentir una determinada atmósfera de vida o un espacio existencial ${ }^{474}$ donde el acto caótico de perderse para después encontrarse va trabajando el sentido del recorrido.

Los troncos que componen el bosque plantean el espacio, lo localizan, al mismo tiempo que descentran el sujeto de la experiencia. Donde antes había apenas el "white cube" de la galería o del museo, siempre aséptico y expresamente desensibilizado, pasa ahora a haber espacio para sentir y pensar que es una forma más completa de presentar el concepto de paisaje. Los troncos verticales no señalan sólo una disponibilidad para su uso, preparan sobre todo e indican una disponibilidad para su ocupación ${ }^{475}$ o acogida que mantiene la libertad para que cada uno se manifieste en su manera propia de habitar la espacialidad. Todas las premisas contenidas en el dibujo de proyecto anuncian lo que el ambiente tiene disponible, para dejar surgir o acontecer, la espacialización del ser, "el espacio espacializa" ${ }^{\text {,46, }}$, por lo tanto, se da, asume que es una dádiva para que el observador participante se realice en él.

La noción de paisaje se deriva del favorecimiento del vacío que abre espacio para que el espectador camine. Con el caminar, se estimula el imaginario como en un mecanismo pre-cinematográfico. "A semejanza de la película, cuya duración en la pantalla de nuestras representaciones es efímera, también el paisaje siempre construido, y por construir, se concibe como suspendido en nuestros pensamientos, con la actitud de un proyecto constante, y surge tan sólo en la medida en que es producida." ${ }^{477}$ En este contexto, el arte ya no es entendido como un espacio que «sea un ataúd pintado para nuestro

\footnotetext{
${ }^{474}$ El espacio como lugar existencial puede ser pensado a partir de la afinidad que Alberto Carneiro tiene con la obra y principalmente con los escritos de Alberto Giacometti que, a partir de 1935, expresa el vacío como lugar todavía posible para el hombre.

${ }^{475}$ La posibilidad de ocupación es garantizada por la atención que A. Carneiro confiere al vacío. De hecho, el interés por el vacío, que ya se encontraba explorado en $A$ flôr (1968/69), aparece en el trabajo de A. Carneiro por dos vías y de forma simultánea; primero, por su interés por las teorías sobre el espacio de A. Giacometti, y después por la atención concedida a las filosofías y religiones orientales. El vacío es, en el contexto de Uma floresta para os teus sonhos, la calidad que se interpone entre el espectador y los troncos de árbol que constituyen la puesta en escena del bosque.

${ }^{476}$ HEIDEGGER, Martin, Heidegger en Castellano, 21 de noviembre de 2008, http://www.heideggeriana.com.ar/textos/arte_y_espacio.htm

477 CAUQUELIN, Anne, A Invenção da Paisagem, Trad. de Pedro Bernardo, Lisboa, Edições 70, 2008, p. 127
} 
cuerpo vivo ${ }^{478}$, sino como lugar para que nuestro cuerpo vivo viva, un lugar de acción y de vida para el propio cuerpo del espectador participante. En este sentido del inventariado de los valores espaciales, Delfim Sardo reconoce que, para pensar la escultura hoy, tendrá que reconocerse la existencia de una genealogía de transformación de lo escultórico, a lo largo del siglo XX, que se sitúa en una "continuidad en relación a los procesos arquitectónicos, ya sea en su absorción, en su continuidad, o en su negación." 479

En varios momentos de nuestra aproximación, la utilización del término paisaje ha oscilado con la utilización del término ambiente en esta búsqueda de comprensión de Uma floresta para os teus sonhos. De hecho, nuestro objeto de estudio se aproxima más a los desarrollos del concepto de paisaje hechos a lo largo del siglo XX en el seno de la cultura anglosajona, acercando o igualando la idea de paisaje a la idea de ambiente. Así, el carácter ambiental del paisaje aparece como un concepto que opera en un campo más vasto que el concepto de paisaje de lejana tradición e invención europea.

Anne Cauquelin identifica claramente las causas de la aparición del concepto de ambiente, para pensar una modalidad más lata y actual de la noción de paisaje. La necesidad del concepto de ambiente se deriva principalmente de la ampliación de las esferas de los varios saberes a su miscegenación. "Una característica del mundo contemporáneo, que se impone sobremanera -la de una ampliación de las esferas de actividad otrora limitadas, bien circunscritas. EI mestizaje de territorios, la ausencia de fronteras entre las propiedades son una clara marca de lo contemporáneo; el paisaje no escapa a esta regla. Su esfera se amplió y ofrece un panorama bien más vasto con el apoyo de la tesis constructivista (...) la primera ampliación, y la más fácilmente perceptible, proviene de aquello que parece más próximo del paisaje -el ambiente físico. Devastado, deteriorado, contaminado, obstruido, clama por un rápido auxilio, un saneamiento y una rehabilitación. Una vez que este ambiente doliente se muestra bajo la forma de paisajes, también ellos devastados, asistimos a una

\footnotetext{
${ }^{478}$ Afirmación realizada por Lazar Markovich Lissitzky en 1923, en una conferencia.

${ }^{479}$ SARDO, Delfim, Finalistas de Escultura, 2006/07, 23 de nov. de 2008, pp. 14-17, http://www.ul.pt.
} 
identificación entre ambiente y paisaje." ${ }^{480}$ Por esta afirmación se desprende que la noción de ambiente comporta también una importante dimensión ética y política que también se encuentra en Uma floresta para os teus sonhos, como en muchas obras del mismo periodo de trabajo.

Entre 1968 y 1972, por lo tanto dentro del periodo que comprende la creación de Uma floresta para os teus sonhos, A. Carneiro escribe Notas para um manifesto ecológico. De alguna manera, este texto contiene algunas respuestas a las preguntas planteadas en Uma floresta para os teus sonhos. En ese manifiesto, el artista propugna una actitud ética y política basada en la ecología. Arte ecológico es para él "árbol en el bosque de cemento." 481 Reconocemos en estas palabras de 1972 una premonición de lo que Joseph Beuys hizo diez años más tarde al plantar robles en Kassel 7000.

Carneiro fue uno de los primeros artistas que, a nivel mundial, se comprometieron con un arte ecológico de fuerte impacto y oportunidad política en las sociedades contemporáneas. Sin embargo, "en su obra, lo ecológico no es un discurso o conocimiento sobre los seres vivos y el ambiente físico y biológico en que viven, ni tampoco es un arte de la tierra o un geoarte -en lo que sería una traducción limitada y limitadora de la expresión Land art- sino más bien un arte que es una comunión, una integración de la tierra como algo de sensorial y fundante de la humanidad." 482 Así, para este artista, "una nube, un árbol, una flor, un puñado de tierra se sitúan en el mismo plano estético en que nos movemos, son parte integrante de nuestro mundo, son un manantial de sensaciones venidas de todos los tiempos, a través de una memoria que tiene la edad del hombre. No la piedra por su lado externo, por la conversión de sus valores formales, sino por las cualidades de su íntimo, por el cosmos que está en ella y que nos es dado poseer en la simplicidad en que la cosa vive." ${ }^{483}$ Esta

\footnotetext{
${ }^{480}$ CAUQUELIN, Anne, A Invenção da Paisagem, Trad. de Pedro Bernardo, Lisboa, Edições 70, 2008, p. 8.

481 CARNEIRO, Alberto, "Notas para um manifesto ecológico". In Das Notas para um Diário e Outros Textos. Antologia, (coord: Catarina Rosendo), Lisboa, Assírio \& Alvim, 2007, p. 26.

${ }^{482}$ CARLOS, Isabel, Alberto Carneiro. A escultura é um Pensamento, Lisboa, Caminho, 2007, p. 15.

${ }^{483}$ CARNEIRO, Alberto, "Notas para um manifesto ecológico". In Das Notas para um Diário e Outros Textos. Antologia, (coord: Catarina Rosendo), Lisboa, Assírio \& Alvim, 2007, pp. 25 y 26.
} 
declaración también defiende y define un modo de actuación político propio, es una respuesta que pretende garantizar la "transformación de las imágenes de lo cotidiano" y dar al hombre la oportunidad de sentir la naturaleza. "La esencia del manifiesto era una aproximación entre lo más profundo del hombre y su naturaleza en que el arte es una segunda naturaleza del hombre.." ${ }^{484}$ En suma, la naturaleza en este manifiesto aparece como una posibilidad de reunión con el hombre. La naturaleza no es para este artista algo limitado y distante, o un producto para ser usado y abusado, sino una categoría que, comprendida en su manifiesto, plantea un sentido ético y estético para la vida. Profundizar la naturaleza y el paisaje es reflexionar poética, estética y políticamente sobre nuestra condición de seres humanos.

Su manifiesto ecológico es también una forma de reponer lo que entre tanto los «factores urbanos y culturales» quisieron borrar en dirección a la aldea global. Simular la existencia humana en su situación natural, en un regreso al origen, implica, según el artista, una rehabilitación de los impulsos primarios y los arquetipos que son esenciales e inmutables, en comparación con el carácter transitorio de cualquier «orden cultural». En este, el arte y el cuerpo emprenden todas sus capacidades físicas y mentales en su relación con el cosmos. "Carneiro en su obra no marca ni establece distancias con la naturaleza, y en sus trabajos la idea de paisaje queda obviada. No encontramos una formulación definida de estilo, por el contrario domina una perspectiva evolutiva y transformadora, desde la que es posible comprender que el proceso artístico implica otro proceso interior de formación a través de la naturaleza. Lo que resulta esencial en sus trabajos es el modo en el que la acción en la naturaleza permite construir y formar una idea de hombre más plena en fusión y en contraste con ella" ${ }^{485}$. La naturaleza y el paisaje reales son asimilados por Alberto Carneiro como punto de partida para sus obras de arte, y estas sirven para recrear cualquier cosa que también se encuentra o encontró en los paisajes reales, la identificación con todo nuestro ser.

\footnotetext{
${ }^{484}$ CARNEIRO, Alberto, "Uma Cultura da Natureza”, Jornal de Letras Artes e Ideias, Lisboa, ㄲo 1022, pp. 12-17, 2 a 25 de Dezembro de 2009.

${ }^{485}$ OLMO, Santiago, B., Alberto Carneiro, Santiago de Compostela, Centro Galego de Arte Contemporánea, Xunta de Galicia, 2001, pp. 119 y 120.
} 


\section{CAPÍTULO V: \\ PROPUESTAS DE ARTICULACIÓN ENTRE EL \\ PAISAJE Y ESCULTURA}

\section{0}

\section{La expresión y la palabra}

La construcción de una tesis, si la entendemos en un dominio convencional, presupone, tal como toda actividad del pensamiento, la actividad del logos. De aquí proviene la primera dificultad: ¿una tesis se dedica a las palabras o a los aspectos expresivos suscitados por las obras? La intención de hacer una tesis teórico-práctica implica en este caso abarcar el dominio conceptual suscitado por el método interpretativo utilizado para explorar los dos bosques de A. Giacometti y A. Carneiro considerados como afinidades. ¿Cómo prestar atención a los aspectos expresivos suscitados por las obras? Este proyecto me conduce a hacer un ejercicio (arriesgado pero necesario) de traducción; traducción entre los dominios del lenguaje plástico y los dominios simbólicos del lenguaje verbal, o sea, en palabras de Susanne Langer, entre los "símbolos presentativos" y los "símbolos discursivos". Cabiendo a los primeros las "formas significativas visuales y auditivas, como los dibujos y combinación de sonidos, que en sus expresiones elementales son los instrumentos más primitivos de la inteligencia, pero que en las formas artísticas adquieren estructuras complejas, constituyen símbolos de honda significación y presentan una articulación lógica peculiar" ${ }^{\text {"86 }}$ y a los "símbolos discursivos" el ámbito del lenguaje propiamente dicho.

\footnotetext{
${ }^{486}$ LANGER, Susanne, Filosofia em Nova Chave. São Paulo, Perspectiva, 1989, p. 100. Op. Cit. Kogan, Jacobo, El lenguaje del Arte, Psicología y Sociología del Arte, Buenos Aires, Editorial Paidós, $1^{\mathrm{a}}$ ed., 1965, p. 25.
} 
Jacobo Kogan, en El Lenguaje del Arte, reseña sobre los escritos de Susanne Langer, recupera los términos en que esta autora establece una clara distinción entre la forma discursiva dominada por el logos y la sistematización, y las formas visuales. Según este autor, a partir del estudio de los escritos de $\mathrm{S}$. Langer, la noción de "forma" es la que existe tanto en el campo del arte como en el de la ciencia. La "forma" no es más que el reconocimiento de una "estructura relacional", siendo que ésta está siempre separada del objeto particular que la ejemplifica. La "forma" así entendida se caracteriza por su similitud, diferencia, relevancia, se aprenden intuitivamente y se constituye a partir de características proto-lógicas. "Las relaciones que integran esta estructura (...) se distinguen como similitud, diferencia, congruencia, relevancia, si congruencia, relevancia, se aprenden intuitivamente y constituyen características protológicas, pues deben ser vistas para ser apreciadas." ${ }^{487}$ La forma es "proto-lógica" en la medida en que antecede a la construcción del campo de la lógica propiamente dicho. El artista portugués Almada Negreiros decía, aún en la primera mitad del siglo XX, que "el arte es una pre-ciencia" en la medida en que anticipa cualquier acontecimiento que pueda ser sistemático.

A esta idea de "forma" o "estructura relacional", S. Langer le da el nombre genérico de "abstracción", ésta, como ya referimos, es común tanto al campo de la lógica como al del arte. Esta idea de que la forma se encuentra separada del objeto particular que la ejemplifica es curiosa; en cierto sentido, encuentro en Giacometti uno de sus practicantes más provechosos. Giacometti, en su texto ya citado titulado "Je ne sais ce que je vois qu'en travaillant", ${ }^{488}$ distingue entre obra de arte y objeto: "para mí un objeto deja de ser una escultura. Para mí, una escultura tiene que ser la representación de una cosa diferente de ella". ${ }^{489}$ Una escultura en este contexto estará próxima de una "existencia con un estatuto de pensamiento". ${ }^{490}$ Esta última formulación llevada a

\footnotetext{
${ }^{487}$ KOGAN, Jacobo, El lenguaje del Arte, Psicología y Sociología del Arte, Buenos Aires, Editorial Paidós, $1^{\mathrm{a}}$ ed., 1965, p. 29.

${ }^{488}$ GIACOMETTI, Alberto. Je ne sais ce que je vois qu'en travaillant. Paris: L'Échoppe, 1988. p. 16

${ }^{489}$ MOLDER, Maria Filomena, O Absoluto Que Pertence À Terra, Lisboa, Edições Vendaval, 2005, op. cit., p. 132.

${ }^{490}$ CHAFES, Rui, O Silêncio de ..., Lisboa, Assírio \& Alvim, 2006, p. 27.
} 
cabo por el artista Rui Chafes es consecuencia de la comprensión del trabajo y de los escritos de Alberto Giacometti, y muestra cómo una escultura no es sólo un objeto, en la medida en que la escultura se debe a un ideal, mientras que "el objeto que no hace justicia a la idea es sucio y está equivocado." ${ }^{491} \mathrm{El}$ artista portugués prosigue afirmando "no hay objeto, hay todos los niveles de esperanza del objeto" 492 porque la materialización del objeto no es más que la fijación necesaria y la materialización de todo un conjunto de ideas, emociones, percepciones. $Y$ toda la materialización tiene tanto de provisional como de definitivo, es por eso que una escultura es un objeto a la fuga de sí mismo.

El artista que se siente afectado por una obra de otro se interesa mucho más por lo provisional, por los movimientos afectivo-intelectuales que la engendraron, que por su calidad formal y material. Esto sucede porque existe una dificultad en llegar a la escultura "hay (...) una deficiencia técnica: no conseguir impedir a la escultura ser objeto. Sin conseguir convertirla en una existencia con estatuto de pensamiento, nos queda la existencia con estatuto de cuerpo." 493 Un cuerpo, como vimos a propósito de la consideración que hace Gilles Deleuze, es algo a partir de lo que se generan intercambios.

Según J. Kogan, a partir de Langer, esta "abstracción" o "forma" en el plano artístico es bastante distinta del plano científico, ya que en el plano del arte la abstracción es representativa, unitaria, orgánica, no discursiva y generalizadora. Se puede hablar de abstracción porque en arte estamos ante la creación de símbolos y formas significativas. La abstracción propia de la ciencia y del logos ya se caracteriza por ser general. Esta abstracción propia de la ciencia está más próxima de los "símbolos discursivos", materializados por el lenguaje propiamente dicho, que de un desarrollo sistemático. Por su parte, la forma del arte "es orgánica, y su cometido es representar la experiencia vital o la estructura dinámica de las emociones. Éstas aparecen relacionadas y articuladas directamente ante los ojos, no primero vistas y luego racionalmente vinculadas. La abstracción es inmediata y es la de un conjunto indivisible, cuyas partes sólo

\footnotetext{
491 Ibidem.

492 Ibidem, p. 28.

${ }^{493}$ Ibidem, p. 27.
} 
tienen sentido dentro del todo, como corresponde al símbolo de un organismo vivo." 494 Por lo tanto, las formas del arte son primero el objetivo de una experiencia; primero se ven y sólo después pueden vincularse racionalmente. Por eso, su abstracción es inmediata, comienza con una percepción sensible que se materializa o condensa en imágenes. "(...) Todo arte genuino es abstracto. Las formas esquematizadas en la pintura y la escultura presentan una invención técnica muy notable con el fin de lograr abstracción artística, pero el resultado no es más ni menos abstracto que el de cualquier obra valiosa en la 'gran tradicional', sea del arte egipcio, peruano o chino." ${ }^{495}$ Así se deduce que es universal.

Para J. Kogan, sistematizando la lectura de S. Langer, "la ciencia es general y el arte particular." ${ }^{496}$ Esto sucede "porque la ciencia va de la denotación general a la abstracción precisa; y el arte, de la precisa abstracción a la connotación vital, sin la ayuda de la generalidad." ${ }^{497}$ Ante esta explicación que, aunque pueda parecer datada e incompleta para referirse a muchas de las obras de la contemporaneidad, tengo que reconocer que encierra en sí una idea fundamental: teniendo el arte las características antes referidas y otras que la contemporaneidad se encargó de forjar, es arriesgado transformar o mostrar aquello que son "símbolos representativos" en "símbolos discursivos". Pues subsiste el problema irresoluble de que "el lenguaje", como definió Susanne Langer, "es un medio pobre para expresar nuestra naturaleza afectiva, fracasa lamentablemente en cualquier intento de comunicar los esquemas en movimiento constante, las ambivalencias y los enredos de la experiencia íntima, la recíproca acción de los sentimientos con pensamientos e impresiones, con recuerdos y ecos de recuerdos, con fantasías fugaces o sus meros rastros entrelazados, conjuntamente transformados en innominado material afectivo." ${ }^{498}$

\footnotetext{
${ }^{494}$ KOGAN, Jacobo, El lenguaje del Arte, Psicología y Sociología del Arte, Buenos Aires, Editorial Paidós, $1^{\text {a }}$ ed., 1965, p. 29-30.

${ }^{495}$ LANGER, Susanne, Problems of Art. New York, Scribner's, 1957, p.163.

${ }^{496}$ KOGAN, Jacobo, Op. Cit., p. 30.

${ }^{497}$ LANGER, Susanne, Op. Cit., p.180.

${ }^{498}$ KOGAN, Jacobo, El lenguaje del Arte, Psicología y Sociología del Arte, Buenos Aires, Editorial Paidós, $1^{\underline{a}}$ ed., 1965, p. 26-27.
} 
Son muchos los artistas que comprendieron este foso entre el lenguaje verbal y el lenguaje del arte. Paul Klee fue uno de ellos: "me quedo un poco aprensivo cuando tomo la palabra con mis obras a la vista, ya que ellas tienen su propio lenguaje, y me pregunto a mí mismo si conseguiré reunir argumentos suficientes o si lo haré de forma concreta. La razón es ésta: por mucho que yo, como pintor, disponga de los medios que permiten a los otros seguir los caminos que yo mismo seguí, no me siento capaz de indicar tales caminos con la misma seguridad a través de la palabra." ${ }^{499}$

También Cézanne desconfía del lenguaje para tratar el fenómeno del arte. En una carta a Émile Bernard, fechada en 26 de Mayo de 1904, a propósito de un próximo artículo sobre su trabajo publicado por el destinatario para la revista Occident, Cézanne defiende que "el pintor debe dedicarse enteramente al estudio de la naturaleza y esforzarse en producir cuadros que sean lecciones. Las charlas sobre arte son casi inútiles (...) el literato se expresa con abstracciones, al tiempo que el pintor concreto lo hace por medio del dibujo y del color." ${ }^{500}$ Podría citar tantos otros nombres, pero no lo hago; esta reticencia a exponer verbalmente mi trabajo parece, a día de hoy, algo anticuado, diseminados como están en la práctica contemporánea del arte el discurso y el arte, sin embargo, incluso en la actualidad pienso que esta alerta es útil para iluminar todo lo que se pueda exponer, pero, sobre todo, lo que se debe omitir sobre el proceso creativo.

En este capítulo quinto, decidí escribir en primera persona del singular; presentar los trabajos que considero relevantes para que cada uno pueda inferir la pertinencia de la relación de afinidad que quise establecer antes con dos obras: La forêt y Uma floresta para os teus sonhos, de A. Giacometti y A. Carneiro respectivamente. Una relación que (espero) pueda continuar lanzando respuestas y otras tantas preguntas sobre el problema de la escultura en su relación con el paisaje. Pero sobre todo mostrar que un proceso creativo

\footnotetext{
${ }^{499}$ KLEE, Paul, Escritos sobre arte, Trad. Catarina Pires e Marta Manuel, Lisboa, Cotovia, 2001, p. 18.

${ }^{500}$ CÉZANNE, Paul, Correspondência Paul Cézanne, Trad. António Paulo Danesi, São Paulo, Martins Fontes, 1992, p.247.
} 
individual es esquivo a una demostración lineal de las consecuencias de la profundización en estas afinidades, porque va mucho más allá de ellas. También debo advertir que este proceso de presentación e indagación sobre mi trabajo práctico sólo sucedió tras la realización de las piezas; así, éstas no surgieron de un programa de trabajo premeditado y con fecha, sino del ritmo propio de la creación, que sufre influencias, más o menos conscientes, de aquello que se va investigando.

Presentaré este capítulo como quien presenta en público su trabajo, como además ya hice en muchas ocasiones durante estos últimos años. Me centraré en la descripción procesual de la realización de los trabajos para después intentar profundizar en algunas consecuencias de ese proceso creativo. Durante este trayecto meditativo, citaré otros artículos, críticas y reseñas elaboradas principalmente a lo largo de los últimos seis años y, a continuación, profundizaré en una nueva cuestión -la de la relación de la fotografía con la escultura y el paisaje- e intentaré exponer la manera cómo, en mi trabajo, la escultura relaciona paisaje, fotografía e incluso dibujo. Mostraré cómo el trabajo se abre más allá de las afinidades citadas que, al final, constituyen una pequeña parte, a pesar de todo importante, de otras afinidades que por conveniencia organizativa para esta disertación no fueron aquí objetivo de profundización.

\section{1}

\section{Paisaje y arte - imagen e instalación ${ }^{501}$}

Podría suponerse a partir de la secuencia de argumentos presentada hasta ahora que esta parte final se circunscribiría al estudio de la problemática de la práctica de la escultura a partir de enfoques más o menos tradicionales. Pero

\footnotetext{
${ }^{501}$ Esta línea argumental que pretende explorar la relación entre fotografía y escultura se publicó como artículo en un libro titulado FILOSOFIA E ARQUITECTURA DA PAISAGEM Um Manual, RAMA, Samuel, Paisagem e Arte Imagem e Instalação, In FILOSOFIA E ARQUITECTURA DA PAISAGEM Um Manual (Coord: Adriana Verissimo Serrão), Lisboa, Centro de Filosofia da Universidade de Lisboa, 2012, pp. 165-176. Proyecto de investigación de filosofía y arquitectura del paisaje (FCT PTDC/FIL-FIL/100565/2008), a la que pertenezco, y que integra lo Centro de Filosofia da Universidade de Lisboa - Facultad de Letras y Centro de Estudos de Arquitectura Paisagista "Prof. Caldeira Cabral" - Instituto Superior de Agronomia.
} 
la verdad es que tanto mi trayectoria, como la relación de la escultura con la cuestión del paisaje, nos obligan a tratar de entender una nueva comprensión de la imagen, principalmente de la imagen fotográfica.

Para poder contextualizar mis propuestas prácticas, propongo que pensemos primero por qué razón Richard Long llama escultura a una imagen fotográfica impresa a partir de un fotograma. Una vez respondidas algunas cuestiones relacionadas con este problema, expondré los procesos y las consecuencias de esta relación constante entre concretizaciones escultóricas tridimensionales y bidimensionales.

Como vimos en el capítulo II, a partir de la segunda mitad del siglo XX, diversos artistas establecen en su práctica artística relaciones varias con el paisaje a través del uso de la fotografía. Su estrategia creativa coloca en el centro de la práctica artística tanto el cuerpo del artista en los lugares del paisaje como, en un segundo momento, el propio cuerpo del espectador que participa en el espacio de la exposición, pensada para crear una cierta experiencia espacial.

En este contexto de apertura de la práctica artística, la fotografía no puede entenderse a partir de su ontología, sino como un medio al servicio de varios protocolos, siendo la escultura el principal. De esta forma, los artistas que utilizan el medio fotográfico lo hacen no tanto pensando en su capacidad para representar el paisaje, sino como documentación activa focalizada en un cierto carácter indexical de la imagen, es decir, en el carácter de las construcciones y acciones realizadas en el paisaje. En este contexto, la imagen fotográfica existe en un contexto proyectual y conceptual en la medida en que la fotografía sólo tiene sentido en un ámbito amplio de la práctica artística que incluye varios media y estrategias creativas, como el uso del dibujo, mapas, la palabra, etc., y que tiene como dispositivo fundamental la exposición. Así, en la relación de lo escultórico con el paisaje, cada imagen fotográfica obedece a un riguroso pensamiento resultante de un proyecto de acción previo en los lugares reales del paisaje. 


\section{2}

\section{El paisaje en el campo de lo escultórico a través de la fotografía}

Tratar de la relación del campo de lo escultórico con el paisaje a través de la fotografía incita a profundizar en el contexto específico de las prácticas de Land Art, lo que implica pensar la escultura en su vasto campo de posibilidades, suscitando cuestiones. ¿Por qué razón la escultura se relaciona con el paisaje que, como vimos en el primer capítulo, fue el tema por excelencia de la pintura? Sabiendo que esta última activa preferentemente el sentido de la visión y que la escultura mantuvo siempre una relación muy privilegiada con el tacto, o con el tacto y la visión en simultáneo, providenciando el sentido háptico, ¿qué le habrá sucedido a la escultura para llegar a establecer esta relación?, ¿por qué se habla de escultura en relación a muchas de las fotografías realizadas por artistas de Land Art si lo que tenemos enfrente no pasa de una imagen bidimensional impresa a partir de un fotograma?, ¿qué nuevas lógicas engendraron los artistas?, ¿qué vínculo mantiene la fotografía con un campo que está en constante expansión y de qué modo proporciona una apertura del campo del arte para fuera de sí y en dirección a los lugares y paisajes concretos?. Y, por último, ¿cuáles son los rasgos dominantes de estas formas de expresión que unen paisaje, fotografía y práctica escultórica?, ¿cómo podemos identificarlos en el vasto ámbito de la práctica del arte contemporáneo?

Partiendo de las preguntas previamente enunciadas, propongo recordar y articular cuestiones abordadas anteriormente y continuar un recorrido meditativo, teniendo como criterio el análisis y la interpretación de algunas obras de artistas plásticos que emplearon la fotografía como medio de relación con el paisaje en el contexto de la reciente práctica escultórica dominada por el dispositivo de la instalación. Todo ello para presentar después algunos trabajos prácticos que hice principalmente durante el periodo de los últimos seis años, 2006-2012, sin olvidar que, para una defensa más articulada de mi práctica artística, que considero distinta a la del Land Art, también tendré la necesidad de convocar trabajos anteriores a 2006. 


\section{2 a. Apertura del campo artístico}

En el plano cultural en general y en el artístico en particular, se asistió a mediados del siglo XX, como abordamos en el segundo capítulo, a una apertura generalizada de varias áreas a los saberes de otras que les eran más o menos contiguas. El paisaje comenzó a formar parte del campo de lo escultórico por vía de la fotografía, y eso sólo fue posible porque los artistas pasaron a disponer de una cantidad de saberes y operaciones estéticas activadas de manera libre. Para que un artista pudiese usar la fotografía en el campo de la práctica escultórica, hubo de existir la posibilidad de una práctica del género, libre de los constreñimientos que los preceptos de la escultura fueron estableciendo y sedimentando a lo largo de su práctica. Esta nueva condición para la creación fue designada por Rosalind Krauss como "the post-medium condition" ${ }^{\text {"202, es }}$ decir, la práctica del género puede, en algunos casos, ser omisa o extraña a los procedimientos tradicionalmente establecidos como naturales o apropiados para la práctica de ese género. En esta nueva condición «post-medium», cada artista activa los conocimientos y los procedimientos de la disciplina que mejor le conviene con vistas a un determinado objetivo. Con esta transformación, ocurrió de manera generalizada el mestizaje de los géneros tradicionales y la consecuente entrada del paisaje en el arte, pero ahora por la vía de la práctica escultórica.

\section{2 b. Paisaje}

Como ya se vio, la palabra paisaje puede referirse tanto a una escena observada a través de la vista como a una imagen realizada a partir de esa mirada, como una pintura o una fotografía. La cuestión de señalar cualquier cosa como paisaje está relacionada con el hecho comunicacional de nominación por vía del lenguaje de un determinado tipo de realidad, o como representación de esa realidad.

\footnotetext{
${ }^{502}$ KRAUSS, Rosalind, Voyage In The North Sea, Art In The Age of The Post-Medium Condition, Thames and Hudson. 1999.
} 
En su génesis renacentista italiana, el paisaje surge sobre todo a partir de una distinción o cisión entre observador y observado, siendo que el observador está en una posición privilegiada en relación al observado. Esto quedó bien patente en el momento de la invención de la perspectiva unifocal del Renacimiento italiano, cuya evolución coincide y es indisociable de la creación cultural de la idea de paisaje durante la modernidad.

La perspectiva renacentista resulta de una comprensión del funcionamiento del ojo y surge como un modelo privilegiado para comprender el espacio y la luz. Este dispositivo ganó adhesión, constituyendo una métrica para el espacio y el tiempo, en la medida en que cualquier espacio es susceptible de ser representado en unidades iguales que repercuten en una constancia organizativa jerárquica.

\section{2 c. La fotografía}

La fotografía es heredera de la perspectiva unifocal del Renacimiento italiano. Curiosamente, las primeras fotografías realizadas fueron, por imperativo procesual, paisajes, pues sólo este referente garantizaba la cantidad de luz suficiente para sensibilizar los soportes que al inicio eran poco sensibles a la impresión de la luz. En el siglo XIX, en Londres, Fox Talbot inventa un proceso de fijación de las sombras sobre papel que vino a designar como "dibujos fotogénicos" ${ }^{503}$. En gran medida, esos dibujos apellidados "iliputianos" eran paisajes fijados en imagen.

Estos "dibujos fotogénicos" pasaron después a llamarse "talbótipos", apropiándose del nombre de su creador, y mas tarde "calótipos". Casi en simultáneo, Daguerre inventaba en Francia otro proceso para fijar las sombras, en este caso utilizando una chapa de metal tratada y sensibilizada como soporte, el "daguerrotipo". Lo que distinguía el proceso de Talbot del de Daguerre era la versatilidad que poseía el método de la calotipia, principalmente por la posibilidad

\footnotetext{
${ }^{503}$ TALBOT, William Henry Fox, "Sobre a Arte Do Desenho Fotogénico Ou Processo segundo o qual os Objectos da Natureza por si mesmos se Desenham sem Socorro de Lápis", Traducción de Jorge Martins Rosa, in Revista de comunicação e linguagens, Lisboa, n.ำ 39 (Jun. 2008), p. 229-241.
} 
de poderse reproducir una imagen en positivo a partir de una misma matriz en negativo de papel.

Uno de los factores que condujo a Talbot hasta uno de los marcos inaugurales en la invención de la fotografía fue el auto-reconocimiento de su inaptitud manifiesta para dibujar de manera realista los paisajes que veía a través de su cámara oscura. Fue esta incapacidad de corresponder con acuidad suficiente en el acto del dibujo al sentimiento de belleza que ciertos paisajes le suscitaban que llevó a Talbot a la invención de su proceso de fijación de las sombras sobre papel.

Este modo de fijar las sombras naturales sobre un soporte artificial constituía, ya desde el inicio, una prueba química de que "aquello existió", de que "aquella realidad fue vista por aquella persona" o, como diría Roland Barthes, de que la fotografía es un «certificado de presencia». La fotografía combatía así la experiencia de lo efímero y eso fue de extrema utilidad cuando los artistas quisieron responder a la aceleración del tiempo exterior, creando acciones performativas y diversas estrategias, desarrolladas en paisajes concretos buscando una relación con el tiempo biológico y geológico integrado en los procesos de cariz escultórico.

La fotografía estuvo, desde el principio, relacionada con lo efímero, con la fijación de una acción que, por ser limitada en el tiempo, suscitaba la necesidad de ser cristalizada. La fotografía puede, a partir de sus determinaciones, parar el tiempo y establecer relaciones con el espacio. Una imagen fotográfica analógica puede constituirse como prueba o certificado químico, una firma de luz que posibilitó al arte, y a la escultura en particular, trabajar en espacios que hasta entonces le eran extraños, tales como desiertos, montañas $u$ otros parajes remotos y lugares distantes hasta el interior de la institución, galería o museo. La fotografía pasó a ser no sólo la prueba y el objeto de la estancia del artista y de su proceso, sino también el único objeto que podría ser transaccionado en el mercado del arte.

La escultura, que siempre fue fijada en materiales duraderos y nobles con el fin de poder cumplir con su vocación evocativa y conmemorativa de 
determinados acontecimientos heroicos humanos, o más recientemente deteniéndose en sus condiciones estéticas específicas, puede ahora, a través de la imagen fotográfica, inaugurar la performatividad de lo banal. Pequeños gestos y acciones pueden tomar ahora una dimensión nunca antes vista en el campo del arte. La fotografía de una línea dibujada por los pies del artista calcando la hierba fresca puede compararse con cualquier obra maestra de arte contemporáneo. Su belleza surge del hecho de presentar un acto interesante y al mismo tiempo inusitado en la práctica artística. Las señales y las marcas más tenues de la vida pueden también expresarse, guardarse y trabajarse en el ámbito artístico.

La fotografía realizada por los artistas del llamado Land Art explora el carácter indexical de la imagen, o sea, cada fotograma deriva y promueve una relación con la intervención paisajista; el certificado de presencia que ella constituye adquiere, en el arte de los años 60 del siglo XX, mayor importancia que su poder representativo. En vez de solamente representar, la fotografía, que documenta las intervenciones en el paisaje, denota y orienta la atención para la marca o impresión dejada por el artista en el paisaje.

\section{2 d. Escultura}

La escultura, como vimos en el segundo capítulo, deriva de un arte mucho más antiguo, la estatuaria, que se caracteriza por ser esencialmente evocativa y celebrativa. El trabajo realizado por Rodin a mediados del siglo XIX constituyó el punto de cambio fundamental para que la escultura fijase sus propios procedimientos y, a partir de ahí, los desarrollase en el sentido de su emancipación a través de la negación de sus procedimientos tradicionales. Los escritos de Rodin ${ }^{504}$, así como la evolución de su obra escultórica, denotan una profundización en una cierta ontología de la escultura, negando la convención ilusionista derivada de la representación bidimensional característica de la estatuaria y presentando una visión crítica de la práctica del arte en general y de la escultura en particular, siendo, en el ámbito de esta comprensión teórica, un punto nodal a partir del cual irradió una práctica modernista de la escultura

${ }^{504}$ RODIN, August, L'Art, Paris, Grasset, 1911. 
animada por una conciencia cada vez más acentuada de lo que le es específico. Una de las contribuciones fundamentales de Rodin fue el hecho de mostrar que trabajar el concepto de escultura implica orientarla en el sentido de una cierta opacidad, o sea, de auto-referencialidad de sus procesos y, en consecuencia, de negación de la estatuaria y de su marcada dimensión evocativa. Así, la escultura sucedió a la estatuaria pero retuvo de ésta la idea de muerte y de ausencia que continuó ligada de forma permanente al proceso escultórico. En este sentido, la escultura del siglo XX se constituye como un trabajo constante sobre la idea de ausencia de un cuerpo que se dislocó para otro lugar, como nos presenta Fullaondo "la ausencia es el resultado de un proceso de desocupación espacial, presencia de una ausencia formal o vacío, se crea, es un resultado, no existe a priori." ${ }^{505}$

\section{2 e. Campo expandido de la Escultura}

A mediados del siglo XX surge una manera de pensar ambigua sobre lo que puede o no ser escultura. Como vimos en el segundo capítulo, la escultura siempre estuvo determinada como objeto tridimensional realizado en un material duradero y empleando el volumen y la forma como medios de expresión. La escultura de Giacometti encaja en esta manera de entender la escultura, aunque ya contenga el germen de una nueva práctica escultórica cada vez más dirigida hacia una existencia en el espacio real. A partir de mediados del siglo XX, y de forma más intensa en los años 70 y con la llegada del arte conceptual, la práctica escultórica pasa a integrar muchas otras cosas, como ambientes y paseos en el campo o incluso imágenes fotográficas y fílmicas incluidas en el espacio de exposición.

La escultura conoció, a mediados del siglo XX, una ampliación extraordinaria de sus márgenes. Podemos decir que dejó de tener exterior o de contener una frontera reconocible. La dificultad en definir qué es la escultura contemporánea viene también por un aumento de intervenciones escultóricas en

\footnotetext{
${ }^{505}$ FULLAONDO, Juan Daniel, Oteiza y Chillida, en la moderna historiografía del arte, Bilbao, Editorial La Gran Enciclopedia Vasca,1976, p. 21.
} 
el espacio público y de la intervención en el día a día real, concreto, de las personas, como por ejemplo el ambiente o instalación de Alberto Carneiro Uma floresta para os teus sonhos, de 1970, estudiado en el capítulo anterior. Este cambio en las prácticas tridimensionales, que trilló el camino que venía de la estatuaria, pasando por la escultura entendida en sentido estricto y, por fin, en un sentido más amplio, no constituye una evolución positivista sino más bien una expansión de lo escultórico, que revindicó para dentro de sí la arquitectura y el paisaje, haciendo que ciertas tipologías creativas como la instalación, la performance, el video, el sonido o hasta incluso ciertas fotografías puedan considerarse dentro del campo de la tridimensionalidad porque la ocupación del espacio continúa siendo su actividad principal.

Rosalind Krauss, en un texto titulado Sculpture in the Expanded Field, de 1979, identifica esta apertura del concepto de escultura presentándonos un retrato de la situación artística.

En los últimos diez años, se ha utilizado el término "escultura" para referirse a cosas bastante sorprendentes: estrechos pasillos con monitores de televisión en sus extremos; grandes fotografías que documentan excursiones campestres; espejos dispuestos en ángulos extraños en habitaciones corrientes; efímeras líneas trazadas en el suelo del desierto. Aparentemente no hay nada que pueda proporcionar a tal variedad de experiencias el derecho a reclamar su pertenencia a algún tipo de categoría escultórica. A menos, claro está, que convirtamos dicha categoría en algo infinitamente maleable. ${ }^{506}$

Recordemos que R. Krauss comienza apuntando en este texto que la escultura siempre fue "no-paisaje" y "no-arquitectura". Es decir, la escultura siempre se destacó de la arquitectura y se diferenció del paisaje. Ésta no es arquitectura porque la escultura no es estructural a un edificio, y no es paisaje porque la estatuaria, instalada en el espacio abierto exterior, no está separada de su dimensión evocativa.

Como vimos en trabajos de artistas que podemos encuadrar en el Land Art, no son ni arquitectura, ni paisaje, pero pueden ser simultáneamente los dos. La naturaleza de estas piezas, que desde el Minimalismo operan modificaciones

\footnotetext{
${ }^{506}$ KRAUSS, Rosalind E., La originalidad de la Vanguardia y otros mitos modernos, Versión española de: Adolfo Gómez Cedillo, Madrid, Alianza Editorial, 2002, p. 289.
} 
espacio-temporales de la percepción del espectador, exigen ampliar el campo más allá de las coordenadas no paisaje/no arquitectura. Así, y a partir de un análisis estructuralista, se añaden paisaje y arquitectura, reclamados por los nuevos trabajos, como parte de la posibilidad en escultura. La escultura pasa a existir en este campo cuaternario dialogando directamente con la arquitectura y el paisaje.

A partir del momento en que la escultura integra en su campo de actuación el paisaje, sus practicantes tienen la necesidad de usar la fotografía como medio expedito y eficaz para documentar pequeñas o grandes intervenciones en el paisaje, normalmente en localizaciones geográficas de difícil acceso. Además de documentar, la fotografía puede manipularse durante la captura; pequeñas variantes como el encuadre y el punto de vista permiten dotar la documentación del trabajo de una gran carga subjetiva.

Casi siempre, los lugares escogidos por los artistas de Land Art para sus intervenciones son de difícil acceso, por distar de las grandes metrópolis o por ser inhóspitos; estos lugares, sin embargo, cuando se revelan en imagen, se vuelven accesibles desde el punto de vista estético. Richard Long puede presentar en una exposición una fotografía mostrando una intervención efímera marcada en un terreno montañoso, pero, al hacerlo, denota muchas veces un sentido romántico del paisaje. En $A$ line in the Himalayas, 1975, la representación de la montaña no sólo obedece al carácter documental que el trabajo en el lugar exige; la imagen muestra al fondo la configuración cristalina de la montaña cubierta de nieve, lo que revela una búsqueda del artista en el sentido de recuperar en imagen una cierta idea de grandeza, espacio natural expansivo y salvaje que remite inmediatamente para una cierta idea de lo sublime, aunque sobre la forma de material conceptual derivado tanto de la sensibilidad como del intelecto.

Creo que el arte, reducido incluso a los medios más simples, puede ser un vehículo para nuevas ideas. Para mí, el mero hecho de caminar permite que la imaginación se libere. Realizar actividades sencillas que no implican al pensamiento, como contemplar el fluir de un río o descansar sobre una piedra, libera y agudiza los sentidos. A través de los ritmos del caminar, dormir, caminar, dormir, comprendo mejor los 
ritmos de la vida y de la naturaleza. Me gusta muchísimo la idea de que puedo, quizás, comenzar un paseo en un lugar remoto y que, después de unos cuantos días de involucrarme en el ritmo y de sentirme progresivamente más relajado, empieza a fluir mi imaginación y encuentro lugares que antes no había visto. Todo parece en esos momentos ocurrir por azar o sin ninguna preparación previa. Soy capaz de crear obras con las que jamás hubiera soñado en esa situación. ${ }^{507}$

Por lo tanto, cada imagen de Richard Long deriva primero de un proyecto que consiste en hacer una caminata por una determinada región, preferentemente inhóspita o inaccesible desde el punto de vista físico, después, el propio proceso de habitar influye y determina el tipo de marcación efímera que se realice en el lugar, así como la naturaleza de la imagen. Ya en el espacio de la galería o museo, el espectador tiene acceso a los vestigios de esta experiencia hecha sensible e inteligible a través de la presentación de las imágenes fotografiadas acompañadas del uso de la palabra que describe, con mayor o menor grado de objetividad, la experiencia que el artista quiere que sea intersubjetiva, apelando en cada uno el sentido del recorrido en los lugares naturales del paisaje.

\section{2 f. El paisaje en el campo de lo escultórico/instalación}

A partir de la segunda mitad del siglo XX, el paisaje y la fotografía entraron en el campo de lo escultórico a través del llamado Land Art. Para los artistas pertenecientes a este lenguaje del arte, lo que interesaba era abrir nuevas posibilidades para el arte, hacerlo salir de los circuitos tradicionales del museo y de la galería, ir hasta los lugares del paisaje y volver a ellos transformado.

En 1967, Richard Long realiza A Line Made by Walking. Se trata de una línea recta dibujada o esculpida directamente sobre la hierba, a través del caminar continuado del artista en la mima dirección de construcción de la línea. El resultado se fotografió, la imagen fotográfica cristalizó lo efímero del recorrido.

\footnotetext{
${ }^{507}$ LONG, Richard, Conversación transcrita del vídeo Stones and Files: Richard Long in Sahara, realizado por Philips Haas, Éditions á Voir, Ámsterdam, 1988, ( pp. 113 - 115) in Land Art, Tonia Raquejo, San Sebastián, Editorial Nerea, 1998.
} 
A través de esta fotografía, podemos reconstruir el tiempo de la caminata inscrito en el espacio de la tierra.

A Line Made by Walking fue una obra fundamental en la época en la que se ejecutó. Rudi Fuchs "lo ha comparado con el cuadrado negro de Kasimir Malevich: «una interrupción fundamental en la historia del arte.» Guy Tosatto la define como «uno de los gestos más singulares y revolucionarios de la escultura del siglo" ${ }^{\prime 50}$. Es importante reparar en que la fotografía que registra esta obra presenta una línea dibujada en la hierba desde un punto de vista que la proyecta virtualmente para el infinito, lo que torna el registro no sólo una mera fijación documental de una intervención, sino también una imagen proyectiva mental, estética y ética, dispuesta y expuesta al cuerpo del espectador.

El trabajo de Richard Long articula la caminata, en cuanto escultura, con el registro de pequeños encuentros e intervenciones en el paisaje. En otros casos construye intervenciones escultóricas efímeras, en su mayoría líneas o círculos en parajes recónditos, pudiendo mostrar las fotografías, en estos casos, planos mayores que fijan la intervención escultórica y su contexto paisajístico.

Además del movimiento de salida del espacio de la galería o museo en dirección al paisaje, Long realiza también el movimiento opuesto, al traer para dentro de la galería o museo los vestigios, esculturas, piedras, que se agrupan para formar intervenciones escultóricas, lama, con los que construye los dibujos brutos sobre las paredes del espacio expositivo, así como mapas del recorrido efectuado y palabras en constelación que inducen el proceso de los encuentros de la caminata. De hecho, buena parte del dispositivo escultórico se sitúa y tiene inicio en el propio cuerpo del artista que emprende una caminata en el paisaje real y que la documenta de modo activo. Ya en la exposición en el interior del museo o galería, las diferentes imágenes fotográficas se escenifican en diversas escalas y disposiciones pensadas para provocar una determinada experiencia espacial en el cuerpo del espectador. Richard Long, tal como otros artistas, no desvinculan el objeto de arte del dispositivo expositivo emanado directamente del constructivismo ruso.

${ }^{508}$ CARERI, Francesco, Walkscapes, El andar como práctica estética, Barcelona, Gustavo Gili, 2002, p. 146. 
En 1970, Robert Smithson creó la Spiral Jetty en el gran Lago Salado de Utah. Se trata de un muelle en espiral construido enteramente por tierra y piedras de basalto negro. Esta espiral se presenta como expresión de su relación con la tierra, constituyendo también la materialización de una visión apocalíptica del mundo, fuertemente influenciada por su obsesión con los procesos entrópicos y por autores como J.G. Ballard. Rosalind Krauss lo describe como un "ciclón inmóvil, y espacio giratorio". ${ }^{509}$ Está claro que su movilidad sólo ocurre cuando el cuerpo del espectador experimenta caminar por el muelle dentro de la segunda mayor masa de agua muerta del mundo, pero la verdad es que el número de personas que experimentó la Spiral Jetty en el lugar es inconmensurablemente menor que el número de aquellos que la conocen por fotografía o incluso filme.

En 1970, cuando se construía la Spiral Jetty, el nivel del agua salada en el lago de Utah era excepcionalmente bajo, debido a un enorme periodo de sequía, hecho que Robert Smithson desconocía. La espiral se mantuvo visible durante algunos años después de construida pero, cuando las aguas del lago volvieron a subir, la Spiral Jetty desapareció, quedando sumergida durante treinta años, restando apenas su fotografía, que constituía un documento importantísimo, pues una vez sumergida la Spiral Jetty dejaba de poder ser experimentada en el lugar. La fotografía de la intervención era la prueba de que la intervención existió y su valor como documento se intensificó de tal modo que se convirtió en monumento, suscitando incluso, recientemente, un movimiento a favor de la restauración de la Spiral Jetty que, en el caso de concretizarse, sería completamente opuesto a los intentos entrópicos de Smithson.

Tal como nos recuerda Rosalind Krauss, la escultura es inseparable de la lógica del monumento. En The Monuments of Passaic de 1967, Smithson explora la fotografía como medio para pensar lo escultórico; retoma el tema de la movilidad y el acto de recorrer el espacio de las periferias suburbanas e industriales de la ciudad de New Jersey, como ya lo había hecho Tony Smith. Forman parte de este trabajo la presentación de un mapa en negativo mostrando la región de los "monumentos" a lo largo de Passaic River y más de veinticuatro

\footnotetext{
${ }^{509}$ KRAUSS, Rosalind E., Caminhos da Escultura Moderna, Trad. Julio Fischer, São Paulo, Martins Fontes, 2001, p. 336.
} 
fotografías en blanco y negro con $3 \times 3$ pulgadas de los dichos "monumentos". Éstos eran puentes, estructuras abandonadas, conductos de aguas residuales y una caja de arena o una maqueta de desierto, remitiendo para una metáfora muerta que equivale al vacío y al sin tiempo, además de parodiar lo pintoresco, característico del género de paisaje.

Smithson invita a quien visita la galería a confrontarse a sí mismo con este espacio concreto, abandonado y entrópico, donde la tierra olvidó el tiempo. Un lugar suspendido entre la ciencia-ficción y los principios caóticos de la humanidad. The Monuments of Passaic es una obra constituida simultáneamente por el territorio suburbano de Passaic River, el acto de Smithson recorriéndolo y la invitación para que todos lo hagan a través del mapa y de las fotografías. Éste es un buen ejemplo de un tipo de trabajo artístico cuya expansión de campo se hace mediante la estética entrópica, por la voluntad política de intervención en el espacio, dando una posibilidad de ser vivido y ordenado por las personas $y$, en consecuencia, de reacción a los espacios tradicionales del arte. Smithson se convierte en una especie de artista-antropólogo al identificar estos espacios en disolución, los "no-lugares", y con los que no es posible establecer relación.

Los monumentos de Smithson presentan una estrategia doble en la organización del paisaje del suburbio: por un lado, puntúan el lugar a medida que era leído, por otro, inscriben en aquel espacio la lógica del monumento y de la escultura, es decir del arte, y hoy podremos afirmar de la propia historia del arte y del urbanismo, en la medida en que el artista propone una lectura posible para esos lugares sin historia, a través de una atención performativa de relación con lo banal, donde no había "pasado, sólo lo que pasa por ser un futuro. Una Utopía sin fondo, un lugar donde las máquinas están ociosas y el sol se ha convertido en vidrio." 510

Aunque las fotografías de la Spiral Jetty cumplan una función distinta de aquellas que componen los Monuments of Passaic, la verdad es que ambas participan de forma distinta de la lógica del monumento. Es decir, si en ambos

${ }^{510}$ SMITHSON, Robert, Un Recorrido por los Monumentos de Passaic, Nueva Jersey, Valencia, IVAM - Centre Julio González, 1993, p. 76. 
casos la fotografía como documento es parte de la noción de monumento, en el segundo, la lógica del documento como monumento es una consciencia inseparable de la concepción de obra que va a buscar una de las determinaciones históricas de la escultura para nombrar todas las construcciones que el artista fotografía como nuevos monumentos, o sea, esculturas. El artista propone, de esta forma, una disolución entre cultura erudita y popular y una aproximación del arte al contexto del mundo real.

Michel Foucault, en Arqueología del Saber, pondera la relación entre documento y monumento en el momento del ejercicio crítico de la historia entendida como ciencia: "la historia en su forma tradicional visaba 'memorizar' los monumentos del pasado, transformarlos en documentos y hacer hablar a esos rasgos que, por sí mismos, muchas veces no son verbales o dicen en silencio cosas diferentes a lo que dicen; en nuestros días, la historia es lo que transforma los documentos en monumentos." ${ }^{511}$ La inversión que propone M. Foucault hace que la historia tienda para la arqueología y no al contrario, como sucedía con la historia tradicional producida antes del siglo XVIII. De esta forma, el cambio de paradigma del documento al monumento es el que permite trabajar las discontinuidades, las multiplicidades de las rupturas, o sea todo aquello que el trabajo conceptual propio del análisis historiográfico difícilmente conseguiría hacer emerger.

Además de la polémica de las fotografías que pasaron de documento a monumento, es importante retener que, en el caso de la obra de Smithson, el uso de la fotografía siempre fue un modo instantáneo de fijar en imagen las "impresiones pasajeras de acciones y lugares entendidos como procesos y no como imágenes que hay que contemplar estéticamente." ${ }^{512}$ Sus fotografías son, según David Campany, un intento de "representar la naturaleza de un modo íntimo y físico, y reflejar nuestra relación con ella, una relación que acostumbra ser inestable y premeditada. ${ }^{513}$ Smithson sitúa todo su raciocinio en cuestionar la

\footnotetext{
${ }^{511}$ FOUCAULT, Michel, A Arqueologia do Saber, trad. Miguel Serras Pereira, Coimbra: Almedina, 2005, p. 33.

${ }^{512}$ CAMPANY, David, Arte y Fotografía, London: Phaidon, 2006, p. 39.

${ }^{513}$ Ibidem.
} 
naturaleza a partir de un contexto cultural.

El portugués Alberto Carneiro, además del trabajo realizado en tres dimensiones, como vimos, esculturas en sentido estricto y en sentido amplio como ambientes 0 instalaciones, también posee numerosos trabajos materializados en fotografía. Este artista no se define como fotógrafo, sintiéndose cómodo con la designación de escultor. De hecho, para este artista, el uso de la fotografía sirve a intentos escultóricos; es, por tanto, instrumental, funcionando como documento y objeto expresivo en sí mismo. A. Carneiro distingue entre la fotografía en blanco y negro y la fotografía en color.

Trabajo con fotografía en blanco y negro. Siendo la naturaleza la materia de mis comunicaciones estéticas, considero que el color aquí sería imitación. La naturaleza natural se basta a sí misma y yo no diré que es una obra de arte "yo apenas la tomo y transformo en obra de arte». La fotografía en blanco y negro permite un distanciamiento afectivo en relación al natural de la naturaleza, transformándola en artificial, en un dato posible para que tenga lugar la obra de arte. ${ }^{514}$

De hecho, el uso de la fotografía en blanco y negro en detrimento de la fotografía en color, además de cumplir con su vocación no mimética de la naturaleza, representa o presenta mejor las formas del paisaje como masas recortadas contra el fondo de la atmósfera, es decir, confiere contorno a esas formas de manera más eficaz.

Alberto Carneiro usa la fotografía como quien usa el dibujo, aparece como mecanismo inductor de movimientos en la conciencia. La sucesión de imágenes fotográficas sirve a un determinado tipo de imaginación capaz de activar, en el espectador en diferido, la primera experiencia del escultor en el lugar real del paisaje.

De entre las varias propuestas de Alberto Carneiro, un trabajo materializado en fotografía, titulado Trajecto de um corpo 1976-77, es especialmente importante en el ámbito del argumento que quiero desarrollar, por convocar para un procedimiento escultórico la movilidad efectiva y metafórica en

\footnotetext{
${ }^{514}$ CARNEIRO, Alberto, 1979 "O Outro Por Ele Mesmo", in Das Notas Para Um Diário E Outros Textos. Antologia, (coord: Catarina Rosendo), Lisboa, Assírio \& Alvim, 2007, p. 39.
} 
el paisaje. En Trajecto de um corpo asistimos a lo largo del tiempo a una transformación ritualizada de una roca redondeada en arte, siendo más precisos, en escultura. El trayecto sirve de pretexto para que el artista revisite lugares significativos de su infancia, marcándolos.

El trabajo se inicia en la playa y prosigue después para la montaña, de manera más precisa para un lugar lleno de grandes piedras que desde el punto de vista de mi relación artística con el paisaje se constituyen como esculturas, sin embargo para que una piedra sea escultura es necesario nombrarla como arte, por eso en un determinado momento la roca ocupa uno de los lugares que autentifican institucionalmente lo que se considera arte, la galería o el museo de arte $e^{515}$

Formado por cuarenta y cuatro fotografías en blanco y negro y sólo dos a color, Trajecto de um corpo (1976-77) es una de sus performances que nunca fueron públicas sino apenas documentadas en fotografía. A través de ese registro organizado de forma expresiva, intuimos el trabajo directo del cuerpo del artista sobre el espacio natural. Es el cuerpo que marca, organiza y delimita el espacio plástico, materializado en obra en las fotografías que después se exponen en el espacio de la galería.

El escultor-cultor A.Carneiro, que en este periodo se le denominó "operador estético", utiliza la fotografía de forma instrumental, es decir, saliendo de su campo disciplinar estricto, para explorar en el espacio del paisaje la idea de marca, de dibujo y de escultura.

\section{$5.2 \mathrm{~g}$. Una propuesta de punto de vista sobre el lugar a través de la fotografía en su relación con lo escultórico}

Desde el inicio de la modernidad europea, el paisaje en el arte encontró siempre en la pintura su medio de expresión natural; fue necesaria, a mediados del siglo XX, una enorme transformación en el sentido de apertura de las prácticas escultóricas, para que el paisaje concreto ganase en el campo artístico

\footnotetext{
${ }^{515}$ CARNEIRO, Alberto, testimonio oral transcrito de la conferencia pronunciada por el artista Alberto Carneiro, en abril de 2004 en el Auditorio de EP 1 de la ESAD. CR/ Instituto Politécnico de Leiria, a invitación de los docentes Samuel Rama y Pedro Cabral Santo. (En Anexo).
} 
una centralidad hasta antes inexistente. Para esa centralidad, contribuyó bastante el uso de la fotografía que se asume en este contexto como medio de relación privilegiado entre el espacio institucional del arte, o sea el no-lugar, y el lugar del paisaje. A través de la fotografía observamos el lugar a distancia; en la fotografía, podemos acceder a la utopía, a lo especular, a lo virtual, al lugar mental y sensible que es estético y, por consiguiente, cultural. Además, observamos el lugar del paisaje a distancia, podemos soñar o ser apelados a visitarlo, a habitarlo con nuestro cuerpo.

El lugar físico, ahora encuadrado por propuestas de ámbito estético, ético y político, sólo fue posible porque hubo un movimiento de salida de la práctica de la escultura hacia fuera de su campo estricto, convocando tanto la arquitectura como el paisaje. A partir del momento en que la práctica escultórica integra el paisaje, sus practicantes tienen la necesidad de usar la fotografía como medio expedito y eficaz para documentar pequeñas o grandes intervenciones en el paisaje, normalmente en localizaciones geográficas de difícil acceso. La fotografía analógica permite erigirse como "certificado químico", pues se trata de una firma de luz que permite fijar un determinado acontecimiento en el tiempo, combatiendo así la experiencia de lo efímero. La fotografía permite, de este modo, parar el tiempo y establecer relaciones con el espacio. Estas condiciones hicieron posible que el arte y la escultura en particular trabajaran en espacios que hasta entonces les eran extraños y, simultáneamente, traerlos como imagen hacia dentro de la galería o museo. Al mismo tiempo, la fotografía pasa a ser el objeto, la prueba de la estancia del artista y de su proceso en un determinado paisaje y también el único objeto duradero que puede ser transaccionado en el mercado del arte.

Desde su aparición, la fotografía mantuvo siempre un fuerte vínculo con el dibujo. La fijación de las sombras sobre el papel devino de la búsqueda de un proceso químico que fijase instantáneamente los contornos de la naturaleza. EI vínculo genético de la fotografía con el dibujo se puede encontrar más tarde en muchos momentos en que se utilizó en su relación con la escultura, o entre ésta y el paisaje; hecho que me interesó sobremanera y que se apreciará en muchos de mis trabajos recientes. Los artistas del llamado Land Art, al inscribir sus 
intervenciones en el paisaje, procedían a su registro fotográfico como una clara idea de que la marca producida en éste sería traducida en imagen como inscripción o índex dibujado. Esta es una de las características que nos permite identificar los rasgos de la relación del paisaje con lo escultórico en la práctica del arte contemporáneo.

La otra característica que permite identificar en la práctica fotográfica la relación del paisaje con el campo de lo escultórico será el trabajo constante sobre la idea de ausencia. Si quisiera encontrar una de las determinaciones más fuertes de lo escultórico, siempre superviviente desde la estatuaria, pasando por la escultura en sentido estricto y ahora en sentido amplio, ésa es la expresión de la idea de ausencia presentada en un determinado medio. La ausencia no es el vacío, sino que significa tan sólo que algo, o alguien, estuvo en un determinado paisaje pero que ya no está; la conciencia de esa retirada es la ausencia. Muchas veces, los dibujos inscritos en el paisaje, mediante excavaciones, muelles de tierra y piedras en espiral, o simplemente resultantes de pisar la hierba, trabajan esa idea.

La interpretación que los artistas del llamado Land Art y otros hacen de la relación del paisaje en el campo de lo escultórico fijado en la imagen fotográfica es sobre todo instrumental. De esta forma, la fotografía sale de su campo disciplinar estricto y los artistas la consideran una forma más intensa y plástica mas allá de lo que es en sí misma, explorando la idea de serie, escala, dimensión, disposición, etc. Lo mismo se aplica a explorar la fotografía como objeto en el espacio real, como medio inductor de espacialidad y, así, inductor de determinadas experiencias y sensaciones en el espectador. Así, otro rasgo distintivo de la fotografía en su relación con el paisaje a través de lo escultórico es la entrada consciente de la imagen bidimensional en el dispositivo instalativo de la exposición. Cada fotografía es, en este contexto, un in visu que pretende apelar y configurar una posible entrada de cada uno de nosotros in situ, vinculando la imagen con el retorno a lo real. Lo que implica reconocer que ya no nos sirve la idea de paisaje como vista. Mediante la entrada en el campo de la escultura de la noción de paisaje, muchos artistas, incluido yo propio, tuvimos la oportunidad de dar continuidad a una idea de paisaje cada vez más amplia, 
capaz de integrar en el proceso creativo y en la cultura tanto la realidad subjetiva del creador como la intersubjetiva, y traer para el plano cultural tanto las calamidades infringidas en el paisaje como la esperanza, el sueño y la metáfora. Esta apertura de la noción de paisaje, una vez llegada aquí, permite quizá su ampliación como concepto muy útil para pensar e intervenir estética, ética y políticamente en la contemporaneidad.

\section{3}

\section{Habitar a Penumbra}

En la serie de imágenes tituladas Habitar a Penumbra (Habitar la Penumbra) 2003, existe una relación entre idea de construcción e imagen. Éstas muestran pequeñas construcciones directamente situadas en el paisaje real, que se fotografían siempre en la alborada o en el crepúsculo. Esas construcciones son cabañas en miniatura previamente construidas con cañas partidas tal como las que hice durante mi infancia. Aquí, lo que imperó no fue un mero retorno a una experiencia infantil, ni hacer excesivamente evidente el carácter autobiográfico de las construcciones, sino que fue más bien una forma de partir de una experiencia que me garantizaba un instrumento importante de evaluación con la mira puesta en la elaboración de una propuesta que tuviera sentido en el contexto del arte contemporáneo.

Las cabañas que muestran las imágenes tituladas Habitar a Penumbra se construyeron en lugares reales del paisaje y se caracterizaban por la capacidad de subvertir la escala. Tal vez la elección de los lugares correspondiese a la idea de que "quizás la aspiración de todo artista es construir un lugar en el que protegerse de las inclemencias de la realidad. Metafórico o real, este espacio es el que permite la creación." ${ }^{516}$ Después, y a través de la

\footnotetext{
${ }^{516}$ SAN MARTIN, Francisco Javier. "Construyendo La Ficción. Algunos Ejemplos Sobre Arquitectura, Ciudad y Fotografía". P. 16-48. Revista Exit 6, Arquitecturas Ficticias, Salamanca, 2002, p. 26.
} 
aproximación del objetivo, el encuadre y el paño de fondo se escogían de acuerdo con lo pretendido para cada imagen.

En una de las imágenes (fig. 54), existe una relación entre dos objetos iguales, dos cabañas, una de las cuales, la del plano del fondo, es más pequeña que la del plano de enfrente. Sin embargo, tal construcción sólo confirma la perspectiva renacentista italiana que genera y gobierna la fotografía. La construcción transformada en imagen, en un primer momento, no repara en la verdadera manipulación que sucede en el espacio real, pues las dos cabañas están integradas en el mismo espacio temporal continuo de la imagen, introduciéndose así el espacio en ésta, una característica que más tarde tendrá repercusiones deliberadamente escultóricas ${ }^{517}$ en la construcción de la imagen. En un segundo momento, y porque en esta serie de imágenes existe una fusión de varias dualidades conceptuales paradójicas como escala real y escala imaginaria, luz y ausencia de luz, lo que sucede entre una y otra cabaña representadas en la imagen de la (fig.54) es un extrañamiento. ${ }^{518}$ En realidad, en un segundo momento y a partir de una mirada atenta hacia el original, el espectador puede reconocer que entre una y otra cabaña podría estar en juego la falsedad de la imagen, en la medida en que el detalle revelado por la presencia

\footnotetext{
${ }^{517}$ Luísa Soares identifica el carácter escultórico del uso de la fotografía en el análisis sobre el carácter fabricado de la imagen. "De hecho, así es: las fotografías de Samuel Rama fijan una verdad. Pero esta verdad está construida por todas las piezas: ni las cabañas se hicieron en la escala que sugieren, ni muchas veces el paisaje es naturalmente aquello que allí quedó como señal del trabajo de la Naturaleza. La realidad que estas imágenes nos muestran, fabricada y construida como un juego por su autor, no es nunca la de la transposición fiel de una imagen encontrada, sino la de una imagen fabricada. En este sentido, se aproxima más a las imágenes que la pintura y la escultura nos dan que a las que son reveladas tradicionalmente por la fotografía. La extrañeza es aún mayor cuando se supone (otra idea hecha) que la fotografía no tiene nada que ver con las artes tradicionales, aquellas que implican apenas la pasividad del artista ante las imágenes exteriores o interiores que le son sugeridas...". SOARES, Luísa, Habitar a Penumbra, texto teórico de apoyo a la exposición, Sala Pahldata, Lisboa, Mayo de 2005.

518 Delfim Sardo, a propósito de la imagen señalada con la (fig.54), hace referencia a esa incomodidad provocada por el propio embuste de la imagen. "El paisaje en la fotografía es misterioso y telúrico. Las cabañas junto al acantilado poseen una reminiscencia romántica, como un último abrigo, un último reducto. Sin embargo, en una mirada más atenta, existe una extrañeza difícil de definir, pero que parece advenir la extrema fragilidad de las construcciones. De hecho, no se trata de cabañas encontradas en el paisaje, sino de un efecto de perspectiva: su fragilidad deriva de ser, en realidad, pequeños modelos que el artista coloca en el paisaje y fotografía, siempre al amanecer o al final de la tarde, construyendo un mundo que es, necesariamente, ficcional. La escala de la imagen es, así, falaciosa y en esa falacia reside su fascinación." SARDO, Delfim, "Sem Título", Expresso, única no1836, 5 de Enero de 2008, p.18-19.
} 
del musgo y de las piedras revela a la mirada la verdadera escala de la construcción. ${ }^{519}$

En esta serie, las imágenes oscilaban entre un registro más pictórico y otro más narrativo o con una propensión más cinematográfica, como es el caso de la imagen señalada en la (fig. 55).

\section{4}

\section{Desenhar, Esculpir, Fotografar}

Lo que estaba en causa en la serie fotográfica titulada Habitar a Penumbra, como en otra serie titulada Desenhar, Esculpir, Fotografar (Dibujar, Esculpir, Fotografíar) de 2004, es el uso de la convención renacentista que gobierna y genera la fotografía para pensar espacialidades en el plano de la representación, al mismo tiempo que se propone cuestionar la idea de verdad de la imagen derivada de la perspectiva renacentista. De hecho, todas las imágenes son el resultado de dibujos previos que después orientan la construcción en miniatura en el lugar y que posteriormente se adaptan a una cierta idea de "campo visual" que sólo es verdadero a partir del punto de vista de la máquina fotográfica. Se construye, de este modo, una desconfianza en relación a la idea del paisaje entendido "como vista".

En la serie Desenhar, Esculpir, Fotografar, de 2004, se muestran imágenes realizadas de nuevo a partir de la aproximación del objetivo en relación al paisaje recreado. En esta serie, el elemento casa se sustituyó por el elemento

\footnotetext{
519 "Todo el trabajo de Samuel Rama es sobre esa relación entre lo micro y lo macro, ya sea en sus esculturas, en sus fotografías o en los vídeos. Si las esculturas son instalaciones colocadas en el suelo, paisajes construidos con arena y agua que, como suelos lunares, piden al espectador una imaginación a partir del detalle y del fragmento, en las imágenes fotográficas la escala se simula pero al mismo tiempo el mecanismo de embuste es visible para quien sea lo suficientemente atento al detalle. Así, lo que Samuel Rama desvela es nuestra capacidad de creencia en la imagen, en su verdad. Todas las imágenes son verdaderas, pero sólo en el plano de la imagen, es decir, sólo en el grado de nuestra expectativa y de nuestra capacidad de reconocimiento. Más allá de ese plano, en un mundo que substituye la creencia en la palabra por la creencia en la imagen, es necesario una mirada más atenta, una sabiduría del detalle, como si todo lo que es micro fuese también macro. Es de esa poética que se alimenta su trabajo y sabemos, si miramos con atención, que coloca el dedo con precisión en la herida abierta entre la verdad y nuestra compulsión de encontrarla." SARDO, Delfim, «Sem Título», Expresso, Única n.- 1836, 5 de Enero de 2008, p. 18-19.
} 
árbol, previamente dibujado y construido. En otros casos, el referente árbol(es) se obtuvo a partir de la realización previa de los moldes de los troncos de pequeñas plantas que después se repitieron.

En la imagen de la (fig. 56), el espacio exhibe de nuevo una situación inestable resultante una vez más de la disolución de dualidades paradójicas como ¿escala real/imaginaria, día/noche, paisaje cubierto de polvo/nieve? En este caso, la noción de espacio está próxima de la idea de collage pues los diversos elementos que componen la jerarquía del paisaje se presentan como adheridos al plano del soporte de impresión fotográfico. Es decir, el plano de enfrente y el plano del fondo casi no existen, debido al uso de una profundidad de campo bastante acentuada, lo que tiende a organizar y a plasmar todos los elementos constitutivos del paisaje en un único plano, haciendo la imagen excesivamente bidimensional.

En una segunda imagen fotográfica de la misma serie (Fotografar, Esculpir, Escavar, 2004) (fig.57), tenemos una imagen fotográfica que representa traicioneramente una montaña, ya que aquello que se construyó y fotografió fue, en realidad, una pequeña concavidad excavada en la tierra. La construcción se realizó en el espacio real y se fotografió durante el crepúsculo, por eso, los tiempos de obturación fueron bastante prolongados, lo que hizo aproximar el proceso fotográfico al tiempo geológico. Una mirada más atenta hacia la impresión de esta fotografía revelará inmediatamente que en lugar de nieve hay una especie de polvo inidentificable y que ese desfiladero no es un lugar montañoso y rocoso, sino un simple montón de tierra organizado en función de la lente de la máquina fotográfica dando una idea de concavidad.

En esta serie de imágenes está implícito el querer frustrar las expectativas en la medida en que los paisajes que se revelan en la imagen "como vista" son en realidad falsos. La fotografía se trabaja a partir de la idea de que la convención es capaz de engendrar una mentira a partir de lo que el uso cotidiano de la fotografía sedimentó como verdad. Como defiende Joan Fontcuberta, "la fotografía miente siempre, miente por instinto, miente porque su naturaleza no le permite hacer otra cosa. Pero lo importante no es esa mentira inevitable. Lo importante es cómo la usa el fotógrafo, a qué intenciones sirve. Lo 
importante, en suma, es el control ejercido por el fotógrafo para imponer una dirección ética a su mentira. El buen fotógrafo es el que miente bien la verdad." ${ }^{520}$ También constituye una forma de entender un determinado modo de concebir y construir un espacio remoto.

Esta idea de que cada imagen es el resultado de una construcción previa toma después un desarrollo más acentuado a partir del momento en que cuestiones como la de la escultura y la del dibujo se intrincan con más determinación.

\section{5}

\section{Árvore(s) Enquanto desejo de posse do desenho}

En Árvore(s) Enquanto desejo de posse do desenho (Árbol(es) Como deseo de posesión del dibujo), 2005, (fig. 61), tenemos la materialización en fotografía de la idea de dibujo, que resulta de un laborioso proceso de trabajo que se constituye como una performance que no fue anunciada al público. Durante el año 2005, tuve la oportunidad de trabajar en Idanha-a-Nova, en la frontera con España, en una exposición que tuvo lugar en un espacio abierto.

La pieza se construyó alrededor de un árbol de alcornoque hace ya algunos años muerto y seco. Primero, al acercarse el crepúsculo, fotografié el árbol seco con todas sus ramas y desde un punto de vista frontal y objetivo. Después, en función de ese primer punto de vista usado en la primera fotografía, comencé a quitar las ramas del árbol de manera que se hacía evidente una cierta bidimensionalidad. Ya estaba implícita, antes de realizar el trabajo, una breve descripción de John Ruskin que en The Elements of Drawing ${ }^{521}$ enseña a sus discípulos a dibujar un árbol que les parezca contener una cierta belleza, pero no un árbol cualquiera. Tendrá que ser preferentemente un árbol que casi no tenga

\footnotetext{
${ }^{520}$ FONTCUBERTA, Joan, El beso de Judas. Fotografía y verdad, Barcelona, Editorial Gustavo Gili, 2002 , p.15.

${ }^{521}$ RUSKIN, John. The Elements of Drawing, London, The Herbert Press, 1991, 1a ed. de 1957 por Smith, Elder \& Co., London. Traducción al español: Técnicas de Dibujo, Barcelona, Laertes S.A. de Ediciones, 1999.
} 
hojas, otra condición que exige al dibujante es una agudeza extrema en el uso del sentido de la vista y que el fondo sea neutro. Preferentemente, el árbol debe presentarse contra un cielo nublado, en esas condiciones de luz anula las modulaciones del volumen, haciendo destacar nuestro modelo contra el fondo y éste es el dibujo. En el ejercicio VI, escribe John Ruskin:

Elige cualquier árbol que te parezca bonito, que casi no tenga hojas y que puedas ver recortado contra el cielo, o contra una pared de color pálido, o contra cualquier otro fondo claro (...) El árbol debe estar en la sombra; y el cielo ha de ser azul, o gris, o de un blanco mate. Para este ejercicio lo mejor es un día gris o lluvioso. Verás que todas las ramas del árbol resultan oscuras recortadas contra el cielo. ${ }^{522}$

A partir del momento en que mi mirada ve la figura del árbol recortada contra el fondo, también ve el árbol como dibujo. Entonces, Ruskin aconseja al dibujante relacionar morfológicamente el árbol con un sistema de ríos a partir del cual se puede establecer una analogía entre la forma del árbol y el mapa de un territorio: "contémplalas como si fuesen otros tantos ríos oscuros que debieran situarse en un mapa con absoluta precisión; y, sin prestar ninguna atención a la redondez de los tallos, cartografíalos todos en sombra plana." ${ }^{523}$

Esta descripción de John Ruskin me interesó porque demuestra que hay un tipo determinado de mirada que, cuando se lanza sobre el paisaje natural y en determinadas condiciones, transforma los objetos de esa realidad tridimensional natural en algo bidimensional y, por lo tanto, en una elaboración a partir de la realidad.

Después, y durante tres días, comencé a pintar con tinta china todos las ramas del árbol, desde las más finas hasta los troncos más gruesos y espesos. La tinta china, como material de dibujo, me interesó porque a la luz del crepúsculo producía iridiscencias que enriquecieron tanto la escultura en el paisaje como la imagen que de ella iría a hacer.

\footnotetext{
${ }^{522}$ RUSKIN, John, Técnicas de Dibujo, Barcelona, Laertes S.A. de Ediciones, 1999, p. 42. ${ }^{523}$ Ibidem.
} 
Estaba claro que, durante la performance no anunciada, modelo, dibujo y dibujante coinciden totalmente ${ }^{524}$ : no hay ninguna distancia que, durante la performance, cumpla la función de afirmar la fisicalidad del árbol en detrimento del árbol como representación o imagen.

Esta performance no anunciada (fig.60), sólo tuvo como público las personas que pasaron accidentalmente por aquel lugar, porque sólo esta asistencia fortuita y reducida podría conferir al proceso una cierta dimensión performativa de lo banal que yo quería, un ejercicio de dibujo en el espacio real implicando un árbol y el cuerpo del artista en el paisaje. De esta performance no se hizo ninguna documentación pasiva o descriptiva de lo que realmente pasó. Pero, después de la tarea de pintura del árbol, hice una segunda imagen fotográfica documentando el árbol ya sin ramas y pintado con tinta china. El lugar del punto de vista fue exactamente el mismo que usé para la primera imagen del árbol a intervenir.

Una vez impresas, las dos imágenes adquieren escalas diferentes. La primera imagen del árbol en bruto, por intervenir, funcionó en una ampliación fotográfica con $100 \mathrm{~cm} \times 100 \mathrm{~cm}$. Ya la segunda imagen del árbol intervenido, podado y pintado, se presenta en una ampliación fotográfica de $9 \mathrm{~cm} \times 9 \mathrm{~cm}$. Idealmente, estas imágenes deben presentarse en la sala de exposición enfrente una a la otra, aunque en el contexto de exposiciones colectivas puedan presentarse lado a lado. Una vez más, se verifica el trabajo sobre la polaridad entre lo grande y lo pequeño. No para explorar la polaridad en sí, sino para explorar el "espacio entre" que al final es el espacio del espectador en su situación de experimentación escultórica materializada a través de imágenes fotográficas expuestas en la sala de la exposición.

Lo infinitamente grande y lo infinitamente pequeño, tanto en la escultura

\footnotetext{
${ }^{524}$ Filipa Oliveira apuntó que, además de la construcción de la imagen, la performance asume especial relevancia pues dota al acto y al objeto del dibujo de fisicalidad. "Samuel Rama da a la serie el título de Árvore(s) Enquanto desejo de posse do desenho. Este elemento lingüístico añade a la obra una nueva capa de significado. El movimiento accionado por el artista con el pintar el árbol se confirma en su deseo de dotar el acto y objeto del dibujo de una fisicalidad y, de esta forma, profundizar en la relación entre el artista y el paisaje donde interviene. La naturaleza no se asume como modelo pasivo sino como espacio de la poética de la propia práctica del dibujo." OLIVEIRA, Filipa, O Espaço do Fogo, Texto teórico de apoyo a la exposición, Museu António Duarte, 2007.
} 
materializada en tres dimensiones como en las dos dimensiones de la fotografía, sólo sirven para instaurar un "espacio entre". Entre la micro escala y la macro escala tienen lugar distinciones entre lo pequeño y lo grande, o sea, un espacio entre inconciliables y, por lo tanto, discontinuo. Es una zona de indiscernibilidad y movimiento, una mezcla de estas dos instancias y no una síntesis que sería estática.

El espectador, cuando está frente a una de las imágenes, está de espaldas a la otra, y viceversa, de modo que aquello que interesa en este trabajo es su capacidad para provocar intercambios y relaciones, al mismo tiempo que el espectador se siente atraído por un extrañamiento familiar ${ }^{525}$ hacia los dos contornos venidos del mismo árbol. La imagen parece sufrir un desplazamiento para otro lugar.

A propósito de este trabajo, João Miguel Fernandes Jorge escribió:

Samuel Rama dio título a su trabajo: "Árvore(s) Enquanto Desejo de Posse do Desenho". Y, de hecho, nombró "in pecto" un árbol de los muchos que dan cuerpo vegetal a la Tapada do Tanque. Hubo quien me preguntase si no quería ver ese árbol escogido. No quise, pues si lo viese, desaparecería mucha de la intención que Rama puso en la fotografía, el color del árbol (...) De nuevo, un árbol de quien se apoderó el fuego. De nuevo, un reconocimiento infinito de un árbol. De su posesión. Pero con un nuevo carácter incorporado, la metamorfosis de un árbol en dibujo, de modo que cuando se posee ya no está el objeto real árbol, ni tampoco el cuerpo ideado árbol. Apenas un dibujo se posee ahora. Además, Samuel Rama tiene la consciencia exacta de que la posesión, el acto de poseer, es un estado imaginado, huidizo, que cuando ya se llega a él solamente encontramos el polvo de su imagen. Por eso nos dice: árbol como deseo. $Y$ no de su posesión fijada, ni siquiera como imagen de árbol. Lo que consigue es el deseo de una imagen, de una imagen de imagen, de cosa que los sentidos relacionaron con un instrumento, el dibujo. También éste habita en fuga. Poseerlo no pasa de un espejismo,

\footnotetext{
525 "Unheimlich" (extrañamiento) de Freud, es un concepto que presenta lo extraño como algo familiar que a pesar de todo es incómodo. El argumento de Freud en el texto "la inquietante extrañeza" es que lo importante es reconocer que lo extraño está fuertemente vinculado a lo familiar, irrumpe de lo familiar, es ahí que reside una inquietante extrañeza. Esta idea fue muy importante para los surrealistas pues ofrecía la hipótesis de concebir y construir espacios que son en simultáneo familiares y extraños "(...)pues ese extraño no es nada nuevo o ajeno, sino algo que es familiar y que está hace mucho establecido en la mente, y que solamente se alienó de ésta a través del proceso de represión. Esa referencia al factor de la represión nos permite, además, comprender la definición de Schelling de lo extraño como algo que debería haber permanecido oculto pero que vino a la luz." FREUD, Sigmund, O estranho (1919) in pt.scribd.com/doc/43021478/O-Estranho-Freud, p. 16.
} 
tan inmaterial como uno que se tiene hasta donde la vista alcanza.

En el texto de presentación de la exposición titulada O Presente: Uma Dimensão Infinita (El Presente: Una Dimensión Infinita), realizada en el Museu Berardo en Lisboa, las comisarias de la exposición relacionan este trabajo con una cierta dimensión antropológica, pues se presentó en la misma sala de exposición en la que se articulaban trabajos de Tácita Dean y de Rodney Graham. "En los últimos años el paisaje ha sido reinterpretado utilizando componentes más racionalistas o conceptuales, pasando por la simbología, la abstracción o la cultura popular, a través de los cuales se apuntó a cuestiones espacio-temporales o relacionadas con la ciencia o la antropología. Es el caso de Gabriela Albergaria, Rodney Graham o Samuel Rama" ${ }^{526}$.

\section{6}

\section{Dobrar a terra}

También forman parte de la misma serie Árvore(s) Enquanto desejo de posse do desenho, otros conjuntos duplicados de imágenes fotográficas como la que se titula Dobrar a terra (Doblar la tierra), 2007 (fig.62). Ésta consiste en dos fotografías, una de $70 \mathrm{~cm} \times 100 \mathrm{~cm}$, representando una concavidad con una escala engañosamente montañosa, y otra de $9 \mathrm{~cm} \times 13 \mathrm{~cm}$, que también deben exponerse idealmente una frente a la otra. Una vez más, se trata de la idea de cráter excavado, pero también de la idea de un espacio cóncavo a la par con otro convexo, que se realizó a partir de dos encuadres del mismo cráter escenificado.

La imagen mayor, de $70 \mathrm{~cm} \times 100 \mathrm{~cm}$, se presentó en el espacio expositivo impresa en blanco y negro; ya la imagen más pequeña se imprimió en color, acentuando de esta forma la tónica afectiva en la idea de convexidad. La intuición para esta alternancia entre impresión en color y en blanco y negro parece haber seguido algunas consideraciones de Andrei Tarkovski,

\footnotetext{
${ }^{526}$ CORRAL, Maria de y CORRAL, Lorena Martínez de, in O Presente: Uma Dimensão Infinita, Catálogo de la Exposición de la Colección Banco Espirito Santo, Lisboa, 24/11/2008 a 15/01/2009, ed. BES y Museu Berardo, 2008, p. 16.
} 
(...) El carácter pictórico de un punto de vista, que en general se debe apenas a la calidad del filme, es más bien un elemento artificial que oprime a la imagen, y es necesario hacer alguna cosa para neutralizar esa tendencia, si el objetivo fuera la fidelidad a la vida. Es necesario intentar neutralizar el color, modificar el impacto que ejerce sobre el público. Si el color se convierte en el elemento dramático dominante (...) significa que el director y el cámara están empleando los métodos del pintor para alcanzar al público. (...) La fotografía en color entra en conflicto con la expresividad de la imagen. Tal vez la manera de neutralizar el efecto producido por los colores sea alternar secuencias coloridas y monocromáticas, de tal manera que la impresión creada por el espectro completo sea espaciada, diluida ${ }^{527}$.

Mientras Alberto Carneiro usa principalmente la fotografía en blanco y negro, en Dobrar a terra, 2007, el color se convierte en una cualidad fundamental para tratar la escenificación de la naturaleza, trabajándola "como materia prima sobre la que el artista inscribe su poética. La exploración en este caso se sitúa en el ámbito del dualismo interior/exterior. La aparente calma externa de la montaña se contrapone a su turbulencia interna que explota como si de un volcán se tratase. El espacio, y el tiempo entre dos imágenes es nuevamente donde ocurre la acción" ${ }^{\text {528. }}$.

La operación en cuestión parece tener que ver con la escultura, en la medida en que se trata de un movimiento de doblaje del espacio; el medio fotográfico es bidimensional, pero el problema es del orden de la tridimensionalidad. Un espacio que era interior o cóncavo pasa a ser exterior o convexo. A través de esta operación plástica, se vuelve hacia fuera el «forro incandescente y colorido del tiempo ${ }^{529}$, o sea, del espacio asociado a la temporalidad que califica siempre al paisaje.

\footnotetext{
${ }^{527}$ TARKOVSKI, Andrei, Esculpir o Tempo, (Die Versiegelte zeit) traducción portuguesa de Jefferson Luiz Camargo, São Paulo, Martins Fontes, 2002, p.166.

${ }^{528}$ OLIVEIRA, Filipa, O Espaço do Fogo, Texto teórico de apoyo a la exposición, Museu António Duarte 2007.

${ }^{529}$ Esta afirmación de Walter Benjamin surge en el contexto del libro de los pasajes donde hace explícito su método de comprensión de la realidad urbana moderna parisina a partir de la utilización de constelaciones contradictorias o dialécticas. Esta afirmación sólo fue recordada tras la realización del trabajo, no sirve para ilustrar pero demuestra los prodigios del método dialéctico que sigue la lógica de la oposición de los extremos que está en la génesis de todos mis trabajos abordados hasta ahora. BENJAMIN, Walter, Libro de los Pasajes, Edición de Rolf Tiedemann, Madrid, Akal, 2005, p.131.
} 
Lo que se puede testimoniar en estas imágenes fotográficas, que ya pretendían establecer una relación entre fotografía, escultura y dibujo, es que aún están de acuerdo con una cierta noción de paisaje como vista jerarquizada y, por eso, están próximas de la perspectiva renacentista, aunque el dispositivo de exposición relativice y haga secundaria esa lógica lineal de entender el espacio paisaje.

\section{7}

\section{Vontade, Fadiga de Estruturas, Wander}

De aquí en adelante, presentaré algunas propuestas que ya están comprendidas en del periodo de tiempo en que transcurrió la investigación realizada para esta tesis. La serie de esculturas, ambientes o instalaciones realizadas con arena y agua serán a partir de aquí el foco de atención. Éstas presentan una nueva noción de espacio que no tiene nada que ver con la noción de espacio jerarquizado característico de la noción de pintura y paisaje «como vista» inaugurada en el Renacimiento italiano.

En Wander, de 2007 (fig.66), presentada en el ámbito de la selección internacional para el IV International Prize of Painting Diputación de Castellón, cuya exposición se realizó en el Museo de Bellas Artes de Castellón, se podía experimentar una construcción realizada en arena y agua que oscilaba entre partes trabajadas y no trabajadas, que aceptaba la horizontalidad como plano de esparcimiento de la pieza y se relacionaba con la superficie de la pared que funcionaba como superficie de apoyo y lugar de proyección de la mirada. Esta pieza tenía relaciones y antecedentes importantes que deben ser aquí recuperados, pues el hecho de que Wander fuera una pieza presentada en el contexto de una exposición colectiva, añadió en principio algunas limitaciones al proyecto, pues este tipo de intervenciones tiende a ocupar por entero una sala de exposiciones neutra.

Para entender Wander, 2007 (fig. 66), tenemos que volver hacia las piezas tituladas Vontade (Voluntad), 2004 (fig. 63) y Fadiga de Estruturas (Fatiga 
de Estructuras), 2005-2006 (fig. 65). Vontade fue la obra que defendió mi primera presentación individual en Portugal. En la galería del espacio Arte Contempo en Lisboa, la pieza se instaló en un espacio confinado donde cada espectador tenía acceso visual a esa sala a través de una única entrada. De este modo, el espacio arquitectónico se presenta a la vista casi como si de una pantalla se tratase. De esta manera, y por esa lógica del uso derivado de la configuración arquitectónica del espacio, me pareció que tenía sentido proponer una construcción hecha a lo largo del tiempo con arena y agua, y que partió de mis recuerdos de la infancia. La arena fue recogida en las orillas de varios bosques, por lo que era una arena que contenía una cierta cantidad de arcilla, materia orgánica y semillas de plantas. Una vez recogida la arena, se trasplantó en el espacio de la galería y después se mezcló con agua en función de las necesidades.

Compuesta de múltiples formas pinaculares, la instalación evoca, en su apariencia final, un conjunto de catedrales barrocas. Como si de un archipiélago se tratase, no hay principio ni fin, apenas islas aisladas pero comunicantes y varias posibilidades de recorridos a su vuelta. Cada elemento protagoniza, así, un juego de equilibrios y tensiones en relación, por un lado, los adyacentes, a la globalidad y a los márgenes $y$, por otro lado, a cada espectador y a su presencia como materia. ${ }^{530}$

Cada "forma pinacular" se construyó a partir de un gesto aprendido por el cuerpo desde la infancia. La acción de agarrar y dejar escurrir un montón, arena y agua, es un gesto simple que hizo surgir la acción escultórica porque pertenece al imaginario colectivo. De esta forma, también estaba utilizando un patrimonio expresivo, perceptivo y emocional que nos pertenece a todos, pues cualquiera, alguna vez, ya hizo este tipo de construcción en la playa o en otro lugar y, por lo tanto, reconocemos en ella el tiempo demorado que exige su elaboración bien sucedida.

Aquello que determina la pieza es la idea de temporalidad estructurante del concepto de paisaje. ${ }^{531}$ Pero también la idea de esparcimiento en el espacio:

\footnotetext{
${ }^{530}$ OLIVEIRA, Filipa, Vontade, Texto teórico de apoyo a la exposición ac\#1, espacio arteContempo, Octubre, Lisboa, 2004.

531 Jean Luc-Nancy, en su libro titulado "Au fond des images", capítulo "Paysage avec dépaysement", presenta la idea de que el "paisaje es temporalidad", NANCY, Jean-Luc, Au fond des images, Paris, Galilée, 2003.
} 
de manera inmediata, cuando las personas observan esta instalación efímera, piensan en el tiempo que se tardó en hacer, porque el tiempo está allí, ya no como temporalidad pura del acontecimiento, sino como temporalidad traducida en espacialidad escultórica. Ésta, a su vez, está ante el espectador que experimenta la instalación, vuelve a revertir $\mathrm{o}$ a traducirse en una experiencia de duración temporal capaz de convocar recuerdos, lugares vividos y no vividos, reales e imaginarios.

Antes de realizar cada intervención citada, caminé por la galería o museo aún vacíos durante bastante tiempo, hasta el punto en que entendí, aprendí, sentí y comprendí aquel espacio como si fuera mi espacio. Una vez realizada esta toma de conciencia de mi cuerpo en relación al espacio, se crearon las primeras condiciones para que ese mismo espacio se convirtiera en el lugar donde podría arriesgar con la formulación de la pieza, tal como sucede en el espacio del estudio. Este aspecto es importante, estoy seguro que de él derivan consecuencias para las cualidades del trabajo presentado. Tanto en Vontade como en Fadiga de estructuras o Wander, dispuse de un tiempo considerable para poder montar la pieza, es decir, de un mes para la primera pieza citada,

Además de éste, muchos otros teóricos del paisaje, como Rosario Assunto, expresan el concepto de paisaje como detentor de una relación muy privilegiada con el tiempo, en la medida en que su experiencia proviene siempre de una presencia del ser situado en él, en su espacio y tiempo, o ante la representación de un espacio que se traduce en una fuerte experiencia temporal. Para este autor, la experiencia del paisaje es la de una temporalidad que sitúa al individuo en el espacio. La experiencia del paisaje articula continuamente en cada uno de nosotros lo que viene de atrás, el pasado, y lanza puentes para adelante, el futuro.

En el campo del paisaje como representación, Tanja Michalsky encuentra en la representación de las nubes un modo de temporalidad asociado tanto a la representación climática como a una cierta permuta entre lleno y vacío en el espacio pictórico del siglo XVII, cuya expresión se traduce en una experiencia animada y por eso temporal, expresando al espectador la transitoriedad propia del paisaje. MICHALSKY, Tanja, "Landschaft beleben. Zur Inszenierung des Wetters im Dienst des hollaendischen Realismus", in Bilderzaehlungen - Zeitlichkeit im Bild (Eds. A. von Hülsen Isen-Esch, H. Körner y G. Reuter), Köln, 2003, pp. 85-105.

Pero esta relación inevitable del paisaje con la idea de tiempo, o mejor dicho, con la idea de que el paisaje es siempre temporalidad, está desde luego vertida en el texto de Georg Simmel titulado "La Filosofía del Paisaje". Si la naturaleza es "el nexo infinito de las cosas, el parto ininterrumpido y la aniquilación de las formas, la unidad ondeante del acontecer, que se expresa en la continuidad de la existencia espacial y temporal", su sucedáneo, el paisaje, retuvo de la naturaleza el vínculo temporal en la medida en que es "un todo unitario, no unido a los significados particulares." SIMMEL, Georg, "Filosofia da Paisagem", In Filosofia da Paisagem. Uma Antologia. Trad. y coord. de Adriana Veríssimo Serrão), Lisboa, Centro de Filosofía de la Universidad de Lisboa, 2011. pp. 42 y 44.

Curiosamente, la invención de la perspectiva renacentista es contemporánea a la aparición de la categoría de paisaje y también a la invención del reloj. La perspectiva renacentista se constituyó como una métrica para el espacio y el tiempo. 
cerca de un mes y medio en el caso de la segunda y más de quince días en el caso de la tercera que, en el contexto de organización y programación de exposiciones en galería o museos, es muy raro. Por lo tanto, estas piezas surgieron en el espacio del museo de la misma forma que surgirían en el espacio del estudio, pero resolviendo la dicotomía identificada por Daniel Buren en su texto titulado Función del estudio, ${ }^{532}$ donde Buren analiza la dicotomía entre estudio y espacio expositivo, galería o museo, e identifica el siguiente embrollo: «o la obra está en su propio lugar, el estudio, y no tiene lugar (para el público), o se encuentra en un sitio que no es su lugar, el museo, y de este modo tiene lugar (para el público)». Esta inadecuación se verifica sobre todo en las obras manipulables, esto es, en obras que, aun siendo producidas en el estudio, sólo encuentran su lugar de visibilidad fuera de él, en el museo o galería. Este problema tiene especial pertinencia en el campo de la escultura, pues ésta, lidiando con el campo de la tridimensionalidad, difícilmente puede -por lo menos en la misma proporción que la pintura tradicional- reiterar para sí un lugar de visibilidad que sea independiente del contexto y condiciones de exposición, pues no usa en la misma proporción las condiciones de virtualidad e ilusión propias de la pintura tradicional.

Cualquier obra de arte, pero sobre todo las obras de carácter escultórico que se producen en el estudio y posteriormente se trasladan al espacio de la galería o museo, se encuentran ante la siguiente contradicción: "por un lado y por definición, es imposible ver una obra en su lugar, y por otro, es el lugar que le sirve de abrigo y en el que vamos a poder observarla el que la marcará, influenciará, mucho más que el lugar donde se hizo y del que fue excluida." ${ }^{53}$ Para resolver este abismo, D. Buren propone una mayor fusión de las realidades del estudio y del museo, en el caso contrario, el artista, al producir "para un estereotipo" para las condiciones de presentación del museo o galería, acaba "por fabricar un estereotipo en sí mismo." 534

\footnotetext{
532 BUREN, Daniel (1979), "A função do ateliê" [Fonction de l'atelier], in LOOCK, Ulrich, Ed., AnArquitectura de Andre a Zittel, Oporto, Público/Fundação de Serralves, 2005, p. 50.

${ }^{533}$ Idem, p. 49.

${ }^{534}$ Ibidem, p. 51.
} 
Usar el espacio del museo o galería de arte como espacio de atelier, implica duración, esto es, sólo a partir de algunos días de rutina de entradas y salidas en aquel espacio, se empieza a notar que se está saboteando la naturaleza cristalizada de esos espacios institucionales. En esta cadencia de construcción de las intervenciones, la instalación se adapta perfectamente al espacio, anula la distancia existente entre el estudio, como lugar de concepción y construcción, y el museo o galería, como lugar de muestra. Hace menos probable la producción de estereotipos, pues en la pieza permanecen accesibles las partes perfectamente acabadas y otras que sugieren estar en curso o "eternamente inacabados (...) todos esos vestigios simultáneamente visibles permiten una comprensión de la obra en curso." ${ }^{535}$ Este proceso no es más que el de una intensificación del gran proyecto llevado a cabo por Klee o Giacometti, que prefirieron mostrar no el mundo acabado, sino el constante hacer de cada uno de nosotros. En estas condiciones, existe un vínculo bastante fuerte entre el arte y la vida, ya que "vivo" es el sentimiento que propongo y que nos atraviesa continuamente a cada uno de nosotros, quiera que deambule en Uma floresta para os teus sonhos, quiera que en Vontade, en Fadiga de estruturas o en Wander.

En el contexto de la producción de las piezas arriba citadas, una vez iniciado el proceso de percepción y aprensión del espacio del museo o galería como si fuera "mi estudio", pude iniciar el transporte de la arena para el interior de la sala de exposición, distribuyéndola por el espacio. Una vez allí, el material fue manipulándose, mudado de un lado para otro, con el fin de pensar la organización y configuración de la instalación.

Existieron dibujos previos que trataban de pensar la configuración inicial de las piezas, sin embargo, estos dibujos sirvieron básicamente, además de para apuntar las diversas vías de resolución de las instalaciones, para pensar la pieza fuera de sus constreñimientos físicos. Cada dibujo intentaba trabajar y anticipar los detalles, sugerir la cesión del edificio por el peso excesivo de la tierra en el espacio del museo o galería. Estos dibujos no formaron nunca un proyecto

${ }^{535}$ Ibidem, p. 52. 
cerrado que después tendría que ejecutarse. De hecho, cada pieza no tiene una configuración que pueda denominarse final. Primero porque las materias utilizadas no permiten un grado elevado de fiabilidad estructural y duración, después porque el propio proceso de construcción es performativo, está permanentemente abierto, hasta el punto de hacerse difícil decidir cuándo está terminada la pieza.

En Vontade, en Fadiga de estruturas y en Wander, la distribución de la arena por el espacio de la galería, o por los museos de la Fundação Calouste Gulbenkian y Museo de Bellas Artes de Castellón, respectivamente, funcionó como una prolongación de la idea de dibujo en el espacio, pues esta acción derivó de la configuración de las piezas. En este contexto, se puede hablar de una cierta noción de dibujo tridimensional, o sea, algo que, derivando directamente de la primera práctica bidimensional, se encontraba ahora ante las características y resistencias propias de la materia y derivado del modo como el gesto de la manipulación suscita nuevas nociones de espacialidad que no estaban presentes antes de ocuparse el espacio.

Después, comencé por construir manualmente pequeños "pináculos", estructuras frágiles resultantes de la manipulación de la arena a la que se añadió agua dentro de un balde. El hecho de llenar salas de grandes dimensiones con gestos circunscritos en una motricidad fina, hizo con que las piezas sólo estuvieran terminadas al final de un mes o mes y medio de trabajo. Cada jornada comenzaba pronto por la mañana y sólo terminaba ya avanzada la noche, sucesivamente durante días, hasta el punto en que las piezas se dieron por concluidas sólo en el mismo día de la inauguración. Este aspecto es importante porque introdujo el componente trabajo como forma de manifestar la idea de que alguien estuvo allí, repitió un gesto y nunca más volvió a hacerlo.

Tras la inauguración, el aspecto que más destacaba era la frescura, el grado elevado de humedad y el olor de la arena que afectaba a la atmósfera de todo el espacio arquitectónico y a todas las personas que se encontraban en él.

Estas construcciones tienen tanto de bello como de escatológico y por lo tanto de fundamental. A raíz de este aspecto, también se puede afirmar que 
estas piezas exhibían tanto un carácter estético positivo como negativo: positivo pues parecían remitir a parajes remotos y hermosos, negativo porque sugerían un espacio asociado a la gruta, al interior de la tierra, a lo grotesco, tal como sucede en La forêt de Alberto Giacometti. Este aspecto es importante pues irá permitir establecer uno de los hilos conductores para esta tesis, que será revelado en las conclusiones de la investigación.

En Vontade, debido a la naturaleza del espacio expositivo, una sala con una única abertura de acceso, la intervención se pensó como dispersión de islas que permitían a los espectadores la posibilidad de realizar varios recorridos meditativos alrededor de esas islas, usando los espacios que se habían dejado vacíos. Otorgando un funcionamiento laberíntico lúdico a cada pieza, que no sería ajena a la experiencia de años atrás en Uma floresta para os teus sonhos de Alberto Carneiro, el espacio transformado en laberíntico hace posible que para cada movimiento haya un nuevo punto de vista sobre la materia organizada, haciendo con que ésta nos parezca siempre nueva y diferente.

Las construcciones, realizadas en arena y agua, llegaban a su máximo de altura en el momento en que las materias, luchando contra la gravedad, ya no se aguantaban más. En Nelson B. Peixoto ${ }^{536}$, encontramos una explicación útil que ayuda a comprender cómo sucede este fenómeno escultórico al nivel de la micro escala. Las pequeñas estructuras realizadas con arena y agua, no hacen sino repetir la lógica del equilibrio dinámico entre orden y caos. Cada pináculo sólo se auto-sustenta lo más alto posible en su punto crítico. N. Peixoto analiza el modelo de la "pila de arena": "Imagine una plataforma horizontal sobre la que se despeja arena de forma lenta y gradual. La configuración rebajada representa el estado de equilibrio, el de menor energía. Se va formando poco a poco un monte, cuyas paredes laterales van aumentando de inclinación. Cuando la inclinación en un local es excesiva, la arena escurre y puede producir una avalancha. Cuanto más arena se despeja, mayor es la inclinación y el tamaño medio de las avalanchas." ${ }^{537}$ Continuando con la descripción del proceso de organización y

\footnotetext{
${ }^{536}$ PEIXOTO, Nelson Brissac, Paisagens Críticas Robert Smithson: arte, ciência e indústria, São Paulo, Editora da Pontifícia Universidade de São Paulo, 2010. Pp. 304-317.

${ }^{537}$ Idem, p. 305.
} 
disolución de esta materia informe, el mismo autor refiere que, "a medida que la altura de la pila alcanza dimensiones proporcionalmente mayores que su base, comienzan a darse deslizamientos mayores, envolviendo todo el sistema y no apenas las áreas vecinas, hasta que surge cierta forma de organización. El sistema alcanza un estado estacionario" ${ }^{153}$ Este estadio estacionario y precario se denomina "punto crítico"; en este punto el autor resalta que cualquier nueva cantidad de arena añadida puede provocar tanto una pequeña como una gran avalancha, o incluso reacciones destructivas imprevisibles y en cadena que pueden afectar tanto a las construcciones mayores como a las menores. EI trabajo manual lida continuamente con estas fuerzas: por un lado, la capacidad que tiene la materia para agregarse y vencer la gravedad, por otro, la cesión de ésta ante la fuerza de la gravedad. Así, puedo afirmar que la escultura es un sumatorio de muchísimos "puntos críticos" que se elevan y que desafían la gravedad.

Durante el tiempo en que las piezas estuvieron patentes, más de un mes en el caso de Vontade y Wander y cerca de seis meses en el caso de Fadiga de Estruturas, las semillas germinaron, las plantas crecieron destruyendo la escala imaginaria de la pieza. Eso consiste en una transformación interesante, pues introdujo directamente en el espacio White Cube de la galería algo que venía de fuera, del mundo natural y que se trajo de forma directa y cruda al interior del espacio, generalmente aséptico, del Museo o de la Galería. Por lo tanto, el ritmo de la vida geológica y biológica invade el territorio cultural del arte. El espacio institucional dejó de ser un espacio inocuo, cerrado al exterior, y pasó a ser un espacio abierto al exterior, al ritmo de las mutaciones lentas del secado de la arena, del crecimiento de las plantas, etc.

Junto con la pieza titulada Vontade, se hizo oportuno realizar una instalación video de 4':30"(fig.64) que analizaba en un medio videográfico esa idea de tiempo lento y geológico que estructura la pieza. Esa instalación se editó en base al registro de la construcción de las estructuras realizadas en arena y agua.

${ }^{538}$ Ibidem, 305 y 306. 
Básicamente, la instalación video (fig.64) está formada por dos secuencias fílmicas que se proyectan en los lados opuestos de una tela más fina que una hoja de papel. La idea era crear un espacio que fuese el resultado del contacto de las dos imágenes; el espacio, la pantalla de tela de proyección, es el lugar de encuentro de las dos secuencias de imagen. Las dos secuencias documentan y trabajan respectivamente una duración basada en la idea de crecimiento orgánico y otra de decrecimiento orgánico. Como las secuencias están en loop, y porque cada una se proyecta a un lado diferente de la misma pantalla opaca, implica que cuando el espectador entra en la sala nunca puede ver las dos secuencias fílmicas en simultáneo, sólo puede ver una de las secuencias y tiene que recorrer físicamente la sala de un lado hacia el otro para poder tener la perspectiva física y vivir la ambivalencia de dos lugares idénticos pero cuyas lógicas de revelación son opuestas en la imagen proyectada. Esta propuesta, aunque se realice en película, implica cuestiones escultóricas, la doble proyección y el acto físico de percepción del cuerpo son quienes realizan la frontera de la pantalla. Su plano fino es el lugar equidistante en relación a los dos proyectores. Cuando el espectador pasa cerca de la pantalla, parece ser finísima, se mueve por la acción de la pequeña circulación de aire que así materializa la pantalla que hasta entonces era virtual.

En Fadiga de Estruturas, presentada en 2005-06 en el ámbito de la exposición bianual titulada 7 Artistas ao Décimo Mês (7 Artistas al Décimo Mes), volví a trabajar con las materias arena y agua, pero esta vez con un nuevo arreglo espacial y nuevas intenciones. En la altura de la invitación para la exposición, que se hizo en una de las salas de exposiciones temporales en la sede de la Fundación Calouste Gulbenkian en Lisboa, pude tomar contacto con la naturaleza propia del espacio. Formaban parte de la sala de exposiciones siete módulos arquitectónicos, correspondiendo para cada artista un módulo que siempre tenía un doble acceso. Inmediatamente, y a partir de la experiencia que había tenido con la construcción de Vontade en el espacio ArteContempo, pensé que tenía sentido reducir el espacio de mi módulo, porque por la naturaleza de mi intervención escultórica, basada en la profusión barroca de materia y detalle, de alguna forma, ocurría una ampliación del espacio a través del tiempo, pues este 
trabajo se puede caracterizar como una transformación literal del tiempo en espacio. Lo que las personas podían experimentar era una cantidad enorme de detalle que sólo era posible por el lento y laborioso trabajo manual.

Esas vellosidades espaciales doblan y redoblan el espacio, implicando que cada espectador necesitara más tiempo para disfrutar la instalación. Como consecuencia de esa distensión temporal de fruición, sucedía una especie de ampliación potencial del espacio. Así, mi módulo fue efectivamente más pequeño pero, en realidad, nadie reparó en ese hecho porque el detalle implicado en la construcción de la pieza era bastante grande, exigía más tiempo al observador, así, tejía, construía, engañaba al espacio real disponible de la sala de exposiciones.

\section{8}

\section{Transformación del tiempo en espacio}

Vale la pena detenernos un poco más en este proceso de transformación del tiempo en espacio porque es estructurante en estas piezas. Escultura y tiempo, realidad espacial y evanescencia, objeto y no objeto respectivamente, parecen transformar la idea de tiempo como materia de la escultura en un conflicto. Sin embargo, en el segundo capítulo, hicimos referencia a la posibilidad operativa de la idea de escultura como metáfora. Partiendo del cine de Andrei Tarkovsky, abrimos la puerta a una comprensión filosófica de la escultura y, de ahí, la idea de escultura a partir de la transformación del tiempo en espacio se hace posible ya sea para el cineasta Andrei Tarkovsky como para la escritora Marguerite Yourcenar. Cuanto al primero, en su publicación Esculpir o Tempo ${ }^{539}$ (Esculpir el Tiempo), centra su preocupación de esculpir fuera de cualquier constreñimiento académico de la noción de escultura, buscando antes los movimientos fundamentales por los que el cine es agente modelador poético de la vida. El director "es libre de seleccionar y combinar eventos extraídos de un

\footnotetext{
${ }^{539}$ TARKOVSKY, Andrei, Esculpir o Tempo, (Die Versiegelte Zeit) traducción portuguesa de Jefferson Luiz Camargo, São Paulo, Martins Fontes, 2002.
} 
«bloque de tiempo» de cualquier anchura o largura" ${ }^{440}$, por lo tanto, Tarkovsky se considera un escultor que opera el acto de esculpir sobre un bloque de tiempo, en analogía al trabajo del escultor clásico que desbasta el bloque de mármol.

Marguerite Yourcenar, en su libro O Tempo esse grande escultor ${ }^{541}$, reconoce que el paso del tiempo se queda marcado en el espacio, en los objetos y en las personas que lo habitan. En este caso, la ampliación de la noción de escultura aparece asociada a la literatura que ve en el paso del tiempo un agente modelador de la vida y, en consecuencia, inductor y rasurador de narrativas.

El tiempo, desde que se inició el proceso de la modernidad, esto es, a partir del momento en que los seres humanos tuvieron conciencia de su finitud, se ve siempre como sucesión. No es por casualidad que la invención de la perspectiva renacentista coincide también con la invención del reloj. A partir del momento en que la eternidad medieval se puso en causa, fue necesario crear formas para entender tanto el espacio como el tiempo.

Para el escritor y filósofo Hermann Broch el tiempo está formado por la serie de todas las subdivisiones posibles desde el primer elemento de la serie, el momento en que se nace, hasta el último momento de la serie, el momento en que se muere. Para este autor, el tiempo se piensa a partir de la medida de la serie de todos los números posibles que se refieren a la vida.

El conflicto entre tiempo y espacio se disuelve, si entendemos el término escultura "como el modo a través del cual el tiempo se traduce en espacio" ${ }^{542}$, es decir, el modo como el tiempo se transforma y materializa en espacio. "Entonces la escultura surge no como objeto inerte sino como acción que va realizando el tiempo, y que es el propio tiempo que va realizando"543. Se trata de una transformación que exige tiempo para realizarse en un determinado tipo de

\footnotetext{
${ }^{540}$ Idem, p. 74.

${ }^{541}$ YOURCENAR, Marguerite. O Tempo, esse grande escultor, Lisboa, Editorial Difel, 1983.

542 SANTOS, Laymert Garcia dos, A escultura do tempo, Intervención presentada en el coloquio "Actualidades do tempo", promovido por el Colégio Internacional de Estudos Filosóficos transdisciplinares y por la Universidade estadual do Rio de Janeiro (EURJ) a 8 de Abril de 1988, y reunida en el libro de Laymert Garcia dos Santos titulado Tempo De Ensaio, São Paulo, Editora Companhia das Letras, 1989, p. 111.

${ }^{543}$ Ibidem.
} 
espacio. Para Hermann Broch todo el combate contra la angustia de la muerte es un combate contra el tiempo como serie; "la angustia de la nada, la angustia del tiempo que conduce a la muerte (...) porque, haga el hombre lo que haga, todo lo que hace tiene por fin anular el tiempo, suprimirlo, y esa supresión se llama espacio.. ${ }^{544}$ Ese combate implica la valorización del espacio y es siempre la transformación del tiempo en espacio. El tiempo "llena el espacio, transforma el tiempo en espacio." ${ }^{545}$ Para $\mathrm{H}$. Broch, la transformación del tiempo en espacio significa siempre la ampliación de la comunidad humana. Esto es, el modelo de espacio se entiende como simultaneidad que se opone a la serie o a la sucesividad, y todo el deseo del ser humano es poder determinar, acentuar, profundizar mejor la simultaneidad, es decir, la posibilidad de un día reunirnos todos alrededor de nuestras propias expresiones de comprensión. ${ }^{546}$

Todo el arte es el resultado de la transformación del tiempo en espacio. Por ejemplo, el tiempo de una experiencia en el paisaje puede transformarse por un pintor en espacio pictórico. Pero esta transformación es reversible, o sea, este espacio después se traduce nuevamente en una experiencia de duración temporal por parte del que observa la pintura. También el tiempo de la memoria apela a la creación de obras de arte. Tanto La forêt como Uma floresta para os teus sonhos, o incluso Vontade y Fadiga de Estruturas partieron de recuerdos de la infancia.

Giacometti tiene una clara consciencia de esta idea de transformación del tiempo en espacio. Escribe: «constatar sin extraer ninguna regla, no emitir juicio alguno, de lejos de muy lejos el tiempo se descompone en el espacio con una espantosa lentitud, todo se mueve apenas, continuamente, se transforma en una lentitud enhiesta, incluso los cataclismos, incluso la erupción de un volcán apenas perceptible ${ }^{547}$ Descomponer el tiempo en espacio es una consciencia

\footnotetext{
${ }^{544} \mathrm{BROCH}$, Hermann, Os Sonâmbulos, volume III Huguenau ou o realismo, Lisboa, Edições 70, 1989, p. 64.

545 Ibidem.

${ }^{546}$ Pensamiento expuesto por Maria Filomena Molder en un seminario de Estética. MOLDER, Maria Filomena, Seminario de "cuestiones de estética» dentro del curso de Máster en Estética, marzo-junio 2006, FCSH-Universidade Nova de Lisboa. Notas de la clase. Mimeografiado.

${ }^{547}$ GIACOMETTI, Alberto, Escritos Alberto Giacometti, Madrid, Editorial Síntesis, 2001, p. 205. En la edición original: "Constater sans en tirer aucune règle, porter aucun jugement, de très loin, de très loin
} 
que Alberto Giacometti tenía ya en los años 1933/34, fecha del texto citado anteriormente, años bisagra en su carrera, pues pasa de una práctica surrealista hacia un regreso al trabajo a partir del modelo. Alberto Giacometti se sirve del modelo como esquema de subjetivación en la búsqueda de lo que es único en la visión que tiene de la relación de sí mismo con lo otro, sin embargo, en la escultura, en analogía a lo que sucedía con el dibujo, todo exhibe una imagen que es indisociable del acontecimiento de manipulación de la materia que le dio origen, construyendo así un espacio abstracto y existencial. En este contexto, se puede afirmar que su práctica, fuertemente dominada por el dibujo, pone al desnudo la importancia del tiempo y literaliza el mecanismo de la transformación del tiempo en espacio, hecho que me interesa sobremanera en la materialización de Vontade, 2004, Fadiga de Estruturas, 2005-2006, Wander, 2007 o, más recientemente, en MAGMA, 2008, y MEGAPARSECS, 2012.

También Gaston Bachelard, en La Poética del espacio, defiende que el sedimento del tiempo se deposita continuamente en el espacio. En el modelo de Bachelard el tiempo no pude concebirse sin espacio. "A veces creemos conocernos en el tiempo, al paso que se conoce apenas una serie de filiaciones en los espacios de estabilidad del ser, de un ser que no quiere pasar en el tiempo: que en el propio pasado, cuando sale en busca del tiempo perdido, quiere «suspender» el vuelo del tiempo. En sus mil alveolos, el espacio retiene el tiempo comprimido. Esa es la función del espacio." ${ }^{548}$

En el contexto de la obra de arte, siempre tenemos que presentar el tiempo en función del espacio; así se hizo en los dos capítulos anteriores dedicados a la interpretación de La forêt y Una floresta para os teus sonhos. Esto porque el espacio es un dato incuestionable de la realidad, mientras que el tiempo es una invención del hombre. Los artistas lidian con la producción de espacio que, por ser de la orden de lo sensible, inteligible y perceptible, se

le temps se décompose dans l'espace avec un ralenti effroyable, tout bouge à peine, continuellement, se transforme dans une lenteur toute debout, même les cataclysmes, même l'éruption d'un volcan à peine perceptible." GIACOMETTI, Alberto, Ecrits, Paris: par Hermann Editeurs des Sciences et des Arts, 1988, p. 161.

${ }^{548}$ BACHELARD, Gaston, A Poética do Espaço, traducción de António Danesi, São Paulo, Martins Fontes, 2000, p. 28. 
transforma en experiencia de duración, de tiempo para el espectador. Aunque ésta sea una característica de todo el arte, considero que la globalidad de mis propuestas propone modos de profundización intensos entre tiempo y espacio, que son dos conceptos clave ya sea para la escultura como para el paisaje. Pude sistematizar un poco mejor estas preocupaciones en una entrevista. "Las líneas de fuerza principales en mi trabajo podrían reducirse a tres conceptos fundamentales: paisaje, temporalidad y relación con a la tierra. El primero intenta pensar el paisaje a partir de la capacidad que tiene para hacer surgir movimientos en la conciencia, esto es, una especie de fondo que apela al movimiento y pensamiento constantes. La temporalidad me interesa principalmente por la exploración de cómo el tiempo se transforma en espacio, es decir, como se va sedimentando la sucesión en el espacio plástico o en simultaneidad, como el movimiento de hacer acompaña al movimiento de pensar. Y por fin la relación con la tierra, que es también un problema de relación con el tiempo geológico y con el absoluto que es la tierra ${ }^{549}$.

Otro rasgo distintivo de mi trabajo proviene de buscar reducir todo a un absoluto, para sólo después intentar edificar alguna cosa. Tal vez por eso use preferencialmente la tierra como material de trabajo y el paisaje como contexto ideal para pensar lo escultórico. En Fadiga de estruturas, dispuse la cantidad de más de un camión cargado de arena dentro de un espacio arquitectónico que tenía aproximadamente $6 \mathrm{~m} \times 11 \mathrm{~m}$. Repitiendo la misma estrategia logística y procesual que se había realizado en el espacio ArteContempo, o sea, colocar primero la arena irregularmente en el espacio y sólo después ir decidiendo la configuración a lo largo del tiempo de ejecución, pude comenzar después a cumplir mi voluntad en la pieza y no repetir la misma organización laberíntica en toda la instalación. En vez de eso, había un desbloqueo en la zona central. Cada usuario de Fadiga de Estruturas sólo podría acceder a la estructura laberíntica de la intervención escultórica hasta un determinado punto. Conforme el usuario se presentase de un lado o del opuesto de la doble entrada en el módulo que me correspondía, no podía atravesar la pieza de un lado al otro. Esto sucedía porque yo quería trabajar dos ideas de extensión del "campo visual" que exigían la

${ }^{549}$ RAMA, Samuel, “Identidades”, Jornal de Letras, Artes e ldeias, № 914, 12 de Marzo de 2008, p. 2. 
construcción de dos "campos de profundidad" distintos en la misma pieza. O sea, a partir de una de las entradas de la sala, la instalación se presentaba ante nuestros ojos con una mayor "profundidad de campo", contrastando con la del lado opuesto que era substancialmente menor.

La idea de "profundidad de campo" transitó de la fotografía y se tradujo en la realidad háptica de la escultura, no como cuestión técnica de la fotografía, sino más bien como problema que sirve para pensar una cierta idea de "campo visual" para la instalación, cuyo carácter paisajístico se funda no en la noción de jerarquía sino en la noción de esparcimiento en el espacio, idea que, como vimos en nuestro estudio, tiene antecedentes en la noción de espacio paisaje de Erwin Straus y de Robert Morris.

Una vez más, Fadiga de Estruturas estuvo patente más de seis meses y, durante ese tiempo, tuvieron lugar cambios de color de la pieza debido a la pérdida de humedad de la misma. El agua se evaporó y el color de la pieza, debido al proceso gradual de secado, pasó del color terroso oscuro para un color cada vez más claro y reflector de la luz, una especie de paisaje lunar monocromático. Durante ese tiempo, los espectadores/usuarios pudieron experimentar una escala imaginaria simultáneamente virtual y real: virtual porque la escala en miniatura de cada "estructura pinacular" recreaba una cierta idea de "campo visual" determinado por una lejanía, y real porque cada uno que experimentaba la instalación lo hacía ya dentro de la pieza, inmerso en el ambiente de su realidad de materia concreta y barroca, sin ningún dispositivo distanciador como la base o el plinto.

Cada "estructura pinacular" de arena y agua en miniatura construía su propia distancia, como sucede en las esculturas de Alberto Giacometti. Cada uno de nosotros no podría dejar de imaginarse como una especie de "Goliat" detentor de una visión picada, o visión de pájaro que sobrevuela el espacio de un paisaje simultáneamente lejano e íntimo. A lo largo del tiempo también crecieron las plantas y, así, se destruyó la escala imaginaria. Finalmente, y porque la exposición estuvo patente mucho tiempo, las plantas se secaron y la escala imaginaria y lejana resurgió de nuevo transformada en un monocromatismo claro. 
Wander 2007 es una consecuencia de las dos piezas anteriores. Sin embargo, por estar incluida en el ámbito de una exposición colectiva, estaba más limitada en el uso del espacio. Esta pieza comprendió tanto el uso de la pared y del suelo, como ya había sucedido en Fadiga de Estruturas y también en Vontade. Wander, por presentarse en el contexto de una exposición colectiva de un premio de "pintura expandida" ${ }^{550}$, valorizó más el propio color de la tierra y su informalidad, que ya ganaba en el ámbito de una secuencia de mi trabajo una presencia diferente, fue cada vez más valorizado, o sea, las áreas trabajadas justificaban la sugestión de micro escala de las áreas adyacentes no trabajadas. Por lo tanto, de esta pieza formaron parte más zonas no trabajadas, en oposición a las piezas anteriores de la misma familia de trabajo.

Wander avanzaba y se lanzaba en uno de sus lados directamente contra la pared, permaneciendo allí los vestigios de la lama que escurrió por la pared, funcionando como un espacio de transición entre la pared plana y la forma tridimensional de la arena recogida en uno de los ríos de Castellón. Más tarde, esta experiencia de confrontar la materia con los límites de la arquitectura se autonomizará en la creación de un monocromo de barro bruto, titulado Mancha \#1, 2009 (fig. 68). Ésta formaba una especie de pasta, irregular e informe, de espesor considerable que aceptaba la retórica de la pintura para mostrarse y para afrontar al espectador, ya que en toda su configuración se reconoce la brutalidad del gesto modelador, lo escatológico, en que el peso parece ceder sobre el espectador. La mirada así atraída convoca la inmersión en la materia o incluso la fusión con ésta.

En todas estas instalaciones de carácter escultórico hay siempre una clara intención de hacer del espacio museológico un estudio. Porque son piezas que exigen mucho tiempo en su realización, el tipo de relación que se establece con el espacio museológico se transforma radicalmente. El hecho de que el artista trabaje durante muchos días en el espacio del Museo, hace con que el espacio pierda un cierto tipo de formalismo y regla aséptica, que siempre lo

\footnotetext{
5502007 - Finalista del IV International Expanded Painting Prize en Castellón (Jurado: Susanne Boecker, Demétrio Paparoni, Philippe Van Cauteren, Javier Panera y Wences Rambla), Museo de Bellas Artes de Castellón, España.
} 
cualifica originalmente. Por otro lado, al traer las materias crudas, la arena, el agua, el barro, la tierra, sus olores, las semillas y las pequeñas raíces en ella contenidas, directamente para el espacio del Museo, se traen al mundo del arte, de la fruición, aspectos que son del orden del tiempo geológico y del tiempo biológico. Me interesa proponer esas escalas temporales más amplias porque contrastan con las escalas de tiempo más inmediatas como son las escalas de tiempo de nuestro día a día.

Todos reconocemos que desde la revolución industrial, pasando por el motor a combustión hasta la era digital, se asistió a la aceleración del tiempo exterior $^{551}$; tal hecho creó una ocultación a la percepción de las escalas de tiempo más prolongadas. La civilización urbana, la única de que disponemos hace ya algún tiempo, vive inmersa en las escalas temporales del instante, de la aceleración brusca del tiempo exterior. En este contexto, es difícil para el hombre contemporáneo reconocer que la naturaleza y la tierra existen.

Estas instalaciones funcionan como una propuesta de arcaísmo y de ralentización del tiempo del día a día, que sirve de contrapunto a la excesiva aceleración del tiempo exterior. En este sentido, estas propuestas contienen un fundamento ético y político en la medida en que, al intentar relativizar las escalas temporales más inmediatas e instantáneas contraponiéndolas con las más lentas, geológicas o biológicas, puede suceder en cada individuo la comprensión de que cada hombre se define mejor por su escala biológica que por aquella que lo hace desequilibrar, definirse como perteneciendo a una sociedad de consumo

\footnotetext{
${ }^{551}$ René Guénon nota esta aceleración del tiempo exterior y afirma: «el tiempo gasta el espacio, de cierta manera, por el efecto del poder de contracción que tiende a reducir cada vez más la expansión espacial a la que se opone; pero en esta acción contra el principio antagonista, el propio tiempo se desarrolla con una velocidad siempre creciente porque, lejos de ser homogéneo como suponen aquellos que lo encaran sólo sobre el punto de vista cuantitativo es, por lo contrario, "cualificado" de manera diferente en cada momento por las condiciones cíclicas de la manifestación a la que pertenece. Esta aceleración se hace más notable que nunca en nuestra época, porque es a finales del ciclo que es más exagerada, aunque exista constantemente del principio al fin de éste; podría decirse, pues, que el tiempo no contrae sólo el espacio, sino que se contrae a sí mismo progresivamente; esta contracción se expresa por la proporción decreciente de los cuatro Yugas, con todo lo que ella implica, incluyendo la disminución correspondiente de la duración de la vida humana. A veces se dice, ciertamente sin comprender la verdadera razón de esto, que hoy los hombres viven más deprisa que antiguamente, y eso es literalmente verdadero; la prisa característica que los modernos ponen en todas las cosas no es, de hecho, más que la consecuencia de la impresión confusa que tienen de ello." GUÉNON, René, O Reino da Quantidade e os Sinais dos Tempos, Lisboa, Dom Quixote, 1989. P. 151.
} 
y entrar en un tipo de carrera que, a largo plazo, es responsable por toda una especie de desequilibrios éticos con contornos muchas veces patológicos.

\section{9}

\section{MEAGAPARSECS}

MEGAPARSECS (fig. 67), presentada de Septiembre a Octubre de 2012 en el Teatro da Politécnica en Lisboa, pretende presentar muchas de las cuestiones aquí profundizadas. Expuesta en una de las salas negras del Teatro da Politécnica, la instalación tuvo como preocupación principal potenciar las características del espacio, al tiempo que proponía una especie de corolario en relación a muchas de las cuestiones que fueron aquí trabajadas.

Ésta no es apenas una exposición de un objeto efímero, sino la creación de las condiciones para que ocurra un acontecimiento capaz de hacernos evadir hacia dos dimensiones del paisaje: una interior, virtual, escenográfica y jerarquizada, justificada por la creación de un campo de visión afín a la pintura y a la escenografía teatral y protagonizada por la intervención en sí, y otra exterior, protagonizada por la luz natural reflejada por los árboles del Jardín Botánico.

La luz, cuando es captada por la blancura piramidal de la tierra, exhibe sus modulaciones sin ninguna interferencia del espacio arquitectónico que, por ser negro, se transforma en una cámara que, por analogía con la propia cámara fotográfica, establece en una escala arquitectónica una relación dialéctica y privilegiada con el exterior. El espacio arquitectónico interior también es neutro en relación a la luz que entra por las ventanas. A veces, nos acordamos de la montaña Saint-Victoire de Cézanne, cuando miramos este vulgar monte de tierra sobre un palco ${ }^{552}$. El espacio negro es entonces una cámara que crea las

\footnotetext{
${ }^{552}$ El palco, en el contexto de esta pieza, es consecuencia tanto de la comprensión de la función de la base de La forêt como de otras obras del mismo período. También es el lugar para que sucedan expresivamente varias dialécticas, como el "Lleno y el Vacío", ya referido en el capítulo anterior, y otras constantes en mi trabajo, como la escala real/imaginaria, luz y ausencia de luz, etc.
} 
condiciones para hacer errar el pensamiento entre lo cercano y lo lejano, entre la experiencia teatral del espacio instalado y la experiencia global del paisaje ${ }^{553}$.

\subsection{0}

\section{MAGMA}

En la exposición titulada MAGMA, presentada en 2008 en la Galeria 111, en Lisboa (fig.69), tenemos la expresión de cómo ese fundamento ético y político, basado en el choque entre dos escalas temporales antagónicas -tiempo del instante / tiempo geológico- toma la delantera ya en el modo de concepción de la pieza.

Constituida por una intervención de carácter escultórico y una serie de fotografías, "MAGMA" presenta una estrategia doble que desemboca en la misma idea. "MAGMA" propone explorar cuestiones anteriormente sondeadas, como el cuestionamiento del paisaje, de la temporalidad y de la relación con la tierra. Los medios utilizados expresan la presentación concreta de la tierra a través de una instalación de carácter escultórico así como la prospección que el régimen de la imagen de la tierra levantada a través de la fotografía que incorpora el dibujo.

\footnotetext{
${ }^{553}$ Luísa Soares de Oliveira, en un artículo, escribe: «Megaparsecs se hace y modifica consonante a lo que pasa: la luz del exterior o su ausencia, presencia de visitantes en la sala o no, posibilidad explícita o implícita de diálogo con la historia y el tiempo del jardín. O lo que la pieza de teatro tarda en representar (...) las montañas que construyó, miniaturas con referencia al modelo que todos traemos dentro de nosotros, se combinan con un espejo oval negro que marca la reflexión que la propia arquitectura de la sala proporciona. Hay todo un juego especular en este trabajo: entre el paisaje y su modelo, entre la miniatura y la unidad de medida del espacio, entre lo infinitamente largo que es el tiempo de la montaña, o lo largo que es el tiempo de los "dragoeiros" del jardín, y los días que la exposición tardó en montarse. En este juego está también presente la cita de lo sublime» SOARES, Luísa, "A idade dos dragoeiros numa montanha de areia", Público, Ípsilon, 14 de Septiembre de 2012, p. 34.

A propósito de esta pieza, José Luís Porfírio escribe: «El paisaje es una evidencia, aunque en este caso sea una segunda evidencia, teatral, acentuada por la estructura y, aún más, por el efecto de irrealidad fantasmagórica que le da el blanco. La temporalidad está inscrita en la propia materia que se erige en la figura de las montañas, donde se siente el trabajo del tiempo, una inevitable erosión que transformará poco a poco, día a día, este paisaje. La relación con la tierra está en el propio crecer de la isla que imaginamos al contornarla. Después hay un pequeño gran vértigo cuando podemos ver el lago como un espejo, cuando a través de la imaginación la escala puede crecer o disminuir en una equivalencia generalizada entre el polvo y la roca, entre el espejo y el espacio, todo el espacio." PORFíRIO, José Luís, "No trilho da montanha branca», Expresso, Actual no 2081,15 de Septiembre de 2012, p. 20.
} 
En la primera, cinco cipreses, recogidos tras ser podados para dejar paso a una autopista, conocieron ahora en el espacio de la galería su condición horizontal, esto es, la negación de su condición de árbol y de bosque. Ahora, el bosque se transforma en tierra en una instalación de carácter escultórico donde no hay trabajo creador de formas, ni de desbaste, ni equilibrio de masas y, por lo tanto, no se asume como un trabajo de escultura en el sentido convencional. El estado mineral informe, descrito por Marguerite Yourcenar como el último estadio de una escultura, es aquí mismo su inicio. El polvo de arcilla roja se fijó, a lo largo de varios meses, en estos árboles que sucumbieron a la gravedad. La verticalidad afirmativa de los cipreses, uno de los símbolos de la melancolía, sucede a la gravedad terrestre. Los árboles, que antes exhibían su verticalidad en el paisaje real, una vez cortados para dar paso a una autopista más, se convierten en tierra, en una masa informe, no narrativa, o en una especie de índice de la muerte del paisaje.

La intervención escultórica pretendió ser literal, mostrando simplemente la brutalidad de varios árboles caídos en el suelo, por la gravedad, impregnación de la tierra roja, masa de barro que los hace ceder. Lo que me interesó fue mostrar la presencia bruta de la materia en el espacio del cubo blanco de la galería que sirve como "marco" para este arcaísmo deliberado.

Una vez más, el tiempo se transforma en espacio. Una vez recogidos los árboles de ciprés, se sometieron a un laborioso proceso de impregnación total en polvo $0^{554}$ de arcilla, sedimentado en todas sus ramas hasta quedar perfectamente

\footnotetext{
${ }^{554} \mathrm{El}$ polvo es una imagen del tiempo continuamente sedimentado en el espacio. Para Louise Bourgeois «recoger el polvo» es una de las tareas del artista que quiere transformar sus memorias en obra. «Tiempo - El tiempo vivido, el tiempo olvidado, el tiempo compartido. ¿Qué implica el tiempo polvo y desintegración? Mis recuerdos me ayudan a vivir el presente, quiero que sobrevivan. Soy una prisionera de mis emociones.» Volver a experimentar o trabajar a partir de mis memorias respeta la ley del tiempo, porque el tiempo no vuelve atrás. BOURGEOIS, Louise, Destruction Of The Father Reconstruction of the Father, Writings And Interviews, 1923 - 1997, Violette Editions, London, 2000, p. 362, "Time - time lived, time forgotten, time shared. What does time inflict - dust and desintegration? My reminiscences help me live in the present, and I want them to survive. I am a prisoner of my emotions.»

También Giacometti tiene especial afinidad con esta imagen «Giacometti respeta tanto la materia que se enfadaría si Annette destruyese el polvo de los cristales de la ventana». GENET, Jean, $O$ estúdio de Alberto Giacometti, Lisboa, Assírio \& Alvim, 1999, p.39. De hecho, es imposible no quedar preso en las numerosas imágenes fotográficas hechas de su estudio, donde se nota perfectamente una atmósfera dominada por el monocromatismo del polvo. ¿Y qué decir de sus pinturas cuya mezcla de colores concluye en un gris vibrante?
} 
monocromáticas de un color rojo tierra. Esta coloración sepia, o rojo tierra, evoca inevitablemente imágenes fundamentales como nacer y morir, sangre, tierra. Algo que el antropólogo André Leroi-Gourhan ya había constatado al darse cuenta de que, durante muchas excavaciones en grutas prehistóricas dominadas cromáticamente por el color sepia, muchos de sus colaboradores pensaban, ante esta atmósfera, en cosas relacionadas con la sangre, comer, morir, nacer, etc.

En esta instalación los árboles, aunque en algunos casos cortados por la mitad, se trajeron al interior de la galería mostrando su escala real. Esa escala 1/1 creó una confrontación con el espacio arquitectónico de la galería, pues los árboles ocuparon inmediatamente una buena parte del espacio de exposición disponible. Los diferentes árboles cubiertos con polvo se llenaron también con arcilla fresca dispuesta de manera informal, ocupando las zonas huecas entre las ramas, como si cualquier árbol dejase de poder tener levedad y fuese masa, peso, gravedad. Su presentación se hizo de un modo deliberadamente caótico, asistemático e informal. No busca construir ninguna narrativa, ningún nivel de interpretación, presentándose apenas con su presencia bruta y concreta. Se trata de una concepción paisajística asentada en la idea de fragmentación y pulverización en el espacio. El espectador es llamado a vaguear con la mirada por el detalle; es en ese punto, donde la macro escala se transforma en micro escala, que el paisaje se hace evidente como fondo donde operan los movimientos de la conciencia.

A esta presencia bruta de la materia se le junta su doble: hacer imagen de la tierra. Un conjunto de catorce fotografías, tituladas genéricamente Sem Título (serie MAGMA), también de 2008, resultantes de la digitalización de calotipos en papel, presenta también un modo paisajístico construido a partir de tomas de vista de lugares abandonados como minas, terraplenes, astilleros, etc., lugares que perdieron su función. En ellos, se dan dos estrategias distintas pero que forman parte del mismo trabajo: los puntos de vista de las fotografías se orientan bien hacia determinadas construcciones pre-existentes en esos lugares, denominándolos como esculturas a través de la fotografía; bien hacia construcciones simples que realicé en esos lugares, como masas 
paralelepípedas que, en este contexto, también se entienden como escultura materializada a través del medio fotográfico ${ }^{555}$.

En estos lugares, o no-lugares, se lee primero la inspiración y después el desprecio o la indiferencia. La tierra emerge con una fuerza nunca antes vista en minas, terraplenes más o menos clandestinos, astilleros deteriorados...Son marcas de una tierra gastada... ¿Qué hacer de la tierra extenuada? Cuando todo se reduce al absoluto de la tierra, es necesario excavarla, confrontarla con el cielo, abrir cráteres o construir masas escultóricas; en el fondo, evidenciar su identidad plástica que es también, a un nivel más profundo, ética y política.

Las imágenes fotográficas presentan esculturas anónimas donde el dibujo, ya incorporado en la lógica de la creación de la imagen, excava el espacio, apila, agrega, acciona continuidades y discontinuidades, marca alternadamente un fragmento, una proximidad, luz y sombra, denuncia barrancos, cavernas, estructuras ambiguas, fisuras. A través del dibujo inscrito directamente sobre el calotipo, el paisaje aparece según un nuevo orden protoescultórico y la mirada se transporta hacia dentro de la materia microscópica del paisaje y de la fotografía.

Las fotografías de la serie MAGMA, como las posteriores, marcaron varias distinciones en relación a las primeras series. Las fotografías señaladas en las figuras 70, 71 y 72, así como las de la serie Escavação"(Excavación) (fig. 73) y Scanning ${ }^{556}$ (fig.74), muestran un cambio importante de procedimiento.

\footnotetext{
${ }^{555}$ En el contexto de la articulación entre fotografía y escultura, Ricardo Nicolau escribió: «Su proceso de trabajo con la fotografía se articula entre meros descubrimientos e intervenciones; varía entre asumir estructuras encontradas como escultura, modificando poco la realidad pre-existente, simplemente registrándola, - asumiendo, en el fondo, que cualquier cosa que exista en la tierra se puede considerar una pieza escultórica - y la construcción de determinados objetos a propósito para fotografiarlos - pero que nunca llegan a tener una existencia autónoma como esculturas. El artista nos confronta de esta forma con dos cuestiones: en primer lugar, cómo la realidad se puede convertir en escultura; en segundo, y visto que la existencia de sus construcciones efímeras como maquetas es siempre denunciada por ligeras desproporciones entre elementos, qué relación existe, al final, entre representación fotográfica y realidad. Téngase en cuenta que, en ambos caso, la fotografía nunca se encara como simple documentación, o como reliquia de un acontecimiento - lo que distingue a estos proyectos de los registros de acciones y performances que marcaron los años 1960-1970. Las imágenes de Samuel Rama sólo son posibles gracias a la colaboración de la fotografía como médium con determinada historia, como verdadera herramienta de pensamiento.» NICOLAU, Ricardo, BES art, O presente Uma dimensão Infinita, Museu Colecção Berardo, Lisboa, 2008, pp. 296- 297.

${ }^{556}$ En las series de fotografías tituladas "Escavação" y "Scanning", presentadas respectivamente en el programa curatorial de Fátima Lambert para la XV Bienal de Cerveira en 2009 y en el Archivo Fotográfico Municipal de Lisboa en 2010, las imágenes expuestas alternaban impresiones en positivo
} 
Primero, comencé usando una máquina fotográfica analógica de gran formato, después, pasé a utilizar el método de la calotipia, el mismo usado por Fox Talbot. Aparece así una arqueología del medio fotográfico de modo a aproximar deliberadamente fotografía y dibujo, pero también escultura, tema en el que a se profundizó. En simultáneo, y de manera paradójica, utilicé los nuevos medios de digitalización e impresión ampliando aún más el carácter fragmentario e huidizo de la imagen, explorando no su carácter solidificado, acabado y bien definido, sino sus grietas, imperfecciones o fisuras.

En Sem Título \#6 (serie MAGMA), 2008 (fig.72), presentada en la $X$ Mostra Unión Fenosa, realizada en el Museo de Arte Contemporáneo Unión

\footnotetext{
y negativo, acentuando así los intentos escultóricos de éstas. Por ejemplo, una concavidad en negativo y una convexidad en positivo y viceversa, tal como la dialéctica que existe en la lógica de los moldes empleados en escultura.
}

Por otro lado, la fotografía positivada tiende a organizar el paisaje como algo que está próximo de la idea de ventana. Próximo, pero no totalmente, en la medida en que en las fotografías de la serie "Scanning" todas las imágenes muestran un dibujo previo y único en cada imagen. Por ejemplo, en Scan \#2 2010 (fig. 74) se ve una línea dibujada ligeramente diagonal que atraviesa la imagen desde el extremo superior al extremo inferior. Esa línea fue previamente dibujada en el calotipo antes de la realización de la fotografía en el lugar, y corresponde a un trabajo de «selección inconsciente» en la relación del dibujo y de la memoria con ciertos paisajes en disolución. Así, la imagen, a pesar de parecer la confirmación de la idea de ventana, no lo es en sentido total, porque el dibujo la corrompe, trayendo a la superficie la naturaleza física de la imagen, en oposición a la fotografía titulada "Escavação \#9" 2009, como otras de la misma serie. Por estar impresa en negativo, tiende a funcionar como "perspectiva invertida", de esta forma, la tierra adquiere una organización que el positivo no le daría nunca. Además, todos los elementos de la imagen tienden a avanzar en nuestra dirección en una imagen cuyo carácter físico y háptico sale enriquecido. En ambas series, el espectador se somete a un vaivén en la forma cómo la imagen se presenta, entre algo que parece ahondarse en el plano, más próximo de la idea de paisaje como ventana o vista, y algo que avanza en nuestra dirección, negando la idea de paisaje como vista o ventana, promoviendo antes una idea de paisaje basada en la errancia háptica y un tipo de afectación que es física.

Pável Florenski, uno de los principales maestros teóricos del Constructivismo Ruso, indaga sobre el tema de la "perspectiva invertida" característica de los iconos rusos y concluye que ésta nos toca más pues instaura un grado de realidad que la perspectiva renacentista italiana no tiene. Conviene recordar que los iconos rusos no representan exactamente, sino que ellos mismos participan de la divinidad. Esta distinción es importante pues ésta, al contrario de la renacentista, no representa en el sentido de ser una imagen segunda en relación a un referente que está primero. En ese sentido, la representación de la perspectiva invertida presupone hacer presente de nuevo. Pavel Florensky escribe: «Para representar un espacio con todo su contenido de puntos es preciso, hablando metafóricamente, o bien pulverizarlo hasta dejarlo convertido en un polvo infinitamente fino $y$, una vez bien mezclado, esparcirlo por la superficie de la representación, de manera que de su organización inicial no quede ni rastro (...) en resumen: es posible representar un espacio sobre una superficie pero solo destruyendo la forma de lo representado. Mientras tanto precisamente la forma y sólo la forma es el objeto del arte plástico" Para Florensky, la perspectiva renacentista no se daba cuenta de la realidad del mundo "apartarse de la unidad perspectiva se considera una traición a la verdad de la percepción, es decir, una distorsión de la realidad misma» FLORENSKI, Pavel, La perspectiva invertida, Trad. Xenia Egórova, Madrid, Siruela, 2005, pp. 79 y 87.

Concluyendo, ese vaivén, promovido por la alternancia de la naturaleza opuesta de las imágenes expuestas, es escultórico. 
Fenosa (MACUF), La Coruña, España, vemos en la imagen un volumen paralelepípedo colocado directamente sobre la tierra. Esta construcción simple fue por mí modelada en el espacio del paisaje, después se fotografió, a continuación intervine dibujando en el papel del negativo, pensando siempre en el resultado que iría a obtener cuando positivase la imagen por el método de contacto. La imagen realizada a partir de este proceso gana un carácter espectral e huidizo que las primeras fotografías que hice no tenían. En ellas, se identifica una cierta negación de la jerarquización del espacio, propia de la perspectiva renacentista, aproximándose más a la idea de "paisaje errante" no sólo porque el proceso de captura y fijación de la imagen es más arcaico, sino también porque la introducción del dibujo manual directamente sobre el espacio de la fotografía introduce en la imagen una lógica espacial que es contraria a la organización jerárquica de la fotografía. O sea, mientras que en una imagen dominada por la perspectiva renacentista todo el espacio se divide y organiza en una constancia métrica convergente en el punto de fuga, en estas imágenes el dibujo manual no se somete a esta constancia, y por lo tanto, es errante, corrompe por eso la perspectiva renacentista propia de la fotografía.

Lo que se pretende en estas imágenes, además de su articulación con el dibujo y la escultura, es intentar añadir en la imagen algo que, además del valor documental, explore su propia condición de imagen, creando un problema o extrañamiento que afecte al sujeto.

Cada imagen fotográfica resultante de la ampliación de un calotipo parece mostrar una cierta idea de continuidad espacial. Sin embargo, ésta es frustrada constantemente en muchos de sus aspectos, sobre todo por la introducción del dibujo que, mimetizando algunos aspectos de la fabricación de la imagen fotográfica, no lo hace sometido a la lógica de la lente, sino a la indecisión y errancia propia del dibujo manual, haciendo con que no haya una unidad sincrética de los elementos impresos. Cada imagen muestra una gran diversidad en la naturaleza de los espacios creados, como en Sem Título \#6 (serie MAGMA) (fig. 72), en que parece haber una diferencia entre el plano 
frontal y el fondo de la imagen. En Sem Título \#3, (serie MAGMA) ${ }^{557}, 2008$ (fig. 71), vuelve a haber la misma naturaleza de intervención, en que el plano de enfrente es deliberadamente distinto del tipo de organización que las estructuras verticales y el cielo demuestran, pareciendo haber en el plano de enfrente un tipo de perspectiva excesivo en relación a la organización de la imagen que se materializa en la sugestión de una especie de abismo. Sem Título \#10, (serie MAGMA), 2008 (fig. 70) es otro ejemplo: una especie de agujero negro situado en el medio de la imagen parece absorber toda la materia $y$, por otro lado, planificando el primer plano que funciona como una especie de muro que, de nuevo, plantea un problema de reconocimiento de un continuo espacio/tiempo propio del paisaje generado a través de la perspectiva renacentista.

En definitiva, de las primerias series de imágenes referidas hasta las más recientes, se nota una transformación que no es ajena a una consciencia mayor de las posibles relaciones de la escultura con el plano de la imagen bidimensional de la fotografía. En las imágenes más recientes sucede, al contrario que en las primeras, la fabricación de imágenes deliberadamente precarias, huidizas, con una clara aproximación al dibujo. Se hizo evidente que las imágenes muy definidas ya no interesaban. Estamos en un mundo repleto de imágenes y existe una batería enorme de autores para recordárnoslo. Un mundo lleno de imágenes implica también una reducción de la importancia de la imaginación porque, precisamente parece, como defiende Domingo H. Sánchez, que ya todo se nos da imaginado. Ante esta constatación, y en una época en la que la fotografía analógica dio lugar a la digital con sus sucesivas actualizaciones técnicas, proponer una cierta arqueología del medio, volver al método de la calotipia y ampliar sus efectos a través de los medios digitales, sirve de convicción de que la imagen que más interesa hoy no es una imagen sólida y acabada, sino aquella que denuncia los procesos por los que la luz la va tejiendo; de esa forma, la imagen reata relaciones con el sujeto, éste puede de nuevo imaginar, apelado por la imagen incompleta que se vincula así con la realidad.

\footnotetext{
${ }^{557}$ Presentada en la exposición titulada "Da Outra Margem do Atlântico - Alguns Exemplos do Vídeo e da Fotografia Portuguesa", comisariada por Paulo Reis, en el Centro de Arte Hélio Oiticica, Rio de Janeiro, Brasil.
} 
Las imágenes de la serie MAGMA, Escavação y Scanning responden mejor a la exigencia contemporánea de valorización de la imaginación porque su proceso está de acuerdo con la naturaleza asistemática de las imágenes ofrecidas por las esculturas o instalaciones. Estas características contrastan fuertemente con la naturaleza de las imágenes que dominan el mundo, ya que éstas tienden a presentarse como sólidas ${ }^{558}$, excesivamente definidas, acabadas, de tal modo que es difícil para quienes acceden a ellas entender su utilidad en la intensificación sincera de la imaginación.

\subsection{1}

\section{Una ética y estética de la tierra}

En mis propuestas plásticas, reconozco una afinidad con una cierta estética y ética de la tierra. Para este propósito, conviene recordar el trabajo de Alberto Giacometti, Alberto Carneiro, Robert Smithson o Robert Morris.

Alberto Giacometti pertenece a un linaje de artistas que, tras la incerteza creada después de la Segunda Guerra Mundial, buscó en la libre expresión formas de luchar contra "la uniformización de la ideología y estética totalitarias." ${ }^{559}$ En este contexto, "los artistas no tuvieron otra alternativa si no volver a lo que íntimamente les une, el artista y su obra, a esas formas que, aunque inciertas, eran formas esenciales, hasta diríamos que matriciales, formas siempre

\footnotetext{
${ }^{558}$ Jean Baudrillard habla de la "perfección inútil de la imagen" para referirse a las imágenes sólidas que perdieron su vínculo con la imaginación y, así, con la vida y lo real. BAUDRILLARD, Jean El Complot del Arte: Ilusión y desilusión estéticos, Editorial AMORRORTU, 2006, p. 14.

En este contexto, considero bastante esclarecedor el texto de Domingo Hernández Sánchez titulado Arte e Imagem. Según este autor, y a propósito de la cita de Baudrillard arriba mencionada, "el arte busca las fisuras, las impurezas y las precariedades de la imagen, sus posibilidades de extensión. Y lo hace precisamente para lograr una re-conexión, una fisura en lo real que permita el aumento de su sentido. El objetivo, por tanto, es pensar la imagen como imagen, eliminando sus pretensiones de completud y solidificación, de realidad, lo que significa en cualquier caso - por principio encontramos su contrario- negarle la dialéctica con lo real que le es inherente." SÁNCHEZ, Domingo Hernández, Arte Dicionário Crítico de Arte, Imagem, Linguagem e Cultura, activo en 6/9/2012 in http://www.arte-coa.pt.

${ }^{559}$ FRÉCHURET, Maurice, l'enfouissement: histoire et imaginaire aux temps précaires du XXe siècle, Paris, Editions d'Art Albert Skira : Réunion des Musées Nationaux, cop. 1995, p. 71.
} 
tumultuosas que se gravaban o incluso entalladas en la rigurosidad de la materia o en la precariedad de los materiales de substitución" 560 Vimos cómo las esculturas de Giacometti presentaban cuerpos de verticalidad afirmativa más frágil, rostros con una gran afinidad entre la carne y el barro.

Durante la situación histórica de posguerra, Giacometti responde reduciendo su trabajo a un absoluto, donde la ética y la estética de la tierra, mundo mineral, toman la delantera. Su preferencia por el modelado del barro o yeso frescos se relaciona con la voluntad de inmersión en las materias de la profundidad. "A semejanza de un geólogo, el artista serpentea las regiones subterráneas, barre los suelos, revuelve la tierra para muchas veces, en la verdad, encontrar el cielo." ${ }^{561}$ Sus esculturas denuncian el carácter mineral del que están hechas. Materia y construcción manual de la forma no se anulan, sino al contrario, en muchos casos la expresividad propia de la materia toma primacía en relación a la forma, tal como acontece en las cabezas de Fautrier.

En esta maraña de gestos, el rostro acaba por ser abolido, por disolverse, "el soterramiento de las formas pasa por una disolución inexorable." ${ }^{562}$ Tal vez por eso pueda afirmarse que el rostro en la obra de Giacometti es sobre todo un objeto insignificante, en la medida en que, como se vio en el tercer capítulo, tanto en el dibujo como en la pintura o escultura, la tentativa de captura realista siempre es frustrada. Como prueba de esa frustración, cada obra revela más el proceso y la materia que la realidad que la hace surgir. Una abstracción, en las palabras de Georges Didi-Huberman, "del rostro apenas quedaba una materia pura y simple, desemejante, abstraída" En la misma obra, el mismo autor reitera este argumento, refiriendo que cada

\footnotetext{
${ }^{560}$ Ibidem. "Les artistes n'eurent guère d'autre alternative que de faire retour à ce qui les fondait intimement, eux et leur œuvre, à ces formes qui, bien qu'incertaines, n'en étaient pas moins des formes essentielles, matricielles pourrait-on dire, formes tumultueuses dans tous les cas, qu'ils inscrivaient, qu'ils incisaient parfois, dans la rugosité de la matière ou dans la précarité des matériaux de substitution".

${ }^{561}$ Ibidem, p. 78 «Tel un géologue, l'artiste arpente les contrées souterraines, fouille les sols, remue la terre pour, il est vrai, parfois y trouver le ciel».

562 Ibidem, p. 88 «l'enfouissement des formes passe par leur dissolution inexorable.»

${ }^{563}$ DIDI-HUBERMAN, Georges, Le Cube et le visage, Autour d'une sculpture d'Alberto Giacometti, Paris, Macula, 1993, p.122, "ne restait souvent du visage qu'une pure et simple matérialité dissemblante, abstraite».
} 
escultura es un "objeto cuyo significado parece de veras enterrado." ${ }^{564}$ También la masa del pedestal acentúa esta misma característica: con formas paralelepípedas o cúbicas, el pedestal de la escultura de Giacometti se presenta como afirmación literal de la materia.

También Alberto Carneiro desarrolla afinidad en su trabajo además de con el árbol, con materias como la arena, el barro y la tierra. En O mar prolongase em cada um de nós (El mar se prolonga en cada uno de nosotros), 1968-69, la arena aparece como contrapunto de la geometría de la pieza en metal, funcionando como un elemento orgánico y efímero capaz de oponerse a la retórica modernista que esta pieza aún tiene. El barro se utilizó, entre otras obras, en la pieza titulada O Laranjal - Natureza envolvente (El Naranjal Naturaleza envolvente), 1969, en la que la tierra se lleva hacia dentro de la galería o museo, sirviendo así de sustento para un árbol vida de naranjo que en ella se planta. El barro también está presente en algunos detalles de la pieza titulada Uma árvore é uma obra de arte quando recriada em si mesma como conceito para ser metáfora (Un árbol es una obra de arte cuando se recrea en sí mismo como concepto para ser metáfora) 1992; en ésta, el barro rellena el interior hueco de los troncos y de las raíces en una vitalidad orgánica afirmativa aunque informe.

La tierra también aparece en la pieza titulada Os quatro elementos (Los cuatro elementos), 1969-70, también aquí como elemento generador de vida, sosteniendo una vez más el crecimiento de un árbol. A. Carneiro se refiere a estas materias como parte de su íntimo. En su biografía tuvo por bien referir que en su infancia siempre jugó con la tierra y que, por eso, entre su "cuerpo y la tierra hubo siempre una identidad profunda." ${ }^{565}$ Su proyecto consistió en trabajar las cosas de la tierra, de su vivencia personal, en estrecho diálogo con el arte más vanguardista que se estaba desarrollando especialmente en el contexto inglés.

\footnotetext{
${ }^{564}$ Idem, p. 13 «un objet dont la signification semble bel et bien enterrée»

${ }^{565}$ CARNEIRO, Alberto, Das Notas Para Um Diário, 5 de Maio de 1965.
} 
Para Robert Smithson, podría decirse que la tierra o las rocas sólo adquieren valor por su contexto; así, se presentan de forma literal y se articulan con un conjunto de acciones y pensamientos que colocan a la tierra como elemento fundamental de una escultura en un campo amplio. Para este artista, y después del aumento del conceptualismo, la tierra puede leerse, sus capas pueden leerse, la tierra es un lenguaje. La tierra también es el lugar donde el tiempo geológico afronta el tiempo del instante o la creación artificial de que el tiempo no desgasta. A través de la estética entrópica, Smithson literaliza la presencia bruta de la tierra y de lo que hicieron con ella. A partir de la exploración dialéctica entre lugar y no-lugar, este trabajo altamente intelectualizado se integra perfectamente en el nuevo impulso creador que, cortando con el territorio secular de la estética europea, abre el campo del arte y de la escultura en particular a nuevas articulaciones con las ciencias naturales y humanas, y a nuevas formas de intervención ética y política.

Robert Morris, en su texto titulado Notas sobre el Arte como Regeneración de la Tierra"566, tal como ya había hecho Smithson, concede especial importancia a los lugares en disolución, en un programa de trabajo que pretende prestar atención a la circunstancia actual del paisaje, reconociendo que "los efectos adversos sobre el medio ambiente abarcan desde los factores estéticos hasta los tóxicos. ${ }^{567}$ Morris se propone regenerar la tierra a través del arte, o sea, propone una mirada cultural hacia un problema ambiental; esta preocupación tiene tanto de estético como de ético y político.

Desde hace un tiempo, existe cierta preocupación pública por los efectos que pueden tener los programas cada vez mas acelerados para la extracción de recursos no renovables de la tierra. Los efectos adversos sobre el medio ambiente abarcan desde los factores estéticos hasta los tóxicos. Al margen de los efectos estéticos, las excavaciones mineras de recursos naturales han provocado los siguientes peligros: perdida de la capa superficial del suelo; erosión a causa del viento y el agua; desprendimiento de tierras; supresión de la fauna; contaminación del agua por ácidos, toxinas o mineralización;

\footnotetext{
${ }^{566}$ MORRIS, Robert, Notas Sobre El Arte Como Regeneración De La Tierra, In Martí Peran y Glòria Picazo (Editores), Naturalezas Una travesía por el arte contemporáneo, (pp. 75-94). Barcelona, MACBA, 2000.

${ }^{567}$ Idem, p. 75.
} 
sedimentación; inundaciones; disminución de la superficie freática del agua; destrucción de los bienes artificiales debido a algunos de estos efectos y a los que provocan las ondas explosivas; también han producido otras degradaciones de carácter social, como las perdidas económicas locales, el envenenamiento del ganado, etc. ${ }^{568}$

Las imágenes señaladas con las figuras 70 y 71 , así como otras que no se encuentran aquí reproducidas, se realizaron en el paisaje de las minas de São Domingos en Portugal que, a semejanza de las minas de Riotinto en Huelva, se presenta como un lugar gastado, donde la tierra se quemó y consumió para alimentar la lógica del pragmatismo del lucro. Estos lugares en disolución son, al final, "no-lugares", cabiendo al arte proponer el desarrollo de la idea de R. Morris: la regeneración de la tierra ${ }^{569}$, capaz de hacer coincidir los aspectos estéticos con los éticos. Tal acción presupone continuar saliendo del estudio hacia los espacios marginales del paisaje. Una vez allí, reconozco el declive de un cierto componente ético ante la naturaleza. Pues no es todo igual: el hombre no es igual a la naturaleza y mucho menos superior a ella porque, simple y llanamente, el hombre es también naturaleza. Cuando el hombre se olvida de este hecho, recordado constantemente por Alberto Carneiro, la extensión de sus destrozos se densifica. El problema no es la existencia de la pedrera, de la mina, de la agricultura, de la ciudad, etc., incluso porque sólo existe paisaje si en él coexisten naturaleza y actividades humanas, el problema está en la extensión de la acción humana. Tal percepción ha influido en mi trabajo, justificando la opción de, en el paisaje, privilegiar la relación de obras efímeras o incluso de no hacer ninguna

\footnotetext{
${ }^{568}$ Idem, pp. 75 y 76.

${ }^{569}$ Maria Leonor Nunes resume en un artículo lo que propongo como regeneración de la tierra. "Para Samuel Rama, que en su trabajo recurre al propio polvo de la tierra o a los troncos de los árboles, la relación entre las preocupaciones del ciudadano y el universo creativo tampoco es directa. "La ecología se transformó en un valor que para mí es bastante importante. Pero eso no implica que mi trabajo busque fijarlo en una mera ilustración o actitud política panfletaria», destaca. "A decir verdad, esa preocupación puede ser el inicio, porque siempre trabajamos a partir de nuestras convicciones, valores, etc. Pero ese es el punto de comienzo, no el punto de llegada». Lo que Rama propone de alguna manera, con sus esculturas, fotografías e instalaciones, es una regeneración de la tierra a través del arte. Su proceso creativo obedece a la «desaceleración», que es como quien dice «escalas de tiempo más lentas como el tiempo biológico o geológico". "Son estas escalas temporales más amplias las que ayudan a relativizar la excesiva aceleración del tiempo ordinario del día a día y que está asociado al pragmatismo del lucro», explica. «Nunca se produjeron tantos bienes materiales como ahora ni nunca tuvimos que librarnos de tantos residuos. Esto nos debe hacer reflexionar, porque por el camino destruimos recursos de la naturaleza, pero también de los individuos»" in NUNES, Maria Leonor, "Uma Cultura da Natureza", Jornal de Letras, Artes e Ideias, oㅡ 1022, de 2 de Diciembre de 2009, pp. 12-17.
} 
intervención en los lugares, sino antes centrar mi atención en ciertos objetos o acciones cuya marca espacio-temporal de la ausencia y del dibujo los haga designarse como esculturas materializadas en el soporte fotográfico.

\subsection{2}

\section{En dirección al paisaje concreto}

Esta consciencia de salida del estudio hacia los lugares del paisaje ha transformado el paisaje, el museo o la galería en un estudio. Tal hecho proviene de la convicción de que la idea de paisaje "como vista" -la idea de ventana- ya no nos sirve; en vez de eso, el proceso creativo expresa, actúa y piensa los lugares concretos.

Paisagem Adoptiva, 2009, presentada en la exposición titulada Identidade e Simulacro, parte de la propuesta que se lanzó a varios artistas para que realizaran varias intervenciones en el interior de la población de Óbidos (Portugal). En este contexto, la pieza pretendió revelar la mina de yeso de Óbidos, que se encuentra fuera de la villa, como escultura en sí misma, es decir, como lugar donde la ética, la estética y la poética de la tierra se encuentran concentradas de una forma bruta y no atravesada por ningún elemento pintoresco. Para reforzar esta visión, la pieza se desdobló en dos intervenciones. Una consistió en la construcción de una señal de once metros de altura, colocada frontalmente en relación a la vista más turística de Óbidos, y que muestra el lugar exacto donde la mina de yeso se sitúa en el paisaje (fig.75). La señal, deliberadamente bidimensional, casi confirma la regla de que, en un espacio turístico, la idea de paisaje está sobre todo vinculada a la idea de vista, más aún, de vista estereotipada; cualquiera puede captar a partir de una cámara fotográfica la vista del paisaje. Ese estereotipo hace que la mirada que se lanza sobre un paisaje sea ya la de una mirada desatenta y desprovista de profundidad. Cualquier imagen que hagamos de aquel lugar será igual a tantas otras imágenes que ya se hicieron de él, la mirada frente al paisaje ya es, en cierto sentido, una mirada transformada en bidimensional. La señal plana en la 
mina, además de localizarla, también acentuaba el carácter bidimensional de esa vista, casi como si pudiésemos señalar el lugar con un rotulador blanco en una fotografía o en un mapa. La otra intervención de Paisagem Adoptiva consistió en fijar varios carteles de formato $\mathrm{A} 0$ en el interior del pueblo, carteles que mostraban imágenes del interior de la mina de yeso y palabras como ETHICS, THEORIA, MACRO, MICRO, GEOSCULPTURE. Los carteles pervirtieron el uso del espacio a propósito cristalizado y excesivamente pintoresco para servir a fines turísticos. Simultáneamente, trajeron urbanidad, publicitan y orientan la atención de los espectadores para una mina que se transforma en arte público. Experimentar esa realidad es tener acceso al paisaje que ya no se puede entender como vista; una vez dentro de la mina, tenemos la experiencia de un lugar que tiene la tierra como límite, que no deja espacio para cualquier tipo de narrativa. Sucede una experiencia extraña. Primero, tenemos un sentimiento de lo sublime ante el gigantismo de la mina, tal como cuando sentimos admiración por un acantilado o un gran desfiladero natural, pero, en un segundo momento, nos asalta la idea de que ese lugar no es natural, sino el resultado de la acción humana de explotación desmedida de los recursos. A partir de ahí, la sensación de placer estético se pone en causa por la conciencia ética de que, en realidad, aquel lugar nació de un desequilibrio, una debilitación del plano ético, que dio origen a una acción desmedida en su proporción y potencial transformador por parte del hombre.

La mina de yeso está en las proximidades de la villa. Esa mina, considerada una escultura en el espacio del paisaje, encierra como vimos sentimientos contradictorios. Es un lugar realizado por obreros que, año tras año, fueron construyendo varias cavidades en el espacio de esa mina a cielo abierto. En este contexto, para mí tenía sentido proponer un tipo de intervención que funcionase como inductor de la relación y encaminamiento del espectador desde la Vila de Óbidos hasta la mina de yeso, o sea, desde dentro del espacio pintoresco de la Vila hacia fuera del espacio de la villa, hacia su espacio bruto y arcaico de la mina de yeso, realizado a partir de las llamadas "herramientas 
estúpidas ${ }^{, 570}$. Ese espacio se niega muchas veces y no se comprende por los habitantes de esa región, quizá porque estos espacios excesivamente arcaicos y profundos, sucios y brutos causen malestar en nuestra civilización basada en lo limpio y en las superficies artificiales, o tal vez porque lo informe de la tierra continúe perturbando.

En Arquitecturas Reflexivas, 2011, presentadas en el ámbito del programa Land Art Cascais ${ }^{571}$, presenté dos tipos de intervención realizados también directamente en el terreno. Arquitectura reflexiva \#1 (fig. 76) se situó en un lugar que proporcionaba el punto de vista más pictórico sobre el terreno y la sierra. Construí una especie de observatorio formado por una estructura puntual metálica vacía, que funcionaba como paralelepípedo o plinto hueco que elevó una cobertura vegetal. Al elevar la cobertura vegetal, el espectador podía subir por una escalera hacia arriba de esa cobertura vegetal y observar todo el caos urbanístico suburbano que se sitúa alrededor del lugar de la exposición, la Quinta do Pisão, al contrario de lo que sucedía en el plano térreo. Pues allí apenas teníamos acceso a una vista pintoresca y traicioneramente pura del lugar.

\footnotetext{
${ }^{570}$ Michel Heizer acuñó el término en una entrevista; las herramientas estúpidas se forman como herramientas que, aunque sean el resultado de un perfeccionamiento técnico contemporáneo, tienen, como defendió Robert Smithson, una afinidad especial con un cierto sentido arcaico primitivo, como excavadoras, camiones, etc. "Las manifestaciones de la tecnología son a veces menos "extensiones" del hombre (el antropomorfismo de Marshall McLuhan) que agregaciones de elementos. Incluso las herramientas y las máquinas más avanzadas están hechas de la materia prima de la tierra. Las herramientas de alta tecnología de la actualidad, sumamente refinadas, no se diferencian mucho en este aspecto de las de los hombres de las cavernas. La mayor parte de los mejores artistas prefieren procesos que han sido idealizados, o diferenciados para dar lugar a significados "objetivos". Palas ordinarias, mecanismos de excavación de aspecto extraño, lo que Michel Heize denomina "herramientas brutas", picos, horcas, la máquina utilizada por los contratistas suburbanos, tractores severos que tienen la torpeza de dinosaurios acorazados, y arados que simplemente remueven la tierra. Máquinas como el tractor a vapor de Benjamin Holt (inventado en 1885): "Repta sobre el barro como un ciempiés." Motores para excavar y otros tractores de oruga que pueden desplazarse sobre terrenos quebrados y pendientes pronunciadas. Taladros y explosivos que pueden realizar pozos y producir terremotos. Podrían excavarse zanjas con la ayuda del "desgarrador" - rastrillos con púas de acero montadas en tractores -. Con este equipo, la construcción adquiere un aspecto de destrucción; quizá por eso ciertos arquitectos odian los bulldozers y las excavadoras. Parecen convertir el terreno en ciudades inconclusas de escombros organizados. Una sensación de planeamiento caótico engulle a solar tras solar. Se hacen subdivisiones; ¿pero con qué fin? La construcción adquiere un asilvestramiento singular conforme los cargadores excavan y arrastran tierra por todas partes.". "Una sedimentación de la mente: Proyectos de tierra". En: SMITHSON, Robert. El paisaje entrópico. Una retrospectiva 1960-1973. Valencia: IVAM, 1993, p.132.

${ }^{571}$ Este conjunto de piezas, además de integrar el programa de LandArt Cascais, se presentó de manera pública en el ámbito del seminario permanente $\mathrm{V}$, perteneciente al proyecto de investigación de filosofia e arquitectura da paisagem (FCT PTDC/FIL-FIL/100565/2008), al cual pertenezco, y que integra el Centro de Filosofia da Universidade de Lisboa - Faculdade de Letras e o Centro de Estudos de Arquitectura Paisagista "Prof. Caldeira Cabral" - Instituto Superior de Agronomia.
} 
Digamos que cada uno, a partir del acto de subida a la plataforma, opera un paisaje de un nivel de consciencia hacia otro nivel de consciencia del lugar, un primero en que el paisaje se entiende sobre todo "como vista" agradable sobre el terreno y sobre la Sierra de Sintra, y otro en que el paisaje se entiende como lugar de desequilibrios señalables, en la medida en que, una vez sobre la plataforma elevada, no podemos ignorar más la presión que existe sobre el paisaje. Una vez llegados allí, el estado placentero que la vista desde el suelo nos había proporcionado se cuestiona y se hace difícil de soportar en el plano superior. Ocurre así una frustración de expectativas y, una vez más, parecen reunirse las condiciones para que ocurra un balance entre la construcción de un plano ético y estético sobre el paisaje.

Esta forma de estructura no será seguro ajena en su formulación a ciertas jaulas encontradas en una escala miniaturizada en el trabajo de Alberto Giacometti. Sucede que la estructura o jaula que pertenece a Arquitectura reflexiva \#1 ya no es una escultura objeto en miniatura. Así como ya no lo es el circuito descrito por las figuras 77 y 78, Arquitectura reflexiva \# 2 e 3, ambas realizadas en el ámbito de la misma exposición, en 2011, cuyo mecanismo repite claramente el mismo dispositivo escultórico que Giacometti ya había formulado en la pieza referida en la última parte del Capítulo III titulada Circuito", de 1931. Pero esta vez, el circuito se realizó en una escala $1 / 1^{572}$ y pide la intervención de las personas, transformándose en una intervención lúdica que se mezcla con el día a día de las personas que visitaron el terreno o el parque de Pisão. En la Quinta do Pisão, esta pieza sirve apenas para que, con el mínimo de medios, podamos activar la memoria de una presencia ausente, una memoria respectivamente de un horno de cal y de un almacén de cal, que funciona como un dibujo blanco sobre la tierra, un dibujo que en Arquitectura reflexiva \# 2 se transforma en un foso abismal que es la apertura de lo que fuera el horno de la cal. Esa esfera, realizada con cal endurecida mediante un método cerámico, al rodar, va erosionando o rasurando el propio dibujo inscrito en el paisaje en

\footnotetext{
${ }^{572}$ Estas piezas pretenden encadenarse en un conjunto de referencias históricas que van desde Alberto Giacometti a Robert Morris, en concreto las instalaciones que expuso en la Tate Gallery en 1971, y que formaban varios objetos escénicos, con una escala arquitectónica, que deberían ser animados por los espectadores observando un conjunto de reglas de uso.
} 
blanco. Al mismo tiempo que sucede este proceso, la esfera va ganando cada vez más masa, volviéndose cada vez mayor e irregular y, en consecuencia, el surco va quedando cada vez más ancho y profundo. 


\section{CONCLUSIONES}

\section{a. Notas preliminares}

Desde el título de esta tesis se observa que el acento se puso en las cuestiones del paisaje en su relación con el campo de lo escultórico. De su esclarecimiento se construye esta tesis a partir de la idea de itinerario meditativo, un recorrido muchas veces inducido por algunas propuestas presentadas en el capítulo V. En este sentido, más importante que haber definido previamente un camino o itinerario meditativo con base en problemáticas rígidas, se hizo imperativo crear las condiciones para que el camino se hiciera caminando.

Este itinerario meditativo fue informado por las motivaciones personales y los objetivos, y requirió una metodología específica para evitar que el camino no degenerase en una deambulación sin fin. La principal motivación personal consistió en integrar la producción plástica propia con los contenidos teóricos que tiene vinculados. La práctica de las artes está en constante transformación y devenir; por eso, ninguna estructura conceptual rígida originada en el contexto académico finalista consigue captarla o tan siquiera tocarla, y mucho menos traducirla enteramente a otro lenguaje, por ejemplo verbal.

\section{b. Arte y lenguaje verbal}

La naturaleza del arte obliga a que la estrategia conceptual usada sea más elástica que rígida, precisamente para que, mimetizando su funcionamiento, le pueda tocar en algunos puntos o por lo menos intentar que no le sea contraria. Se puede intentar describir la naturaleza del arte como un acontecimiento dinámico que cualifica el espacio rítmicamente; es así tanto desde el punto de vista de su recepción por un espectador, como de su realización por un artista. Esto porque las estructuras espacio-temporales engendradas por una obra de arte no son homogéneas y estáticas, sino, antes bien, son diferenciadas y están en movimiento. En este contexto, cualquier ejercicio que quiera estabilizar el arte, como la mayoría del método científico hace en relación a la naturaleza, sale 
frustrado. Si así hiciéramos tan sólo conseguiríamos captar sus indicios más pobres, como composición, estilo, materialidad, etc. Todo descodificaciones que situarían el arte en el contexto de la comunicación y que olvidarían su cuestión más distinta, la expresión.

Siendo el ejercicio de la palabra una actividad racional, queda quien quiere comprender el fenómeno artístico en tanto que expresión, corriendo detrás de los vestigios dejados por la naturaleza dinámica y provisional del arte. Esta caminata, que se configuró durante un itinerario meditativo, tuvo que ser concebida sin un propósito finalista. Prever todo el recorrido de la caminata es limitar todas las posibilidades de descubrimiento, o -como diría Giacometti a propósito de la escultura- prever o proyectar una escultura antes de hacerla, redunda durante su ejecución a hacer una copia del pensamiento. Esto es, en el entender del artista, reductor, además de no revelar nada acerca del modo distinto del funcionamiento del arte.

Paradójicamente el ejercicio advertido del pensamiento y del lenguaje verbal ayuda al esclarecimiento y la construcción de puntos de vista privilegiados para hacerlo. Siguiendo a Espinosa, se nos ocurre defender que ningún itinerario meditativo será bien orientado sin haber definido primero puntos de apoyo y vectores para su orientación, adonde deben confluir las energías creativas necesarias para la construcción del carácter autoral de un artista. Fue eso lo que tratamos de hacer al partir de la auscultación de los datos de la práctica artística para hacer la selección de las referencias e ideas a profundizar y regresar al trabajo práctico propio tras la recogida de los beneficios de la investigación.

\section{c.Naturaleza, Paisaje y Ambiente}

La naturaleza, de la que el bosque constituye en nuestro imaginario su índice más intenso, fue descrita por Georg Simmel como "la infinita conexión de las cosas, la ininterrumpida procreación y aniquilación de formas, la unidad fluyente del acontecer, que se expresa en la continuidad de la existencia 
temporal y espacial. ${ }^{573}$ La naturaleza es siempre una totalidad y nunca puede, al contrario del paisaje, ser una parte de esa totalidad. Precisamente el paisaje surge en la modernidad europea como resultado de la división dilacerante entre el hombre y la naturaleza. En la misma época surge el dispositivo que confirma esa división, la perspectiva monofocal del Renacimiento Italiano, este producto cultural instaura la idea de paisaje "como vista", que es válida tanto para quien contempla la realidad como para quien hace una imagen a partir de esa realidad.

En cualquiera de los casos, el paisaje es un producto cultural que se encuentra siempre entre el sujeto y la naturaleza que se transforma en objeto contemplado. "El paisaje es así una forma de pensamiento que se constituye en cada acto perceptivo." ${ }^{\text {574 }}$, siendo de esta forma de pensamiento de donde emerge el paisaje como arte, materializado preferentemente en pintura, medio privilegiado para ello, en la medida en que se relaciona esencialmente con el sentido de la vista. Así, ante la naturaleza, un sujeto puede crear un acto de adhesión anímica responsable de la aparición de la sensación de paisaje; en un primer momento, el paisaje así surgido no es aún representación, pero contiene ya el germen de esa forma particular de expresión artística humana.

Es precisamente en la reducción de la naturaleza a la condición de objeto contemplado donde reside la clave para la comprensión de la noción de paisaje en el arte, ya sea como representación, ya como presentación. Al mismo tiempo la evolución del mundo desde el Renacimiento hasta la actualidad obligaron al reconocimiento de que la categoría de paisaje sólo puede existir en transición ${ }^{575}$, ya que a la noción de paisaje parece haberle sucedido, o por lo menos completado, otra noción más amplia, la de ambiente.

\footnotetext{
${ }^{573}$ SIMMEL, Georg, "Filosofia da Paisagem", In Filosofia da Paisagem. Uma Antologia. Trad. y coord. de Adriana Veríssimo Serrão), Lisboa, Centro de Filosofía de la Universidad de Lisboa, 2011. p. 42.

574 SERRÃO, Adriana Veríssimo, "A transição como essência da paisagem", in Conferencia Internacional - Paisagens Em Transição, Projecto de Investigação Filosofia e Arquitectura da Paisagem (FCT PTDC/FIL-FIL/100565/2008) 7 de octubre de 2011, Lisboa, Sala 1, Fundación Calouste Gulbenkian, Notas de conferencia. Mimeografiado.

${ }^{575}$ Idem. En esta conferencia la filósofa Adriana Veríssimo Serão expuso la idea de que la categoría del paisaje se encuentra desde su inauguración en constante transformación, no sólo porque los paisajes han cambiado mucho desde el inicio de la modernidad, sino también porque la noción de paisaje ha sido ella mista agente modelador y transformador de los paisajes.
} 
La noción sucedánea de paisaje, pasó a ser para muchos teóricos del paisaje, principalmente anglosajones, la noción de ambiente. Anne Cauquelin identifica la aparición del concepto de ambiente, como posibilidad para pensar una modalidad más lata y actual de la noción de paisaje. La necesidad del concepto de ambiente se deriva principalmente de la ampliación de las esferas de los varios saberes y de su consiguiente mestizaje. La noción de ambiente, por ser más amplia, ${ }^{576}$ comporta, además de la dimensión estética, la ética y la política en relación al paisaje real.

\section{d.Escultura, noción en constante transformación}

Si, en relación a la evolución del concepto de paisaje, podemos decir que parte de la naturaleza, se establece durante la modernidad y evoluciona, o se actualiza, en el concepto de ambiente, curiosamente podemos hacer el mismo paralelismo entre las transformaciones de la noción escultura, en la medida en que procede de la estatuaria, instaurándose en sentido estricto con Rodin, pero comprobamos que su existencia fue efímera, prolongándose en la práctica hasta mediados del siglo XX.

La escultura deriva de un arte bien más antiguo, la estatuaria, que se caracteriza por ser esencialmente evocativa y celebrativa. El trabajo realizado por Rodin a mediados del siglo XIX representa el punto fundamental de cambio para que la escultura fijara sus propios procedimientos $y$, a partir de ahí, los desarrollara en el sentido de su emancipación a través de la negación de sus procedimientos tradicionales. Los escritos de Rodin, así como la evolución de su obra escultórica, denotan una profundización de una cierta ontología de la

\footnotetext{
${ }^{576}$ La noción de ambiente, por su mayor amplitud, podría confundirse con la de naturaleza, pero Luís Sá identifica dos grandes distinciones, " a) la autonomía ontológica de la naturaleza, una vez que ésta existe independientemente de un sujeto que la observe y que viva en ella. Eso contrasta con la necesidad de interrelación presente en el concepto de ambiente; el ambiente es el conjunto de relaciones que se establece entre quien vive en él y lo que lo circunda y en él ejerce influencia; b) la esencia sintética del concepto de naturaleza impide un análisis sin pérdida de significado o, como mínimo, convirtiendo ese análisis en una reflexión pobre y desvirtuando la propia noción de naturaleza una y total. El estudio o la apreciación de una parcela de la naturaleza se deriva en una incapacidad de aprehenderla.» SÁ, Luís, "O regresso da natureza à experiência estética", In Filosofia e Arquitectura da Paisagem. Um Manual, (coord: Adriana Veríssimo Serrão), Lisboa, Centro de Filosofía de la Universidade de Lisboa, 2012. p. 194.
} 
escultura, negando la convención ilusionista derivada de la representación bidimensional característica de la estatuaria y presentando una visión crítica de la práctica del arte en general y de la escultura en particular, siendo, en el marco de esta comprensión teórica, un punto nodal a partir del cual irradió la práctica moderna de la escultura animada por una conciencia cada vez más acentuada de lo que le es específico. Una de las contribuciones fundamentales de Rodin fue el hecho de haber mostrado que trabajar el concepto de escultura implica orientarla en el sentido de una cierta opacidad, o sea, de auto-referencialidad de sus procesos y, en consecuencia, de negación de la estatuaria y de su marcada dimensión evocativa. Así, la escultura en sentido estricto sucedió a la estatuaria pero retuvo de ésta la idea de ausencia que continuó y continúa de forma permanente vinculada al proceso escultórico. En este sentido, la escultura del siglo XX representa un trabajo constante sobre la idea de ausencia de un cuerpo que se ha desplazado a otro lugar, como nos presenta Fullaondo: "la ausencia es el resultado de un proceso de desocupación espacial, presencia de una ausencia formal o vacío; se crea, es un resultado, no existe a priori." ${ }^{577}$

La forêt (fig. 24) es una escultura creada por un artista altamente comprometido con la historia: con la historia del arte pero sobre todo con una historia existencial y de concepción. ${ }^{578}$ Sus figuras de frágil pero afirmativa verticalidad se conectan simultáneamente con la historia de la estatuaria y con la de la escultura en sentido estricto, y contiene también una promesa de abertura a la noción de escultura en el campo expandido. Las figuras dispuestas sobre la base resultan de un trabajo directo de modelado de la mano que es la clave para la comprensión de las cualidades del vacío. En palabras de Hildebrand, hasta en

\footnotetext{
${ }^{577}$ FULLAONDO, Juan Daniel, Oteiza y Chillida, en la moderna historiografía del arte, Bilbao, Editorial La Gran Enciclopedia Vasca,1976, pág. 21.

578 Son prueba del valor de la copia para Giacometti los muchos dibujos realizados en páginas de libros de historia del arte. En «El diálogo con la historia del arte, Alberto Giacometti», exposición realizada en el IVAM en 2001, observamos que Giacometti estableció desde muy pronto una relación productiva incluso con las imágenes impresas de la historia del arte. El dibujo, como muy bien comprendió Giacometti, tiene una relación diferente con la cadena histórica en la que es producida; por ser absolutamente transparente e inmediato; revela, como vimos, el proceso de su creación. Incluso cuando estamos ante una reproducción, podemos observar que Giacometti comprende la obra a través del valor de la copia, en cuya acción no sólo busca la información, sino también la restitución de una determinada experiencia en diferido a partir de la experiencia primera de quien creó la obra original.
} 
la estatuaria el modelado de una figura inacabada en arcilla, "penetra el aire y el espacio real," ${ }^{579}$ precisamente porque las figuras en Giacometti son siempre el resultado de un proceso erosivo de raspado que corroe, más allá de la noción de figura o de rostro acabado. Este vacío expresa el abandono y el terror a los que la experiencia de dos guerras mundiales no es extraño. Pero su potencial no se agota en ese contexto circunstancial. El vacío instaura el espacio de lo sublime, en La forêt como en un bosque real o importante, no son los árboles, si no, como diría Rainer Maria Rilke, "el espacio sublime y patético entre ellos". Ahora bien, lo sublime, especialmente según fue teorizado por Burke, invierte la polaridad de la atención del cuerpo del espectador en relación al objeto contemplado, en la medida en que el cuerpo del espectador, en vez de proyectarse hacia el exterior, lo hace hacia el objeto. Es antes afectado por éste, por su estructura errante, informe y teatral. Así podemos referir que la estructura errante de La forêt es la responsable de la proyección de ésta en dirección al espacio real, algo que viene en la continuidad de otras obras del periodo surrealista ${ }^{580}$. A mediados del siglo XX surge un entendimiento dudoso sobre lo que puede o no ser escultura. Como profundizamos en el segundo capítulo, la escultura, primero determinada como siendo un objeto tridimensional realizado en un material durable y que tiene como medio de expresión el volumen y la forma, construyendo una realidad y unidad plástica interna a sí misma, comprensible en su relación con el escultor y definida como un conjunto de superficies exteriores. Pasa a poder ser entendida como realidad interior, en la misma medida que la arquitectura. La concepción de espacio escultórico presente en el Merzbau de Kurt Schwitters y en el Espacio Proun de El Lissitzky, ambos datados de 1923, fueron revalorizados a partir de la

\footnotetext{
${ }^{579}$ HILDEBRAND, A. Von, El problema de la forma en la obra de Arte, Trad. al castellano de María Isabel Peña Aguado, Madrid, Visor, 1988, p. 103.

${ }^{580}$ De las obras del periodo surrealista que problematizaron el avance hacia el espacio real destacan: Cabeza/Paisaje, 1932, una obra en la que, en función de que se coloque en posición vertical u horizontal, la escultura asume la condición bien de cabeza bien de paisaje, esta posibilidad de doble funcionamiento atestigua la fuerte conciencia del artista en relación al espacio de exposición y al protocolo que este instaura en el espectador. En otros casos la escultura tiene un funcionamiento en laberinto, exhibe un espacio errante o requiere la interacción del espectador para que éste anime sus partes móviles, como sucede con Circuito, 1931. Buena prueba de la pertinencia contemporánea del trabajo de Giacometti es la presencia de La forêt en la exposición titulada "Silêncios», comisariada por Marin Karmitz, que tuvo lugar en 2010 en el Museu Berardo, en Lisboa. Ocupando el centro del montaje de la exposición organizada en forma de laberinto, "La forêt" de Giacometti se sitúa cerca de otras obras de artistas más afines, como Juan Muñoz o Christian Boltanski, hasta otros menos probables como Bruce Nauman o llya y Emilia Kabakov.
} 
instauración de lo que Rosalind Krauss denominó «La escultura en el campo expandido", en este contexto que aún es el actual, pues aún se verifica la expansión del campo de lo escultórico. La práctica escultórica pasó a poder trabajar, además del no-paisaje y no-arquitectura, también el paisaje y la arquitectura. Ciertas prácticas escultóricas de mediados del siglo XX pasaron a denominarse precisamente ambientes, como es el caso de Uma floresta para os teus sonhos (fig. 41). La apertura de la práctica escultórica vino a cuestionar la tradicional dialéctica del campo de la estética, basada en un observador que se encuentra fuera del campo que observa. Algo ocurrió a mediados del siglo XX para que se pudiera dar esta transformación, que fue designada por la crítica con el término de posmodernidad, que corresponde a una perspectiva crítica sobre la modernidad. Muchas fueron las transformaciones producidas en ese periodo, tras dos grandes guerras mundiales y de que el mundo hubiera conocido el poder destructivo de la bomba atómica, de las convulsiones sociales y políticas. Se hizo difícil sostener la idea de que los asuntos del arte eran sus propios modelos de funcionamiento. Es decir, la idea moderna de que el arte debe tratar de profundizar sus lógicas internas u ontología, entró en decadencia en favor de prácticas heterodoxas de carácter holístico derivadas de un proceso y de un proyecto que sólo está completo cuando el cuerpo del espectador en su movilidad usa y experimenta un espacio escultórico a lo largo del tiempo, casi como si de una arquitectura se tratara.

\section{e. Lanzar puentes hacia adelante}

La decisión de profundizar desde el punto de vista interpretativo en La forêt y Uma floresta para os teus sonhos se derivó de los primeros ejemplos de trabajo práctico personal presentado en el capítulo V. Después, a medida que la investigación interpretativa teórica fue avanzando, sus cuestiones transitaron de ésta, a la práctica artística. Este trayecto desde la práctica pasando por la teoría y acabando de nuevo en la práctica puede ser testimoniado y unificado en torno esencialmente de tres momentos de creación que agrupan varias piezas escultóricas. En el primer momento, se incluyen Vontade, 2004, (fig. 63), Fadiga 
de Estruturas, 2005-2006, (fig. 65) y Wander, 2007 (fig. 66). Debe señalarse que la primera obra citada fue realizada antes del inicio de la presente investigación, y las restantes se encuentran ya en la transición y en pleno proceso de investigación que desencadenó esta tesis. Fueron estas piezas citadas las que llevaron a la elección de las dos esculturas de Giacometti y A. Carneiro objeto de estudio: La forêt y Uma floresta para os teus sonhos, respectivamente. De su interpretación emergió naturalmente, y sin que su creación fuera el resultado de una acción programática, la obra MEGAPARSECS, 2012, (fig.67) que funcionó como corolario de todo el proceso de investigación anterior. Por el medio, se encuentra un conjunto de otras obras creadas, entre las que destaca MAGMA, 2008, (fig. 69). En ésta se profundizó en la imagen del tiempo geológico, la relación entre estética y ética de la tierra recurriendo tanto a piezas tridimensionales como bidimensionales intentando entender cómo ambas se articulan entre sí y cómo la fotografía puede formar parte de las propuestas escultóricas contemporáneas.

Intentamos arrojar luz a lo largo de este recorrido sobre la relación entre arte y naturaleza, la constante transformación de la noción de paisaje, su relación con el campo de lo escultórico, poniendo la tónica en la implicación físico y mental del cuerpo del artista que ejecuta la escultura como de quien la experimenta, y en ese sentido entender el valor del vacío y de la ausencia y finalmente la articulación de la estética con la ética.

En Vontade y Fadiga de Estruturas, las materias de la naturaleza, el agua y la arena de los bosques son llevadas hacia dentro del museo, tal como ya lo había hecho el Land Art. Esta entrada de las materias naturales en estado bruto al interior del espacio ascético del museo o la galería de arte viene a frustrar una serie de reglas de funcionamiento de esas instituciones, especialmente el hecho de la permanencia de los artistas durante los montajes sea normalmente corta y los materiales de sus esculturas sea constantemente filtrado desde el punto de vista de la seguridad, degradación y durabilidad. En verdad, las instituciones legitimadores son por esencia conservadoras y es por cualificarse de esa forma en el espacio de la ciudad por lo que las propuestas escultóricas como Vontade y Fadiga de estruturas, adquieren todo su sentido, 
pues por un lado son llevadas al interior de los espacios institucionales las materias brutas de la naturaleza cualificadas por su tiempo geológico y biológico. Por otro, el espacio del museo o galería es usado por el artista como taller durante el tiempo de ejecución de las piezas citadas, que transcurrieron durante un mes en el caso de la primera y durante un mes y medio en el caso de la segunda.

Del contraste de las materias brutas de la naturaleza con los espacios institucionalizados de la galería o museo, resulta el choque deliberado entre el tiempo geológico y biológico de éstas, con el tiempo del instante característico del modo de vida urbano. Del uso de esos espacios institucionalizados como taller resulta una mejor y mayor articulación entre la idea de la pieza y el lugar arquitectónico de su exposición, haciendo que cada nueva presentación sea realmente diferente, no sólo porque la experiencia acumulada obliga a reeditar las cuestiones plásticas, pero también porque a cada nuevo espacio arquitectónico induce una nueva concepción de espacio para la intervención escultórica. De esta forma cada pieza no es el resultado de un producto anunciado o hecho aceptable o dócil al público por la batería de información disponible, pero pretende ser algo que plantea realmente nuevas preguntas, porque su producto sólo sucede después de un demorado y laborioso proceso de trabajo físico e intelectual con las materias brutas de la naturaleza.

Trabajar a partir de memorias pareció un modo especialmente eficaz de convocar el máximo de energía física y mental en la elaboración y posterior valoración sensible e intelectual del trabajo realizado. En el origen de las piezas realizadas con arena y agua están memorias de infancia del autor, sin embargo esas memorias que se derivan de la construcción de estructuras simples usando esos materiales con la única finalidad de alcanzar el máximo de altura en equilibrio, no son exclusivas del autor, encuentran eco en todos, independientemente de la edad o condición social. Este hecho crea un plano de entendimiento de la escultura que se extiende a todos. La acción de agarrar y dejar escurrir un montón, arena y agua, es un gesto simple que hizo surgir la acción escultórica porque pertenece al imaginario colectivo. La escultura usa así un patrimonio expresivo, perceptivo y emocional que nos pertenece a todos, pues 
cualquiera, alguna vez, ya hizo este tipo de construcción en la playa o en otro lugar $\mathrm{y}$, por lo tanto, reconocemos en ella el tiempo demorado que exige su elaboración bien sucedida. Tanto La forêt como Uma floresta para os teus sonhos se derivan de la explotación de la memoria. $\mathrm{Y}$ ambas son hitos importantes en la creación de cada uno de los autores, precisamente porque la memoria es una de las modalidades más creativas del pensamiento. En el contexto de todas las piezas ahora citadas, el ejercicio de la memoria devenido momento que hace concebir, ejecutar y presentar la escultura es bastante útil porque incorpora las intensidades de un determinado lugar en el paisaje vivido por el cuerpo y que se desea de nuevo poseer una vez más, ahora en la condición de adulto y encuadrado por el campo cultural de las artes plásticas.

Vontade y Fadiga de Estruturas son tanto el resultado de la ejecución realizada por el trabajo manual, como el resultado de una concepción del arte en tanto que idea, porque la producción de espacio escultórico se hace poniendo la tónica en el proceso de trabajo físico entre la mano y el cerebro. Pero también porque previamente existe todo un trabajo de concepción de las piezas "como idea" informada por el uso del dibujo de proyecto, de todos los estudios y reflexiones escritas que dictaron las cuestiones que serían transformadas y expresadas en espacio escultórico. Podemos afirmar que el trabajo manual eminentemente intuitivo está atento a la creación de cada estructura pinacular u objeto dotado de un campo de visión en miniatura y al trabajo de concepción proyectual cabe tener una visión unificadora de todas las estructuras u objetos pinaculares realizados en arena y agua en el todo de la instalación, que sólo cobra sentido cuando ocupa la totalidad del espacio arquitectónico disponible de la sala de exposiciones.

Al trabajo manual cabe la construcción de todo el espacio virtual y al trabajo proyectual cabe, como percibimos por la profundización de Uma floresta para os teus sonhos, la creación de las condiciones para que el cuerpo de la escultura por entero se insinúe sobre los cuerpos de los espectadores, induciéndoles a caminar y en esa circunstancia cada uno recrea en sí una nueva virtualidad dada por una experiencia pre-cinematográfica que no es más que imaginar a partir de la constante periferización del espacio. Precisamente porque 
en su todo, estas piezas parecen tener la capacidad de insinuarse en nuestros cuerpos a dos niveles. Al primer nivel corresponde la inmersión del cuerpo en el dispositivo teatral del ambiente construido y considerado a escala $1 / 1$. $Y$ al segundo nivel correspondería la virtualización dada por el hecho de que cualquiera pueda escoger simplemente detenerse en éste o en aquel aspecto más restringido de las construcciones realizadas en arena y agua.

Estos dos modos que tienen las obras de insinuarse en los cuerpos, por un lado a una escala ambiental, por otro, a una escala miniaturizada, parecen convocar una mezcla de sensaciones, precisamente porque parecen tratar de ofrecer experiencias distintas de "espacio paisaje". Pero no, estamos sin duda presentando dos niveles de una misma experiencia que nunca se producen separadamente, uno real y otro virtual, uno realizado en el contacto con una escala ambiental $1 / 1$, y otro en el contacto con una escala miniaturizada. Es decir, uno realizado pensando en el cuerpo del usuario de la escultura que camina por entre la estructura laberíntica y que edita para sí mismo una experiencia pre-cinematográfica dada por la imaginación y otro realizado por la mirada de quien, parando de caminar, mira, y se detiene en la relación de cada estructura construida con la medida de la mano, conducida por la intuición material y por el juicio intuitivo de la mirada del artista. A partir de estas constataciones podríamos ser llevados a defender que a un nivel de experiencia de estas piezas, corresponde una noción de espacio paisaje "como inmersión", y otro a una noción de espacio paisaje "como vista". Pero no ocurre así, precisamente porque la distinción de estos dos niveles de experiencia sólo tiene sentido en este contexto de traducción a lenguaje verbal de una realidad multisensorial ofrecida por la experiencia efectiva del cuerpo en contacto con las intervenciones escultóricas en sus lugares de exposición. Así, consideramos preferible presentar la misma noción de paisaje para ambos niveles de experiencia, la noción de paisaje "como deambulación". Ésta es útil no sólo para tratar de la insinuación escultórica que afecta a la mirada como de la que afecta a todo el cuerpo.

Cuando presentamos las determinaciones paisajísticas de La forêt llegamos a la conclusión de que el espacio escultórico de Giacometti no proponía 
una noción de paisaje "como vista" precisamente porque las figuras del plano frontal no se encontraban en el mismo continuo espacial que las figuras del fondo. Así, no podemos estar ante la noción de espacio paisaje "como vista" porque precisamente este espacio inaugurado por el renacimiento Italiano sólo se produce en el arte cuando existe distinción jerárquica de los planos delantero, intermedio y del fondo, presuponiendo que en cada imagen, ya sea bidimensional o tridimensional, se exhiba un espacio que es "cortado" y organizado en una constancia métrica convergente hacia un punto de fuga.

La noción de espacio paisaje "como deambulación" nos pareció el modelo más acertado para entender la naturaleza espacial de La forêt, pero también, y a otro nivel de Uma floresta para os teus sonhos. Si a propósito de la primera, convocamos para su comprensión a autores como Cézanne, Erwin Straus y Maurice Merleau-Ponty, a propósito de la segunda convocamos también a Maurice Merleau-Ponty, Anton Ehrenzweig y Robert Morris. Pero no nos engañemos, a pesar de estar citando a autores diferentes -con M. Merleau-Ponty como denominador común-, estamos refiriéndonos a la misma naturaleza espacial. Incluso podemos establecer una evolución del concepto de espacio paisaje "como deambulación", partiendo de las concepciones de Erwin Straus pasando por las de Merleau-Ponty, lector de E. Straus y atento a la producción plástica de Cézanne, hasta llegar a las de Robert Morris lector de Merleau-Ponty y del trabajo del psicoanalista Anton Ehrenzweig.

Cualifiquemos entonces esta noción de paisaje como deambulación; Giacometti a partir de 1935, tal como Cézanne, no representa exactamente aquello que ve, sino cómo lo ve ${ }^{581}$; es decir, se trata de una representación en directo, no mediada por códigos y convenciones. Por eso, esa representación no funciona en segundo grado, sino en primer grado: presenta una posibilidad de expresión derivada de la recogida y la transformación plástica inmediata de los

\footnotetext{
581 Al trabajar a partir del modelo, algo que en pleno modernismo era visto como un signo de debilidad, Giacometti prosiguió su proyecto que consistía en «intentar restituir lo que ven los ojos, y en descubrir que sólo sabe lo que sus ojos ven en el momento en que está pintando y dibujando o esculpiendo». Traducción libre. In MOLDER, Maria Filomena, O Absoluto Que Pertence A Terra, Lisboa, Vendaval, 2005, pp. 131-132.
} 
datos de la percepción y que funcionaba en su escultura del mismo modo que en el dibujo ${ }^{582}$.

La inscripción en el dibujo y la fijación rápida de la greda fresca son animadas por el propio gesto de edificación y raspado, funcionando así de forma superpuesta. De este modo, las obras se autogeneran, resultan de un grado de excitación y dinamismo del autor e inducen esas mismas características en el observador, que se convierte en participante en el sentido de que cada obra no muestra el mundo hecho sino en proceso de ser hecho continuamente por cada uno de nosotros. Por lo tanto, el mundo, el paisaje en tanto que arte realizado en estas condiciones no es concebido, ejecutado y presentado "como vista" porque es altamente dinámico: el espectador deja de ser pasivo y pasa a ser profundamente activo, pues implica la movilidad de la mirada y de la atención que hacen desencadenar las sensaciones.

Mientras que en la idea de paisaje "como vista" tenemos acceso a una relación jerarquizada, descriptiva y mediada culturalmente por códigos y convenciones del espacio basado en la delimitación de objetos por el uso de la línea de contorno en el dibujo o de la figura que se destaca contra un fondo en la escultura. En el paisaje "como deambulación" no hay relación jerarquizada del espacio, no es descriptiva y resiste a ser mediada culturalmente por códigos y convenciones, ningún punto se diferencia en relación a otro, en vez de una línea de contorno en el dibujo o de figuras destacadas en la escultura, tenemos múltiples contornos, múltiples figuras o múltiples contornos dentro de las figuras que alimentan la posibilidad de que la percepción se pierda en las muchas fusiones posibles entre figura y fondo, esto en el caso de la obra de Giacometti, a partir de 1935, sucede incluso cuando estamos ante una figurita aislada.

\footnotetext{
${ }^{582}$ En su búsqueda por captar las apariencias más profundas del mundo, sus pinturas y esculturas se encuentran estéticamente con la noción de dibujo, más precisamente, este autor inauguró una verdadera teoría del dibujo, en la medida en que es la comprensión de este medio de expresión que abre la puerta a la comprensión de la totalidad de su obra, independientemente de que sea pintada, esculpida o propiamente dibujada. «Bastaría con que supiéramos dibujar y podríamos pintar todos los cuadros y hacer todas las esculturas que quisiéramos.» defiende Giacometti, porque tanto la pintura como la escultura obedecen a las premisas del dibujo. Para este artista buena parte de la comprensión de su obra se encuentra ya inscrita en la comprensión del dibujo. Traducción libre. In GIACOMETTI, Alberto. Je ne sais ce que je vois qu`en travaillant. París: L’Échoppe, 1988, p. 8.
} 
Las características del trabajo de Giacometti, anteriormente mencionadas, y que se verifican tanto en La forêt como en todas sus obras del periodo existencialista encuentran eco en los trabajos realizados por la fenomenología de la primera mitad del siglo XX. Maurice Merleau-Ponty ve el cuerpo como único campo de test posible después de que todos los códigos y convenciones se hayan revelado ineficaces y de que se hayan instalado un conjunto de servidumbres inhibidoras de la libertad individual. Merleau-Ponty defiende en varios momentos de su exploración fenomenológica, que nuestro cuerpo es lo que nos da acceso al espacio. En la medida en que es siempre el avance del cuerpo situado en el espacio que cualifica el propio espacio. Este autor se dedicó al estudio de la obra de Cézanne y encontró en éste el corolario ideal para pensar la nueva exigencia del arte que tuvo que implicar cada vez más el cuerpo del espectador incitándolo a la movilidad, a ser la sede de una transformación perceptiva que impele al desplazamiento y al deslizamiento, cuestiones que Merleau-Ponty agrega en la idea de paisaje.

Sin embargo, estas ideas sobre la noción de paisaje como deambulación tienen origen en Erwin Straus. Para este autor, el paisaje se da al ser, no es ni una categoría, ni una experiencia antropológica, sino una experiencia precultural y preantropológica. En estos términos, el paisaje sólo puede ser deambulación. Según los criterios de este autor, buena parte de los paisajes pintados por el renacimiento italiano no exhiben espacio paisaje y extrañamente la pintura de Cézannne, exhiba ella paisajes, naturalezas muertas o retratos, según Henry Maldiney todas expresan espacio paisaje, precisamente porque desplazan al individuo de la rigidez de la cultura hacia el espacio amable y universal del sentir. Así, el paisaje no depende de los medios usados en la producción artística, ni tampoco del contexto, sino de una disponibilidad del sujeto que es siempre participante en la medida en que se deja afectar tanto por el espectáculo del mundo visible, de la naturaleza que se convierte en paisaje, como por la complejidad de una determinada obra de arte, ya se trate de una pintura o una escultura. Por lo tanto, todo depende de cómo son percibidos en una experiencia cotidiana un paisaje real o hecho arte. En este contexto la experiencia del paisaje no requiere saber, sino tan sólo disponibilidad para ser en él. El espacio paisaje 
es aquí el espacio del sentir, es una experiencia muda y salvaje y por eso primitiva, es un espacio que escapa a la noción de objeto y que por lo tanto dispensa la constitución de un sujeto. Implica en cualquier caso un ser humano atravesado por un "momento pático" 583 que así se funde o pierde en el ambiente del paisaje, teniendo de esta forma simple y descomprometida acceso a la pura percepción de la forma y no a la descodificación de esa forma.

Al hilo del conocimiento de la fenomenología de Maurice Merleau-Ponty, y de la noción de no-diferenciación propuesta por el psicoanalista Anton Ehrenzweig, Robert Morris propone un nuevo modo de coincidencia entre paisaje y escultura. Para ello propone una redefinición de los criterios del funcionamiento espacial de la escultura que desde siempre, incluso en el minimalismo, asentó y necesitó ser definida como una figura o conjunto de figuras, que se definía(n) perfectamente recortada(s) en el campo visual contra un fondo. En vez de eso, Morris propone una concepción de la escultura basada en la idea de expansión por todo el espacio de la arquitectura, constituyéndose de ese modo un campo de visión y un ejercicio de la mirada que no comporta cualquier tipo de figura recortada contra un fondo. Estas piezas se caracterizan por ser dispositivos escultóricos basados en la dispersión de materias no-diferenciadas, que precisamente inducen al espectador al sentimiento del espacio paisaje propuesto por E. Straus. Algo que se verifica en Vontade, Fadiga de Estruturas, Wander y de cierto modo en Uma floresta para os teus sonhos, de Alberto Carneiro. En el caso de esta última obra debe referirse su estructura laberíntica y lúdica que promueve la desorientación y la movilidad del cuerpo del desorientado; de esa forma, la obra de arte recrea las condiciones del ser en el paisaje. Al desplazarse en el espacio de Uma floresta para os teus sonhos, un cuerpo construye espacialidad, convoca y segrega espacio paisaje, ya no como representación, sino como presentación.

\footnotetext{
${ }^{583}$ Para Erwin Straus, el momento pático es el momento en que el individuo se funde o se pierde con el ambiente del paisaje, construye así el espacio paisaje que es el espacio de la pura percepción de la forma y no de la descodificación de esa forma.
} 


\section{f. La noción de espacio paisaje "como vista" ya no nos sirve}

En realidad tanto en Robert Morris como en algunos ambientes de Alberto Carneiro encontramos una actualización en el campo de la instalación de una idea de espacio paisaje como deambulación. La comprensión de este tipo de concepción de paisaje basado en la deambulación, en la movilidad del individuo y no en el estatismo exigido e inducido al sujeto por el paisaje "como vista", es fundamental en la medida en que resulta de una transformación de civilización con consecuencias en el plano cultural.

La división entre hombre y naturaleza no fue un proceso estático ocurrido solamente en el inicio de la modernidad. Prosiguió después y de hecho continúa aún hoy a suceder, la modernidad vista por este enfoque es sobre todo un proceso de pérdida. Pérdida del paisaje, pérdida de los recursos que alimentan y constituyen ese paisaje, pérdida de la asimetría que alimenta el plano ético etc. Ante esto, el hombre a la medida que la modernidad avanzaba asistió a constantes divisiones y subdivisiones de su mundo y habrá asistido incluso a la muerte del paisaje ${ }^{584}$. Desde la revolución industrial pasando por la invención de la máquina de vapor hasta la actual revolución digital, asistimos a una vertiginosa aceleración del mundo exterior. El hombre del siglo XIX, cuando ve el paisaje desde dentro de un tren a vapor, no lo ve como duración, sino como recorrido que se extiende entre dos puntos, A y B. Según Erwin Straus ${ }^{585}$, el viaje intencional moderno hecho en tren, por su velocidad, desdibuja el segmento que media entre los dos extremos del viaje. Para este autor la evolución tecnológica contribuye a un apartamiento cada vez mayor en relación a la experiencia del espacio paisaje. Por el contrario, los antiguos medios de transporte, más lentos, hacían que todos los puntos del viaje fueran importantes, porque el movimiento de locomoción acompaña el movimiento de la sensación.

\footnotetext{
${ }^{584}$ Sobre esta idea de la muerte de la paisaje debe leer: AA.VV, Mort du paysage? Philosophie Et Estétique Du Paysage, (dir.) François Dagognet, Seyssel, Champ Vallon, 1982.

${ }^{585}$ STRAUS, Erwin, The Primary Word of Senses, Londres, The Free Press of Glencoe. 1963, pp. 319-320.
} 
Esta aceleración del tiempo exterior, que tuvo lugar a partir de la revolución industrial, tuvo consecuencias en el propio arte. Ante la pérdida de un conjunto sustancial de experiencias que nunca habrán sido compensadas por la ganancia de otras, es perfectamente comprensible que el romanticismo se haya detenido con especial nostalgia ante ciertos bosques, montañas valles y planicies. El hombre romántico sabía que estaba en pérdida. La aceleración del tiempo exterior es proporcional a las divisiones y subdivisiones operadas continuamente por el proceso de la modernidad. Ante esta constatación, ante las capacidades tecnológicas ilimitadas el hombre de hoy puede tener a su disposición un poder que nunca antes había tenido. Véanse sus consecuencias en el paisaje: agricultura intensiva, canteras y minas a cielo abierto, algunas gigantescas, como las de Riotinto en Huelva y las de São Domingos en Portugal. Véase el avance de las ciudades en cantidad y su correlato en la llamada «burbuja inmobiliaria». Evidentemente que por detrás de todo esto está, también, la decadencia de una cierta componente ética ante la naturaleza. Pues no todo es igual, el hombre no es igual a la naturaleza, y mucho menos superior a ella, porque pura y simplemente el hombre es también naturaleza. Es cuando este hombre se olvida de este hecho, constantemente recordado por Alberto Carneiro, que la extensión de los daños aumenta. El problema no es la existencia de la cantera, de la mina, de la agricultura, de la ciudad, etc., incluso porque sólo existe paisaje cuando en él coexisten naturaleza y actividades humanas. En Landscape And Memory, de Simon Schama, incluso los paisajes que nos parecen libres de acción humana en realidad no lo son, y da el ejemplo de los valles y prados floridos de Yosemite en California, y ello apesar de haber sido considerados la primera área natural convertida en parque protegido en el mundo, como si de un Edén en la tierra se tratara. Esos paisajes son en realidad el resultado de las quemas de los primeros habitantes indios. Así, "el brillante prado que sugirió a sus primeros panegiristas un prístino edén no es sino el resultado de los primeros fuegos provocados por sus ocupantes, los indios Ahwahneeche, practicados de forma regular". ${ }^{586}$ Para este autor esta

\footnotetext{
586 "The brilliant meadow-floor which suggested to its first eulogists a pristine Eden was in fact the result of regular fire-clearances by its Ahwahneechee Indian occupants" in SCHAMA, Simon, Landscape And Memory, Londres, Harper Collins, 1996, p. 9.
} 
constatación no debe ser motivo de un sentimiento de culpa o de tristeza, sino de celebración.

Sin embargo, no todo es motivo de celebración, de hecho el problema no reside en la esperable relación/acción transformadora entre hombre y naturaleza, sino en su extensión. En lo que concierne a las transformaciones del suelo, por ejemplo, ante una mina abandonada o una cantera, inmediatamente nos gana el mismo sentimiento de paisaje sublime que podríamos experimentar ante un acantilado. No obstante, este sentimiento, que para Kant sólo era posible porque estábamos en un lugar seguro a partir del cual podíamos contemplar, se transforma súbitamente por la vía del reconocimiento ético de la extensión de la destrucción, en un sentimiento de displacer, de desconfianza en relación al futuro, precisamente porque reconocemos que ya no estamos en ese lugar seguro que cumplía la noción de paisaje "como vista".

Ante estos nuevos lugares en disolución cada uno entra en un balance paradójico entre adhesión y repulsa. Adhesión por la grandiosidad de las intervenciones, por la profundidad abismal de los cráteres o bocas horadadas, por la desnudez de las rocas, etc. Repulsa por el reconocimiento de que tal cosa al final fue hecha por el hombre, dicha herida abierta en el paisaje difícilmente cicatrizará sin provocar daños colaterales. Hoy difícilmente podemos creer que los nuevos incendios más extensos y persistentes puedan ser tan benéficos como lo fueran aquellos que otrora atizaron los indios Ahwahneeche en Yosemite. Difícilmente acreditamos que las enormes cantidades de azufre, arsénico y todo tipo de metales pesados existentes en las minas de São Domingos o de Riotinto podrán desencadenar una acción regeneradora del paisaje. ¿Y como pensar que nuestras ciudades alguna vez podrán ser viables y sostenibles si perdieron su vínculo osmótico con los campos y los bosques? En vez de eso tenemos un inmenso sprawl urbano, la proliferación de los no-lugares.

La intuición de la clave para la comprensión del estado actual de degradación de la naturaleza ya aparecía desde luego en el pensamiento más esclarecido del siglo XIX. Tanto en Baudelaire como en Víctor Hugo lo que une la ciudad y la naturaleza es el concepto de ruina. Tal vez por eso V. Hugo emergió como una de las primeras voces que alertaron sobre una emergencia ética de 
cariz ecológico. en un diario de viaje después de haber pasado por los bosques de los Alpes y los Pirineos, escribió: "En la relación de los seres humanos con los animales, con las flores, con los objetos de la creación existe un gran vacío ético, pero que eventualmente emergerá, surgiendo como un complemento de la ética humana [...] Sin duda primero fue necesario civilizar a los hombres en sus relaciones con los otros hombres. Se debe empezar por aquí y los varios legisladores del espíritu humano tuvieron razón en sacrificar a ésta todas las demás preocupaciones [...] Pero es igualmente necesario civilizar las relaciones de los seres humanos con la Naturaleza. En este dominio está todo por hacer." 587 Al otro lado del Atlántico, Henry David Thoreau escogió vivir en el bosque. En Walden o la vida en los bosques ${ }^{588}$, considerada un clásico de la ética ambiental, reflexiona sobre las consecuencias nefastas de la revolución industrial y apela a la liberación interior de cada individuo, preconizando ya en el siglo XIX, una actitud de sostenibilidad de la vida frente a los recursos naturales existentes.

A mediados del siglo XX emerge el pensamiento ecológico, que los artistas han interiorizado de formas muy variadas. Alberto Carneiro, cuyo arte ha sido calificado por alguna crítica de "conceptual ecologista", escribe entre los años 1968-72 las Notas para um manifesto ecológico, cuya escritura coincide con la creación de Uma floresta para os teus sonhos. En él, el artista propugna una actitud ética y política basada en la ecología. Arte ecológico es para él "árbol en el bosque de cemento." ${ }^{589}$ Reconocemos en estas palabras de 1972 una premonición de lo que Joseph Beuys hizo diez años más tarde al plantar robles en Kassel 7000. Hoy no somos ecologistas por elección sino por necesidad, ese hecho hace que, por un lado, ese problema deba ser contemplado en los datos que lanzan la concepción del trabajo plástico, porque forma parte del conjunto de valores a observar. Por otro, en el momento de la ejecución y presentación de cada trabajo plástico, el resultado no puede ser un objeto ilustrativo o panfletario

\footnotetext{
${ }^{587}$ HUGO, Victor, Voyage-Alpes et Pyrénées, París, J. Hetzel, 1890, pp. 180-181 (entrada de 11 de agosto de 1843).

${ }^{588}$ THOREAU, H. D., Walden ou a vida nos bosques, Trad. de Astrid Cabral, Lisboa, Antígona, 2009.

${ }^{589}$ CARNEIRO, Alberto, Notas para um manifesto ecológico. In Das Notas Para Um Diário E Outros Textos antología, (coord: Catarina Rosendo), Lisboa, Assírio \& Alvim, 2007, p. 26.
} 
de esa misma preocupación, sino que debe emanar de una transformación plástica derivada del proceso de trabajo que busca transformar la urgencia del aquí y el ahora, en una expresividad que se quiere durable.

La idea de paisaje "como vista" encontró su fijación hegemónica en la fotografía, que fue generada y gobernada por los criterios de la perspectiva monofocal renacentista. Pero paradójicamente el siglo de la invención de la fotografía fue justamente el tiempo que más combatió esta visión del paisaje "como vista". Recuérdese el trabajo de relativización de la perspectiva renacentista llevado a cabo por los impresionistas y posimpresionistas, o incluso el asombro a veces incómodo que ofrecen los mejores ejemplos de lo sublime romántico. Los propios pioneros de la fotografía, a pesar de la fascinación del descubrimiento, se encargarían a su modo de relativizar o por lo menos actualizar esta noción de espacio "como vista". Como reflejan las primeras fotografías de Fox Talbot, en las que el positivo y el negativo eran expuestos lado a lado, y donde predominaba la estética del fragmento totalmente sintonizada con el romanticismo, a la que se juntaron otras tantas imágenes realizadas por contacto directo de los objetos sobre la superficie fotosensible del papel ${ }^{590}$. De cualquier modo, es innegable que este modo de concebir el espacio "como vista" encontró en la fotografía su corolario más perfecto y su posibilidad de difusión más amplia más allá del medio artístico.

Si aún hoy el sentido común confunde una imagen fotográfica impresa en dos dimensiones con la propia realidad, atribuyendo a la fotografía estatuto de verdad, eso testimonia la eficacia y el poder hegemónico que todavía posee la idea de espacio "como vista". Pero no nos engañemos, dentro del medio artístico los mejores ejemplos del uso de la fotografía, y específicamente de paisaje, no proceden de artistas ingenuos, sino de aquellos que emprendieron posturas más críticas y creativas. Así, el espacio paisaje basado en la "idea de vista", siguió su

\footnotetext{
${ }^{590}$ En 2001, en el Museo Nacional Centro de Arte Reina Sofía, se realizó una exposición del trabajo de Fox Talbot, titulada «Huellas de LuZ». Esta exposición se encuadra en un movimiento de interés creciente por estas imágenes que hoy nos parecen extremadamente precarias y huidizas y que, por lo tanto, encajan perfectamente en las necesidades estéticas de la actualidad. Tal vez por eso Gail Buckland, autora de una monografía sobre Fox Talbot, sitúe el trabajo de Talbot en la senda de la invención del espíritu moderno, de Cézanne y del Cubismo.
} 
camino, por más que hoy ya no se le reconozca la capacidad transformadora e integradora del mundo y de la realidad que la contemporaneidad exige.

La exposición MAGMA, realizada en 2008 en la Galeria 111, en Lisboa y Oporto, pretendió repensar la noción de escultura a partir de la problematización de la tierra, tanto en tanto que cosa concreta, como en su régimen de imagen. Así fueron presentadas una intervención tridimensional y un conjunto de fotografías impresas a partir del método de la calotipia, inventado por Talbot, que funcionaban en conjunto, intentando problematizar la escultura en su relación con el paisaje tanto desde el punto de vista estético, como ético y político, proponiendo la instauración de una ética de la tierra basada en la tentativa de una regeneración de la tierra por la estética. La intervención tridimensional consta de la presentación de 5 árboles de ciprés recogidos después de haber sido talados para dar lugar a una autopista. Estos árboles fueron posteriormente cubiertos con polvo de barro rojo y rellenados con barro fresco en su interior. Por su parte, las imágenes fotográficas fueron realizadas justamente en los lugares en disolución, vertederos clandestinos, recintos de obras y de minas abandonadas, como la de São Domingos en Portugal.

En la intervención tridimensional son presentados árboles con una escala $1 / 1$, en los que el estado mineral informe, descrito por Marguerite Yourcenar como el último estadio de una escultura, funciona aquí como su inicio. El polvo de arcilla roja se fijó, a lo largo de varios meses, en estos árboles que sucumbieron a la gravedad. La verticalidad afirmativa de los cipreses, uno de los símbolos de la melancolía, sucede a la gravedad terrestre. Los árboles, que antes exhibían su verticalidad en el paisaje real, una vez cortados para dar paso a una autopista más, se convierten en tierra, en una masa informe, no narrativa, o en una especie de índice de la muerte del paisaje. A esta presencia bruta de la materia se le junta su doble: hacer imagen de la tierra. Un conjunto de catorce fotografías, tituladas genéricamente Sem Título (serie MAGMA), también de 2008, resultantes de la digitalización de calotipos en papel, presenta también un modo paisajístico construido a partir de tomas de vista de lugares abandonados como minas, vertederos, astilleros, etc., que más tarde perdieron su función. En ellos, se dan dos estrategias distintas pero que forman parte del mismo trabajo: 
los puntos de vista de las fotografías se orientan ya sea hacia determinadas construcciones preexistentes en esos lugares, denominándolos como esculturas a través de la fotografía; ya hacia sencillas construcciones que realicé en esos lugares, como masas paralelepípedas que, en este contexto, también se entienden como escultura materializada a través del medio fotográfico.

En estos lugares, o no-lugares, se lee primero la inspiración y después el desprecio o la indiferencia. La tierra emerge con una fuerza nunca antes vista en minas, vertederos más o menos clandestinos, astilleros deteriorados... Son marcas de una tierra gastada... ¿Qué hacer de la tierra extenuada? Cuando todo se reduce al absoluto de la tierra, es necesario excavarla, confrontarla con el cielo, abrir cráteres o construir masas escultóricas; en el fondo, evidenciar su identidad plástica que es también, a un nivel más profundo, ética y política.

Las imágenes fotográficas presentan esculturas anónimas donde el dibujo, ya incorporado en la lógica de la creación de la imagen, excava el espacio, apila, agrega, acciona continuidades y discontinuidades, marca alternadamente un fragmento, una proximidad, luz y sombra, denuncia barrancos, cavernas, estructuras ambiguas, fisuras. A través del dibujo inscrito directamente sobre el calotipo, el paisaje aparece según un nuevo orden protoescultórico y la mirada se transporta hacia dentro de la materia microscópica del paisaje y de la fotografía. La imagen realizada a partir de este proceso gana un carácter espectral e huidizo que las primeras fotografías que hice no tenían. En ellas, se identifica una cierta negación de la jerarquización del espacio, propia de la perspectiva renacentista, aproximándose más a la idea de "paisaje errante" no sólo porque el proceso de captura y fijación de la imagen es más arcaico, sino también porque la introducción del dibujo manual directamente sobre el espacio de la fotografía introduce en la imagen una lógica espacial que es contraria a la organización jerárquica de la fotografía. $O$ sea, mientras que en una imagen dominada por la perspectiva renacentista todo el espacio se divide y organiza en una constancia métrica convergente en el punto de fuga, en estas imágenes el dibujo manual no se somete a esta constancia, y por lo tanto, es errante, corrompe por eso la perspectiva renacentista propia de la fotografía. 
Lo que se pretende en estas imágenes, además de su articulación con el dibujo y la escultura, es intentar añadir en la imagen algo que, además del valor documental, explore su propia condición de imagen, creando un problema o extrañamiento que afecte al sujeto.

Cada imagen fotográfica resultante de la ampliación de un calotipo parece mostrar una cierta idea de continuidad espacial. Sin embargo, ésta es frustrada constantemente en muchos de sus aspectos, sobre todo por la introducción del dibujo, que, mimetizando algunos aspectos de la fabricación de la imagen fotográfica, no lo hace sometido a la lógica de la lente, sino a la indecisión y deambulación propia del dibujo manual, haciendo que no haya una unidad sincrética de los elementos impresos; más, en las series tituladas Escavação y Scanning las imágenes expuestas alternaban impresiones en positivo y negativo, acentuando así los intentos escultóricos de éstas. Por ejemplo, una concavidad en negativo y una convexidad en positivo y viceversa, tal como la dialéctica que existe en la lógica de los moldes empleados en escultura. Las impresiones en negativo tienden a funcionar como "perspectiva invertida"; de esta forma, la tierra adquiere una organización que el positivo no le daría nunca. Además, todos los elementos de la imagen tienden a avanzar en nuestra dirección en una imagen cuyo carácter físico y háptico sale enriquecido. En ambas series, el espectador se somete a un vaivén en la forma como la imagen se presenta, entre algo que parece ahondarse en el plano, más próximo de la idea de paisaje como ventana o vista, y algo que avanza en nuestra dirección, negando la idea de paisaje como vista o ventana, promoviendo antes una idea de paisaje basada en la deambulación háptica y un tipo de afectación que es física.

Las imágenes de la serie MAGMA, Escavação y Scanning responden mejor a la exigencia contemporánea de valorización de la imaginación porque su proceso está de acuerdo con la naturaleza asistemática de las imágenes ofrecidas por las esculturas o instalaciones. Estas características contrastan fuertemente con la naturaleza de las imágenes que dominan el mundo, ya que 
éstas tienden a presentarse como sólidas ${ }^{591}$, excesivamente definidas, acabadas, de tal modo que es difícil para quienes acceden a ellas entender su utilidad en la intensificación sincera de la imaginación.

Todas las propuestas prácticas que articularon en el ámbito de lo escultórico intervenciones tridimensionales, juntamente con imágenes impresas, se configuran ahora como una propuesta de punto de vista sobre el lugar a través de la fotografía en su relación con lo escultórico. Esta propuesta se deriva del reconocimiento de que la práctica escultórica, al abrirse a partir de mediados del siglo XX, convocó al paisaje hacia dentro de sus correlatos espaciales. Así el paisaje adquirió en la contemporaneidad una centralidad que no había tenido antes. A partir del momento en que la práctica escultórica integra el paisaje, sus practicantes tienen la necesidad de usar la fotografía como medio expedito y eficaz para documentar pequeñas o grandes intervenciones en el paisaje, normalmente en localizaciones geográficas de difícil acceso. La fotografía analógica permite erigirse como "certificado químico", pues se trata de una firma de luz que permite fijar un determinado acontecimiento en el tiempo, combatiendo así la experiencia de lo efímero. La fotografía permite, de este modo, parar el tiempo y establecer relaciones con el espacio. Estas condiciones hicieron posible que el arte y la escultura en particular trabajaran en espacios que hasta entonces les eran extraños $\mathrm{y}$, simultáneamente, traerlos como imagen hacia dentro de la galería o museo.

El desarrollo de la relación de lo escultórico con el medio fotográfico es hecho a través de la articulación de tres conceptos fundamentales, el dibujo, la ausencia y el espacio. El primero parte de la constatación de que existe un

\footnotetext{
591 Jean Baudrillard habla de la "perfección inútil de la imagen" para referirse a las imágenes sólidas que perdieron su vínculo con la imaginación y, así, con la vida y lo real. BAUDRILLARD, Jean, El Complot Del Arte: Ilusión y desilusión estéticos, Editorial Amorrortu, 2006, p. 14.

En este contexto, considero bastante esclarecedor el texto de Domingo Hernández Sánchez titulado "Arte e Imagem". Según este autor, y a propósito de la cita de Baudrillard arriba mencionada, "el arte busca las fisuras, las impurezas y las precariedades de la imagen, sus posibilidades de extensión. Y lo hace precisamente para lograr una re-conexión, una fisura en lo real que permita el aumento de su sentido. El objetivo, por tanto, es pensar la imagen como imagen, eliminando sus pretensiones de completitud y solidificación, de realidad, lo que significa en cualquier caso - por principio encontramos su contrario- negarle la dialéctica con lo real que le es inherente." In HERNÁNDEZ SÁNCHEZ, Domingo, Dicionário Crítico de Arte, Imagem, Linguagem e Cultura, activo en 6/9/2012 en http://www.arte-coa.pt.
} 
vínculo genético de la fotografía con el dibujo, en la medida en que éste se constituyó desde la aparición de la fotografía como fijación de las sombras sobre el papel. Uno de los pioneros de la fotografía, Fox Talbot, llamó a esas primeras imágenes, "dibujos fotogénicos", y no propiamente fotografías. Más tarde, pudimos constatar cómo los artistas del llamado Land Art, al inscribir sus intervenciones en el paisaje, procedían a su registro fotográfico como una clara idea de que la marca producida en éste sería traducida en imagen como inscripción o índex dibujado. En la serie de imágenes tituladas MAGMA, Scanning o Escavação, a las marcas en el paisaje fijadas en fotografía se les juntan a veces las marcas dibujadas en la propia superficie de la fotografía.

Cada toma de vista explora en el ámbito del trabajo práctico la idea de ausencia, busca en los lugares abandonados del paisaje las marcas de la retirada de los hombres que se produce casi siempre tras la dilapidación de los recursos de la tierra.

Una utilización de la fotografía en este contexto presupone un entendimiento de que este medio no existe dentro de un campo disciplinar estricto, sino que crea sentido al servicio del protocolo de la escultura. Así, cada imagen, además de su capacidad virtual, debe ser concebida como objeto en el espacio real, siendo de este modo agente modelador de la experiencia del espectador dentro del espacio de la sala de exposiciones. Cada fotografía es, en este contexto, un in visu que pretende apelar y configurar una posible entrada de cada uno de nosotros in situ, vinculando la imagen con el retorno a lo real. Lo que implica reconocer que ya no nos sirve la idea de paisaje como vista.

Desde el inicio de este itinerario meditativo presentamos varias representaciones de bosques, precisamente porque consideramos que eran el exponente máximo de lo natural en el plano cultural. Intentamos incluso hacer una pequeña arqueología del tema, que, aunque naturalmente incompleta, reveló cualidades que ahora nos interesan para concluir. A pesar de que la gran mayoría de las representaciones de bosques abordadas presentan el espacio "como vista", conviene observar que, si en la memoria colectiva, el gran, denso y oscuro bosque medieval era el territorio donde se depositaban memorias, mitos, leyendas, fábulas, creencias, visiones aterradoras y de seres sobrenaturales que 
constituían un bestiario grotesco, entonces en sus representaciones existe una propensión hacia una cierta estética negativa, siendo el escenario de actividades violentas o terroríficas. El bosque es el lugar de la caza, como en las cuatro tablas de la historia de Nastagio degli Onesti, (fig. 5), de Botticelli, donde resulta particularmente intrigante, surgiendo como espacio de una escena macabra donde el erotismo se mezcla con lo siniestro, la muerte y lo informe ${ }^{592}$. En San Jorge en el Bosque, pintada por Altdorfer en 1510, encontramos una representación contraria a la idea de espacio jerarquizado tematizado por la perspectiva renacentista italiana, en la que San Jorge es casi tragado por el frondoso bosque que llena todo el cuadro. En esta imagen de Altdorfer, la vegetación se presenta como amenazadora, pesada y orgánica. Ya en la primera mitad del siglo XX, véase el exorcismo del terror de la muerte, presente en la pintura de Max Ernst titulada Bosque y Pájaro, 1927, y de tantos otros ejemplos del surrealismo. En esta línea veremos cómo el sentimiento estético asociado a estas representaciones es sobre todo negativo.

El pensamiento de Arnold Berleant, que a pesar de sólo ahora ser traído a colación puede ayudarnos a entender de qué modo el sentimiento estético negativo asociado a lo sublime presente tanto en La forêt, como en la parte práctica presentada en el capítulo $V$, es la clave para una nueva propuesta de paisaje, ya no basada en la idea de vista, sino en la implicación del ser humano en relación a la globalidad del espacio con implicaciones éticas y estéticas.

Arnold Berleant ${ }^{593}$ es uno de los autores contemporáneos que mejor sustenta y articula puntos de vista críticos sobre la idea de paisaje que demuestran ser de gran utilidad para la nuestra conclusión de que la idea de paisaje "como vista", ya no nos sirve. Para este autor, si el paisaje es una forma

\footnotetext{
${ }^{592}$ Georges Didi-Huberman se dedica al estudio de estas características presentes en la obra de Botticelli en su libro Venus Rajada. DIDI-HUBERMAN, Venus Rajada, trad. Juan Salabert, Madrid, Editorial Losada, 2005.

${ }^{593}$ Nos apoyamos en los textos "The Aesthetics of Art and Nature" y "O Significado Mutável da Paisagem", de Arnold Berleant, para concluir desde el punto de vista teórico de que el paisaje "como vista" ya no nos sirve. BERLEANT, Arnold, "The Aesthetics of Art and Nature", Primera publicación in Salim Kemal e Ivan Gaskell (eds.), Landscape, Natural Beauty and the Arts, Cambridge: Cambridge University Press, 1993. Traducción portuguesa, BERLEANT, Arnold, "A estética da arte e a natureza", In Filosofia da Paisagem Uma Antologia, Trad. Luís Sá, (coord: Adriana Veríssimo Serrão), Lisboa, Centro de Filosofía de la Universidad de Lisboa, 2011, pp. 282- 298.
} 
cultural que se instituye entre el sujeto observador y la naturaleza que es objeto de esa observación o contemplación realizada a distancia, entonces, el paisaje que incorporó la idea de ventana generada a partir de la invención de la perspectiva monofocal del Renacimiento italiano, funciona como cualquier cosa que es exterior al sujeto observador. A raíz de esta separación surgió, según A. Berleant y Augustin Berque, una de las causas de los problemas identificados en la contemporaneidad, los problemas medioambientales que todos los días nos afectan, precisamente porque si el individuo engendró su condición fuera de la naturaleza, ha creado la ilusión de que no es afectado por ella, por eso no se hace responsable de sus desequilibrios, la gran mayoría de ellos de su entera autoría. Esta circunstancia acabaría por legitimar toda suerte de atropellos y abusos de los seres humanos contra la naturaleza, constatación ésta que requiere la construcción de un nuevo paradigma que articule estética y ética.

Como nos recuerda A. Berleant "vivimos en un mundo profundamente afectado por la acción humana, no sólo en la destrucción casi completa de la primitiva naturaleza salvaje del planeta y en la distribución de la flora y la fauna lejos de sus hábitats originales, sino también en la alteración de las formas y de las características de la superficie terrestre, de su clima y de la propia atmósfera." ${ }^{594}$ Según este autor, la solución desde el punto de vista estético para comprender la situación actual pasa por la comprensión de lo sublime ${ }^{595}$ en el contexto amplio de la experiencia del paisaje; o sea, del paisaje como ambiente

\footnotetext{
${ }^{594}$ Idem, p. 289.

595 A diversas nociones de sublime, corresponden pequeños cambios no despreciables si consideramos la implicación del observador. Por ejemplo, el entendimiento de lo sublime en Edmund Burke, que usamos en la interpretación de "La forêt" de Giacometti, es distinto del tratado por Kant. Del primero al segundo, existe una mayor distancia del sujeto en relación al fenómeno. Por eso la categoría de lo sublime en Burke se asocia al miedo y al terror, como mostramos en el capítulo III y en Kant lo sublime está asociado a un tipo de placer que, no obstante, no pone al sujeto bajo cualquier influencia o sentimiento de peligro. Sin embargo, en ambos casos, pero con mayor intensidad en el primero, el modo de funcionamiento de la imagen sublime contienen el fondo en el cual radica la ética, el hombre colocado ante una experiencia de conmoción se ajusta de forma duradera a su lugar en el mundo un lugar en que éste reconoce ser inferior a la naturaleza.
}

KANT, Emmanuel, Crítica da Faculdade do Juízo, Trad. y notas de António Marques y Valério Rohden, Oporto, Imprensa Nacional Casa da Moeda, 1997.

BURKE, Edmund. A Philosophical Enquiry into the Origin of our ldeas of the Sublime and Beautiful (1757), Oxford: Blackwell Ltd., 1987. 
donde se articulan estética y ética, que curiosamente se encuentra bien documentada por la práctica del arte contemporáneo.

Si comparamos el funcionamiento de una pintura de paisaje típica del Renacimiento Italiano, con una romántica, observamos que la primera, al funcionar como ventana, crea una adhesión del espectador basada en la proyección positiva hacia el exterior, evadiéndose de sí mismo en dirección al reconocimiento de la belleza y la forma del espacio jerarquizado, sin ningún recelo. Por el contrario, ante una pintura romántica la adhesión del espectador se realiza por un proceso radicalmente diferente: se siente afectado, a veces receloso por lo informe y, por lo tanto, es dominado por la grandiosidad de la naturaleza. Ese afecto, tanto en Kant ${ }^{596}$ como en Bruke, radica en el miedo, que en el caso del primer autor es esencialmente ficcional y en el del segundo sustancialmente más concreto. Siguiendo la noción de sublime de Burke, hay una implicación del sentido de sí mismo, una purga por la debilidad. Este sentimiento procede sobre todo del hecho de que en estas condiciones el hombre recupera su condición ética fundamental, reconoce que está integrado en la naturaleza, es naturaleza y que, por lo tanto, por pertenecer a algo que es bien mayor y más importante, no se reconoce como siendo igual o superior a ella. "Lo sublime se basa en el dolor, mientras que lo bello se basa en el placer. Desde luego la cuestión se plantea desde el punto de vista del cuerpo, de lo que se siente en la piel." ${ }^{597}$ Asociada a esta idea de incomodidad, lo sublime induce desplazamiento al sujeto a través de una cierta "estética negativa". El observador no está solamente fuera, observando una bella escena de paisaje, se reconoce

\footnotetext{
${ }^{596}$ El profesor António Marques, en la introducción a la Crítica del Juicio de Kant, refuerza esta idea, «La estética de lo sublime va a abrir por primera vez en el pensamiento occidental la posibilidad de concebir otra relación con la mencionada materialidad, basada en la ruptura, en la extrañeza y en el displacer. No obstante, paradójicamente, no se abandona el dominio de lo estético, por el contrario este saldrá incluso reforzado y ampliado." MARQUES, António, "Introdução da Crítica da Faculdade do Juízo", in Crítica da Faculdade do Juízo de Emmanuel Kant, Introducción de António Marques y Trad. y notas de António Marques y Valério Rohden, Oporto, Imprensa Nacional Casa da Moeda, 1997. p. 12

En esta línea se plantea reforzar la idea de que el espacio que más ecos crea en la contemporaneidad no es tanto el espacio euclidiano, pero el espacio de una cierta extrañeza familiar, glosando el término Unheimlich de Freud. FREUD, Sigmund, $O$ estranho (1919) in pt.scribd.com/doc/43021478/O-Estranho-Freud, p. 16.

${ }^{597}$ CARLOS, Isabel, "Do Problema do Sublime (e a Arte)", in catálogo de la exposición Do Sublime, Lisboa: Sociedade Lisboa 94, 1994, p. 12.
} 
afectado por una imagen de paisaje que no se presenta como forma, ordenada, o jerarquizada; en vez de ello está ante una imagen dominada por el informe ${ }^{598}$. En ciertas pinturas románticas impera un sentido ético fuerte sostenido por imágenes que demuestran el dominio de la naturaleza sobre el hombre. Este tipo de imágenes se opone a todas las otras, que contaminadas de racionalidad, materialismo y positivismo, testimonian la inversión de la polaridad hombre/ naturaleza conduciendo a que ésta última estuviera sujeta de forma evidente a partir del siglo XIX al poder del primero que así puede dominar la tierra y el paisaje, revelando paradójicamente un mundo abstraído del sujeto.

Aunque la teoría de Arnold Berleant se refiera a los paisajes reales, es un hecho que cualquier simulacro o paisaje en tanto que representación, aunque no se confunda con el propio paisaje real, ha retenido de ésta en algún momento algunos índices importantes de la relación del sujeto con el paisaje. Por otro lado, los modos de presentación escultórica ambientales escenifican el mismo tipo de relación del cuerpo con el paisaje.

Ante la constatación de que ya no tenemos un punto de vista seguro para realizar una idea de paisaje "como vista", a lo largo de este itinerario meditativo hemos propuesto, además de la profundización de afinidades, una noción de paisaje en su articulación con lo escultórico capaz de servirnos para la contemporaneidad. A esa noción la denominamos paisaje "como deambulación".

\section{g.MEGAPARSECS}

MEGAPARSECS, presentada en septiembre de 2012 en una de las salas negras del Teatro da Politécnica de Lisboa, funciona como corolario de esta investigación. No se trata de algo premeditado, si no que, como ya mencionamos, la profundización de las afinidades incorpora siempre "puentes hacia adelante". De la obra citada forman parte dos montones de tierra

\footnotetext{
${ }^{598}$ En el cuadro de Caspar David Friedrich «El naufragio del Esperanza», de 1824, vemos el dominio de la naturaleza sobre el hombre, que se expresa por las grandes masas de hielo que hicieron naufragar el barco de la expedición de William Parry al Ártico en 1819-1820.
} 
blanquecina, una base o estrado con 9X6 $\mathrm{m}$ y un depósito raso elíptico lleno de aceite de automóvil quemado, formando de esta forma un espejo negro.

Además de la pieza hay que considerar el contexto. La exposición fue realizada en una sala completamente negra en su interior: De esta forma, tal como en una cámara fotográfica, se establece una relación dialéctica con el exterior, en la medida en que el interior durante el día se encuentra persistentemente oscuro al contrario del exterior, formado por el espacio del Jardín Botánico de Lisboa, que se encuentra persistentemente iluminado, la comunicación entre el interior y el exterior se hace por una gran cantidad de ventanas que se abren al jardín. Estas características tienen consecuencias a nivel del funcionamiento de la luz en el espacio.

La intervención pretendió ser sencilla, pero aglutinadora de varias dualidades conceptuales, encima de un estrado raso y blanco se dispusieron dos montones de tierra blanquecina unidos por un istmo diagonal. La percepción se balancea entre el vulgar montón de tierra y la idea de montaña dada por la imaginación. Su funcionamiento apela al espectador dos concepciones de paisaje distintos, el del paisaje "como vista" dado por la jerarquización de los dos montones/montañas o islas encima del estrado, y el espacio del entorno dado por la estrategia teatral y por el reconocimiento de que la percepción y el entendimiento de cada visitante de la exposición se define por dos fuerzas contradictorias, una centrípeta y otra centrífuga derivadas del hecho de que la intervención se constituya como un espacio dentro de otro espacio. La primera fuerza y orienta la adhesión del espectador hacia el objeto y hacia el campo visual instalado, y la segunda, centrífuga, orienta al espectador hacia fuera del objeto instalado en dirección al entorno arquitectónico y hacia el exterior del jardín botánico.

La luz que incide en los árboles del jardín se refleja y entra en la sala sin sufrir cualquier tipo de transformación, siendo recibida por los montones, montañas 0 islas causando en ellos modulaciones lumínicas y cromáticas constantes... Imposible no acordarse de la montaña de Saint-Victoire, tantas veces pintada por Cézanne, ahora encerrada en un vulgar montón de tierra sobre un estrado. Eso sólo se hace posible porque toda la intervención fue siendo 
pensada a partir de la idea de resta, muchos elementos fueron saliendo de la versión inicial hasta quedar aquellos que eran absolutamente esenciales. De ahí resultó una exaltación del vacío en su dialéctica con el lleno. Formando parte de esta tendencia expresiva estaba también el depósito raso relleno de aceite quemado de automóvil, que funciona como espejo, reflejando no sólo los montones, montañas o islas, sino también todo el contexto propio de una sala de teatro, como el sistema de iluminación, etc. Este aceite hacía oscilar nuestra percepción entre algo agradable y una idea de sublime negativo, pues cualquier sensación de placer positivo dado por la observación de los montes, montañas o islas era inmediatamente frustrado por el olor y la presencia viscosa y brillante de ese aceite.

Reducir todo a un absoluto para después intentar edificar alguna cosa es un ejercicio que busca un arte simple. Pero la búsqueda de lo concreto y de lo absoluto que es capaz de originar objetos sencillos requiere una constante profundización intelectual. La investigación y el trabajo continúan... 


\section{CONCLUSIÓN PRÁCTICA - SU IMPACTO EN EL MEDIO CULTURAL}

Recepciones críticas de la instalación escultórica MEGAPARSECS, realizada en el Teatro da Politécnica, en Lisboa, entre el 5 de septiembre y el 20 de octubre de 2012. Ver Fig. 67, MEGAPARSECS, 2012, Arena, metal y aceite quemado sobre un estrado, alt $260 \times$ anc $900 \times \operatorname{lar} 600 \mathrm{~cm}$.

EXPOSIÇCOES

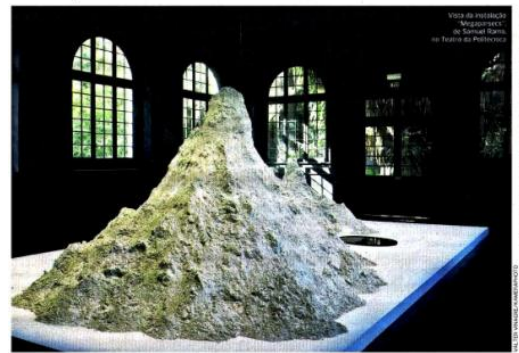

No trilho da montanha branca

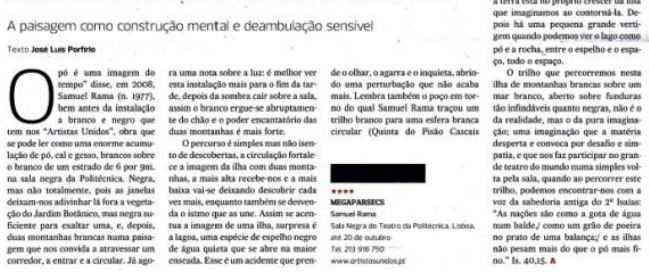

\section{No trilho da montanha branca}

A paisagem como construção mental e deambulação sensível. Texto de José Luís Porfírio.

O pó e uma imagem do tempo" disse, em 2008, Samuel Rama (n. 1977), bem antes da instalação a branco e negro que tem nos "Artistas Unidos", obra que se pode ler como uma enorme acumulação de pó, cal e gesso, brancos sobre o branco de um estrado de 6 por $9 \mathrm{~m}$. Na sala negra da Politécnica. Negra, mas não totalmente, pois as janelas deixam-nos adivinhar lá fora a vegetação do Jardim Botânico, mas negra suficiente para exaltar uma, e, depois, duas montanhas brancas numa paisagem que nos convida a atravessar um corredor, a entrar e a circular. Já agora uma nota sobre a luz: e melhor ver esta instalação mais para o fim da tarde, depois da sombra cair sobre a sala, assim o branco ergue-se abruptamente do chão e o poder encantatório das duas montanhas e mais forte.

O percurso e simples mas não isento de descobertas, a circulação fortalece a imagem da ilha com duas montanhas, a mais alta recebe-nos e a 
mais baixa vai-se deixando descobrir cada vez mais, enquanto também se desvenda $o$ istmo que as une. Assim se acentua a imagem de uma ilha, surpresa e a lagoa, uma espécie de espelho negro de água. Quieta que se abre na maior enseada. Esse e um acidente que prende o olhar, o agarra e o inquieta, abrindo uma perturbação que não acaba mais. Lembra também o poço em torno do qual Samuel Rama traçou um trilho branco para uma esfera branca circular (Quinta do Pisão Cascais2011); para além da lagoa negra do cinema de serie b, evoca também a ideia do buraco negro, dai talvez uma pista para o título desta instalação: "Megaparsecs". Samuel Rama serve-se por vezes de palavras incomuns para intitular as suas exposições (Acrecção Galeria 111, 2010), que podem funcionar como um enigma verbal prévia à visita. Confesso que este título me transportou aos meus longínquos tempos de leitor dos primeiros livros da Argonauta dos Livros do Brasil - com as bel as capas do Cândido Costa Pinto onde parsecs e megaparsecs apareciam a sugerir espaços de uma extensão inimaginável, 0 que corresponde realmente a essa medida astronómica, já que 1 Megaparsec $=1.000 .000$ parsecs e que 1 Parsec $=3.08568025 \times 1016$ metros.

"As principais linhas de força do meu trabalho poderiam ser reduzidas a três conceitos fundamentais: Paisagem, temporalidade e relação com a terra" (Samuel Rama em entrevista ao "JL" citada na folha de sala). A paisagem e uma evidencia, muito embora neste caso seja uma evidencia segunda, teatral, acentuada pelo estrado e, mais ainda; pelo efeito de irrealidade fantasmática que o branco lhe da. A temporalidade esta inscrita na própria matéria que se ergue na figura das montanhas, onde se sente o trabalho do tempo, uma inevitável erosão que Ira transformar, pouco a pouco, dia a dia, esta paisagem. A ligação a terra esta no próprio crescer da ilha que imaginamos ao contorna-la. Depois há uma pequena grande vertigem quando podemos ver o lago como um espelho, quando pela imaginação a escala pode crescer ou diminuir numa equivalência generalizada entre o pó e a rocha, entre o espelho e o espaço, todo o espaço.

O trilho que percorremos nesta ilha de montanhas brancas sobre um mar branco, aberto sobre funduras tão infindáveis quanto negras, não e 0 da realidade, mas o da pura imaginação; uma imaginação que a matéria desperta e convoca por desafio e simpatia, e que nos faz participar no grande teatro do mundo numa simples volta pela sala, quando ao percorrer este trilho, podemos encontrar-nos com a voz da sabedoria antiga do $2^{\circ}$ Isaías: "As nações são como a gota de água num balde,/ como um grão de poeira no prato de uma balança;/ e as ilhas não pesam mais do que o pó mais fino." Is. 40,15.

Porfírio, José Luís, "No trilho da montanha branca”, Semanário Expresso, Actual no 2081, 15 de septiembre de 2012, p. 20. 


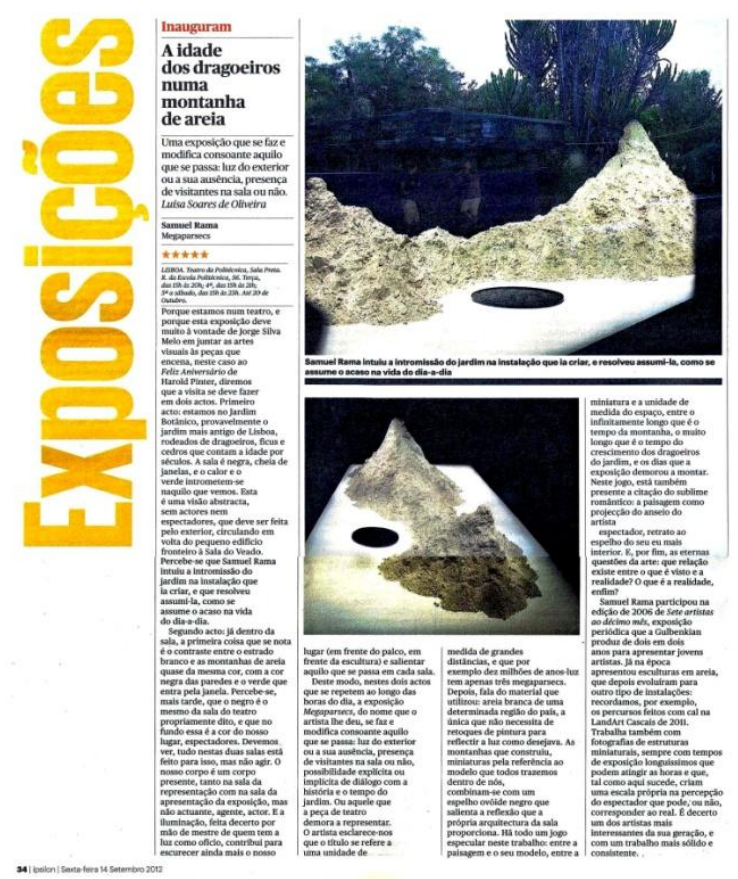

\section{A idade dos dragoeiros numa montanha de areia}

Uma exposição que se faz e modifica consoante aquilo que se passa: luz do exterior ou a sua ausência, presença de visitantes na sala ou não. Luísa Soares de Oliveira.

Porque estamos num teatro, e porque esta exposição deve muito a vontade de Jorge Silva Melo em juntar as artes visuais as peças que encena, neste caso ao Feliz Aniversario de Harold Pinter, diremos que a visita se deve fazer em dois actos. Primeiro acto: estamos no Jardim Botânico, provavelmente o jardim mais antigo de Lisboa, rodeados de dragoeiros, ficus e cedros que contam a idade por séculos. A sala e negra, cheia de janelas, e o calor e o verde intrometem-se naquilo que vemos. Esta e uma visão abstracta, sem actores nem espectadores, que deve ser feita pelo exterior, circulando em volta do pequeno edifício fronteiro a Sala do Veado. Percebe-se que Samuel Rama intuiu a intromissão do jardim na instalação que ia criar, e que resolveu assumi-la, como se assume $o$ acaso na vida do dia-a-dia.

Segundo acto: já dentro da sala, a primeira coisa que se nota é o contraste entre o estrado branco e as montanhas de areia quase da mesma cor, com a cor negra das paredes e o verde que entra pela janela. Percebe-se, mais tarde, que o negro é o mesmo da sala do teatro propriamente dito, e que no fundo essa é a cor do nosso lugar, espectadores. Devemos ver, tudo nestas duas salas está feito para isso, mas não agir. O nosso corpo é um corpo presente, 
tanto na sala da representação com na sala da apresentação da exposição, mas não actuante, agente, actor. E a iluminação, feita decerto por mão de mestre de quem tem a luz como ofício, contribui para escurecer ainda mais o nosso lugar (em frente do palco, em frente da escultura) e salientar aquilo que se passa em cada sala.

Deste modo, nestes dois actos que se repetem ao longo das horas do dia, a exposição Megaparsecs, do nome que o artista lhe deu, se faz e modifica consoante aquilo que se passa: luz do exterior ou a sua ausência, presença de visitantes na sala ou não, possibilidade explícita ou implícita de diálogo com a história e o tempo do jardim. Ou aquele que a peça de teatro demora a representar.

O artista esclarece-nos que o título se refere a uma unidade de medida de grandes distancias, e que por exemplo dez milhões de anos-luz tem apenas três megaparsecs. Depois, fala do material que utilizou: areia branca de uma determinada região do pais, a (mica que não necessita de retoques de pintura para reflectir a luz como desejava. As montanhas que construiu, miniaturas pela referencia ao modelo que todos trazemos dentro de nós, combinam-se com um espelho ovóide negro que salienta a reflexão que a própria arquitectura da sala proporciona. Há todo um jogo especular neste trabalho: entre a paisagem e o seu modelo, entre a miniatura e a unidade de medida do espaço, entre o infinitamente longo que e o tempo da montanha, o muito longo que e o tempo do crescimento dos dragoeiros do jardim, e os dias que a exposição demorou a montar. Neste jogo, está também presente a citação do sublime românico: a paisagem como projecção do anseio do artista espectador, retrato ao espelho do seu eu mais interior. E, por fim, as eternas questões da arte: que relação existe entre o que é visto e a realidade? o que e a realidade, enfim?

Samuel Rama participou na edição de 2006 de Sete artistas ao decimo mes, exposição periódica a que a Gulbenkian produz de dois em dois anos para apresentar jovens artistas. Já na época apresentou esculturas em areia, que depois evoluíram para outro tipo de instalações: recordamos, por exemplo, os percursos feitos com cal na LandArt Cascais de 2011. Trabalha também com fotografias de estruturas miniaturais, sempre com tempos de exposição longuíssimos que podem atingir as horas e que, tal como aqui sucede, criam uma escala própria na percepção do espectador que pode, ou não, corresponder ao real. É decerto um dos artistas mais interessantes da sua geração, e com um trabalho mais sólido e consistente.

Soares, Luísa, “A idade dos dragoeiros numa montanha de areia”, Jornal Público, Ípsilon, 14 de septiembre 2012, p. 34. 


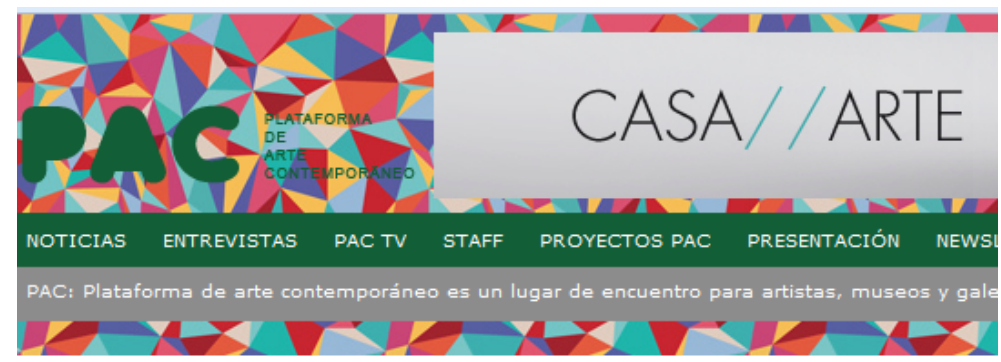

\& Anterior

Siguiente $»$

MEgaparsecs de Samuel Rama, en el Teatro da Politécnica,

Lisboa

11 Oct. 2012 Laura Pérez Pastor

f) Recomendar 36

$y$ Twittear $4 4 \quad 8 + 1 \longdiv { 0 }$

Hasta el 20 de Octubre. Teatro da Politécnica. Rua da Escola Politécnica 56, Lisboa.

Samuel Rama presenta MEGAPARSECS, una instalación de carácter escultórico en la sala negra del Teatro da Politécnica que dialoga con el entorno circundante del Jardín Botánico de la Universidad de Lisboa.

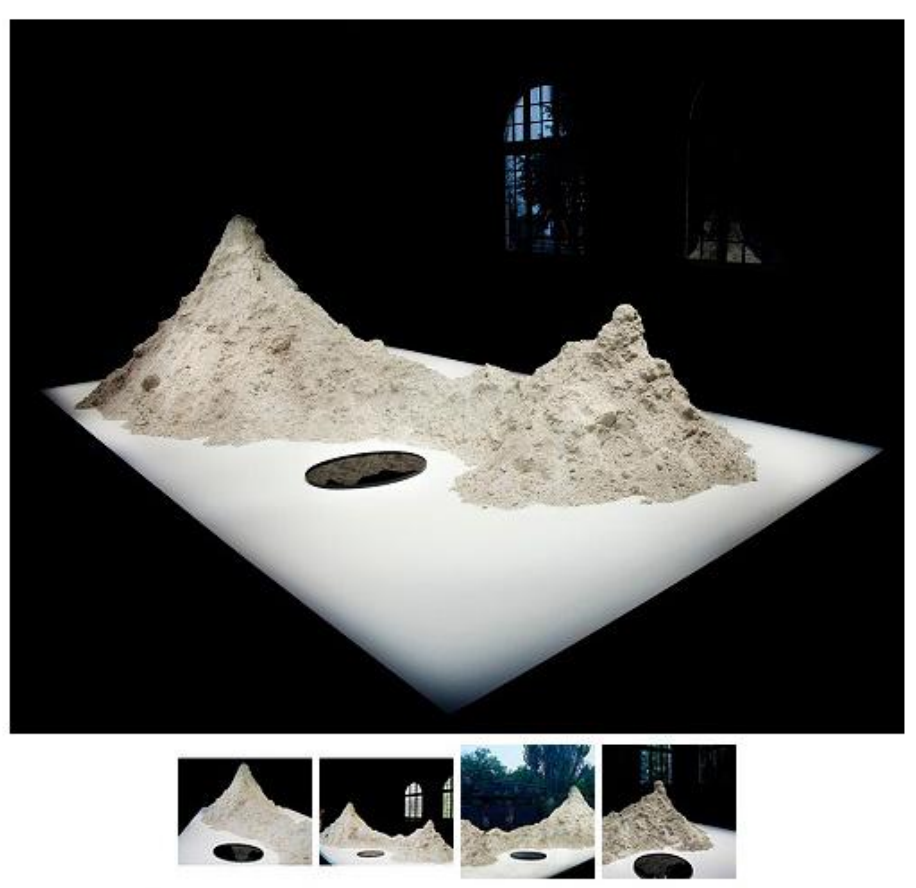

Arena, metal, aceite quemado y un palco son los elementos con los que Samuel Rama (1977, Coimbra, Portugal) construye MEGAPARSECS. El título alude a una unidad de medida astronómica, el megapársec (Mpc) equivalente a unos 3,26 millones de años luz. 
La escala es sin lugar a dudas un elemento clave en esta instalación cuya montaña de arena blanca convenientemente iluminada nos transporta a un paisaje remoto (casi lunar por la noche, rodeado de vegetación durante el día), en este juego con la escala real y la imaginaria.

En MEGAPARSECS se da un constante diálogo exterior-interior (jardín-espacio expositivo) a nivel perceptivo de la pieza -más aislada en su negra sala por la noche, rodeada del verde que entra por las ventanas de día-. Rama crea un paisaje propio que acaba por integrar el paisaje y el tiempo circundantes, el accidente, las variaciones de luz y las propias alteraciones en la disposición de la arena sobre el palco con el paso del tiempo.

Un tiempo natural, podría decirse que geológico, que en esta instalación se transforma en espacio. Una experiencia temporal que el espectador recorre, paseando alrededor de la pieza, influenciado por el ritmo de esta atmósfera.

El artista portugués anota: "Ésta no es apenas una exposición de un objeto efímero, sino la creación de las condiciones para que ocurra un acontecimiento capaz de hacernos evadir hacia dos dimensiones del paisaje: una interior, virtual, escenográfica y jerarquizada, justificada por la creación de un campo de visión afín a la pintura y a la escenografía teatral y protagonizada por la intervención en sí, y otra exterior, protagonizada por la luz natural reflejada por los árboles del Jardín Botánico."

Samuel Rama que, representado por la Galeria 111 de Oporto, ya presentó su obra en ARCO 2011, resume las principales líneas de fuerza de su trabajo en tres conceptos fundamentales: paisaje, temporalidad y relación con la tierra.

Etiquetas: Samuel Rama, Teatro da Politécnica

Posteado en Centros de arte, Exposiciones, Instalación, Lisboa |

Pastor, Laura Pérez, MEGAPARSECS de Samuel Rama, www.
Plataformadeartecontemporaneo.com

\section{MEGAPARSECS}

Nome complicado para designar, neste caso, uma instalação de caráter escultórico de Samuel Rama que, curiosamente, como se fizesse parte da peça de Pinter no Teatro da Politécnica, numa sala ao lado. Quem for ver o espetáculo teatral não devia olvidar-se de entrar nessa sala escura, estranhamente iluminada pela própria matéria que geologicamente se enforma no espaço vazio. Que belo cenário! Ampliado, vejo-o bem numa ópera onde o abstrato e o concreto se amalgamam.

Jorge Listopad, "MEGAPARSECS”, Jornal de Letras, Artes e Ideias, no 1095, 19 de Sept. 2012, p. 35. 


\section{IMÁGENES}

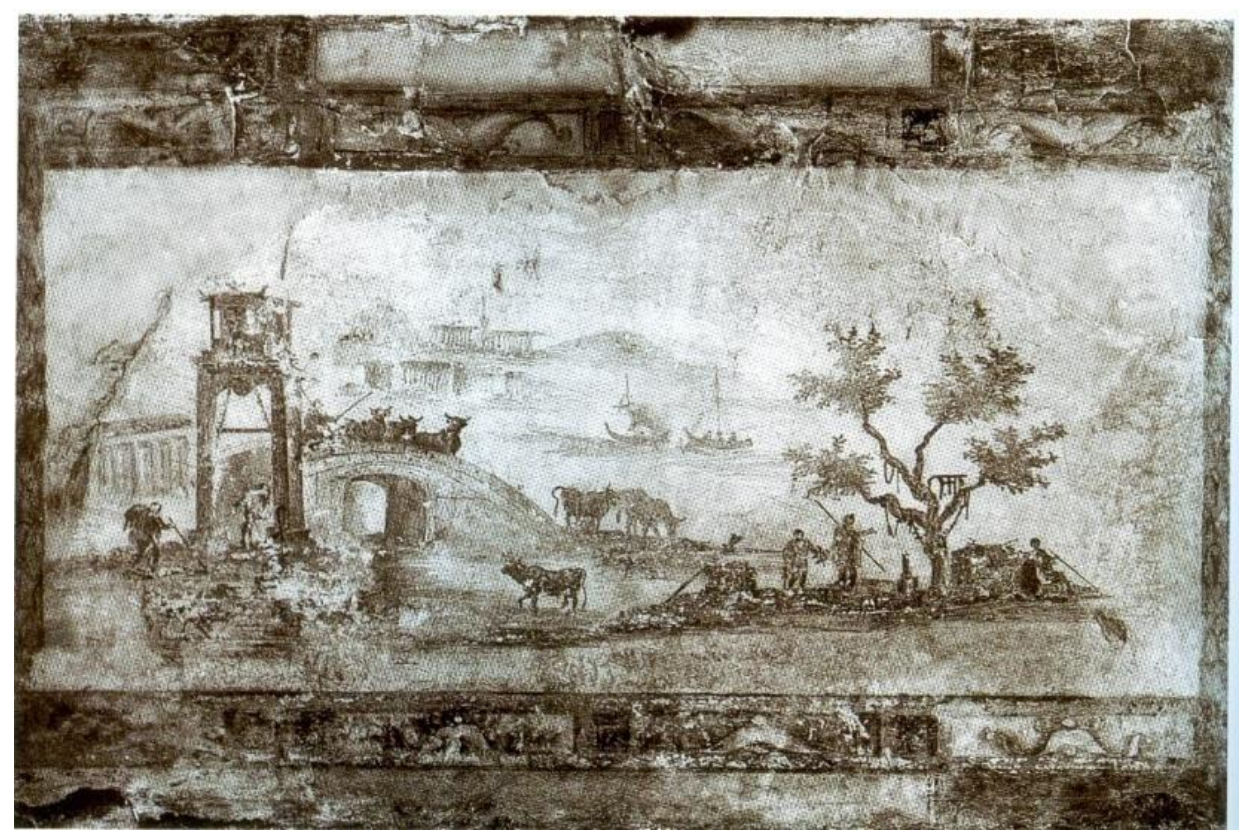

Fig. 1 Paisaje, siglo. I, Pintura mural, Villa Albani, Roma

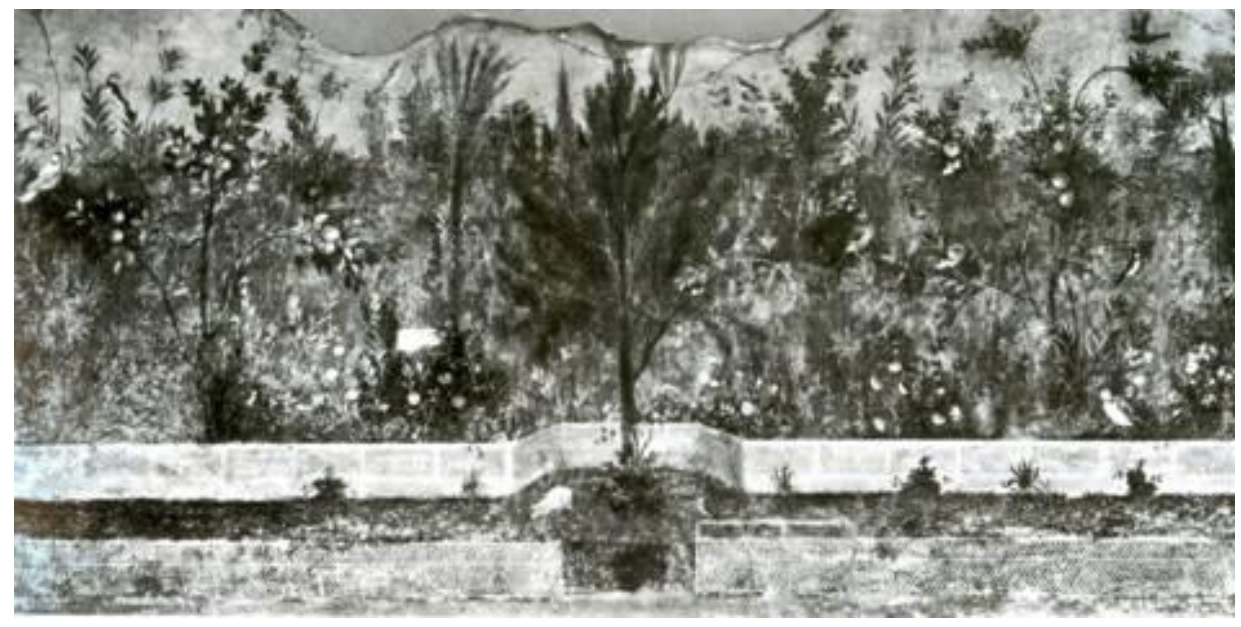

Fig. 2 Vista de un Jardín, pintura mural de la Villa de Livia, en Primaporta.C. 20 a. C., Museo delleTerme, Roma 


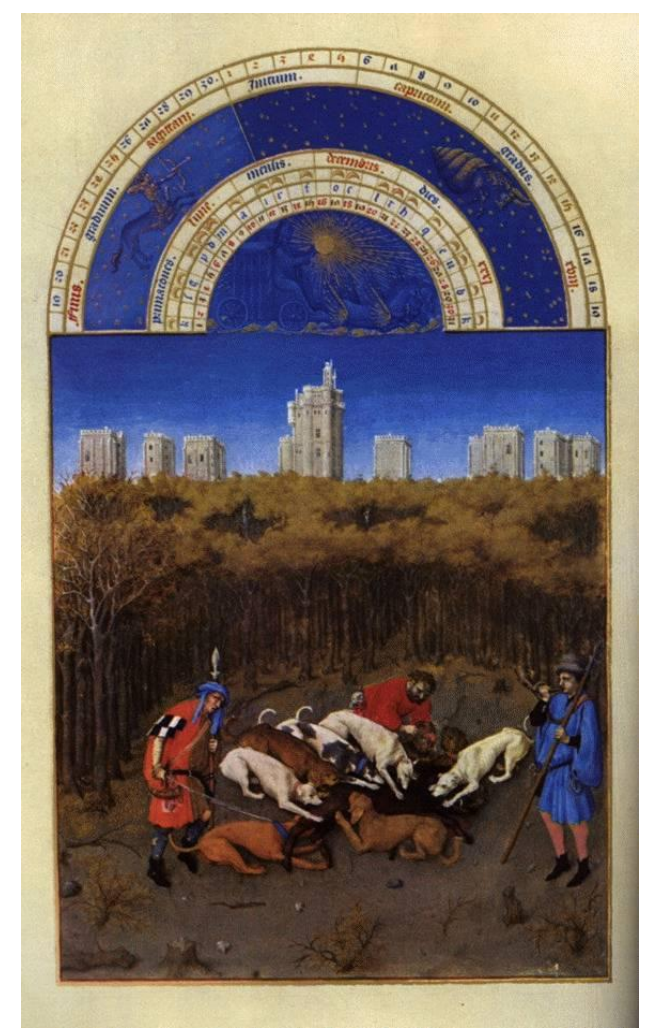

Fig. 3 Hermanos Limbourg, Diciembre, miniatura en pergamino de Les Très Riches Heures del Duque de Berry. 1413-16. (Château de Vincennes), Francia

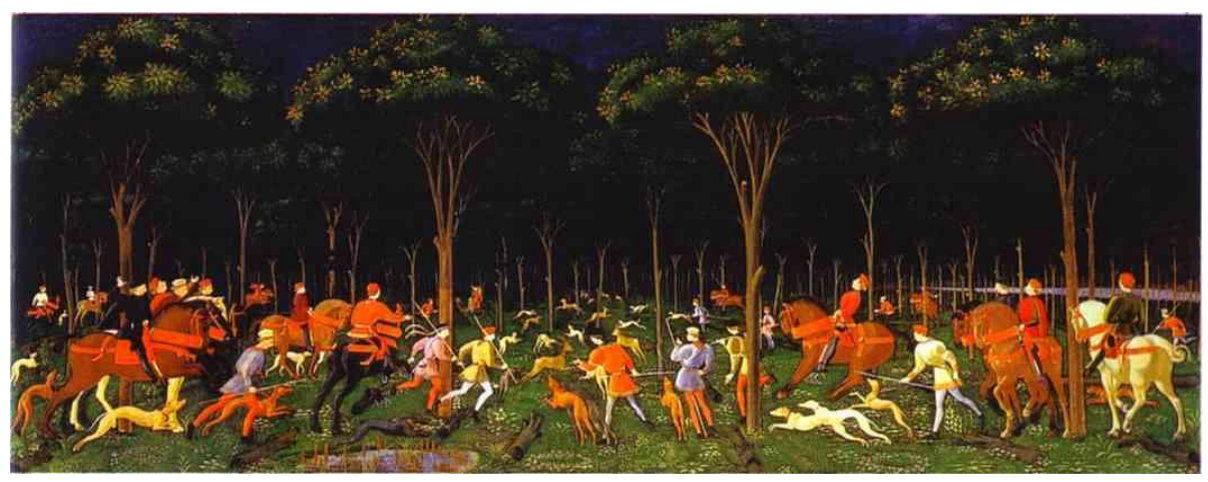

Fig. 4 Paolo Uccello, La Caza, después de 1460. 75x178 cm, Ashmolean Museum, Oxford 


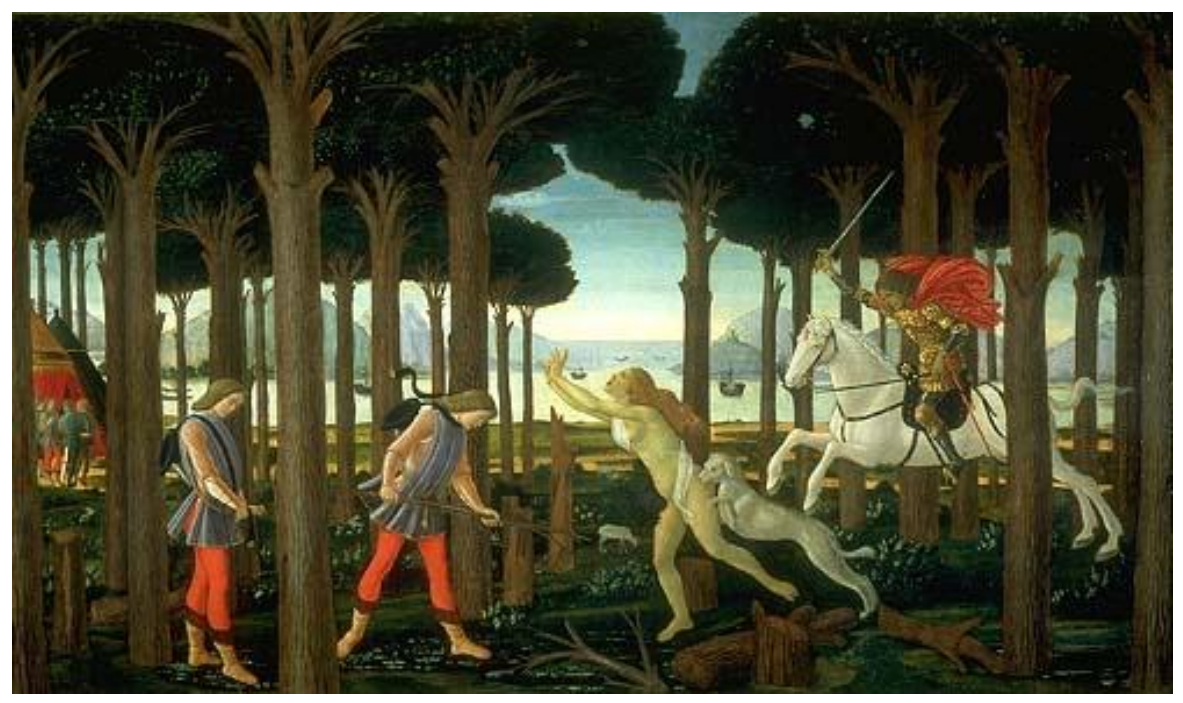

Fig. 5 Sandro Botticelli, tabla I, II y III (Museo del Prado) y tabla IV ( Palacio Pucci de Florencia) historia de Nastagio degli Onesti, 1482-1483, témpera sobre tabla.

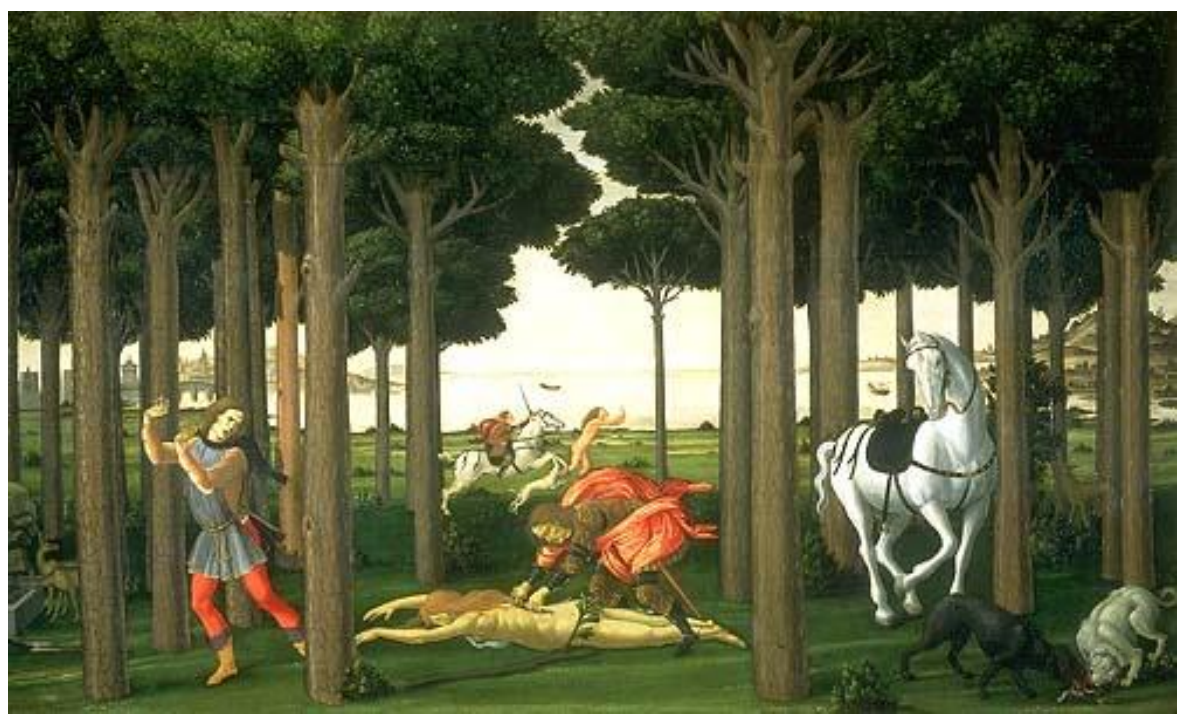

Sandro Botticelli, tabla II (Museo del Prado) de la historia de Nastagio degli Onesti, 1482-1483, témpera sobre tabla. 


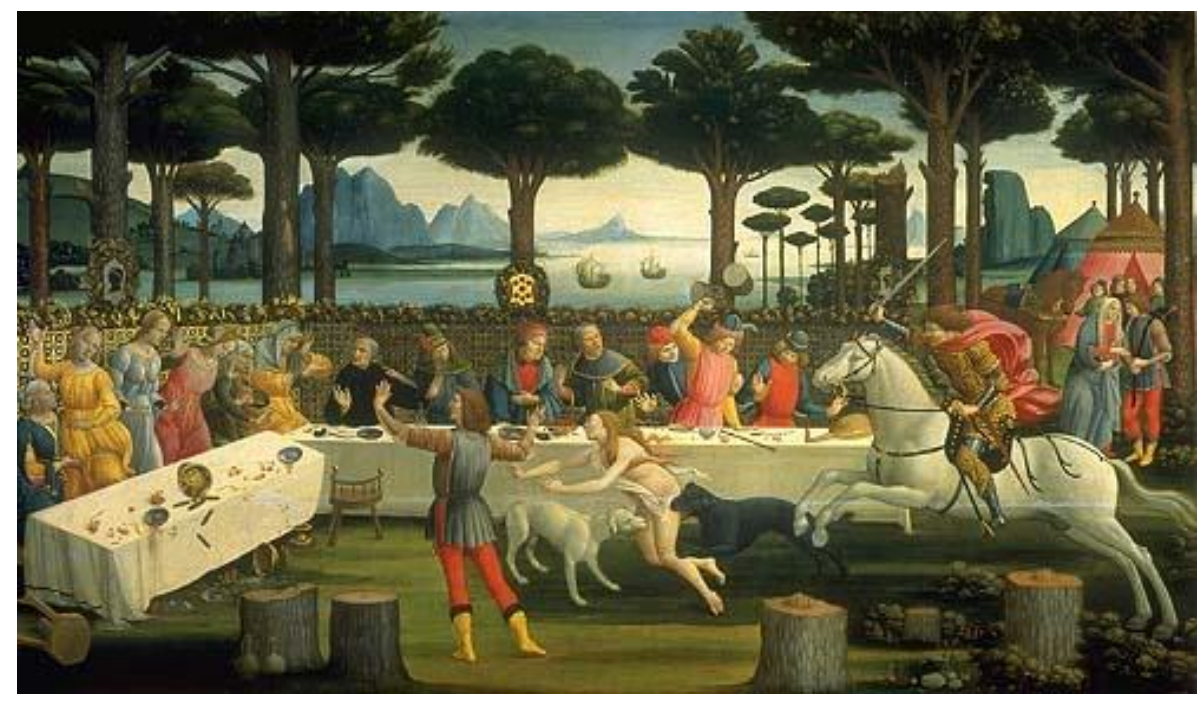

Sandro Botticelli, tabla III (Museo del Prado) de la historia de Nastagio degli Onesti, 1482-1483, témpera sobre tabla.

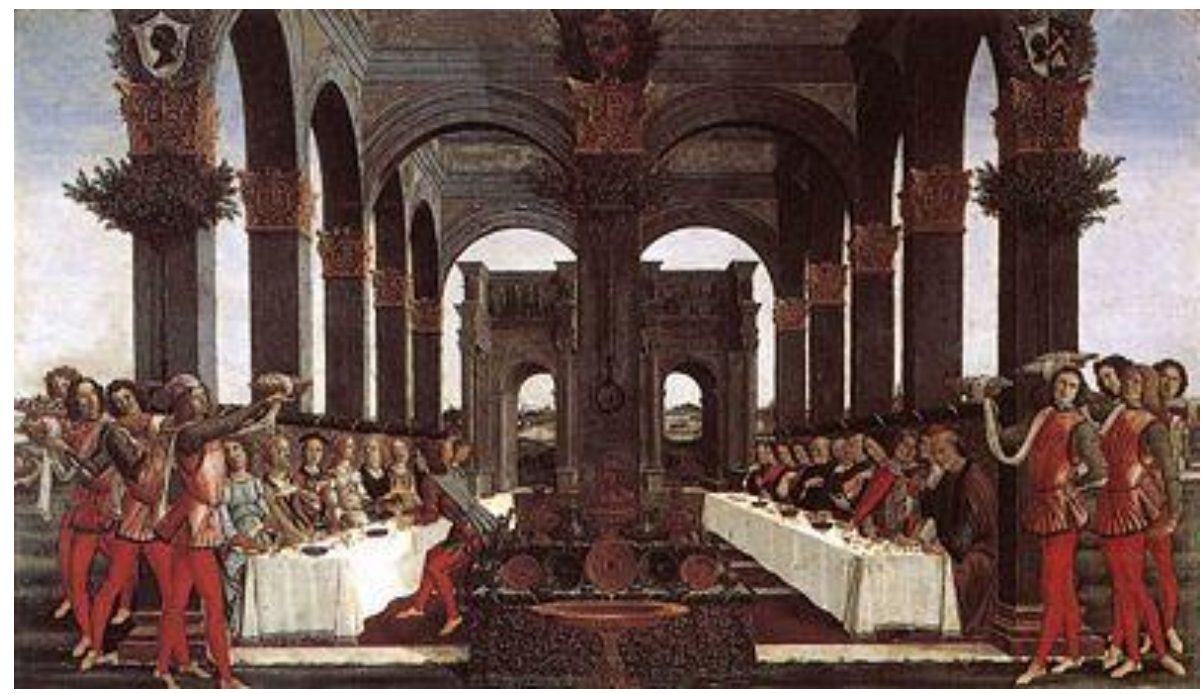

Sandro Botticelli, tabla IV ( Palacio Pucci de Florencia) de la historia de Nastagio degli Onesti, 1482 1483 , témpera sobre tabla. 

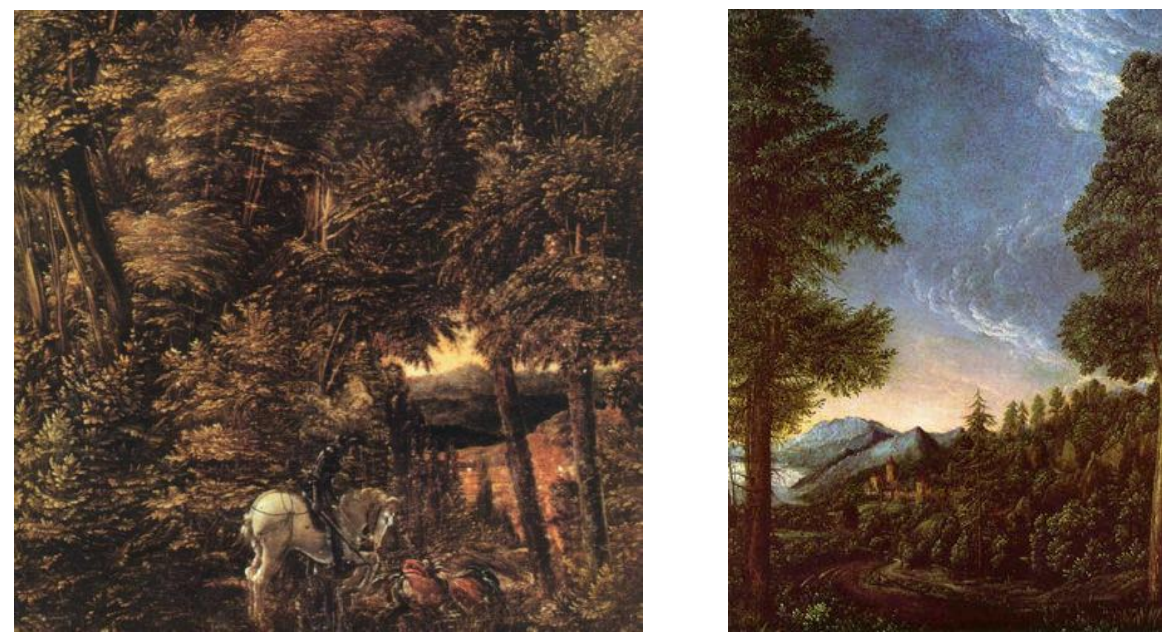

Figs. 6 y 7 Altdorfer, San Jorge en el Bosque, 1510 y Vista del valle del Danubio, 1520-25, Pinacoteca de Munich.

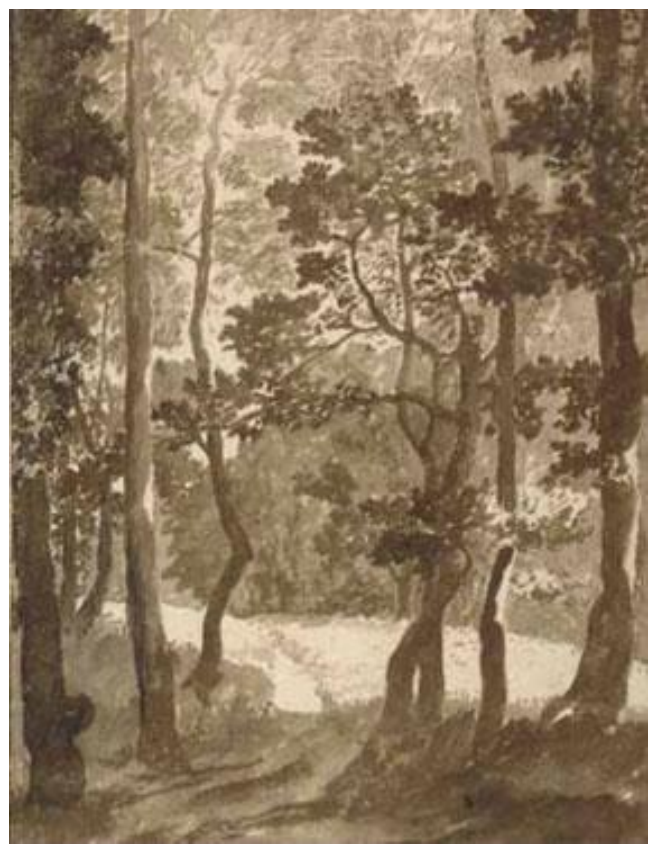

Fig. 8 NicolasPoussin, Trayecto que conduce a un claro en el bosque, c. 1635-1640. Dibujo a pluma y aguada marrón, 38,6 X 24,6 cm, J. Paul Getty Museum, Los Ángeles. 


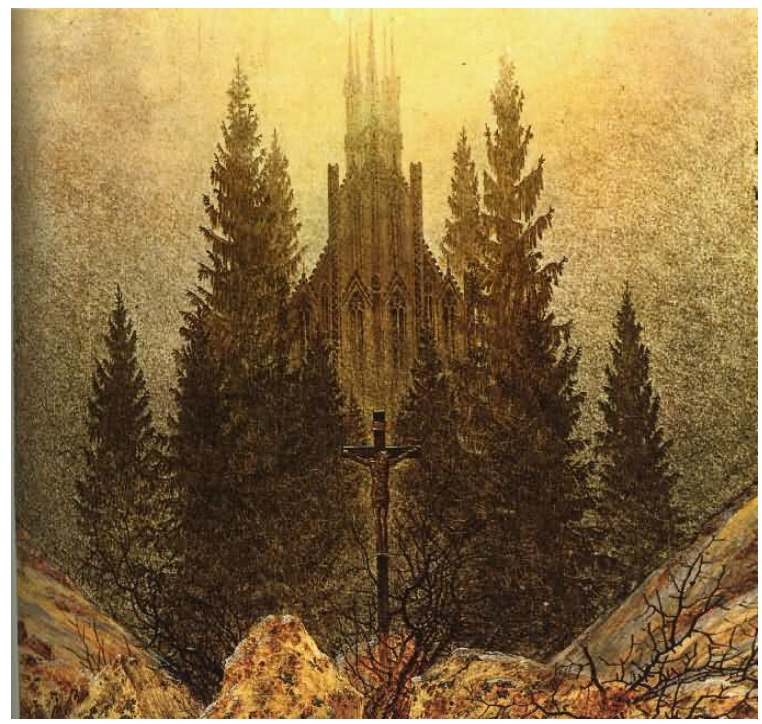

Fig.9 Caspar David Friedrich, La cruz en la montaña, 1812. Óleo sobre tela, $44,5 \times 37,4 \mathrm{~cm}$, Dusseldorf, KunstPalast

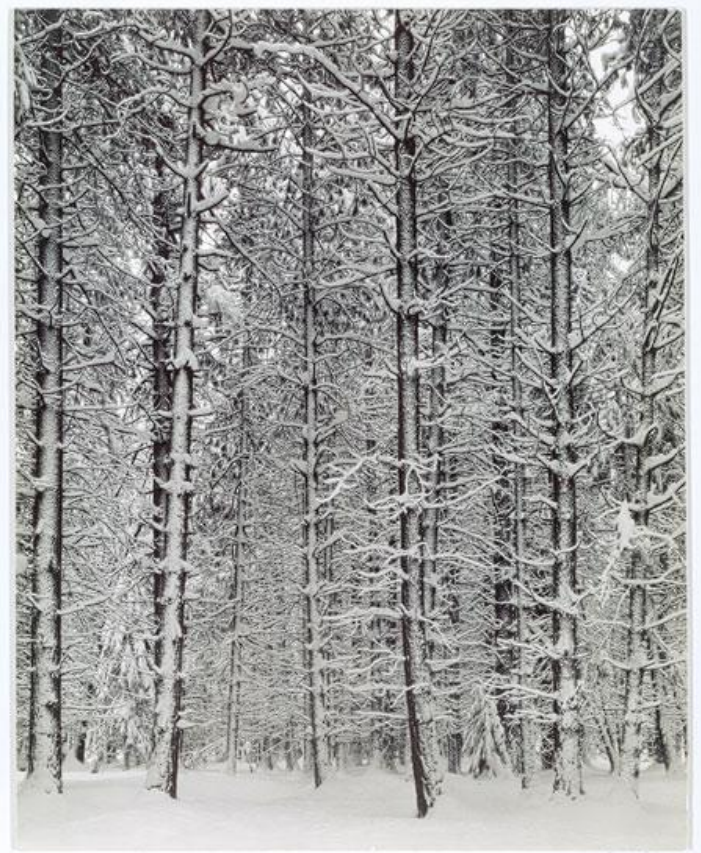

Fig. 10 Ansel Adams, Winter Yosemite Valley, 1933-34, Gelatina de Plata 23,4x18,5 cm, Colección de Alfred Stieglitz. 


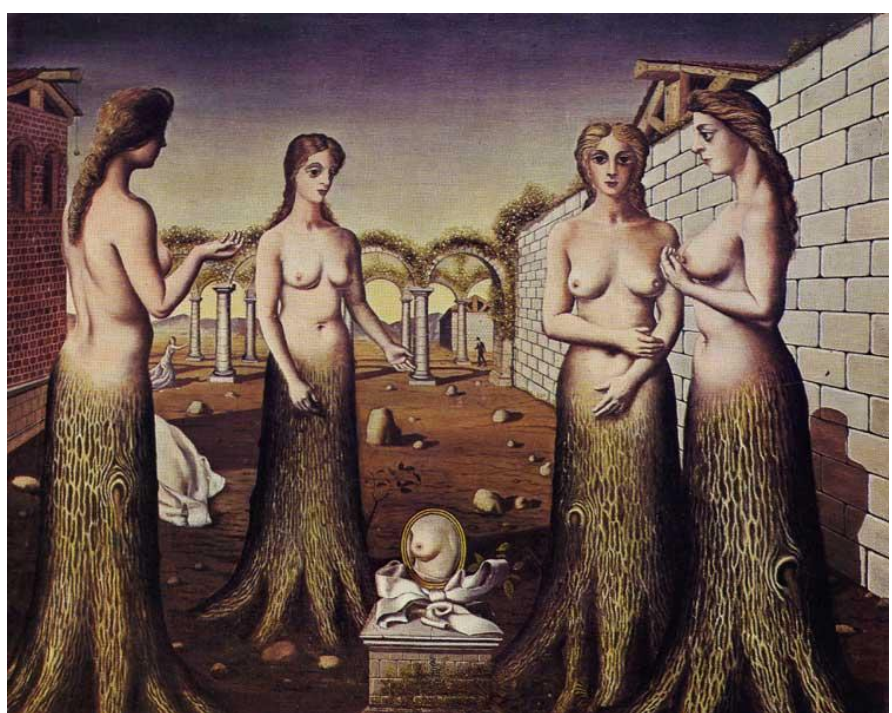

Fig.11 Paul Delvaux, El Crepúsculo, 1937, Fundación Peggy Guggenheim, Venecia

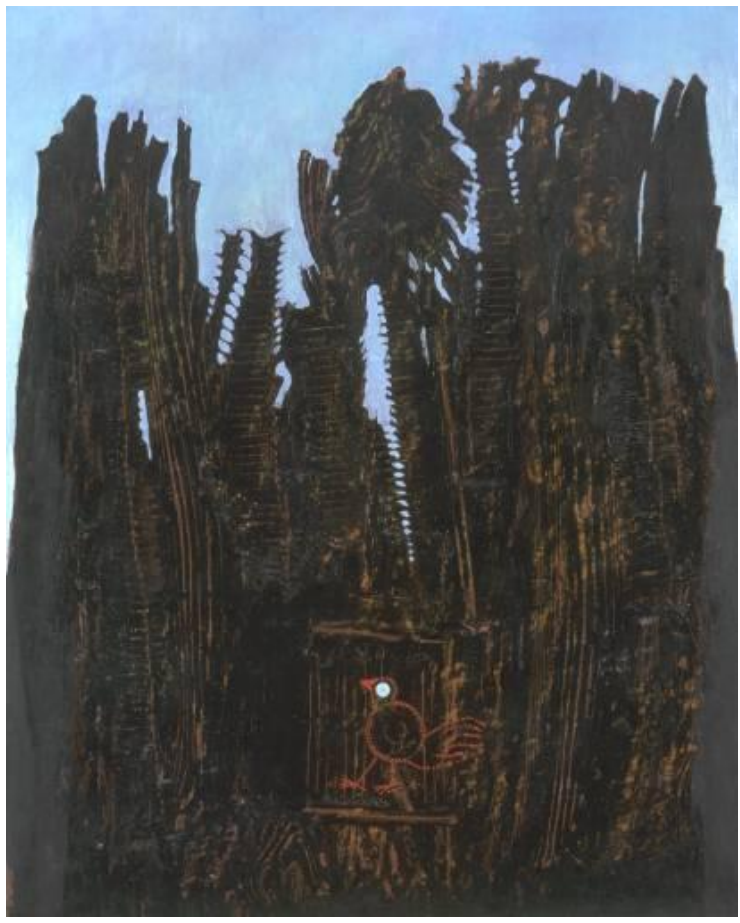

Fig. 12 Max Ernst, Bosque y Pájaro, 1927, Tate Gallery 


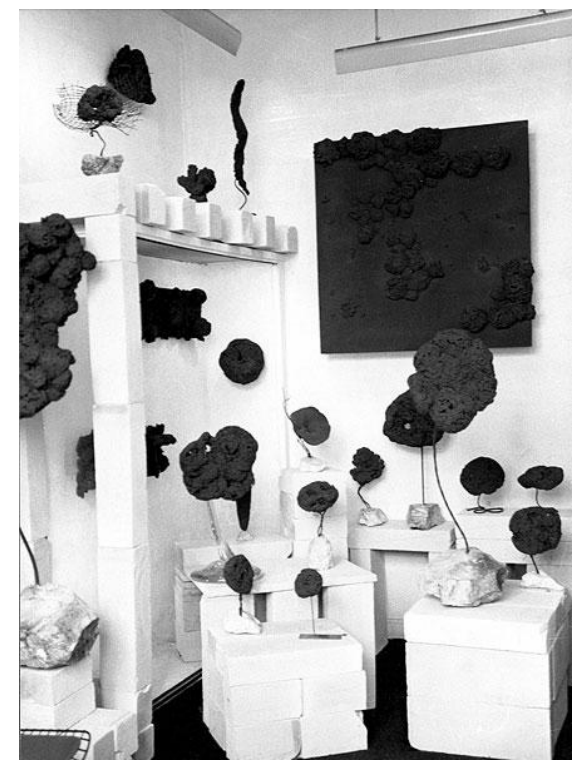

Fig. 13 Yves Klein, La forêt d'éponges et les bas-reliefs monochromes, Galería Iris Clert, París, junio de 1959.

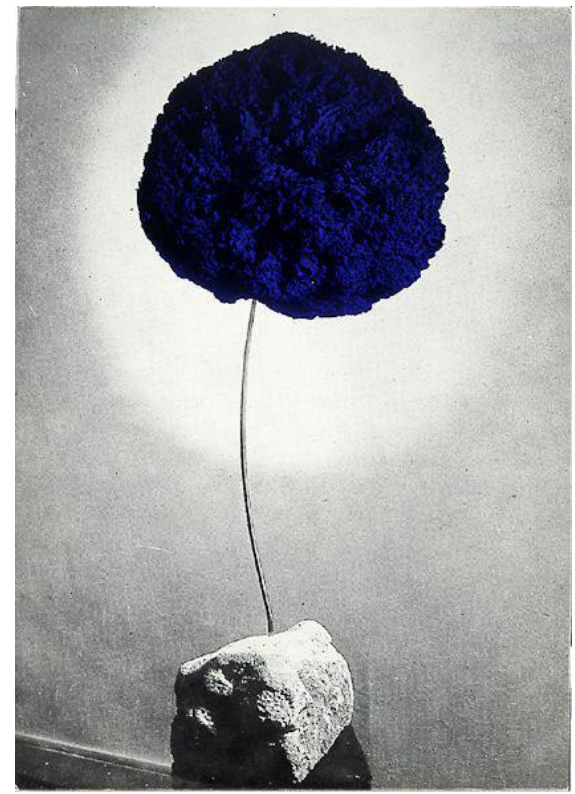

Fig. 14 Yves Klein, Sculpture éponge. Pigmento puro y resina sintética sobre esponja, varilla de metal y piedra, $60 \times 23 \times 16 \mathrm{~cm}, 1959$. 


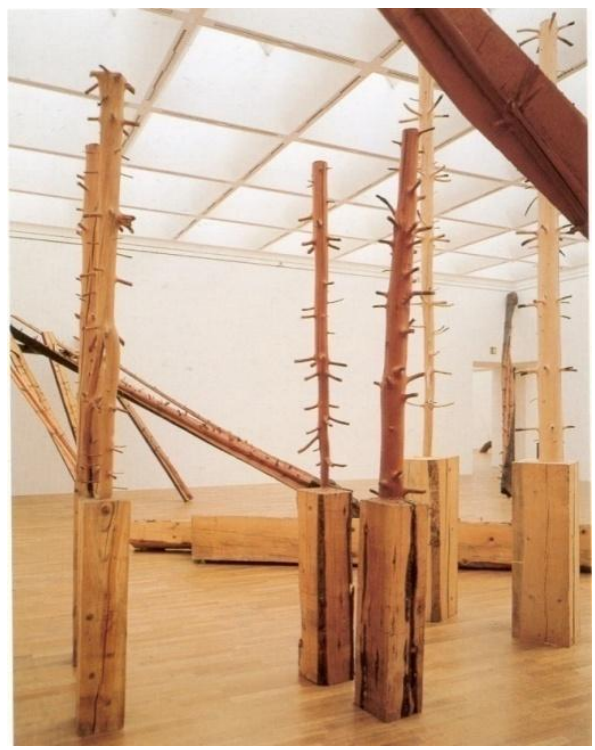

Fig. 15 Giuseppe Penone, repetir el bosque, ripetere il bosco. Instalación: Kunstmuseum, Bonn, 1997

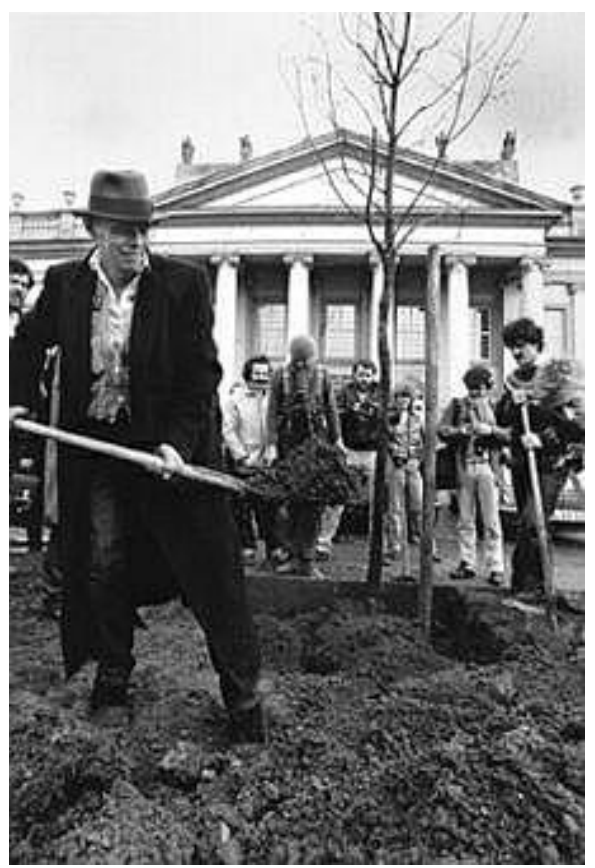

Fig.16 Joseph Beuys, 7000 Robles, Documenta 7, Kassel, 1982. El primer roble plantado en Friedrichplatz. 


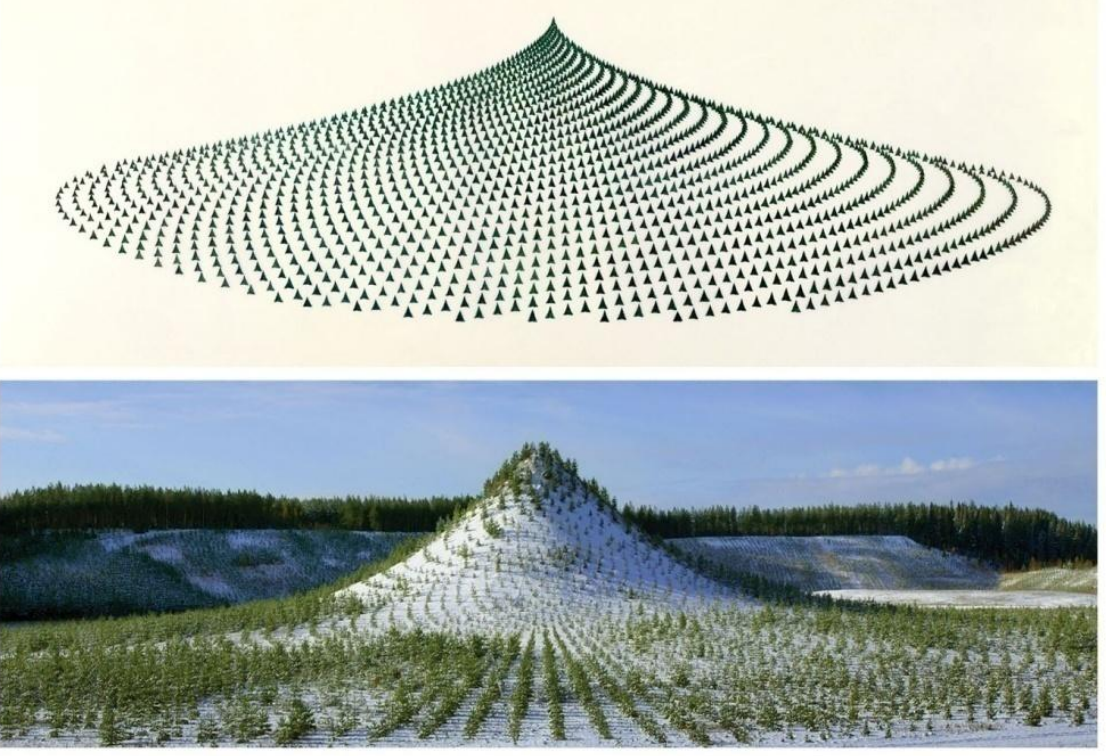

Fig. 17 Agnes Denes, Tree mountain - A living time capsule, 10.000 Trees, 10.000 People, 400 Years, 1982

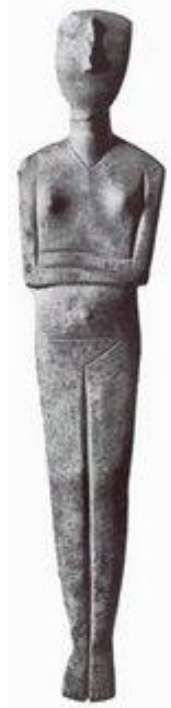

Fig. 18 Ídolo, Amorgos.2500-1100 a.C, Mármol, alt. 0.76 m, Ashmolean Museum, Oxford 


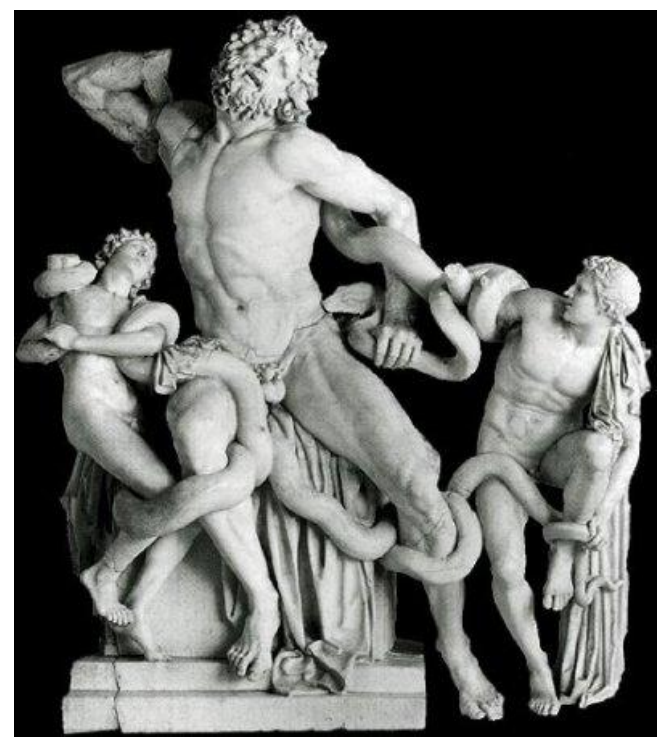

Fig. 19 Grupo de Laocoonte.Copia romana del original,obra probable de Agesandro, Athenodoro y Polydoro, de Rodas, Siglo. I a.C. Mármol, alt. 213 m. Museo del Vaticano, Roma

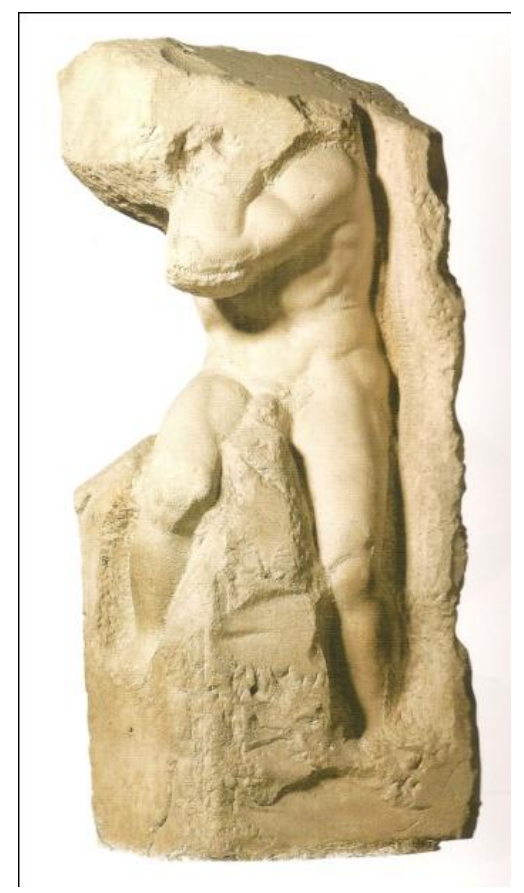

Fig. 20 Miguel Ángel, El Atlas, 1519, Mármol, 277 cm, Galería de la Academia, Florencia. 


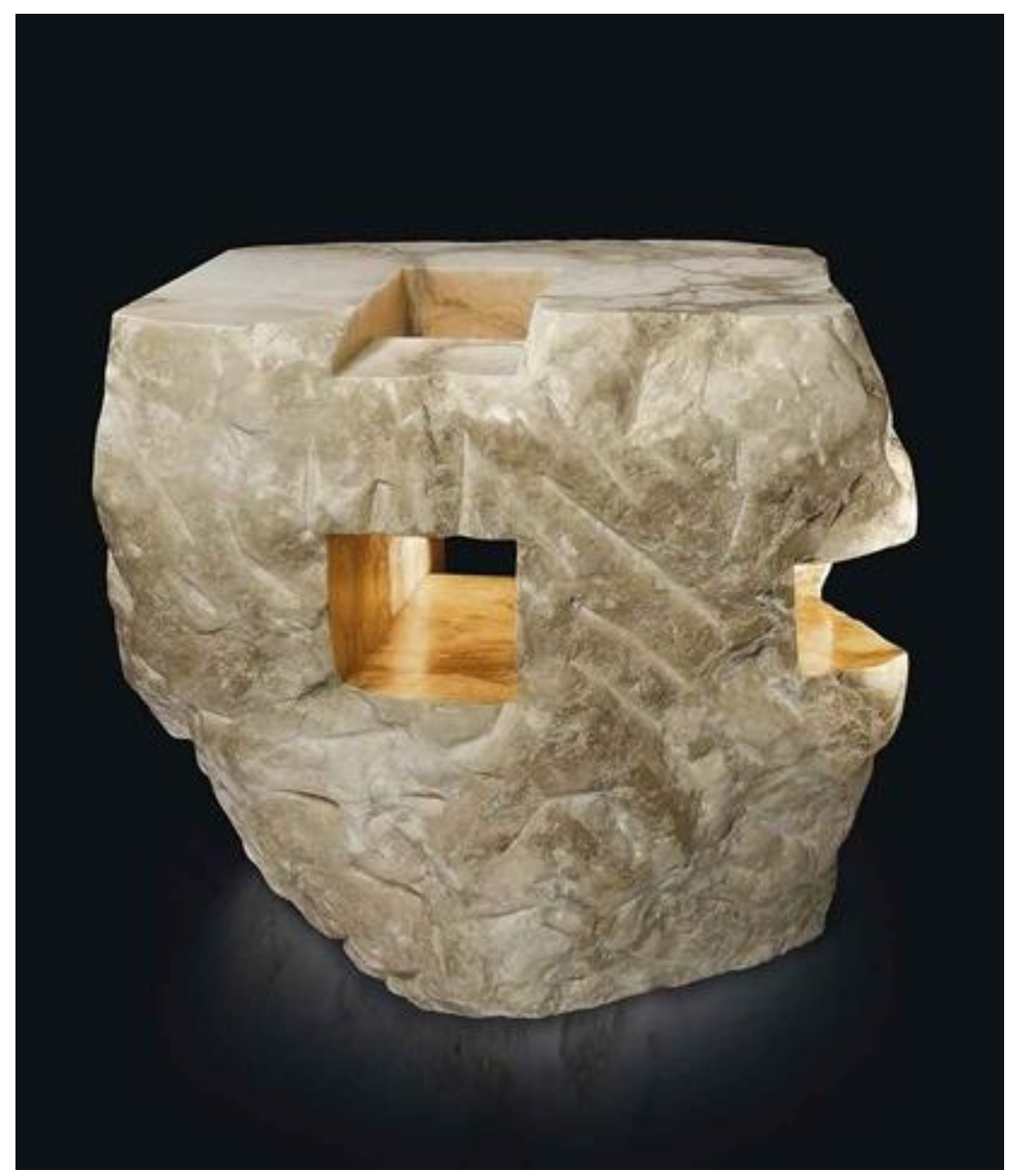

Fig. 21 Eduardo Chillida, Lo profundo es el aire XX ,1998, Alabastro, 76 × 88 × $70 \mathrm{~cm}$. 


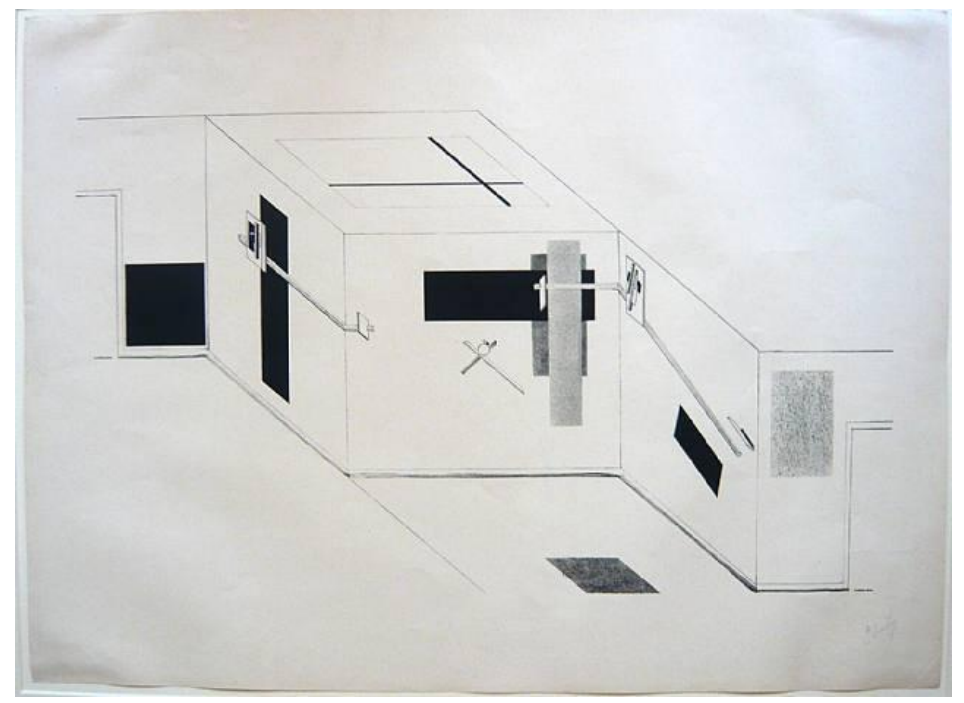

Fig. 22 El Lissitzky, Proyecto PROUN, 1923

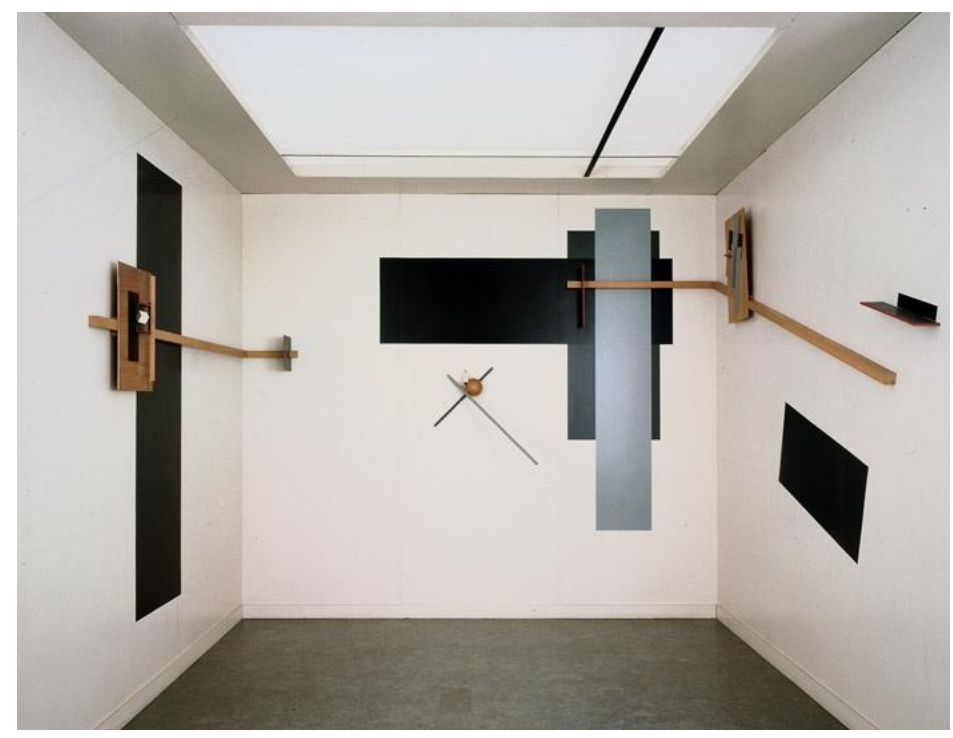

Fig. 23 El Lissitzky, Espacio PROUN, 1923 


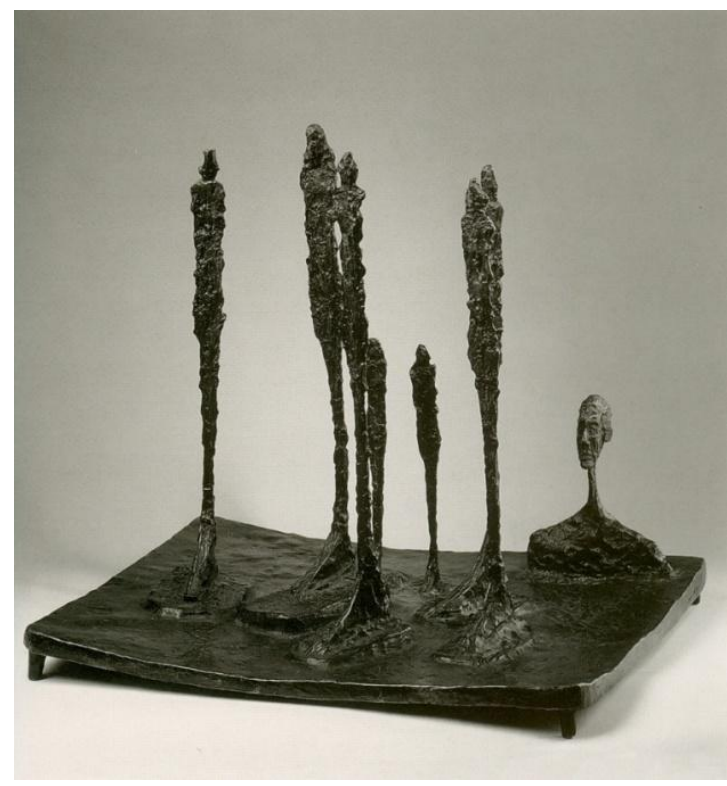

Fig. 24 Alberto Giacometti, La forêt (El Bosque),1950, bronce, $57 \times 61 \times 49,5$ cm, Fundación Maeght

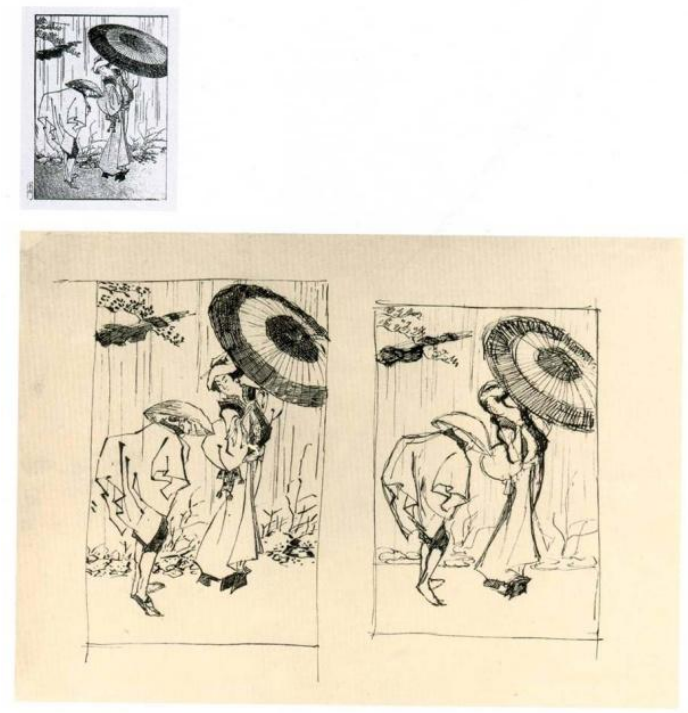

Fig. 25 Alberto Giacometti, copia de un dibujo de Katsushika Hokusai, Viajeros bajo la lluvia, circa 1820-30, Pluma y tinta sobre papel, $33,5 \times 25,2 \mathrm{~cm}$, no firmado, sin fecha. 

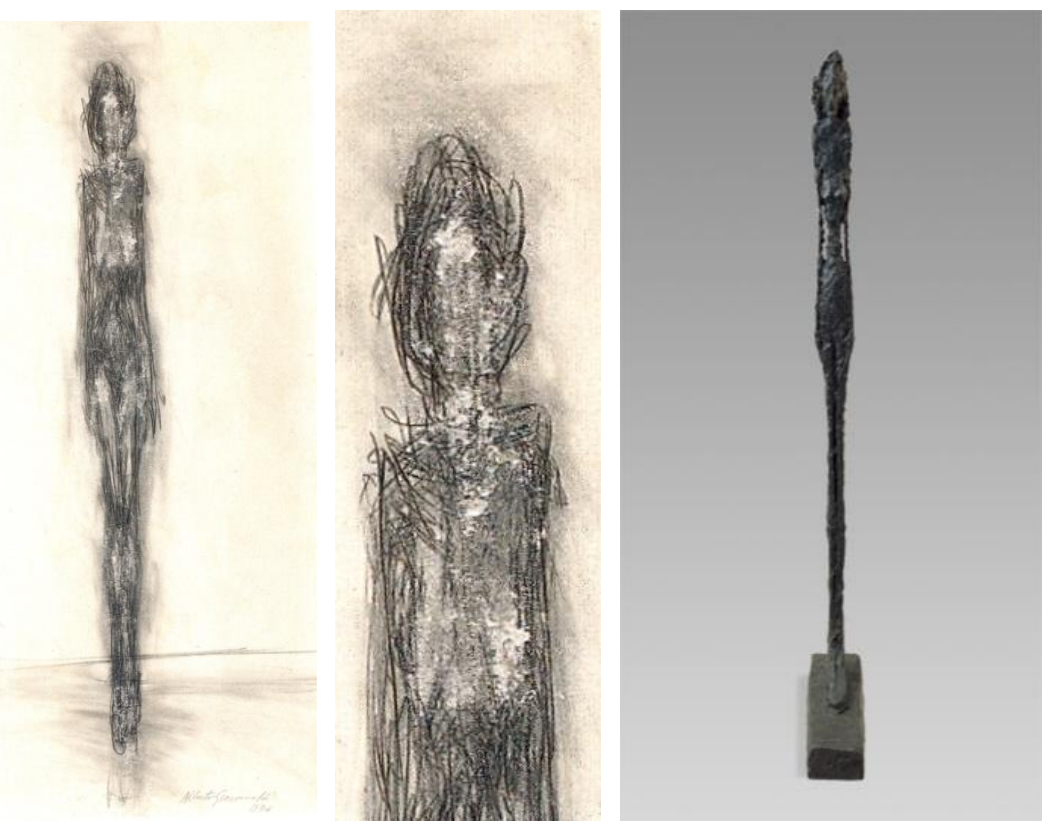

De izquierda a derecha Fig. 26 Alberto Giacometti, Femme debout (Mujer de pie), 1946, Lápiz sobre papel, 53,5X28,5 cm, Col. Jan et Marie -Anne Krugier - Poniatowski, Ginebra. Fig. 27 Fragmento ampliado del dibujo de la fig. 26. Fig. 28 Alberto Giacometti, (Femme debout), 1947 (cast 1957). Bronce, 60 1/4 pulgadas $(153 \mathrm{~cm})$ Col. Guggenheim NY.

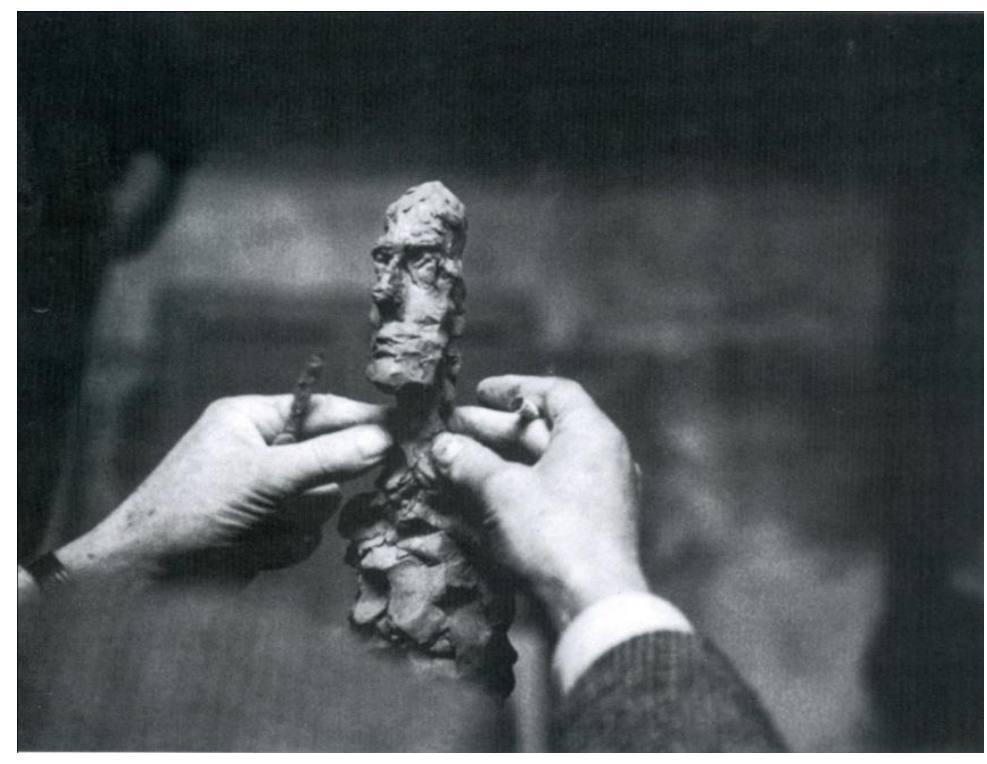

Fig. 29 Fotografía de René Burri: Giacometti trabajando en un busto de Diego, 1960. 


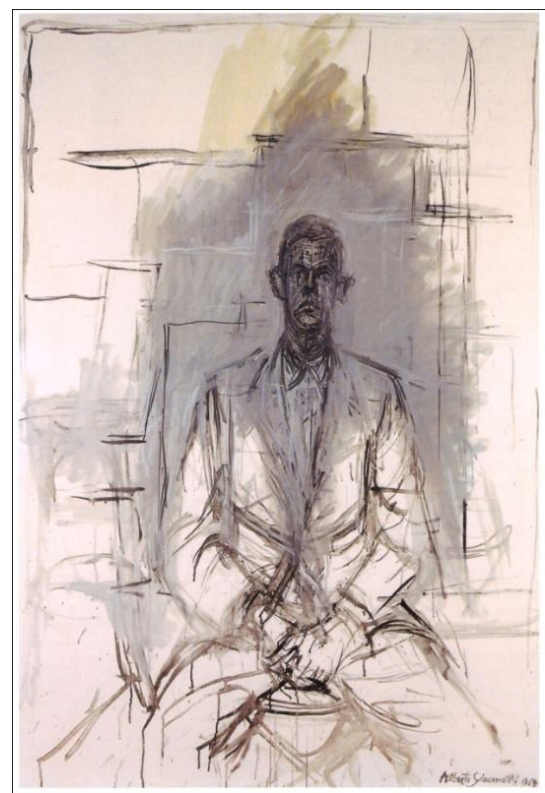

Fig. 30 Alberto Giacometti, James Lord, 1964, Óleo sobre lienzo, 177 X 81,5 cm
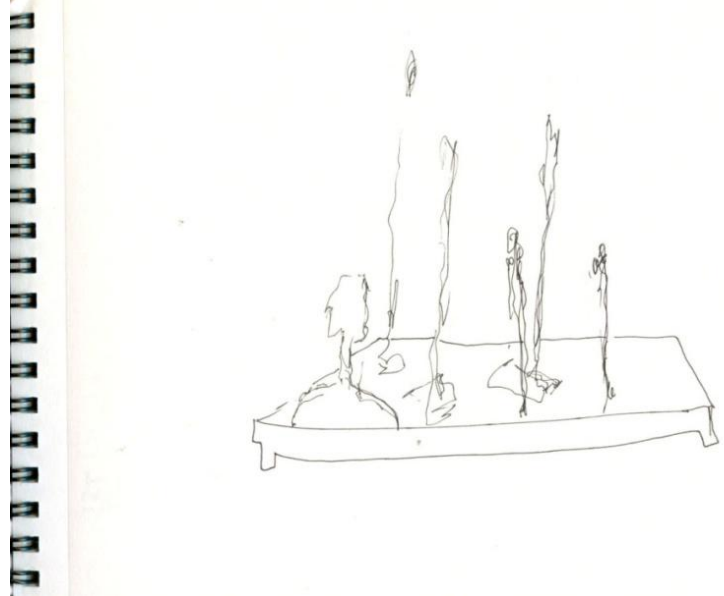

Fig. 31, 32,33 y 34 Dibujos realizados a partir de la escultura de A. Giacometti titulada La forêt, tras varias visitas a la exposición titulada Silêncios, ${ }^{599}$ realizada en el Museu Berardo entre 26 de octubre de 2009 y 10 de enero de 2010.

\footnotetext{
${ }^{599}$ Comisariada por Martin Karmitz, que organizó toda la exposición a partir de la idea de laberinto, asumiendo como pieza central La forêt de Alberto Giacometti.
} 


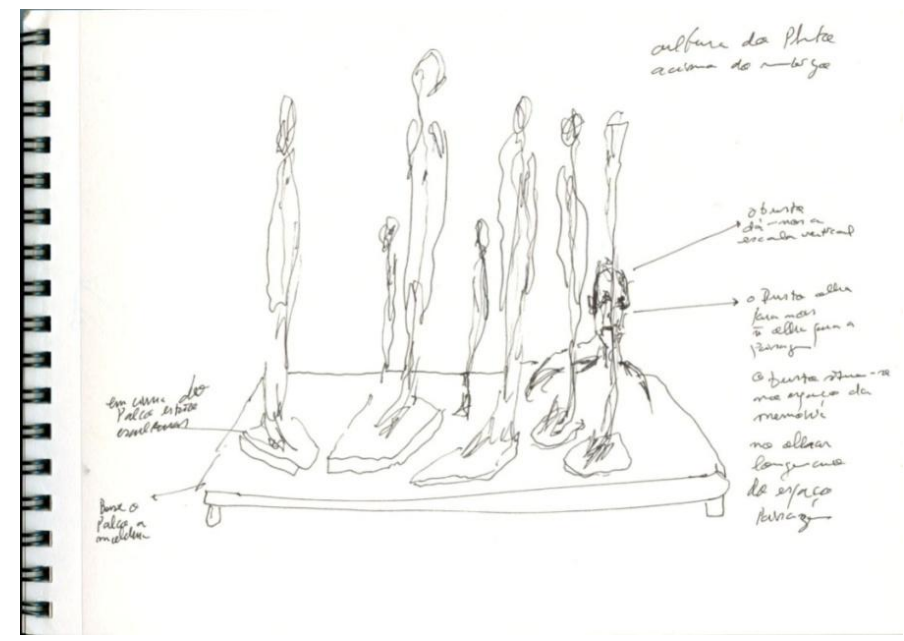

Fig. 32

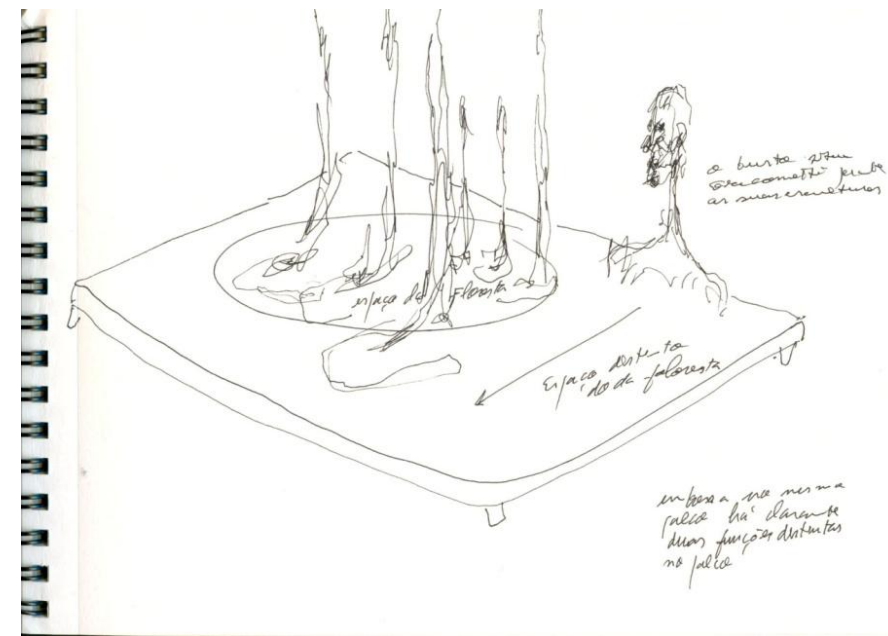

Fig. 33 


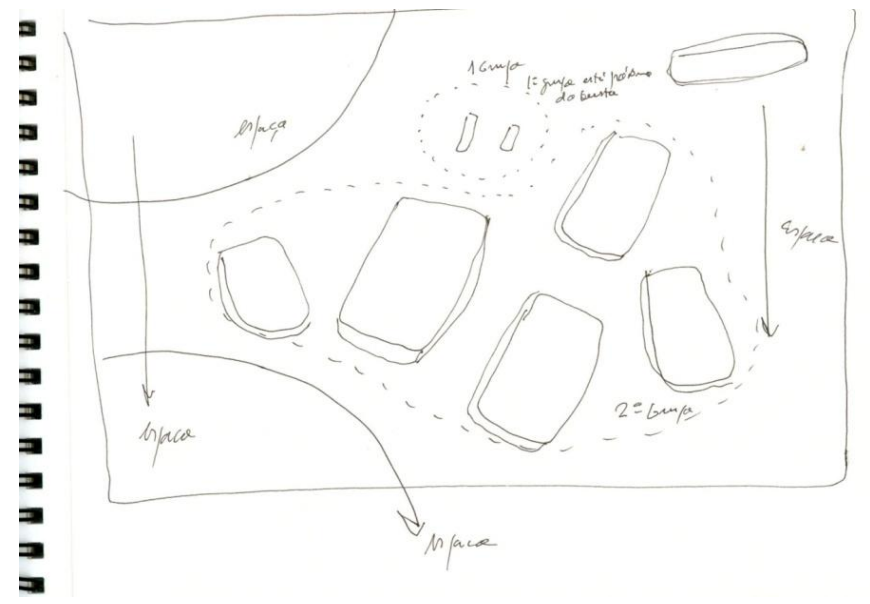

Fig. 34

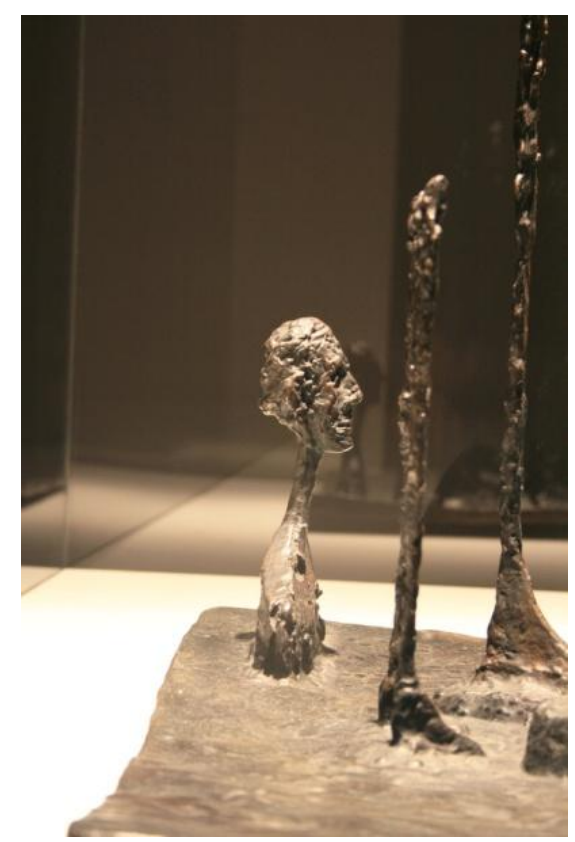

Fig. 35 y 36 Fotografías realizadas a partir de la escultura de A. Giacometti titulada La forêt, tras varias visitas a la exposición titulada Silêncios, ${ }^{600}$ realizada en el Museu Berardo entre 26 de octubre de 2009 y 10 de enero de 2010.

${ }^{600}$ Comisariada por Martin Karmitz, vide nota anterior. 


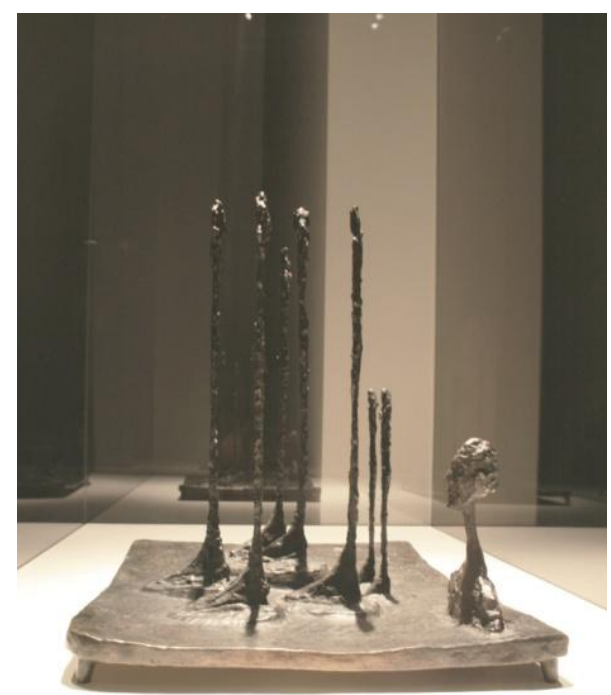

Fig. 36

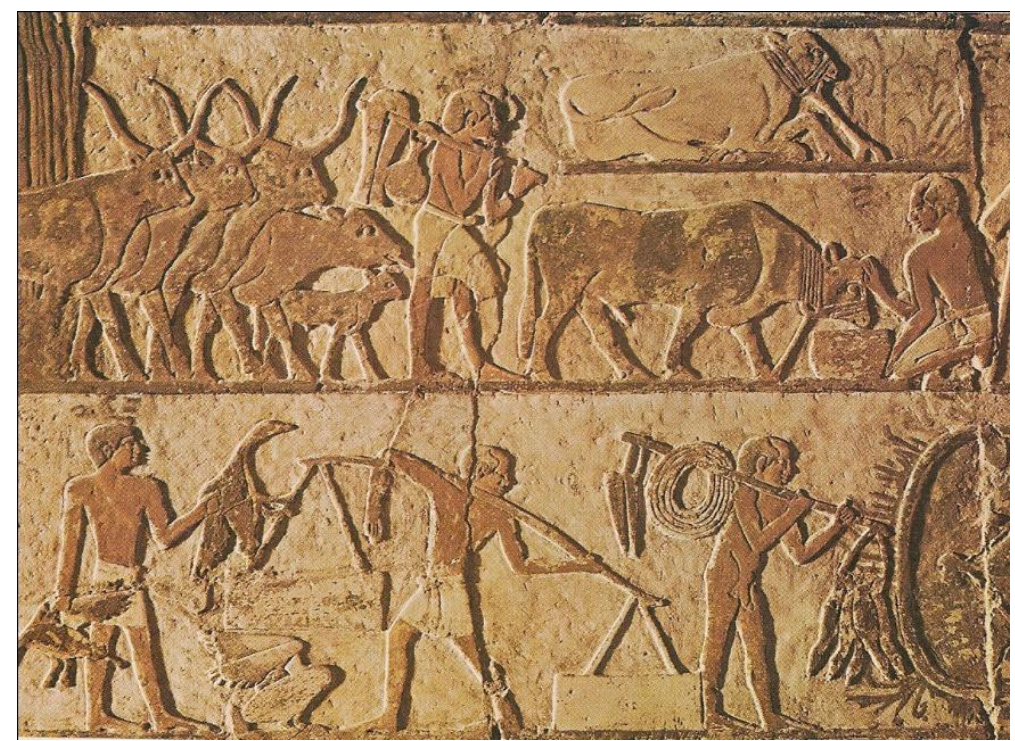

Fig. 37 Relieve polícromo de un túmulo del antiguo imperio, en Saqqara, Egipto. 


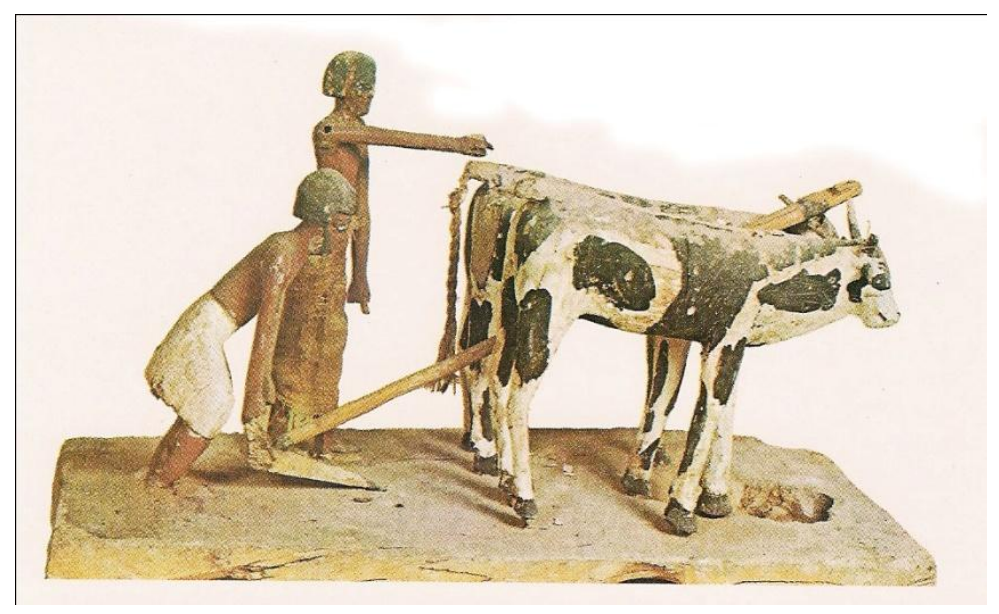

Fig. 38 Escena de labranza reproducida con los ushabti, (pequeñas estatuillas funerarias de madera) Dinastía XI.

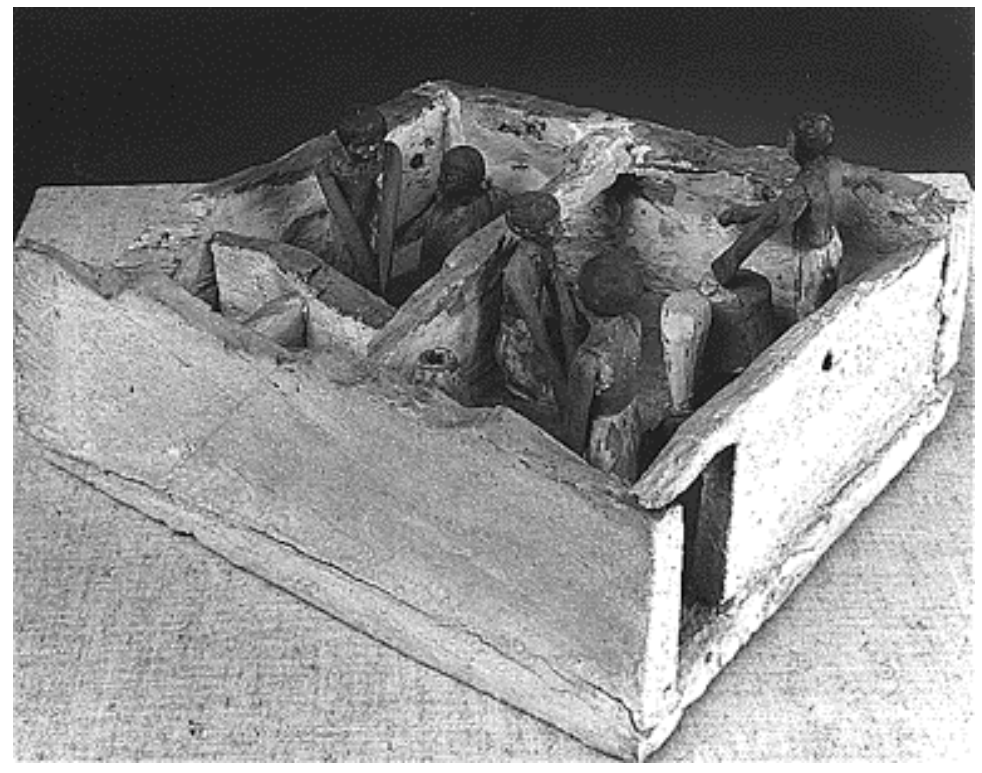

Fig. 39 Figura Periodo medio, Dinastía XII, Madera Pintada. Procedencia: El Berscheh 


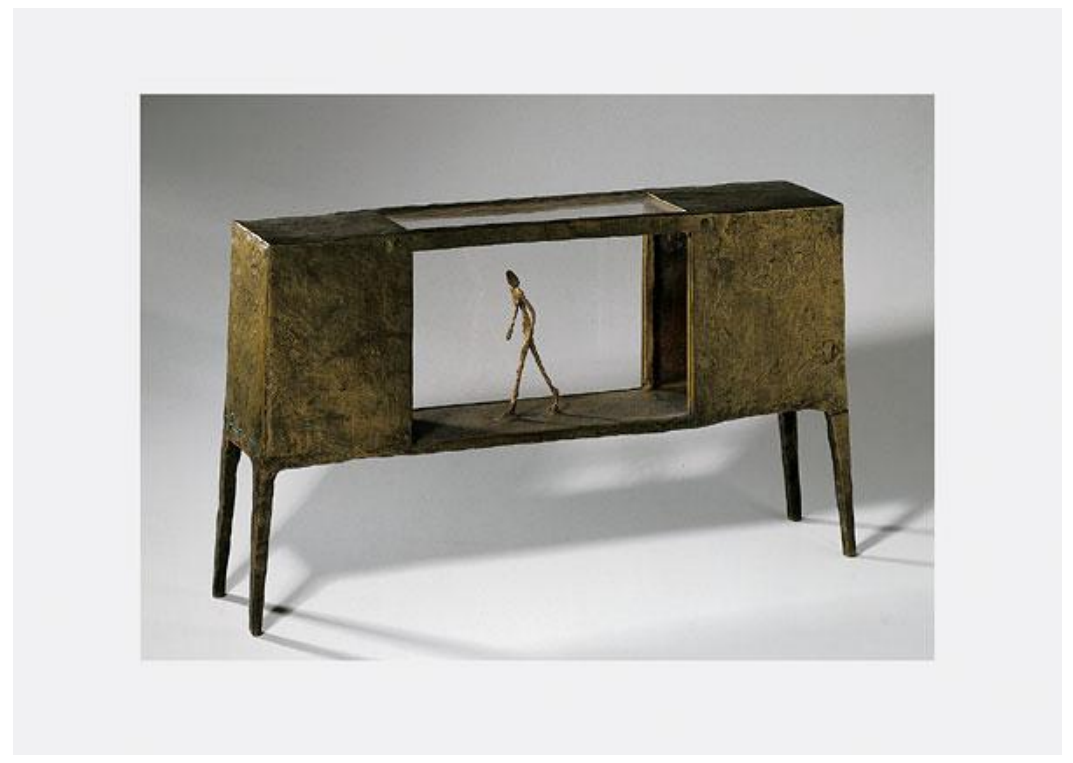

Fig. 40 Alberto Giacometti, Figurine Dans Une Boîte Entre Deux Maisons, (Figura en una caja entre dos casas), 1950, Bronce pintado y plexiglás, 30X54X9,5 cm, Colección Particular

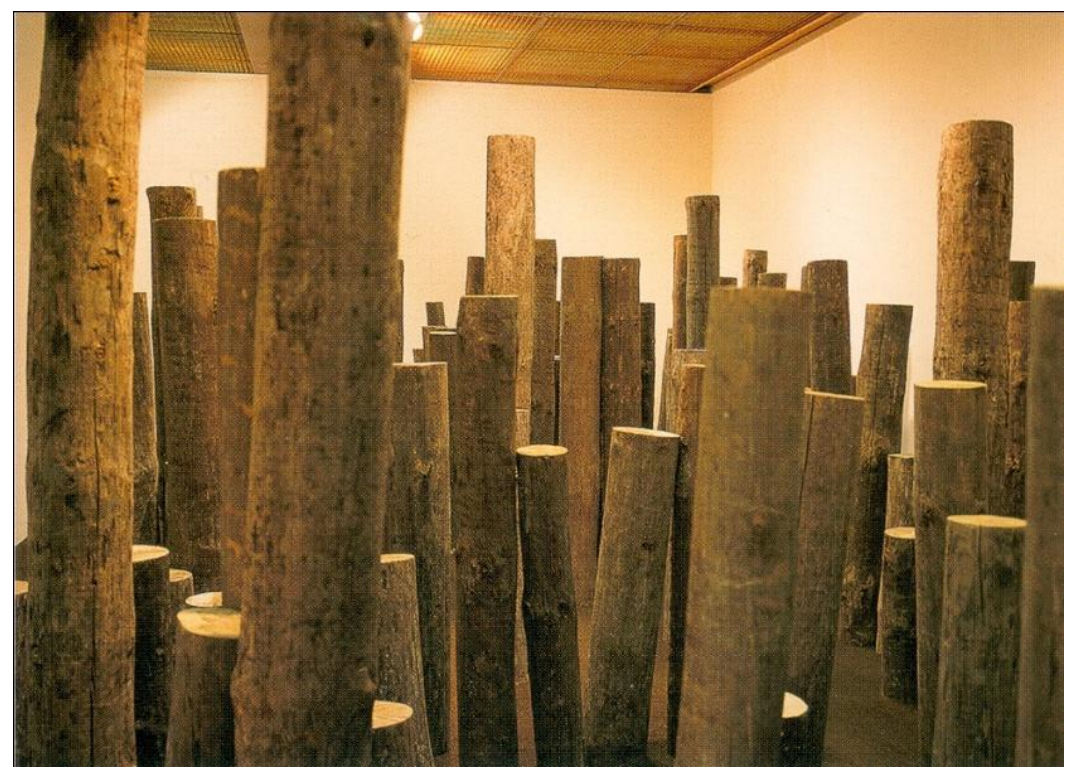

Fig. 41 Alberto Carneiro, Uma Floresta para os teus Sonhos, (Un bosque para tus sueños), 1970, Troncos cortados de pino; dimensiones variables, Colección Centro de Arte Moderno de la Fundación Calouste Gulbenkian, Lisboa. 

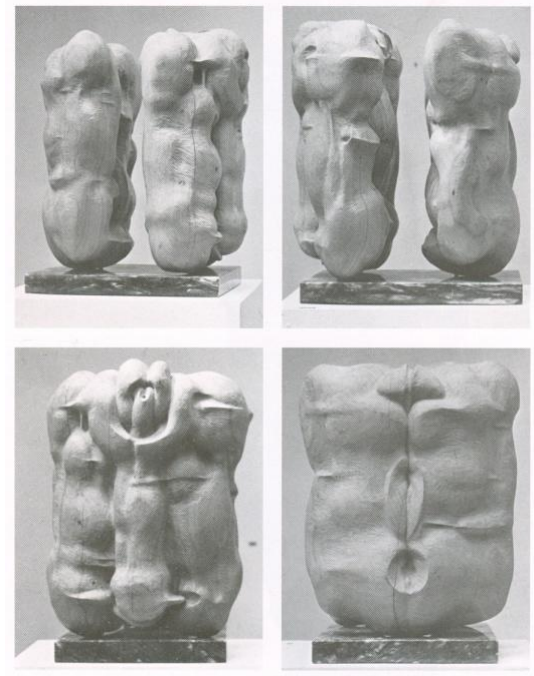

Fig. 42 Alberto Carneiro, Macho - fêmea, madera,1965-66

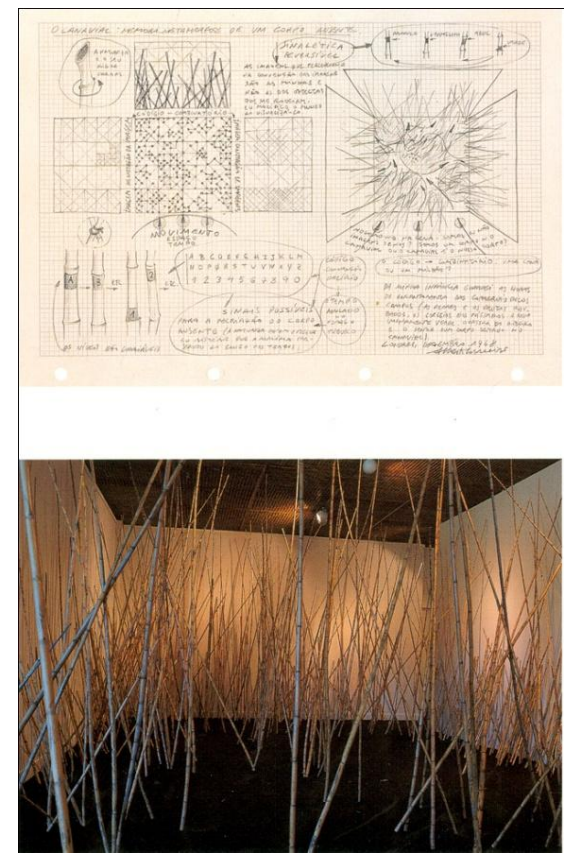

Fig. 43 Alberto Carneiro, O canavial: memória metamorfose de um corpo ausente, (El Cañaveral: memoria metamorfosis de un cuerpo ausente), 1968, Cañas, cintas de color, letras de calco, rafia; dimensiones variables, Colección Caixa Geral de Depósitos 

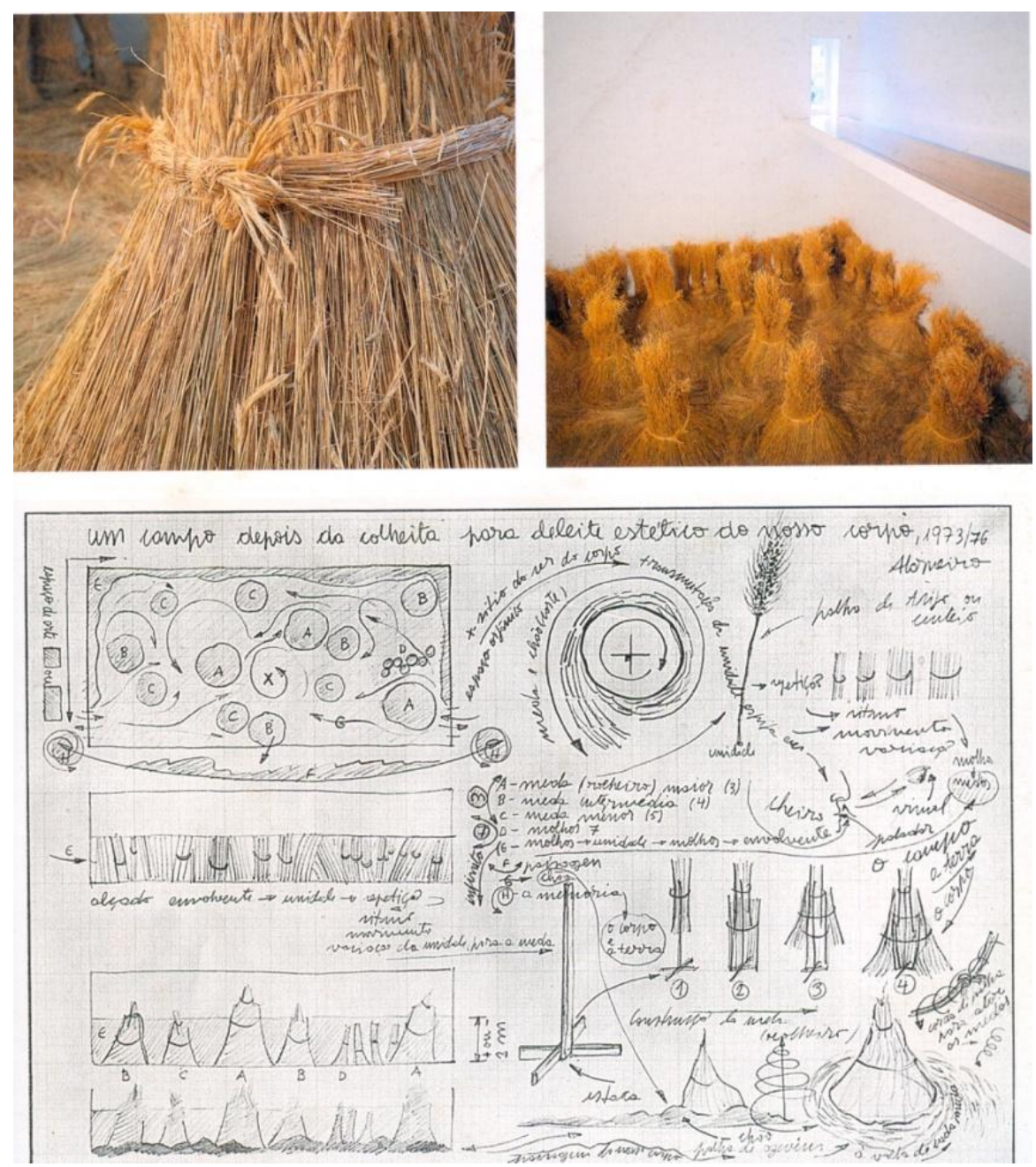

Fig. 44 Alberto Carneiro, Um campo depois da colheita para deleite estético do nosso cuerpo (Un campo después de la cosecha para deleite estético de nuestro cuerpo),1973-76, Centeno, heno; Dimensiones variables, Colección del artista, Instalación en el CGAC - Centro Galego de Arte Contemporánea, Santiago de Compostela, 2001. 


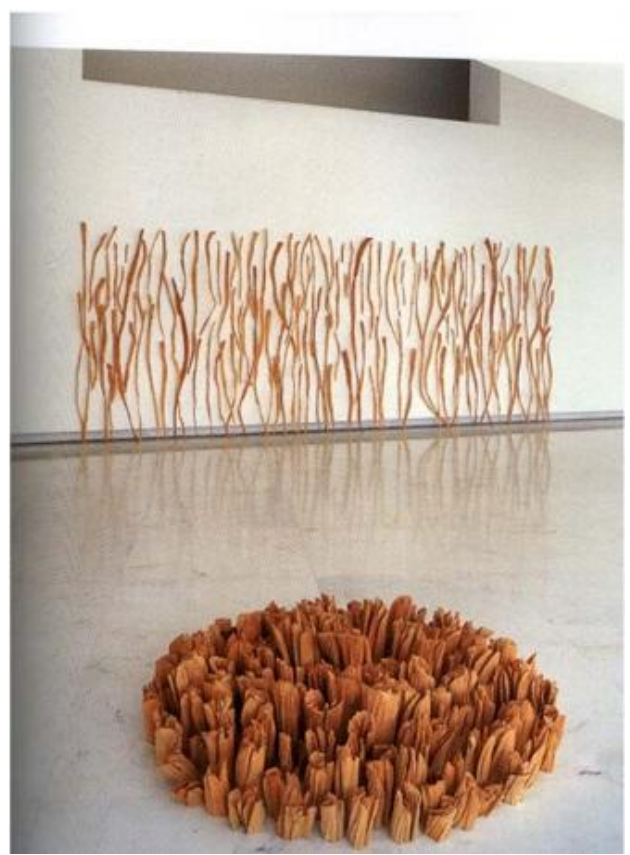

Fig. 45 Alberto Carneiro, Sobre o meu jardim (Sobre mi jardín) 1998-99. Madera; 38 x $180 \times 180 \mathrm{~cm}$, Colección del artista, Instalación en el CGAC Centro Galego de Arte Contemporánea, Santiago de Compostela, 2001

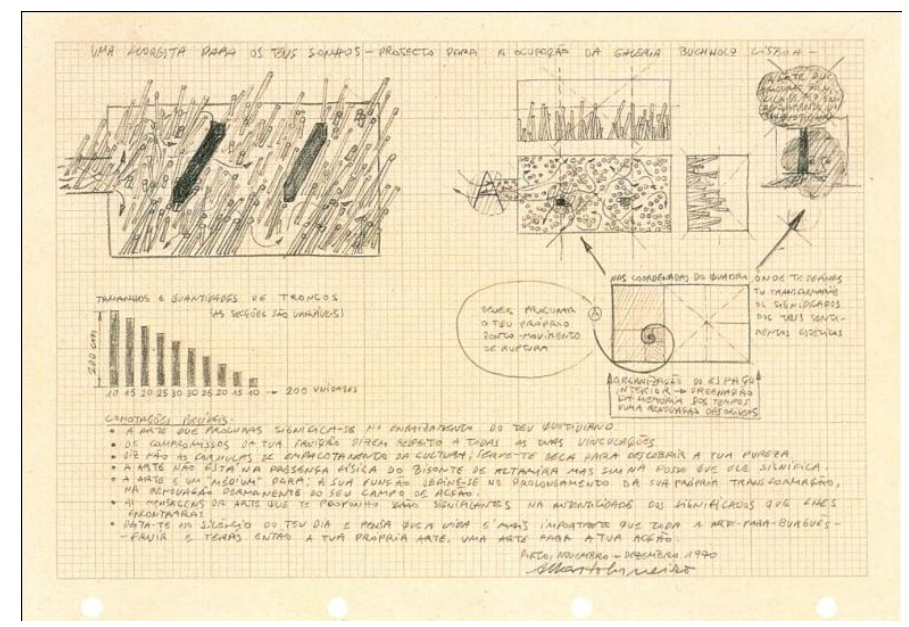

Fig.46 Alberto Carneiro, Proyecto para Uma floresta para os teus sonhos (Un bosque para tus sueños), 1970, Grafito sobre papel milimétrico, 21×29,5 cm, Colección Fundação Luso- Americana para o Desenvolvimento 


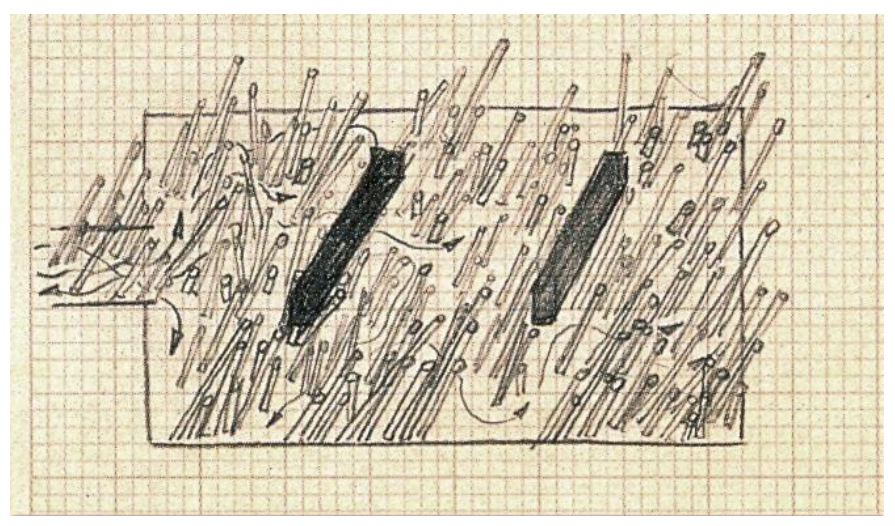

Fig. 47 Fragmento del dibujo de Uma Floresta para os teus Sonhos, 1970.

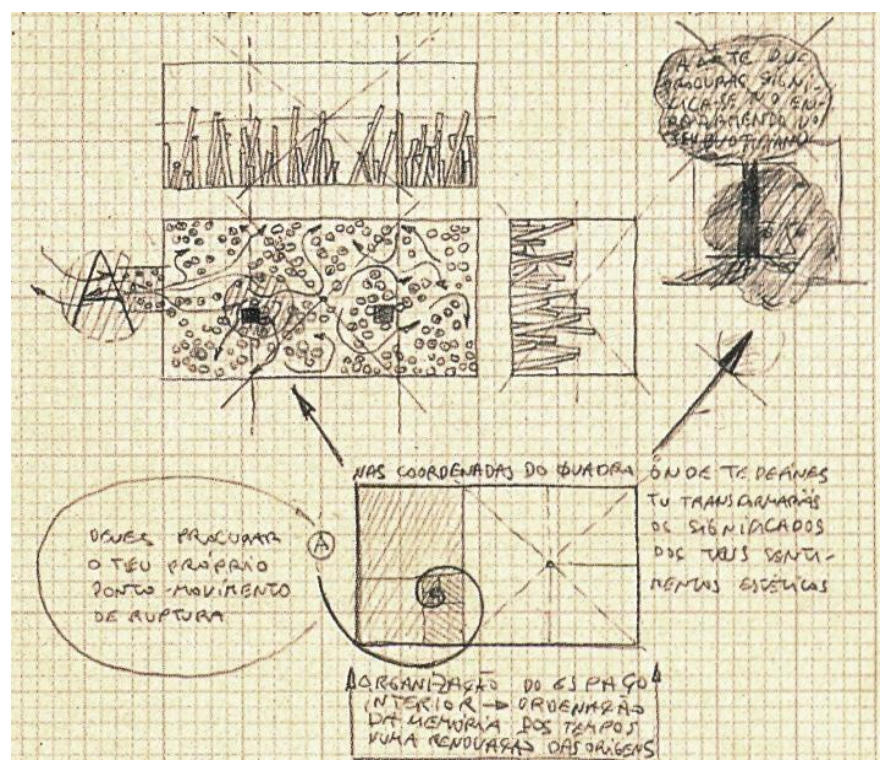

Fig. 48 Fragmento del dibujo de Uma Floresta para os teus Sonhos, 1970. 


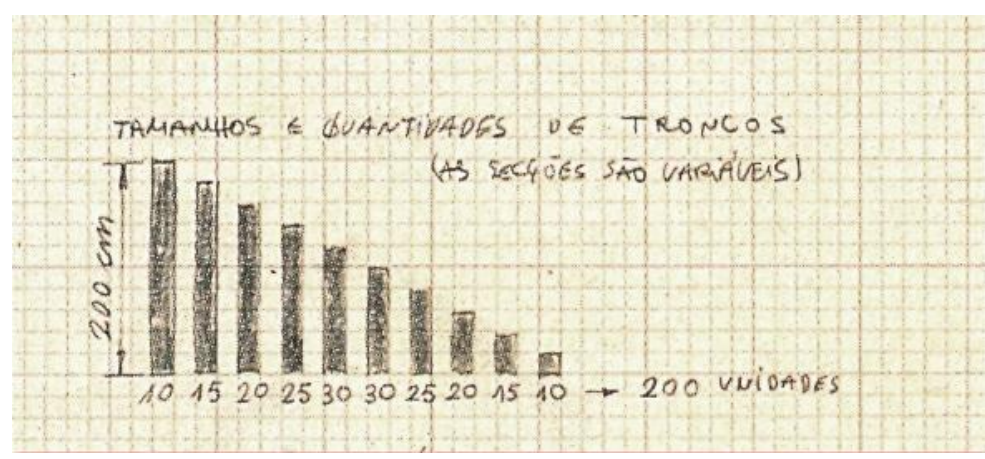

Fig. 49 Fragmento del dibujo de Uma Floresta para os teus Sonhos, 1970.

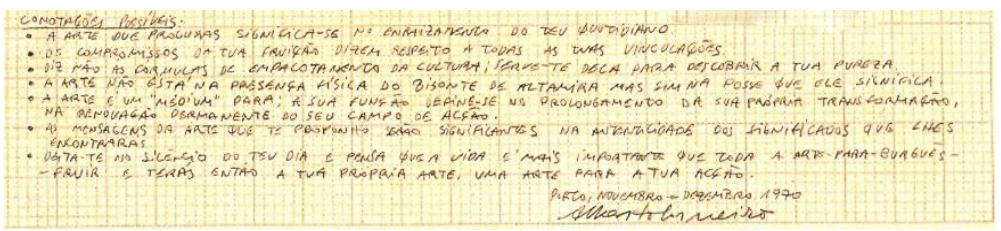

Fig. 50 Fragmento del dibujo de Uma Floresta para os teus Sonhos, 1970.

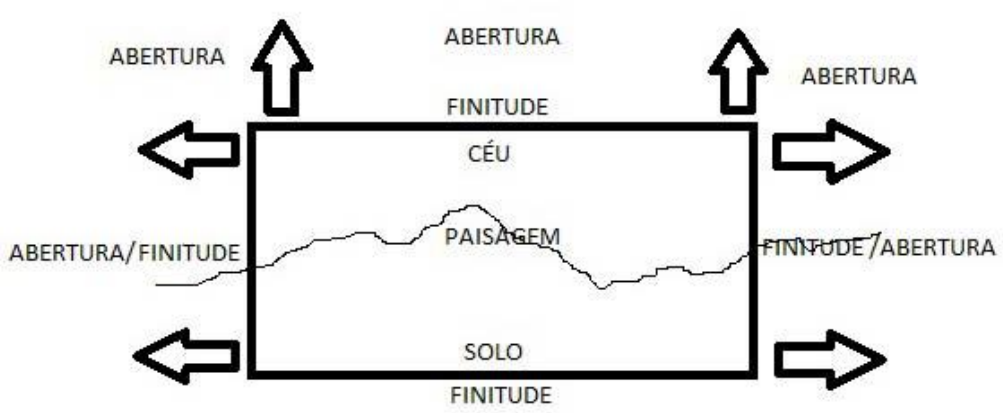

Fig. 51 Esquema interpretativo de la noción de espacio paisaje de Rosario Assunto. 

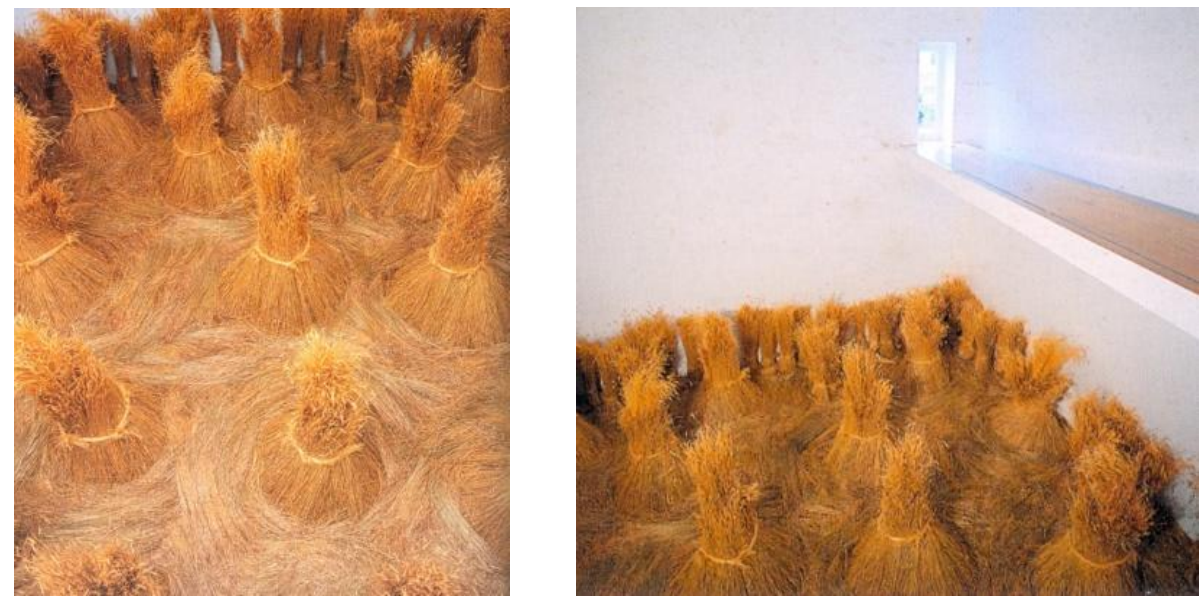

Fig. 52 y 53 Alberto Carneiro, Um campo depois da colheita para deleite estético do nosso cuerpo, (Un campo después de la cosecha para deleite estético de nuestro cuerpo), 1973-76. Centeno, heno; Dimensiones variables, Colección del artista, Instalación en el Centro Galego de Arte Contemporánea, Santiago de Compostela, 2001.
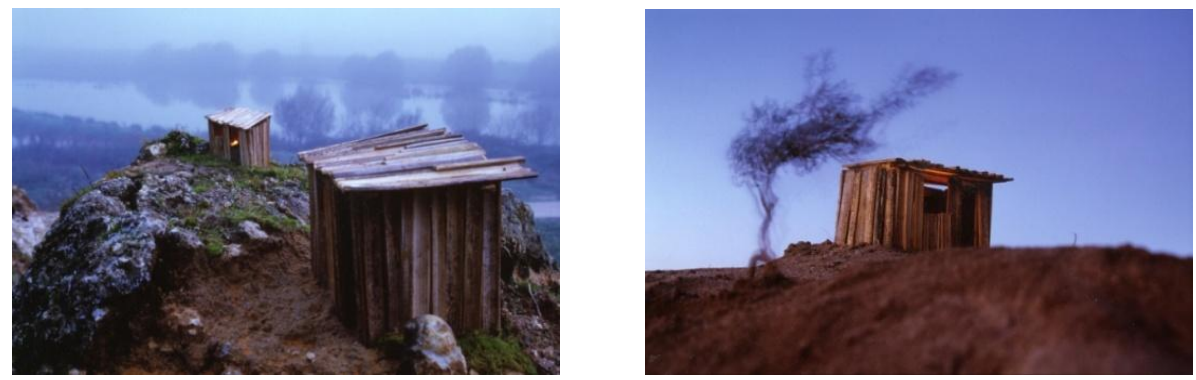

Fig. 54 Samuel Rama, S/Título - Serie Habitar a Penumbra, 2003, Fotografía a color, Impresión Ilfochrome Polyester, 27×40 cm Fig. 55 Samuel Rama, S/Título - Serie Habitar a Penumbra, 2003, Fotografía a color, Impresión Ilfochrome Polyester, $40 \times 60 \mathrm{~cm}$. 

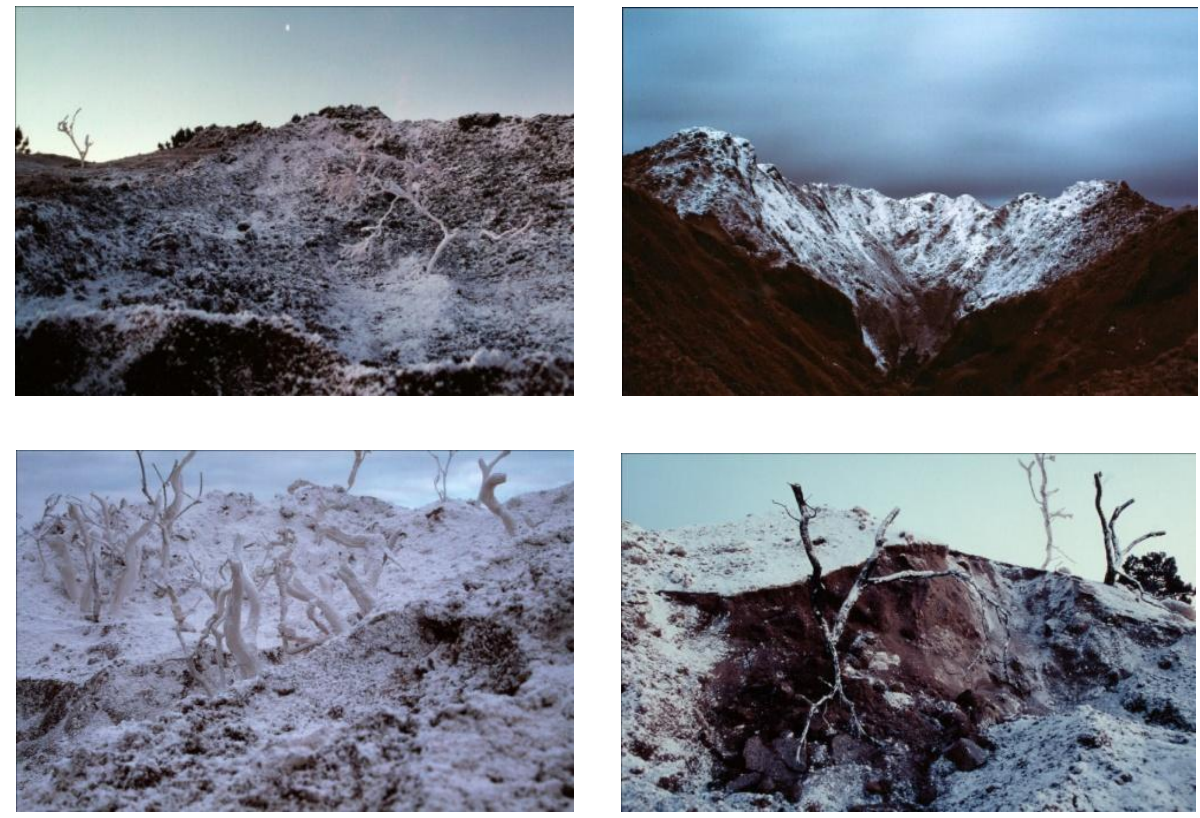

Fig.56 Samuel Rama, S/Título - Serie desenhar- esculpir - fotografar, 2004, Fotografía a color, Impresión Ilfochrome Polyester, 70x50 cm. Fig. 57 Samuel Rama, S/Título - Serie desenhar- esculpir - fotografar, 2004, Fotografía a color, Impresión Ilfochrome Polyester, 70x50 cm. Fig. 58 Samuel Rama, S/Título - Serie desenhar- esculpir - fotografar, 2004, Fotografía a color, Impresión llfochrome Polyester, 70x50 cm. Fig 59 Samuel Rama, S/Título - Serie desenhar- esculpir - fotografar, 2004, Fotografía a color, Impresión Ilfochrome Polyester, $70 \times 50 \mathrm{~cm}$. 


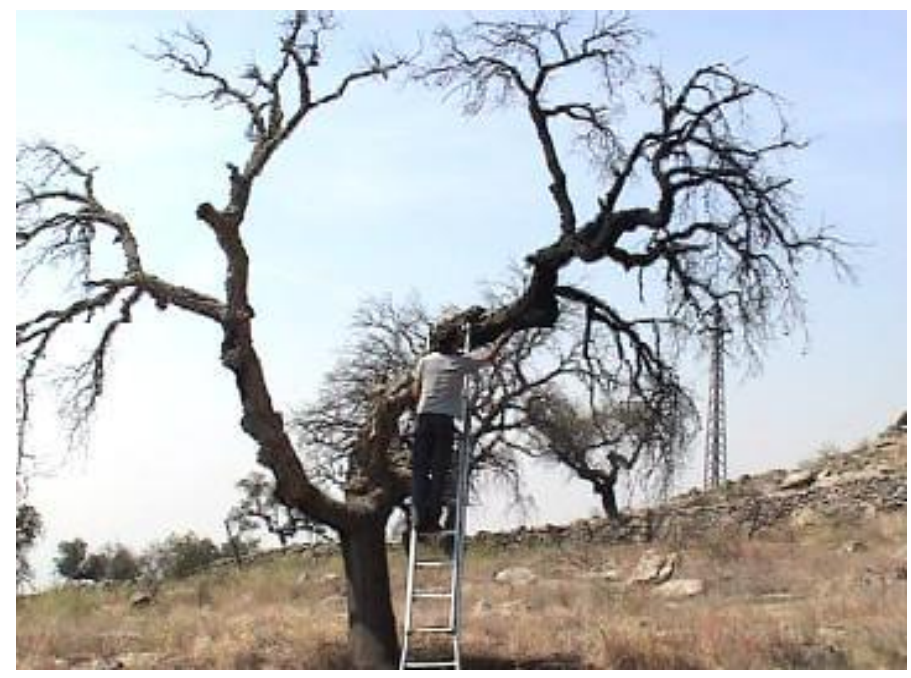

Fig. 60 Samuel Rama, Registro de la performance de pintura del árbol con tinta china a lo largo de tres días.
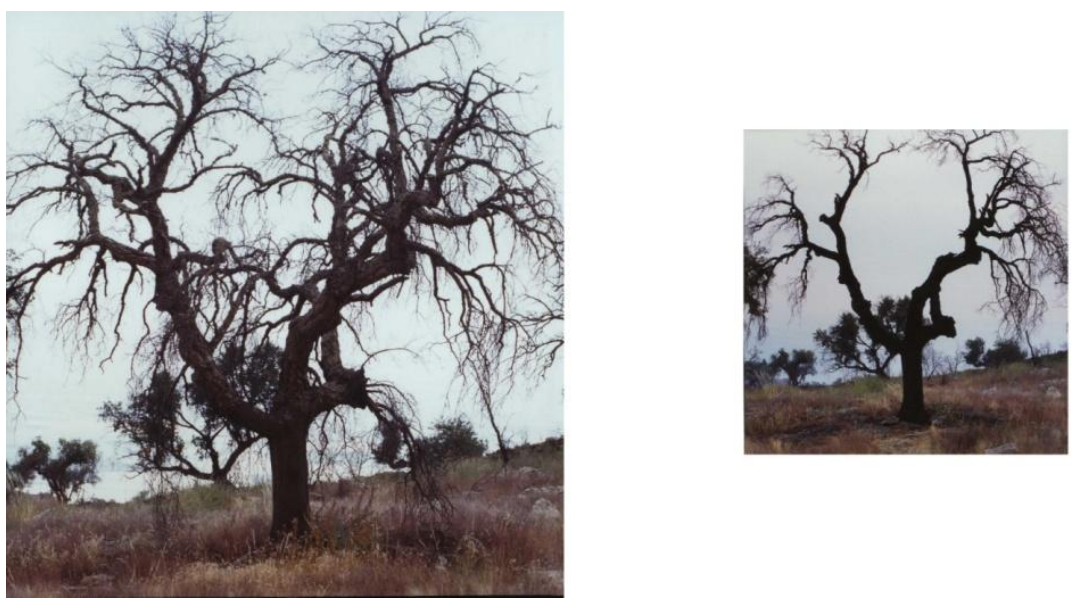

Fig. 61 Samuel Rama, Árvore(s) Enquanto desejo de posse do desenho, 2005, Impresión llfochrome Polyester, $2(100 \mathrm{~cm} \times 100 \mathrm{~cm})+(9 \mathrm{~cm} \times 9 \mathrm{~cm})$ 

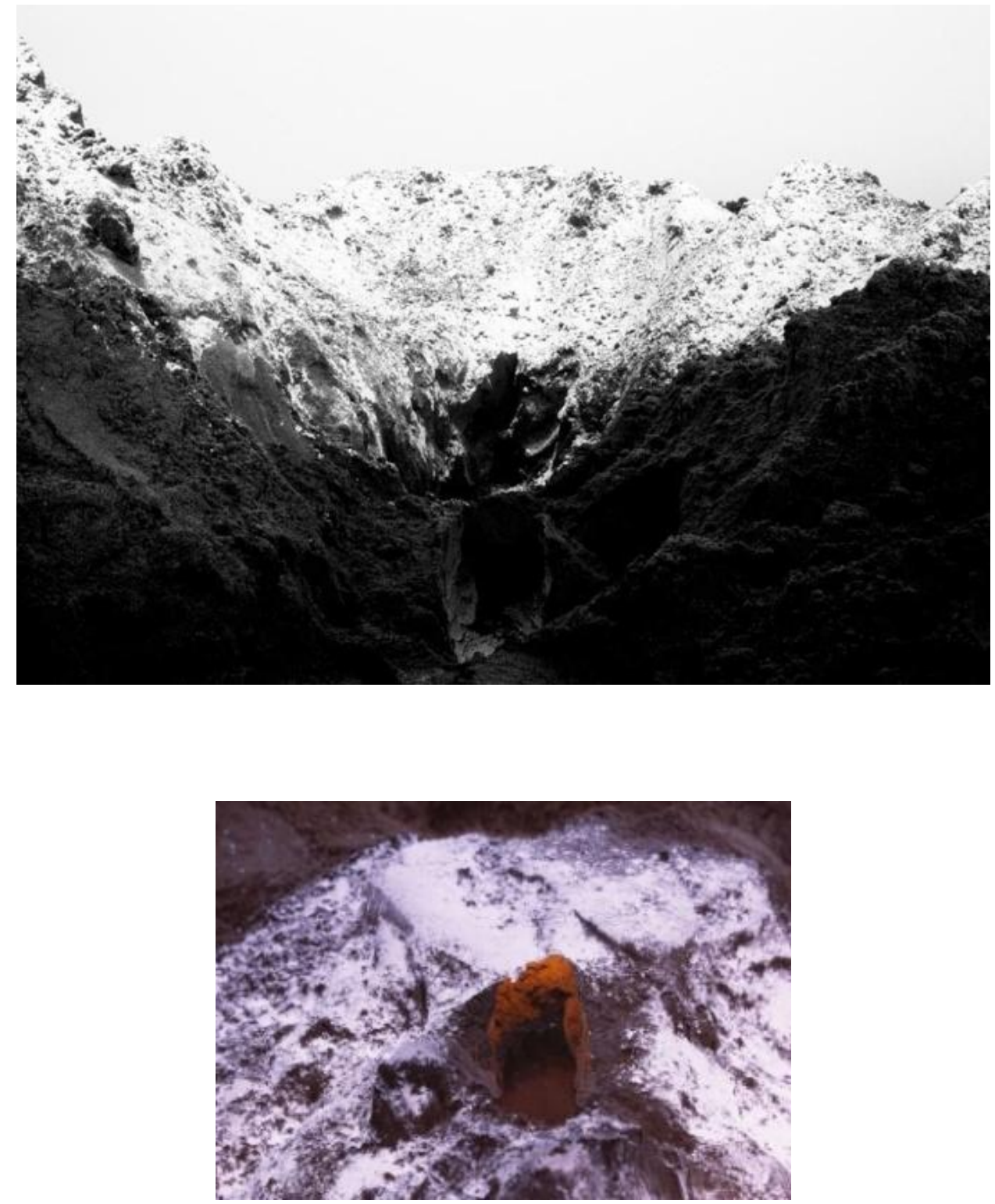

Fig. 62 Samuel Rama, Dobrar a terra, 2007, Impresión chorro de tinta larga duración sobre papel Fine art, $2(70 \mathrm{~cm} \times 100 \mathrm{~cm})+(9 \mathrm{~cm} \times 13 \mathrm{~cm})$ 

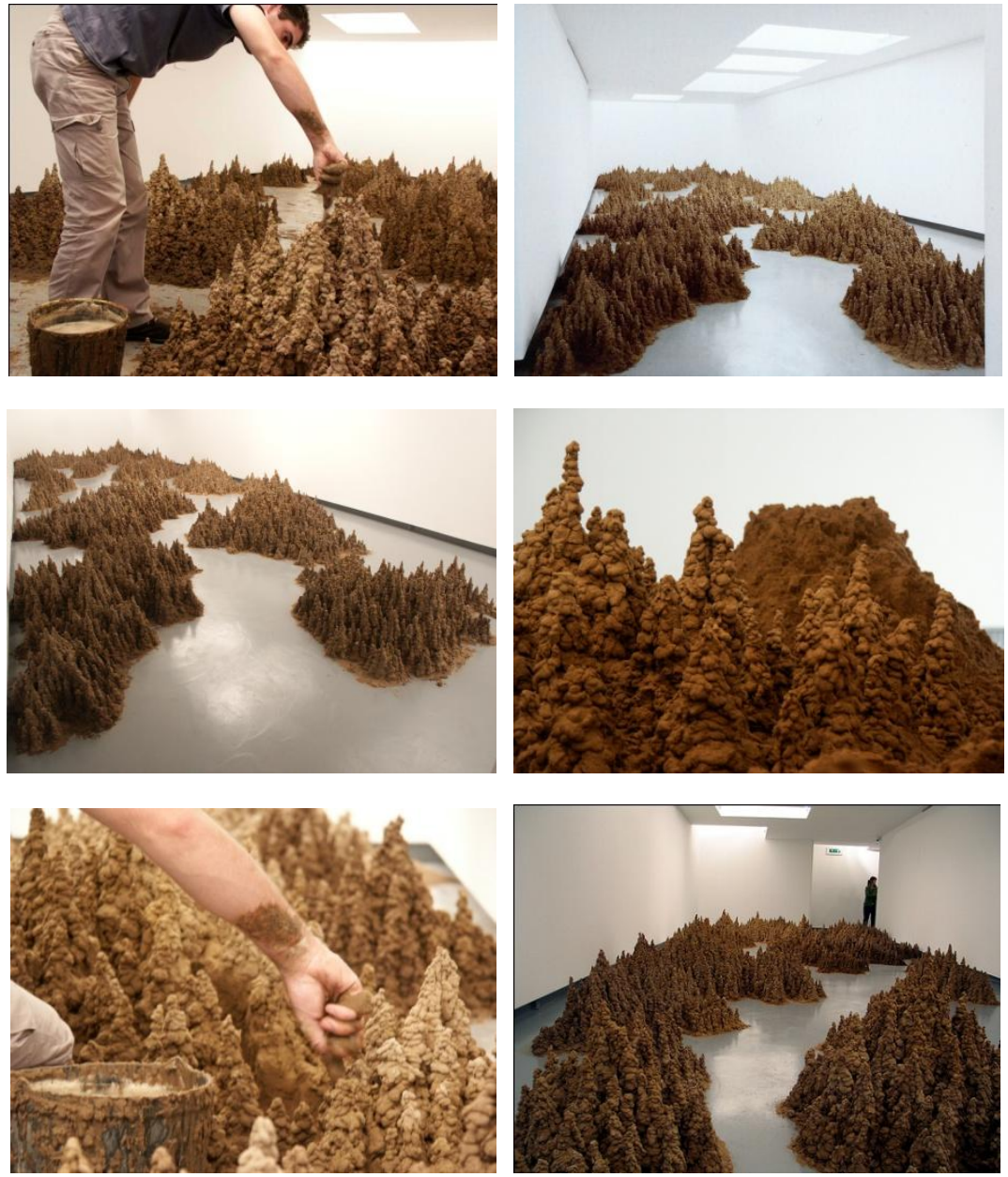

Fig. 63 Samuel Rama, Vontade, 2004, Apariencia de la instalación en el Espaço AC, Lisboa, Arena y agua en un área de $600 \times 400 \mathrm{~cm}$. 

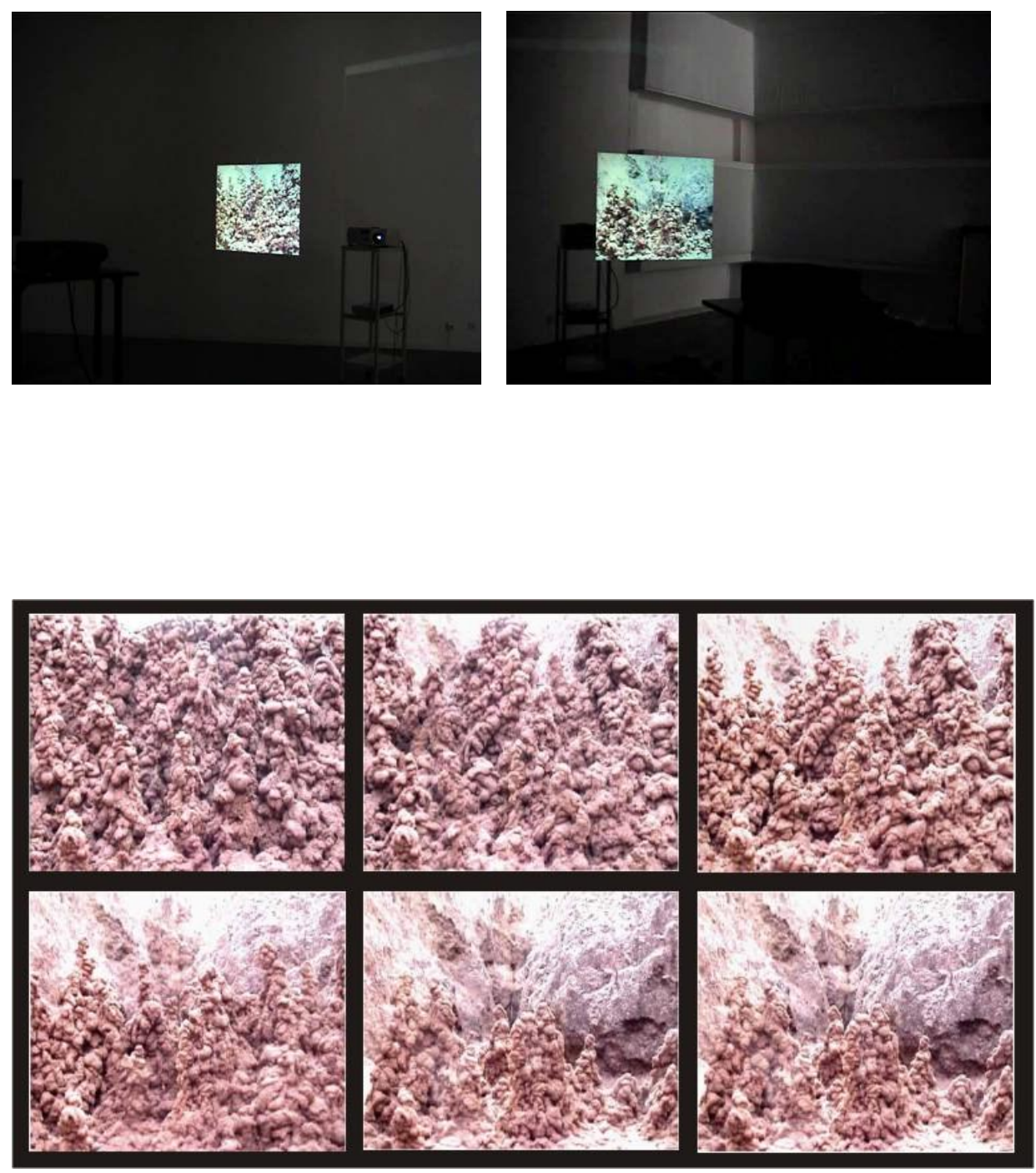

Fig. 64 Samuel Rama, S/ Titulo, 2004, 4’30", Loop, Instalación video. 

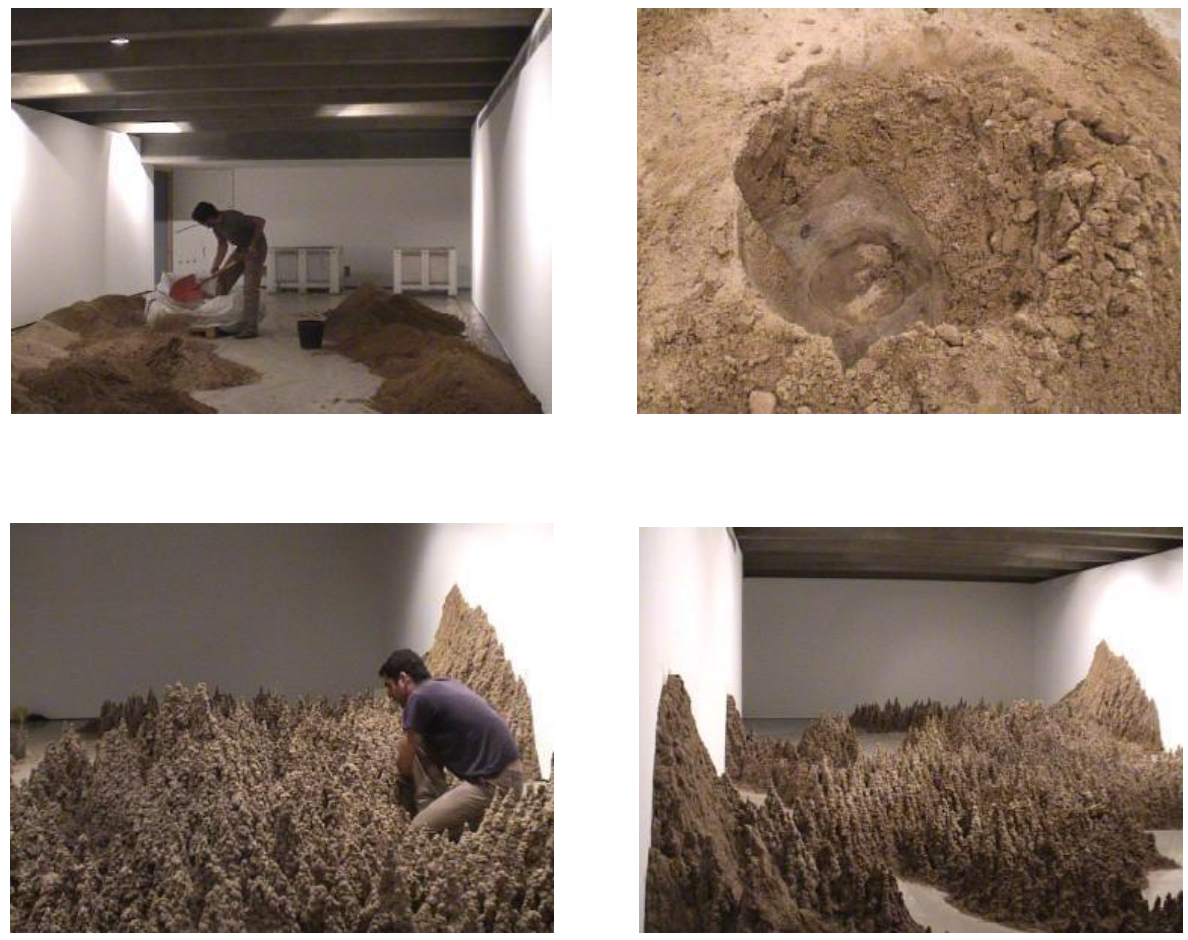

Fig. 65 Samuel Rama, Construcción de Fadiga de Estruturas.

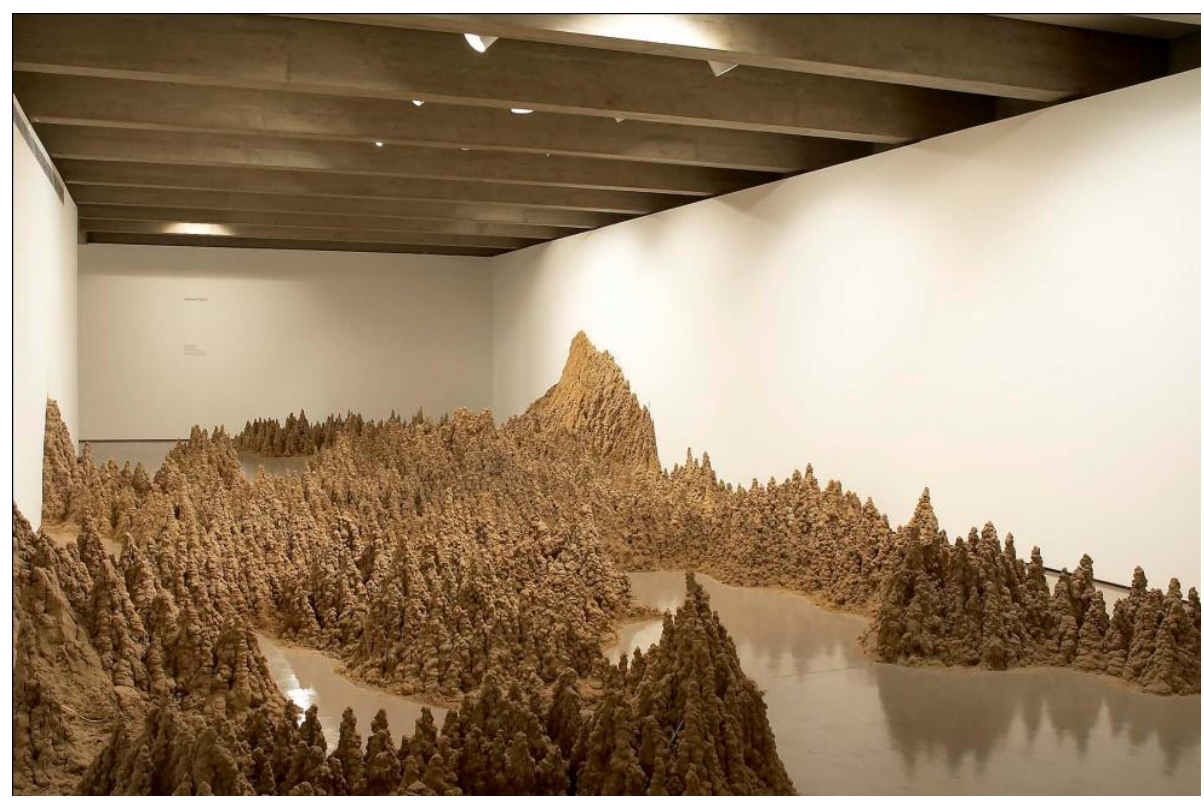




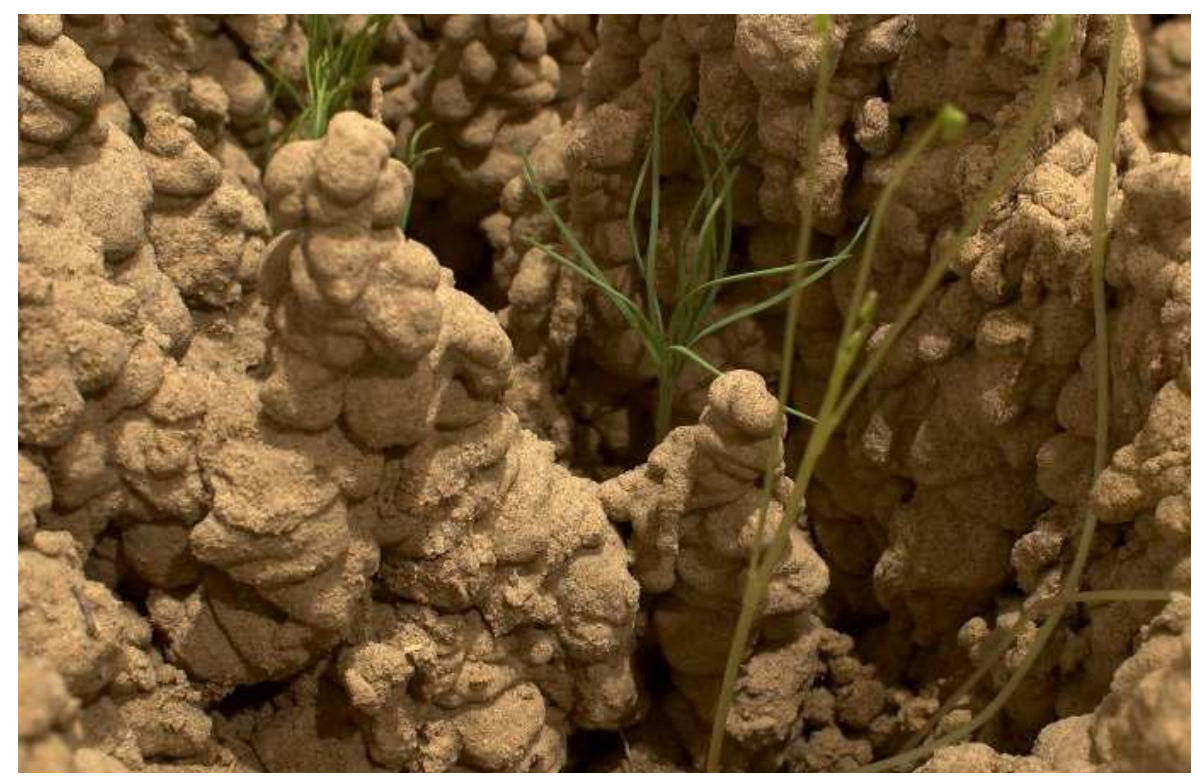

Fig. 65 Samuel Rama, Fadiga de estruturas, 2005-06, Vista de la Instalación realizada en la sede de la Fundación Calouste Gulbenkian, Lisboa, en un área de 600 X $1150 \mathrm{~cm}$.
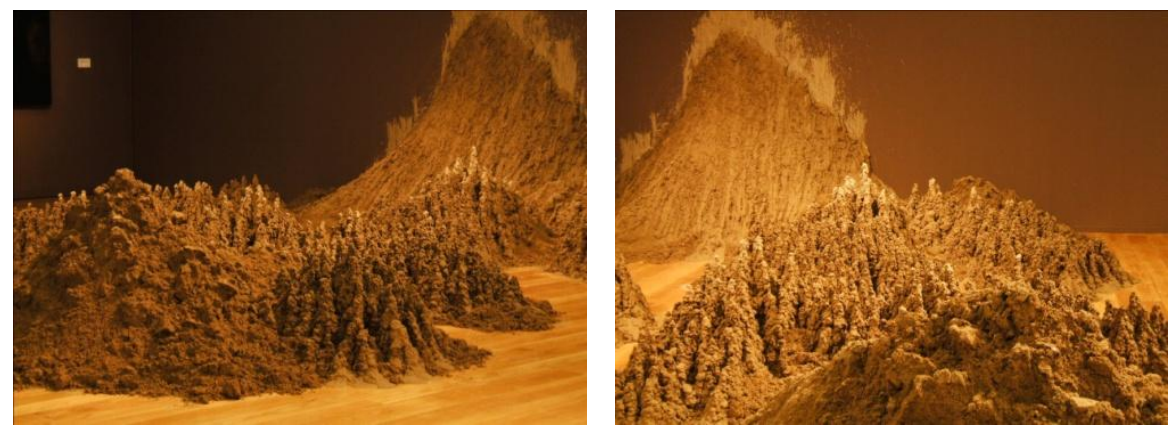

Fig. 66 Samuel Rama, Wander, 2007, Vista de la Instalación realizada para el IV International Prize of Painting Diputación de Castellón realizada en el Museo de Bellas Artes de Castellón, España, en un área de $600 \times 400 \mathrm{~cm}$. 


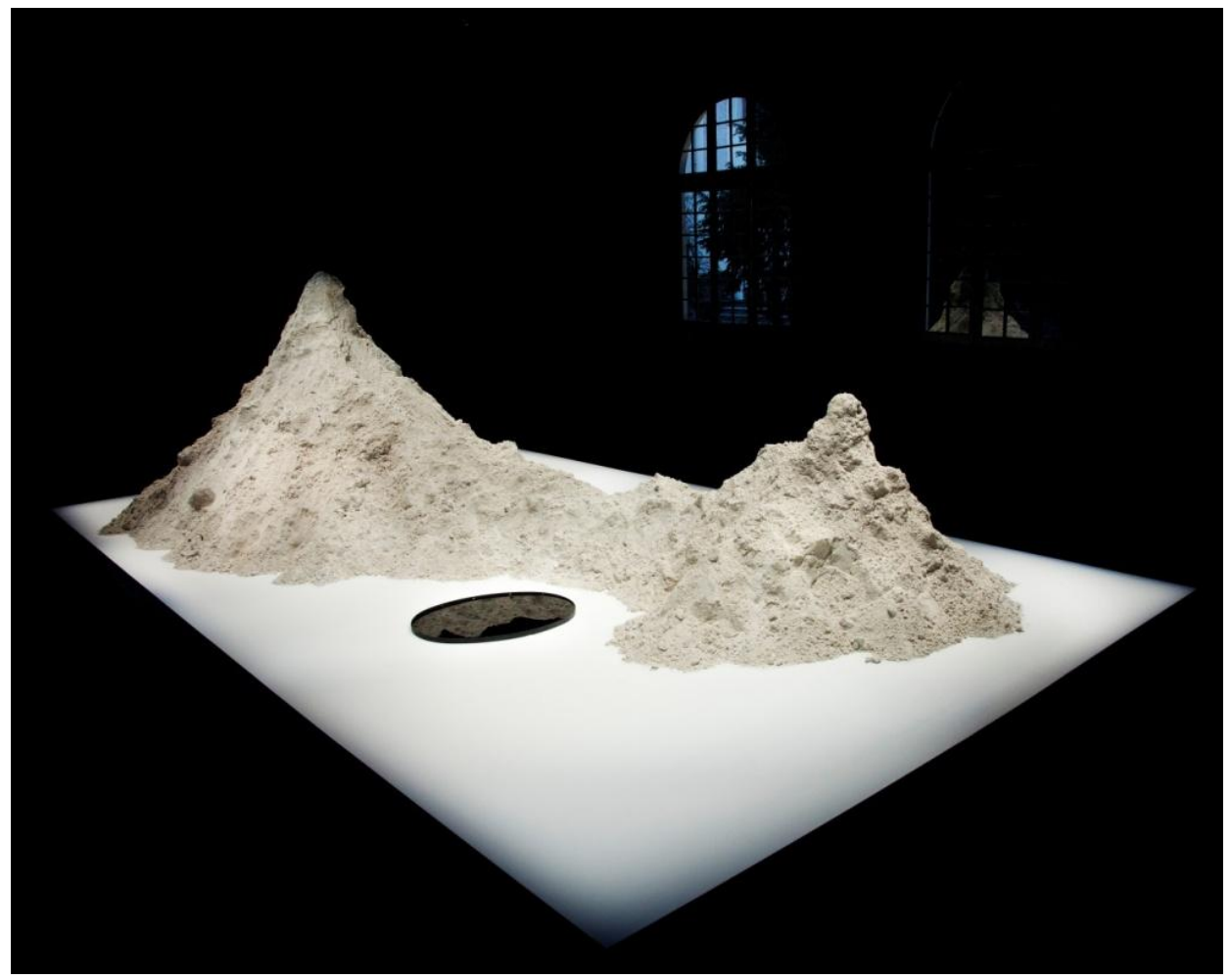

Fig. 67 Samuel Rama, MEGAPARSECS, 2012, Arena, palco, metal y aceite quemado Instalación Teatro da Politécnica, alt $260 \times$ larg $900 \times$ prof $600 \mathrm{~cm}$. 


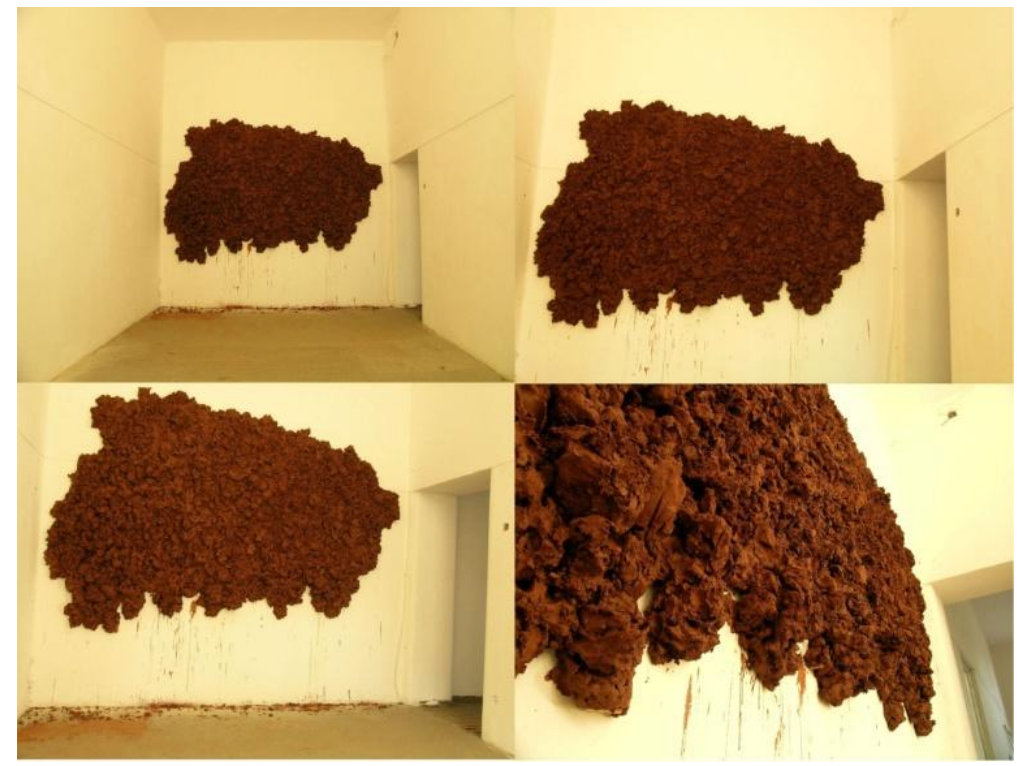

Fig. 68 Samuel Rama, Mancha \# 1, Barro sobre arquitectura,Dimensiones variables, 2009

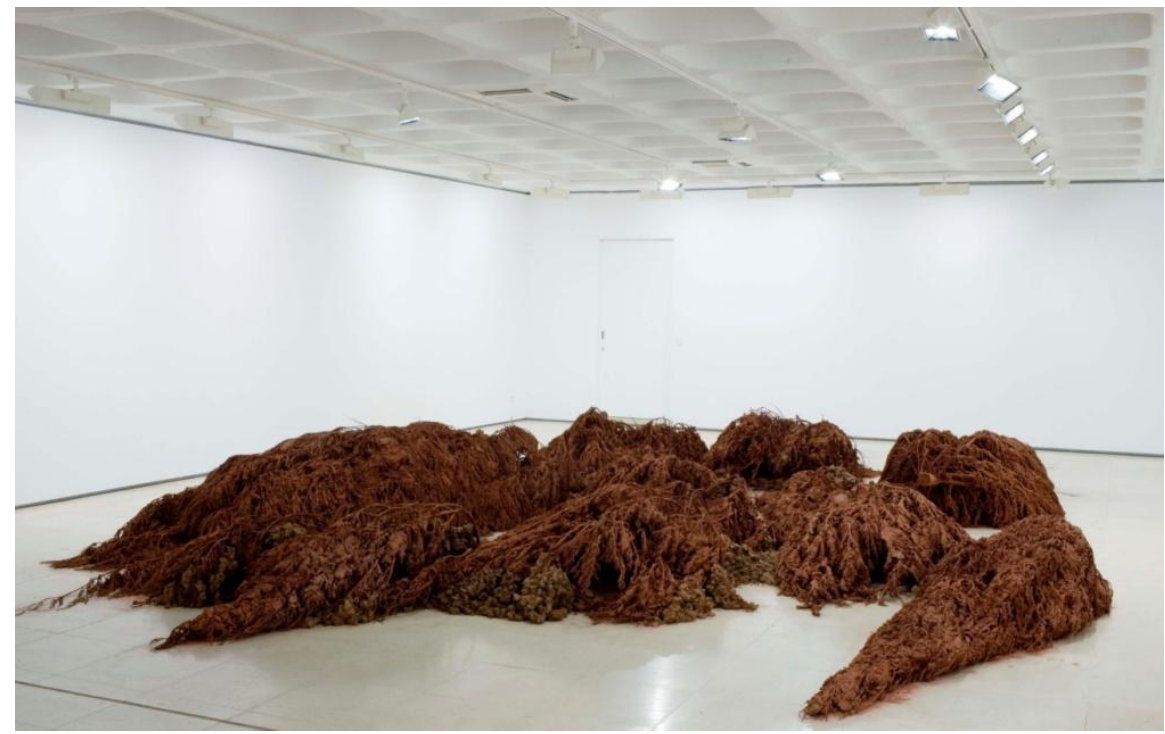

Fig. 69 Samuel Rama, MAGMA, 2008, Vista de la instalación Galeria 111. Árboles de ciprés, polvo de arcilla y barro fresco en un área de $10000 \times 10000 \mathrm{~cm}$ 


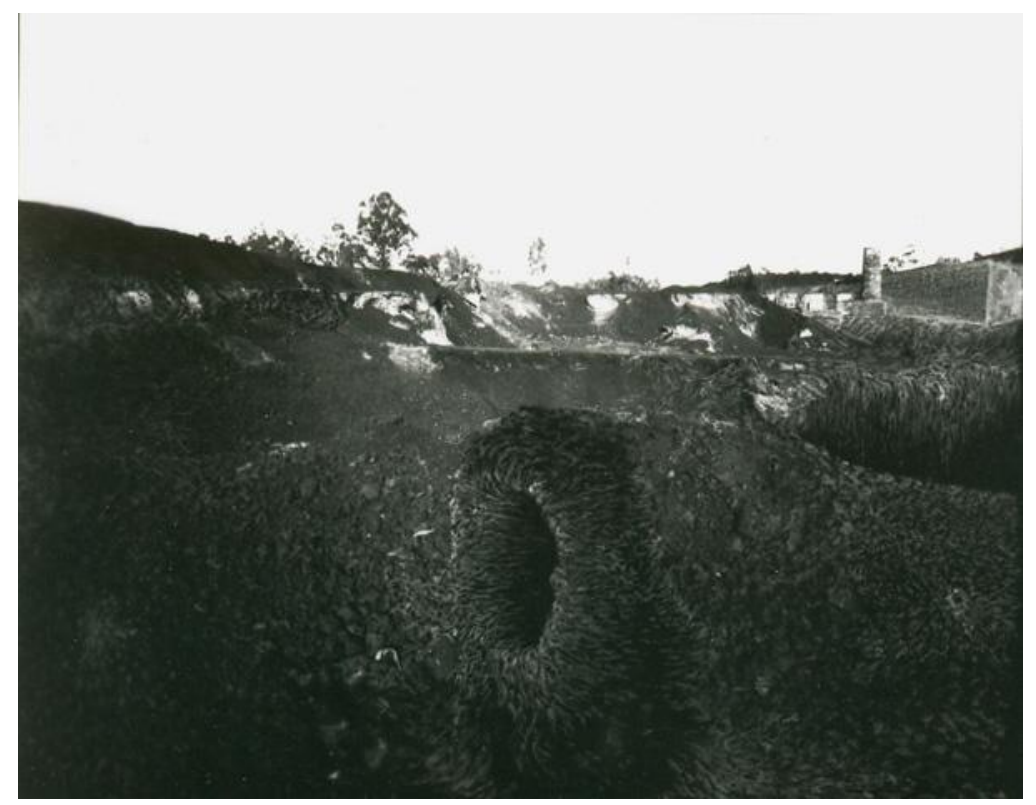

Fig. 70 Samuel Rama, Sem Título \#10, (serie MAGMA), 2008. Impresión chorro de tinta larga duración sobre papel Fine art $98 \mathrm{~cm} \times 124 \mathrm{~cm}$

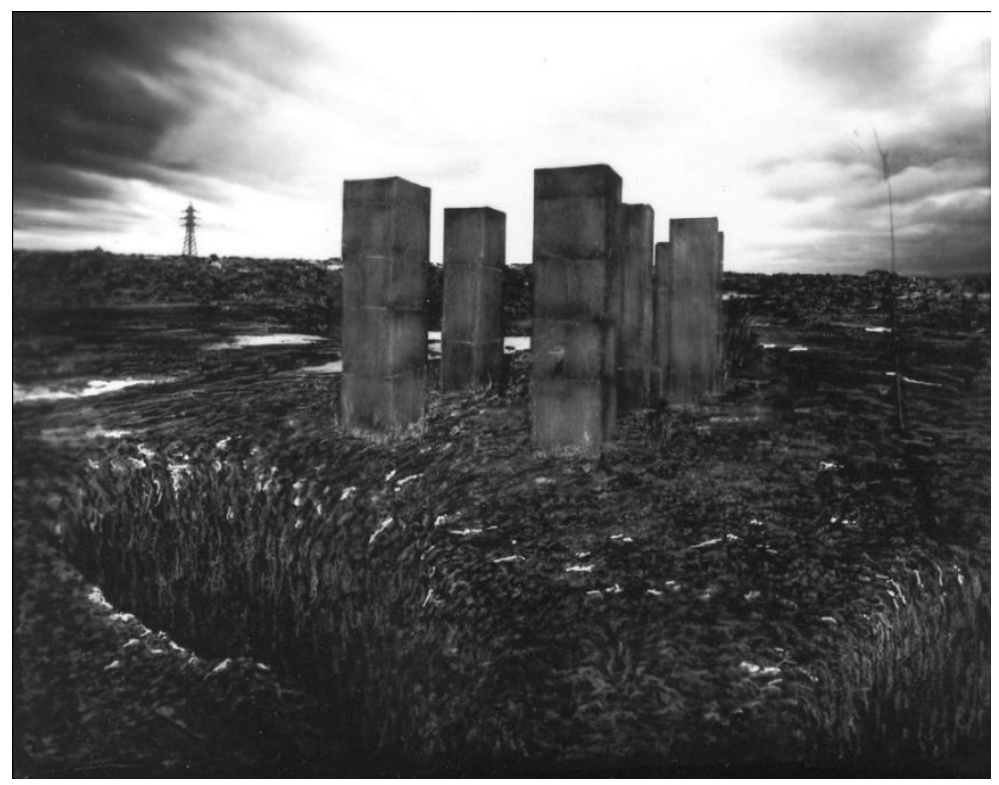

Fig. 71 Samuel Rama, Sem Título \#3, (serie MAGMA), 2008. Impresión chorro de tinta larga duración sobre papel Fine art $98 \mathrm{~cm} \times 124 \mathrm{~cm}$ 


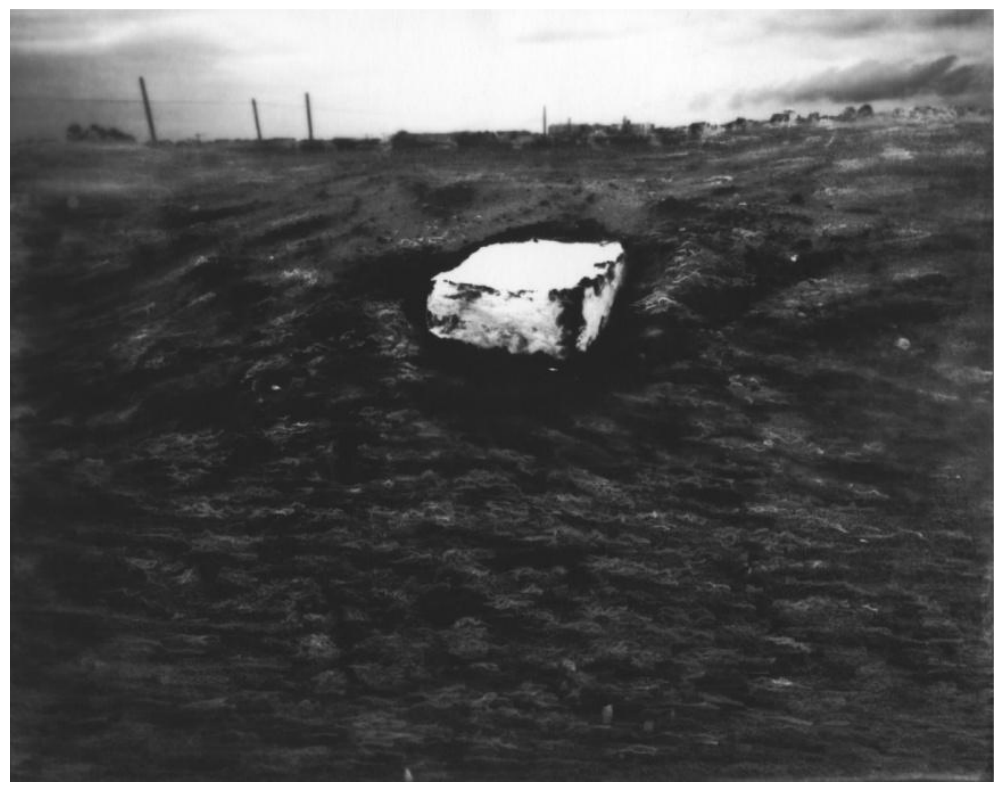

Fig. 72 - Samuel Rama, Sem Título \#6, (serie MAGMA), 2008. Impresión chorro de tinta larga duración sobre papel Fine art, $98 \mathrm{~cm} \times 124 \mathrm{~cm}$.

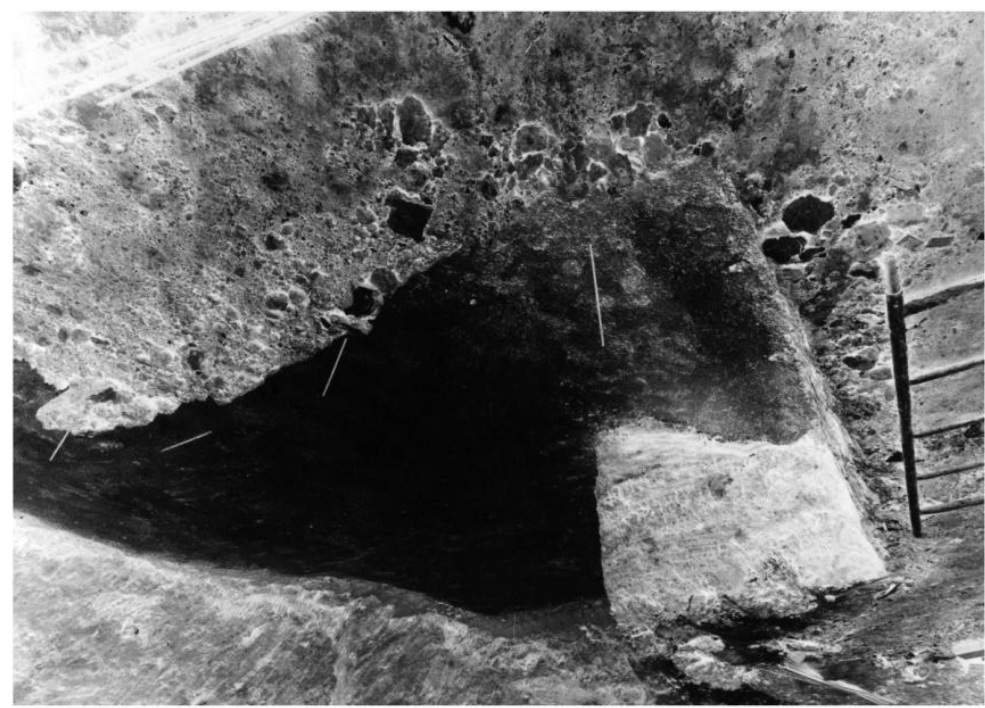

Fig. 73 Samuel Rama, Escavação \# 19, 2009. Impresión chorro de tinta larga duración sobre papel Fine art, $98 \mathrm{~cm} \times 124 \mathrm{~cm}$ 


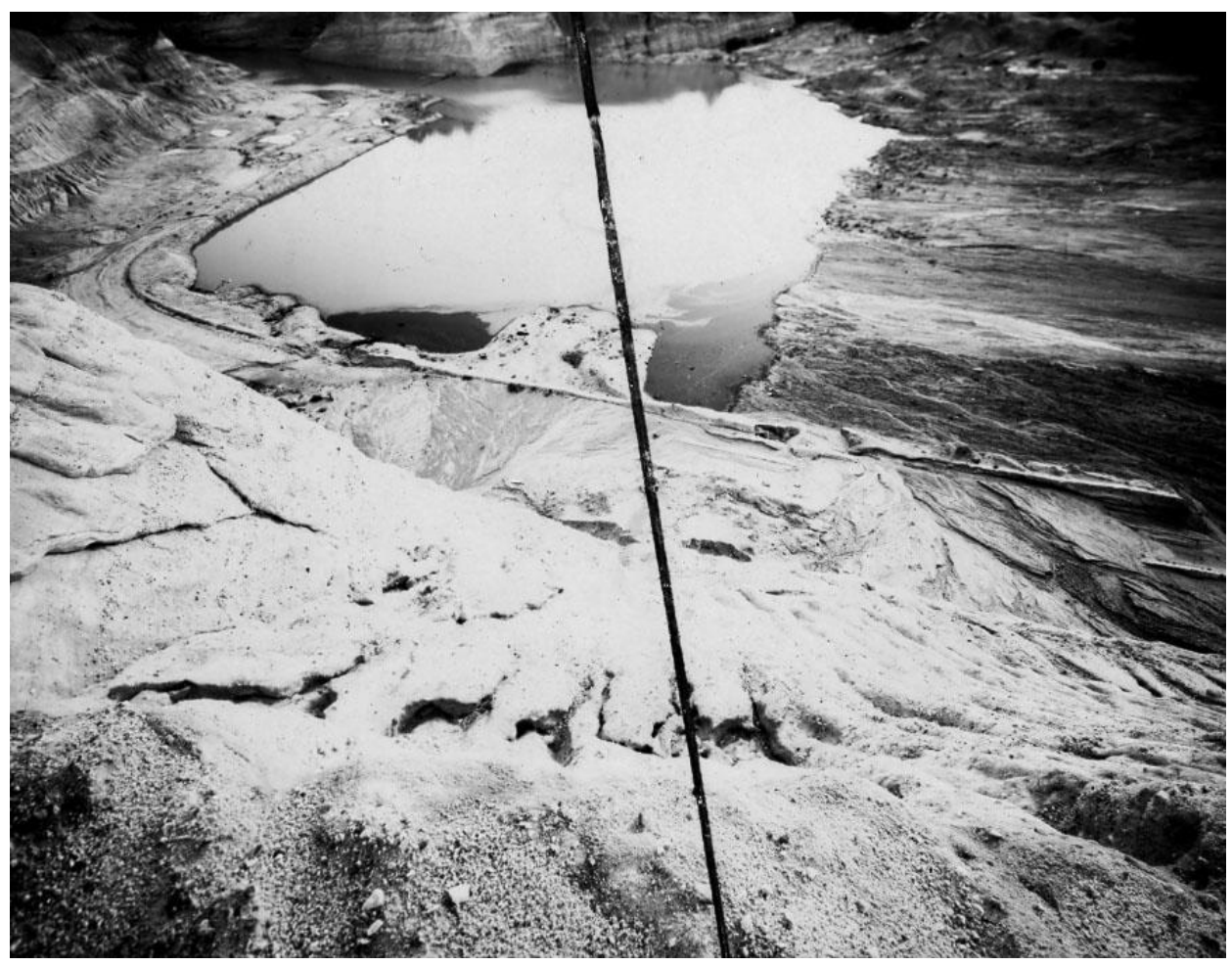

Fig. 74 Samuel Rama, Scan \# 2 , 2010. Impresión chorro de tinta larga duración sobre papel Fine art $98 \mathrm{~cm} \times 124 \mathrm{~cm}$ 

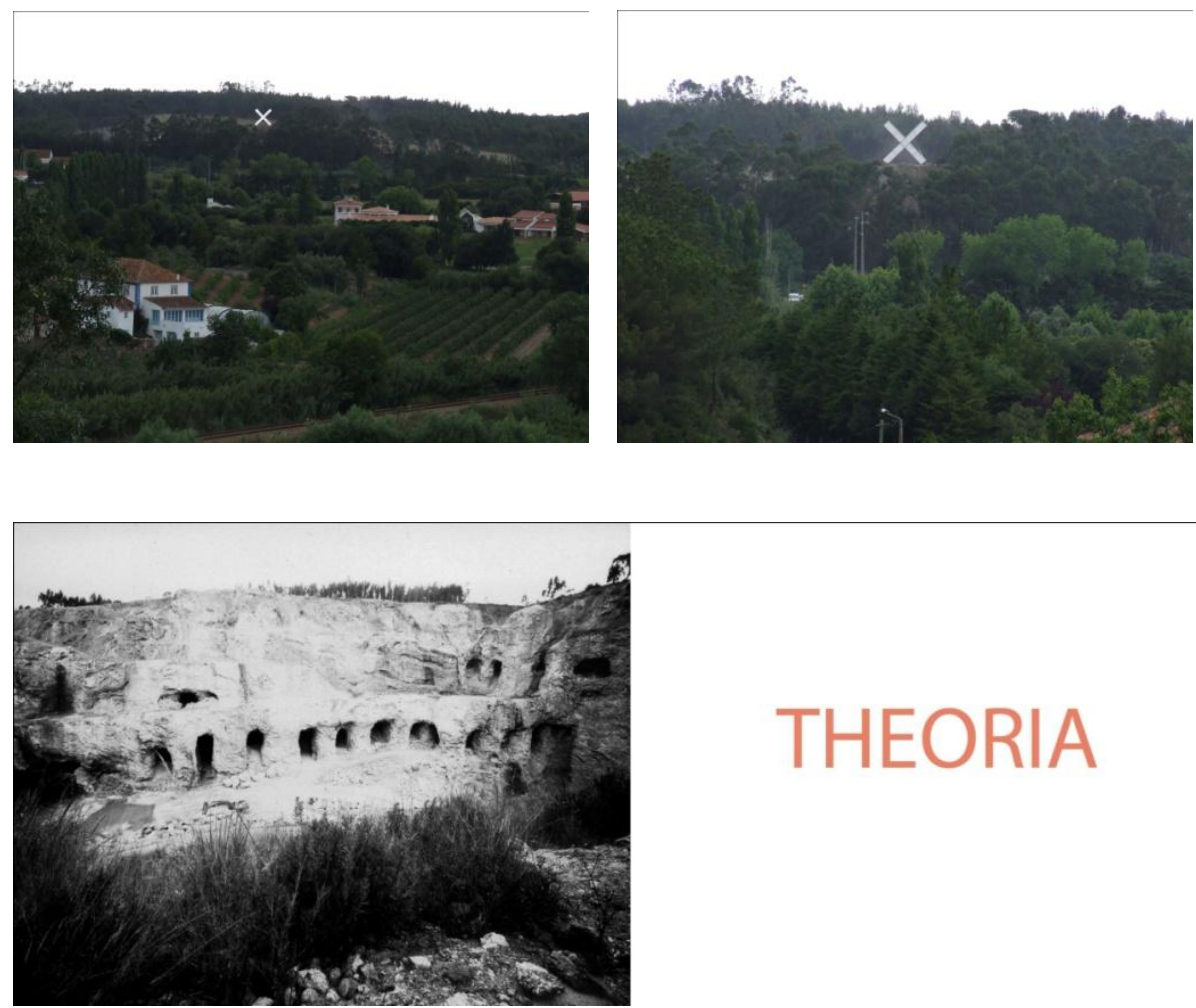

\section{THEORIA}

Fig. 75 Samuel Rama, Paisagem Adoptiva, 2009. Arriba, Instalación en la mina de yeso; abajo, uno de los carteles instalados en la Vila de Óbidos.
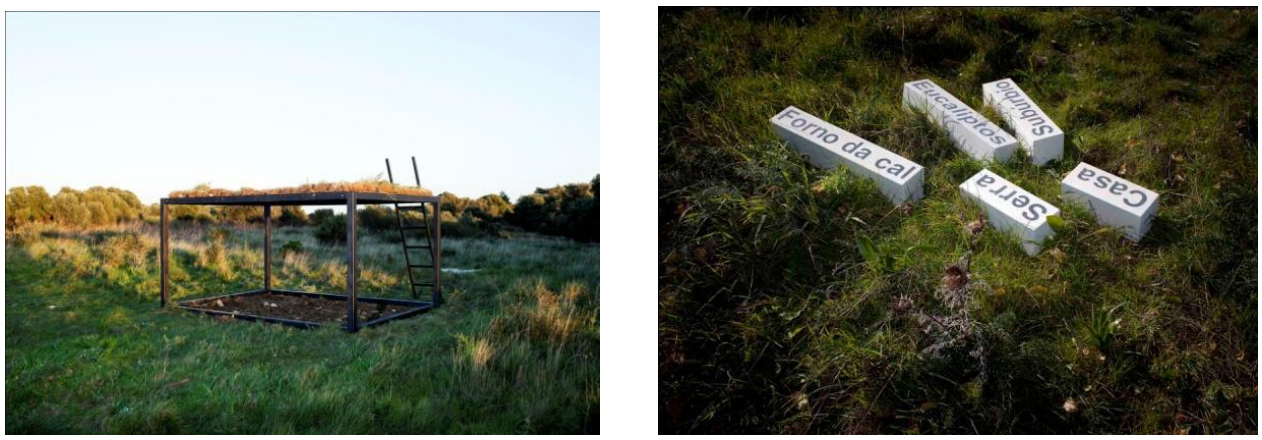

Fig. 74, Arquitectura Reflexiva \# 1, 2011. Estructura de metal, piedra calcárea, escalera y cobertura vegetal $2.40 \mathrm{~m} \times 3 \mathrm{~m} \times 4 \mathrm{~m}$. 

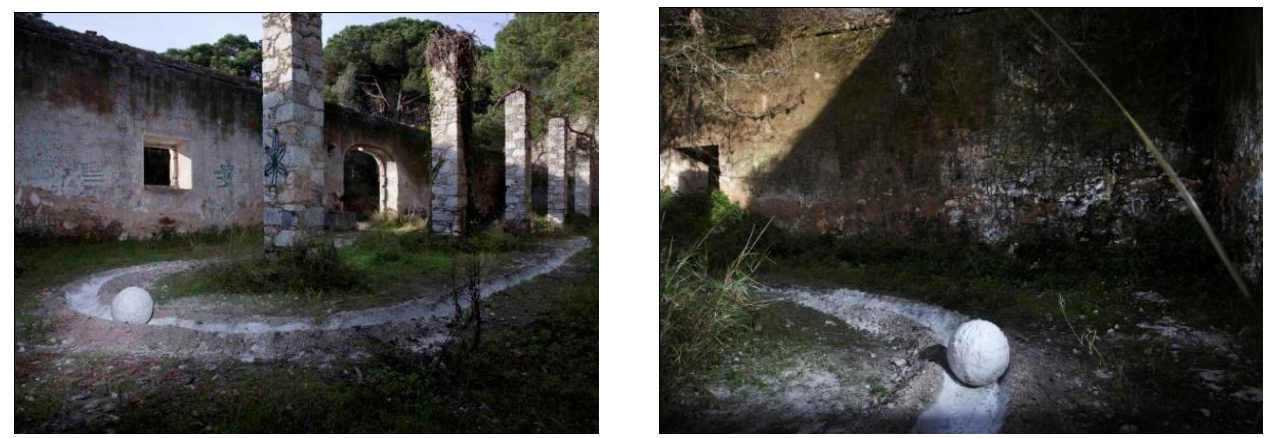

Fig. 77 Samuel Rama, Arquitectura reflexiva \# 3, 2011, Surco cavado en la tierra, cal y esfera de cal endurecida en un área de $8 \mathrm{~m} \times 12 \mathrm{~m}$.

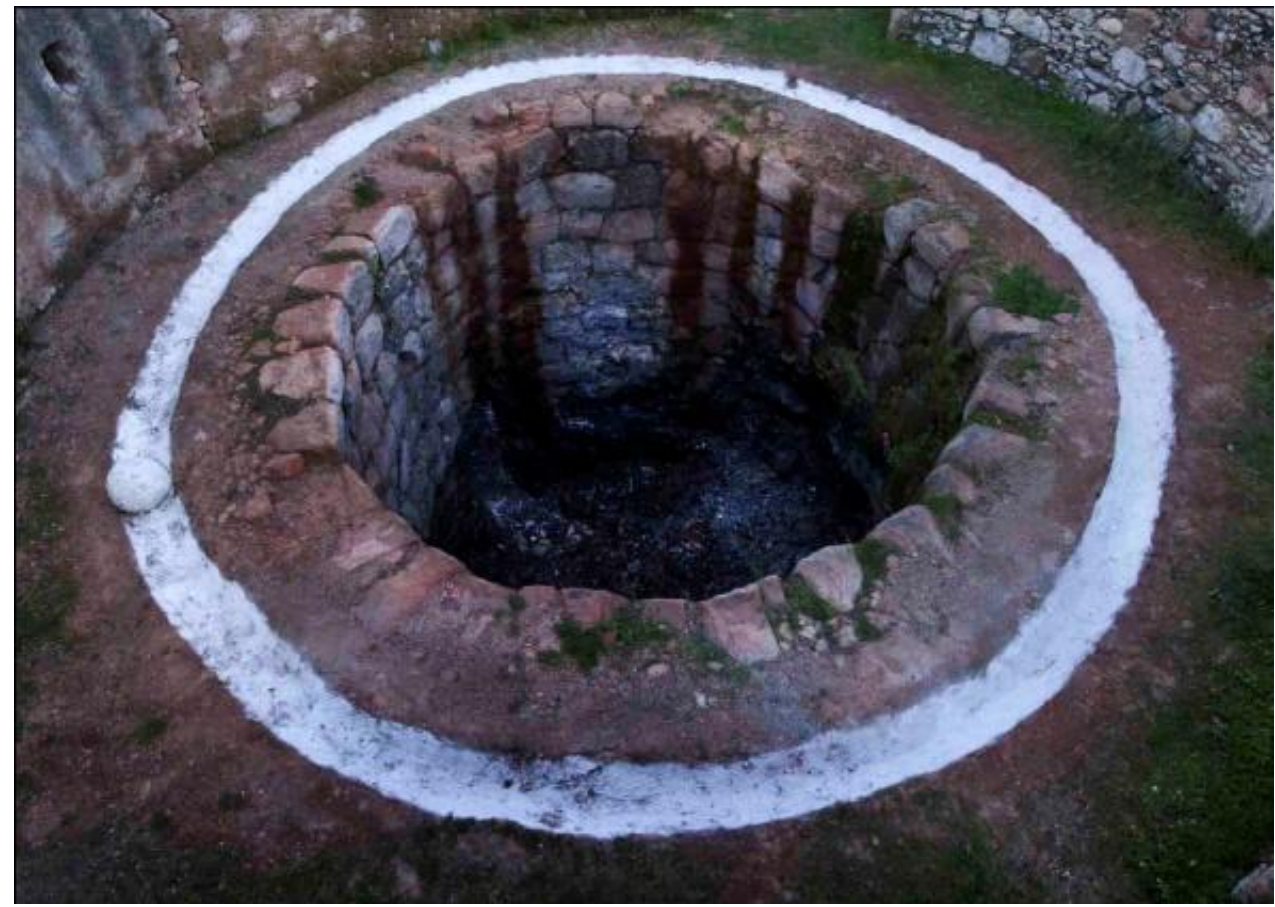

Fig. 78 Samuel Rama, Arquitectura reflexiva \# 2, 2011. Surco cavado en la tierra, cal y esfera de cal endurecida Diámetro de $9 \mathrm{~m}$. 


\section{BIBLIOGRAFÍA}

\section{a. Bibliografía Citada}

VV. AA. "El Paisaje”, Javier Maderuelo (dir.), In Arte y Naturaleza, Huesca, 1996.

VV. AA. Paisaje y Pensamiento, Javier Maderuelo (dir.) Madrid ABADA Editores, 2006.

VV.AA. Mort du paysage? Philosophie et Estétique du Paysage, (dir.) François Dagognet, Seyssel, Champ Vallon, 1982.

ALMEIDA, Bernardo Pinto, "Idade de Homem", in Alberto Carneiro, Exposição Antológica, Lisboa, Oporto, Fundação Calouste Gulbenkian, Fundação de Serralves, 1991.

ANDREWS, Malcolm, Lansdscape and Western Art, Oxford, Oxford University Press, 1999.

ASSUNTO, Rosario, Il paesaggio e l'estetica, 2 vols., Napoli: Giannini, 1973.

ASSUNTO, Rosario. In Filosofia da Paisagem: Uma Antologia, Trad. Pedro Sargento (coord.) Adriana Veríssimo Serrão, Lisboa, Centro de Filosofia da Universidade de Lisboa, 2011.

ARENDT, Hannah, A Condição Humana, Trad. Roberto Raposo, Lisboa, Relógio D'Água, 2001.

ARNALDO, Javier, Yves Klein, Madrid, Editorial Nerea, 2000.

BABO, Maria Augusta, "Do Corpo Protésico ao Corpo Híbrido", Revista de Comunicação e Linguagens, ㄲo 33, «Corpo, Técnica e Subjectividade», Junio 2004.

BACHELARD, Gaston, A Poética do Espaço, Trad. de António Danesi, São Paulo, Martins Fontes, 2000.

BACHELARD, Gaston, O Ar e os Sonhos, São Paulo, Martins Fontes, 1991. 
BACHELARD, Gaston, A Poética do Devaneio, Trad. de António Danesi, São Paulo, Martins Fontes, 2001.

BARAÑANO, Kosme, "Chillida: desarrollo de la obra". In Maria M. Argila (Coord.) ¿Qué es la escultura moderna? Del objeto a la arquitectura. (pp. 241-262), Madrid, Fundación Cultural MAPRE VIDA, 2003.

BARRERO, Manuela, "Giacometti-Sartre. Transformaciones absolutas", Anales de Historia del Arte, Madrid, Universidad Complutense de Madrid, 2002.

BAUDELAIRE, Charles, A Invenção da Modernidade (Sobre Arte, Literatura e Musica), Trad. y Notas Pedro Tamen, Relógio D’Água, 2006.

BAUDRILLARD, Jean, El Complot del Arte: Ilusión y desilusión estéticas, Buenos Aires, Editorial Amorrortu, 2006.

BECKETT, Samuel, À espera de Godot, trad. José Maria Vieira Mendes, Lisboa, Cotovia, 2001.

BENJAMIN, Walter, A Modernidade. Obras escolhidas de Walter Benjamin. Edición y traducción de João Barrento, Assírio \& Alvim, 2006.

BENJAMIN, Walter, Libro de los Pasajes, Edición de Rolf Tiedemann, Madrid, Akal, 2005.

BERGER, John, Sobre el Dibujo, Trad.: Pilar Vázquez, Barcelona, Editorial Gustavo Gili, 2011.

BERLEANT, Arnold, "A estética da arte e a natureza", In Filosofia da Paisagem: Uma Antologia, Trad. Luís Sá, (coord: Adriana Veríssimo Serrão), Lisboa, Centro de Filosofia da Universidade de Lisboa, 2011.

BERQUE, Augustin, "O pensamento paisageiro: uma aproximação mesológica", In Filosofia da Paisagem. Uma Antologia, Trad. Andreia Saavedra Cardoso (coord: Adriana Veríssimo Serrão), Lisboa, Centro de Filosofia da Universidade de Lisboa, 2011.

BERQUE, Augustin, "L'écoumène, mesure terrestre de l'Homme, mesure humaine de la Terre: pour une problématique du monde ambiant", L'Espace géographique 4, 1993. 
BESSE, Jean-Marc, Ver a Terra. Seis Ensaios sobre a Paisagem e a Geografia, Trad. de Vladimir Bartalini, São Paulo, Editora Perspectiva, 2006.

BESSE, Jean-Marc, "Las Cinco Puertas del Paisaje, Ensayo de una Cartografía de las Problemáticas Paisajeras Contemporáneas", in Paisaje y Pensamiento, Javier Maderuelo (dir.) Madrid, Abada Editores, 2006,

BEUYS, Joseph, Joseph Beuys in America Writings By And Interviews With The Artist, Compilado por Carin Kuoni, Nueva York, Four Walls Eight Windows, 1990.

BOCOLA, S. El Arte de la Modernidad. Barcelona: Ediciones del Serbal, 1999.

BOURGEOIS, Louise, Destruction Of The Father Reconstruction of the Father, Writings And Interviews, 1923 - 1997, Violette Editions, Londres, 2000.

BRAUDEL, Fernand, Veneza in Braudel/ Duby, O Mediterrâneo, os homens e a herança, trad. Portuguesa de Manuela Torres, Teorema, 1987

BROCH, Hermann, Os Sonâmbulos, vol. III Huguenau ou o realismo, Lisboa, Edições 70, 1989.

BUCI- GLUCKSMANN, Christine, "La folie de voir. De l'esthètique baroque", París: Galilée, 1986.

BUREN, Daniel (1979), "A função do ateliê" (Fonction de l'atelier), in LOOCK, Ulrich, Ed., AnArquitectura de Andre a Zittel, Oporto, Público/Fundação de Serralves, 2005.

BURKE, Edmund. A Philosophical Enquiry into the Origin of our ldeas of the Sublime and Beautiful (1757), Oxford: Blackwell Ltd., 1987.

CALDAS, Manuel Castro, "Topos Outopos" in Catálogo O Génio do Olhar: Desenho como disciplina 1991-1999, Instituto de Arte Contemporânea, Lisboa, 2000.

CALABRESE, Omar, A ldade Neobarroca, Lisboa, Edições 70, 1999.

CAMPANY, David, Arte y Fotografía, Londres: Phaidon, 2006.

CARLOS, Isabel, Alberto Carneiro: a escultura é um pensamento, Lisboa, Caminho, 2007. 
CARLOS, Isabel, "Do Problema do Sublime (e a Arte)", in catálogo de la exposición Do Sublime, Lisboa: Sociedade Lisboa 94, 1994.

CARNEIRO, Alberto, testimonio oral transcrito de la conferencia pronunciada por el artista Alberto Carneiro, en abril de 2004, en el Auditorio de EP 1 de la ESAD. $\mathrm{CR} /$ Instituto Politécnico de Leiria, a invitación de los docentes Samuel Rama y Pedro Cabral Santo.

CARNEIRO, Alberto, O caderno preto (ideias e projectos 1968/1971), Oporto, Galeria Alvarez, 1971.

CARNEIRO, Alberto, "Mi Cuerpo y el Paisaje», in VVAA, Paisaje y arte, Dir. Javier Maderuelo, Madrid, Abada Editores, 2007.

CARNEIRO, Alberto, Uma Cultura da Natureza, Jornal de Letras Artes e Ideias, Lisboa, № 1022, 2 a 25 de Dez. de 2009.

CARNEIRO, Alberto, Das Notas Para Um Diário e Outros Textos antología, (coord: Catarina Rosendo), Lisboa, Assírio \& Alvim, 2007.

CARERI, Francesco, Walkscapes. El andar como práctica estética / Walking as an aesthetic practice. Trad. de Maurici Pla, Barcelona: Gustavo Gili, 2002.

CARTIER-BRESSON, Henri, O imaginário segundo a natureza, Barcelona, Ediciones Gustavo Gili, 1996.

CASSIRER, Ernst, Ensaio sobre o Homem, Introdução a uma filosofia da cultura humana, trad. de Tomás Rosa Bueno, São Paulo, Martins Fontes, 2005.

CAUQUELIN, Anne, A Invenção da Paisagem, Trad. de Pedro Bernardo, Lisboa, Edições 70, 2008.

CÉZANNE, Paul, Correspondência Paul Cézanne, Trad. de António Paulo Danesi, São Paulo, Martins Fontes, 1992.

CHAFES, Rui, O Silêncio de ..., Lisboa, Assírio \& Alvim, 2006.

CHENG, François, Vacío y Plenitud, trad. al castellano de Amelia Hernández y Juan Luis Delmont, Madrid, Siruela, 2010. 
CHILLIDA, Eduardo, in Entrevista de Sanjuana Martínez a Eduardo Chillida (www. Babab.com)

CHRISTIANE Mennicke: "You Have to Be Pigheaded. A Conversation with Louise Bourgeois", Feb. 1994, in: Beatrice E. Stammer et al. (Ed.): Louis Bourgeois. Intime Abstraktionen, Berlín, Akademie der Künste 2003.

Clark, Lygia, in Lygia Clark. Série Arte Brasileira Contemporânea, Rio de Janeiro, Edição Funarte, 1980.

CLARK, Kenneth, Paisagem Na Arte, Trad. de Lúcia H. O. Gerardi y Silvana M. Pintaudi, Lisboa, Editora Ulisseia, 1969.

CORRAL, Maria de y CORRAL, Lorena Martinez de, in O Presente: Uma Dimensão Infinita, Catálogo de la Exposición de la Colección Banco Espirito Santo, Lisboa, 24/11/2008 a 15/01/2009, ed. BES y Museu Berardo, 2008.

DAMISCH, H., L'origine de la perspective. París: Flammarion. 1987.

DEBORD, Guy E., Théorie de la derive, in Les Lèvres Nues, 8/9, Bruselas, Nov. 1956.

DELEUZE, Gilles y GUATTARI, Félix, Mil Platôs Capitalismo e Esquizofrenia, trad. de Ana Lúcia de Oliveira, 5 vols., São Paulo, Editora 34, 1997.

DELEUZE, Gilles y GUATTARI, Félix, Rizoma, Trad. de Rafael Godinho, Lisboa, Assírio \& Alvim, 2004.

DELEUZE, Gilles, Francis Bacon. Lógica de la sensación, Trad. de Isidoro Herrera, Madrid, Arena Libros, 2005.

DELEUZE, Gilles, A dobra. Leibniz e o Barroco, Trad. de Luís B. L. Orlandi, São Paulo, Papirus Editora, 1992.

DELEUZE, Gilles. Espinosa, Filosofia Prática. São Paulo: Editora Escuta, 2002.

DERRIDA, Jacques, A voz e o fenómeno, Trad. de Maria José Semião, Lisboa, Edições 70, 1996. 
DIAS, Isabel Matos, Uma Ontologia do Sensível - A aventura filosófica de Merleau-Ponty, Lisboa, Edições Centro de Filosofia da Universidade de Lisboa, 1999.

DIDI- HUBERMAN, Georges, Ante el tiempo, Historia del arte y anacronismo de las imágenes, Trad. de Oscar Antonio Oviedo Funes, Buenos Aires, Adriana Hidalgo editora, 2005.

DIDI-HUBERMAN, Georges, Le Cube et le visage, Autour d'une sculpture d'Alberto Giacometti, París, Macula, 1993.

DIDI-HUBERMAN, Venus Rajada, trad. de Juan Salabert, Madrid, Editorial Losada, 2005.

DUMAS, Robert, Tratado da Árvore, Ensaio de uma Filosofia Ocidental, Trad. de Maria Jorge Vilar De Figueiredo, Assírio \& Alvim, 2007.

DURAS, Marguerite, $A$ Dor, Trad. de Tereza Coelho, Lisboa, Difel, $2^{\underline{a}}$ ed., 1986.

DUPIN, Jacques, "Una Escritura Sin Fin”, In Escritos de Alberto Giacometti, Trad. de José Luis Sánchez Silva. Madrid: Síntesis, 2001.

ECO, Umberto, Obra Aberta, Trad. de João Rodrigo N. Furtado, Lisboa, Difel, 1989.

EHRENZWEIG, Anton, A Ordem Oculta da Arte - A Psicologia da Imaginação Artística, Río de Janeiro, Zahar Editores, 1977.

FLORENSKI, Pavel, La perspectiva invertida, Trad. de Xenia Egórova, Madrid, Siruela, 2005.

FLÓREZ, Fernando Castro, "Robert Smithson. El dibujo en el campo expandido", in Estrategias del Dibujo en el Arte Contemporáneo, Capítulo XV, Madrid, Cátedra, 2002.

FLÓREZ, Fernando Castro, "Apuntes y Visiones del Desierto", in El Paisaje, Javier Maderuelo (dir.), Huesca, Arte y Naturaleza, 1996.

FOCILLON, Henri, A Vida Das Formas. Seguido de Elogio da Mão, Trad. de Ruy Oliveira, Lisboa, Edições 70, 2001. 
FONTCUBERTA, Joan, El beso de Judas. Fotografía y verdad, Barcelona, Editorial Gustavo Gili, 2002.

FOUCAULT, Michel, "Of Other Spaces: Utopias And Heterotopias", in Rethinking Architecture a Reader in Cultural Theory, Ed. por Neil Leach, p. 238.

FOUCAULT, Michel, "Espaços outros", in Revista de Comunicação e Linguagens, $n^{\text {os }} 34 / 35,2005$.

FOUCAULT, Michel, A Arqueologia do Saber, trad. de Miguel Serras Pereira, Coimbra: Almedina, 2005.

FRÉCHURET, Maurice, l'enfouissement: histoire et imaginaire aux temps précaires du XXe siècle, París, Editions d'Art Albert Skira: Réunion des Musées Nationaux, cop. 1995.

FREUD, Sigmund, O estranho (1919) in pt.scribd.com/doc/43021478/O-EstranhoFreud.

FRIED, Michael. "Art and Objecthood". In: BATTCOCK, Gregory (org). Minimal Art, A critical Anthology. E. P. Dutton, NY, 1968.

FULLAONDO, Juan Daniel, Oteiza y Chillida en la moderna historiografía del arte, Bilbao, Editorial La Gran Enciclopedia Vasca, 1976.

GAMARD, Elisabeth Burns, Kurt Schwitters Merzbau The Cathedral of Erottic Misery, Nueva York, Princeton Architectural Press, 2000.

GARCÍA YELO, María. "El Sublime Espacio de Alberto Giacometti". In Anales de Historia del Arte. Madrid, Servicio de Publicaciones de la Universidad Complutense, Facultad de Geografía e Historia. n.ำ 14, 2004.

GENET, Jean, O Estúdio De Alberto Giacometti, Trad. de Paulo da Costa Domingos, Lisboa, Assírio \& Alvim, 1999.

GIACOMETTI, Alberto. Je ne sais ce que je vois qu`en travaillant. París: L’Échoppe, 1988.

GIACOMETTI, Alberto. Escritos. Trad. de José Luis Sánchez Silva. Madrid: Síntesis, 2001. 
GIACOMETTI, Alberto, "Alberto Giacometti. Carta a Pierre Matisse", in Teorias da Arte Moderna, São Paulo, Martins Fontes, 1999.

GIL, José, Movimento Total. O Corpo e a Dança, Lisboa, Relógio D’Água, 2001.

GILCHIST M. y LINGWOOD J., «El entropólogo», in Robert Smithson. El paisaje entrópico, Valencia, Instituto Valenciano de Arte Moderno, 1993.

GOETHE, J. W, Escritos de arte, Madrid, Editorial Sintesis,1999.

GOETHE, J.W. Máximas e Reflexões, Trad. Miranda Justo, Lisboa, Relógio D'Água, 2000.

GONZÁLEZ, Oscar, "Alberto Giacometti: un Escultor". In Revista de Cultura (Fortaleza, São Paulo). N. 24, mayo de 2002. http://www.revista.agulha.nom.br/ag24giacometti.htm.

GOMBRICH, E. H., La Historia del Arte, Trad. de Rafael S. Torroella, Madrid, Debate, 2003.

GOMBRICH, Ernst Hans, A Teoria da Arte no Renascimento e a elevação da Paisagem, Trad. de Alexandra Lopes y Helena Buescu, In Concerto das Artes, Lisboa, Campo das Letras, 2007.

GOURHAN, André Leroi, O Gesto E A Palavra, Memória e Ritmos, Trad. de Emanuel Godinho Lisboa, Edições 70, 2002.

GRAHAM, Dan, "Dan Graham in relation to architecture", Dan Graham, Works 1965-2000, Oporto, Fundação de Serralves, 2001.

GUATTARI, Félix y DELEUZE, Gilles, O Que é a Filosofia? Trad. de Margarida Barahona y António Guerreiro, Lisboa, Editorial Presença, 1992.

GUÉNON, René, O Reino da Quantidade e os Sinais dos Tempos, Lisboa, Dom Quixote, 1989.

HEIDEGGER, Martin, Heidegger en Castellano, 21 de noviembre de 2008, http://www.heideggeriana.com.ar/textos/arte y espacio.htm.

HILDEBRAND, A. Von, El problema de la forma en la obra de Arte, Trad. de María Isabel Peña Aguado, Madrid, Visor, 1988. 
HOHL, Reinhold, Alberto Giacometti. Nueva York: Abrams, 1971.

HUGO, Victor, Voyage, -Alpes et Pyrénées, París, J. Hetzel, 1890, pp. 180-181 (entrada de 11 de Agosto de 1843).

JANSON, H. W., História da Arte, Lisboa, Fundação Calouste Gulbenkian, 1992.

JELLICOE, Geoffrey y Susan, The Landscape of Man. Londres, Thames and Hudson, 1996.

JUDD, Donald, "Specific Objects", in Thomas Kellein, Donald Judd: Early Work, 1955-1968, Nueva York: D.A.P., 2002. Editado originalmente en Arts Yearbook 8, 1965.

KANT, Emmanuel, Crítica da Faculdade do Juízo, Trad. y notas de António Marques y Valério Rohden, Oporto, Imprensa Nacional Casa da Moeda, 1997.

KARMITZ, Marin, Silences un propos de Martin Karmitz, Lisboa, Museu Berardo, 2009, pp. 16.

KLEE, Paul, Escritos sobre arte, Trad. de Catarina Pires y Marta Manuel, Lisboa, Cotovia, 2001.

KRAUSS, Rosalind E., Caminhos da Escultura Moderna, Trad. de Julio Fischer, São Paulo, Martins Fontes, 2001.

KRAUSS, Rosalind E., La originalidad de la Vanguardia y otros mitos modernos, Versión española de Adolfo Gómez Cedillo, Madrid, Alianza Editorial, 2002.

KRAUSS, Rosalind, Voyage In The North Sea, Art In The Age of The PostMediun Condition, Thames and Hudson, 1999.

KOGAN, Jacobo, El lenguaje del Arte: Psicología y Sociología del Arte, Buenos Aires, Editorial Paidós, 1965.

LANCRI, Jean, "Modestas proposições para as condições de uma pesquisa em artes plásticas na Universidade", in O meio como ponto zero, Metodologia de Pesquisa em Artes Plásticas, Instituto de Artes- URFGS, Porto Alegre, 2002.

LANGER, Susanne, Filosofia em Nova Chave, trad. de Janete Meiches y J. Guinsburg, São Paulo, Ed. Perspectiva, 1989. 
LANGER, Susanne, Problems of Art, Nueva York, Scribner's, 1957.

LEIRIS, Michel, "Giacometti Oral y Escrito", In Escritos de Alberto Giacometti, Trad. de José Luis Sánchez Silva. Madrid: Síntesis, 2001.

LIPPARD, Lucy. Six Years: The dematerialization of the art object from 1966 to 1972. Berkeley/Los Angeles: University of California Press, 2001.

LONG, Richard, vídeo Stones and Files: Richard Long in Sahara, realizado por Philips Haas, Éditions á Voir, Ámsterdam, 1988, ( pp. 113 - 115) in Land Art, Tonia Raquejo, San Sebastián, Editorial Nerea, 1998.

LORD, James, Retrato de Giacometti, trad. de Amaya Bozal, Madrid, La Balsa de la Medusa, 2005

MADERUELO, Javier, La Idea de Espacio en la Arquitectura y el Arte Contemporáneos 1960-1989, Madrid, Akal, 2008.

MADERUELO, Javier, La pérdida del pedestal, Madrid, Círculo de Bellas Artes, 1994.

MALDINEY, Henri, "Le Dévoilement de la Dimension Estetique dans la Phenomenologie d'Erwin Straus". Regard, Parole, Espace. París, L'Age d'Homme, 1994.

MAYER, Michael, "Un Cambio de Perspectiva", in Máquinas de Mirar - o cómo se originan la imágenes. El Arte Contemporáneo mira la colección Werner Nekes, Sevilla, Centro Andaluz de Arte Contemporáneo, Consejería de Cultura, 2010.

MCLUHAN, Marshall, Os meios de comunicação como extensões do homem, São Paulo, Cultrix, 2002.

MCLUHAN, Marshall, A galáxia de Gutenberg: a Formação do homem tipográfico, Trad. de Leonidas G. De Carvalho y A. Teixeira, São Paulo, Univ. de São Paulo, 1969.

MEIRELES, António José Santos, As paisagens do desenho: características formais do desenho de paisagens. Lisboa: Universidade de Lisboa, Faculdade de Belas Artes, 2004. 
MERLEAU-PONTY, Maurice, Palestras, trad. Artur Mourão Lisboa, Edições 70, 2003.

MERLEAU-PONTY, Maurice, Fenomenologia da Percepção, Trad. de Carlos A. Ribeiro de Moura, São Paulo, Martins Fontes, 1999.

MERLEAU-PONTY, Maurice, O Visível e o Invisível, Trad. de José Artur Gianotti y Armando Mora d' Oliveira Santos, São Paulo, Editora Perspectiva, 2000.

MERLEAU-PONTY, Maurice, O olho e o espírito, Trad. de Luís M. Bernardo, Lisboa, Vega, 1997.

MICHALSKY, Tanja, "Landschaft beleben. Zur Inszenierung des Wetters im Dienst des hollaendischen Realismus", in Bilderzaehlungen - Zeitlichkeit im Bild (Eds. A. von Hülsen Isen-Esch, H. Körner y G. Reuter), Köln, 2003.

MIRANDA, Bragança de, Seminario de "Cibercultura» en el marco del curso de maestría en comunicación y cultura contemporánea, marzo-junio 2006, FCSHUniversidade Nova de Lisboa. Notas de la charla. Mimeografiado.

MOLDER, Maria Filomena, O Absoluto Que Pertence À Terra, Lisboa, Vendaval, 2005.

MOLDER, Maria Filomena, O Químico e o Alquimista - Benjamin Leitor de Baudelaire, Lisboa, Relógio d’Água, 2011.

MOLDER, Maria Filomena, Seminario Internacional Goethe. A Botânica das Cores, Anfiteatro de la Fundación de la FCUL, 20 Noviembre de 2009. Notas de seminario. Mimeografiado.

MOLDER, Maria Filomena, Seminario de "cuestiones de estética» organizado en el marco del curso de Máster en Estética, marzo-junio 2006, FCSH-Universidade Nova de Lisboa. Notas de la clase. Mimeografiado.

MORRIS, Robert, Continuous Project Altered Daily, The Writings of Robert Morris, Massachusetts, MIT Press, 1995.

MORRIS, Robert, "Notas Sobre el Arte como Regeneración de la Tierra”, In Martí Peran y Glòria Picazo (Editores), Naturalezas Una travesía por el arte contemporáneo, Barcelona, MACBA, 2000. 
MOULIN, Joëlle. L'autoportrait au XXe Siècle. París: Adam Biro, 1999.

NANCY, Jean-Luc, Au fond des images, París, Galilée, 2003.

NANCY, Jean-Luc, "Cinquenta e oito indícios sobre o corpo", Revista de Comunicação e Linguagens, ㄲo 33, "Corpo, Corpo, Técnica e Subjectividade», Junio de 2004.

NAVARRO, Herrnández, Miguel Á. Robert Morris, San Sebastián, Editorial Nerea, 2010.

NICOLAU, Ricardo, BES art, O presente Uma dimensão Infinita, Museu Colecção Berardo, Lisboa, 2008.

NUNES, Maria Leonor, "Uma Cultura da Natureza", Jornal de Letras, Artes e Ideias, no 1022, de 2 de Diciembre de 2009.

OLIVEIRA, Filipa, Vontade, Texto teórico de apoyo a la exposición ac\#1, espacio arteContempo, Octubre, Lisboa, 2004.

OLIVEIRA, Filipa, O Espaço do Fogo, Texto teórico de apoyo a la exposición, Museu António Duarte, 2007.

OLMO, Santiago, B., Alberto Carneiro, Santiago de Compostela, Centro Galego de Arte Contemporánea, Xunta de Galicia, 2001.

PANOFSKY, E., A perspectiva como forma simbólica. Lisboa: Edições 70, 1999.

PARINAUD, André, ¿Por qué soy escultor?, Entrevista a Giacometti, in Alberto Giacometti, Obras, Escritos, Entrevistas, Dir. Ángel González, Barcelona, Polígrafa, 2006.

PEIXOTO, Nelson Brissac, Paisagens Críticas Robert Smithson: arte, ciência e indústria, São Paulo, Editora da Pontifícia Universidade de São Paulo, 2010.

PETRARCA, Francesco, La ascensión al Mont Ventoux, 26 de Abril de 1336, Asociación de Amigos del Museo de Bellas Artes y Artium de Álava, 2002.

PLINIO, el Viejo. Historia Natural. XXXV.151.

PORFÍRIO, José Luís, "No trilho da montanha branca", Expresso, Actual ㄲo 2081, 15 de Septiembre de 2012. 
RAMA, Samuel, Paisagem e Arte Imagem e Instalação, In Filosofia e Arquitectura da Paisagem. Um Manual (Coord: Adriana Verissimo Serrão), Lisboa, Centro de Filosofia da Universidade de Lisboa, 2012, pp. 165-176.

RAMA, Samuel, "Identidades", Jornal de Letras, Artes e ldeias, № 914, 12 de Marzo de 2008, p. 2. Entrevista concedida a Maria Leonor Nunes.

RAWSON, Philip, Drawing, Philadelphia, University of Pennsylvania Press, $2^{\underline{a}}$ ed., 1987

READ, Herbert, O Significado da Arte, Trad. de A. Neves Pedro, Lisboa, Editora Ulisseia, 1968.

REITHMAN, Max, Regards sur Giacometti, in catálogo da exposición Giacometti, La Collection du Centre Georges Pompidou, Musée National d'Art Moderne, programación del Musée d'Art Moderne de Saint-Etienne 1999.

RIEGL, Alois, Late Roman Art Industry, Roma, Giorgio Bretschneider Editore, 1985.

RITTER, Joachim. Paysage, fonction de l'esthétique dans la societé moderne. Besançon, Les Éditions de l'Imprimeur, 1997.

RODIN, August, L'Art, París, Grasset, 1911.

ROGER, Alain, Breve tratado del paisaje, Trad. de Maysi Veuthey, Ed. Javier Maderuelo, Madrid, Editorial Biblioteca Nueva, 2007.

ROSAS, Maria Ángeles Layuno, Richard Serra, Hondarribia, Editorial Nerea, 2001.

ROSENDO, Catarina, Alberto Carneiro. Os primeiros anos (1963-1975). Lisboa, Edições Colibri-IHA/EAC, 2007.

ROSENDO, Catarina, "Uma ideia da paisagem através da obra de Alberto Caeiro". In Margarida Acciaiuoli, Joana Cunha Leal y Maria Helena Maia (Coord) Arte \& Paisagem. (pp. 275-288) Lisboa, Instituto de História da Arte Estudos de Arte Contemporânea, 2006.

RUSKIN, John, Técnicas de Dibujo, Barcelona, Laertes S.A. de Ediciones, 1999. 
SCHAMA, Simon, Landscape And Memory, Londres, Harper Collins, 1996.

SÁ, Luís, "O regresso da natureza à experiência estética", In Filosofia e Arquitectura da Paisagem: Um Manual, (coord: Adriana Veríssimo Serrão), Lisboa, Centro de Filosofia da Universidade de Lisboa, 2012.

SÁNCHEZ, Domingo Hernández, Arte Dicionário Crítico de Arte, Imagem, Linguagem e Cultura, activo en 6/9/2012 in http://www.arte-coa.pt.

SAN MARTIN, Francisco Javier. "Construyendo La Ficción. Algunos Ejemplos Sobre Arquitectura, Ciudad y Fotografía", pp. 16-48. Revista Exit 6, arquitecturas Ficticias, Salamanca, 2002.

SANTOS, Laymert Garcia dos, "A escultura do tempo", Intervención presentada en el coloquio "Actualidades do tempo", organizado por el Colégio Internacional de Estudos Filosóficos transdisciplinares y por la Universidade estadual do Rio de Janeiro (EURJ) a 8 de Abril de 1988, y reunida en el libro de Laymert Garcia dos Santos titulado Tempo De Ensaio, São Paulo, Editora Companhia Das Letras, 1989.

SARDO, Delfim, Obras-primas da Arte Portuguesa. Século XX, Artes Visuais, Lisboa, 2011.

SARDO, Delfim, Instalação in http://www.arte-coa.pt, activo el 16 de agosto de 2011.

SARDO, Delfim, Finalistas de Escultura, 2006/07, 23 de nov. de 2008, pp. 14-17, http://www.ul.pt.

SARDO, Delfim, "Sem Título", Expresso, Única nำ1836, 5 de enero de 2008.

SARGENTO, Pedro, Rosario Assunto. In Filosofia da Paisagem: Uma Antologia, (coord: Adriana Veríssimo Serrão), Lisboa, Centro de Filosofia da Universidade de Lisboa, 2011.

SARTRE, Jean-Paul, A Imaginação, Trad. de Manuel João Gomes, Lisboa, Difel, 2002.

SARTRE, Jean-Paul, L'Imaginaire. Psychologie Phénoménologique de I'Imagination. París, Galimard, 1948. 
SARTRE, Jean-Paul, "Les peintures de Giacometti", Derrière le miroir, №. 65, Mayo de 1954.

SCHNECKENBURGER, Manfred, "Posições no Pós-Guerra: O existencial e o Abstracto", in Arte do Século XX, Vol. II, Trad. Ilda Boavista. (pp. 487-498), Colonia, Taschen, 2005.

SERRÃO, Adriana Veríssimo, "A transição como essência da paisagem", in Conferencia Internacional - Paisagens Em Transição, Projecto de Investigação Filosofia e Arquitectura da Paisagem (FCT PTDC/FIL-FIL/100565/2008) 7 de octubre de 2011, Lisboa, Sala 1, Fundação Calouste Gulbenkian, Notas de conferencia. Mimeografiado.

SERRÃO, Adriana Veríssimo, O que é uma paisagem para a filosofía. Texto amablemente cedido por la autora, que sirvió de base de apoyo para el curso de reflexión sobre el tema del paisaje. Departamento de Filosofía de la Facultad de Letras de la Universidad de Lisboa.

SILVA, Raquel Henriques, "Alberto Carneiro: los cuerpos de la escultura", in Alberto Carneiro, Santiago de Compostela, Centro Galego de Arte Contemporánea, Xunta de Galiza.

SILVANO, Filomena, Antropologia do Espaço, Oeiras, Edições Celta, 2001.

SIMMEL, Georg, "Filosofia da Paisagem", In Filosofia da Paisagem. Uma Antologia. Trad. y coord. de Adriana Veríssimo Serrão), Lisboa, Centro de Filosofia da Universidade de Lisboa, 2011.

SMITHSON, Robert, Robert Smithson: The Collected Writings, California, Editado por Jack Flam, University of California Press, 1996.

SMITHSON, Robert, Un Recorrido Por Los Monumentos De Passaic, Nueva Jersey, Valencia, IVAM - Centre Julio González, 1993.

SIMÕES, Reinério luiz Moreira, A Imaginação Material Segundo Gaston Bachelard, tesis de máster presentada en la Universidad de Rio de Janeiro, orientación de la Prof ${ }^{a}$. Dra. Marly Bulcão L. Brito. Rio de Janeiro, 1999. 
SOARES DE OLIVERIA, Luísa, Habitar a Penumbra, Texto teórico de apoyo a la exposición, Sala Pahldata, Lisboa, Mayo de 2005.

SOARES, Luísa, "A idade dos dragoeiros numa montanha de areia", Público, Ípsilon, 14 de Septiembre de 2012.

STEINER, George, Nostalgia do Absoluto, Trad. de José Gabriel Flores, Lisboa, Relógio D’Água, 2003.

STRAUS, Erwin, Du Sens Des Sens, Grenoble, Jérome Millon, 1989.

STRAUS, Erwin, The Primary Word of Senses, Londres, The Free Press of Glencoe. 1963.

TALBOT, William Henry Fox, "Sobre a Arte do Desenho Fotogénico ou Processo segundo o qual os Objectos da Natureza por si mesmos se Desenham sem Socorro de Lápis", Trad. de Jorge Martins Rosa, in Revista de comunicação e linguagens, Lisboa, $\mathrm{n} . \stackrel{0}{39}$ (Jun. 2008).

TARKOVSKY, Andrei - Esculpir o tempo, trad. de Jefferson Luiz Camargo, São Paulo, Martins Fontes, 2002.

TAVARES, Gonçalo, M. Arquitectura Natureza e Amor, Oporto, edição André Tavares \& João Rosmaninho Dafne editora, Julio 2008, pp. 3, www.dafne.com.pt. THOREAU, H. D., Walden ou a vida nos bosques, Trad. de Astrid Cabral, Lisboa, Antígona, 2009.

TIBERGHIEN, Gilles A., "Horizontes", in Arte público: naturaleza y ciudad", Javier Maderuelo (ed.), Lanzarote, Fundación César Manrique, 2001.

TSE, Lao, Tao Te King, O Livro da Via e da Virtude, Trad. de António Melo, Lisboa, Editorial Estampa, 2000.

UMBELINO, Luís António, "Percepção e Imagem: o exemplo do cinema no contexto da meditação Fenomenológica de Merleau-Ponty sobre a Experiência Perceptiva", Phainomenon, Revista de Fenomenologia, n.․ 10, Primavera de 2005.

VIRILIO, Paul, O Espaço Crítico, Trad. de Paulo Roberto Pires, São Paulo, Editora 34, 2005. 
VALÉRY, Paul, Degas Dança Desenho, Trad. de Christina Murachco y Célia Euvaldo, São Paulo, Cosac \& Naify, 2003.

WATTS, Allan W., O Budismo Zen, Trad. de Carlos Grifo Babo, Lisboa, Editorial Presença, 2000.

WOLLHEIM, Richard, "Minimal Art", In Gregory Battcock (coord.) Minimal Art A Critical Anthology, Califórnia, University of Callfornia Press,1995.

WÖLFFLIN, Heinrich, Renacimiento y Barroco, Barcelona, Ediciones Paidós, 1986.

Wölfflin. H., Prolegomena to a Psychology of Architecture, Empathy, forms and Space. K.W. F. Julia Bloomfield, Thomas F. Reese. Santa Monica, The Getty Center for the History of Art and the Humanities, 1994.

WORRINGER, Wilhelm, Abstracción y Naturaleza, Trad. de Mariana Frenk. 2. a ed., México-Buenos Aires, Fondo de Cultura Económica, 1966.

YOURCENAR, Marguerite, O Tempo Esse Grande Escultor, trad. de Helena Vaz da Silva, Lisboa, Difel, 1983.

\section{b. Otra Bibliografía de referencia consultada}

VV. AA. "El Jardín como Arte", Javier Maderuelo (dir.), Huesca, In: Arte e Naturaleza, 1997.

VV. AA. "Arte Público", Javier Maderuelo (dir.), Huesca, In: Arte e Naturaleza, 1999.

VV. AA. El Paisaje, Génesis de un concepto, Javier Maderuelo (dir.), Madrid, Abada Editores, 2005.

VV. AA. Paisaje e historia, Javier Maderuelo (dir.), Madrid, Abada Editores, 2009.

VV. AA. Paisaje y arte, Javier Maderuelo (dir.), Madrid, Abada Editores, 2007. 
VV. AA. Arte Efímero y Espacio Estético, (coord.) José Fernandez Arenas, Barcelona, Anthropos Editorial del Hombre, 1988.

VV. AA. Del paisaje reciente [de la imagen al territorio], Madrid, Fundación ICO, 2006

ALMEIDA, Bernardo Pinto de, "Mesostico para Alberto Carneiro", in Artes \& leilões, Lisboa, A. 1, № 4 (Abr.-Mayo 1990), pp. 99-102

ALVARENGA, Fernanda, "De Duchamp a Giacometti do Ready -Made à morte do objecto real na arte", in Colóquio Artes, Lisboa, S.2, a 31, o 80 (Mar. 1989), pp. 30-35.

ARENDT, Hannah, Homens Em Tempos Sombrios, trad. de Ana Luísa Faria, Lisboa, Relógio D’Água, 1991.

AZEVEDO, Ana Francisca, A ideia de paisagem, Oporto, Figueirinhas, 2008.

BACHELARD, Gaston, O Direito de Sonhar, trad. de José Américo Motta Pessanha, Jacqueline Raas, Maria Lúcia de Carvalho Monteiro y Maria Isabel Raposo, Lisboa, Difel, 1986

BACHELARD, Gaston, A Água e os Sonhos Ensaio sobre a imaginação da matéria, Trad. de António de Pádua Danesi, São Paulo, Martins Fontes, 2002.

BACHELARD, Gaston, A Psicanálise do Fogo, trad. de Maria Isabel Braga, Lisboa, Editorial Estúdios Cor, 1972.

BALL, Philip, La Invención del color, trad. José A. Vitier, México: Fondo de Cultura Económica, 2001.

BARRIÈRE, Gérard, Alberto Giacometti: le peintre de l'homme précaire, in l'oeil, Lausanne, n.. 437 (déc. 1991), pp. 52-57.

BATAIILE, Georges, O Erotismo, trad. de João Bénard da Costa, Lisboa, Edições Antígona, 1988.

BEAUVOIR, Simone de, El Existencialismo y la Sabiduría de los Pueblos, trad. de Horacio Pons, Barcelona, Edhasa, 2009. 
BERLEANT, Arnold, "O significado mutável da paisagem", In Filosofia e Arquitectura da Paisagem: Um Manual, (coord: Adriana Veríssimo Serrão), Lisboa, Centro de Filosofia da Universidade de Lisboa, 2012.

BERNÁRDEZ, Carmen, Joseph Beuys, Madrid, Nerea, 2003.

BERQUE, Augustin, El Pensamiento paisajero, trad. de Maysi Veuthey, Javier Maderuelo (dir.), Madrid, Editorial Biblioteca Nueva, 2009.

BEUYS, Joseph, Ensayos y entrevistas, trad. de Miguel Salmerón, Madrid, Editorial Síntesis, 2006.

BEUYS, Joseph, Cada Homem Um Artista, trad. de Júlio do Carmo Gomes, Oporto, Editora 7 nós, 2001.

BONÉSIO, Luisa, Geofilosofia del Paesaggio, Milán, Mimesis, 2001.

BONÉSIO, Luisa, Oltre il paesaggio. I luoghi tra estética e geofilosofia, Casalecchio, Arianna, 2002.

BONNEFOY, Yves, Alberto Giacometti: biographie d'une oeuvre, París, Flammarion, cop. 1991.

BONNEFOY, Yves, Alberto Giacometti, París, H Kliczkowski, 1998.

BONNEFOY, Yves, "Giacometti: le problème des deux époques", in Connaissance des arts, París, n.ำ 478 (dic. 1991), pp. 60-77.

BONNEFOY, Yves, Alberto Giacometti, París, Éditions Assouline, 1998.

BORER, Alain, Joseph Beuys, São Paulo, Cosac \& Naify Edições, 2001.

BOVI, Arturo, Alberto Giacometti, trad. de Lluís Gil, Barcelona, Nauta, 1974.

BRENSON, Michael, "Figures in space", in Art In América, Springfield Massachusetts. - V. 80, n.ำ11 (Nov. 1992), pp. 61-63.

CABANNE, Pierre, Marcel Duchamp Engenheiro Do Tempo Perdido, trad. de António Rodrigues, Lisboa, Assírio \& Alvim, 2002. 
CÂMARA, José Bettencourt da, Expressão e Contemporaneidade. A Arte Moderna segundo Merleau-Ponty, Lisboa, Imprensa Nacional-Casa da Moeda, 2005.

CAMPO, Eva Fernández del, Anish Kapoor, Madrid, Nerea, 2006.

CLÉMENT, Gilles, Manifesto del Tercer paisaje, Barcelona, Editorial Gustavo Gili, 2007.

COLAFRANCESCHI, Daniela, Landscape + 100 palabras para habitarlo, Barcelona, Editorial Gustavo Gili, 2007.

DELEUZE, Gilles, A IMAGEM-TEMPO CINEMA 2, Introd. y trad. de Rafael Godinho, Lisboa, Assírio \& Alvim, 2006.

DIDI- HUBERMAN, Georges, O Que Vemos, O Que Nos Olha, trad. de Paulo Neves, São Paulo, Editora 34, 1998.

DUCHAMP, Marcel, O Acto Criativo, trad. de Rui Cascais Parada, Lisboa, Edição Água Forte, 1997.

DUFRÊNE, Thierry, Giacometti-Genet: Masques et portrait moderne, París, l'insolite, 2006.

DUFRÊNE, Thierry, Les "places" de Giacometti ou le "monumental à rebours", in Histoire de l'art, París, n.․․ 27 (oct. 1994), pp. 81-92.

DUPIN, Jacques y SCHNEIDEGGER, Ernst, Alberto Giacometti, París: Maeght, 1962.

DUPUIS, Jules-François, História Desenvolta do Surrealismo, trad. de Torcato Sepúlveda, Lisboa, Edições Antígona, 2000.

FOSTER, Hal, El Retorno de lo Real, Trad. Alfredo Brotons Muñoz, Madrid, Akal, 2001.

FRANÇA, José-Augusto, "Arp + Giacometti 1966", In Colóquio Artes, Lisboa, n.o 43 (Abril 1967), pp. 35-39.

GALOFARO, Luca, Artscapes El arte como aproximación al paisaje contemporáneo, Barcelona, Editorial Gustavo Gili, 2003. 
JELLOUN, Ben, Giacometti \& Tahar Ben, París, Flohic, cop. 1991.

GOETHE, J.W., As Afinidades Electivas, trad. de Maria Assunção P. Correia, Relógio d’Água, 1999.

GOETHE, J. W. - Johann Wolfgang Von Goethe Paisajes: Catálogo de la exposición celebrada en el Círculo de Bellas Artes de Madrid entre el 31 de enero y el 6 de abril de 2008. Comisarios Javier Arnaldo y Hermann Midenberger, Madrid, Círculo de Bellas Artes, 2008.

GOLBERG, Roselee, Performance Art - from futurism to the present, Londres, Thames \& Hudson, 1996.

GRAHAM, Dan. - Dan Graham: works: 1965-2000, Ed. Marianne Brouwer; textos Eric de Bruyn...[et al.]; trad. de Brian Holmes, Peter Ingham, Victor Josrph. Dusseldorf : Richter Verlag, 2001.

GUITTON, Jean, Justificação Do Tempo, trad. de José Barata Moura, Lisboa, União Gráfica,1969.

HARRISON, Robert, Forêts-Essai sur l' imaginaire occidental, París, Flammarion, 1994.

HERRIGEL, Eugen, Zen e a Arte do Tiro com Arco, Lisboa, Assírio \& Alvim, 2007.

HOHL, Reinhold, Alberto Giacometti, Clairefontaine, 1971.

JAKOB, Michael, El jardín y la representación, trad. de María Condor, Madrid, Siruela, 2010.

JULIET, Charles, Giacometti, París, Hazan, 1985.

KASTNER, Jeffrey y Wallis, Brian, Land And Enenviromental Art, Londres, Phaidon, 1998.

KEARNEY, Richard, Poética do Possível Fenomenologia Hermenêutica da Figuração, trad. de João Carlos Silva, Lisboa, Instituto Piaget, D.L. 1997.

KUBLER, George, A forma do tempo observação sobre a história dos objectos, trad. de José Vieira de Lima, Lisboa, Veja, 1998. 
LAMARCHE-VADEL, Bernard, Alberto Giacometti, in Nouvelles Éditions Françaises, París, cop.1984.

LANGER, Susanne K., Sentimento e Forma, trad. de Ana M. Goldberger Coelho y J. Guinsburg, São Paulo, Editorial Perspectiva, 2006.

LORD, James, Alberto Giacometti drawings, Londres, Secker \& Warburg, 1971.

LORD, James, Mythic Giacometti, Nueva York, Farrar, Straus and Giroux, 2004.

LYOTARD, Jean-François, A Condição Pós-Moderna, trad. de José Bragança de Miranda, Lisboa, Gradiva, 1989.

LYOTARD, Jean-François, O Pós-Modernismo Explicado Às Crianças, Publicações D. Quixote, 1999.

MADERUELO, Javier, El espacio raptado: interferencias entre arquitectura y escultura, Madrid, Mondadori, 1990.

MADERUELO, Javier, Alberto Carneiro: sobre los árboles y el agua, Alberto Carneiro. Huesca, Diputación de Huesca, 1999.

MAROT, Sébastien, Suburbanismo y el arte de la memoria, trad. de Maurici Pla, Barcelona, Editorial Gustavo Gili, 2006.

MERLEAU-PONTY, Maurice, A Natureza, trad. de Álvaro Cabral, São Paulo, Martins Fontes, 2000.

MILANI, Raffaele, El arte del paisaje, trad. de Carmen Domíngues, Ed. Federico López Silvestre, Editorial Biblioteca Nueva, 2007.

MOLDER, Maria Filomena, Matérias Sensíveis, Lisboa, Relógio d’Água, 1999.

NANCY, Jean-Luc, Resistência da Poesia, trad. de Bruno Duarte, Lisboa, Vendaval, 2005.

NARBAIITS, Xavier, "Giacometti, Frank, James: comment naît le style d'une époque", in l' oeil, Lausanne. N.ㅇ 465 (oct. 1994), pp. 58-59.

PERNIOLA, Mario, A Estética do Século XX, trad. de Teresa A. Cardoso, Editorial Estampa, 1998. 
PENONE, Giuseppe, Respirar la sombra, Galicia, Centro Galego de Arte Contemporánea, 1999.

POMAR, Júlio, "Giacometti", Artes e Letras (Abr. 1972), S. 2, a. 14, n. 7, Lisboa, pp. 35-39.

PRIESTLEY, J. B, El Hombre y el Tiempo, trad. Juan Garcia Puente, Aguilar, Madrid, 1‥ Reimp., 1969.

RAGON, Michel, "Alberto Giacometti: peintre et sculpteur", in Jardin des arts. S.n.. - 158, Ene. 1968, pp. 3-9.

RANQUEJO, Tonia, Land Art, Madrid, Nerea, 2003.

RÉGNIER, Gérard, "Alberto Giacometti", in La revue des arts, S.I.. - 4-5, 1969, pp. 287-294.

ROSENGARTEN, Ruth, Giacometti: uma mobilidade ansiosa, Lisboa, Arte Ibérica, n. 19 (Nov. - Dez. 1998), pp. 30-33.

SANTARCANGELI, Paolo, El Libro De Los Laberintos, Historia de un mito y de un símbolo, prólogo de Humberto Eco y trad. de César Palma, Madrid, Ediciones Siruela, 2002.

SARAIVA, Tânia, "Alberto Carneiro. De artesão a artista. De artista a operador estético», In http://www.apha.pt/boletim/boletim4, activo el 11 de enero de 2010.

SCHULZ-DORNBURG, Julia, Arte y Arquitectura: nuevas afinidades, trad. de Elena Llorens Pujol, Barcelona, Editorial Gustavo Gili, 2002.

SOUSA, Ernesto de, "A arte ecológica e a reserva lírica de Alberto Carneiro", in Colóquio Artes, Lisboa, n. 16 (Fev. 1974), pp. 26-34.

SOUSA, Ernesto de, "Alberto Almeida Carneiro conhecido por Alberto Carneiro", In Colóquio Artes, n.ำ 16 (Fev. 1974), pp. 26-34.

SYLVESTER, David, Looking at Giacometti, Londres, Chatto \& Windus, 1994.

TRAQUINO, Marta, A Construção do Lugar Pela Arte Contemporânea, Vilarinho das Cambas, Edições Humus, 2010. 
TREPAT, Cristòfol A. Comes, Pilar, El tiempo e el espacio en la didáctica de las ciencias sociales, Universidad de Barcelona y Editorial GRAÓ, 2008.

TRÍAS, Eugenio, O belo e o sinistro, trad. de Miguel Serras Pereira, Lisboa, Fim de Século, 2005.

TSVIETAIEVA, Marina, O Poeta e o Tempo, trad. de Fernando Pinto do Amaral, Lisboa, Hiena Editora, 1993.

WIESINGER, Véronique, varia Alberto Giacometti, Isabel Nicholas, Correspondances, Lyon, Éditions Fage, 2007.

\section{c. Catálogos sobre la obra de Alberto Giacometti y Alberto Carneiro}

CARNEIRO, Alberto. - Alberto Carneiro, Exposição Antológica 1968- 2003, Funchal: Museu de Arte Contemporânea - Fortaleza de São Tiago, Lisboa: Assírio \& Alvim, Funchal, Porta 33, catálogo de la exposición de 22 de Marzo a 31 de Mayo de 2003.

CARNEIRO, Alberto. - Alberto Carneiro: evocações d'água; (textos de Alberto Carneiro, Bernardo Pinto de Almeida). Oporto: Galeria Pedro Oliveira, 1993.

CARNEIRO, Alberto. - Alberto Carneiro: desenhos 1962-2004, coord. Fernando Santos; texto Manuel António Pina, Alberto Carneiro; design Rui Mendonça. Oporto, Galeria Fernando Santos, 2005.

CARNEIRO, Alberto. - Alberto Carneiro, (texto de) Bernardo Pinto de Almeida. Lisboa, Cesar Galeria, 1998.

CARNEIRO, Alberto. - Alberto Carneiro: a Oriente na floresta de Ise Shima, (textos de) Jorge Molder, Rui Sanches, Delfim Sardo. Lisboa, Fundação Calouste Gulbenkian, Centro de Arte Moderna, 1997.

CARNEIRO, Alberto. - Alberto Carneiro: percursos na paisagem, catorze desenhos e uma escultura, 1982-83. Lisboa, Galeria Quadrum, 1983. 
CARNEIRO, Alberto. - Alberto Carneiro: esculturas, (coord.) Fernando Santos; trad. de A. Vasconcelos, Cláudia Oliveira. Tavira: Câmara Municipal, D. L. 2004.

CARNEIRO, Alberto. - Alberto Carneiro: meu corpo vegetal, (coord.) Fernando Santos; texto Fernando Francês; trad. David Prescott, Claudia Oliveira, Oporto: Galeria Fernando Santos, 2003.

CARNEIRO, Alberto. - Alberto Carneiro: nas margens de um rio. Lisboa : Centro Cultural de Belém, 1993.

CARNEIRO, Alberto. - Alberto Carneiro: exposição antológica, (coord.) Alberto Carneiro, Maria Helena de Freitas. Lisboa: Fundação Calouste Gulbenkian. Centro de Arte Moderna, 1991.

CARNEIRO, Alberto. - Sortilégios: instalações de Gerardo Burmester, Alberto Carneiro, Albuquerque Mendes, (textos de) Manuela de Melo, João Fernandes, Bernardo Pinto de Almeida. Oporto: Câmara Municipal, Pelouro de Animação da Cidade, 1992.

CARNEIRO, Alberto. - Alberto Carneiro, (coord.) Célia Pereira, (textos de) Alberto Carneiro, traducciones Elena Expósito, Josephine Watson, Santiago de Compostela : Xunta de Galicia, 2001.

GIACOMETTI, Alberto. - Alberto Giacometti, sculptures, peintures, dessins. 2ème éd. París : Musée d'Art Moderne de la Ville de Paris, D.L. 1992.

GIACOMETTI, Alberto. - Alberto Giacometti: the complete graphics, by Herbert C. Lust ; introduction by John Lloyd Taylor ; catalogue raisonné revised and supplemented by Alan Wofsy. Revised edition. San Francisco: Alan Wofsy Fine Arts, 1991.

GIACOMETTI, Alberto. - Alberto Giacometti: dessins 1914-1965, Alberto Giacometti, texte d'André du Bouchet, [s.I.], Maeght,1969.

GIACOMETTI, Alberto. - Alberto Giacometti: sculptures: peintures: dessins / conception graphique Sophie Noack ; traductions Edith Alexandre... [et al.]. 2ème ed. París, Musée d'Art Moderne de la Ville de Paris, cop. 1991. 
GIACOMETTI, Alberto. - La passion du lithographe: Alberto Giacomett: oeuvre gravé / textes Jean Genet... [et al.]. París: Maeght Éditeur, cop. 1990.

GIACOMETTI, Alberto. - Bourdelle et ses élèves: Giacometti, Richier, Gutfreund / Helena Staub ; [preface] Rhodia Dufet-Bourdelle. París: Paris musées, cop. 1998. GIACOMETTI, Alberto. - Albert Giacometti, catalogue réalisé par André Kuenzi; coordination Annette Ferrari ; [traductions] Monique et Dario Bondolfi, Charles Descloux. Martigny : Fondation Pierre Gianadda, 1986.

GIACOMETTI, Alberto. - Alberto Giacometti, 1901-1966, Toni Stooss, Patrick Elliott ; [foreword] Timothy Clifford, Richard Calvocoressi. Edinburgh: National Galleries of Scotland, 1996.

GIACOMETTI, Alberto. - Alberto Giacometti : la collezione di un amatore, sculture, dipinti, dissegni, grafica - la collection d'un amateur, sculptures, peintures, dessins, estampes - die Sammlung eines Liebhabers, Sculptures, Bilder, Zeichnungen, Graphik - A connoisseur's collection, sculptures, paintings, drawings, graphics, [introdução] Pieter Coray ; traduzione Rudolf Koella ; [texto] James Lord. Milano, Skira Editore, cop. 1995.

GIACOMETTI, Alberto. - Alberto Giacometti: col. Fundação Maeght, [introd.] José Sommer Ribeiro ; coord. Ivonne Felman Cunha Rego; coord. técnica Marina Bairrão Ruivo ; trad. de Anne Corrêa Guedes, Paula Mascarenhas, Lisboa, Fundação Arpad Szenes - Vieira da Silva, D. L. 1998.

GIACOMETTI, Alberto. - Alberto Giacometti: dessins, pref. Pierre Schneider, París, Galerie Claude Bernard, 1985.

GIACOMETTI, Alberto. - Alberto Giacometti: dibujo escultura pintura, pref. Kosme Maria de Baranano, Barcelona, Lunixurg, 1990.

GIACOMETTI, Alberto. - Alberto Giacometti. Saint-Etienne, Musée d'Art Moderne de Saint-Etienne, 1999.

GIACOMETTI, Alberto. - Alberto Giacometti: el diálogo con la historia del arte, coord. Maria Casanova; diseño Manuel Granell; trad. Ricardo Lázaro e Karel Clapshaw. Valencia: Generalitat Valenciana, IVAM Centre Julio González, 2000. 
GIACOMETTI, Alberto. - Alberto Giacometti, disegni, sculture e opere grafiche / a cura di Marilena Pasquali, Lorenza Selleri; redazione Doriana Comerlati. Milano: Mazzotta, cop. 1999.

GIACOMETTI, Alberto. - Barcelona, Fundació Caixa Catalunya, Giacometti, Jean-Louis Prat, catálogo de la exposición celebrada de 7 de marzo a 28 de mayo de 2000.

GIACOMETTI, Alberto. - Madrid, Museo Nacional Centro de Arte Reina Sofía, Alberto Giacometti, Kosme María de Barañano, Marianne Adelmann, Lunwerg Editores, 1990.

GIACOMETTI, Alberto. - Alberto Giacometti: Le dessin à l'oeuvre, Centre Ponpidou, essays; Jean Louis Schefer e Florian Rodari, exposición en el Centre Georges Ponpidou 2 Enero-abril 92001.

\section{d. Otros Catálogos}

Barcelona, Museu d'Art Contemporani de Barcelona MACBA, Um teatro sem teatro, exposición coproducida por el MACBA de Barcelona y el Museu Colecção Berardo de Lisboa, dir: Manuel J. Borja - Villel, 16 de Nov. - 17 Fev. 2008 en Lisboa.

Bilbao, Museo Guggenheim Bilbao, Anish Kapoor: catálogo de la exposición, Guggenheim, 16 de marzo - 12 de octubre 2010, edición: Eva Fernández del Campo. - Turner, 2010.

Caldas da Rainha, Museu José Malhoa, Instituto de Arte Contemporânea, Paisagens no Singular, Wandschneider, Miguel, co-aut; Faria, Nuno, co-aut.; Alves, José Manuel Costa, catálogo de la exposición, de 9 de enero a 7 de febrero de 1999.

Lisboa, Colecção Berardo, Silêncios, Marin Karmitz, Éditions des Musées de la Ville de Strasbourg, 2009. 
Oporto, Fundação de Serralves, Na Paisagem Colecção da Fundação de Serralves, Almeida, Marta Moreira de, catálogo de la exposición, de 13 de Marzo a 7 de Abril de 2002.

Santiago de Compostela, Guiseppe Penone 1968-1998, catálogo de la exposición, Comisario Miguel Fernández - cid, 22 de Enero a 4 de Abril de 1999.

\section{e. Material áudio y vídeo}

Alberto Carneiro, Dificilmente o que habita perto da origem abandona o lugar. Dirección de Olga Ramos e Investigación de Catarina Rosendo. Producción: Laranja Azul, Año: 2008, Duración: 50 min.

Alberto Carneiro 1991/93, (Registo vídeo), Bernardo Pinto de Almeida, Lisboa, Galeria Valentim de Carvalho, 1993.

Alberto Giacometti, Il Sogno di una testa - Testimonianze per Alberto Giacometti (1901-1966), un documental realizado por Giorgio Soavi y GrytzkoMascioni, RAI, 1977.

INGOLD, Tim, University of Aberdeen, Creativity - Abduction or Improvisation? (Conference at Keble College, Oxford, UK, 2011.20.06, frag.).

\section{f. Diccionarios}

Dicionário de Língua Portuguesa, Porto Editora, 8. ㄹ ed., 1999.

Dicionário de Alemão Português, $1^{\mathrm{a}}$ ed., Oporto, Porto editora,1985.

Lucie-Smith, Edward, Dicionário de Termos de Arte, trad. Ana Cristina Mântua, Lisboa: D. Quixote, 1995. 
UITTERHOEVE, Wilfried y MOORMANN, Eric M. Temas sobre la mitología griega en la literatura, música, teatro y artes plásticas, trad. de Jesús Martínez Sánchez, Madrid, Akal Ediciones, 1997.

\section{g. Recepción crítica de las exposiciones realizadas durante el curso de la investigación (selección de artículos)}

AMADO, Miguel, "Uma Extensão do Olhar", Público, Suplemento mil Folhas, 22 de enero de 2005,

AMARO, Carla, "Arte na paisagem", Notícias sábado no 271, 19 de marzo de 2011.

CARVALHO, José Maçãs de, "As Escolhas de ...", Jornal de Letras, Artes e Ideias, ํo 911, de 31 de Agosto de 2005, pp. 2,

CUNHA, Nuno, "Samuel Rama: Do tempo ao espaço", Diário de Notícias e Jornal de Notícias, revista Notícias sábado, días 19 y 20 de Junio de 2008, p. 52.

DUARTE, Ricardo, "7 artistas ao $10^{\circ}$ mês", Jornal de Letras, Artes e Ideias, n.. 914, de 12 de octubre de 2005, pp. 8-11.

FRANÇA, Carlos, "A Terra das imagens", Primeiro de Janeiro, 14 de Julio de 2008, p. 3.

JORGE, João Miguel Fernandes, "Projectado sobre o que se denomina Vida", Telhados de Vidro, no 5, Novembro de 2005, pp. 127- 129.

JORGE, João Miguel Fernandes, "Árvore(s) Enquanto Desejo de Posse do Desenho”, Processo em arte, Lisboa, Relógio d’ Água, 2008, pp. 298-300.

JÜRGENS, Sandra Vieira, "XV Bienal de arte internacional de Cerveira anuncia prémios aquisição", in Artes \& Leilões, № 21 setembro de 2009.

LAMBERT, Fátima, "Espaço feliz, estética escondida" - casa \& sujeito, París, Montruoge, Hauts de Seine, Salon Européen des Jeunes Créateurs 2004, (Cood: 
Adrien Pasternak, Mário Pasqualotto, Fátima Lambert), Catálogo de la Exposición, París, 2004.

LAMBERT, Fátima, Samuel Rama, Cerveira, Fundação Bienal de Cerveira, Catálogo de la XV Bienal de Cerveira, Coord. Fátima Lambert, 25 de Julio a 25 a 26 de Septiembre de 2009. pp. 64-67.

LISTOPAD, Jorge "MEGAPARSECS", Jornal de Letras, Artes e Ideias, ํㅡ 1095, 19 de Sept. 2012, p. 35.

MAGALHÃES, João, "Geração AC", $L$ + arte, no 7, Dezembro de 2004, p.37.

MAGALHÃES, João, "Transformar o Tempo", $L+\operatorname{arte,~n.~}{ }^{\circ}$ 8, enero de 2005, pp. 24-29.

MARQUILHAS, Maria Beatriz, «CARPE DIEM, Terceiro programa de exposições», http://www.artecapital.net. 2011.

MARTINS, Celso, "Oh Dear!", Expresso, Actual no 1648, 29 de Mayo de 2004, pp. 39.

MARTINS, Celso, «Lugares novos para os novos », Expresso, Actual ํㅜ 1670, 30 de Octubre 2004, p. 39.

MARTINS, Celso, «Samuel Rama», Expresso, Actual no 1703, 18 de Junio 2005, pp. 49-50.

MARTINS, Celso, "MAGMA", Expresso, Actual no 1848, 29 Marzo de 2008, p. 29.

MARTINS, Celso, "Em todas as direcções, A colecção de Fotografia de um banco Português: O coleccionismo institucional privado mostra trabalho", Expresso, Actual no 1885, 13 de Dezembro de 2008, p. 34.

MARTINS, Celso, "Balanço Exposições", Expresso, Actual no 1887, 27 de Dezembro de 2008, p. 9.

MARTINS, Celso, «No Rasto Da Medusa», Expresso, Actual ㄲo1945, 6 Fevereiro de 2011, p. 20.

MARTINS, Celso, «Scanning», Expresso, Actual ㄲo1947, 20 de Fevereiro de 2010, p. 21. 
MARTINS, Celso, "O Peso e a Ideia», Expresso, Actual nํ2064, 19 de Maio de 2011, p. 19.

MONCHIQUE, Eurico, "7 artistas ao 10. Mês na Gulbenkian sob o signo das instalações», in Jornal Público, 11 de Outubro de 2005.

Nazaré, Leonor, Samuel Rama, Lisboa, Catálogo da Exposição, Sete artistas ao $10^{\circ}$ mês, Centro de Arte Moderna, Fundação Calouste Gulbenkian, 11 Outubro 2005/08 Janeiro 2006, pp. 54-61.

NAZARÉ, Leonor, «projecto» in Newsletter OFundação Calouste Gulbenkian, N.은 67 Outubro de 2005, pp. 18-19.

NICOLAU, Ricardo, BES art, O presente Uma dimensão Infinita, Museu Colecção Berardo, Lisboa, 2008, pp. 296- 297

NUNES, Maria Leonor, Identidades Samuel Rama, Jornal de Letras, Artes e Ideias, nº 914, de 12 de Outubro de 2008, p. 2.

NUNES, Maria Leonor, O Mundo da Escultura, Jornal de Letras, Artes e Ideias, № 921, de 12 de Outubro de 2007, pp 2,

NUNES, Maria Leonor, Uma Cultura da Natureza, Jornal de Letras, Artes e Ideias, no 1022, de 2 de Diciembre de 2009, pp 12-17

NUNES, Maria Leonor, O pó do desenho, Jornal de Letras, Artes e Ideias, no 1019, de 21 de outubro a 3 de Novembro de 2009, pp 29,

OLIVEIRA, Filipa, Vontade, texto teórico de apoio à exposição ac\#1, espaço arte contempo, Outubro, Lisboa, 2004.

OLIVEIRA, Filipa, O Espaço do Fogo, Texto teórico de apoio à exposição, Museu António Duarte 2007

PASTOR, Laura Pérez, MEGAPARSECS de Samuel Rama, www. Plataformadeartecontemporaneo.com

PINTO, Sandra, Actividades Culturais, in revista visão, N.9 940, 10 a 16 de março de 2011. p. 8 
POEIRAS, Fernando, Scanning, texto teórico de apoio à exposição SCANNING, Arquivo Fotográfico Municipal de Lisboa, 2 Fevereiro a 26 Março de 2010, Lisboa.

PORFÍRIO, José Luís, «ACREÇÃO», Expresso, Actual no 1978, 25 de Setembro de 2010, p. 27.

PORFÍRIO, José Luís, “No trilho da montanha branca», Expresso, Actual no 2081, 15 de Septiembre de 2012.

POMAR, Alexandre, XXX (1975-2005), Expresso, Actual no 1699, 21 de Maio 2005, pp. 60.

POMAR, Alexandre, "A abrir a temporada», Expresso, Actual ํo1715, 10 de Setembro 2005, pp.42.

RATO, Vanessa e Oliveira, Marcia, "Agosto de Norte a sul, Amarante », Público, Mil Folhas, 3 de Julho 2004, pp. 28.

ROSA, Tomás. Paisagens e $(m)$ Conflito, Magazine Artes,nํ36, Janeiro de 2006, pp32-36.

RUIVO, Ana. "Geração 2003», in Expresso, Actual no 1627, 3 de Janeiro de 2004, pp. 29.

RUIVO, Ana. «Sete espaços para sete artistas», Expresso, Actual ํㅜ 1721, 22 de Outubro de 2005, pp. 38.

RUIVO, Ana. "Vitalidades Emergentes», in Expresso, Actual ํo 1731, 30 de Dezembro de 2005, pp. 21.

SARDO, Delfim, «Sem Título», Expresso, única ํㅜ1836, 5 de Janeiro de 2008, pág. 18 e 19.

SOARES, Luísa, "O Espaço dos Jovens», Público, 22 de Outubro de 2005, pp 22.

SOARES, Luísa, Habitar a Penumbra, Texto teórico de apoio à exposição, Sala Pahldata, Lisboa, Maio 2005, 
SOARES, Luísa, Questões de escala, público, Ípsilon, 28 de Março de 2008, pp. 47.

SOARES, Luísa, «Monumentos, recordações e outras ruínas», Público, Ípsilon, 16 de Janeiro de 2009, p. 33.

SOARES, Luísa, "A idade dos dragoeiros numa montanha de areia», Público, Ípsilon, 14 de Septiembre de 2012, p. 34.

SYNEK, Manuela, "Reflexões sobre o tema da Paisagem na Arte. Novos caminhos em questões da Natureza nas obras dos artistas plásticos», in WWW.apha.pt, Associação Portuguesa de Historiadores de Arte. Boletim 3.

SYNEK, Manuela, "Samuel Rama Provoca uma paragem no tempo", in umbigo, no 35, 2010.

ULRICH, Sofia e Magalhães, João, entrevista com Miguel Amado, L + arte, no 15, Agosto de 2005, pp.31.

\section{h. Catálogos y libros relacionados con las exposiciones realizadas durante el curso de la investigación (selección)}

Algés, Centro de Arte Manuel de Brito, catálogo da Exposição Going South, CAMB, Coord. Manuel Augusto Araújo, 29 de Janeiro a 16 de Maio de 2010. p. 1 30.

Amarante, Museu Municipal Amadeo de Souza - Cardoso, Catálogo da exposição do 8o Prémio Amadeo de Souza - Cardoso, 22 de Outubro a 30 de Dezembro de 2011.

Bragança, Centro de Arte Contemporânea Graça Morais, catálogo da Exposição Em Bragança Apontamentos de arte Contemporânea, Coord. Hugo Dinis, 14 de Março a 04 de Maio de 2009. pp. 1- 30.

Caldas da Rainha, Atelier Museu António Duarte, catálogo da exposição «0 espaço do fogo", 18 maio - 15 de Junho de 2007. 
Cascais, Centro Cultural de Cascais, catálogo Land Art Cascais Fernanda Fragateiro, Samuel Rama, Robert Smithson, 05 de Março a 10 de Abril de 2011.

Cerveira, Fundação Bienal de Cerveira, catálogo da XV Bienal de Cerveira, Coord. Fátima Lambert, 25 de Julho a 26 de Setembro de 2009. pp.64-67.

Cerveira, Fundação Bienal de Cerveira, catálogo da 16ำ Bienal de Cerveira, 16 de Julho a 25 a 17 de Setembro de 2011. pp.204-205.

Coimbra, CAV Centro de Artes Visuais, catálogo da exposição Uma Extensão do Olhar entre a fotografia e a imagem fotográfica - obras da colecção da fundação PLMJ, 2005. pp. 66-67, 132, 146.

Coruña, Museo de Arte Contemporâneo Union Fenosa, catálogo da X Mostra Internacional Union Fenosa, Coord; Manolo Q. Villarejo, David Barro, Paulo Reis e Rafael Doctor, 23 de Julho a 30 de Outubro de 2008, p. 21-23.

Faro, Capital Nacional da Cultura, Galeria Trem, Catálogo da exposição, ArmaPosta, 2005. pp. 2-3.

Idanha-a-Nova, Centro Cultural Raiano, catálogo da exposição Tapada do Tanque, 2 de Julho a 30 de Setembro de 2005. pp.29-33 e 44.

Lisboa, Centro de Arte Moderna José de Azeredo Perdigão, Coord. Leonor Nazaré, 11 de Outubro de 2005 a 8 de Janeiro de 2006 | 11 October 2005 to 08 January 2006, p. 58-61.

Lisboa, Museu Berardo, catálogo da exposição BESart, Museu Berardo e Banco Espírito Santo, Cood: María de Corral e/and Lorena Martínez de Corral, 24 de Novembro de 2008 a 25 de Janeiro de 2009. pp. 15,16, 296,297, 414.

Lisboa, Fundação PLMJ, options \& futures Works From The Collection Of The PLMJ Foundation, Coord. Miguel Amado, 2010. p. 54-55.

Lisboa, Edifício XXI Polo Tecnológico Lisboa Carnide, Somafre \& IPL, exhibition catalog, 90-10 Exposição 20 Anos Artes Plásticas ESAD.CR, 29 de Abril - 15 Maio 2011. p. 164.165.

Lisboa, Galeria 111, Gabriel Abrantes, Eduardo Batarda, Isabelle Faria, Fátima Mendonça, Samuel Rama, 2011. p. 27-29. 
Lisboa, Associação Industrial Portuguesa, Arte Lisboa, catálogo da Feira de Arte Contemporânea de Lisboa, Galeria 111, 7 a 12 de Novembro de 2007, pág. 16 17.

Madrid, ARCO 2011, Madrid catálogo da Feira de Arte Contemporânea de Madrid, Coord. Maria Teresa M. Faraldo, Juan Carlos Lozano, 16 a 20 de Febr. 2011.

Tavira, Casa das Artes de Tavira, catálogo da exposição Bartolomeu XIX, CAT. 2 a 22 de Agosto de 2008. P. 20.

O Espaço do Fogo, Texto teórico de apoio à exposição, Museu António Duarte 2007.

París, European Exhibition for Young Creators, Ville de Montrouge, exhibition catalog, Ville de Montrouge, April - June 2004.

São João da Madeira, Centro de Arte de São João da Madeira, Catálogo da Exposição MINA, Centro de Arte de São João da Madeira, Coord. Luísa Soares de Oliveira, 18 Setembro a 8 de Novembro de 2009. pp. 1-11.

São João da Madeira, Centro de Arte de São João da Madeira, 1986-2011 25 anos do Centro de Arte S. João da Madeira, Coord. Victor Costa, 2011. p. 86-87.

\section{9. ÍNDICE DE IMÁGENES PRESENTADAS}

Fig. 1 - Paisaje, siglo. I, Pintura mural, Villa Albani, Roma

Fig. 2 - Vista de un Jardín, pintura mural de la Villa de Livia, en Primaporta. C. 20 a. C., Museo delleTerme, Roma

Fig. 3 - Hermanos Limbourg, Diciembre, miniatura en pergamino de Les Très Riches Heures del Duque de Berry. 1413-16. (Château de Vincennes), Francia

Fig. 4 - Paolo Uccello, La Caza, después de 1460. 75x178 cm, Ashmolean Museum, Oxford. 
Fig. 5 - Sandro Botticelli, tabla I, (Museo del Prado) II, (Museo del Prado) III (Museo del Prado) y IV (Palacio Pucci de Florencia) de la historia de Nastagio degli Onesti, 1482-1483, témpera sobre tabla.

Fig. 6 - Altdorfer, San Jorge en el Bosque, 1510, Pinacoteca de Munich.

Fig. 7 - Altdorfer, Vista del valle del Danubio, 1520-25, Pinacoteca de Munich.

Fig. 8 - Nicolas Poussin, NicolasPoussin, Trayecto que conduce a un claro en el bosque, c. 1635-1640. Dibujo a pluma y aguada marrón, 38,6 X 24,6 cm, J. Paul Getty Museum, Los Ángeles.

Fig.9 - Caspar David Friedrich, La cruz en la montaña, 1812. Óleo sobre tela, $44,5 \times 37,4 \mathrm{~cm}$, Dusseldorf, KunstPalast

Fig. 10 - Ansel Adams, Winter Yosemite Valley, 1933-34, Gelatina de Plata 23,4×18,5 cm, Colección de Alfred Stieglitz.

Fig.11 - Paul Delvaux, El Crepúsculo, 1937, Fundación Peggy Guggenheim, Venecia

Fig. 12 - Max Ernst, Bosque y Pájaro, 1927, Tate Gallery.

Fig. 13 - Yves Klein, La forêt d'éponges et les bas-reliefs monochromes, Galería Iris Clert, París, junio de 1959.

Fig. 14 - Yves Klein, Sculpture éponge. Pigmento puro y resina sintética sobre esponja, varilla de metal y piedra, 60×23×16 cm, 1959 .

Fig. 15 - Giuseppe Penone, repetir el bosque, ripetere il bosco. Instalación: Kunstmuseum, Bonn, 1997.

Fig.16 - Joseph Beuys, 7000 Robles, Documenta 7, Kassel, 1982. El primer roble plantado en Friedrichplatz.

Fig. 17 - Agnes Denes, Tree mountain - A living time capsule, 10.000 Trees, 10.000 People, 400 Years, 1982.

Fig. 18 - dolo, Amorgos. 2500-1100 a.C Mármol, alt. 0.76 m, Ashmolean Museum, Oxford 
Fig. 19 - Grupo de Laocoonte. Copia romana del original, obra probable de Agesandro, Athenodoro y Polydoro, de Rodas Siglo. I a.C. Mármol, alt. 213 m. Museo del Vaticano, Roma.

Fig.20 - Miguel Ángel, El Atlas, 1519, Mármol, 277 cm, Galería de la Academia, Florencia.

Fig. 21 - Eduardo Chillida, Lo profundo es el aire XX 1998, Alabastro, 76 x 88 x $70 \mathrm{~cm}$.

Fig. 22 - El Lissitzky, Proyecto PROUN, 1923.

Fig. 23 - El Lissitzky, Espacio PROUN, 1923.

Fig. 24 - Alberto Giacometti, La forêt (El Bosque), 1950, bronce, 57×61×49,5 cm, Fundación Maeght.

Fig. 25 - Alberto Giacometti, copia de un dibujo de Katsushika Hokusai, Viajeros bajo la lluvia, circa 1820-30, Pluma y tinta sobre papel, 33,5X25,2 cm, no firmado, sin fecha.

Fig. 26, 27 y 28 - Alberto Giacometti, (Mujer de pie), Femme debout, 1946, Lápiz sobre papel, 53,5X28,5 cm, Col. Jan et Marie -Anne Krugier - Poniatowski, Ginebra. (Fig. 27) Fragmento ampliado del dibujo de la fig. 26. (Fig. 28) Alberto Giacometti, (Femme debout), 1947 (cast 1957). Bronce, 60 1/4 pulgadas (153 $\mathrm{cm})$ Col. Guggenheim NY.

Fig. 29 - Fotografía de René Burri: Giacometti trabajando en un busto de Diego, 1960.

Fig. 30 - Alberto Giacometti, James Lord, 1964, Óleo sobre lienzo, 177 X 81,5 $\mathrm{cm}$.

Fig. 31, 32,33 y 34 - Dibujos realizados a partir de la escultura de A. Giacometti titulada "La forêt", tras varias visitas a la exposición titulada Silêncios,295 realizada en el Museu Berardo entre 26 de octubre de 2009 y 10 de enero de 2010.

Fig. 35 y 36 - Fotografías realizadas a partir de la escultura de A. Giacometti titulada "La forêt", tras varias visitas a la exposición titulada "Silêncios", realizada en el Museu Berardo entre 26 de octubre de 2009 y 10 de enero de 2010. 
Fig. 37 - Relieve polícromo de un túmulo del antiguo imperio, en Saqqara, Egipto.

Fig. 38 - Escena de labranza reproducida con los ushabti, (pequeñas estatuillas funerarias de madera) Dinastía XI.

Fig. 39 - Figura Periodo medio, Dinastía XII, Madera Pintada. Proveniencia: EI Berscheh.

Fig. 40 - Alberto Giacometti, Figurine Dans Une Boîte Entre Deux Maisons (Figura en una caja entre dos casas), 1950. Bronce pintado y plexiglás, $30 \times 54 \times 9,5 \mathrm{~cm}$, Colección Particular.

Fig. 41 - Alberto Carneiro, Uma Floresta para os teus Sonhos (Un bosque para tus sueños), 1970, Troncos cortados de pino; dimensiones variables, Colección Centro de Arte Moderno de la Fundación Calouste Gulbenkian, Lisboa.

Fig. 42 - Alberto Carneiro, Macho - fêmea, madera,1965-66.

Fig. 43 - Alberto Carneiro, O canavial: memória metamorfose de um corpo ausente (El Cañaveral: memoria metamorfosis de un cuerpo ausente), 1968. Cañas, cintas de color, letras de calco, rafia; dimensiones variables, Colección Caixa Geral de Depósitos.

Fig. 44 - Alberto Carneiro, Um campo depois da colheita para deleite estético do nosso cuerpo (Un campo después de la cosecha para deleite estético de nuestro cuerpo), 1973-76. Centeno, heno; Dimensiones variables Colección del artista Instalación en el CGAC - Centro Galego de Arte Contemporánea, Santiago de Compostela, 2001.

Fig. 45 - Alberto Carneiro, Sobre o meu jardim (Sobre mi jardín) 1998-99. Madera; $38 \times 180 \times 180 \mathrm{~cm}$, Colección del artista, Instalación en el CGAC Centro Galego de Arte Contemporánea, Santiago de Compostela, 2001.

Fig.46 - Alberto Carneiro, Proyecto para Uma floresta para os teus sonhos,(Un bosque para tus sueños), 1970, Grafito sobre papel, milimétrico, $21 \times 29,5 \mathrm{~cm}$, Colección Fundação Luso- Americana para o Desenvolvimento.

Fig. 47, 48, 49 y 50 - Fragmentos del dibujo de Uma Floresta para os teus Sonhos, 1970.

Fig. 51 - Esquema interpretativo de la noción de espacio paisaje de Rosario Assunto.

Fig. 52 y 53 -Alberto Carneiro, Um campo depois da colheita para deleite estético do nosso cuerpo, (Un campo después de la cosecha para deleite estético de nuestro cuerpo), 1973-76. Centeno, heno; Dimensiones variables 
Colección del artista,Instalación en el Centro Galego de Arte Contemporánea, Santiago de Compostela, 2001.

Fig. 54 - Samuel Rama, S/Título - Serie Habitar a Penumbra, 2003, Fotografía a color, Impresión llfochrome Polyester, $27 \times 40 \mathrm{~cm}$.

Fig. 55 - Samuel Rama, S/Título - Serie Habitar a Penumbra, 2003, Fotografía a color, Impresión llfochrome Polyester, $40 \times 60 \mathrm{~cm}$.

Fig. 56 - Samuel Rama, S/Título - Serie desenhar- esculpir - fotografar, 2004, Fotografía a color, Impresión llfochrome Polyester, $70 \times 50 \mathrm{~cm}$.

Fig. 57 - Samuel Rama, S/Título - Serie desenhar- esculpir - fotografar, 2004, Fotografía a color, Impresión Ilfochrome Polyester, $70 \times 50 \mathrm{~cm}$.

Fig. 58 - Samuel Rama, S/Título - Serie desenhar- esculpir - fotografar, 2004, Fotografía a color, Impresión llfochrome Polyester, $70 \times 50 \mathrm{~cm}$.

Fig 59 - Samuel Rama, S/Título - Serie desenhar- esculpir - fotografar, 2004, Fotografía a color, Impresión Ilfochrome Polyester, $70 \times 50 \mathrm{~cm}$.

Fig. 60 - Samuel Rama, Registro de la performance de pintura del árbol con tinta china a lo largo de tres días.

Fig. 61 - Samuel Rama, Árvore(s) Enquanto desejo de posse do desenho, 2005, Impresión Ilfochrome Polyester, $2(100 \mathrm{~cm} \times 100 \mathrm{~cm})+(9 \mathrm{~cm} \times 9 \mathrm{~cm})$.

Fig. 62 - Samuel Rama, Dobrar a terra, 2007, Impresión chorro de tinta larga duración sobre papel Fine art, $2(70 \mathrm{~cm} \times 100 \mathrm{~cm})+(9 \mathrm{~cm} \times 13 \mathrm{~cm})$.

Fig. 63 - Samuel Rama, Vontade, 2004, Apariencia de la instalación en el Espaço AC, Lisboa, Arena y agua en un área de $600 \times 400 \mathrm{~cm}$.

Fig. 64 - Samuel Rama, S/ Titulo, 2004, 4’30", Loop, Instalación video.

Fig. 65 - Samuel Rama, Fadiga de estruturas, 2005-06, Vista de la Instalación realizada en la sede de la Fundação Calouste Gulbenkian, Lisboa, En un área de $600 \times 1150 \mathrm{~cm}$.

Fig. 66 -Samuel Rama, Wander, 2007, Vista de la Instalación realizada para el IV International Prize of Painting Diputación de Castellón realizada en el Museo de Bellas Artes de Castellón, España, en un área de 600 X $400 \mathrm{~cm}$.

Fig. 67 - Samuel Rama, MEGAPARSECS, 2012, Arena, palco, metal y aceite quemado, Instalación Teatro da Politécnica, alt $260 \times$ larg $900 X$ prof $600 \mathrm{~cm}$. 
Fig. 68 - Samuel Rama, Mancha \# 1, Barro sobre arquitectura, Dimensiones variables, 2009,

Fig. 69 - Samuel Rama, MAGMA, 2008, Vista de la instalación Galeria 111, Árboles de ciprés, polvo de arcilla y barro fresco, En un área de $10000 \times 10000$ $\mathrm{cm}$.

Fig. 70 - Samuel Rama, Sem Título \#10, (serie MAGMA), 2008, Impresión chorro de tinta larga duración sobre papel Fine art, $98 \mathrm{~cm} \times 124 \mathrm{~cm}$.

Fig. 71 - Samuel Rama, Sem Título \#3, (serie MAGMA), 2008, Impresión chorro de tinta larga duración sobre papel Fine art, $98 \mathrm{~cm} \times 124 \mathrm{~cm}$.

Fig. 72 - Samuel Rama, Sem Título \#6, (serie MAGMA), 2008, Impresión chorro de tinta larga duración sobre papel Fine art, $98 \mathrm{~cm} \times 124 \mathrm{~cm}$.

Fig. 73 - Samuel Rama, Escavação \# 19, 2009, Impresión chorro de tinta larga duración sobre papel Fine art $98 \mathrm{~cm} \times 124 \mathrm{~cm}$.

Fig. 74 - Samuel Rama, Scan \# 2 , 2010, Impresión chorro de tinta larga duración sobre papel Fine art, $98 \mathrm{~cm} \times 124 \mathrm{~cm}$

Fig. 75 - Samuel Rama, Paisagem Adoptiva, 2009. Instalación en la mina de yeso y uno de los carteles instalados en la Vila de Óbidos.

Fig. 76 - Samuel Rama, Arquitectura Reflexiva \# 1, 2011, Estructura de metal, piedra calcárea, escalera y cobertura vegetal, $2.40 \mathrm{~m}$ X $3 \mathrm{~m} \mathrm{X} 4 \mathrm{~m}$.

Fig. 77 - Samuel Rama, Arquitectura reflexiva \# 3, 2011, Surco cavado en la tierra, cal y esfera de cal endurecida, En un área de $8 \mathrm{~m} \times 12 \mathrm{~m}$.

Fig. 78 - Samuel Rama, Arquitectura reflexiva \# 2, 2011, Surco cavado en la tierra, cal y esfera de cal endurecida, Diámetro de $9 \mathrm{~m}$. 


\section{ANEXOS}

Transcripción de la conferencia pronunciada por Alberto Carneiro en abril de 2004, en el auditorio de la Escola Superior de Artes e Design de Caldas da Rainha, IPL, invitado por Samuel Rama en el marco de la asignatura de Escultura II, perteneciente al tercer curso de la titulación de Artes Plásticas.

Samuel Rama: «Alberto Carneiro nasceu em S. Mamede do Coronado, Sto․ Tirso, a 20 de Setembro de 1937. Durante a sua adolescência, trabalhou numa oficina de santeiros onde se iniciou nas tecnologias da madeira, pedra e marfim.

Licenciou-se em Escultura na Escola Superior de Belas Artes do Porto, tendo participado, entre muitas exposições em Portugal e no estrangeiro representando Portugal, na Bienal de Veneza em 1976 e na Bienal de São Paulo em 1977. A sua última grande exposição foi em 2001, no CGAC (Centro Galego de Arte Contemporânea). Personalidade multifacetada, foi responsável pela orientação artística e pedagógica do Círculo de Artes Plásticas de Coimbrade 1972-85. Participou em diversos congressos e conferências sobre Arte e o seu Ensino. É responsável pelos encontros de Escultura em Sto Tirso que conjugam artistas, arquitectos e outros agentes na implementação de esculturas no espaço público. Actualmente, a par do seu trabalho como artista, é professor de desenho na Faculdade de Arquitectura da Universidade do Porto.»

Alberto Carneiro: «Sinto-me honrado pelo convite e espero não defraudar expectativas. Penso que é fundamental passar o testemunho da experiência que cada um tem no seu campo de actividade e creio que é uma responsabilidade cívica fazer isso. Gostaria de referir um pouco qualquer coisa que tem que ver com a minha formação, dado que considero que todo o meu 
trabalho, toda a minha obra, isto é, desde o princípio até agora, é portador de significado e experiência, olhando agora para um percurso e para as suas transformações sucessivas.

- Tenho de fazer algumas referências de carácter biográfico. Nasci no meio rural, numa família sem meios económicos muito substanciais. Os meus pais trabalhavam, eu, por morte dos meus dois irmãos, fiquei filho único. Esta situação é muito importante. No sítio onde eu vivia, existiam duas casas: a minha e a do meu amigo Zacarias, que tem a minha idade, e com quem eu brincava portanto.

- Mas eu brincava muito sozinho no quintal da casa que era pequenino. Tinha uns $18 \mathrm{~m}^{2}$ e tinha uma pequena horta. Havia um grande pinhal ao pé da minha casa (que hoje não existe) e que era o meu território.

- E naturalmente não havia dinheiro para comprar brinquedos. Naquela época, ninguém comprava brinquedos. Estávamos no século passado, em 1938, 39, 40,portanto, no tempo da Segunda Guerra Mundial. Não havia dinheiro em lado nenhum. Havia muita fome em todo o lado. E portanto, eu tive de inventar todos os meus brinquedos com a terra, com bocados de troncos de couvesgalegas, com as cascas dos pinheiros, com os bugalhos que apanhava dos carvalhos, com várias coisas que serviam para inventar os brinquedos, para brincar como todas as crianças brincam. No meio rural, as crianças brincam inventando os seus brinquedos, naturalmente! $E$ isto é importante! Muito importante!

- Brincava como todas as crianças brincam. Foi uma necessidade lúdica e uma necessidade natural da construção do meu esquema corporal.

- Como sabem, o esquema corporal nasce e é criado dentro de nós e projecta-se constantemente para fora, todas as vezes que nós temos de nos confrontar como o mundo exterior. Naturalmente, a minha imagem tem esses índices muito fortes, muito marcados! 
- Depois fiz naturalmente a minha instrução primária. Tive a sorte de sempre ser uma criança protegida, quer pelo padre Antero, quer pelos professores primários. Acabei a minha escola primária como uma espécie de menino esperto.

- O padre, as professoras e mesmo os meus pais achavam isso, dado que era um menino muito piedoso - eu hoje sou agnóstico - achavam que eu deveria ser padre. Mas eu como criança devo ter alguma coisa por cima de mim que me protege sempre, não sei bem o quê, disse que não, quando toda a gente esperava que eu dissesse que sim!

- Bom, os meus pais não tinham dinheiro para me pôr a estudar e continuar os meus estudos na Escola Secundária; puseram-me numa oficina de santeiros.

- São Mamede do Coronado era na época o centro mais importante do norte do país de produção de imagens religiosas. Existiam 5 oficinas que dependiam dessa actividade. Eu entrei na oficina mais prestigiada, ainda menino, aos dez anos de idade e comecei a aprender o ofício. Essa aprendizagem foi fundamental para a minha vida de artista, produtor de objectos artísticos, e para a minha vida de pedagogo, de professor. Todos os meus programas tomavam em consideração o modo como eu aprendi, a minha experiência de aprendizagem numa oficina de santeiros.

- Aprendia-se sem palavras! Aprendia-se com objectos. A hierarquia da oficina era um pouco estruturada à maneira medieval; era constituída pela escala de aprendiz, oficial e mestre. Era a ordem que se esperaria. E não se acedia aos vários patamares de qualquer modo: conquistavam-se esses estados! E quando havia um erro de execução do trabalho, não havia palavras para dizer que se errou: a mão do oficial caía de cima para baixo! «Cloque» - Era assim que se chamava à mão fechada que passava pela cabeça raspando. Doía muito! Coçava-se a cabeça! Naturalmente não havia queixas! Não havia motivo para tal, era a prática e nós aprendíamos que deveríamos pensar sobre aquilo que errávamos para aprender. 
- Outra questão importante era a utilização dos instrumentos. Este dedo que vocês vêm tem uma cicatriz que vai daqui aqui (dedo polegar da mão esquerda com uma cicatriz com cerca de $10 \mathrm{~cm}$ ). Eu aprendi uma coisa importante. No dia em que comecei a cortar um pedaço de madeira, ninguém me ensinou como é que devia pegar num pedaço de madeira e, naturalmente, os ferros que servem para cortar a madeira estão muito afiados, são afiadíssimos, e cortam mesmo bem! Eu pus o dedo à frente e, naturalmente, quando estava a cortar a lâmina do formão, falhou, cortou-me o dedo e este ficou com uma abertura. Não fui à farmácia nem nada! Desinfectou-se com o que havia, atou-se com um pano e isto cicatrizou.

- Mas eu aprendi que nunca mais colocaria as mãos à frente do formão no sentido do corte da madeira. Isto é apenas para referir que esta questão da aprendizagem do ofício foi fundamental para mim, não pelo facto de eu aprender a trabalhar muito bem a madeira, a pedra ou o marfim, mas pelo facto de ter aprendido a disciplina do ofício, pelo facto de ter aprendido a trabalhar as coisas como quem aprende a andar de bicicleta ou a nadare depois tem que esquecer a bicicleta e tem que esquecer a própria água para nadar bem ou andar bem de bicicleta.

- Isto é, no processo de aprendizagem é indispensável aprender o ofício e depois esquecê-lo.

- E portanto, andei dos 10 aos 21 anos, altura de ir para a tropa, a fazer santinhos. Guardo umas imagens de Cristo que fiz e que acho interessantes. Naturalmente que nem tudo o que fiz nessa fase foi importante. Era uma fase copista. Raramente há um santeiro que inventa alguma coisa!

- Aos 18 anos, trabalhava eu ainda na oficina de santeiros, descobri que no Porto, a $20 \mathrm{~km}$ de S. Mamede, havia um curso nocturno na Escola de Artes Decorativas Soares dos Reis, que era o equivalente a uma formação profissional artística. O curso tinha um nome curioso, chamava-se: Curso de Aperfeiçoamento Profissional. Isto é, um curso para gente pobre, miserável! De 
qualquer modo, havia uma hipótese de fazer alguma coisa desse curso porque os meninos ricos iam para a Escola Secundária.

- Eu descobri o curso e passei a fazer diariamente, ao longo de aproximadamente 4 anos e após quatro horas de trabalho na oficina, uma hora de bicicleta para o Porto, com chuva e sol etc., quatro horas de aulas de Segunda a Sábado inclusive regresso a casa outra vez de bicicleta, perfazendo um total de $40 \mathrm{~km}$ num sentido e no outro, mais uma hora de regresso. E hoje quando olho para este percurso digo: «que grande paciência tiveste Alberto!». Posso garantir-vos que nunca deixei de namorar! Nunca deixei de me divertir! Naturalmente tudo isso tinha de ser feito com uma grande disciplina.

- Quando vim da tropa, decidi que não queria ser mais santeiro! E para arranjar dinheiro para comer e pagar o resto dos meus estudos secundários, tive de trabalhar por um lado como professor de ginástica, aproveitando os conhecimentos que tinha aprendido na tropa, e como repórter desportivo em part-time, no Jornal de Notícias do Porto, uma actividade que sempre detestei, mas que tive de fazer para obter sustento.

- Depois entrei para a Escola Superior de Belas Artes do Porto com 24 anos, fiz o meu curso com uma grande responsabilidade ética, sendo um aluno bastante contestatário relativamente ao processo académico que vigorava na escola. E depois de ter feito a tese de final de curso, a Gulbenkian deu-me uma bolsa para ir estudar para a Saint Martin'sSchoolofArt de Londres. Aí, tive a oportunidade de me confrontar com uma dinâmica completamente diferente que hoje é difícil de perceber face aos constrangimentos culturais que existiam na época.

- Não existiam livros na biblioteca da Escola Superior de Belas Artes do Porto. Havia pouca coisa, a escola assinava duas revistas internacionais da época: aStudyInternational e a ArtInternational, que eram no fundo o único acesso a informação sobre aquilo que se estava a fazer fora do país. 
- Conhecia-se pouco! Viajava-se pouco naturalmente! Eu estava proibido de entrar em Portugal porque tive o passaporte caçado pela PIDE durante quatro anos, quando estive envolvido em actividades contra o regime.

- Em Londres, finalmente pude ver todos os filmes que não tinha visto. Logo no primeiro ano vi 154 filmes, pude ouvir toda a música que não tinha ouvido, portanto filmes e obras musicais que eram proibidas cá em Portugal.

- Eu viajei para Londres em Setembro de 1968. Portanto, estávamos em plena ebulição do Maio de 68, em Paris, e Londres faz a ressaca do Maio de 68 em 69, com todas as problemáticas relacionadas com o colonialismo e, naturalmente, eu faço parte desse movimento!

- O nosso curso de Pós-graduação na Saint Martin'sSchool era constituído por um grupo de 15 estudantes: 2 ingleses e 13 estrangeiros vindos de todo o mundo, gente que coincide no plano internacional como David Lamelas, Reinhard klessinger, Peter Rosman, etc.

- A situação é a seguinte; eu faço o meu curso, tinha uma posição muito crítica relativamente à situação da Escola Superior de Belas Artes do Porto, por uma razão simples: predominantemente não havia discurso teórico na escola, as aulas práticas eram dadas de uma maneira muito fácil - "faça isto, faça aquilo, está bem, está mal, está melhor do que estava"- não passavam de um comentário superficial e naturalmente eu estava à espera de um plano de exigência maior. E faço, em simultâneo com as actividades lectivas, um trabalho paralelo de Atelier. Consegui arranjar atelier durante o meu segundo ano de curso onde eu vivia.

- A partir do segundo ano, recuso-me determinantemente a fazer escultura humana fora da cadeira de Escultura de modelo vivo. Por outro lado, o material em que trabalhava era o barro que, como sabem, era sempre um material de transição. Isto é, executava-se um trabalho para depois passar a bronze, a ferro, madeira ou qualquer outro material. 
- O sistema da ESBAP era académico, fundado ainda no sistema de Beaux - Arts, marcado pela tradição Francesa, muito pouco referenciado por qualquer outra cultura, de costas voltadas para o que se tinha passado inclusivamente no Modernismo.

- As grandes referências dominantes paradigmas para os professores poderiam ir quando muito até Rodin, ou pouco até Bourdelle. Mas não passava daí! Brancussi, os modernistas todos, incluindo os construtivistas etc. não eram desconsiderados, nem deixavam de ser! Eram pura e simplesmente ausentes!

- Em 1967, tive a sorte também, e sem nunca o ter pedido, de ter sido convidadopelo director da ESBAP, o Arquitecto Carlos Ramos, a quem eu presto homenagem todas as vezes que tenho a possibilidade de o fazer porque estava atento ao que se passava na escola e, sendo arquitecto e sendo professor de arquitectura, curso que era bastante mais estruturado, exigente e aberto, o Arquitecto Carlos Ramos, como director da ESBAP, sabia o que se passava nas artes plásticas. Era um homem muito inteligente.Convidou-me em 1967, ainda sem ter feito a tese de final de curso, a fazer uma exposição individual no salão de exposições da escola que cruzava trabalhos em escultura que não continham figura humana, realizados no âmbito académico e no meu atelier, e também desenhos.

- Durante essa exposição, houve reacções interessantes. Uma delas foi uma frase de um dos meus professores que dizia: "Ah,ah,ah! O Alberto Carneiro tem ali uma exposição, são tudo vulvas e falos!" De facto, o meu trabalho nessa época tinha uma nítida e forte carga erótica, uma das peças chamava-se inclusivamente "a cópula".

- E essa exposição é importante porque todas as manhãs, durante o período em que a exposição estava fechada, sentei-me a vê-la e pensava se era por ali que eu queria seguir... E cheguei à conclusão que não era por ali que eu queria ir! No entanto, posso vos dizer que a exposição estava a ser um êxito e eu poderia ter seguido aquela via que resolveria os meus problemas económicos. 
- No ano seguinte, foi-me dado o prémio nacional de escultura com a peça apresentada como tese de final de curso que, infelizmente, ardeu num incêndio.

- A partir da primeira exposição individual na ESBAP, eu já sabia que não era por ali que queria ir. Mas não sabia por onde queria seguir com o meu trabalho. É fácil sabermos por onde não queremos ir, mas é mais difícil saber por onde queremos desenvolver o nosso trabalho. O caminho que vamos seguindo é qualquer coisa sobre cujas premissas vamos elaborando e reelaborando, sistematicamente.

- Eu tinha produzido nos anos 66/68 algumas esculturas antes de ir para Londres: cinco esculturas em folhas de metal recortado e articulado, sendo que três dessas cinco peças formaram o trabalho que eu levei à IV Bienal de Paris em 1969.

- Entretanto fui para Londres e, para concorrer ao lugar no curso de pósgraduação, tive de enviar o meu portfólio documentando fotografias do meu trabalho. E recebi uma carta que ainda hoje guardo porque me perguntavam do lado de lá Saint Martin's: «o senhor com esta obra já feita, o que é que vem fazer à escola?». - Naturalmente, eu ia para a escola porque a Gulbenkian me obrigava a estar matriculado numa escola para poder ter bolsa.

- Não sabia como era a escola, sabia que ia trabalhar com gente importante como Anthony Caro e Philip King.

- Quando chego a Londres, faço a minha última escultura na linha das coisas que tinha feito durante esses últimos anos, em metal recortado.

- Depois aconteceu uma coisa interessante, pois mais uma vez, eu descobri que não queria ir por ali!

- Entretanto fiz uma série de experiências com acrílico, coisas que só mostrei uma vez. Um dia destes, vou fazer uma exposição com essas coisas que são importantes, onde eu abordo as questões que irão servir de base para o meu 
trabalho. Penso que para as pessoas que analisam o meu trabalho, pode ser uma tarefa muito interessante!

- Eu trabalhei já em Londres, entre Novembro de 1968 e Fevereiro de 1969, numa série de esculturas em acrílico transparentes com cor, e eu produzi várias centenas de desenhos e será esse material que eu um dia quero mostrar.

- Mas entretanto, como devem calcular, andava inquieto, pois tinha acabado de concluir que não era por esse tipo de trabalho que queria continuar. Já tinha concluído uma vez tal decisão na escola de Belas Artes do Porto e agora, em Londres, voltei a concluir da mesma forma.

- Estava no meu quarto. Eu vivia num sítio magnífico, mesmo no centro da cidade de Londres. Andava inquieto e então tive uma revelação de uma obra em que eu conheço exactamente a hora e o dia em que ela nasceu: $O$ canavial. Nasceu no dia 16 de Dezembro às duas e meia da tarde. 

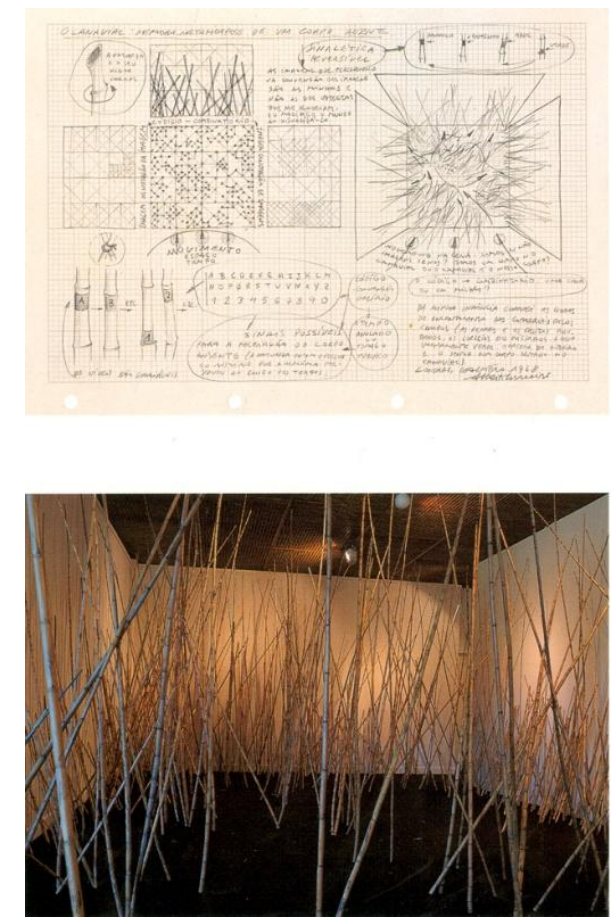

Alberto Carneiro, O canavial: memória metamorfose de um corpo ausente, 1968 Canas, fitas de cor, letras, ráfia, dimensões variáveis, Colecção Caixa Geral de Depósitos

- E foi uma espécie de anamnese, um flash que teve que ver com a minha primeira experiência erótica real com o meu amigo Zacarias.

Como todos sabem, aos 5 anos de idade iniciam-se as pulsões, que são naturais e portanto não há uma noção do que é ser menino ou menina. Trata-se de um impulso biológico e essa experiência apareceu num canavial que existia muito próximo da nossa casa. Hoje o canavial já não existe.

- O Canavial surge assim em torno de uma experiência muito forte. Para além de ter inventado o canavial nesse dia, e de ter inventado uma série de outras obras em seguida, colocou-se-me um problema: «afinal onde está a minha formação artística? Onde é que eu aprendi? Quando é que eu comecei a ter consciência destas coisas? Quando é que o meu esquema corporal começou a 
ficar marcado por esse tipo de relações?» E naturalmente comecei a partir daí a trabalhar a partir das minhas experiências de menino.

- A partir daquele momento, comecei a trabalhar, não a partir de um jogo formal qualquer, mas na recolha de sensações, de anamneses, de reminiscências. Não são memórias, nem recordações, atenção! Nem é qualquer tipo de nostalgia.

É qualquer coisa que toca a essência de mim mesmo. Naturalmente, isto é acompanhado por uma reflexão muito grande.

- Eu sempre escrevi, não para comunicar mas para reflectir sobre mim mesmo e só tenho publicado aquilo que acho que devo publicar, para exactamente me distanciar dos meus comentadores. E também é curioso que grande parte dos meus comentadores - eu não lhes chamo críticos - se colam aos meus próprios textos; é interessante constatar isso! $\mathrm{E}$ provavelmente isso interessa-me!

- E os meus textos são qualquer coisa como uma referência para mim.

- Eu sempre fui um leitor compulsivo e, nessa sequência, aconteceu um encontro fulgurante, por volta de 1964/1965. Foi quando li pela primeira vez o Gaston Bachelard. E o primeiro livro que li dele foi a "Poética do espaço», e depois li todos os livros sobre a poética da matéria que ele escreveu.

- Como sabem, o Gaston Bachelard é uma figura importantíssima porque é o inventor da epistemologia e porque é um homem que vem da ciência e que depois sobre uma reflexão realizada a partir da obra de Freud realiza os ensaios sobre a matéria.

Na poética da matéria, publicou livros famosos como:O Ar e os Sonhos, A psicanálise do fogo, etc.

- Esse encontro com Gaston Bachelard foi fundamental porque ele tinha a teoria que eu tinha intuído mas não podia dizer. E naquele instante, eu descubro qualquer coisa que era uma coincidência entre a minha experiência 
que era não-verbal, naturalmente, e uma experiência que estava teorizada na palavra de Gaston Bachelard.

- Gaston Bachelard conduz-me naturalmente para Jung. O Jung queria ser um discípulo de Freud, acabando por se afastar dele acima de tudo por uma aproximação às figuras e às teorias orientais e particularmente a uma figura fundamental que vai ser predominante na minha obra que é a Mandala.

A Mandala é uma figura que aparece representada numa relação de quadrados círculos, triangulações. E é uma figura da meditação que é provavelmente a síntese mais espantosa que um dia o homem oriental inventou relativamente a algum suporte possível da relação do eu interior e o cosmos.

Naturalmente, essa via leva-me a descobrir logo a seguir o Zen, o Tao, o Tantra que são sobretudo noções com forte relação espiritual de transcendência da realidade criadas pelos orientais.

- E por essa altura há uma coisa fundamental que é a descoberta do Tao, numa leitura fulgurante de «O Caminho da Verdade e da Virtude ${ }^{601}$ », de Lao Tse, filósofo e poeta chinês do século VI antes de Cristo. O Tauismo diz: «O que está em cima é igual ao que está em baixo, o que está à direita é igual ao que está à esquerda, o que está à frente é igual ao que está atrás. O que é importante não é o que está em cima nem o que está em baixo, é o que está «entre»! O importante não é o que está á esquerda nem há direita é o que está «entre»! O importante não é o que está á frente nem o que está atrás mas o que está «entre»!»

Esta noção leva a considerar uma questão que me preocupava: se até 1968 eu realizava escultura no sentido tradicional - e embora eu já tivesse recusado o pedestal porque as minhas peças dessa altura já não tinham pedestal - eu ainda circulava em torno delas e era para lá que se concentrava toda a atenção. Era um universo, apesar de tudo, fechado.

601 - Tse, Lao, Tao Te King, O Livro da Via e da Virtude, Trad. de António Melo, Lisboa, Editorial Estampa, 2000. 
- A partir desse momento (1968) e com o Canavial, eu começo a considerar que o fundamental é a abertura que se faz...Isto é, nunca podemos fruir uma obra ou o que quer que seja, se não estivermos dentro disso.

Entretanto, esta relação entre o dentro e o fora que eu vou trabalhar em algumas obras a que eu chamei envolventes e penetráveis, isto é, o espectador não pode ver a obra de fora, tem que penetrar no seu interior e no momento em que penetra ${ }^{602}$ passa a ser a obra ele mesmo porque o espectador que vê o outro dentro da obra também está dentro da obra, e assim sucessivamente.

- E esta é a questão fulcral que irei desenvolver a partir daí no meu trabalho, mesmo hoje. Por um lado estão as relações espaciais, e a partir dessa consciência, passou a interessar-me não tanto a forma, mas o espaço, ou seja, aquilo que a forma gera e onde é gerado.

- Passou a interessar-me não tanto o cheio, mas o vazio. Portanto passou a interessar-me muito mais a ausência do que a presença.

- É evidente que isto é muito oriental, muito Zen ou Tantra.

- Em 1965, há um encontro muito importante que se veio a tornar numa influência no plano teórico: Marshall Mcluhan e particularmente com um livro publicado em 1965, "A Galáxia de Gutenberg». Mcluhan foi o primeiro a falar de aldeia global, ${ }^{603}$ como utopia, porque toda a gente achava que era uma utopia. Mas o que é facto é que o avanço em direcção ao esclarecimento daquilo a que se chamou aldeia global foi tão rápido que deixou de ser entendida no plano utópico.

- E McLuhan falava nas chamadas extensões do homem. O arco é uma extensão da mão, a roupa é uma extensão da pele, a bicicleta, o carro etc. são extensões do corpo. Isto é, o homem inventa as ferramentas para andar mais

\footnotetext{
${ }^{602}$ Alberto Carneiro insiste no acto de penetrar que, para além de significar uma relação da obra do tipo erótica, revela também os penetráveis como uma dimensão do interior no exterior dentro da arquitectura do espaço de exposição. Sobre esta questão, deve ser chamada à memória os Merzbau de Kurt Schwitters.

603 "Uma Floresta para os teus Sonhos" pode ser entendida como uma possibilidade de representação do mundo: natureza cidade, labirinto não têm dimensão definida, é uma ideia que se expande e que pode convocar para a sua compreensão a ideia de obra de arte total de Wagner.
} 
depressa, para vencer a morte e conquistar a eternidade. É evidente que esta é a minha leitura!

- E essa noção de extensão para mim foi fundamental na medida em que acentuou a minha consciência de que a obra de arte é uma extensão do corpo humano. E passou-me a interessar a consciência corporal e, por essa época, também me aproximei dos estudos da psicologia profunda e da dinâmica corporal, isto é, pela presença e mobilidade do corpo no espaço. No plano prático, há também afinidades importantes com Giacometti, Brancussi, com alguma escultura medieval, com as esculturas pré-Colombianas ou primitivas, com a escultura grega primitiva e clássica, com Bernini. Por exemplo, eu sempre que vou a Roma é sacramental, pois é certo que vou ver o «êxtase de Santa Teresa». É para mim uma das obras mais sublimes que algum dia algum escultor produziu.

- Evidente que estas referências são também influências no sentido de se constituírem como afinidades fortes como com Giacometti. No entanto, a minha obra não tem nada a ver no plano formal com a de Giacometti. 


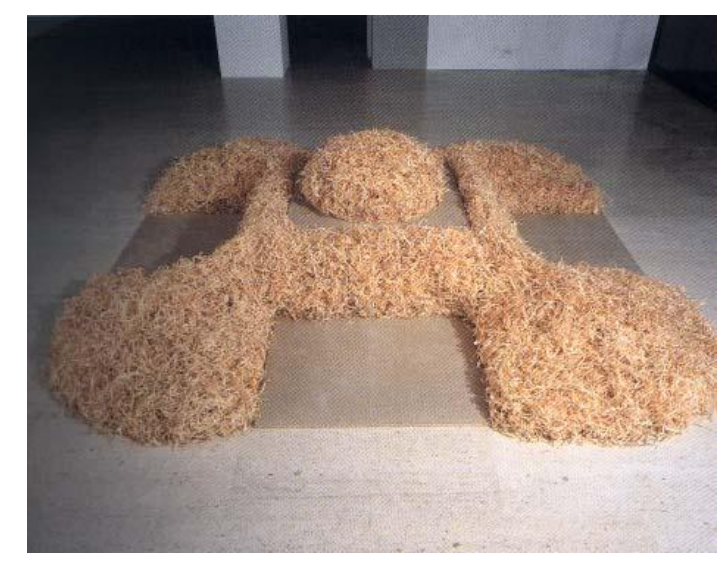

Alberto Carneiro, Flor, 1968-69
Palha de Madeira
Colecção Centro de Arte Moderna da Fundação Calouste Gulbenkian

- Esta obra é também de 1968 e está na Gulbenkian. É uma obra feita com materiais muito simples: com placas de aglomerado e aparas de madeira, a mesma palha de madeira que se usa para as embalagens.

Esta obra tem a ver com as minhas preocupações em torno das filosofias orientais e com a recusa da "manualidade".

- Por volta do final dos anos 60 , em 68 , estou a trabalhar nos projectos que constituem o caderno preto e que foi publicado em $1971^{604}$.

Nessa época, eu recuso o trabalho com as mãos porque tinha uma grande suspeição relativamente às minhas habilidades ${ }^{605}$. Eu encaro essa recusa da "manualidade" nesta época e vai durar entre 1968 a 1982.

${ }^{604}$ Carneiro, Alberto, O caderno preto (ideias e projectos 1968/1971), Porto, Galeria Alvarez, 1971. 


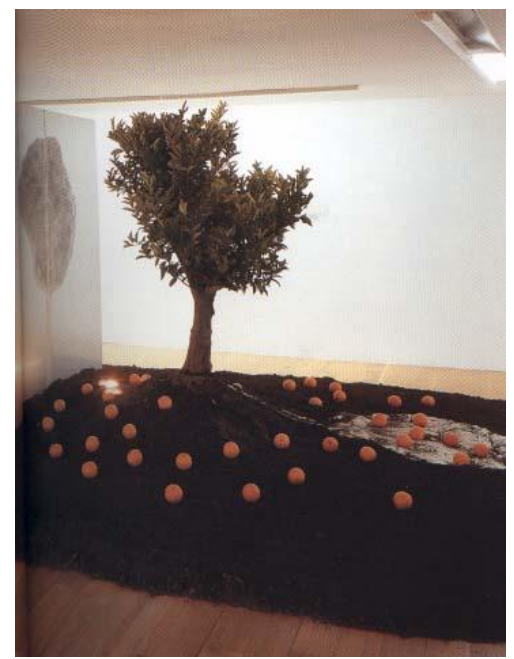

Alberto carneiro, O Laranjal - Natureza envolvente Terra, laranjeira, metal, laranjas, tela, audio, luz; dimensões Variáveis Exposição no CGAC - Colecção Centro Galego de Arte contemporânea.

- É uma peça que está no caderno preto. É de 1969 e é uma das obras em que coloco o primado da percepção em todo o corpo, não apenas no olhar, mas numa percepção global, através dos olhos, ouvidos, nariz, boca, através do corpo em movimento numa relação cinestésica neste trabalho que é o laranjal, cujo elemento central é uma laranjeira viva.

- Eu por esta altura trabalhava, comomedida, o cubo de $2 \mathrm{~m} \times 2 \mathrm{~m}$, que era aquele que o meu corpo abarcava. $\mathrm{E}$ a partir daí e até hoje, parto sempre dessa matriz que é a medida do meu próprio corpo. Muitas vezes esta informação não é explícita no trabalho porque não é necessário, porque há

\footnotetext{
${ }^{605}$ Alberto Carneiro conta uma história que se passou consigo e que ilustra bem essa desconfiança em relação à sua habilidade manual: «a minha actividade de santeiro foi muito repetitiva e em certo sentido adquiri imensos gestos automáticos na reprodução das imagens como ícone. De maneira que andei muitos anos a fazer pés e mãos de nossa senhora, como devem calcular! Um dia tive uma revelação curiosa no sentido em que emergiu e tornou-se consciente qualquer coisa que fazia de forma automática e que só se torna objecto de questionamento em certas circunstâncias: estava na aula de modelo na ESBAP, modelando em barro, tarefa que não apresentava para mim qualquer dificuldade em modelar o rosto, o tronco, que rapidamente se faziam, mas quando às mãos e aos pés, curiosamente aquilo que fazia eram sempre mãos e pés de nossa senhora.
} 
coisas que são apenas importantes para o artista e não o são para o espectador, porque não são fundamentais.

- Por estes anos começo a trabalhar a partir da consciência do meu próprio corpo.

Curiosamente, a minha pedagogia no curso de desenho pertencente à faculdade de arquitectura do Porto e todo o meu programa foram muito apoiados sobre a enfeze colocada na mobilidade do corpo no espaço.

- O cubo de O Laranjal tem uma série de imagens. E vou trabalhar a partir daqui sobre uma noção fundamental que me foi dada através da leitura de «Alice para além do espelho» de Lewis Carroll. Isto é: trabalhando simultaneamente com a realidade e com a sua virtualidade ou o seu lado virtual, trabalhando com a luz e com as sombras, com a imagem e a sua projecção etc., isto é, trabalhando com o lado exterior da nossa consciência e com o lado interior da nossa consciência.

Aquilo que sabemos sobre nós próprios ainda é pouco relativamente àquilo que é determinante sobre o nosso comportamento. Isto significa que estamos sempre perante a evidência de alguma coisa que desconhecemos.

- Este trabalho coloca de forma algo lúdica os cinco sentidos em acção. A terra no centro do cubo, brilhante, é a silhueta de uma árvore que funciona como espelho enquanto imagem diluída onde os pormenores se apagam. No centro do cubo e na terra há um emissor de som, onde a terra conta a história da laranjeira. A história é contada em quatro fases que correspondem aos momentos das estações do ano: a Primavera, o Verão, o Outono e o Inverno. Conta a história da laranjeira, descreve o modo como a laranjeira vive na terra, como é que se alimenta, como se vai transformando ao longo das estações, que visitantes tem (as abelhas, os pássaros, etc.)

Depois os espectadores têm acesso ao cheiro da terra, e a terra está germinando sementes, é um organismo vivo durante a exposição. A laranjeira é também um organismo vivo durante a exposição. 
Há também no canto da sala um monte de laranjas e as pessoas são convidadas a comer uma laranja enquanto fruem a obra. Há uma intenção de globalizar uma relação estética que não passe só pelo primado da visão que, como se sabe, é dominante na cultura ocidental.

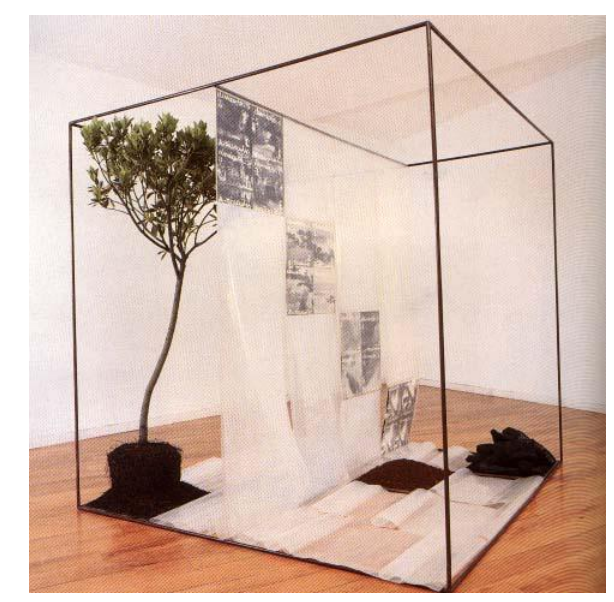

Alberto Carneiro, Os quatro Elementos - 1969/70

Ferro, plástico, fotografia, elementos naturais; 200×200X200 cm Colecção Fundação de Serralves

A peça "Os quatro Elementos" é mais uma vez composta por um cubo com dois metros. Trata-se da primeira obra em que se introduz a fotografia a preto e branco $0^{606}$ para criar distanciamento em relação ao natural.

- Eu sempre trabalho a natureza, mas sempre digo que transformo a natureza em qualquer outra coisa. A natureza está sempre a cumprir e a produzir significado.

\footnotetext{
${ }^{606}$ Alberto Carneiro usa sempre a fotografia a preto e branco excepto no trajecto de um corpo, 197677 , em que as únicas fotografias a cores são aquelas em que o corpo pedra ocupa o espaço da galeria.
} 


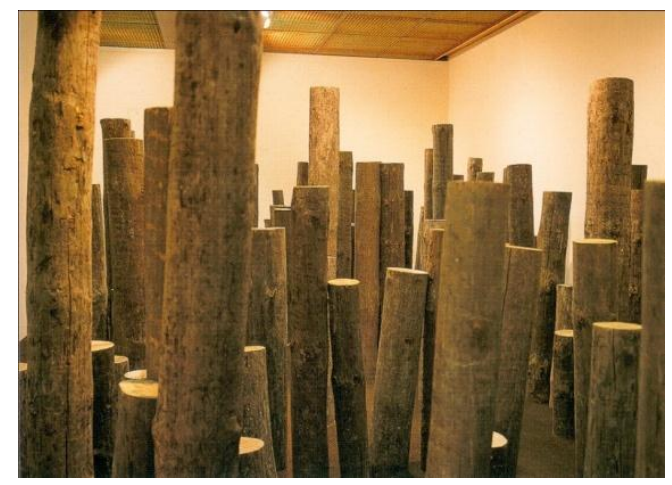

Uma Floresta para os teus Sonhos, (Um bosque para tus sueños) 1970,

Troncos de madeira de pinho tratado, dimensões variáveis,

Colecção Centro de Arte Moderna da Fundação Calouste Gulbenkian, Lisboa.

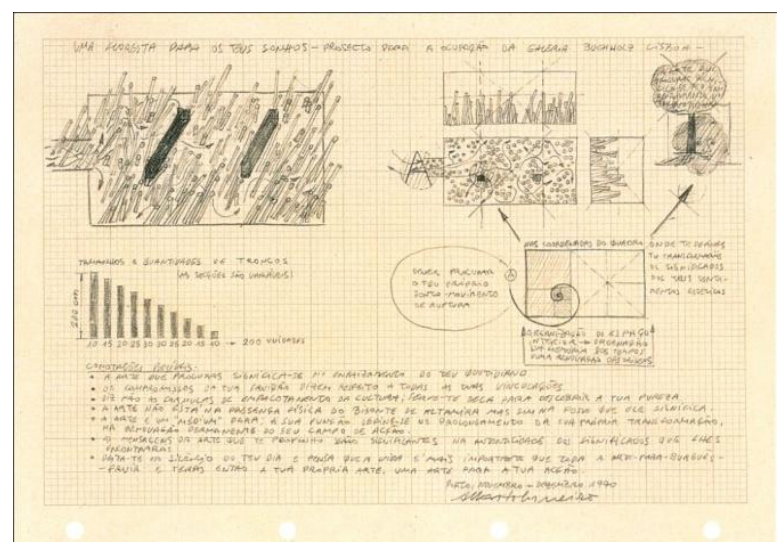

Projecto para; Uma floresta para os teus sonhos

(Um bosque para tussueños), 1970

Grafite sobre papel milimétrico, $21 \times 29,5 \mathrm{~cm}$

Colecção Fundação Luso- Americana para o desenvolvimento

É um projecto de 1970 que foi mostrado na galeria Buchholz, em Lisboa, em 1971, e que na altura foi um escândalo.

A exposição foi na cave da galeria Buchholz, em Lisboa, e as dificuldades começaram logo com a direcção da galeria que levantou imensos problemas. De qualquer modo, Rui Mário Gonçalves teve a força necessária para realizar e manter a exposição. 
Colocam-se aqui problemas de ordem filosófica, as pessoas desciam as escadas até à sala de exposição e ficavam à mercê da floresta em que o contacto físico com os toros de madeira era inevitável.

Acho que é contra a natureza da escultura a proibição de tocar nas coisas que podemos constatar como acontece nos museus.

Esta peça faz apelo ao toque e, por consequência, à materialidade dos troncos de madeira.

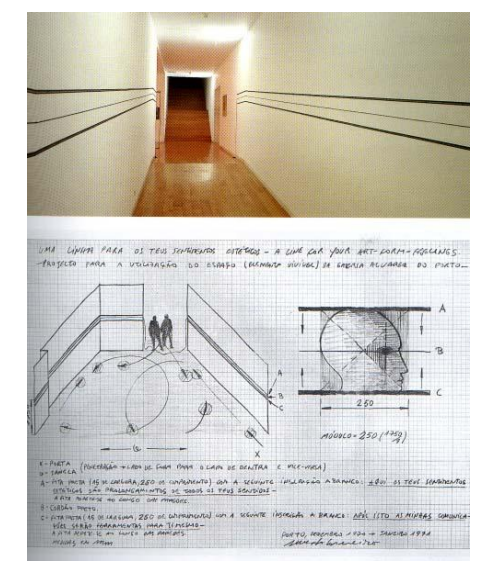

Alberto Carneiro, Uma linha para os teus sentimentos estéticos, 1970-71, Papel impresso, corda de algodão, dimensões variáveis Colecção museu do Chiado

Esta é provavelmente a minha obra mais conceptual - embora eu diga sempre «foi um artista conceptual, landart, corpo etc.», creio não fazer sentido esta diferença de géneros. ${ }^{607}$

\footnotetext{
${ }^{607}$ Alberto Carneiro explica que, tanto as questões de género, como a divisão em categorias académicas, hoje já não fazem sentido. Por isso, prefere falar das artes plásticas em sentido lato porque culturalmente foi operada essa transformação que Alberto Carneiro qualifica de contaminação produtiva.
} 
Quando me perguntam sobre aquilo que faço em termos de género, eu digo «sou escultor!» Faço escultura, mas digo-o apenas para delimitar o campo de referência.

Uma linha para os teus sentimentos estéticos foi mostrada pela primeira vez na galeria Alvarez no Porto, e o esquema apresentado em desenho é desse espaço: trata-se de uma linha que percorre todo o espaço da parede e, quando há um intervalo (interrupção da parede da sala de exposição), ela é estendida no chão, como sempre acontece quando nós temos um vazio, os nossos sentidos orientam-se para o chão.

É uma linha que percorre todo o espaço, à altura da minha cabeça medida a partir do corpo descalço. A linha superior e inferior estão no limite da minha cabeça. Há uma frase que se repete em cima e outra que se repete em baixo. A frase em cima diz: «aqui os teus sentimentos estéticos são prolongamentos de todos os teus sentidos».Em baixo, diz: «após isto, as minhas comunicações serão ferramentas para ti mesmo».

Esta linha pode ter imensos quilómetros, assim como $O$ canavial e a Floresta podem ter milhões de elementos. Portanto, são obras que se adaptam sempre ao espaço onde estão a ser expostas ${ }^{608}$.

Isto para falar de um «processo de investigação que não se esgota, assim como ninguém tem uma obra perfeita», dando como paradigma desta ideia Miguel Ângelo que, quando produz a sua última obra, põe em causa imensa coisa.

\footnotetext{
608 Alberto Carneiro em seguida explica que é preciso fazer violência ao pensamento para poder pensar e inventar - isto implica estar com muita atenção ao que se faz.

A. Carneiro dá também a imagem do desatar do nó - o nó-górdio - para explicar em que consiste o trabalho do artista como alguém que nunca consegue desatar o nó porque ele se vai agigantando.
} 


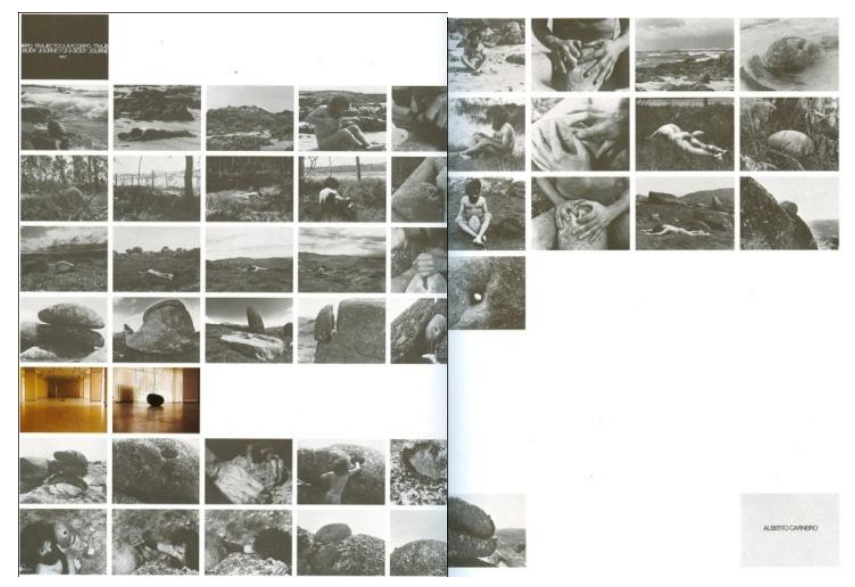

Alberto Carneiro, Trajecto de um corpo 1976-77
Fotografias; 48 elementos de $18 \times 24 \mathrm{~cm}$
Colecção museu de Serralves, Porto

- Este trabalho corresponde ao período que engloba os anos 74/75/76

- Há dois trabalhos que têm um cariz autobiográfico muito forte e um deles é Trajecto de um corpo, que é uma reflexão que faço em dois percursos simultâneos. Um percurso através da paisagem em sítios que relativamente à minha própria infância me eram íntimos, onde tinha tido uma relação forte. Um deles era o mar; tenho uma relação muito forte com a água, tão forte quanto com a terra. E depois no Vale Coronado, onde nasci, no seu ribeiro, que hoje foi desviado devido à passagem da auto-estrada, e a montanha. É um trabalho em que eu passo através da pedra, através de um buraco escavado numa pedra recolhida no mar, numa praia que fica relativamente perto do sítio onde vivo. A pedra é um calhau rolado recolhido no mar. O calhau rolado tem uma simbologia do seu espaço/tempo porque, pela acção dos movimentos, aquela forma resulta do impacto, da energia que esculpe aquela pedra. Houve depois uma ritualização entre o meu corpo e a pedra, trabalhando a marcação do espaço.

- O começo do trabalho é a criação de uma passagem na pedra. Esse buraco é aberto nos três momentos de passagem. Houve um fotógrafo que me acompanhou e tirou imensas fotografias e eu escolhi apenas as necessárias. 
O trabalho começa na praia, vai a um sítio na montanha, que é um sítio com grandes calhaus rolados, onde vão aparecer pedras que naturalmente do ponto de vista da sua relação com a paisagem constituem esculturas. E podiam ser esculturas! Mas são naturais, são formas determinadas pela acção do tempo.

Mas é necessário autenticar a pedra entretanto furada enquanto arte.

E é aqui que se põe um problema sério: o que é arte? É arte aquilo que nomeamos arte, naturalmente! Isto é, tudo o que é arte é relativo, pois tem que ser nomeado como tal. Daí que seja possível hoje, em 2004, nós considerarmos situações artísticas ou objectos de arte coisas que naturalmente há cem anos não eram possíveis de serem consideradas como arte.

- Uma das instituições que confere aos objectos o estatuto de arte é a galeria ou o museu de arte. A pedra, o corpo, vai então para o espaço da galeria. Aí, são tomadas duas fotos a cores da deslocação da pedra nesse local e depois ela sai para fora, para a paisagem e perde-se de novo nela. Ainda hoje ela lá está entre duas pedras grandes de granito. Há pouco tempo fui lá e reparei que um pastor lhe tinha feito uma cama de palha.

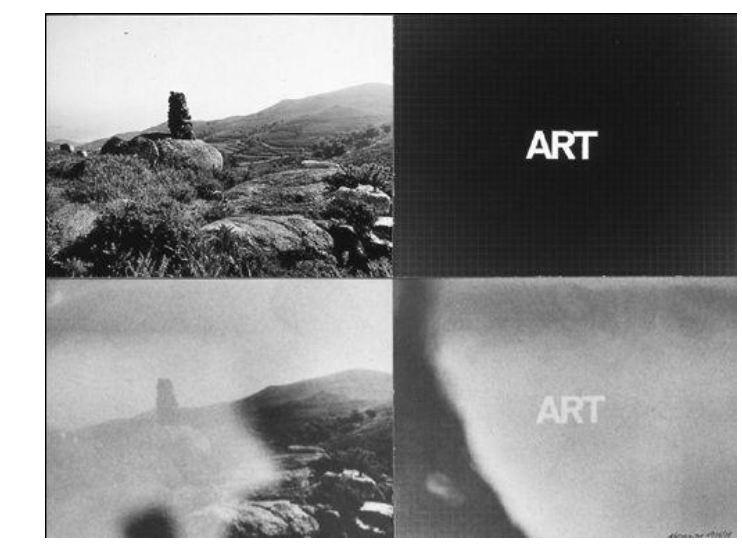

Alberto Carneiro, fragmento de,Arte corpo/corpo arte, 1976-78, Fotografias; 10elementosde $45 \times 35 \mathrm{~cm}$

Colecção Fundação Luso-Americana, Lisboa

- São uma série de obras feitas no parque do Gerês, perto de um lindíssimo bosque de bétulas e que têm a ver com a ideia de construção. São 
trabalhos que faço em privado e depois tomam e são comunicação no conveniente meio que é a fotografia.

- A mim nunca me interessou a fotografia do ponto de vista técnico ou tecnológico. Interessa-me a fotografia como me interessa a madeira, a árvore, a pedra, a montanha.

- Estamos em 1980, de modo que estamos à distância de 12 anos, desde que eu disse não à manualidade!

- E comecei a pensar que, em certo sentido, aquela via estava esgotada no sentido em que tudo aquilo que eu pudesse desenvolver a partir daí seria uma variação, em certo sentido, académica de mim mesmo, repetição de coisa e portanto não tinha grande margem, nem prazer pessoal.

- Eu sou muito crítico relativamente às obras de grandes criadores contemporâneos como, por exemplo, Richard Long que teve um papel fundamental na inauguração de certos procedimentos, mas que depois vai repetindo a obra continuamente.

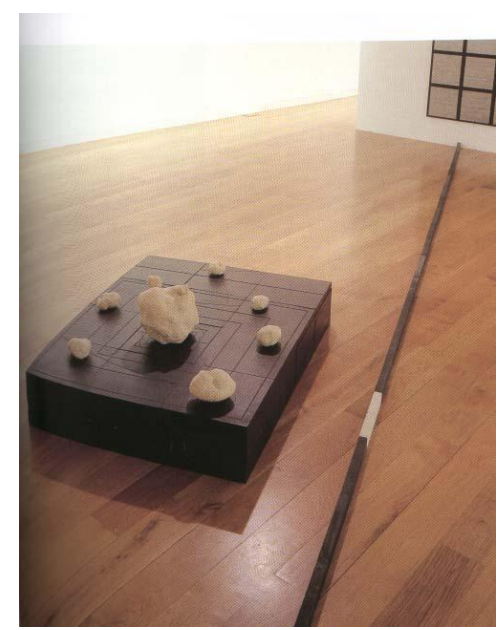

Alberto Carneiro, Corpo Subtil, 1980-81

Pedra calcária, grafite sobre papel; dimensões variáveis

Colecção Museu de Serralves, Porto 
- Este trabalho intitulado "corpo subtil", 1980-81, é um trabalho que desenvolvo ao longo de dois anos e marca um período de reflexão relativamente ao período de trabalho anterior; trata-se da escrita de 84 aforismos trabalhando uma certa ideia de tempo.

Eu tinha concluído que este era o meu testamento, que a partir deste trabalho eu iria parar e não produziria mais nenhuma obra.

- Assim foi, premeditadamente parei!

- Não aconteceu nada durante os primeiros dois messes, mas aí pelo terceiro mês eu comecei a ficar inquieto e comecei a entrar em depressão. Mas estava acautelado porque tinha feito um trabalho muito grande com três amigos entre os quais dois psiquiatras e conclui rapidamente que estava a passar por uma carência catártica que o meu trabalho constituía para mim mesmo.

- Regressei ao trabalho, mas não podia continuar a fazer as mesmas coisas como prova o trabalho laborioso de Corpo subtil.

Reconsiderei a "manualidade" e pensei no que é que me deu para, a dada altura, sonegar uma parte de mim mesmo...

- E então voltei a trabalhar fazendo uso das aptidões manuais. Tinha acautelado as ferramentas, protegendo-as da corrosão, e fui à caixa onde elas estavam e limpei-as a todas!

- E disse para mim mesmo: «Já agora, vou ver o que se passa depois de treze anos de paragem, $68-81$ ». E coloquei um grande pedaço de tronco pronto para ser trabalhado e deixei que o rio corresse sem pensar em nada. Aquilo que fiz foi qualquer coisa que estava próximo do que tinha feito antes de 1968. Isto é, eu de facto não tinha esquecido nada, mas também não me interessava ir por ali. Eu só fiz uma experiência e aquilo que se tornou urgente foi colocar em toda a minha obra toda a experiência que tinha sido feita. 


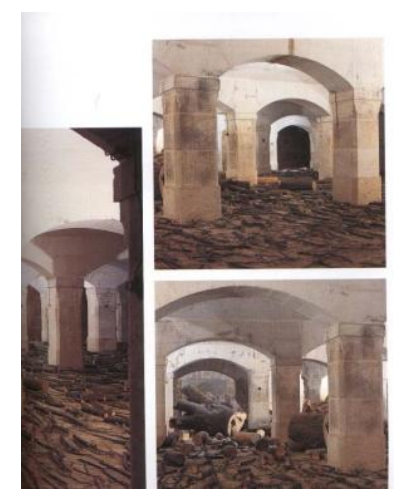
Alberto Carneiro, Uma árvore é uma obra de arte quando recriada em si mesma como conceito para ser metáfora
Madeira de Tília, barro, espelhos, fotografia, dimensões variáveis, Instalação na alfândega do Porto, Porto, 1992

- A peça que se vê na imagem não é feita de maneira manual, mas antes de maneira mecânica com uma electro - serra. É óbvio que eu hoje tenho a mesma sensibilidade na ponta da electro - serra que tinha na ponta da goiva.

- Esta imagem pertence a uma exposição que fiz na Alfândega do Porto, nas jornadas de arte contemporânea em 1992. Para esta peça foi usada uma grande tília cujo interior corroído fez com que tivesse de ser cortada pois estava num pátio de uma escola primária ${ }^{609}$.

\footnotetext{
${ }^{609}$ Alberto Carneiro explica que nunca cortou nenhuma árvore para fazer as suas esculturas. Pelo contrário, diz ter salvado muitas e costuma dizer que «quando pego na madeira é para transformar a madeira em árvores outra vez. Quando pego num bocado de tronco, procuro perceber que árvore é aquela, como é que ela cresceu, e nunca trabalho a árvore a não ser de dentro para fora, isso também eu aprendi na oficina de santeiros, porque a primeira actividade que tive foi a de desbastar, "tirar a alma ao santo" - que é uma expressão lindíssima.

- O que é que isto representa?

- Se tomarem como exemplo os santos barrocos acomodados aos seus nichos; estes por trás não têm nada, são ocos, o centro da madeira foi desgastado e retirado completamente. Porque é preciso cortar o cerne, a árvore cresce de dentro para fora e quando seca, de fora para dentro, a madeira rebenta e abre. E se cortar o cerne, ela tem a possibilidade de contrariar essas forças que a fazem abrir.

- A madeira, como sabem, é sempre viva. A árvore cortada não é uma árvore viva mas continua as suas mutações que participam do ciclo da vida etc. A minha primeira actividade na oficina de santeiros foi a de vazar o interior do pedaço de tronco de madeira de que o santo é constituído de modo a que apenas ficasse uma camada de madeira o mais fina possível».
} 
Esta obra foi feita expressamente para o espaço da Alfândega do Porto. Por esta altura, eu estava a escrever o manifesto pelo espectador lançado durante a exposição.

O trabalho começou ainda com a árvore no recreio da escola. Depois, para realizar a obra, teve que ser pedida a colaboração do pessoal da Câmara. E começou com um grande buraco no chão, porque eu queria que me retirassem a raiz na sua máxima dimensão possível.

- Mas antes de a árvore descer, tivemos de arranjar uma escada telescópica porque a árvore tem que ser abatida, não do modo mais comum, mas em fragmentos de $50 \mathrm{~cm}$ e de cima para baixo.

- Foi lindíssimo o diálogo com as pessoas e o corte da árvore; ao longo de dois dias, a árvore foi colocada no espaço da Alfândega. A peça contém espelhos, tem barro com as marcas fragmentadas do meu corpo. E para esta peça participava também na envolvência o cheiro em todo o grande espaço que a escultura ocupava.

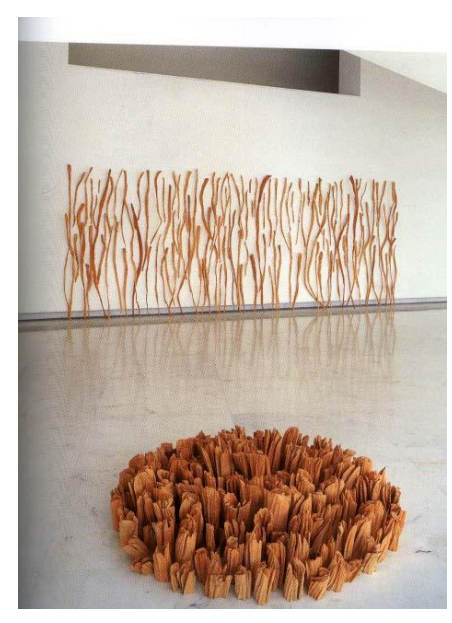

Alberto Carneiro, Sobre o meu jardim 1998-99

Madeira; $38 \times 180 \times 180 \mathrm{~cm}$

Colecção do artista, Instalação no Centro Galego de Arte contemporânea. 
Nesta imagem podem ser vistas duas obras que foram expostas no centro Galego de Arte Contemporânea. A que está em primeiro plano chama-se "Sobre o meu jardim», 1998-99, esta obra serve para vocês perceberem o modo como eu trabalho.

- Esta obra,Sobre o meu jardim, é constituída por 163 elementos que formam um círculo e é feita ao longo de dois anos. Há muitas obras minhas que, desde há uns anos a esta parte, eu tenho sentido que só são possíveis porque tenho o privilégio de viver no sítio magnífico onde nasci e onde cuido da minha horta, das minhas flores, das minhas coisas etc. e do meu trabalho que não separo do resto.

- Uma das soluções que eu adoptei para a minha exposição na porta 33, no Funchal, foi testada no destacamento dos meus feijoeiros.

- Sobre o meu jardim resulta do meu jardim porque tenho muitas rosas, dálias, zineas e muitas árvores com flor e fruto. Gosto muito, de manhã, de dar a minha volta pelo quintal, tratar ou estacar aquilo que deve ser estacado. E enquanto plantava uma plantinha, vinha para dentro com o sentimento, com o sentir, com a impressão. E traduzia essa impressão, não no sentido figurativo, nem no sentido de reproduzir a planta, mas no sentido de produzir uma equivalência de sentidos que fosse equivalente àquele que tive, ao plantar a planta. 


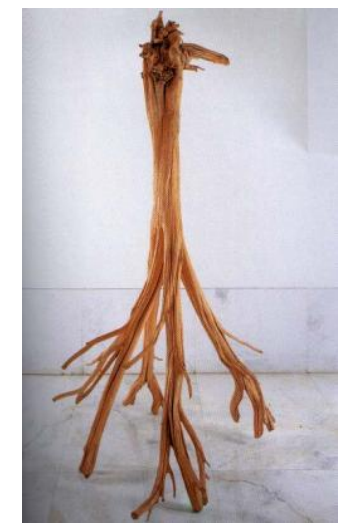

Alberto Carneiro, Árvore da vida, 1998-2000 Madeira de tangerineira; $335 \times 200 \times 180 \mathrm{~cm}$ Colecção do artista

- Esta é uma foto que mostra a peça instalada no CGAC. E esta peça começou na quinta do meu amigo Sobreira que fica mesmo ali ao lado da minha casa. $^{610}$

- A obra está "upsidedown" e eu trabalho muito com árvores invertidas por razões que têm também que ver com a energia - e energia é, para mim, o fundamento de toda a criação artística e de toda a vida e portanto, como eu entendo, energia são emissões novas dentro de uma determinada árvore.

- Como sabem, a árvore é o elemento simbólico - eu diria o mais constante da história humana - porque podemos encontra-la em todas as civilizações como referência simbólica de coisas variáveis, é certo, mas sempre presente na vida e na cultura das pessoas. Trabalhar com a árvore invertida

\footnotetext{
${ }^{610}$ Alberto Carneiro simula a sua conversa com o seu amigo Sobreira: «Eu vou deitar abaixo uma tangerineira, você quere-a?» A que Alberto Carneiro responde: «Claro que quero, vou lá vê-la!» E a árvore foi desenraizada com cuidado e a obra começou naquele local.
} 
implica ter em atenção uma relação de equilíbrio. $\mathrm{Na}$ obra, os poucos elementos que estão apoiados no chão colocam a árvore em suspenso. ${ }^{611}$

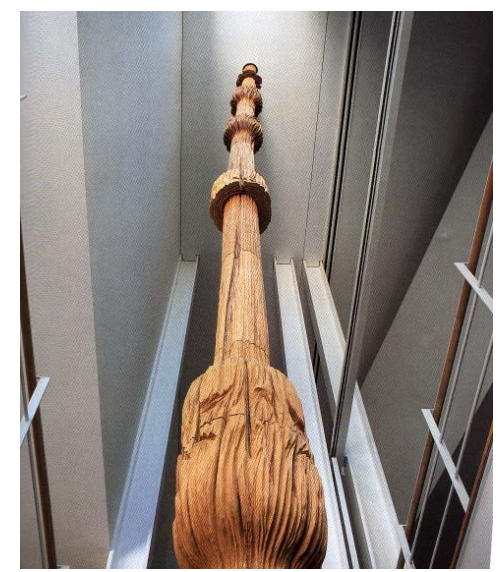

Alberto Carneiro, Uma coluna sem fim, 1999-2001

Madeira; $1.200 \times 50 \times 50 \mathrm{~cm}$

Biblioteca Almeida Garret, Porto

- Esta é a minha coluna sem fim e é, em certo sentido, uma homenagem ao Brancusi. O Brancusi não inventou a coluna sem fim, mas foi o primeiro a inventar a imagem da coluna sem fim relativamente à escultura.

No plano formal, a minha escultura é completamente distinta da de Brancusi. É uma peça que nasce do chão, atravessa o tecto virtualmente e está na biblioteca Almeida Garrett, no palácio de cristal e que foi realizada há quatro anos. Tem doze metros de altura e apresenta-se com um aspecto muito frágil.

\footnotetext{
${ }^{611}$ Alberto Carneiro explica que se costuma distanciar dos trabalhos para ver melhor o espaço que eles criam e, nesta peça, ocorreu-Ihe colocar a mão a tapar parte do campo visual que era ocupado pela escultura árvore, até ao ponto em que decidiu suprimir um dos quatro pontos de apoio, ficando a árvore a ser definida a partir da sua condição de equilíbrio frágil simulado a partir dos três pontos de contacto com o chão. Alberto Carneiro usa este exemplo para explicar que muitas vezes a solução do trabalho está em soluções subtis e que nem sempre sabemos qual é, se é fácil ou não encontrá-la. Alberto Carneiro acrescenta ainda que "nenhum processo de criação vinga, se nós tivermos á partida um esquema demasiado rígido para a excussão da obra. Há sempre naturalmente uma imagem inicial, uma convicção, uma ideia de partida, mas é necessário não fechar o processo, de modo a que seja possível questionar esse ponto de partida e pólo mesmo em causa. "
} 
Aqui, o escultor tem que resolver problemas muito delicados ${ }^{612}$ no sentido da engenharia estrutural da peça responder à gravidade e ao peso da matéria, mas a luta do escultor é exactamente a de criar a ilusão de ausência de gravidade, isto é, para obrigar o espectador a andar no espaço e a habitar a escultura em todos os seus momentos."

\footnotetext{
${ }^{612} \mathrm{~A}$ propósito dos problemas que esta escultura exigiu resolver e no que se refere ao equilíbrio, Alberto Carneiro afirma que "na ordem dos géneros, o pintor tem uma liberdade maior que o escultor e o escultor tem uma liberdade maior que o arquitecto". Depois prossegue, com um exemplo da construção de uma grande pirâmide invertida: "Para um pintor, essa tarefa de representar uma pirâmide invertida é relativamente fácil. Para um escultor, já se afigura mais difícil mas eventualmente possível recorrendo por exemplo a maquetas. Mas para o arquitecto, essa tarefa torna-se impossível porque para além de ter que lidar com a gravidade, como o escultor, tem que transformar a pirâmide num objecto habitável, isto é, que tenha um sentido funcional".
} 
